\author{
UNIVERSIDADE DE SÃO PAULO (USP) \\ ESCOLA DE COMUNICAÇÃO E ARTES \\ PROGRAMA DE PÓS-GRADUAÇÃO EM MÚSICA (PPGM)
}

CYRO MAURICIO DELVIZIO

Os 12 Estudos para violão de Francisco Mignone: um estudo de caso sobre a solução de problemas técnicos violonísticos 


\section{Os 12 Estudos para violão de Francisco Mignone: um estudo de caso sobre a solução de problemas técnicos violonísticos}

Tese apresentada à Escola de Comunicação e Artes da Universidade de São Paulo para a obtenção do título de Doutor em Música.

Área de concentração: Processos de criação musical.

Linha de pesquisa: Performance

Orientador: Prof. Dr. Edelton Gloeden

São Paulo 
Autorizo a reprodução e divulgação total ou parcial deste trabalho, por qualquer meio convencional ou eletrônico, para fins de estudo e pesquisa, desde que citada a fonte.

Catalogaçăo na Publicaçăo

Serviço de Biblioteca e Documentaçăo

Escola de Comunicaçöes e Artes da Universidade de Säo Paulo

Dados inseridos pelo(a) autor(a)

Delvizio, eyro Mauricio

Qa 12 Eetudos para violào de Frariciseo Mignorief un estude

de craso sobre a soluçăo de problemas técnicos violonisticos,

Cyro Mauricio Delvizio orientador, Bdelton Gloeden.

Saco Pauto, 2019

324 P.: il.

Iese (Doutorado) - Programa de p6s-Graduaçào em Muisica -

Eroola de Comunicanóses e Artes / Universidade de Bắ Paulo.

Elbliografia

Verảo cortiglda

1. nilisics 2. Violäo 3. resoluçăo de problentas 4 .

performance I. Gloeden, Edelton II. Título.

CDD 21 wed. -780 


\section{Agradecimentos}

À Capes por nos fornecer nos dois últimos dois anos de curso o apoio financeiro necessário para a conclusão da presente pesquisa.

À Francisco Mignone, In Memoriam que com sua habilidade musical privilegiada ofereceu ao violão doze estudos de inspirada musicalidade, tecnicamente ricos e desafiadores e que nos serviram de matéria-prima ao presente trabalho.

À nosso orientador, prof. Dr. Edelton Gloeden pelo trato sempre hospitaleiro, respeitoso e engajado em nossa orientação, compartilhando de nosso grande apreço pela música de Mignone e de nosso mesmo ânimo na busca de soluções violonística para a obra selecionada.

À família Mignone, notadamente sua esposa, Maria Josephina Mignone, que nos ouviu executar todos os estudos e atendeu à vários de nossos questionamentos e à sua filha, Anete Mignone, sempre entusiasmada e dedicada na divulgação da relevante obra de seu pai.

À Carlos Barbosa-Lima, que também nos ouviu tocar a obra pesquisada e nos presenteou com seus inestimáveis conselhos, sempre com uma invejável paixão pela música e pelo violão.

À Maria Emília Camargo por seu auxílio inestimável em valorosas questões de ordem prática à feitura desta pesquisa.

Aos colegas de curso sempre colaborativos, com destaque especial à Cauã Canilha que nos introduziu e nos esclareceu vários procedimentos burocráticos dentro do campus.

À nossa grande família (pais, irmãos e sogros) com seu apoio e incentivo sempre presente. E à nova família que se formou concomitantemente à esta pesquisa, com o nascimento de nosso primeiro filho, acontecimento mais transformador e edificante que experienciamos.

À Manu e Vicente, meus dois amores mais profundos. 


\title{
Resumo
}

Tratando música e performance violonística como um problema a ser resolvido e procurando por ferramentas que facilitassem o processo de solução de problemas a presente pesquisa levantou vários conceitos em outras áreas do conhecimento, notadamente o Pensamento Divergente de Joy P. Guilford (1950), o Método Científico (principalmente a partir de Tang, 1984), o Pensamento Reflexivo de John Dewey (1933), o Brainstorm de Alex F. Osborn e a Heurística (segundo Duailibi e Simonsen, 1990) e os aplicou à obra selecionada, a saber, os 12 Estudos para Violão de Francisco Mignone (1897-1986), criando inúmeras soluções de execução de suas passagens, expressas pelos 875 exemplos musicais contidos na tese, no intuito de demonstrar como estes conceitos podem auxiliar na solução de problemas violonísticos. O presente trabalho foi realizado com apoio da Coordenação de Aperfeiçoamento de Pessoal de Nível Superior - Brasil (CAPES) - Código de Financiamento 001.

\section{Palavras-chave}

Violão, performance musical, técnica violonística, solução de problemas, 12 Estudos para Violão, Francisco Mignone, Pensamento Divergente, Pensamento Reflexivo, Brainstorm, Heurística.

\begin{abstract}
By considering music and musical performance as a problem to be solved and searching ways of facilitate this problem-solving process this research gathered many concepts or tools of problem solving as the Divergent Thinking by Joy P. Guilford (1950), the Scientific Method (mainly based in Tang, 1984), the Reflexive Thinking by John Dewey (1933), Brainstorm by Alex F. Osborn and the Heuristic (mainly by Duailibi and Simonsen, 1990) and applied then to the selected work, the 12 Guitar Studies by Francisco Mignone (1897-1986). With this approach many solutions where created for it's passages, and where expressed by 875 musical exemples, wishing to demonstrate how this concepts can assist the guitar problem solving process. This study was financed in part by the Coordenação de Aperfeiçoamento de Pessoal de Nível Superior - Brasil (CAPES) - Finance Code 001.
\end{abstract}

\section{Keywords}

Guitar, musical performance, technique, problem solving, 12 twelve guitar studies, Francisco Mignone, Divergent Thinking, Reflexive Thinking, Brainstorm, Heuristic. 


\section{SUMÁRIO}

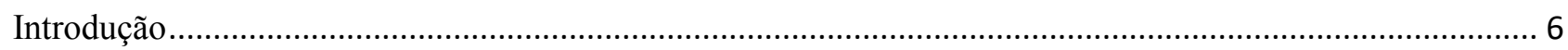

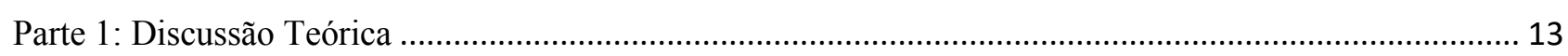

1.1: Modelo do Intelecto e o Pensamento Divergente .......................................................................... 13

1.2: Método Científico e a performance violonística ........................................................................ 20

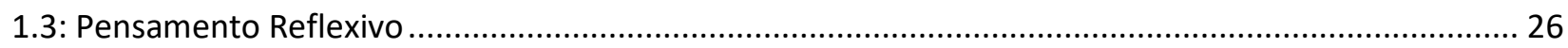

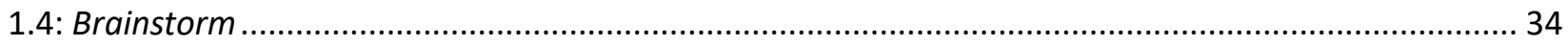

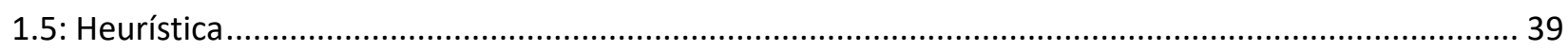

Parte 2: Comparação entre os estudos violonísticos de Villa-Lobos e Francisco Mignone ............................ 44

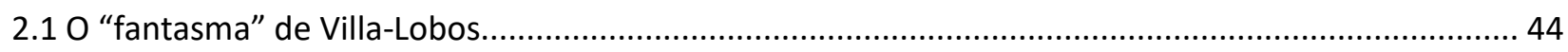

2.2 Relação com violão em ambos os casos ................................................................................... 47

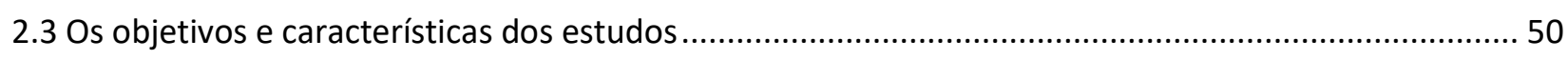

2.3.1 Descrição de alguns objetivos técnicos dos 12 Estudos para violão de Heitor Villa-Lobos .......... 50

2.3.2 Descrição de alguns objetivos técnicos dos 12 Estudos para violão de Francisco Mignone ....... 52

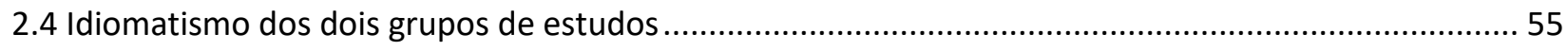

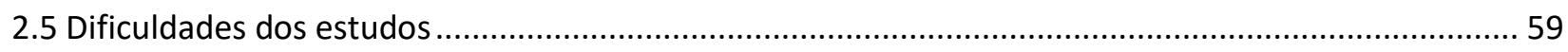

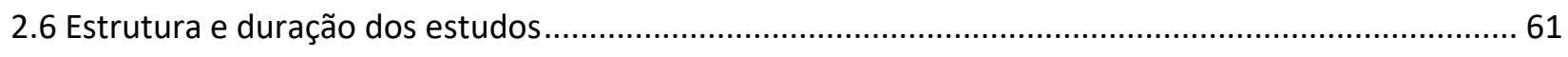

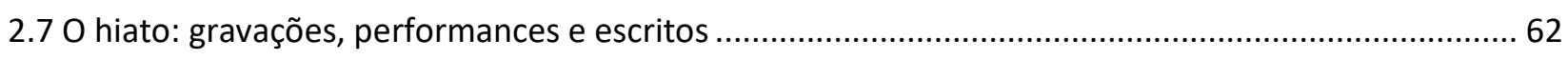

2.8: Revisão da Literatura disponível sobre a obra violonística de Francisco Mignone............................. 65

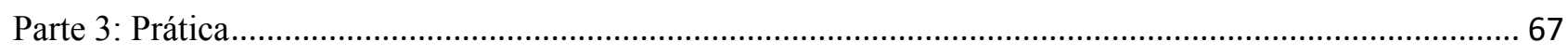

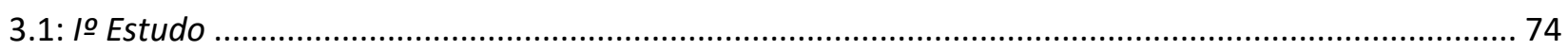

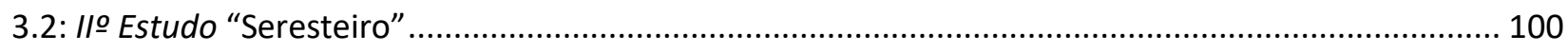

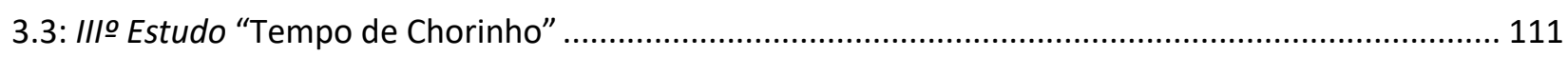

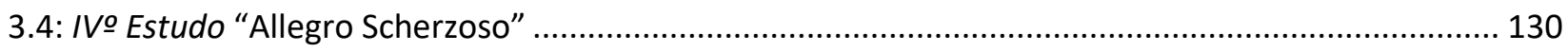

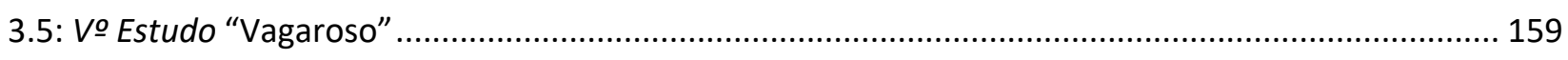

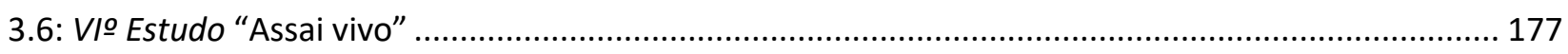


3.7: VIIO Estudo "Cantiga de ninar"

3.8: VIIIo Estudo "Allegro"

3.9: IXo Estudo "Allegro moderato"

3.10: Xo Estudo "Lento e com muito sentimento"

3.11: XIo Estudo "Andante" /"Spleen"

3.12: XIIo Estudo "Com velocidade"

Considerações Finais . 307

Fontes Bibliográficas 


\section{Introdução}

Qualquer prática musical está sedimentada cognitivamente por um caminho muito pessoal de aprendizado e desenvolvimento (mesmo que sob a tutela de um professor). Semeada no fértil porém nebuloso e subjetivo terreno da criatividade, ela é de difícil estruturação em termos metodológicos. Essa dificuldade de sistematização de estudo e aprendizado é particularmente visível na prática violonística (mesmo com uma profusão de métodos publicados) e é agravada por vários motivos: 1) por se tratar de instrumento recente (se comparado a outros ${ }^{1}$ ), 2) estar em plena transformação de construção (acreditamos que muitas delas geram adaptações de técnica do instrumentista) e 3) ser extremamente democrático (possuindo muitos adeptos, mas por outro lado muitos de histórico informal).

No decorrer do aprendizado formal ou informal de como tocar um novo instrumento ou uma nova obra, assim como em qualquer outra atividade humana, inúmeros desafios serão encontrados, solucionados ou não. No caso musical, muitas deles são de ordem técnica/gestual ${ }^{2}$ ou interpretativa ${ }^{3}$, que por sua vez pode demandar mudanças técnicas, havendo também dificuldades de leitura (ou compreensão da grafia musical), memorização, entre muitas outras. As decisões de como solucioná-las são normalmente regidas pelo senso estético do intérprete em questão através de sua experiência e conhecimentos adquiridos anteriormente.

Pode parecer polêmico ou curioso tratar música como um problema, ou ao menos reconhecer a existência de problemas em nossa área quando ela é normalmente sinônimo de algo prazeroso e sublime para os leigos. Eles talvez desconheçam que para atingir este resultado final, muitos dilemas tiveram de ser encontrados e sanados durante horas de prática e posteriormente sua solução teve de ser memorizada durante mais outras inúmeras horas. Por outro lado, até mesmo alguns músicos nem notem a existência de tais obstáculos, pois os resolvem de forma inconsciente e até mesmo instantânea ou automática. Conscientes ou não, esses problemas existem e são, portanto, o foco da presente pesquisa que tenta analisar o processo de solução dos mesmos no violão, provendo uma discussão teórica sobre o tema e buscando demonstrar a

\footnotetext{
${ }^{1}$ A sistematização do modelo de construção do violão moderno é atribuída a Antonio de Torres Jurado (1817-1892).

${ }^{2}$ Ex.: uma tensão no pulso, um acorde que demanda abertura da mão esquerda, etc.

${ }^{3}$ Ex.: um fraseio condizente para uma passagem, etc.
} 
aplicabilidade de tais conhecimentos teóricos. A hipótese é de que existam maneiras de facilitar ou propiciar a solução de problemas performáticos no violão.

Seria difícil negar que solucionar dilemas de forma eficaz é uma necessidade de qualquer área do conhecimento, principalmente com ritmo alucinantemente rápido do fluxo de informações e curtos prazos para decisões exigidos na pós-modernidade. E mesmo que o prazo seja abundante, obter uma boa solução para um impasse é sempre uma necessidade. Como se não fosse o bastante, na atualidade a existência de um grande número de pessoas ou empresas ativas em uma determinada área ainda força a demanda por inovadoras e criativas soluções para problemas novos ou mesmo seculares $^{4}$, seja para criar um novo sabor de sorvete ou resolver a última equação de Hilbert $^{5}$. Mesmo reconhecendo a ignorância humana frente à imensidão do universo ("ipse se nihil scire id unum sciat" ou "só sei que nada sei" ${ }^{6}$ ) é difícil encontrar área do conhecimento que não tenha sido minimamente explorada, ou ao menos suscitada anteriormente. Lembrando a máxima de Lavoisier "na natureza nada se cria, nada se perde, tudo se transforma", muitos problemas parecem nascer em decorrência de questões anteriores assim como aparentes novas soluções muitas vezes são decorrência de respostas anteriores ou da combinação das mesmas.

$\mathrm{Na}$ música e na arte por sua vez, todos os problemas parecem nascer para atender o juízo estético sendo portanto de ordem subjetiva, mas não por isso menos problemáticos. Graças a tal subjetividade não há uma única solução correta para cada impasse, e assim sendo, a criatividade é ainda mais vital neste processo.

Um panorama pela história da música deixa claro que a estética mudou ao longo do tempo e ao intérprete atual cabe a missão de tocar música de épocas anteriores enquanto seus colegas de profissão de séculos passados tocavam apenas música de seu presente (Lawson, 2002, p. 5-11). Como, portanto, conseguiremos "falar" convincentemente um idioma musical do passado e de uma terra estrangeira? Como conciliar a exigência crescente por acuidade histórica de interpretação musical pelos especialistas com a demanda por interpretações renovadas e criativas pelo público apreciador? Como conciliar as intenções do compositor com as inquietudes do

\footnotetext{
${ }^{4}$ Que por sua vez podem exigir abordagens diferentes dos mal-fadados predecessores.

${ }^{5}$ O alemão David Hilbert (1862 - 1943) propos uma lista de 23 problemas matemáticos, dos quais vinte foram resolvidos ou abordados satisfatoriamente, dois já não são considerados importantes.

${ }^{6}$ Frase atribuida a Sócrates por Platão em “Apologia de Sócrates". Ver: www.revistaliteraria.com.br/plataoapologia.pdf.
} 
intérprete $^{7}$ ? Como fazer soar fisicamente a imagem mental que temos de uma determinada música?

Essas questões são um pequeno exemplo de como os impasses estéticos são um dilema cotidiano de qualquer musicista. Mesmo sendo extremamente habituais, estudos (como os de Whitaker, 1996; Oare, 2011; Broomhead, 2005; Walle e Holbrook, 1987 e Byo, 2004) mostram o quanto a solução de problemas não é uma habilidade ensinada em sala de aula. Com isso, queremos demonstrar que esta pesquisa nasce não somente de uma busca (pessoal) para entender maneiras de enfrentar e solucionar desafios musicais, mas também para tentar suprir uma demanda da comunidade musical e violonística.

Devido ao provável ineditismo da proposta, somado a jovialidade da performance musical como área de estudo musicológico (ainda em visível expansão), o levantamento inicial (principalmente realizado na plataforma JSTOR) deparou-se com poucas fontes musicais sobre o tema. Por outro lado, tal ineditismo nos levou a uma natural interdisciplinaridade a fim de sanar tal lacuna. Com isso, a falta de estudos sobre como se dá a "solução de problemas" e "tomada de decisões" na prática musical levou a busca em outras áreas do conhecimento (como neurociência, cognição, memorização, psicologia, filosofia, marketing, etc.), configurando-se terreno fértil ao trazer novos conceitos aplicáveis à prática musical e por vezes provendo métodos de estudo.

Assim, um levantamento mais amplo nos levou a vários conceitos úteis e aplicáveis à performance musical e violonística. O primeiro deles, e talvez o mais central desta pesquisa é o "Pensamento Divergente", uma das características do "Modelo do Intelecto Humano" proposto por Joy Paul Guilford (1897-1987), e que pode ser resumida como a capacidade de encontrar múltiplas soluções para um problema ou usos para um objeto, presente em todos os seres humanos em maior ou menor grau e considerada a matéria-prima da criatividade. As conexões de tal conceito com música são muitas, bastando dizer que existem inúmeras maneiras "corretas" de "decodificar" ou "interpretar" uma mesma partitura, já que um mesmo intérprete (ou vários) pode $(\mathrm{m})$ interpretá-la de maneiras diferentes e até díspares e ainda igualmente convincentes, considerando música uma arte essencialmente temporal.

Além do campo da interpretação, o violão também é uma demonstração viva do Pensamento Divergente na técnica instrumental, já que possibilita a execução de uma

\footnotetext{
${ }^{7}$ Esta questão foi brilhantemente discutida por Apro, 2004.
} 
mesma nota em várias de suas cordas pela mão esquerda $(m e)^{8}$, enquanto o contato direto da mão direita $(m d)^{9}$ na ativação das cordas propícia diferentes ataques (ex. toque livre, toque apoiado, rasgueado, etc.) e diferentes timbres (dependendo da posição da $m d$, ângulo e quantidade de unha ou carne), resultando em uma gama enorme de recursos viáveis para cada passagem musical.

Embora ignorada por muitos, a conexão entre método científico e prática musical suscitada por alguns autores (Tang, 1984 e Oare, 2011, entre outros) também configura ferramenta importante na solução de problemas e consequentemente também será exploradas por esta pesquisa.

Outro aspecto importante na resolução de impasse violonísticos e musicais nos parece ser o engajamento do "Pensamento Reflexivo" proposto e analisado por John Dewey (1859-1952) em "How We Think" (1933). Nossa experiência didática em concordância com autores pesquisados (como Whitaker, 1996; Oare, 2011; Broomhead, 2005; Walle e Holbrook, 1987 e Byo, 2004) atestou a tendência dos estudantes no maior uso do pensamento não reflexivo, comumente chamado de intuição. A capacidade intuitiva é muito útil como ferramenta biológica sobretudo em questões urgentes (nos permitindo escapar de muitos perigos) e também o é na prática musical, embora sua eficácia por vezes seja limitada. Percebemos que muitos alunos de violão, ao usar exclusivamente o pensamento intuitivo, se mantém tocando passagens de uma obra com a mesma digitação que a leram da primeira vez, sem refletir sobre a mesma, sobre suas qualidades e defeitos. Além do mais, tocando-a da mesma forma inicial durante anos eles se lastimam em não perceber melhora, quando a mudança é o pré-requisito do progresso. O "Pensamento Reflexivo" possibilita solucionar problemas e explorar a miríade de possibilidades digitais que o violão oferece, e que são em nossa opinião, não somente uma de suas características marcantes mas também uma de suas maiores qualidades ao oferecer variedade de visões e interpretações. Dewey também explora o uso do que chamou de "memórias consolidadas" na busca de novas soluções. Para

\footnotetext{
${ }^{8}$ Por exemplo, o Mi 3 (altura absoluta) pode ser executado em todas as seis cordas do instrumento, em diferentes posições: a primeira corda solta já soa nesta altura, enquanto a segunda corda deve ser retesada na quinta casa, a terceira na nona casa, a quarta na décima-quarta, a quinta na décima nona e a sexta na vigésima-quarta em harmônico. Outros instrumentos possuem essa capacidade de emitir a mesma altura por meio de diferentes recursos mas nenhum de forma tão frequente quando o violão. $\mathrm{Na}$ flauta e no trompete, por exemplo, isso é possível apenas em algumas poucas alturas. Já nos arcos, trata-se de fenomeno um pouco mais ocorrente, porém menos utilizado por se tratarem de instrumentos com menos cordas e de mais uso melódico que harmônico. Um exemplo oposto (ou anti-exemplo) seriam os instrumento de tecla (com exeção do órgão) que possuem apenas uma tecla para cada nota de sua extenção.

${ }^{9}$ A partir de agora, as mãos serão referidas sinteticamente como me (mão esquerda) e $m d$ (mão direita).
} 
construir tais memórias, consideramos pertinente a construção de uma "caixa de ferramentas" gestuais do violonista (em clara metáfora ao artigo "The Canons in the Musicology Toolbox" de Dan Michael Randel, 1992). Dessa forma, acreditamos que uma maior paleta de gestos adquiridos pelo instrumentista propiciará uma maior gama de soluções para situações futuras.

Por mais surpreendente que possa parecer, as técnicas de Brainstorm idealizadas por Alex Faickney Osborn (1888-1966), comumente empregadas no ambiente empresarial também são úteis como método de resolver obstáculos musicais, ao propor a separação das fases de criação e de julgamento de ideias e ao entender que todas as ideias concebidas merecem ser dignas de registro, melhoria e verificação.

Por fim, da filosofia provém a Heurística, ciência que estuda a solução de problemas. Em termos simples, a Heurística configura um conjunto de leis ou procedimentos padrão (flexíveis e até contraditórios) que facilitem o esclarecimento de questões de uma área do conhecimento. Assim, existem Heurísticas computacionais para confecção de programas, Heurísticas matemáticas, de marketing e etc. Dessa forma, acreditamos ser possível recolher ou verificar na literatura violonística uma série de procedimentos padrões que configurem regras Heurísticas, além de emprestar Heurísticas de outras áreas e aplicá-las no estudo violonístico.

Mas teorizar tais conceitos ainda seria insuficiente para dar conta de um tema tão amplo e arenoso, havendo portanto a necessidade de aplicar tais conceitos norteadores a uma obra, ou conjunto de obras. Para uma melhor demonstração, foram elencadas algumas características para seleção da obra em questão: seria 1) uma obra pouco habitual do repertório, 2) não previamente estudada por nós, 3) preferencialmente criada por um compositor não violonista e 4) prioritariamente de autor nacional, já que este repertório ainda carece de estudos acadêmicos e maior divulgação.

Das várias obras que poderiam atender estes parâmetros, os 12 Estudos para violão de Francisco Mignone (1897-1986) nos pareceram uma opção mais do que satisfatória, pois além de suprir todos os quesitos, trata-se de um dos maiores monumentos do repertório brasileiro, celebrizado internacionalmente como árduo tecnicamente e por este mesmo motivo, pouquíssimo tocado. Ou seja, com tal escolha optou-se por uma peça onde muitos de seus problemas eram considerados quase insolúveis pela comunidade e com isso nasceu também o desafio de tentar resolvê-los, dentro do possível. Isso configurou fator motivacional relevante também favorecido por se tratar de material musical de nosso agrado. 
Além disso, julgamos que quanto mais se discute (academicamente ou não) uma obra cria-se um corpo de conhecimento sobre a mesma, uma compreensão geral de como abordá-la técnica e expressivamente o que é bom por um lado, ao torná-la cada vez mais executada, mas ao mesmo tempo por vezes cria uma homogeneidade de interpretações, algo artisticamente desaconselhável. Tal compreensão é mais um fenômeno do que uma característica boa ou ruim. Inegável é que com o crescimento desse "conhecimento coletivo" sobre uma obra, crescem também o número de suas performances e gravações, havendo porém muitas vezes um grande hiato entre composição e este fenômeno. O exemplo maior que nos vem em mente é o dos 12 Estudos para violão de Heitor Villa-Lobos (1887-1959. Compostos "na década de 1920" (Amorim, 2009, p. 127), somente receberam uma performance e gravação integral cerca de 33 anos após sua composição. Esse foi o tempo necessário para iniciar a dissolução do descompasso entre a obra e esse "conhecimento coletivo" e a partir de então mais performances e gravações desses estudos foram realizados, tornando-a passo obrigatório de qualquer estudante do instrumento. Se nos colocarmos no contexto dessa época, os problemas e compreensão da grafia de efeitos violonísticos, hoje considerados de certa forma óbvios, naquele momento eram uma completa novidade. Foi necessário construir uma compreensão cumulativa e coletiva dos mesmos e isso demanda tempo.

Seria um erro acreditar que queremos com este exemplo propor uma receita para o sucesso de uma obra, afinal seria difícil, ou impossível, delimitar os inúmeros aspectos que fazem uma obra se canonizar. O caso dos 12 Estudos para violão de Mignone é peculiar: eles nos parecem estar "canonizados" e respeitados como uma obra de árdua execução e por este mesmo motivo permanecem pouco tocados, em um círculo vicioso. No meio internacional, outra barreira a sua popularização é sua linguagem mais brasileira (se comparada aos estudos villa-lobianos) que se somam as já penosas dificuldades técnicas.

Após 46 anos da data de composição dos estudos de Mignone, acreditamos que grande parte da responsabilidade por seu entrave está em sua pouca discussão acadêmica ou mesmo extra-acadêmica. Almejamos, com este trabalho, auxiliar neste processo, embora não tenhamos a pretensão de resolvê-lo por definitivo mesmo acreditando que a aplicação dos conceitos enumerados possibilitará um sem-número de soluções para esta obra.

Para cumprir nosso duplo objetivo, organizamos este trabalho de tese em três partes: a primeira delas, "Discussão Teórica", tratará em cinco tópicos os vários 
conceitos supracitados a respeito da solução de problemas. Por se tratar e trabalho interdisciplinar que envolve saberes específicos em áreas do conhecimento diversas e avançadas (como a psicologia, por exemplo) seria impossível ao pesquisador abordá-las com a profundidade de um especialista e por outro lado um grande aprofundamento nestes assuntos também poderia ser pouco proveitoso para a comunidade violonística, público-alvo do presente trabalho. Dessa forma, optamos por explicar os conceitos de outras disciplinas apenas o bastante para que fossem compreendidos pelo leitor (provavelmente sem conhecimento específico em tais áreas) e fazê-los úteis a aplicação na prática violonística.

A segunda, nomeada "Comparação entre os estudos violonísticos de Villa-Lobos e Francisco Mignone", introduz o leitor à obra selecionada de uma maneira não exatamente habitual, ao olhá-la à luz de seu antecessor maior, os 12 Estudos para violão Villa-Lobos, tendo em mente o marco histório fixado por este ciclo. Dessa forma buscou-se elencar algumas de suas similaridades e diferenças destes grupos de estudos visando uma comparação mais "neutra" que evitasse os preconceitos e juízos de valor habituais e até possivelmente os desmistificasse.

A terceira e última parte, "Prática", honrando a linha de pesquisa que rege este trabalho, busca aplicar os conceitos de solução de problemas ao aspecto digitacional dos doze estudos selecionados de Francisco Mignone. De caráter bastante específico ela está destinada especialmente ao público violonístico (de nível médio ou avançado), que saberá ler os 875 exemplos musicais que dão suporte ao desenvolvimento de nosso pensamento, iluminado pelos conceitos norteadores. A leitura desta última seção é inevitavelmente árdua e será melhor aproveitada se for realizada junto a um violão, para que seja possível o teste imediato das soluções digitais dos referidos estudos. 


\section{Parte 1: Discussão Teórica}

\section{1: Modelo do Intelecto e o Pensamento Divergente}

A criatividade parece estar em alta como palavra de ordem na pós-modernidade. É tema habitual de incontáveis palestras empresariais, livros para o aumento de produtividade e autoajuda, e foco de centenas pesquisas cognitivas, comportamentais e neurológicas, seja pelo fascínio que ela nos exerce ou pela inegável parcela de responsabilidade que possui na resolução de problemas e na promoção de inovações. Mas nem sempre foi assim. Sua maior popularidade como "palavra de ordem" bem como a multiplicação de estudos sobre o tema se deu principalmente após a década de 50 tendo o psicólogo Joy Paul Guilford (1897-1987) como um dos principais responsáveis por fazer a psicologia voltar sua atenção para esta capacidade (Deliège e Wiggins, 2006, p. 1).

Guilford envolveu-se no desenvolvimento de testes para a seleção de candidatos ao treinamento de pilotos durante a Segunda Guerra Mundial e expandiu seus interesses ao testar várias outras capacidades intelectuais. Até então a criatividade era entendida como um resultado natural da inteligência, que por sua vez era mensurada pelo teste de QI (Quociente de Inteligência). Em artigo da "American Psychological Association" (Guilford, 1950, p.444-454) proveu seu olhar sobre o campo e anunciou sua intenção de usar técnicas analíticas a fim de começar a isolar os vários fatores do pensamento, separando assim, criatividade e outras habilidades dos fatores mensurados pelos testes de QI. "Suas pesquisas subsequentes focaram-se no desenvolvimento do Modelo Estrutural do Intelecto das habilidades mentais do ser humano" (Gorder, 1980, p. 34), publicado em "The nature of human intelligence" (1967) e "Way beyond the IQ" (1977), para guiar os desenvolvimentos de testes adequados a cada uma das dimensões, bem como suas possíveis combinações, esperando que uma pessoa poderia ser excelente em uma categoria e precário em outras. Assim, este modelo do intelecto organizou essas várias habilidades em três dimensões de um cubo, a saber - conteúdo, produto e processo - como apontado no diagrama mais abaixo.

Por "conteúdo" ele se referia ao tipo ou tipos de estímulos (visual, auditivo, simbólico, semântico e comportamental) no qual uma pessoa tendia a prestar mais atenção ou pensar mais efetivamente. 
Os "produtos" dizem respeito ao tipo, tamanho ou medida da informação que foi processada, como unidades (palavras, formas, etc.), classes (organização de unidades em grupos coerentes), relações (entre duas unidades), sistemas (relações entre mais de duas unidades), transformações (como rotações de figuras ou mudança de sentido de palavras) e implicações (expectativa gerada por uma informação).

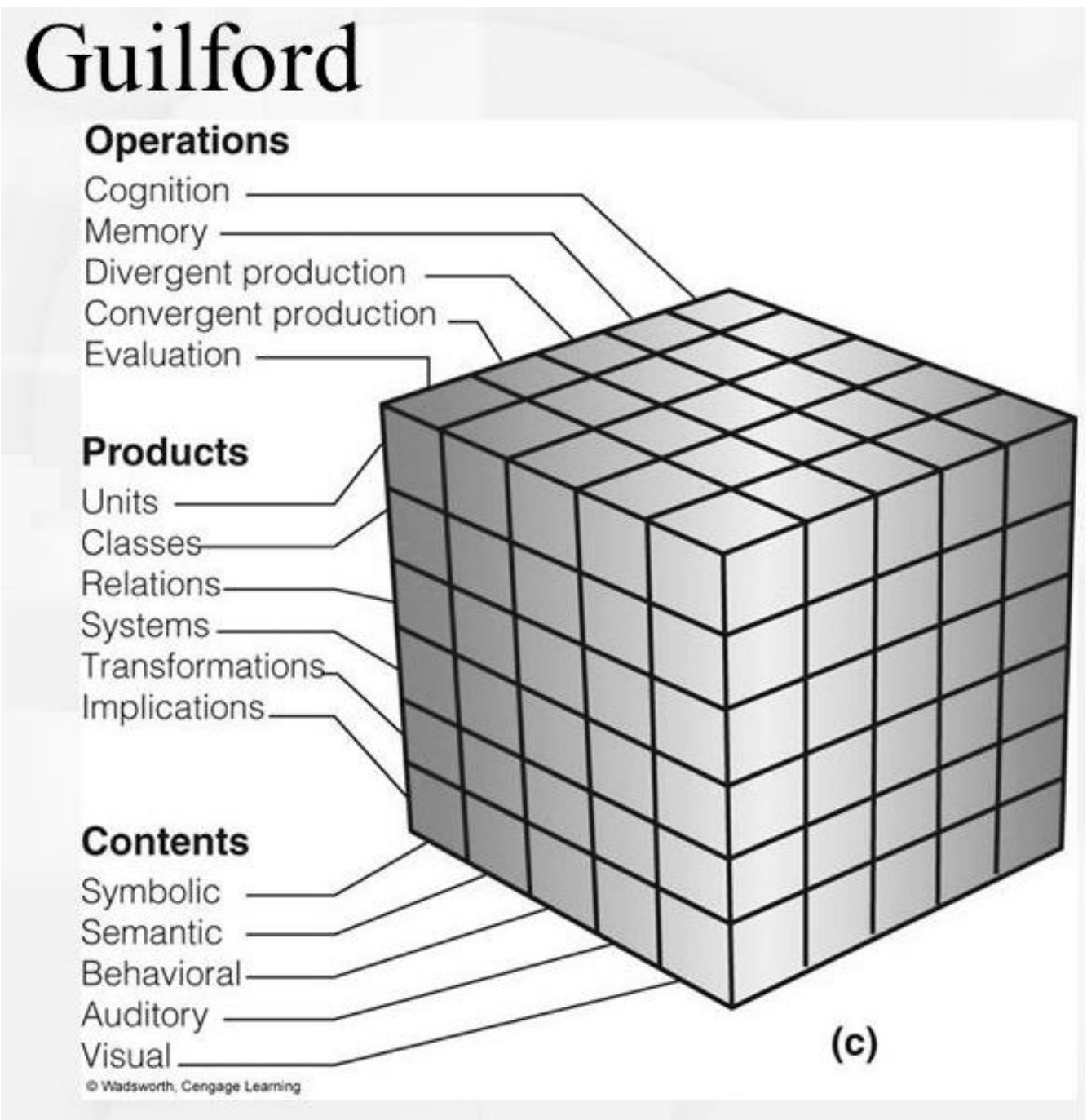

(Sternberg, 2012, p. 445)

Já as "operações” descrevem o que o cérebro faz com esses tipos de informação: cognição (a habilidade de perceber vários itens), memorização (armazenamento da informação), produção divergente (habilidade de acessar a memória e procurar por várias coisas que atendam um determinado critério), produção convergente (habilidade de procurar por uma resposta correta, podendo ser aparentemente um resultado da produção divergente), avaliação (habilidade de julgar informações).

Com esses fatores é possível identificar 150 habilidades distintas que contribuem na solução de problemas. 
Dessa multitude de habilidades, nos pareceria possível prover exemplos de que todas as "operações" e "produtos" são ativados na prática musical (conteúdo auditivo) e por conseguinte, passíveis de estudos mais aprofundados, mas nos absteremos dessa tarefa para nos focar na importância da "produção divergente" (também chamada de Pensamento Divergente ou lateral) no estudo violonístico.

Tal capacidade foi definida pelo próprio autor como "a geração de alternativas lógicas a partir de uma informação dada onde a ênfase é a variedade, quantidade e relevância dos resultados da mesma fonte"10 (Guilford e Hoepfner, 1971) e foi "hipoteticamente considerada como a base da habilidade criativa" (Gorder, 1980, p. 3435), porque, "tanto na arte quanto na ciência, é da quantidade que se extrai a qualidade quanto maior o número de ideias colocadas ao nosso dispor, maiores as chances de encontrarmos aquele que realmente representará a solução do problema” (Duailibi e Simonsen, 1990, p. 44).

É preciso dizer que não há juízo de valor entre o Pensamento Convergente e Divergente, já que ambos são úteis em diferentes situações: "o Pensamento Convergente funciona melhor com problemas bem definidos que tem uma resposta clara, enquanto o Pensamento Divergente é mais adequado para problemas não estruturados e indefinidos"11 (Gibson, Folley e Park, 2008, p. 1) e ambos merecem ser conciliados para a solução de um impasse. O que Guilford parece ter feito foi demonstrar a importância do Pensamento Divergente quando havia (e ainda existe) uma tendência à supervalorização do pensamento convergente, sendo que "de acordo com Guilford, é o Pensamento Divergente que provém as bases para a produção criativa pois esta demanda a procura conceitual sem fronteiras direcionadas"12 (Gibson, Folley e Park, 2008, p. 1). "Desde a contribuição inspiradora de Guilford no estudo da criatividade, o Pensamento Divergente continuou como um elemento conceitual (interno e externo) válido para o processo criativo" (Gibson, Folley e Park, 2008, p. 1).

No que tange nossa área de atuação, Grassi e dos Anjos (2010), baseados em Galvão (2006), revelam que os impasses musicais normalmente recaem na segunda situação, anteriormente descrita:

\footnotetext{
10 "the generation of logical alternatives from given information where emphasis is upon variety, quantity and relevance of output from the same source" (Guilford \& Hoepfner, 1971).

11 "Convergent thinking works best with welldefined problems that have a clearly defined response, while divergent thinking is best suited for poorly defined or unstructured problems" (Gibson, Folley e Park, 2008, p. 1).

12 "According to Guilford, it is divergent thinking that provides the foundation for creative production because it requires ideational searching without directional boundaries" (Gibson, Folley e Park, 2008, p. $1)$.
} 
"Deve-se considerar que os problemas musicais não são como problemas matemáticos. Na música, os problemas são mais frequentemente caracterizados como mal estruturados, o que permite que, em determinadas situações, muitas respostas possam ser consideradas corretas, dependendo das perspectivas específicas, como por exemplo, no caso da digitação ou da interpretação de um determinado trecho musical" (Grassi e dos Anjos, 2010, p. 76, baseado em Galvão, 2006).

Dessa noção nasce nossa hipótese de que, se em performance musical irrompem principalmente problemas de ordem mais nebulosa (ex. o quão forte/rallentando/acellerando/etc o compositor concebeu esta passagem?) e se o Pensamento Divergente é apontado como o mais adequado para sua resolução, porque não adotá-lo como metodologia específica na solução de impasses durante a preparação de uma obra? Essa pergunta tentará ser respondida na terceira parte da presente tese, quando aplicaremos na obra selecionada o Pensamento Divergente e outros conceitos de solução de problemas (elencados ainda nesta discussão teórica).

Aprofundando seu conceito, Guilford ainda demonstrou quatro habilidades básicas de produção divergente (ainda segundo Gorder, 1980, p. 34-35):

1. Fluência: a produção de múltiplas respostas a mesma informação dada, em um tempo limitado.

2. Flexibilidade: a produção de mudanças de significado em resposta a uma mesma informação dada.

3. Elaboração: a produção de informação detalhada ou complexa, além daquela esperada em resposta a determinada informação.

4. Originalidade: a produção de respostas raras para a população na qual o sujeito se encontra, inteiramente nova, ou remotamente associada à informação dada [Guilford \& Hoepfner, 1971].

(Gorder, 1980, p.34-35) ${ }^{13}$ [tradução nossa].

As aplicações dessas habilidades divergentes em música são amplas, dependendo da informação a ser avaliada. Neste sentido Gorder (1980, p. 35) traça alguns paralelos musicais para as definições de Guilford:

(a) fluência musical - a produção de ideias ou frases (conteúdo) a partir de uma informação musical; (b) flexibilidade musical - a produção de ideias ou frases que são pontuadas por mudanças no caráter do conteúdo; (c) elaboração musical - a produção de ideias ou frases que são pontuadas pelo detalhamento ou complexidade das características de conteúdo empregadas; (d) originalidade musical - a produção de ideias ou frases que são pontuadas pelo uso de características raramente utilizadas pela população à qual o sujeito pertence. E em adição, uma quinta habilidade

\footnotetext{
13،1. Fluency -the production of multiple answers from the same given information, in limited time. 2. Flexibility -the production of shifts of meaning in response to the same given information. 3. Elaboration - the production of detail or complexity of informa- tion, above that called for in response to given information. 4. Originality--the production of responses rare in the population to which the subject belongs, novel, or remotely associated with the given information" (Guilford \& Hoepfner, 1971).
} 
musical foi hipotetizada, (e) qualidade musical - a produção de ideias ou frases de atrativo à sensibilidade de outros músicos (Gorder 1980, p. 35) ${ }^{14}$ [tradução nossa].

Se considerarmos, por exemplo, a informação dada como sendo a partitura musical, mais especificamente a dos 12 Estudos para violão de Francisco Mignone, a "fluência" seria a capacidade de prover múltiplas soluções técnicas e interpretativas para uma determinada passagem musical; a "flexibilidade" (consideravelmente mais subjetiva e difícil de exemplificar) poderia ser a mudança de um parâmetro dado (como dinâmica, por exemplo), sem alterar o sentido original geral da passagem; a "elaboração" seria a adição de parâmetros não especificados pelo autor, desde articulações (como pizzicati ou rasgueios) a ornamentos e variações; a "originalidade" poderia ser considerada qualquer solução não habitual, como o uso de pestanas não usuais (com dedos 2, 3 ou 4 da me), uso do polegar (me) na frente do espelho para digitações de acordes, etc; e a "qualidade musical" (critério adicionado por Gorder) seria obviamente a capacidade de gerar não só uma multiplicidade de respostas, mas uma resposta com valor passível de reconhecimento por seus pares.

O curioso é que apesar de ser um conceito "válido para o processo criativo" (Gibson, Folley e Park, 2008, p. 1) e sendo música um desses processos, encontramos poucos trabalhos acadêmicos que o relacionem ao saber musical e menos ainda que o abordem pelo ponto de vista da performance musical, como pretendemos aqui.

Dos artigos acadêmicos levantados (10) na plataforma JSTOR que aplicavam o Pensamento Divergente em música, encontramos a maioria (sete) voltada à educação musical (a saber: Feinberg 1974, Webster 1979, DeLorenzo 1989, Hickey 2001, Kiehn 2003, Hill 2009 e Grassi e dos Anjos 2010), dois voltados exclusivamente à cognição musical (Sadek 1993/1994 e Gibson, Folley e Park, 2008 sendo que este último neurocientífico), um voltado exclusivamente ao desenho de testes de criatividade (Gorder, 1980) e outros, citados anteriormente no quesito educacional, também com viés de aferir a criatividade em crianças (Webster 1979, Kiehn 2003 e Hickey 2001). É preciso ressaltar que essas categorias não são absolutas, se inter-relacionam e também abarcam outros assuntos, como etnomusicologia, composição, apreciação e performance

\footnotetext{
14 “(a) musical fluency - the production of musical ideas or phrases (content) from given music information; (b) musical flexibility - the production of ideas or phrases that are scored for shifts in content character; (c) musical elaboration - the production of musical ideas or phrases that are scored for the detail or complexity of content characteristics employed; (d) musical originality- the production of musical ideas or phrases that are scored for the use of musical content characteristics rarely used by the population to which the subject belongs. In addition, a fifth musical ability was hypothesized, (e) musical quality - the production of musical ideas or phrases that appeal to musicians' musical sensitivity" (Gorder 1980, p. 35).
} 
musical. Esta última aparece como pano de fundo em alguns desses trabalhos (quando buscam aferir a criatividade em composições ou performances de grupos de estudantes), mas raramente (para não dizer nunca) é tratada prioritariamente e sob um viés pessoal e instrumental como almejado pela presente tese.

Enquanto a literatura acadêmica se demonstrou ainda embrionária na relação entre este conceito e música, consideramos que alguns métodos violonísticos existentes podem indicar o emprego não proposital ou consciente do conceito de Guilford.

O que seriam os 120 estudos de arpegios de Mauro Giuliani (1781 - 1829) se não a aplicação do Pensamento Divergente em dois acordes no violão desenvolvendo para os mesmos múltiplos padrões de funcionamento da $m d$ ?

Assim também consideramos ocorrer em vários métodos que se baseiam em “cobrir" em seus exercícios todas, ou ao menos inúmeras, possibilidades de permutação de dedos (me e $m d$ ) no violão como: A modern method for the guitar (school of Tárrega) in three volumes (1917) de Pascual Roch, Escuela Razonada de la Guitarra baseada en los principios de la técnica de Tárrega (1934) de Emilio Pujol (ambos baseados em Tárrega), os quatro Cuadernos (1966) de Abel Carlevaro (sendo que o segundo livro apresenta 197 fórmulas em cima de um único acorde diminuto em translado cromático), Pumping Nylon (1995) de Scott Tennant (baseado em Tárrega, Giuliani e etc), além de muitos outros.

A existência de múltiplas visões acerca de uma mesma obra, dessa vez por intérpretes diferentes, pode ser aferida por meio das 93 gravações existentes dos 12 Estudos para violão de Villa-Lobos (listadas por Amorim, 2007, Anexos, p.231-234), das quais bastaria escutar as realizadas por Andres Segóvia, Abel Carlevaro, Turíbio Santos, Eduardo Abreu e Manuel Barrueco para já perceber o quão distintas podem ser as interpretações e resoluções técnicas dos mesmos estudos. Outro exemplo, igualmente significativo são obras que receberam várias edições, cada uma com revisor diferente, como os estudos de Matteo Carcassi (1792 - 1853), que recebeu edições de Simon Wynberg (Chanterelle, 1985), Brian Jefferey (Tecla Editions, 2006), Miguel Llobet (Ricordi, 1974), Giovanni Podera e Giulio Tampalini (Edizioni Curci, 2015) e Cauã Canilha (dissertação de mestrado, 2018).

Com essas ponderações e antecedentes violonísticos (informais), acreditamos que esse conceito, embora aparentemente simples, poderá ter implicações profundas e benéficas se aplicado ao nosso instrumento como método sistemático de auxílio na 
solução de problemas, aplicação esta que será aprofundada na terceira parte da presente tese, usando os 12 Estudos para violão de Francisco Mignone como estudo de caso.

No entanto ele não encerra nossa discussão teórica sobre a solução de problemas violonísticos. Pelo contrário, apenas inicia tal jornada e se atrelará aos outros conceitos e ferramentas relacionados ainda na presente seção. 


\title{
1.2: Método Científico e a performance violonística
}

O processo mais tradicional e conhecido de se obter respostas aos questionamentos e problemas humanos provavelmente pode ser considerado o Método Científico. Hoje reconhecido e difundido pela academia e com bom grau de aceitação no ambiente exta-acadêmico sua aparência atual advém de um longo processo de depuração, que acompanha boa parte da história da própria humanidade:

\begin{abstract}
"Desde que o homem começou a tomar consciência do mundo exterior e a interrogar-se a respeito dos fatos da natureza, foi movido por um impulso de 'querer saber'. Esse desejo de conhecimentos levava, necessariamente, à vontade de 'saber fazer', isto é, de descobrir os caminhos que pudessem conduzi-lo a seu objetivo. Surgiu assim a necessidade do 'método'. O método é o caminho que se percorre na busca do conhecimento. Etimologicamente, método é uma palavra que vem do grego methodos (meta+hodós), 'caminho para se chegar a um fim'.

Embora a noção da necessidade de um 'caminho' ou caminhos na busca do conhecimento existisse desde os primeiros impulsos do 'querer saber', as ideias básicas dos métodos científicos de pesquisa passaram a ser formalizados por René Descartes (1596-1650), pensador e filósofo francês, no 'Discurso do Método'.

Descartes, para quem só existe o pensamento e dele tudo depende, postula a ideia fundamental de que é possível chegar ao conhecimento por intermédio da razão ... a partir da dúvida, proveniente da falibilidade dos conhecimentos.
\end{abstract}

Para a linha de raciocínio cartesiana, é fundamental determinar o problema, dividi-lo em partes, ordenar os conceitos, simplificando-os, enumerar todos os seus elementos e determinar o lugar de cada um no conjunto da dedução" (Andrade, 2008, p. 8-9).

O método de Descartes foi questionado por Francis Bacon (1561-1626) e mais tarde a ciência ganharia mais uma ferramenta: o "método experimental" pelo físico e astrônomo italiano, Galileo Galilei (1564-1642), publicado na obra "Diálogo sobre as novas ciências" (1638) (Andrade, 2008, p. 10). Tal método poderia ser sintetizado nas seguintes etapas: 1) Observação das manifestações da realidade (rigorosa, precisa, metódica); 2) Hipótese (explicação provisória do fenômeno ou solução do problema passível de confirmação ou negação); 3) Experimentação (controle da hipótese, observação do fenômeno em condições determinadas pelo experimentador); 4) Comparação (classificação, análise e crítica dos dados recolhidos); 5) Abstração (verificação dos pontos de acordo e desacordo dos dados recolhidos); 6) Generalização (estender a outros casos semelhantes um conceito obtido pelos fenômenos observados) (resumido a partir de Andrade, 2008, p. 12). Além dos métodos supracitados, há uma profusão de outros, dependendo sempre da natureza do objeto a ser pesquisado e dos objetivos do pesquisador.

No entanto, graças aos numerosos resultados (tecnológicos entre outros) das ciências exatas e naturais e ao impacto gerado pelos mesmos na vida cotidiana humana, 
sua visão de mundo virou a vigente em detrimento das demais, como bem expresso por Carlos Alberto Pereira Silva (2017, p. 1):

\begin{abstract}
"Ao pesquisar acerca das origens da ciência moderna, constatei que o seu nascimento está relacionado a um contexto no qual imaginação, fé, magia, intuição e emoção estavam indissociavelmente interligadas na prática dos cientistas. Em sua origem, no século XVII, quando a ciência ainda era uma atividade periférica, os cientistas, impulsionados por ideias, mitos e sonhos, eram simultaneamente filósofos e artistas. Conforme destaca Edgar Morin (2008, p. 53), em sua reflexão acerca da emergência das ciências da complexidade, na raiz das explicações científicas sempre esteve a imaginação que, juntamente com o empirismo, o racionalismo e a verificação, constitui as 'quatro pernas da ciência'.

Sobretudo no século XIX, época da plena consolidação do pensamento científico e do surgimento de diversas áreas do conhecimento, a fragmentação do saber e do ser foi potencializada. Com a consolidação do conhecimento científico e a expansão da tecnologia, resultante do crescimento das atividades industriais, o discurso derivado da ciência colocou-se como única forma de conhecimento válido. Ao separar-se da arte e da filosofia, a ciência constituiu o seu próprio domínio. Com a expansão do industrialismo e da urbanização, na medida em que acontecia a separação entre as atividades científicas, artísticas e filosóficas, a ciência desdobrou-se e objetivou-se na tecnologia. Encantados pelos poderes reais e imaginários da tecnociência, os cientistas, possuídos pela razão fechada, passaram a negar valor às outras formas de conhecimento" (Silva, 2017, p. 1).
\end{abstract}

Com isto, "o sucesso da ciência em muitos campos tecnológicos em que ela germinou, levou muitos a verem a disciplina com respeito, até com temor e reverência" valorizando e generalizando-a como algo objetivo e sistemático, "controlado por fatos lógicos, empíricos e objetivando a formulação de verdades sobre o mundo natural" (Tang, 1984, p. 261). No entanto, trabalhando no campo da filosofia da ciência, e portanto questionando e refletindo sobre a mesma, Tang pondera que com esta visão "nós tendemos a subestimar a ciência como expressão da criatividade humana" nos fazendo perder o aspecto humano da descoberta científica". Dessa forma, "o retrato do cientista como ser humano frio e isolado que descobre as grandes verdades por métodos sistemáticos e controles rigorosos, distorce ... a natureza subjetiva da ciência" (Tang, 1984, p. 261). A partir de então, Tang concentra sua argumentação em demonstrar que "a descoberta em ciência difere pouco da criatividade em artes" (Tang, 1984, p. 261), algo que para nós, artistas, é bastante revelador, já que nossos esforços muitas vezes estão voltados a tentativa de provar para os demais pesquisadores, o valor da produção científica de nossa área. Ele descreve então, ambos os processos, sempre de forma instigante:

"Em ciência, não menos do que na música, especulação e imaginação não são o produto final, mas apenas o primeiro passo em direção a descoberta cientifica final ou a criação musical. Este estágio subjetivo é seguido por outro centrado em regras de caráter objetivo, que no caso da ciência permite ao pesquisador a condução de experimentos, manipulação de ideias e submeter sua hipótese a análise crítica. 
Similarmente, o compositor, após o estágio preliminar de especulação e imaginação, procede para a ordenação de seus materiais musicais - como melodia, ritmo, harmonia e forma. O compositor também os submete a experimentação, por exemplo, ao tocar certas passagens ... Essa manipulação dos materiais e recursos musicais pode ser vista como um método objetivo e governado por regras para validar a especulação subjetiva inicial”"15 (Tang, 1984, p. 261) [tradução nossa].

Tal comparação também é valida ao se substituir a figura do compositor pela do intérprete, que ao se deparar com a leitura a partitura, dará início a um processo subjetivo e especulativo (consciente ou não) de escolha de soluções técnicas e interpretativas hipotéticas, e as passará por testes objetivos que almejam mensurar sua eficácia (limpeza das notas, precisão rítmica), acuidade estética, conformidade com a imagem mental do intérprete e memorização (entre outros inúmeros aspectos), sempre retornando ao processo inicial em casos insatisfatórios, a exemplo do diagrama abaixo:

\begin{tabular}{|ll|}
\hline \multicolumn{2}{|c|}{ THE SCIENTIFIC METHOO IN PRACTICE } \\
\hline The Method: & Example: \\
Select a problem & My tone is fuzzy. \\
\hline $\begin{array}{l}\text { Review the knowled8e } \\
\text { base }\end{array}$ & What affects tone? \\
\hline Develop a hypothesis & My embouchure is weak. \\
\hline $\begin{array}{l}\text { Test through experimen - } \\
\text { tation }\end{array}$ & $\begin{array}{l}\text { Play with a firmer } \\
\text { embouchure. }\end{array}$ \\
\hline Collect data & Listen \\
\hline Analyzedata & $\begin{array}{l}\text { It's a little better, but I } \\
\text { still hear some fuzz }\end{array}$ \\
\hline Interpret the results & $\begin{array}{l}\text { A firmer embouchure helps } \\
\text { my tone - but there's more! }\end{array}$ \\
\hline
\end{tabular}

(Oare, 2011, p. 46)

\footnotetext{
${ }^{15}$ 'In science, no less than in music, speculation and imagination are not the final products, but only the first step toward the final scientific discovery or final musical creation. This subjective stage is followed by a rule-centered objective stage, which, in the case of science, allows the researcher to conduct experiments, manipulate ideas, and subject his hypotheses to critical scrutiny. If the hypothesis(es) is (are) validated they are then subjected to testing by others. Similarly, the composer, after the preliminary stage of speculation and imagination, proceeds to order his musical materials - such as melody, rhythm, harmony and form. The composer also subjects them to experiment by, for exemple, playing certain passages ... This handling of the musical materials and resources may be seen as an objective rulegoverned method of validating the original subjective speculation" (Tang, 1984, p. 261).
} 
Embora consideramos pertinente a revelação da subjetividade científica e da objetividade musical fomentada por Tang, ainda parece existir uma boa dose de subjetividade na fase de testes objetivos em música. Quando, por exemplo, um músico define uma digitação ou interpretação possível para uma passagem e a testa objetivamente, a confirmação ou não de sua validade recai sob seu crivo estético. É bem verdade que alguns critérios podem ser mensurados e aferidos de forma exata neste processo - a precisão rítmica e de afinação podem ser submetidas a metrônomos, afinadores e softwares computacionais - no entanto, a decisão estética de integrar o "erro ${ }^{16 "}$ (e alterações do conteúdo do texto musical) como parte da performance ainda poderia ser aceitável (e até despercebida) em arte, mas dificilmente o seria na ciência.

Outra diferença considerável está no produto final da música, que é mais dificilmente passível de generalizações e replicações se comparada à ciência (esse seria o último estágio do método científico experimental anteriormente exposto), já que nem todas as condições do sucesso do experimento serão sempre mantidas: como garantir que uma passagem estudada sairá sempre "perfeita" de acordo com nossos critérios estéticos, sendo que muitos aspectos (como clima, nervosismo, fadiga, desatenção, barulho, etc) podem interferir em uma performance e são de certa maneira incontroláveis?

No entanto, a reflexão fomentada por Tang é muito pertinente à área da performance musical ao demonstrar uma semelhança entre os caminhos que música e ciência percorrem para obter seus resultados, inclusive envolvendo o Pensamento Divergente, conforme diagrama abaixo.

\footnotetext{
${ }^{16}$ Por erro, consideramos não somente sua acepção inicial, mas também e principalmente pequenos desvios comuns e até esperados em uma performance musical, como por exemplo um rubato (de milissegundos ou mais), que poderia ser considerado um erro se comparado a rigidez metronômica.
} 


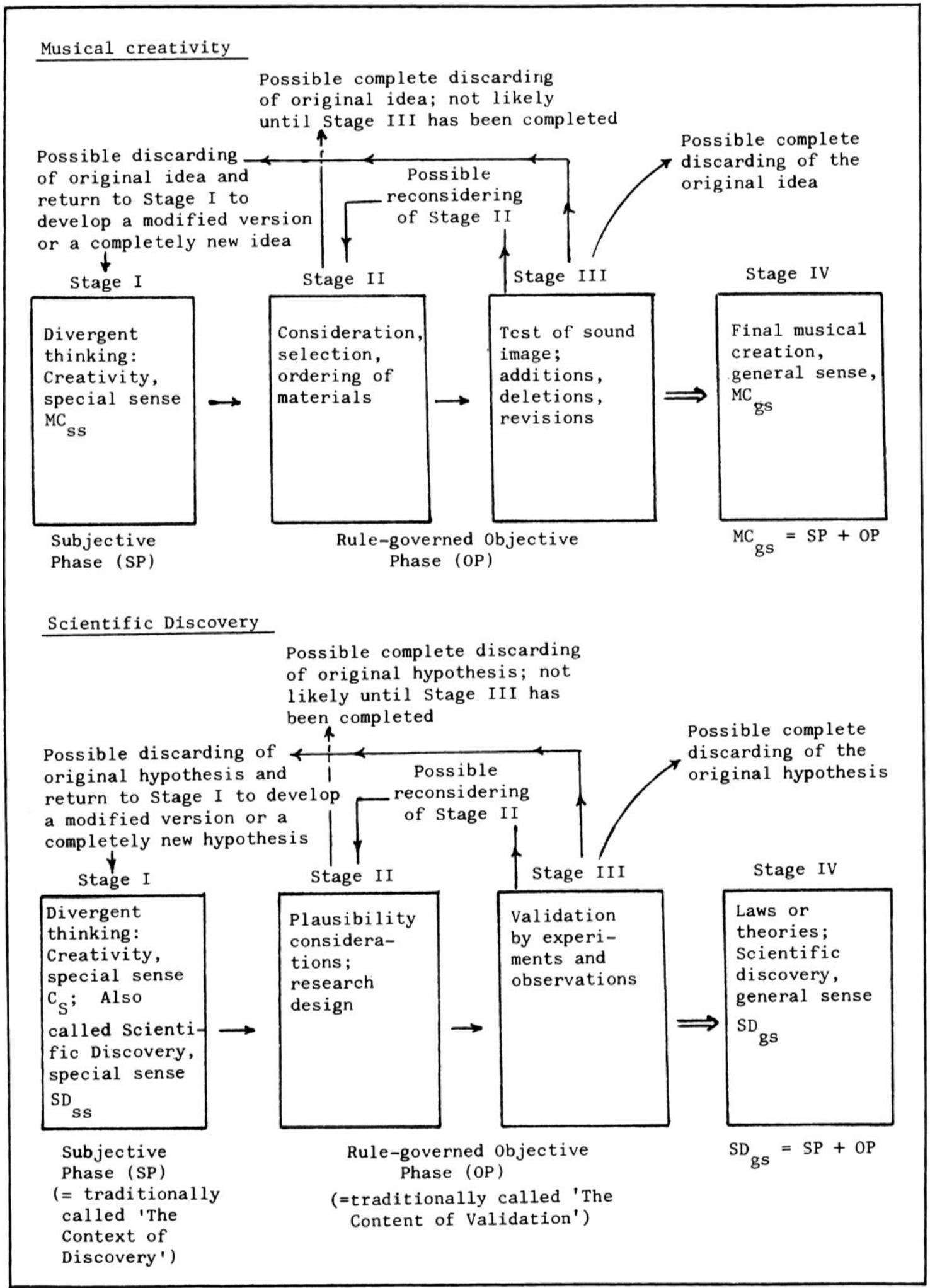

(Tang, 1984, p.266)

Simplificando o diagrama, percebemos que tanto a descoberta científica quanto a criatividade musical se iniciam por uma fase subjetiva (governada pelo Pensamento Divergente), passando por dois estágios objetivos de experimentação de possíveis soluções que, caso refutadas, levam ao retorno das fases anteriores e, caso comprovadas, levam ao produto final. 
Nas artes tendemos a acreditar que este processo é comumente inconsciente e de breve duração, quando, por exemplo, um compositor escreve uma melodia e "procura" pelas próximas notas, testando vários caminhos em questão de segundos ou minutos. Por outro lado, a consciência deste processo, bem como seu uso deliberado e expandido pode ser muito útil à prática musical (e sobretudo violonística), por propiciar uma metodologia de estudo que abdique da repetição mecânica e desmotivadora para voltarse ao reconhecimento de problemas, ao "desenho" de possíveis soluções e ao teste da eficácia das mesmas (o que pode levar semanas ou meses), para finalmente "construir" a versão que será levada ao palco.

Isso nos leva ao modelo proposto por Sternberg (2012), nitidamente ligado aos anteriores (Oare e Tang) e ao Método Científico porém um pouco mais detalhado. Nele, a solução de problemas seria um processo cíclico onde o indivíduo identificaria e definiria (estágios 1 e 2) seu problema, construiria estratégias de solução (3), organizaria as informações disponíveis acerca do problema (4), alocaria recursos (tempo, dinheiro, etc) para sua solução (5), monitoraria o progresso na busca por uma solução (6) e finalmente avaliaria se a solução testada foi eficaz (7).

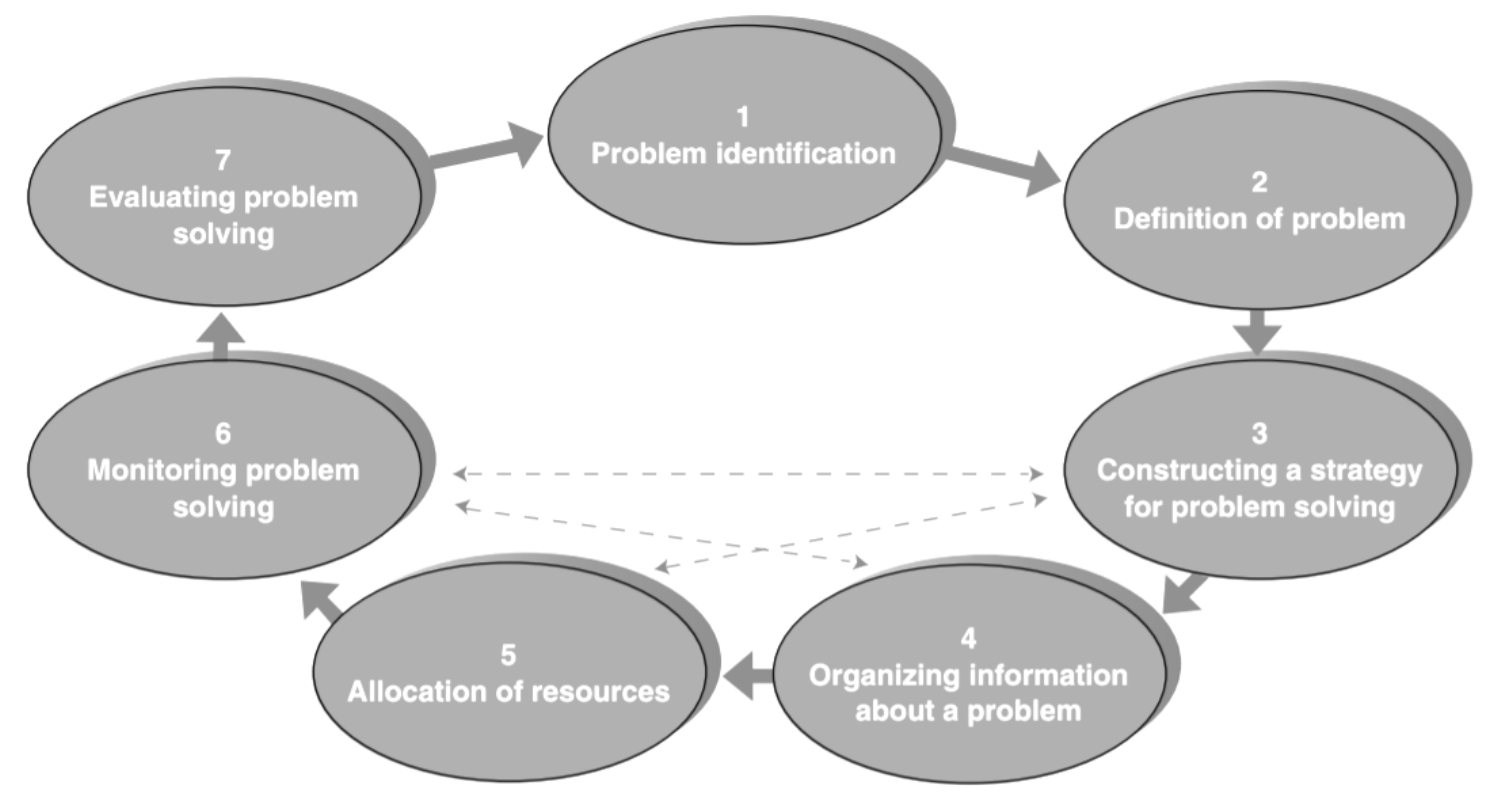

(Sternberg, 2012, p. 445)

$\mathrm{Na}$ união entre música e Método Científico, fecha-se também o "ciclo" de mais uma ferramenta útil à resolução de problemas. 


\section{3: Pensamento Reflexivo}

O processo científico é comumente atrelado ao ócio criativo, à observação e a reflexão, bastando evocar ao leitor a anedota comumente contada de Isaac Newton (1647 - 1727) “descobrindo" a lei da gravidade ao observar uma maçã caindo do pé, ou lembrar da escultura “O Pensador” de Auguste Rodin (1840 - 1917), onde um homem reflete ao relaxar com a mão no queixo.

Esse aspecto reflexivo a ser engajado na busca por soluções de impasses, ou mesmo para fomentar a busca por problemas em si foi teorizado por John Dewey em “How We Think" (1933).

A aplicação musical dos conceitos deste autor é oferecida por Nancy Whitaker (1996) ao perceber que a filosofia vigente de ensino está baseada na imitação, que por sua vez não favorece a formação de músicos livres-pensadores:

"Um dos problemas que emergiram de pesquisas na prática da educação musical foi que muito do que os professores de música fazem é imitação acrítica e inconsciente. Este foi o modelo conservatorial: toque, cante ou ensine 'assim' - imite com exatidão e você obterá sucesso. Este modelo está 'vivo e vivaz' em muitas instituições de treinamento de professores e também em conservatórios e isso afeta não apenas as aulas individuais, mas cursos de condução e construção de métodos também. Um histórico de imitação não é um bom presságio para fomentar a disposição a criar pensadores musicais independentes" ${ }^{17}$ (Whitaker, 1996, p.1) [tradução nossa].

Como resultado, segundo a autora, as pesquisas se focalizam muito pouco no processo de compreensão musical (em outras palavras, o processo de absorver e criar sentido ao confrontar-se com uma experiência musical):

$\mathrm{O}$ alicerce das pesquisas em pensamento musical inclue audiação ${ }^{18}$, percepção, habilidade e atitude mas contém relativamente pouca pesquisa no processo de compreenção das experiências musicais. Não é de admirar que educadores musicais abracem qualquer pacote pedagógico de "habilidades de reflexão" ou considerem a atual ênfase em reflexão meramente uma variação do "pensamento científico""19 (Whitaker, 1996, p.1) [tradução nossa].

\footnotetext{
17" One of the problems that has emerged from research studies of music education practice is that much of what music teachers do is uncritical unconsidered imitation. This has been the conservatory model: play or sing or teach it "like this" - imitate exactly, and you will experience success. This model is "alive and well" in many teacher-training institutions as well as in conservatories and it affects not only the individual music lesson but conducting and methods courses as well. A history of imitation does not bode well for fostering the disposition to create independent musical thinkers (Whitaker, 1996, p.1).

${ }^{18}$ Cunhado por Edwin Gordon (2000) em 1980, "Audiação" significa a capacidade de ouvir e compreender musicalmente quando o som não está fisicamente presente (ex: relembrar mentalmente uma melodia ou compor sem auxílio de instrumentos, etc).

19 "The research base for musical thinking includes audiation, perception, aptitude, and attitude, but contains relatively little research into the process of making sense of musical experiences. It is no wonder that music educators uncritically adopt any "thinking skills" instructional package or consider the current emphasis on thinking merely a variation on the "higher order" or "scientific" thinking"(Whitaker, 1996, p.1).
} 
Buscando auxiliar na mudança desta realidade, seu estudo parte da aplicação dos conceitos de Dewey na análise de protocolos verbais (método onde se estimula os voluntários a verbalizar seus pensamentos enquanto estudavam) para investigar o pensamento de músicos novatos e experientes, nos oferecendo também um proveitoso estudo sobre como se dá o processo de solução de problemas em nossa área. A autora busca mensurar o quanto os músicos praticam ou não o "Pensamento Reflexivo" tal qual formulado por Dewey e parece acreditar na validade desta teorização do pensamento humano como método alternativo de ensino musical que forma alunos autossuficientes.

O Pensamento Reflexivo “é o processo temporal baseado na interação de experiências consolidadas (experiências únicas e pessoais pregressas) e experiências imediatas (que ocorrem naquele momento)" (Whitaker, 1996, p. 2). Em outras palavras diz respeito a como o seu cérebro concatena, usa, ou reutiliza em novas situações, as experiências adquiridas anteriormente. Mas o Pensamento Reflexivo, ao contrário do instinto, resulta da "supressão da impulsividade", da "inibição da ação imediata ou crença" na busca de "avaliar o terreno de uma solução inicial" (Whitaker, 1996, p. 2) e completa:

"O ato de refletir é exatamente isto: uma experiência consolidada conduz o sujeito a ter/interpretar uma experiência imediata de uma maneira particular, em um pensamento propositadamente direcionado a partir da avaliação da nova experiência em relação às experiências consolidadas, suspendendo a decisão até que sejam formuladas as possíveis direções de ação ou crença" ${ }^{20}$ (Whitaker, 1996, p. 2) [tradução nossa].

No que diz respeito ao campo da performance musical e sobretudo violonística, suspender uma decisão imediata e impulsiva frente a uma partitura ou problemas derivados dela abre caminho para a oportunidade de se empregar o Pensamento Reflexivo e assim avaliar uma multiplicidade de opções técnicas e interpretativas antes desconsideradas. Isso é especialmente válido no violão, instrumento que permite várias digitações para uma mesma passagem, conforme já expusemos anteriormente.

Dewey considera que este processo de integração entre experiências diretas e pregressas na solução de problemas é ordenado em "termos de pensamento" ou fases residuais [ou melhor, cumulativas] e diretivas [ou melhor, direcionadoras], em "que são

\footnotetext{
${ }^{20}$ The act of reflection is precisely that: a fund of experience leading a person to have and interpret immediate experience in a particular way, purposeful thought directed from assessment of the experience to funded experience, suspension of decision until possible directions of action or belief have been formulated (Whitaker, 1996, p. 2).
} 
ligadas entre si formando um movimento contínuo em busca de um objetivo comum" (Dewey, 1933, p.4).

Sete fases do Pensamento Reflexivo flertam muito com o método científico experimental e com os modelos de Oare (2011), Tang (1984) e Sternberg (2012), anteriormente descritos: 1) Pré-reflexão, 2) Sugestão, 3) Intelectualização, 4) Hipóteses, 5) Racionalização, 6) Teste ou Imaginação e 7) Pós-Reflexão (Dewey, 1933, p. 107114). Segundo o autor, o Pensamento Reflexivo não precisa passar por esta ordem de fases ou por todas estas fases para ocorrer, dependendo das condições externas e das experiências consolidadas do sujeito.

Por sua vez, as experiências consolidadas foram categorizadas por Dewey da seguinte maneira: 1) Conhecimento (fundamentado em preparação acadêmica), 2) Sentimentos, 3) Experiência e 4) Imaginação. Todas essas categorias de experiências pregressas poderão participar na solução do impasse em questão.

Dessa forma, o pensamento de Dewey pode ser sintetizado pelo gráfico a seguir: 


\section{REFLECTIVE THINKING}

Components

1. The recognition of a problem

2. Selected dimensions of funded experience

knowledge grounded in academic preparation

feelings that the thinker may have about or bring to a dimension of immediate experience

practice-based experience, which includes experience as a performer, arranger, conductor, or composer as well as more general musical experience

imagination as part of how a problem is construted in the mind of the thinker as well as a part of what he or she creatively brings to the encounter with immediate experience

3. The reflective process itself

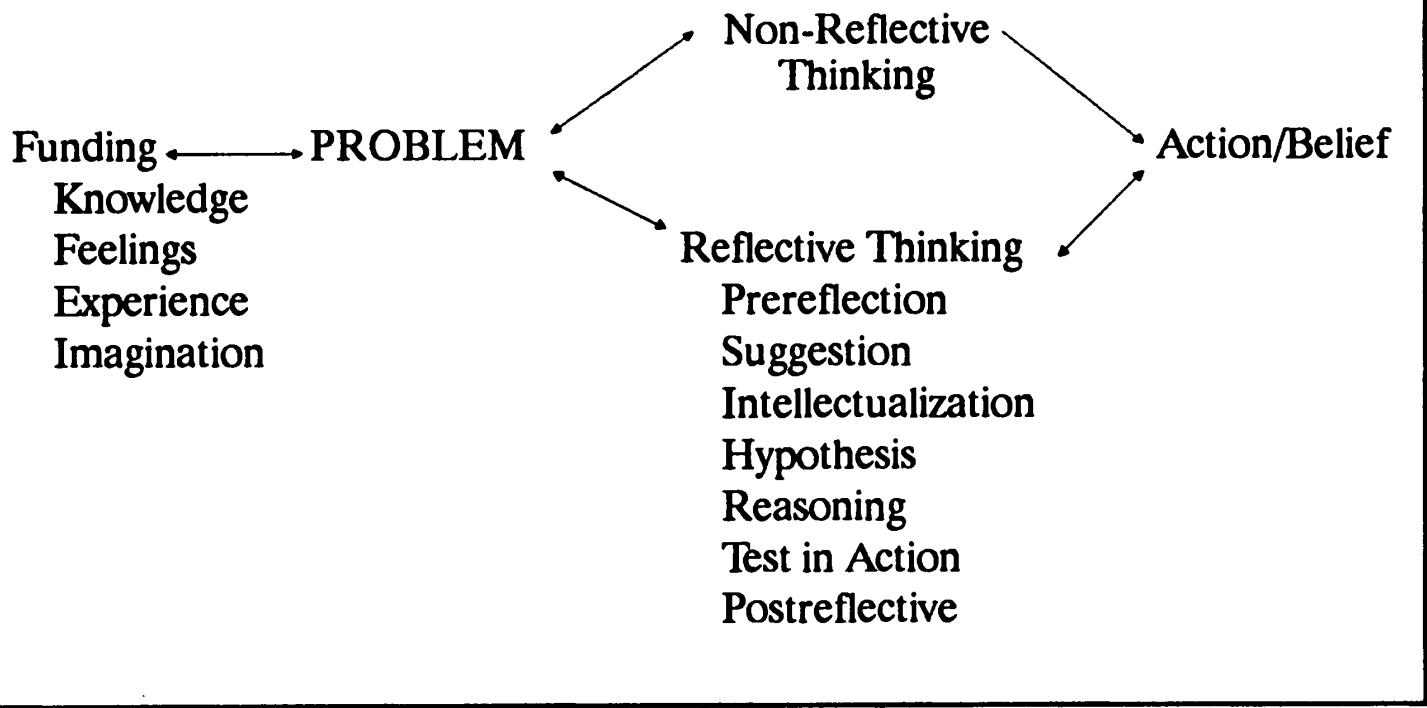

(Whitaker, 1996, p.3)

Para Dewey "a experiência está entrelaçada no reconhecimento do problema, bem como uma fonte de soluções ou decisões para a ação" (Whitaker, 1996, p. 8). Esta afirmação leva o músico à compreensão de que a cada novo problema, sua memória é ativada na busca de soluções anteriores em uma "espiral eterna que coloca experiências pregressas em uso para solução de um impasse, que por sua vez também pode ser armazenada como uma experiência útil no futuro ... portanto completamente pessoal e individual" (Whitaker, 1996, p. 10), o que Dewey nomeia como "continuidade", que por sua vez está relacionado à "interação" dos fatores internos (a experiência pregressa) e externos (a experiência imediata): 


\begin{abstract}
"A interação desses dos fatores cria o que Dewey se refere como situação. Um indivíduo usa suas condições internas para suportar a experiência imediata e sua experiência consolidada o permite dar sentido a situação. Sem a presença de uma experiência pregressa que tenha alguma relação com a situação a experiência parece uma confusão barulhenta crescente: não há compreensão alguma da situação" ${ }^{21}$ (Whitaker, 1996, p.12) [grifo e tradução nossas].
\end{abstract}

Ou seja, "o indivíduo usa sua experiência pregressa como entendimentos que interagem com a situação e lhe provém sentido" (Whitaker, 1996, p.12). Isso nos leva a importância de nutrir um estudante com o máximo de experiências, por exemplo, ao estimular a ampliação de seu repertório mesmo que com peças que possivelmente estejam acima de seu nível, pois um maior vocabulário de soluções anteriores facilitará soluções futuras, onde serão reutilizadas, modificadas e combinadas. Toda forma de conhecimento pregresso poderá ser colocada em funcionamento ao se defrontar com novos impasses.

Corroborando com esse pensamento, Sir Joshua Reynolds defendia que "a invenção nada mais é do que novas combinações daquelas imagens que já haviam sido previamente recolhidas e depositadas na memória. Nada pode ser feito do nada; aquele que não juntar material não produzirá combinações" (apud Duailibi e Simonsen 1990, p. 40).

Neste sentido que o estudo técnico de qualquer instrumento musical é muito similar a uma "caixa de ferramentas" gestual (em clara metáfora ao artigo "The Canons in the Musicology Toolbox" de Dan Michael Randel, 1992), que vai adquirindo ou coletando aos poucos uma multitude de recursos que facilitará a resolução de situações futuras. No violão, tal "banco" de gestos técnicos será normalmente composto por variados padrões de arpejos, escalas (binárias e ternárias), tremolos, ligados (ascendentes, descendentes, triplos e defasados), aberturas, compressões, pestanas, pizzicato e pizzicato Bartók, harmônicos naturais e artificiais, efeitos variados de percussão, domínio das diferentes articulações de $m d$ (toque livre, toque apoiado, rasgueios e técnicas escovadas ${ }^{22}$, repetição por deslizamento) e cruzamentos, apenas

\footnotetext{
21 "The interaction of the two factors creates what Deweys refers to as situation (p.39). The individual brings his internal conditions to bear on immediate experience, and funded experience enables him to make sens of that situation. Without the presence of funded experience having some relationship to the situation the experience appears as 'one great blooming, buzzing, confusion' (1933, p. 141): theres is no grasp of the situation at all" (Whitaker, 1996, p.12).

${ }_{22}$ A digitação escovada se dá pela articulação convencional de um dedo da $m d$, mas aplicada a várias cordas em movimento quase simultâneo e diametralmente oposto a um rasgueado.
} 
para citar alguns itens ${ }^{23}$. A ideia que é quanto maior o conhecimento dos recursos disponíveis no instrumento e seu domínio, mais fácil será enfrentar problemas vindouros.

Porém Whitaker argumenta que a função da "bagagem" pregressa é apenas parcial, pois "a experiência somente estimula o Pensamento Reflexivo se há evidência de perplexidade, de desafio às crenças apresentadas como parte da experiência consolidada do indivíduo" (Whitaker, 1996, p. 10), nos lembrando em muito o estado constante de curiosidade, dúvida e perplexidade buscado pelos cientistas, ao olharem o mundo "sob os olhos de uma criança", algo também a ser procurado por músicos em sua prática diária. Este estado de contestação permanente parece favorecer $o$ Pensamento Reflexivo e com ele novas perguntas e possíveis respostas:

\begin{abstract}
"Um indivíduo, ao encontrar uma situação pode, nos termos de Dewey, a interpretar no local e não encontrar nenhum elemento de dúvida: ele se deparou com o problema em algum momento anterior e o resolveu. A solução está em sua experiência consolidada e ele resolve o problema usando o pensamento não reflexivo. Quando um segundo indivíduo enfrenta um problema similar com dúvida ou perplexidade isso lhe faz passar por alguma forma de Pensamento Reflexivo"24 (Whitaker, 1996, p.10-11).
\end{abstract}

Baseado no primeiro caso, conjecturamos que o Pensamento Não Reflexivo (onde a solução é imediata) pode ser apenas uma manifestação mais rápida e intuitiva do Pensamento Reflexivo assim como o Pensamento Convergente pode ser uma manifestação mais veloz e intuitiva do Pensamento Divergente. Mesmo assim, acreditamos que o estudo violonístico (e musical em geral) possibilita tempo para reflexões podendo ser muito mais do que meras repetições mecânicas e desestimulantes de passagens musicais.

Não queremos com isso ignorar a importância da repetição na aquisição de qualquer conhecimento. No entanto, ela tem sido supervalorizada na prática musical e constantemente gera o desinteresse do estudante. Essa visão é derivada da "teoria da programação motora" de James (1890), onde cada movimento precisa ser dominado e armazenado separadamente pelo cérebro, levando a práticas fixas e repetitivas. Quase um século depois, o contraponto foi provido por Schmidt (1975) com a "teoria do

\footnotetext{
${ }^{23}$ Esta listagem é livremente inspirada em aula de extensão ministrada pelo Prof. Dr. Nícolas de Souza Barros na UNIRIO há cerca de 10 anos atrás e na dissertação de Fabio Adour (1999) a qual recomendamos a leitura.

24 "One individual, encountering a situation may, in Dewey's terms, read the situation at sight and find no element of doubt: he has encountered the problem at some point previously and has resolved it. The solution is in his funded experience, and he resolves the problem using nonreflective thinking. When the second individual encounters a similar problem he experiences a doubt or perplexity that causes him to experience some form of reflective thinking" (Whitaker, 1996, p.10-11).
} 
esquema", onde movimentos com padrões similares remetem a um único modelo (esquema) armazenado pelo cérebro, o que demonstrou a maior eficiência de práticas variadas de estudo (Leathwood, 2016, p.1). O cérebro tende a entender toda repetição como algo redundante e por isso não digno de nossa total atenção o que explica o porquê da repetição fixa comumente ser monótona e desestimulante. Com esse novo modelo, a repetição continua a existir, mas não de forma literal, mantendo assim o interesse crescente do cérebro naquela atividade. Leathwood, em memorável palestra no "Guitar Foundation of America International Convention 2016" brilhantemente demonstrou o uso do improviso como forma de estudo de passagens musicais. De forma similar, acreditamos que a busca constante por novas soluções e métodos (fazendo maior uso do Pensamento Reflexivo e do Pensamento Divergente) pode também fomentar maior diversidade e engajamento no estudo musical.

Atento a necessidade de se fomentar o ensino do Pensamento Reflexivo em música Whitaker ainda lista procedimentos didáticos e indica que parte da abordagem reside em demonstrar a variedade de interpretações que um texto musical (e seus consequentes impasses) permite, atrelando-o a nosso ver ao Pensamento Divergente:

\begin{abstract}
"Como então alguém pode encorajar mais o Pensamento Reflexivo prospectivo na educação musical? Primeiro considerando a bagagem individual de conhecimento acadêmico, sentimentos, experiência e imaginação que o pensador reflexivo prospectivo trás à prática musical. A bagagem individual que Dewey se refere como condições 'internas'. Segundo, provendo os pensadores reflexivos prospectivos com uma variedade de situações envolvendo experiências diretas em música como um performer, apreciador e criador e recriador: as condições 'objetivas'. No entanto, o reconhecimento das diferenças individuais e a rica oferta de experiências diretas não são o suficiente: nós temos de nutrir a disposição ao raciocínio reflexivo mais do que ao meramente impulsivo. Se o indivíduo é provido apenas com experiências que representam pouco ou nenhum desafio às suas crenças, ele não irá desenvolver a disposição a pensar reflexivamente ... Nós precisamos reconhecer e demonstrar que existem problemas musicais que se adequam a múltiplas interpretações, para encorajar a autonomia musical pensativa e reflexiva em nossos estudantes, não importando sua idade" ${ }^{25}$ (Whitaker, 1996, p.12) [grifo nosso].
\end{abstract}

\footnotetext{
${ }^{25}$ How then, can one best encourage the prospective reflective thinker in music education? First, by acknowledging the individual fund of academic knowledge, feelings, experience, and imagination that the prospective reflective thinker brings to a musical experience. The individual funding Dewey refers to as the "internal" conditions. Second, by providing the prospective reflective thinker with a variety of experiences involving the direct experience of music as a performer, listener, and creator and re-creator: the "objective" conditions. However, the acknowledgment of individual differences and provision of a wealth of direct experiences with music are not sufficient: we must nurture the disposition to think reflectively rather than be merely impulsive. If the individual is provided only with experiences that represent little or no challenge to belief, he will not develop the disposition to think reflectively ... We need to acknowledge and demonstrate that musical problems exist that can support multiple interpretations, to encourage thoughtful, reflective musical autonomy in our students, regardless of age level (Whitaker, 1996, p.12).
} 
Além dessa conexão com o Pensamento Divergente, as fases do Pensamento Reflexivo também parecem intimamente ligadas ao método científico e aos modelos de Tang, Oare e Sternberg. No entanto, Dewey acrescenta pelo menos dois novos elementos interessantes à solução de problemas: 1) a participação da memória na busca por novas soluções (o que ele chamou de experiências consolidadas) e 2) a importância da supressão da decisão como elemento catalisador de reflexão (e com isso fomentadora do Pensamento Divergente). 


\section{4: Brainstorm}

Surpreendentemente, nossa pesquisa pelo processo de soluções de problemas musicais e sobretudo violonísticos nos levou a traçar paralelos com esta prática habitual no mundo empresarial.

Duailibi e Simonsen, baseados no modelo de Piéron afirmam que "toda educação formal dá ênfase a três [das quatro] funções mecânicas da mente humana: a absorção, a retenção e o julgamento... Debate-se, delibera-se, pesam-se os prós e contras. Mas que passos são tomados, conscientemente, para desenvolver a mente criadora?" e concluem que "nossa educação, por tentar desenvolver apenas as três funções, é fundamentalmente bloqueante" transforma "nossas mentes em instrumentos reflexivos" e não criadores de forma que "muitos de nós nem sequer tentamos usar a parte criadora da mente, a não ser forçados pelas circunstâncias" (Duailibi e Simonsen, 1990, p. 43).

Dessa forma, por estarmos pouco acostumados com o processo de criação, "a criatura humana tem a tendência de utilizar duas das funções de sua mente ao mesmo tempo - isto é, criar e julgar", configurando um "obstáculo maior para o desenvolvimento da criatividade" (Duailibi e Simonsen, 1990, p. 44). Isso é particularmente mais ocorrente no ensino tecnicista onde "quanto mais treinadas, menos criativas serão tais pessoas ... já que o técnico tende ao seu nível de incompetência criativa, rotulada como 'incapacidade treinada', devido principalmente ao fato de sempre julgar as ideias ao mesmo tempo que as cria", e assim "submetidas a uma crítica precoce, morrem no nascedouro inúmeras ideias" (Duailibi e Simonsen, 1990, p. 45). Concordando, Alberto Dell'Isola (2002, p. 99) diz que “infelizmente, é comum tentar fazer os dois processos simultaneamente":

\footnotetext{
Pense em um exemplo esdrúxulo: você precisa criar um novo sabor de pizza. Imagine que, durante o processo de criação, você eleja cogumelos como um possível ingrediente. Nesse momento, diversas ideias avaliativas podem surgir: 'cogumelos são caros', 'nem todos gostam de cogumelos', 'uma pizza de cogumelos pode ser enjoativa'... Todas essas ideias acabam por limitar o processo criativo, visto que o impedem de pensar em outros possíveis ingredientes. Além disso, ideias avaliativas prematuras costumam agregar pessimismo e pensamentos negativos, diminuindo o potencial criativo. Assim, antes de iniciar qualquer processo de geração de ideias, lembre-se que a melhor maneira de se geras novas ideias é impedir o julgamento. Desse modo, deixe qualquer análise e o pensamento crítico para posteriori, após todas as ideias possíveis já terem sido geradas. Posteriormente, avalie os prós e contras de cada uma das ideias geradas (Dell'Isola, 2002, p. 98-99).
}

Para Dell'Isola a explicação deste fenômeno parte do Modelo do Intelecto Humano de J. P. Guilford: 
Ao gerar novas ideias, separe a criação da avaliação. Você dificilmente será capaz de atingir seu potencial criativo se não seguir esse princípio. O motivo é simples: o processo criativo envolve dois tipos de pensamento - o convergente e o divergente. Desse modo, o processo de criação de novas ideias é um processo divergente, visto que deseja obter o maior número possível de ideias. Em contrapartida, o processo de avaliação de ideias é um processo convergente, já que, dentre as diversas ideias geradas, deseja-se selecionar aquelas que são mais interessantes e convenientes. Assim, ao tentar-se fazer as duas atividades ao mesmo tempo (criação e avaliação), você possivelmente não fará qualquer uma das duas adequadamente (Dell'Isola, 2002, p. 98-99).

“O Brainstorm consiste na alteração deliberada dessas duas etapas do pensamento, a criação e o julgamento" ativando "primeiro o espírito da imaginação e, somente depois, o de julgamento" num processo também chamado de "julgamento adiado" (Duailibi e Simonsen, 1990, p. 42, 46 e 48), relembrando em muito o "Pensamento Reflexivo" de Dewey (1933) anteriormente exposto, que é catalisado pela supressão da decisão.

Segundo Dell'Isola o Brainstorm ou Brainstorming "foi popularizado nos anos 1930 pelo americano Alex Faickney Osborn (1888-1966) e, desde então, tem sido vastamente utilizada em todo o mundo para a geração de ideias, principalmente no campo de relações humanas e publicidade e propaganda". Osborn "acreditava que qualquer pessoa possuía um potencial criativo, que poderia ser trabalhado de maneira a transformar qualquer individuo em uma pessoa extremamente criativa" e que "os grupos poderiam até duplicar seu potencial criativo ao utilizar essa técnica" (Dell'Isola, 2002, p. 122).

Em linhas gerais um Brainstorm "é uma reunião de interessados aos quais um problema foi exposto e que, numa sessão de livre associação, começam a sugerir soluções". Partindo da máxima de Winston Churchill de que "nenhuma ideia é tão maluca que não mereça ser considerada com seriedade e firmeza", "busca-se que as ideias sejam 'expelidas' pelos participantes no momento exato em que vêm à mente" e dessa forma "todas as ideias que surgirem serão anotadas, quaisquer que sejam elas, mas nunca julgadas na mesma hora" (Duailibi e Simonsen, 1990, p. 46).

A avaliação se dará em outro momento, normalmente formado por número ímpar de integrantes (para facilitar a votação) que selecionará "as melhores ideias para uma possível implementação ou estudo adicional”, ou seja, maiores lapidações para finalmente “sujeitá-las a testes práticos” (Dell’Isola, 2002, p. 128) atrelando-o de certa forma ao método científico experimental. 
Mas o sucesso de uma seção de Brainstorm também está atrelado a uma boa definição do problema e/ou a uma subdivisão de problemas demasiadamente complexos, como pondera Dell'Isola:

\begin{abstract}
Antes de iniciar alguma seção de brainstorming, é importantíssimo que de defina o problema. Ele precisa ser claro, não muito grande e passível de ser enquadrado por alguma pergunta específica, por exemplo 'de que maneira poderíamos diminuir os custos de transporte em nossa empresa?'... Perguntas muito amplas devem ser evitadas, por exemplo, 'como ganhar dinheiro?'. Se o problema foi muito longo ou complexo, é necessário que ele seja dividido em diversos problemas menores, cada qual com uma pergunta específica" (Dell'Isola, 2002, p. 127-8).
\end{abstract}

Apesar de ter sido concebida e celebrizada como uma prática para grupos, "é comum encontrarmos pessoas que se familiarizaram tanto com o processo que o utilizam até sozinhos" (Dell'Isola, 2002, p. 133) favorecendo com essa "desburocratização", sua maior periodicidade e tornando-o mais adequado, a nosso ver, ao estudo violonístico, notadamente solitário.

Aplicando este Brainstorm individual, o estudo violonístico passa a se basear inicialmente na identificação de problemas (preferencialmente bem definidos, ou subdivididos caso demasiadamente complexos ou longos) - de uma maneira sensata, mais ou menos isenta e relaxada, sem ser mordaz ou desestimulante - para posteriormente (com julgamento idealmente desligado) formular várias soluções possíveis ou ao menos estratégias de trabalho, sejam elas tradicionais, criativas ou até polêmicas, que serão por sua vez igualmente grafadas e/ou memorizadas (neste aspecto a terceira parte de nossa tese proverá algumas maneiras de facilitar a grafia de opções simultâneas em um mesmo pentagrama).

Em outro momento (preferencialmente outro dia ou seção de estudo), dessa vez com julgamento em plena atividade, será feita a escolha da(s) opção(ões) mais promissora(s) para iniciar a fase de teste, ou seja, de estudo, automatização e memorização, porém ainda aberta a lapidações ou ao levantamento de novos problemas, que por sua vez podem dar novo início ao processo. A avaliação dos resultados do experimento será provavelmente de ordem subjetiva do intérprete e caso insatisfatória, também retornará ao início do processo.

Um aspecto importante que Dell'Isola sugere para auxiliar na eliminação do julgamento durante a fase criativa é a remoção de obstáculos (Dell'Isola, 2002, p. 130). Dessa forma, no momento prospecção violonística deve-se evitar pensar em empecilhos como prazos, andamentos, intensidades, embates mentais ou de qualquer outra ordem, pois deixá-los para o momento posterior favorecerá o nascimento de novas soluções. 
Percebam que esta abordagem violonística do Brainstorm não é exatamente literal e está aberta outras adaptações subjetivas pessoais, mas mesmo assim, ao respeitar os momentos de identificação de problemas, livre criação e posterior avaliação, consideramos que o intérprete tomará decisões mais embasadas ou ao menos pautadas em informações mais "amplas" (no sentido de ele dispor um conhecimento de um número mais considerável de soluções) além de suspeitarmos que suas seções de estudo serão possivelmente mais dinâmicas, participativas, improvisatórias (no sentido de buscas soluções inusitadas) e com isso mais motivadas.

Outro aspecto interessante levantado por essa prática é que ela pode "valoriza(r) o olhar do leigo" já que "grandes empresas costumam criar sessões de brainstorming que envolvam setores diferentes, com o objetivo de tornar o pensamento o mais divergente e não condicionado possível” (Dell’Isola, 2002, p. 123), incluindo "um número bastante significativo também de pessoas sem o menor conhecimento do assunto" para fomentar o pensamento fora da "incapacidade treinada" dos especialistas (Duailibi e Simonsen, 1990, p. 48), ou em outras palavras, sob outras óticas menos "viciadas" (esse aspecto remete à quarta lei Heurística que veremos mais à frente).

Dessa forma, o Brainstorm, "valoriza o Pensamento Divergente (pessoas diferentes e ideias aparentemente incompatíveis) em busca de novas perspectivas e relações entre os conceitos a serem discutidos" (Dell'Isola, 2002, p. 123).

Esse tipo de opinião pode ser útil à prática musical e violonística, mas talvez em um momento posterior de teste das ideias selecionadas e minimamente estudadas por algum tempo. Submetê-las aos ouvidos de um elemento externo, não tão envolvido em sua prática diária, como um professor, outro músico, parentes, colegas, amadores ou até leigos, para aqueles que sabem ouvir criticas, geralmente pode gerar benéficas colaborações, problematizações, soluções antes desconsideradas e com isso consequente amadurecimento.

Embora possa "parecer estranho um processo criativo ser regido por regras" o Brainstorm se apoia em quatro bases essenciais para tentar estimular a criatividade:

1. Foque na quantidade: essa regra é uma forma de se aumentar a produção do Pensamento Divergente, promovendo a geração do máximo de soluções para o problema em pauta. É uma questão de estatística: ... quanto maior o número de ideias geradas, maior a chance de se produzir uma solução original e eficaz.

2. Suspenda o criticismo: o brainstorming ... separa muito bem as duas etapas do processo de geração de ideias: a criação e a avaliação. Durante o processo de criação, o criticismo é suspenso para que todos os participantes sintam-se à vontade para criar suas novas ideias.

3. Ideias inusitadas são bem-vindas: ... tem o objetivo de encorajar os participantes a sugerir qualquer ideia que lhes venha à mente, sem preconceitos e sem medo que 
isso os vá avaliar imediatamente. Ainda que sejam ideias ambíguas e desconexas à primeira vista, posteriormente poderá ser encontrada uma relação entre todos esses conceitos...

4. Combine e melhore as ideias: procure melhorar as ideias que surjam - ainda que não sejam criação sua. Às vezes, você é capaz de dar uma nova perspectiva a uma ideia anteriormente lançada por um colega... (Dell'Isola, 2002, p. 124).

Além dessas regras, a fim manter acesa a criatividade do grupo quando ela estiver diminuindo o checklist de Osborn prevê uma série de verbos ou perguntas que objetivam fomentar ainda maiores opções com base nas soluções já encontradas. Dell'Isola (2002, p. 131-132) prescreve a aplicação dos verbos usar, adaptar, modificar, aumentar, diminuir, substituir, rearranjar, inverter e combinar. Já Duailibi e Simonsen (1990, p. 102) formulam frases (com base em muitos dos verbos anteriores, além de outros), como:

“1) Imagine outros usos, outras aplicações; 2) Imagine uma adaptação; 3) Imagine uma ampliação, ou uma adição; 4) Imagine uma diminuição, ou redução; 5) Imagine uma substituição; 6) Imagine um rearranjo; 7) Imagine o inverso; 8) Imagine uma combinação" e ainda adicionam mais uma: "9) Imagine deixar como está" (Duailibi e Simonsen, 1990, p. 102).

No âmbito do estudo violonístico vários desses verbos ou perguntas podem ser aplicados nas opções já existentes para criar outras soluções e estimular o Pensamento Divergente. Por exemplo, é possível substituir um dedo em uma passagem, modificá-la

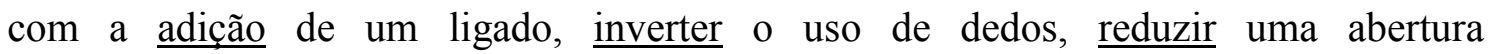
desconfortável, combinar soluções digitacionais, e sempre, após atestar a insuficiência de melhores opções, é possível deixar uma passagem como estava.

Dessa forma, Brainstorm parte da ideia de que "tanto na arte quanto na ciência, é da quantidade que se extrai a qualidade" já que "quanto maior o número de ideias colocadas ao nosso dispor, maiores as chances de encontrarmos aquela que realmente representará a solução do problema" (Duailibi e Simonsen, 1990, p. 44). Basta lembrar a figura de Pablo Picasso (1881-1973) e sua experimentação artística, pintando em grande quantidade numa eterna busca estética, sendo dessa forma um exemplo vivo do Pensamento Divergente. Para um quadro monumental como Guernica (1937) inúmeros esboços das figuras isoladas e em conjunto foram feitos antes de plasmá-los na tela final. Em música, tratando-se de arte igualmente subjetiva, de forma similar não consideramos justo escolher um caminho técnico/interpretativo antes de considerar o máximo de possibilidades, e somente então, à guisa dessa profusão de opções, fazer uso do senso estético para a tomada de decisões. Esperamos com isso, ter demonstrado como o Brainstorm pode ser uma ferramenta útil neste intuito. 


\section{5: Heurística}

A Heurística, vinda do grego heuriskein (descobrir) é originalmente o ramo da ciência que cuida da solução de problemas, sendo particularmente útil na matemática (Heurísticas de Pólya) e computação. Em oposição ao Algoritmo, definido como "uma regra ou uma lei, ou uma verdade que sempre que aplicada a premissas conhecidas, produz resultados senão conhecidos, pelo menos esperados... por exemplo quando dizemos que a ordem dos fatores não muda o produto", a Heurística, "é uma verdade circunstancial", portanto não verificável, "obtida através de tentativas e erros, ou conforme Thorndike, por seleção e conexão e mudança associativa", admitindo contradição e sendo particularmente comum na "sabedoria popular" (Duailibi e Simonsen, 1990, p. 6). As Heurísticas são regras de conduta que facilitam e propiciam a obtenção, não necessariamente da melhor solução, mas de uma solução válida, de forma que "qualquer checklist é por si mesmo, heurístico" (Duailibi e Simonsen, 1990, p. 11).

Ao aplicar este conceito para fomentar a criatividade no marketing, Duailibi e Simonsen (1990, p. 8-10) nos apresentam seis leis que julgamos úteis à prática violonística:

1) "Lei da Parcimônia: ... determina que, entre duas soluções, é provável que a correta seja a mais simples" (Duailibi e Simonsen, 1990, p. 8). De forma análoga, a simplicidade digitacional no violão é algo a ser buscado, já que o provérbio "para que simplificar as coisas, se é tão fácil complicá-las?" (Duailibi e Simonsen, 1990, p. 7) é ocorrente em nossa prática.

2) “Lei da Soberania das informações: 'Nunca lute contra as informações', diz ela. O primeiro passo é sempre aceitar como verdadeiras todas as informações de que se dispuser. Somente se elas não conseguirem explicar determinado fenômeno deveremos questioná-las" (Duailibi e Simonsen, 1990, p. 8). Assim sendo, devemos usar as informações deixadas, por exemplo, em uma partitura pelo compositor, revisor ou editor, como ponto de partida para nossas próprias conclusões, entendendo que elas representavam uma "verdade" no momento que foram registradas e que foram soluções viáveis naquele momento para aquelas pessoas. Portanto, seguir soluções já testadas pode ser um valioso atalho.

3) "Lei de Friedrich": Segundo Karl J. Friedrich, deve-se sempre partir do conceito de que 'a criatura humana mente'. Também chamada de The man lie Law,

\footnotetext{
${ }^{26}$ Duailibi e Simonsen apresentam a "Lei de Freidrich" antes da "Lei da soberania das informações". A inversão dessas leis foi proposital, a fim de deixá-las ainda mais didáticas.
} 
determina que nunca se deve aceitar nada a priori, deve-se questionar tudo" (Duailibi e Simonsen, 1990, p. 8). Como é típico na Heurística, essa lei contradiz a anterior ao reprisar de certa forma uma qualidade buscada pelos cientistas, anteriormente mencionada por nós. A posição de ativa contestação pode ser benéfica aos violonistas, por exemplo, ao duvidar respeitosamente das informações deixadas em uma partitura por um revisor, editor ou mesmo pelo próprio compositor, considerando que todos eles são humanos e são passíveis de incorrer em erro. Por outro lado, isto também vale para a constante avaliação de suas próprias escolhas e soluções, nunca espécie de auto contestação e auto avaliação.

4) "Lei da Despersonalização: ... é preciso sair do seu próprio ambiente para poder percebê-lo ... 'se alguém um dia descobriu a água, esse alguém não era um peixe' ... Assim, essa lei nos manda, para aumentar a nossa percepção, olhar um objeto conhecido como se nunca o tivéssemos visto antes" (Duailibi e Simonsen, 1990, p. 8). De maneira similar, um violonista pode deixar o terreno da performance para se tornar um ouvinte de sua própria gravação, e assim, em posição privilegiada para auto avaliação, poder obter novas respostas ou mesmo questionar aspectos antes negligenciados.

5) “Leis de Murphy: 'Em um projeto, se puder acontecer uma só coisa errada, essa coisa acontece' ... suas outras 'leis', por exemplo, dizem: deixadas a si próprias, as coisas sempre vão do ruim para o pior; se há alguma possibilidade de que várias coisas não deem certo, aquela única coisa que não dará certo é a que causará maior prejuízo; a natureza sempre toma o partido dos defeitos ocultos; se tudo parece andar bem, obviamente algo passou despercebido" (Duailibi e Simonsen, 1990, p. 9-10). Dessa forma, o estudo para cobrir todos os eventuais problemas, erros e percalços deve ser diligente, porém também deveria considerar que imprevistos são uma possibilidade real e a performance sendo uma situação extrema é o palco perfeito para sua ocorrência. Basta um dedo "calçar" mal uma nota e tudo pode desmoronar. Nossas unhas raramente estarão idealmente boas em dias de concertos, causando desconforto. Uma pequena conversa mental pode facilmente desviar nossa atenção. Essas e inúmeras outras situações também devem tentar ser abarcadas pelo estudo e quando o erro for inevitável, ele pode e deve ser incorporado à performance.

6) "Lei da obsolescência: Se algo funciona, está obsoleto. Aparentemente paradoxal ... o projeto torna-se obsoleto no momento em que deixa sua prancheta" (Duailibi e Simonsen, 1990, p. 10). É preciso ter em conta que por mais adequadas que 
sejam nossas soluções, outras poderão ser encontradas e estando a música governada pela subjetividade, as soluções atuais podem nem sempre atender o critério estético futuro.

Dessa forma, seria possível ampliar essa lista ao transformar em Heurísticas alguns dos conselhos aqui anteriormente expostos, oportunizando também sua revisão:

Defina o problema: parte da solução começa na definição do problema. Muitos alunos nem mesmo enxergam seus problemas e repetem mecanicamente $\mathrm{e}$ desnecessariamente passagens inteiras sem notar que a falha está na execução duas notas devido a um problema de digitação não percebido, por exemplo. $\mathrm{O}$ uso da constante atenção, da auto avaliação crítica, da despersonalização acima mencionada ou mesmo do Brainstorm podem ajudar na melhor definição dos objetivos.

Subdivida o problema: se a passagem em questão é muito longa e complexa, apresentando várias dificuldades e desafios, subdividi-los é sempre uma boa conduta para melhor direcionar o foco em busca de soluções. Assim como pianistas estudam com mãos separadas, algumas peças permitem a mesma atitude no violão, a exemplo do Estudo $n .1$ de Villa-Lobos. Passagens longas sempre podem ser divididas em trechos menores. Esse conselho foi anteriormente comentado na seção sobre Brainstorm.

Lei da suspensão da decisão: sempre que o tempo disponível permitir, tentar suprimir a decisão auxiliará a ocorrência do Pensamento Reflexivo (teorizada por Dewey) e com ele novas opções podem se abrir.

Hora de criar, criar/ Hora de julgar, julgar: baseado na prática do Brainstorm, delimitar um momento para a livre criação e adiar o julgamento costuma favorecer a solução de impasses.

Se for viável, teste: sempre tentar testar as possibilidades antes de descartá-las, já que mesmo com o conselho anterior, nos parece que muitas boas ideias violonísticas são descartadas antes da fase de teste.

Primeiro foque quantidade, depois na qualidade: de acordo com o Pensamento Divergente e as técnicas de Brainstorm, com o maior número de opções vem também o maior número de soluções adequadas. Lembre-se que é possível usar os verbos do checklist de Osborn para obter mais soluções a partir das já existentes.

Mas além da adaptação dessas leis a nossa área, consideramos ser possível criar a partir da literatura violonística ou mesmo em nossa própria prática pessoal, Heurísticas concebidas especialmente para esta atividade: 
Lei da economia de energia/esforço: Lee Ryan (1991) e Scott Tennant (1995) aconselham a redução do excesso de tensão em inúmeras ocasiões, desde ligados a pestanas, por exemplo. O segundo diz ainda que a economia de esforço é a palavra de ordem de seu livro (Tennant, 1995, p. 10). Para ele, os ligados dever sem abordados mais pela proximidade e velocidade dos dedos do que pela pressão dos mesmos (Tennant, 1995, p. 13). Similarmente, em pestanas ele fala da possibilidade de se apertar apenas as falanges do dedo necessárias ao acorde em questão, deixando as demais relaxadas (Tennant, 1995, p. 23). Citamos estes dois casos apenas para nortear o leitor acerca do conceito que queremos aqui resumir.

Avalie o que pode ser ou não vencido pelo estudo: dificuldades e problemas serão ocorrentes na vida cotidiana de um violonista. No entanto, é comum recorrer-se a repetição mecânica de passagens pensando-se que a superação de seus impasses é apenas uma questão de tempo e estudo. Mantenha continuamente avaliação sobre suas decisões, pois se a obra não evoluir com tempo de estudo, pode ser um indício de que suas soluções precisam de revisão. Neste caso, basta recorrer às outras opções geradas pelo Pensamento Divergente e devidamente anotadas.

Encoste e pressione antes de tocar: Lee Ryan (1991) e Scott Tennant (1995), decompõem, cada um a sua maneira, as fases do toque digital da mão direita, que podem ser sinteticamente dividida em 1) aproximação, 2) contato, 3) pressão 4) toque, 5) relaxamento e 6) reaproximação. Ambos os autores ressaltam a importâncias das fases 2 e 3, normalmente negligenciadas por estudantes. $\mathrm{O}$ estudo de tais fases, o desenvolvimento consciente das mesmas e a justaposição delas no funcionamento de múltiplos dedos passou a ser chamado de "toque preparado" devido à colocação rapidamente antecipada dos dedos nas cordas. Tal procedimento propicia maior tempo de contato dos dedos com as cordas, maior intensidade sonora, maior controle trímbrico e sonoro e maior precisão do toque, para citar alguns benefícios de seu emprego.

Evitar saltos: o salto de me configura uma desconexão total dos dedos dessa mão com o instrumento, apresentando sempre um risco em potencial à performance. Apesar de ser um recurso ocorrente e merecedor de estudo e domínio pelo instrumentista, sua aparição muitas vezes pode ser evitada por meio de outras digitações, em outras regiões ou com avanço mais progressivo de casas do instrumento, pelo uso de aberturas, dedos guias ou pelo auxílio de cordas soltas que proverão sustentação das notas do discurso musical enquanto o salto é efetuado. 
Se o salto é inevitável, primeiro a visão, depois a mão: título autoexplicativo. Se um salto tiver de ser realizado, fazer uso antecipado da visão, até mesmo virando o rosto e focando-se bem na região (inclusive casa e corda) onde o(s) dedo(s) deverá(ão) recair e com isso diminuindo a chance de lapsos.

Evitar o dedo 4 em posições extremo agudas: conselho advindo de encontro informal de Odair Assad com alunos de violão da Escola de Música da UFRJ em 2005, por intermédio do prof. Bartolomeu Wiese. Este violonista, acostumado a utilizar a região extremo-aguda do instrumento comentou adotar esse procedimento, ou seja, a redução ${ }^{27}$ do uso do dedo 4 em regiões acima do $12^{\circ}$ traste, privilegiando os dedos 1,2 e 3.

Todos esses "procedimentos padrões" visam facilitar o aprendizado de uma obra ao violão, mas tem caráter pessoal e portanto, podem ser ignorados, modificados ou implementados por outros intérpretes na construção de suas condutas individuais de execução. O intuito aqui foi citá-las para demonstrar ao leitor exemplos do processo de concepção de Heurísticas violonísticas pessoais, para que o mesmo, crie suas próprias "regras", "metodologias" ou "pontos de apoio" recorrentes no estudo uma obra.

Por meio da Heurística sintetizamos em enunciados simples principais conceitos norteadores a serem empregados nas terceira parte da presente tese, onde os aplicaremos aos 12 Estudos para violão de Francisco Mignone.

\footnotetext{
${ }^{27}$ verbo diminuir do checklist de Osborn.
} 


\section{Parte 2: Comparação entre os estudos violonísticos de Villa-Lobos e Francisco Mignone}

Antes de nos dedicarmos à aplicação dos conceitos selecionados aos 12 Estudos para violão de Francisco Mignone é preciso introduzi-lo melhor ao leitor. No entanto, ao invés buscar uma descrição formal enfadonha, optaremos por abordá-lo dentro de seu contexto, olhando para ciclo mais célebre de estudos que o precede, também de um renomado compositor brasileiro.

Aos violonistas parece impossível não olhar para os estudos mignonianos sem compará-los a seu antecessor maior, os 12 Estudos para violão de Heitor Villa-Lobos, obra frequentemente visitada no aprendizado violonístico mundo afora (chegando a ser obrigatória em algumas ementas universitárias) por tal quebra de paradigmas técnicos que gerou, finalmente inserindo o violão na modernidade, quando este insistia em estar atrelado a um repertório de ideal romântico.

Por outro lado tais comparações são habitualmente informais, muito subjetivas (para não dizer rasas) em termos argumentativos e frequentemente imersas em preconceitos. Para confrontar tal atitude, neste momento buscaremos tecer comparações mais isentas entre estes dois corpos de estudos violonísticos, elencando suas semelhanças e diferenças a fim de entender (ou ao menos tentar entender) o fenômeno que os cerca.

Não poderíamos deixar de citar a existência dos 10 Estudos para violão de Radamés Gnatalli, de igual valor técnico musical, mas nos absteremos de comentá-los, para não nos desviarmos de nosso foco inicial.

É preciso também declarar que tópico nasce das citadas comparações informais entre os referidos estudos de Villa-Lobos e Mignone, além de tomar como ponto de partida os trabalhos de Gilson Antunes e Marcelo Fernandes (2009) e de Thiago Abdalla (2005). Os referidos artigos além de precursores são bem redigidos e intencionados, mas não poderiam (e nem parecem ter pretendido) encerrar tal discussão, que a nosso ver se beneficiará com maiores e mais numerosos trabalhos acadêmicos.

\subsection{0 "fantasma" de Villa-Lobos}

É preciso dizer que uma tendência mundial é a de canonizar. Esta não é uma exclusividade musical, já que somos estimulados desde cedo a escolher nossa cor 
preferida a nossa futura profissão. Embora fenômeno generalizado em nossa cultura, ele é bastante visível e usual nas artes em geral, especialmente na música de concerto.

É como se tivéssemos um rol de compositores que uma vez celebrizados passam a ser inatingíveis, "gênios" acima de qualquer suspeita, protegidos de qualquer crítica. Como se não bastasse, sua música passa a apagar as demais, ser mais executada em detrimento das demais e passa a ser base de uma comparação desleal, onde o comparado é sempre injustamente inferiorizado, já que os critérios são viciados. Como comparar a força rítmica de Stravinsky com o melodismo de um Tchaikovsky? O resultado será sempre incompleto, subjetivo. Assim seria se de um Chopin fosse esperado um colorido orquestral compatível com Ravel, quando contexto histórico, vocabulário, estética geral e instrumento de expressão (o primeiro era pianista e o outro habilidoso orquestrador) de ambos são completamente diferentes.

Se qualquer comparação já é injusta entre compositores canônicos, imagine se fosse colocado um compositor menos celebrizado nessa balança...

Não queremos nos estender aqui neste assunto amplamente discutido por Philip V. Bohlman em "Musics and Canons" (1992). Queremos apenas trazer este tema a nossa realidade para atestar que a música erudita brasileira sofre do "fantasma" de Villa-Lobos (na mesma medida em que os argentinos em relação à Astor Piazzolla ou inúmeros outros casos). Sendo um compositor de valor superlativo, frequentemente se espera dos compositores a sua volta, ou posteriores, características que não poderiam jamais ter, pois não são Villa-Lobos. Tudo é comparado a Villa-Lobos, para no fim, ser inferior. Não queremos com isso negar a contribuição indiscutível desse compositor à nossa nação, queremos apenas alertar que julgar outros compositores a partir dessa bússola tem sido comumente um trabalho improfícuo, como bem problematizou Edelton Gloeden:

"De fato, o fenômeno Villa-Lobos exerce enorme fascínio não só entre violonistas. Sua importância para a arte brasileira é incontestável e sua posição no cenário internacional continua sendo de crescente afirmação, o que por vezes pode contribuir para colocar a produção de nossos importantes compositores em segundo plano e, no caso da produção violonística, num quase total esquecimento. Naturalmente, neste sentido, não podemos abordar o fenômeno Villa-Lobos como o "vilão" da situação atual da música brasileira para violão, esta, uma matéria que deve ser revista com cuidado, pois o violão brasileiro sem o criador dos Choros seria difícil de ser imaginado" (Gloeden, 2002, p. 1-2) [grifo nosso].

Assim também o faz Barbosa-Lima, em entrevista a Flávio Apro (2004):

"Qual sua opinião a respeito das frequentes comparações feitas entre Francisco Mignone e Heitor Villa-Lobos?

Lembro-me do Festival de Toronto, no Canadá, em 1975, em que fiz o concerto de abertura e toquei seis Estudos. Houve uma crítica, que dizia 'Mignone is the worthy 
sucessor of Villa-Lobos'. A respeito disso, há uma eterna mania, no Brasil e no resto do mundo, de se querer categorizar os talentos. É ridículo querer afirmar que Brahms é melhor que Bruckner, ou que Bach é melhor que Haendel. Nada disso é correto, todos foram gênios e cada um aportou seu talento à sua maneira.

... a melhor forma seria afirmar que Villa-Lobos foi um gênio espetacular, assim como também foram geniais Mignone, Gnatalli (que inclusive foram até mais ecléticos que Villa-Lobos) e outros tantos ... O resultado negativo disso é que estamos bem familiarizados com a música de Villa-Lobos, mas a obra de Mignone, que é vasta, não a conhecemos nem trinta por cento" (São Paulo, 10 de fevereiro de 2003)" (Apro, 2004, “anexos" p.8) [grifo nosso].

Neste ponto o leitor poderia imaginar que recaímos em contradição, já que propomos mais uma comparação entre compositores. Contra isso, queremos sim propor uma comparação, mas uma que não busque julgá-los um à luz do outro, mas entender e valorizar suas qualidades, defeitos, similitudes e diferenças.

Além disso, pretendemos trazer para o âmbito acadêmico e fomentar uma discussão que tem perdurado décadas na informalidade, povoada de habituais preconceitos e juízos de valor, já que muitos (senão todos) os estudos para violão compostos após os de Villa-Lobos automaticamente tem sido comparados aos mesmos (e normalmente apenas pelo critério de gosto pessoal). Por outro lado, essa comparação é natural e compreensível já que "essas são as obras, também, de maior envergadura técnico-musical para o violão dentre as composições desses mesmos compositores" (Antunes e Fernandes, 2009, p. 29-30) o que tem sido motivo o bastante (e diríamos até, irresistível) para tais comparações.

Tão natural é esta comparação que até mesmo Mignone teceu sua opinião sobre Villa-Lobos:

"Dentro do campo da atualidade brasileira me interessam grandemente Villa-Lobos e Camargo Guarnieri (...) Assim pensando quero fixar, na medida de possível e das minhas forças, o que os dois apontados autores da atualidade representam na música do nosso país. Começarei por Villa-Lobos, o rei do acaso, cujo destino foi prefixado pelas próprias qualidades.

Villa-Lobos é Besta, o elemento de irracionalidade irrompente, vulcânica, destruidora, colossal, no bom e no mau sentido. Villa-Lobos é genial? Não se sabe. Sentimo-lo genial pelo que a música dele nos ilumina, nos força, nos desvirgina, nos sangra em nossas transitoriedades. Mas quem pode afirmar que essas forças que encontramos na música dele e nos transformam em iluminação são forças permanentes?

Não temos, na realidade, nenhum elemento para decidir que o Villa-Lobos seja de fato genial e que dentro de cem ou duzentos anos ele será, mais ou menos, a figura formidável que nós sentimos agora. $\mathrm{O}$ que não podemos negar é que Villa-Lobos é a Besta, é uma força magnífica, apaixonante, mesmo sublime, das cavernas da irracionalidade. O oposto do sapientíssimo e racionalíssimo Ravel! O verdadeiro ângulo de posição crítica diante de Villa-Lobos tem de ser o de se colocar no centro do próprio Villa, com perdão da palavra ou imagem. A forma de Villa-Lobos tem de ser concebida, estudada, apreciada em relação a Villa-Lobos. E quando ele faz uma fuga a gente ri, está claro, mas deverá perceber, analisar, gostar, repudiar, ou aplaudir a forma que o Villa deu à fuga dele e não em relação à Fuga. Nós fazemos isso em relação às fugas de Frescobaldi ou de Mozart, porque não o faremos 
também em relação ao Villa! E o mesmo quanto a outros problemas técnicos. Dizem que na orquestração do Villa-Lobos há uma porção de chinesices instrumentais que não soam. Mas isso encontramos milhares de vezes, até nos maiores sinfonistas. Não devemos esquecer que uma disposição nova da orquestra, uma disposição de alto-falantes, poderiam fazer soar as chinesices... Mas de que vale discutir particularidades villescas, discutimos sim o fenômeno Villa-Lobos.

É certo que ele jamais se preocupou em se dar um destino, mas ele é Besta, forçado ao destino que vai tendo. E como é um safado consciente, vai vencendo e se destinando, até com prejuízo da própria composição. E ninguém poderá negar que até com safadeza, e fazendo besteiras incríveis, ele está se dando um forte e histórico destino (...) Mas, repito, sem o Villa-Lobos, Mário de Andrade, Lorenzo Fernandez e Luciano Gallet ele [Camargo Guarnieri] não poderia de forma nenhuma, nem que fosse gênio, fazer a música que está fazendo" (Mariz, 1997, p. 42-43).

Dessa forma, realizaremos comparações entre as obras propostas por diversos ângulos diferentes, que julgamos complementares, desde o contexto histórico da relação de ambos com o instrumento, passando pelos objetivos de cada estudo, suas características idiomáticas, estrutura formal, grau de dificuldade, etc.

\subsection{Relação com violão em ambos os casos}

A primeira diferença entre tais séries de estudos reside na relação de seus autores com o instrumento: enquanto "o violão esteve presente na vida e na obra de Heitor Villa-Lobos" “desde sua primeira composição - possivelmente dedicada ao instrumento, até a década final de sua vida" (Amorim, 2009, p. 19), Mignone somente se aproximaria mais efetivamente já maduro.

A aproximação de Villa-Lobos com o réprobo instrumento se deu mais provavelmente após o falecimento de seu pai, figura em certo modo conservadora aliada a proibição por sua mãe de se aproximar do piano, o que lhe fomentou a extravasar sua musicalidade em escapadas noturnas junto aos chorões (Amorim, 2009, p. 47-49), com seu violão, que mantinha escondido (segundo o próprio) amarrado no "estrado da cama, para que Dona Nôemia não o quebrasse" (Carvalho 1988, apud Amorim, 2009, p. 48).

Embora o aprendizado junto a um professor seja "improvável, devido às suas circunstâncias financeiras", Villa-Lobos fruiu nesses encontros da companhia de violonistas populares da estirpe de Sátiro Bilhar, José do Cavaquinho, João Pernambuco, Donga, e Quincas Laranjeiras, entre outros, de onde muito provavelmente bebeu da fonte, em um aprendizado informal" (Amorim, 2009, p. 50). Declarou (em diálogo com Andrés Segovia) também ter estudado os principais métodos da época (Carulli, Sor, Aguado e Carcassi) (Taborda, 2004, p. 77), fato provavelmente verdadeiro já que alguns dos mesmos estavam listados em catálogos de casas de música da cidade 
(Taborda, 2004, p. 58-59) e/ou eram possuídos por Quincas Laranjeiras, notório pedagogo do instrumento, atividade esta, que o próprio Villa-Lobos comprovadamente também atuou em meados de 1911 (Amorim, 2009, p. 50).

Todo esse interessante e intenso histórico de aproximação com o instrumento, aliado a apreciação de gravações do próprio Villa-Lobos executando seu Prelúdio $n^{\circ} 1$ e o Choros $n^{\circ} 1$, além do depoimento de chorões da época (como Alexandre Gonçalves Pinto, Donga e Pixinguinha) (Taborda, 2004, p. 77-78), levaria Taborda a seguinte conclusão:

"À exceção de João Pernambuco que marcou nome na história do violão pelas composições e de Quincas Laranjeiras que nos legou a tradição de ensino, acreditamos que o grande conhecedor de violão no Rio de Janeiro nesse período, foi de fato (e surpreendentemente) Heitor Villa-Lobos" (Taborda, 2004, p. 76).

Já Mignone, embora também tivesse frequentado os chorões, o fez com sua flauta ao invés do violão, o qual não se há notícia de ter tocado, mas isso ao menos parece ter deixado uma marca estética em sua produção e um conhecimento do vocabulário do popular do instrumento. Mesmo com tal proximidade, Mignone tardou a acreditar no valor artístico e solístico do violão, instrumento por muito tempo marginalizado. Há registro ${ }^{28}$ que o coloca como pianista acompanhador em uma mesma apresentação (no dia 10 de janeiro de 1919 no salão do Conservatório Dramático de São Paulo) que o célebre violonista paraguaio Agustín Barrios (em meio a outros artistas), o que aparentemente poderia ter sido um estímulo precoce a escrita para este instrumento. Mas isso não ocorreu. Em defesa de Mignone, não há garantia que ele tenha de fato escutado Barrios (afinal o paraguaio entrava no palco em seus poucos momentos descanso no programa apresentado) e deve-se ponderar que ele ainda estava em início de carreira (com 21 anos na época), e que portanto estava mais preocupado em se afirmar como compositor para grandes formações e com estética europeia do que para um instrumento até então desacreditado e com poucos intérpretes. Tanto isso é provavelmente verdadeiro, que Mignone se mudaria no ano seguinte (1920) para Milão onde iniciaria sua primeira ópera "O Contratador de Diamantes" (terminada em 1921).

Suas primeiras investidas no violão datam de 1953, em quatro obras, que lamentamos não ter acesso às partituras para podermos nos estender com propriedade ${ }^{29}$. Mesmo assim, podemos garantir que a maior parte da produção violonística do

\footnotetext{
28 Jornal “O Estado de São Paulo", Sexta-feira, 10 de janeiro de 1919, p. 03. Artes e Artistas - Concerto.

${ }^{29}$ Elas não se encontram no acervo da viúva do compositor, em sua residência e tampouco no acervo da Acadêmia Brasileira de Música, local para onde foi transferido as obras de Mignone constantes no acervo da divisão de música da Bibliotaca Nacional.
} 
compositor viria mesmo a partir de 1970, quando impactado por concerto de Barbosa Lima, se pôs a compor dois trabalhos de grande envergadura: os 12 Estudos para violão em (agosto e setembro) e as 12 Valsas para violão no mesmo ano (sendo este último o primeiro ciclo para o instrumento no Brasil a explorar todos os tons menores). Posteriormente compôs obras para violão até o fim de sua vida, não só para o instrumento solo, mas também para duo de violões, orquestra de violões e um concerto para violão e orquestra (também disponível em versão com piano) (apud: Flávio Silva, 2007 p.54-56).

Sobre seus estudos é interessante notar, em próprio depoimento do autor, que o incentivo para escrevê-los partiu em muito da obra homônima de Villa-Lobos, apresentadas ao compositor por Barbosa Lima que, nesta ocasião, o fez finalmente atestar a falta de repertório nacional para o instrumento e sentir-se então engajado a supri-la:

"Em 1970, durante a realização do $2^{\circ}$ Festival Internacional Violonístico de Porto Alegre, promovido pelo então Liceu Palestrina, Francisco Mignone, convidado pelos organizadores do Festival, teve oportunidade de conhecer pessoalmente $\underline{o}$ festejado violonista Barbosa-Lima. Este tocou para o compositor vários prelúdios e estudos de Villa-Lobos. Após a execução magistral dessas obras, o intérprete perguntou e solicitou a Mignone: "por que o Sr. não escreve algo para meu instrumento dedicando-me a obra?" E, disse mais, "dos nossos autores toco apenas obras de Villa-Lobos porque não possuo e nem tenho de outros brasileiros". De pronto, prometi, entusiasmado pela solicitação, de pensar seriamente em atendê-lo. $\mathrm{E}$, ao regressar ao Rio, de um jato, compus quatro estudos que, imediatamente, remeti ao Barbosa-Lima. Este gostou e gabou as obras e fê-lo com tal calor que me estimulou a escrever mais oito estudos. $\mathrm{E}$, com isso, tenho a plena certeza e convicção que enriqueci o patrimônio da literatura violonística brasileira que, excetuando a obra genial de Villa-Lobos, era muito pobre e insignificante e, no mais das vezes, baseada em arranjos ou transcrições. Villa-Lobos indiscutivelmente deu ao violão novas e insuspeitadas possibilidades. E é justamente pensando nisso que, relendo e estudando Villa-Lobos, me propus a ampliar e especular ainda mais as possibilidades do mais romântico dos instrumentos de corda. Cada estudo, por mim escrito, tem uma peculiaridade técnica que permite ao executor o emprego de todos os seus recursos artísticos interpretativos. São esses predicados que Barbosa-Lima aplica e desfruta com grande maestria e, sobretudo, admirável autoridade. Como autor não poderia desejar maior e melhor intérprete. Muito obrigado. Francisco Mignone (apud Flávio Apro, 2004, p.127).

Edelton Gloeden confirma tal necessidades de obras nacionais ao atestar o perfil habitual do intérprete de violão brasileiro até a década de 1980:

"Nossa abordagem, até aquele momento, estava quase inteiramente voltada ao repertório internacional. A inclusão de obras do repertório brasileiro era rara, exceto a obra de Heitor Villa-Lobos (1887-1959), um dos pontos altos da história do instrumento, alvo de numerosos ensaios, pesquisas, estudos acadêmicos e gravações pelos mais importantes ensaístas, musicólogos e intérpretes” (Gloeden, 2002, p. 1) 
Ajudando a suprir tal demanda por obras nacionais para o instrumento e tendo Villa-Lobos como referência, Mignone nos leva ao próximo assunto: os objetivos técnicos/interpretativos de cada série de estudos.

\subsection{Os objetivos e características dos estudos}

Trataremos de descrever (principalmente sob nossa ótica) os principais objetivos de desenvolvimento da técnica violonística almejados em cada estudo, baseado em estruturas texturais, articulações, efeitos, etc.

\subsubsection{Descrição de alguns objetivos técnicos dos 12 Estudos para violão de Heitor Villa-Lobos}

No que diz respeito ao intuito didático dos estudos villa-lobianos, Antunes e Fernandes os dividem em duas porções: "até a primeira metade, eles são direcionados à técnica instrumental específica, sendo que os seis últimos são mistos de estudos de técnica com questões musicais mais abrangentes em termos de interpretação" (Antunes e Fernandes 2009, p. 30). Nós proveremos nossa interpretação pessoal acerca do mesmo assunto, mas de maneira individualizada para cada estudo.

Estudo 1 (Mi menor / A-B monotemática): Estudo de arpejos (ritornellos a cada compasso). Em padrão fixo a $m d$ ascende e descende em cordas muitas vezes não adjacentes. A me trabalha em um acorde estático por compasso. Ocorrência de acorde paralelos na me. Ocorrência de uma escala com ligados. Parece-nos um estudo mais focado em $m d$ do que em me. Há ritornellos na maior parte dos compassos.

Estudo 2 (Lá maior / A-B monotemática): Estudo de arpejos com ligados (ritornellos a cada compasso). A me também trabalha com um acorde por compasso, mas agora não estático, ou seja, há amplo translados e saltos. Ocorrência de uma escala que atravessa quase toda a extensão do instrumento. Segundo Amorim "na escrita, talvez seja o menos audacioso", porém demanda "alto nível de exigência técnica" para sua execução (Amorim 2009, p.133). Segundo Turíbio Santos (1975, p.16, apud Amorim 2009, p.133) parte de uma ideia básica de Dionísio Aguado enquanto Thiago Abdalla (2005, p. 30) vê semelhanças com o Estudo 20 de Mateo Carcassi.

Estudo 3 (Ré maior / Seção única monotemática): Estudo de acordes plaqué e arpejos aplicados por vezes em notas ornamentais (apogiaturas e bordaduras) em ligados da me, dando uma impressão escalar (na me e na grafia musical) ainda que tocados com um padrão de arpejo na $m d$. Há ritornellos a cada compasso. "A existência 
de arpejos (como é explícito, logo abaixo do título na edição de 1953) é de importância secundária perto do intenso trabalho na técnica dos ligados" (Abdalla 2005, p. 30).

Estudo 4 (Sol maior / A-A'-B-B'-Coda): É um estudo de acordes repetidos, onde a $m d$ trabalha em blocos e por vezes salta pelas cordas. A escrita polifônica utiliza "harmonia a quatro partes onde impera o movimento paralelo das vozes, a não resolução dos acordes e as modulações sem preparações" (Pereira, 1984, p. 38, Amorim, 2009, p.135). "Há nada menos que 20 alternâncias da unidade" de compasso neste estudo (Amorim, 2009, p.135).

Estudo 5 (Dó maior): É um estudo polifônico (a 3 vozes), consequentemente exigindo independência de movimentos dos dedos de ambas a mãos e legato. Para Antunes e Fernandes (2009, p. 30) "há uma nítida alusão à viola caipira, com acompanhamento em terças [paralelas] e melodia propositadamente monótona".

Estudo 6 (Mi menor / Seção única repetida variada): É também um estudo de acordes, mas agora trocados rapidamente (em colcheias) exigindo maior movimentação da me aplicada inicialmente à trabalho em blocos da $m d$. O estudo é repetido com padrão mais complexo de $m d$ onde os blocos de acorde são alternados contra o polegar.

Estudo 7 (Mi maior / A-B-A '-C): Há trabalhos técnicos diferentes em cada seção, respectivamente, escalas, arpejos (com 3 planos diferentes: melodia, baixo e "recheio" harmônico), acordes paralelos plaqué contra baixo e trinados (de $m d$ em acordes paralelos).

Estudo 8 (Dó sustenido menor / Introdução-A-A'-A-Coda monotemática): Estudo também com vários trabalhos texturais distintos. A introdução trabalha em dois planos com intervalos paralelos nas cordas graves contra baixo. A melodia exposta no baixo é repetida na seção seguinte pela voz superior, agora em arpejo em três planos diferentes (similar a Estudo 7). Há passagens em ligados que lembram o Estudo 3 do mesmo autor e ocorrências interessantes de arpejos em sextinas "elemento técnico que será foco de toda a seção central do Estudo $n^{\circ} 11$ (arpejo circular $\left.p, i, m, a, m, i, p, \ldots\right)$ " (Abdalla 2005, p. 35).

Estudo 9 (Fá sustenido menor / Seção única repetida variada): Para Amorim “a ideia fundamental consiste nas variadas ornamentações do tema principal ... muito simples, consistido de uma melodia em graus conjuntos de caráter descendente" (Amorim 2009, p.135). Para Antunes e Fernandes "é mais voltado, principalmente à sua segunda parte, aos ligados, e sua alusão novamente à viola caipira é preponderante" (Antunes e Fernandes, 2009, p. 30). 
Estudo 10 (Si menor / A-B-C-A'-Coda): Estudo principalmente de independência da me. Possui introdução e codas cujo trabalho da $m d$ realiza saltos em acordes similares ao Estudo 4, enquanto a me segura acordes paralelos ascendentes, alternados com figuração de ligados, que passam a ser o foco principal na seção seguinte em ostinato onde é introduzida nova melodia nos baixos, em textura semelhante ao Estudos 3 e 9. Este estudo é normalmente finalizado pelos intérpretes com rasgueios e com arpejo de digitação escovada na $m d$, embora isto não esteja expresso na partitura original.

Estudo 11 (Mi menor / A-B-A'-B'-A): possui trabalhos de melodia acompanhada (em três planos, com melodia principal agora na voz intermediária), terças repetidas contra melodia (também em terças) no baixo, acordes de arpejo descendente com translados verticais do indicador (ou outro dedo) da $m d$ (escovados), arpejo em sextinas $m d$ (com 3 cordas em uníssonos) com movimento paralelo da $m e$, toque duplo de polegar $m d$. Abdalla $(2005$, p. 33) encontra semelhanças com o Estudo 4 no que tange a ocorrência de acordes repetidos, que neste estudo aparecem em terças maiores.

Estudo 12 (Lá menor / A-A'-B-A-Coda): Estudo de portamento (glissando) de acordes paralelos da $m e$, aliado a movimento repetitivo em blocos da $m d$. Também aparecem escalas (com modelo de imitação vertical na me), acordes de arpejo descendente com translados verticais de dedos da $m d$ (normalmente realizado pelos intérpretes com os dedos $p, i$ ou $a$ - $m$ escovados) e seção de melodia nas cordas graves sobre pedal da sexta corda solta (resolvido tecnicamente de várias formas). Registra-se a existência de trocas constantes de fórmula de compasso.

\subsubsection{Descrição de alguns objetivos técnicos dos 12 Estudos para violão de Francisco Mignone}

I $\boldsymbol{I}^{\boldsymbol{O}}$ Estudo - "Vivo" (Lá menor): estudo de arpejos em tercinas, com longa melodia cantabile normalmente na voz superior, mas por vezes a atenção melódica se volta a outras vozes. Faz uso de grande parte da extensão do instrumento. Também há a ocorrência de ligados e harmônicos artificiais (este último apenas no final da obra).

$\boldsymbol{I I}^{\boldsymbol{o}}$ Estudo - "Seresteiro" (Ré menor): Estudo seresteiro em forma ABA. Primeira seção se baseia em longa melodia com acompanhamento de acordes. Já a segunda focaliza diferentes padrões de arpejo no acompanhamento, primeiro com 
melodia na voz inferior e posteriormente na voz superior. Há passagens escalares cadenciais entre frases ou seções.

III $\boldsymbol{I}^{\boldsymbol{E}}$ Estudo - "Tempo de chorinho" (Sol maior): Estudo de grandes e súbitas mudanças de agógica, inicia-se por trabalho de melodia com respostas no baixo (alla "baixaria" 30 de choro). O aspecto melódico é tratado em escalas e em intervalos de terças, sextas, décimas e em blocos de acordes com 3 ou 4 notas, com conotação caipira.

IV $V^{o}$ Estudo - "Allegro Scherzoso" (Mi menor): Estudo de ligados de grande agilidade em ritmo de galope. Primeiramente apresenta ligados ascendentes aplicados a arpejos (com notas de passagem) de grande extensão e em seguida, ligados descendentes acompanhados por pontuações de acordes. Há seção central lenta com melodia na voz inferior acompanhada por acordes no contratempo que depois é repetida em arpejos.

$V^{o}$ Estudo - "Vagaroso" (Lá menor): Estudo lento e interpretativo também de caráter seresteiro com uma considerável variedade de texturas. Inicia-se com blocos de acordes (4 notas) contra baixo (com uma voz a três vozes), gerando saltos verticais de $m d$ similares a repetição do Estudo 6 de Villa-Lobos. A segunda seção (que é rememorada no final) apresenta acordes de cinco notas com notas ligadas, o que trabalha independência da me e a dinâmica suave exige controle da $m d$. A melodia principal do estudo somente é apresentada na segunda página, primeiramente na voz inferior (polegar) acompanhada por pontuações de acordes chapados e arpejados. No compasso 64, a mesma melodia aparece na voz superior acompanhada por acordes quebrados. Também há aparições de escalas cromáticas, acordes plaqués repetidos insistentemente e harmônicos artificiais.

VI $\boldsymbol{I}^{\boldsymbol{O}}$ Estudo - "Assai Vivo" (Sol maior): De caráter amaxixado, trabalha principalmente arpejos variados, mas com ocorrência de outras texturas, como escalas (seja de ligação ou cadenciais) e melodia no baixo pontuada por acordes. O tema principal (re)aparece nos compassos 1, 55 e 76 sempre com tratamento textural distinto. Na primeira seção ocorrem notas repetidas no meio dos arpejos em textura pouco usual ao instrumento, mas que se tornou idiomática de Mignone.

$V I^{o}$ Estudo - "Molto Lento/Cantiga de ninar"31 (Fá sustenido menor): Estudo interpretativo em "tonalidade pouco familiar entre os violonistas" (Antunes e

\footnotetext{
30 "Baixaria" é o nome que os músicos populares, tocadores de choro e samba, dão às passagens escalares graves (nos bordões) normalmente sublinhando os encaminhamentos harmonicos.

${ }_{31}^{31}$ Subtítulo no manuscrito.
} 
Fernandes, 2009, p. 31) criando dificuldades severas de sustentação de legato na me, mesmo com o alerta do compositor no rodapé da partitura ao dizer que a obra "foi escrita desse jeito apenas para que o executor faça vibrar os sons o mais que possível”. Tais dificuldades podem ser sanadas por digitação atenciosa. A textura é de melodia (1 ou 2 vozes paralelas) acompanhada por pontuações de acordes densos. Há ocorrência de harmônicos naturais e artificiais, por vezes duplos (no manuscrito).

VIII ${ }^{o}$ Estudo - "Allegro" (Sol menor): "Um dos mais difíceis da série, possui elementos de trabalho que vão de arpejos e escalas até a rasgueados e notas repetidas" (Antunes e Fernandes, 2009, p. 31). Contrastando com a harmonia áspera e ritmo frenético predominante da peça, a peça é finalizada com acordes maiores paralelos de conotação também caipira.

IX $X^{o}$ Estudo - "Allegro Moderato" (Sol maior): Também preconiza o trabalho de arpejos (em posição fechada), mas neste caso com muitas mudanças de padrões $(m d)$ que às vezes ocorrem a cada compasso, em atitude pouco habitual ao instrumento mas benéfica ao estudo. A sonoridade da primeira e longa seção remete algo entre uma "levada" de choro e o ponteio de uma viola caipira, sendo esta segunda ainda mais evidenciada na seção lenta, por suas lentas melodias em terças, décimas e em blocos de acordes. Há ocorrência eventual de escalas ligando seções.

$X^{o}$ Estudo - "Lento e com muito sentimento" (Fá menor): "Mostra os desafios de melodia acompanhada com o peso correto dos acordes" (Antunes e Fernandes, 2009, p. 31) sobretudo na primeira e última seção, que em tonalidade pouco favorável somada a andamento lento, também exige molto legato realizável apenas atencioso com trabalho de independência de movimentação dos dedos da me. A seção central também trabalha melodia acompanhada, mas agora em arpejo também em posição fechada.

$\boldsymbol{X I}^{\boldsymbol{o}}$ Estudo - "Andante" (Ré menor): "Com seu subtítulo Spleen (que nos remete rapidamente a aspectos da literatura romântica, inclusive a de autores brasileiros da primeira metade do século XIX), é novamente mais um estudo de interpretação (Antunes e Fernandes, 2009, p. 31)”. A primeira seção apresenta melodia que se movimenta primeiramente em blocos de acordes plaqué na região médio-grave, contra pontuações no baixo, exigindo trabalho em blocos da $m d$. Em seguida a melodia é desenvolvida pela voz superior com acompanhamento mais complexo, levando ao clímax no compasso 26 com interessante e rara figuração em quiálteras de sete. O final sutil é alcançado pelo uso de harmônicos e reexposição variada da introdução. 
XII' Estudo - "Com velocidade" (Mi menor): É considerado um dos mais difíceis da série, principalmente por sua extenuante primeira seção de escrita muito pianística e consequentemente pouco violonística (sobretudo para me), que trabalha acordes plaqué com melodia em ligados, passagens escalares, arpejos, finalizada por uma interessante rememoração do tema no baixo. A seção contrastante é diametralmente mais simples, com melodia (em décimas e oitavas) quase "folclórica" (Apro, 2004, p.111), num nítido propósito de dar descanso ao intérprete. Após repetição da primeira seção, há retorno a este tema quase folclórico, agora levemente modificado e tocado em acordes cheios sob a indicação molto arpeggiato, finalizados com súbita escala descendente e acordes sforzando.

\subsection{Idiomatismo dos dois grupos de estudos}

Apesar de parecer novamente contradizer os objetivos iniciais desta seção, tomaremos como ponto de partida o tópico "Síntese dos elementos que caracterizam a escrita de Villa-Lobos para violão" do livro de Amorim (2009, p.167-172) onde o mesmo enumera não menos que 47 características da escrita villa-lobiana para violão (que coincidentemente são frequentes nos estudos), para comparar alguns destes itens com os procedimentos habituais dos estudos de Mignone, anunciados a seguir ${ }^{32}$ :

"Paralelismo horizontal": para Amorim, trata-se de movimentos paralelos de acordes com grande translado. Em Villa-Lobos esse movimento é empregado em acordes diminutos e meio diminutos (comp. 9-14 do Estudo 4 e comp. 6-11 do Estudo б) enquanto em Mignone aparece em acordes maiores (VII Estudo, comp. 32) e acordes de sétima (III ${ }^{o}$ Estudo, comp. 65-68).

"Utilização de paralelismos verticais": para Amorim, trata-se de movimento de desenho igual desenho na me que são repetidos em várias cordas. Villa-Lobos nos compassos 44-45 do Estudo 10 e compassos 22-29 do Estudo 12. Em Mignone é encontrado no início e final da Coda do XII Estudo.

"Uso idiomático das cordas graves $\left(4^{\mathrm{a}}, 5^{\mathrm{a}}\right.$ e $\left.6^{\mathrm{a}}\right)$ ": Amorim, provavelmente se refere ao uso melódico dessas cordas. Mignone também faz este uso normalmente de forma mais breve (nos $I I I^{o}, V^{o}, V I^{o}, I X^{o}$ e $X I I^{o}$ Estudos), mas não sendo violonista não o faz de forma tão idiomática e proposital quanto Villa-Lobos.

\footnotetext{
${ }^{32}$ Lembrando que a parte em negrito dos enunciados advém sempre do tópico citado de Amorim (2009, p. 167-172).
} 
"Harmônicos": para Amorim, Villa-Lobos faz uso extensivo de harmônicos naturais, enquanto Mignone utiliza mais os harmônicos artificiais, e por vezes (principalmente no manuscrito) os utiliza em duas (no $V^{\mathbf{0}}, V I I^{\mathbf{0}}, X I^{\mathbf{0}}$ e $X I I^{\mathbf{0}}$ Estudos) e até três notas simultâneas (apenas no final do $V I I^{\circ}$ Estudo), o que exige certo "malabarismo" do intérprete e assim sendo, são comumente simplificados pela maioria dos intérpretes, sem grande prejuízo musical.

"Uso de tonalidades que privilegiam as cordas soltas": Villa-Lobos o faz em sete de seus estudos, enquanto Mignone em seis, mas nem sempre parece fazê-lo pautado na existência de cordas soltas, que em nossa impressão existem em menor número em sua obra (contabilizar essa ocorrência em ambos os ciclos seria demasiado fastidioso).

"Uso de cordas soltas como efeito pedal": ambos os compositores o usam. Villa-Lobos no compassos 15-20 do Estudo 1 e Mignone no compassos 57-61 do $I^{o}$ Estudo e compassos 52-58 do $I V^{o}$ Estudo, por exemplo.

“Uso da afinação natural do instrumento como elemento musical”: embora seja um procedimento villa-lobiano ocorrente em várias obras (Concerto para violão, Prelúdio $n^{\circ} 3$ e Distribuição das Flores), mas não nos seus estudos, citamos este elemento por ele curiosamente também ocorrer nos Mignone, mesmo sem ser violonista, no comp. 67-69 do $I V^{\boldsymbol{o}}$ Estudo. Este procedimento, por exemplo, virou uma das marcas da Sonata op.47 de Alberto Ginastera, por iniciar-se com este acorde de cordas abertas.

"Exploração de toda a extensão do instrumento": ambos os compositores sabem "passear" pelos registros do instrumento com maestria. Villa-Lobos nas escalas do Estudo 2 e nos comp. 9-14 do Estudo 4, enquanto Mignone o faz no comp. 37-43 e 57-67 do $I^{o}$ Estudo, comp. 31-32 do $I^{o}$ Estudo, comp. 65-69 do III ${ }^{o}$ Estudo, comp. 3133 do $I V^{o}$ Estudo, comp. 90-95 do $V I^{o}$ Estudo, comp. 1-4, 15-17 e 48-50 do XII Estudo.

"Uso extensivo de sinais e recursos de expressão": ambos os compositores o fazem, mas Mignone mais frequentemente e de maneira às vezes hiperdetalhista (como no $I I I^{o}$ Estudo, por exemplo). Além disso, Villa-Lobos possui vários erros de edição, fruto de falta de revisão, enquanto Mignone declara: “... sou e serei sempre um eterno insatisfeito, refaço cinco ou mais vezes as minhas obras" (Francisco Mignone aos 80 anos, excertos da entrevista ao Jornal do Brasil, a 6/4/1968, apud Mariz, p. 45, 1997) o que não o isenta de erros, mas diminui sua incidência. 
"Utilização do ritornelo como recurso técnico e expressivo": Villa-Lobos o usa mais frequentemente, mais especificamente em seus três primeiros estudos. Mignone apenas no $I V^{o}$ Estudo, embora tenha preferido a grafia por extenso de repetição de compasso.

"Exigência do intérprete de fino controle tímbrico e dinâmico do instrumento": intimamente ligado aos sinais interpretativos descritos em tópico anterior, ambos os ciclos necessitam de tal habilidade.

"Melodias acompanhadas por acordes quebrados": Villa-Lobos os usa no comp. 15-23 do Estudo 8 e Mignone a partir do comp. 64 do $V^{o}$ Estudo, em padrão menos orgânico.

"Linhas cromáticas": existentes em ambos os ciclos.

"Exploração do potencial harmônico do violão": cada qual o faz à sua maneira, Villa-Lobos mais voltado a elementos orgânicos como fôrmas de acordes, paralelismos (horizontais e verticais) e Mignone, embora também use paralelismo e fôrmas, o faz menos frequentemente, mas não deixa de ser menos inventivo no uso arrojado do violão como instrumento harmônico (o VII ${ }^{o}$ Estudo basta para comprovar isso).

“Exploração das capacidades polifônicas do violão": enquanto Villa-Lobos dedica um estudo especificamente a este procedimento composicional e ainda o utiliza “nos Estudos no 3 (compassos 3-5, 8, 12, 13, 19-22 e 26 -30), diversas secções do n ${ }^{\circ}$ s e 9, na parte $B$ do $n^{\circ} 7$, em quase totalidade do $n^{\circ} 8$, na parte $B$ do $n^{\circ} 10$ (em que temos a sobreposição de notas fixas com ligados - um dos momentos de maior dificuldade técnica do ciclo) e, no Estudo $n^{\circ} 11$, de modo geral" (Abdalla 2005, p. 30), Mignone praticamente não o utiliza, privilegiando a melodia acompanhada (que por sua vez às vezes sugere vozes distintas) e havendo no máximo insinuações polifônicas mas normalmente justapostas e não simultâneas.

"Uso constante de quiálteras": ocorrente em ambos compositores.

"Intercalação de passagens atonais em peças tonais": ocorrente em ambos compositores. Villa-Lobos nos Estudos 1,10 e 12, Mignone nos $I^{o}, I^{o}$ e VIII Estudos.

"Passagens de grande intensidade sonora": ocorrente em ambos compositores. Em Mignone chamamos atenção para o uso de dinâmicas extremas, como no $V^{\boldsymbol{o}}$ Estudo, por exemplo.

"Alternância de unidade de compasso em uma mesma peça": Amorim ressalta o exemplo do Estudo 4 de Villa-Lobos, onde ocorrem 20 alternâncias de 
unidade em apenas 65 compassos. Mignone usa este recurso mais parcimoniosamente (apenas nos $I V^{o}$ e $V_{I I I}{ }^{o}$ Estudos).

“Escalas com digitações oblíquas": ocorrente nos Estudos 7 e 10 de VillaLobos e não ocorrente em Mignone.

"Utilização de ornamentos como recurso principal na composição": tratando-se de ideia totalmente villa-lobiana nos Estudos 7, 9 e 10, ela não ocorre em Mignone.

"Uso de notas repetidas como transição entre seções ou partes de seções": novamente um procedimento bastante villa-lobiano consequentemente não explorado por Mignone. Em contrapartida este último autor as explora de maneira distinta dentro de arpejos, provendo-lhes articulação rítmica (o $V I^{o}, V I I I^{o}$ e $I X^{o}$ Estudos são os exemplos mais contundentes). Apesar de procedimento criativo ele é pouco usual para os violonistas, embora seja musicalmente eficaz e passível de ser absorvido com estudo.

"Utilização de rasgueios de mão direita": Este procedimento totalmente característico do instrumento não está expressamente indicado por ambos os compositores em seus manuscritos, porém muitos intérpretes os adicionam em alguns acordes, como no $I V^{o}$ Estudo de Mignone e Estudo 12 de Villa-Lobos, entre outros.

"Arpejos com efeito de trêmulo": trata-se de efeito praticamente de ocorrência rara na história violonística ${ }^{33}$, onde Villa-Lobos propõe, no Estudo 11, passagem de uníssono em três cordas diferentes, tocadas em arpejo rápido de sextinas resultado em um trêmulo. No entanto, o efeito habitualmente nomeado trêmulo pelos violonistas (rápida e insistente reiteração de uma nota em una corda) não é utilizado por nenhum dos compositores, sendo outro vocabulário técnico merecedor de estudos específicos.

"Capacidade de interpenetrar idiomatismos de instrumentos distintos": Amorim nota a semelhança de passagens dos estudos villa-lobianos com o violoncelo, instrumento também tocado pelo compositor. Mignone apresenta atitude semelhante, mas em relação aos dois instrumentos que tocava, a flauta e o piano, mas parece, em muitos momentos de seus estudos, querer fazer com que o violão soe próximo a uma viola caipira.

\footnotetext{
${ }^{33}$ Um outro exemplo deste tremolo em arpejos ocorre em Respuesta Impromptu (1922) de Miguel Llobet (1878 - 1938), aparecendo na introdução em duas cordas em uníssonos na nota Si (e outras cordas em oitavas) e posteriormente em três cordas em uníssonos na nota Mi de forma similar (e provavelmente anterior) ao Estudo 11 Villa-Lobos, também em sextinas. Não sabemos se há uma possível relação de influência entre estas duas obras.
} 
"Caráter programático de algumas peças": Villa-Lobos não o faz em seus estudos, mas em seu ciclo de prelúdios, enquanto Barbosa-Lima sugere que Mignone tinha a ideia de colocar subtítulos dessa natureza em seus estudos, apenas parcialmente realizada (há estudos com subtítulos de "seresteiro", "tempo de chorinho", "cantiga de ninar", o que não são o bastante para serem chamados de programáticos).

\subsection{Dificuldades dos estudos}

Uma das questões mais polêmicas em relação a estas séries de estudos remete à suas dificuldades. A tendência habitual (e de certa forma errônea) é se pensar que o ciclo de Mignone é "mais difícil" simplesmente baseando essa opinião numa impressão auditiva ou na repetição de verdades alheias (em outras palavras o "ouvi falar...”), fato compreensível quando poucos se aventuraram a tocar tais estudos.

Por outro lado, muitos estudantes são apresentados muito cedo a estudos (por vezes difíceis) de Villa-Lobos e essa exposição precoce somada ao estudo intenso e prolongado os faz, anos depois, julgá-los "fáceis" simplesmente por estarem em sua zona de conforto.

Com esses fatores em conta, gostaríamos de desmistificar essa falsa relação de dificuldade entre os estudos, ao relembrar que o critério de dificuldade é muito relativo (sobretudo em estudos tão complexos e variados tecnicamente como os aqui discutidos). Dessa forma, cremos que um estudante pode ter uma facilidade na execução de escalas do Estudo 7 de Villa-Lobos e não apresentar a mesma propensão para os ligados do Estudo 3 ou 10 do mesmo autor, para citar alguns exemplos.

As dificuldades aparentes na obra violonística de Mignone são derivadas de um duplo fenômeno: por um lado sua escrita é menos orgânica (algo esperado em se tratando de compositor não violonista) e por outro suas características composicionais e passagens problemáticas foram menos decifradas e discutidas quanto as de Villa-Lobos. Portanto, acreditamos ser menos uma questão de dificuldade e mais uma questão de aproximação da comunidade violonística à música de Mignone.

Dentro do vocabulário textural de seus estudos, a dificuldade mais marcante de Mignone parece ser a maneira espremida com que os dedos da $m d$ trabalham em algumas passagens, em algo que Cauã Canilha (2017) chama de disposição intermediária. Para este autor a disposição "é a maneira como os dedos $i-m-a$ estão distribuídos entre as cordas" (Canilha, 2017, p. 77) e está dividida em: diagonal (onde cada dedo do conjunto $i-m-a$ ocupa um corda, como em um arpejo habitual), linear 
(onde o grupo $i-m-a$ ocupa uma única corda como num tremolo) e por fim a intermediária (onde dois dedos estão alinhados a uma corda e outros não). A nosso ver essa terceira situação está menos absorvida pelos violonistas e é bastante ocorrente nos estudos de Mignone, por vezes devido à presença de notas repetidas dentro de arpejos. Ainda há ocasiões com o agravante dessa disposição intermediária ainda incluir o polegar também trabalhando na mesma corda que outro dedo (provavelmente $i$ ) aspecto que requer cuidado para evitar o choque entre esses dedos.

Esse uso mais ocorrente da disposição intermediária é uma dificuldade inicial aos estudos de Mignone, mas sobreponível com algum tempo de estudo. Ademais julgamos que esse é um recurso interessante da técnica violonística e parece auxiliar num amadurecimento do funcionamento e controle da $m d$ em arpejos. Assim sendo, “enfrentar" alguns dos estudos de Mignone pode ser algo recomendado aos estudantes no intuito de absorver esse recurso técnico.

Mesmo com esta ressalva, há estudos de Mignone acessíveis do ponto de vista mecânico como os de número 2, 10 e 11 e de nível intermediário como o 3, 5 e 7, dependendo sempre da especificidade de quem estiver julgando.

A título de exemplo, reproduzimos abaixo tabela de Thiago Abdalla, a qual expõe uma proposta de hierarquização de dificuldades entre estudos brasileiros de quatro autores, mesmo que não seja indiscutível.

Para exemplificar o quão distintas podem ser as opiniões, nossa avaliação teria algumas diferenças em relação à de Abdalla no que tange às obras de Villa-Lobos e Mignone. Em nosso julgamento a ordem dificuldade progressiva dos estudos de Mignone, seria mais ou menos a seguinte: $2,11,10,7,5,3,1,4,6,9,8$ e 12 . Mesmo assim não consideremos nossa opinião isenta. Tomamos como exemplo os de número 4 e 6 que foram os primeiros a serem estudados por nós e que portanto podem estar sendo subestimados nesta hierarquização.

Já na relação entre os ciclos de estudos, custamos acreditar que o 4 de Mignone e 5 de Villa-Lobos tem o mesmo nível de dificuldade (como exposto na tabela) por exigirem habilidades completamente distintas sendo assim sua comparação de dificuldade totalmente pessoal. 
Com isso queremos enaltecer o valor da proposta de Abdalla, mas não sem deixar o leitor ciente de sua subjetividade.

Tabela II - Cruzando entre as dificuldades das peças (Thiago Abdalla, 2005, p.7)

\begin{tabular}{|c|c|c|c|c|}
\hline $\begin{array}{l}\text { ORDEM DE } \\
\text { DIFICULDADE }\end{array}$ & $\begin{array}{l}\text { GUERRA-PELXE } \\
10 \text { LUDICAS }\end{array}$ & $\begin{array}{c}\text { FRANCISCO MIGNO- } \\
\text { NE } \\
12 \text { ESTUDOS }\end{array}$ & $\begin{array}{c}\text { RADAMÉS GNATTA- } \\
\text { LI } \\
\text { 10 ESTUDOS }\end{array}$ & $\begin{array}{l}\text { VILLA-LOBOS } \\
12 \text { ESTUDOS }\end{array}$ \\
\hline 01 & 5 & & 4 & \\
\hline 02 & 2 & & & \\
\hline 03 & 1 & & 2 & \\
\hline 04 & 4 & 2 & & \\
\hline 05 & 3 & & 5 & \\
\hline 06 & 7 & 10 & & \\
\hline 07 & 9 & & & 6 \\
\hline 08 & 10 & & 10 & \\
\hline 09 & 8 & 3 & & \\
\hline 10 & 6 & & & 8 \\
\hline 11 & & 11 & & \\
\hline 12 & & & 9 & 11 \\
\hline 13 & & 9 & & \\
\hline 14 & & & 8 & 4 \\
\hline 15 & & 5 & & \\
\hline 16 & & & & 9 \\
\hline 17 & & & 6 & \\
\hline 18 & & 4 & & 5 \\
\hline 19 & & 6 & & \\
\hline 20 & & & & 3 \\
\hline 21 & & & 3 & \\
\hline 22 & & & 7 & 1 \\
\hline 23 & & 7 & & \\
\hline 24 & & & & 7 \\
\hline 25 & & 8 & & \\
\hline 26 & & & & 2 \\
\hline 27 & & 1 & & \\
\hline 28 & & & & 12 \\
\hline 29 & & & & 10 \\
\hline 30 & & 12 & & \\
\hline
\end{tabular}

\subsection{Estrutura e duração dos estudos}

Outra diferença notável entre séries de estudos é sua duração, sendo a de Mignone mais longa que a de Villa-Lobos, já que este possui certa tendência a peças curtas, onde inclusive demonstra sua maior habilidade, segundo Mário de Andrade e Humberto Amorim:

"'Por mim eu creio que a personalidade criadora de Villa-Lobos se expressa, por tendências íntimas, muito melhor dentro das formas estruturalmente de pequena duração no tempo. Como é o caso tão característico de Schumann, cuja genialidade não consegue de fato ... se manifestar satisfatoriamente nas obras estruturalmente monumentais' (Andrade, 1945b apud Amorim 2009, p.125)

Os 12 Estudos são, dentre as obras de Villa-Lobos para violão, as mais curtas em duração de tempo... Nesse sentido, Villa-Lobos parece ter encontrado no instrumento um canal de expressão muito próprio a um estilo de composição no qual parecia expressar-se de forma mais convincente... Alguns autores já fizeram restrições às suas realizações de maior porte: falta de unidade formal, dificuldade de desenvolvimento de temas, ideias soltas e não concatenadas... no entanto, parece ter encontrado nessa fraqueza os caminhos para a forma singular de sua música... $\mathrm{O}$ violão parece mesmo ter sido o grande confidente das 'pequenas grandes' criações do compositor... Tal argumento é patente nos ciclo dos 12 Estudos: imaginados 
isoladamente, não seriam capazes de dar a real dimensão das inovações na escrita; do alargamento das possibilidades musicais e técnicas do instrumento; da complexidade que resultou, paradoxalmente, do uso - simples e direto - das características próprias do violão" (Amorim 2009, p. 125).

Assim sendo, reunimos na tabela abaixo as durações médias de ambos os ciclos, para melhor sua visualização.

\begin{tabular}{|c|c|c|}
\hline Estudos & Duração aprox. - Villa-Lobos ${ }^{34}$ & Duração aprox. - Mignone ${ }^{35}$ \\
\hline 1 & $11^{\prime} 50$ & $3^{\prime} 40$ \\
\hline 2 & $1^{\prime} 20$ & $55^{\prime} 00$ \\
\hline 3 & 2'19 & $2^{\prime} 20$ \\
\hline 4 & $3 \prime 28$ & $33^{\prime} 34$ \\
\hline 5 & 3'07 & $55^{\prime} 00$ \\
\hline 6 & $1^{\prime} 36$ & $2 \prime 38$ \\
\hline 7 & $2^{\prime} 23\left(5^{\prime} 00\right.$ com ritornello) & $3 \prime 00$ \\
\hline 8 & $3 \prime 47$ & $3 \prime 00$ \\
\hline 9 & $33^{\prime} 35$ & 3'44 (6'44 com ritornello) \\
\hline 10 & $2^{\prime} 26$ & $33^{\prime} 26$ \\
\hline 11 & $44^{\prime} 43$ & $2^{\prime} 22$ \\
\hline 12 & $2 \prime 25$ & $44^{\prime} 44$ \\
\hline Duração total: & de $28^{\prime}$ a $35^{36}$ & De $42^{\prime} 25$ a $45^{\prime}$ \\
\hline Média por estudo & $2^{\prime} 20$ a 2'40 & $3^{\prime} 30$ a 3'45 \\
\hline
\end{tabular}

Ao realizar tal organização dos tempos dos estudos lado a lado, podemos colocar em números uma impressão (comum da comunidade violonística) de que os estudos de Mignone tendem mais ao desenvolvimento de ideias (característica apreciada por uns e detestada por outros), resultando em uma diferença de 7-17 minutos entre a duração total dos ciclos e consequentemente, também em uma diferença da duração média das peças, onde as de Mignone tendem a ter ao menos 1 minuto a mais que as de VillaLobos.

Tudo o que foi exposto aqui não é um demérito, apenas uma constatação das diferentes características dos compositores.

\subsection{O hiato: gravações, performances e escritos}

Um último grande fator a ser considerando nesta comparação e habitualmente ignorado em obras desse calibre é a ocorrência de grande descompasso entre a composição (e sua consequente publicação) e sua absorção (tanto pelos instrumentistas

\footnotetext{
${ }^{34}$ Durações aproximadas de acordo com Amorim, 2009, p. 133-144.

${ }^{35}$ Durações de acordo com gravação de estudo do próprio autor do artigo.

${ }^{36}$ Média das durações das gravações listadas em Amorim, 2007, Anexos, p. 231-234).
} 
quanto pelo público apreciador). Obviamente esse fenomeno não ocorre em qualquer obra musical, mas é frequente, sobretudo em obras que contenham inovações técnicas, musicais ou de qualquer outra ordem, como ocorre nas duas séries de estudos analisados, cada um a sua maneira. É como se além do tempo de gestação da obra pelo compositor, ela muitas vezes precisasse de uma segunda gestação, agora pelos intérpretes (para resolverem suas questões técnico/interpretativas e de grafia) e público (para absorverem suas inovações de sonoridade até finalmente conseguir apreciá-las).

A história comprova que esse fenômeno é verdadeiro em relação ao Estudos de Villa-Lobos. Compostos "na década de 1920, durante as duas passagens de Villa-Lobos por Paris: de 1923 a 1925 e de 1927 a 1930" (Amorim, 2009, p.127), eles foram publicados apenas em 1953 pela editora francesa Max Eschig (mais de 20 anos depois). Mesmo dedicados ao espanhol Andres Segóvia, violonista mais célebre de sua época e com prefácio do mesmo, estes estudos ainda tardariam muito a encontrar intérpretes capazes de divulgá-los a um público maior. Segóvia, embora declarasse em seu prefácio que considerava os estudos "de surpreendente eficácia para o desenvolvimento das técnica de ambas as mãos" e "de valores estéticos permanentes de obras de concerto" (Max Eschig, 1953 p.1) somente tocou e gravou os estudos de números 1, 7 e 8. Conhecendo-se a personalidade e preferências do espanhol (que em suas encomendas estava sempre voltado para a música com nacionalista de seu país e sempre pesava por obrigar seus alunos a seguir suas digitações em masterclasses), podemos imaginar que o ciclo de estudos villa-lobianos não se adequava a este intérprete, tanto por estética, quanto por ter de se sujeitar às digitações de Villa-Lobos para fazê-los funcionar. Ele mesmo revela que "não quis variar nenhuma digitação que Villa-Lobos marcou" e que "devemos estrita obediência a seu desejo, mesmo a custa de nos submetermos a maiores esforços de ordem técnica" (Max Eschig, 1953 p.1). Essa declaração, simplesmente não soa como Segovia, conhecido por impor o seu ímpeto artístico sobre as obras em uma visão artística do romantismo tardio. Imaginamos que talvez, ele não quis mexer no que não conseguia decifrar, ou ao menos que não quis gastar seu precioso tempo revisando obras de uma estética que não estava comprometido... Mas isso recai no âmbito da pura conjecturação.

Enquanto Segóvia deu pouco proveito à obra a ele dedicada, o brasileiro Turíbio Santos soube aproveitá-la para lançar sua carreira (somada a outros feitos) se tornando o concertista ideal para a tarefa de defendê-la frente aos apreciadores do violão. Em 1963 ele gravaria os 12 estudos a convite de Arminda Villa-Lobos e os apresentaria no dia 21 
de novembro daquele mesmo ano no Palácio Gustavo Capanema do Rio de Janeiro, configurando a primeira performance integral em concerto (Santos, 2015, p. 29). Resumidamente, a partir dai (do esforço deste intérprete, entre inúmeros outros) os estudos ganharam mundo, criando-se uma reação em cadeira para sua popularização e consequente divulgação. Para dar-se conta de seu sucesso atual, basta dizer que Amorim levantou a existência de ao menos 93 gravações parciais ou integrais desses estudos (ver Amorim, 2007, Anexos, p. 231-234), sendo que o próprio Turibio os gravaria quatro vezes...

Com isso podemos contabilizar um espantoso hiato de aos menos 33 anos entre a composição e o momento de início de sua aceitação, consagração e mais, sua compreensão pelo meio violonístico. Hoje os estudos de Villa-Lobos integram programas de conservatórios e universidades, sendo parte indispensável de qualquer formação violonística, ao mesmo tempo em que figuram nos concertos dos mais prestigiados intérpretes internacionais e pode-se dizer que há certo consenso de como resolver seus problemas técnicos, interpretativos e de grafia.

Por outro lado, eis a situação dos estudos de Mignone: compostos em 1970 eles foram editados logo em seguida em 1973 pela Columbia Music Company, e não tardaram tanto a ser gravados em LP pelo próprio dedicatário da obra em 1978 pela Philips Polygram (fora de catálogo há muitos anos), que também nos declarou ter feito várias performances parciais do ciclo em concertos. Porém, após esse pontapé, temos conhecimento de poucos intérpretes que se dedicaram aos mesmos (dos quais elencaríamos Fábio Zanon, Flávio Apro e o próprio autor desta tese) havendo apenas a gravação de Flávio Apro disponível comercialmente. Nestes anos este ciclo ganhou indiscutível notoriedade mas infelizmente aliada a uma reputação de que suas dificuldades seriam intransponíveis.

O âmbito acadêmico também não tem sido favorável ao ciclo mignoniano: enquanto a obra violonística de Villa-Lobos foi foco direto ao menos 22 pesquisas de mestrado e doutorado (resultando em dissertações e teses) e indireto de mais sete (esses números foram contabilizados nas referências bibliográficas de Amorim, 2009, p. 179183) sem falar em incontáveis artigos. Enquanto isso, temos conhecimento de apenas cinco dissertações dedicadas à obra violonística de Mignone somadas à cerca de quatro artigos (alguns deles de foco indireto).

Acreditando na circularidade de conhecimentos entre a prática e teoria, entre o universo acadêmico e extra-acadêmico, temos certeza que quanto mais numerosas 
forem as discussões sobre estes estudos de Mignone (acadêmicas ou não), tal como ocorreram com os de Villa-Lobos, sua absorção pela comunidade violonística crescerá (e também consequentes performances e gravações) e com tal desmistificação virá a revitalização de um ciclo brasileiro da maior importância histórica, estética, técnica e musical. Passados 46 anos desde a composição dos 12 Estudos para violão de Mignone, acreditamos ter chegado o momento de a comunidade violonística reavaliar a atenção que tem dado a esta obra.

2.8: Revisão da Literatura disponível sobre a obra violonística de Francisco Mignone

Consideramos dispensável a realização de uma revisão de literatura específica sobre as investidas de Mignone ao violão, justamente por entendermos que este tópico já foi abordado satisfatoriamente por outros autores, notadamente Flávio Apro (2004, p. 60-64), portanto, nos ocuparemos apenas à listagem dos referidos trabalhos para eventual consulta por parte do leitor.

BARBEITAS, Flávio T. Circularidade Cultural e Nacionalismo nas Valsas de Mignone. Dissertação de mestrado, UFRJ, 1995.

BORGES, João Pedro. O Violão na Obra de Francisco Mignone. In: MARIZ, Vasco (org.). Francisco Mignone, O homem e a obra. Rio de Janeiro, p.45, Funarte \& ED.UERJ, 1997, p.101-105.

SOARES, Albérgio Claudino Diniz. Orientadores Técnicos nos Estudos IV e VII de Francisco Mignone. Dissertação de Mestrado. UFBA. 1998.

GLOEDEN, Edelton. As 12 Valsas Brasileiras em Forma de Estudos para Violão de Francisco Mignone: um ciclo revisitado. Tese de doutorado, USP, 2002.

APRO, Flávio. Os Fundamentos da Interpretação Musical: Aplicabilidade nos 12 Estudos para Violão de Francisco Mignone. Dissertação de mestrado, UNESP, 2004.

ABDALLA, Thiago. Análise Técnico-Interpretativa dos Ciclos de Estudo para Violão de César Guerra-Peixe (Lúdicas), Radamés Gnattali e Heitor Villalobos. Trabalho de Conclusão de curso (TCC). ECA-USP, 2005. 
OLIVEIRA, Rodrigo Carvalho de. Estudos para Violão de Villa-Lobos, Mignone e Gnattali: o idiomatismo revisitado. Dissertação de mestrado em música. UFG. 2006.

KOLODZIEISKI, Allan. Os Doze Estudos para Violão de Francisco Mignone. Artigo. Anais do II Simpósio de Violão da Embap, 2008.

ANTUNES, Gilson e FERNANDES, Marcelo. Aplicações TécnicoInstrumentais e Similaridades nos Estudos para Violão De Heitor Villa-Lobos, Radamés Gnattali e Francisco Mignone. Simpósio Internacional Villa-Lobos, USP, 2009. Disponível no link http:/www2.eca.usp.br/etam/vilalobos/resumos/CO005.pdf acesso em 03/12/2016. 


\section{Parte 3: Prática}

\section{(Aplicação dos conceitos selecionados nos "12 Estudos para violão" de Francisco Mignone)}

\section{Esclarecimentos: aspectos metodológicos, padronizações de notação musical e de} grafia de digitações

Entendendo os 12 Estudos para violão de Francisco Mignone como um problema ser resolvido e tendo encontrado um campo teórico satisfatório sobre a solução de problemas em várias áreas do conhecimento, finalmente chegamos ao ponto de convergência onde tais conceitos teóricos se cruzam com os referidos estudos.

O processo aqui descrito será bastante pessoal, por entender que esta seria uma experiência válida (e talvez precursora) na união destes conceitos ao universo musical/violonístico e que futuramente poderia ser aplicada e absorvida por outros intérpretes em suas práticas de estudo. Também por uma questão de delimitação, será apenas aplicado ao critério digitacional da obra, dessa forma desconsiderando propositadamente outros inúmeros e impressindíveis aspectos musicais que compõem uma interpretação. Em outras palavras, discutiremos mais a respeito da configuração dos dedos de cada passagem do que de sua interpretação musical.

Vimos que os diagramas de Oare (2011) e Sternberg (2012) e na descrição de uma seção de Brainstorm por Dell'Isola (2002) começavam por uma definição clara do problema. No nosso caso, este poderia ser resumido em "tocar os 12 Estudos de Mignone". Nossa "estratégia de solução" (segundo passo do diagrama de Sternberg, 2012) foi consultar métodos de solução de problemas em outras áreas e os transpor para nossa prática.

Seguindo as Heurísticas formuladas no tópico 1.5 desta tese, quando o problema já estivesse bem definido, o próximo passo seria subdividi-lo. Nesse sentido, a estrutura musical já nos ofereceu divisões naturais para esta segmentação. O "grande problema", portanto, poderia ser dividido em 12 obras, que por sua vez poderiam ser subdivididas em seções, frases, semifrases, compassos, tempos, etc.

Mas talvez a colaboração mais decisiva desse campo teórico à nossa abordagem foi a da "suspensão da decisão" prevista pelo "Pensamento Reflexivo" de Dewey, também chamado de "julgamento adiado" pelas técnicas de Brainstorm, de forma que o conjunto escolhido de estudos não foi abordado com pressa na obtenção de resultados, mas sim com o intuito de fomentar em nós o uso deliberado do Pensamento Divergente 
na busca por soluções. Dessa forma, as obras foram lidas e sua digitação foi sendo delineada sempre de forma aberta, provisória.

O item 2 proposto por Oare (2011) "reveja o conhecimento de base" também foi seguido no intuito de se consultar as soluções anteriores ao problema proposto, ou seja, neste caso, observar as digitações propostas por Barbosa-Lima na edição Columbia Music Company (1973) e gravações comerciais do mesmo intérprete (Philips, 1978) e de Flávio Apro (Tempus Clásico, 2013), bem como os poucos trabalhos acadêmicos sobre o tema.

Obedecendo a "Lei da Soberania das informações" (Duailibi e Simonsen, 1990) que aconselha a confiar nas informações que nos são dadas, a digitação proposta por Barbosa-Lima sempre foi o nosso ponto de partida, por entender que ela é uma solução viável (dentre a infinidade de soluções viáveis) e que foi funcional para este intérprete e que também pode o ser para outros. Mesmo assim, deve-se ter em mente que BarbosaLima possui uma técnica admirável que lhe fez conquistar palcos internacionais, porém muito pessoal e pouco habitual para a maioria dos violonistas o que nos leva ao uso respeitoso da "Lei de Friedrich" (Duailibi e Simonsen, 1990) que prevê (contraditoriamente) o questionamento de tudo na busca por novas opções. Os comentários aqui expostos sobre as digitações de Barbosa-Lima não irão mudar a firmeza de nossa profunda admiração pelo trabalho deste intérprete que sempre nos serviu de inspiração na conduta profissional. Soma-se a isto que o fato de ser dedicatário da obra em questão, junto a seu pioneirismo em editá-la, tocá-la e gravá-la, configurando aspectos o bastante para torná-lo referência histórica inegável para os referidos estudos.

Ressaltamos que o próprio Barbosa-Lima nos anos seguintes à edição Columbia (1973) modificou diversos aspectos em sua performance dos estudos que ficariam registrados em sua gravação para Philips Polygram em 1978 e em anotações pessoais em suas partituras de estudo diário, usando a edição Columbia como base. Uma cópia desse documento foi "gentilmente cedida pelo violonista" a Flávio Apro (2004, lista de abreviaturas), que comenta as mudanças:

\footnotetext{
"A versão PH é aquela que foi registrada na gravação de Barbosa Lima lançada pelo selo Philips em 1978. Trata-se da própria partitura CL [Columbia] pertencente ao violonista, com revisões adicionais, novos dedilhados e, em certos casos, longos trechos reescritos. Chega a ser quase uma transcrição [da gravação]. Ao efetuarmos a comparação entre essa versão e o manuscrito BN [Manuscrito de Mignone que na época estava na Biblioteca Nacional], detectamos cerca de 140 diferenças, algumas bastante oportunas e outras equivocadas ou desnecessárias" (Apro, 2004, p.73) [grifo nosso].
} 
Sobre essa nova revisão o próprio Barbosa-Lima revela: "tenho as anotações de todas as correções, o que me permite regressar facilmente a eles em qualquer momento para tocar ou para passar para algum aluno" (Apro, 2004, Anexos). E preocupado com a desatualização da edição Columbia, atenta para necessidade de se publicar uma nova edição revisada: "um passo importante nesse momento seria publicar uma nova edição revisada, explicada, com uma análise não muito extensa de cada um, e depois buscar a gravação que fiz em 1978 para a Philips e lançá-la em CD” (Apro, 2004, Anexos).

Lamentavelmente tentamos sem sucesso obter tal documento com Barbosa-Lima que estava em meio a várias viagens internacionais e não conseguiria ter acesso à seu acervo motivo que nos fez usar a versão Columbia como ponto de partida.

Mas o que queremos com tal argumentação é demonstrar que o próprio revisor fez autoavaliações subsequentes que podem até coincidir com nossas ressalvas às digitações registradas na edição Columbia. Queremos com isso reduzir o peso de nossas críticas, pois realmente somos apreciadores do violonista em questão, mas ao mesmo tempo reconhecemos possuir outra bagagem técnica, advinda de outra anatomia ou facilidade gestual, outra vivência, outro momento histórico, diferenças que também poderão ocorrer em relação aos futuros executantes dos estudos de Mignone.

Será com essa postura respeitosa, mas ao mesmo tempo questionadora que sempre nos reportaremos à revisão de Barbosa-Lima.

Desta forma, a cada passagem (sendo tratada como um pequeno problema a ser superado), associávamos a "suspensão da decisão" ao primeiro estágio do Método Científico, a "observação", o que consequentemente nos levou por vezes a identificação de novos problemas (ex.: uma abertura desconfortável, falta de sustentação de uma nota, etc.) e ao segundo passo do Método Científico, a formulação de novas perguntas (ex.: "e se esta passagem fosse tocada na posição V?", "é possível tocar essa passagem sem ligados?) ou hipóteses (ex.: "acho que o ligado dos dedos 1 e 3 funcionaria melhor com os dedos 2 e 4 nessas notas", "acho que esse acorde poderia soar bem com rasgueios de indicador", etc.), ou seja, soluções provisórias que necessitariam de posteriores testes e novas observações para aferir sua eficácia.

Como resultado deste processo, cada passagem ganhou várias possibilidades de execução desenvolvendo principalmente a habilidade de "Fluência" ${ }^{37}$ " do Pensamento Divergente. Comumente tais opções serão expandidas pelo o uso de alguns verbos do

\footnotetext{
${ }^{37}$ Busca por múltiplas soluções.
} 
checklist de Osborn (usar, adaptar, modificar, aumentar, diminuir, substituir, rearranjar, inverter, combinar, deixar como está) anteriormente citados no tópico 1.4 da presente tese. Como tais verbos serão utilizados inúmeras vezes, optou-se por mencioná-los em notas de rodapé para não atrapalhar a leitura do texto.

Por vezes, mencionaremos que combinações ${ }^{38}$ são possíveis entre nossos exemplos, sem contudo demonstrá-las de fato com um novo exemplo, por critério de praticidade, visto que os exemplos musicais já são demasiado numerosos.

A maior parte dessas possibilidades foi testada em nossa prática diária por maiores ou menores períodos de tempo (e por várias vezes em concertos), sem contudo obedecer a uma metodologia especial. Tal período de teste gerou satisfatoriamente nossas opções finais de execução das obras (a nosso ver), mas obedeceu na maior parte das vezes, critérios subjetivos e pessoais. Por tais motivos, a parte "experimental" das possibilidades será um assunto secundário no decorrer deste trabalho, mantendo nosso foco principal em demonstrar como aplicar o Pensamento Divergente e conceitos afins nas obras selecionadas.

O objetivo é, de acordo com as técnicas de Brainstorm, oferecer uma quantidade suficiente de opções aos futuros intérpretes da obra, bem como demonstrar a eficácia da valorização do Pensamento Divergente como metodologia e prover um modelo para sua maior aplicação.

Por questões de clareza de argumentação, o texto não cumprirá a "lei do julgamento adiado" (Duailibi e Simonsen, 1990) e proverá avaliações de cada passagem junto ao exemplo exposto, evitando, dentro do possível, exprimir critérios de valor. Por outro lado, o texto tentará em alguns momentos, simular o fluxo de pensamento que nos guiou na resolução das passagens, na tentativa de fazer com que o leitor se encontre dentro do processo que trilhamos.

Assim, é preciso deixar o leitor ciente das nossas padronizações na grafia dos exemplos musicais já que notações específicas foram necessárias para registrar mais de uma opção em um só exemplo musical.

Os dedos da me são representados com os números arábicos padrões, sempre próximos a cabeça da nota em questão: $1=$ indicador, $2=$ médio, $3=$ anular, $4=$ mínimo. O único acréscimo será o número 5 que representará o polegar da me, que vem tendo aos poucos um uso mais frequente. A lógica dessa decisão é manter a grafia

\footnotetext{
${ }^{38}$ verbo do checklist de Osborn.
} 
habitual dos dedos 1 a 4 e apenas acrescentar um novo número para o polegar, mesmo que fora de uma ordem orgânica ${ }^{39}$. Achamos isso preferível a nomear este dedo com a letra $p$, algo que o confundiria com a $m d$.

Mais de uma opção de dedos será grafada com < ao lado dos números, que significará a palavra "ou":

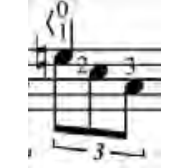

O dedo guia, ou seja, um transporte (sem portamento, ou seja não sonoro) de dedos entre notas será grafado com um pequeno traço ao lado do dedo da me em questão (por exemplo: 1-). O falso guia, dedo que sofre o translado mas que não é o mesmo da nota alvo (ou seja, é substituído durante o translado) será grafado com o mesmo traço acompanhado dos dizeres "falso guia".

O dedo pivot ou fixo (que permanece parado enquanto outros se movem) será grafado com um pequeno triângulo acima ou abaixo do dedo:

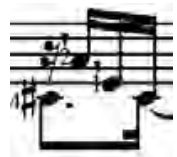

As pestanas $(\mathrm{C} 2)$ e meias-pestanas $(\mathbb{C} 2)$ terão sua grafia habitual com um numeral arábico representado a casa de referência do dedo 1 e sempre acima do pentagrama.

A posição da me será grafada acima da partitura por numerais romanos (ex: I, VI, IX, etc.) sempre em relação à casa ocupada pelo dedo 1. Como os numerais romanos não possuem representação do número zero, será atribuído o número I para a posição na qual o dedo 1 está posicionado antes da primeira casa (situação de rara ocorrência).

Os ligados (articulação de notas pela me) serão grafados normalmente com uma linha curva $(\frown)$ entre duas ou mais notas. Tenha em mente que, com raras exceções, as articulações de ligados de me não excedem muito mais do que três notas de forma que, todas as ligaduras maiores foram previstas pelo compositor e dizem respeito ao fraseio e/ou nível de legato de uma passagem (como a pedalização em peças de piano). Ligados opcionais serão grafados com a mesma linha curva, porém tracejada. Ligados "defasados" ou "atrasados" (entre notas não contíguas) também receberão a linha curva tracejada, mas com o dizer "defasado".

As cordas obedecerão a grafia padrão, onde números de 1 a 6 dentro de círculos representam as cordas da mais aguda a mais grave.

\footnotetext{
${ }^{39}$ para os pianistas por exemplo, a numeração é feita de "dentro para fora” em ambas as mãos, ou seja, iniciando pelos polegares com o número 1 em direção ao dedo mínimo com o número 5.
} 
Os dedos da $m d$ também irão obedecer ao habitual: $p=$ polegar, $i=$ indicador, $m$ $=$ médio, $a=$ anular, com o acréscimo de $c h=$ mínimo (advindo de chiquito, nome coloquial hispânico para este dedo, para não confundi-lo com o dedo médio atribuindolhe com um $m$ ). O toque apoiando será grafado com as mesmas letras sublinhadas (ex.: a), porém será explicitado apenas em momentos onde isso for relevante. A "palhetada", movimento onde o indicador e polegar se agrupam para imitar um plectro, será grafada com $p i$, porém é raramente usada.

A grafia de $m d$ sempre virá abaixo do pentagrama e os dedos aparecerão em linha abaixo de suas referidas notas, no intuito de possibilitar a listagem de várias digitações simultâneas de $m d$ para o mesmo trecho. Sempre que houver mais de um dedo (um abaixo do outro) para uma única nota, entenda-se que são opções viáveis para a mesma:

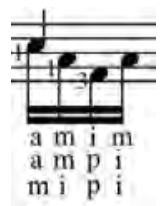

A digitação de $m d$ para acordes será vertical e as distintas opções estarão lado a lado, com um ${ }^{\wedge}$ significando a palavra "ou":

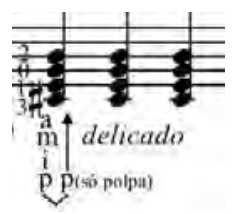

A repetição de um padrão de $m d$ pode ser abreviada pela palavra "etc.", acompanhada de uma chave definindo o tamanho do padrão a ser repetido:

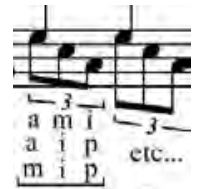

Setas indicarão a repetição de dedos (com ou sem apoio) e normalmente só serão utilizadas para mais de duas repetições do mesmo dedo. Elas também indicarão rasgueios (articulação com as costas dos dedos por movimento extensor) ou escovamentos (articulação praticamente simultânea de duas ou mais notas por um mesmo dedo por movimento flexor), uma vez que essas técnicas também configuram o uso de um mesmo dedo para mais de uma nota.

Os abafamentos (que por vezes também cumprem a função de ponto de apoio) serão grafados pelo dedo seguido de um " $\mathrm{x}$ " e a corda a ser abafada (ex.: p×(6) ).

Divergências entre a edição Columbia e o manuscrito estão assinalados com (m.s.) significando que aquela nota ou detalhe advém do original do compositor. Notas que opcionalmente podem ser suprimidas em alguma versão estão entre parêntesis. Notas excluídas ou substituídas por nós em alguma versão estarão assinaladas por 
escrito assim como eventuais mudanças de oitava. Os exemplos musicais sempre serão referenciados pelo seu compasso de início, mesmo quando possuíam vários compassos.

Também padronizamos dinâmicas (abaixo da partitura) e agógicas (acima da partitura) conforme padrão internacional, sempre que possível. Esta falta de padronização nos foi evidenciada pela revisão do Primeiro trio para flauta, violoncelo e piano de Mignone realizada por Ricardo Santoro (2010) que alerta esta ocorrência neste compositor. Acrescentamos uma revisão no uso de acidentes de cautela, suprimindo sua grafia em trechos desnecessários (para controlar o excesso de "poluição" visual da partitura), acrescentando acidentes onde havia real necessidade e finalmente alertando também ocorrências de notas dúbias. Também tomamos a liberdade de realizar enarmonias (sempre assinaladas) com o objetivo de facilitar a leitura.

Aconselhamos o leitor a sempre ter em mãos a edição Columbia/Barbosa-Lima, já que nem sempre transcreveremos os trechos selecionados, por critério de brevidade. Também solicitamos atenção aos exemplos advindos dos manuscritos e da edição Columbia pois os cortes realizados para demonstrar compassos de meio ou final de sistema inevitavelmente excluem a clave de sol, armadura de clave e fórmula de compasso que vem ao início de cada linha.

Consideramos também oportuno registrar que os exemplos foram concebidos e testados em um violão modelo "Contemporâneo" construído pelo luthier argentino Ricardo Louzao em 2006, que possui escala elevada (tipo "Millennium" de Thomaz Humpfrey) e ausência do tróculo, características que facilitam o uso de digitações a partir da XI posição.

Também aproveitaremos a ocasião para eventualmente, elucidar questões interpretativas e ou de revisão de grafia (notas, ritmos, enarmonias, etc.), embora este não seja nosso objetivo primordial.

Sugerimos que a realização da leitura desta parte prática seja feita com instrumento à mão, pois ele será essencial na decodificação dos exemplos e na compreensão de nosso raciocínio instrumental na resolução de problemas. 


\section{1: I $I^{o}$ Estudo}

Abrindo a série em forma de prelúdio, o $I^{o}$ Estudo já se inicia com duas informações levemente conflitantes: o andamento "Vivo" (mínima $=84)$ associado à indicação cantando, que pode se referir tanto ao emprego de certo rubato na melodia e/ou a apenas definir seu maior destaque, ou intensidade. A contradição existe por que este andamento torna difícil "cantar" a melodia, assim, cada intérprete dará seu peso a essas duas indicações. É possível tocar no andamento prescrito com um cantabile discreto ou inexistente, ou numa interpretação diametralmente oposta, cantá-la com um rubato mais acentuado e assim tocá-la em andamento muito inferior.

\section{Ao grande violonista Barbosa-Lima \\ $I^{\circ}$ ESTUDO}

Fingered by Carlos Barbosa-Lima Vivo $(d=84)$

FRANCISCO MIGNONE (1970)

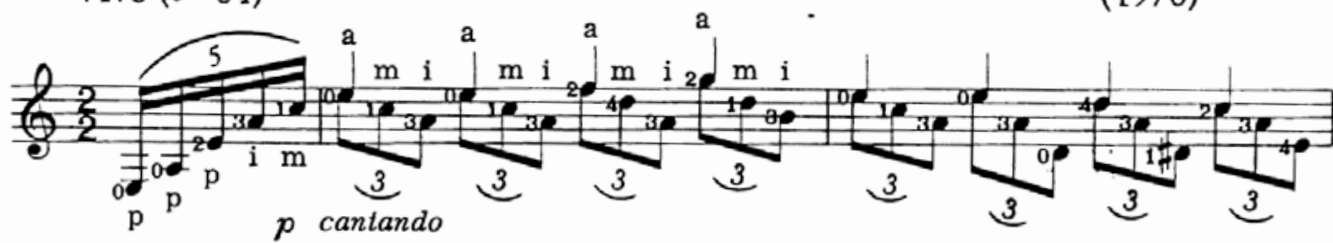

Exemplo 1: $I^{o}$ Estudo, primeiro sistema. Edição Columbia/Barbosa-Lima.

Buscando um meio-termo a este impasse, em nossa interpretação optamos por um leve decréscimo no andamento para melhor frasear a melodia, assim como o uso do toque apoiado na melodia e um leve rubato no primeiro tempo do compasso. Dessa forma, o primeiro tempo fica mais "cantado" e ou outros mais "vivos", fazendo conviver as duas indicações do compositor.

Sérgio Abreu, que teve a oportunidade de escutar o próprio compositor tocando ao piano seus estudos para violão em 1970 (ou seja, no mesmo ano de sua composição), comenta também o equilíbrio entre melodia e acompanhamento nesta obra:

O Estudo $\mathrm{N}^{\mathrm{o}} 1$ (sic.), por exemplo, o Mignone o tocou de uma maneira muito cantada, em que a melodia se destacava totalmente e o acompanhamento não era muito articulado. Quase como se ele estivesse pensando numa melodia para voz ou para um instrumento de sopro, por exemplo um clarinete, com o piano acompanhando num delicado murmúrio. Esse efeito é dificílimo de se conseguir no violão, e me lembro que comentei com o Mignone que esse estudo poderia dar uma excelente peca para 2 violões, mas ele respondeu que preferia que esse estudo fosse tocado apenas como solo de violão e depois ele pensaria em alguma coisa para 2 violões (Sérgio Abreu em entrevista à Flavio Apro, apud Apro, 2004, p.196)

No aspecto técnico a obra também já está sujeita a várias possibilidades de emprego do Pensamento Divergente, característica visível desde sua anacruse inicial: 


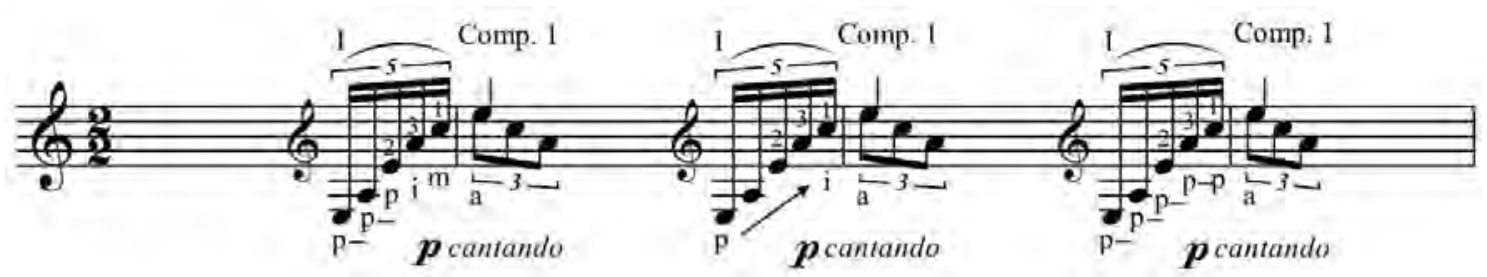

Exemplo 2: I Estudo, compasso 1.

Partindo da opção de Barbosa-Lima (a partir daqui BL) de digitar este trecho pela posição I, registramos no exemplo 2 primeiro a sua opção de $m d$, juntamente a duas outras, com maior participação do polegar. O padrão BL parece partir da premissa inteligente de já colocar os dedos $i$ e $m$ nas cordas que seguirão tocando no próximo compasso. No entanto, as duas outras possibilidades funcionam com igual desenvoltura, sendo que a última oferece maior igualdade as notas da quintina por serem todas tocadas com o polegar.

Explorando o trecho, chegamos ainda a outras duas opções, uma pela quinta casa, que requer o uso de um ligado na quinta corda e outra integrando harmônicos à quintina. Embora ambas usem posições avançadas ${ }^{40}$, elas continuam se conectando com eficiência (por meio de salto) ao compasso seguinte na posição I, devido uso da corda solta na melodia. Registramos que o uso de harmônicos provém caráter mais suave (e levemente desequilibrado) ao trecho, enquanto as outras opções se demonstram mais robustas.

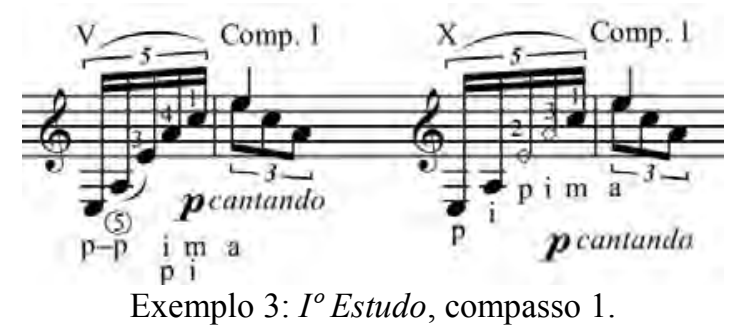

A sequência leva a definição do padrão de $m d$ a ser empregado nos arpejos em tercinas que irão permear toda a obra:

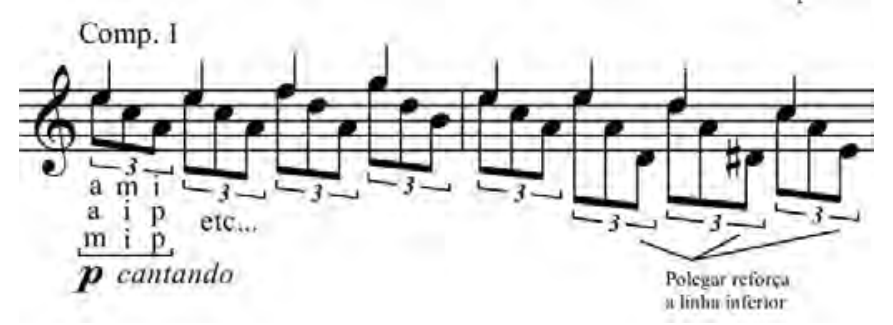

Exemplo 4: $I^{o}$ Estudo, compasso 1. Padrão de $m d$.

O primeiro padrão $a-m-i$ é o empregado satisfatoriamente por $\mathrm{BL}$, onde provavelmente o anelar trabalha em toque apoiando. Os outros dois padrões incluem o

\footnotetext{
40 Por "avançadas", nos referimos à posições de maior valor númerico e não necessariamente à necessidade de maior habilidade do intérprete para alcançá-las.
} 
polegar sempre na nota inferior, o que facilita seu destaque em momentos onde esta voz ganha interesse por sua movimentação cromática. Estes baixos também podem ser prolongados para prover maior legato, como no exemplo seguinte.

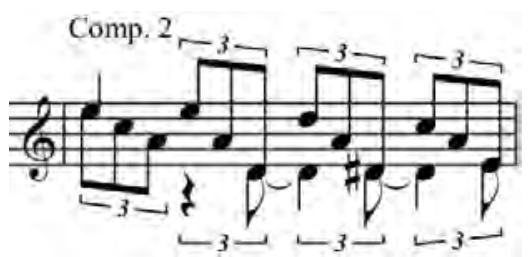

Exemplo 5: $I^{o}$ Estudo, compasso 2.

O compasso 3 recebe normalmente uma abordagem com ligados (por BL e outros) demonstrada no exemplo 6, mas pode também receber versões (exemplo 7) em campanella (efeito de popularização de certo modo recente, que ainda não era ocorrente na época da revisão de BL e que julgamos não fazer parte de seu universo digitacional $^{41}$ ). Embora proporcionem maior sustentação (em efeito que lembra uma harpa), as digitações em campanella costumam gerar menos padrões de $m d$, o que as tornam mais difíceis para esta mão. Mesmo assim, a primeira delas é bastante acessível. Já a segunda (os harmônicos são opcionais) envolve cordas não contíguas, o que configura um desafio adicional mas que ainda sim pode ser superado pelo estudo.

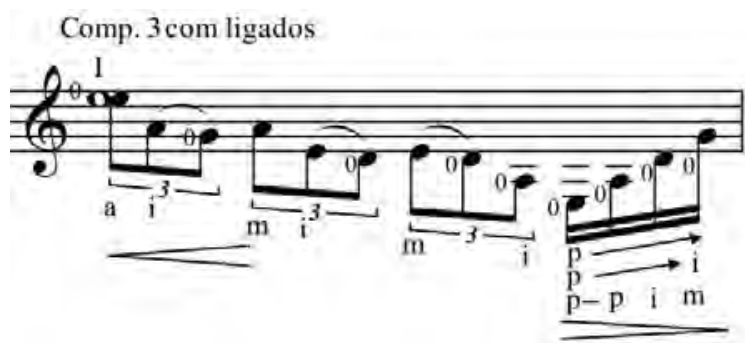

Exemplo 6: $I^{\circ}$ Estudo, compasso 3.

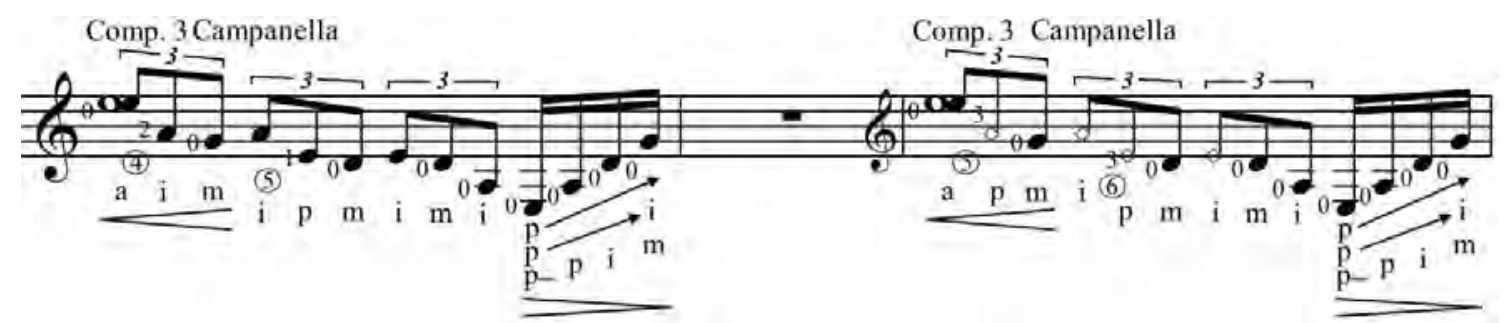

Exemplo 7: $I^{\circ}$ Estudo, compasso 3.

O último tempo do compasso 3 , relembra de forma similar e mais curta o levare inicial da obra, portanto recebe opções análogas de $m d$.

\footnotetext{
${ }^{41}$ Não sabemos precisar a primeira ocorrência moderna das digitações em campanella, embora suspeitamos que tenha sido pelo Duo Presti-Lagoya em meados dos anos 50 do século passado, no entanto, seu uso parece ter se popularizado somente na primeira década do presente século. Como essa maior difusão ocorreu muito tempo após a técnica de Barbosa-Lima ter se solidificado, percebemos que este intérprete (ao menos nos 12 Estudos para violão de Francisco Mignone) não recorre a este recurso técnico.
} 
No compasso 4, o legato necessário da melodia configura complexidade à me e isso gera muitas opções digitacionais. A opção de BL para o trecho (exemplo 8) é funcional, mas oferece uma abertura (primeiro tempo) e uma contração (segundo tempo) ainda seguidas por um salto (terceiro tempo) não muito acessível a qualquer intérprete:

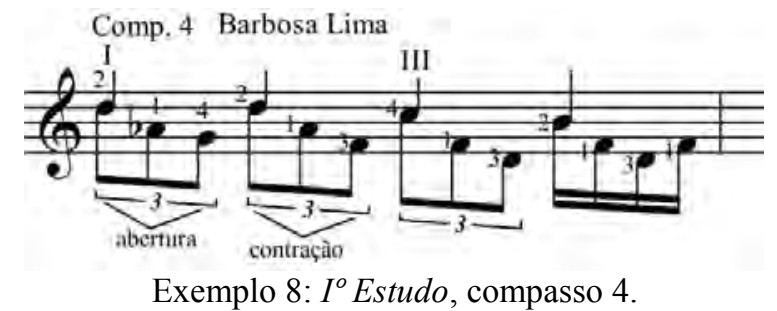

O exemplo 9 apenas inclui uma corda solta no último tempo ${ }^{42}$, a fim de facilitar o salto para o próximo compasso:

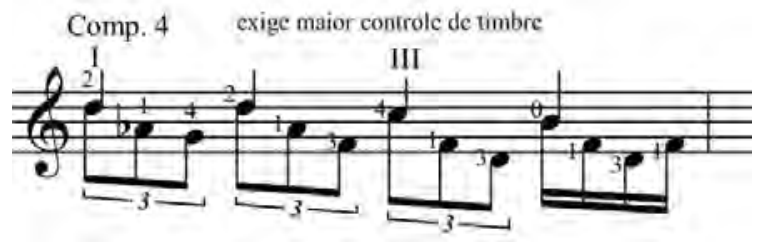

Exemplo 9: $I^{\circ}$ Estudo, compasso 4.

Os exemplos 10, 11 e 13 exploram digitações com ligados, o primeiro usando principalmente os dedos 1 e 4 , o segundo 1 e 3 e o terceiro mantendo a melodia na segunda corda o tempo todo. O último tempo possui um ligado não muito musical (julgamento subjetivo nosso) e pode ser executado como nas versões anteriores ${ }^{43}$. Também devemos ressaltar que os ligados neste trecho, embora facilitadores, podem soar um pouco discrepantes musicalmente em relação aos compassos adjacentes (anterior e posterior).

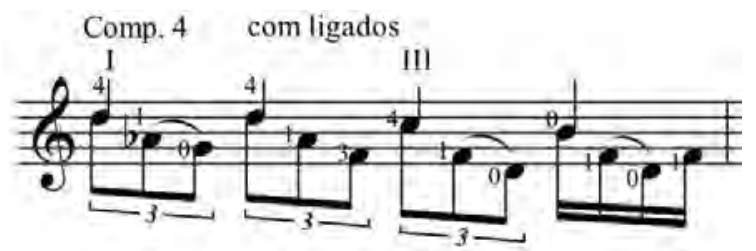

Exemplo 10: $I^{o}$ Estudo, compasso 4.

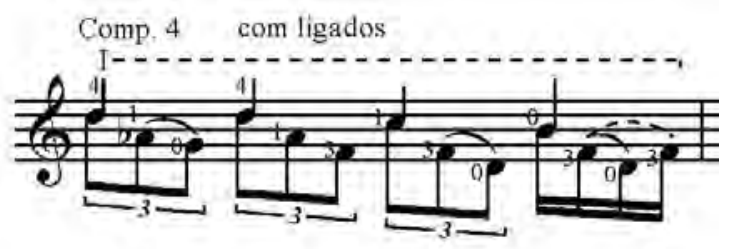

Exemplo 12: I ${ }^{o}$ Estudo, compasso 4.

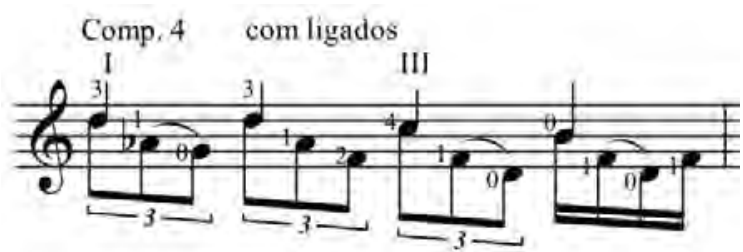

Exemplo 11: $I^{o}$ Estudo, compasso 4.

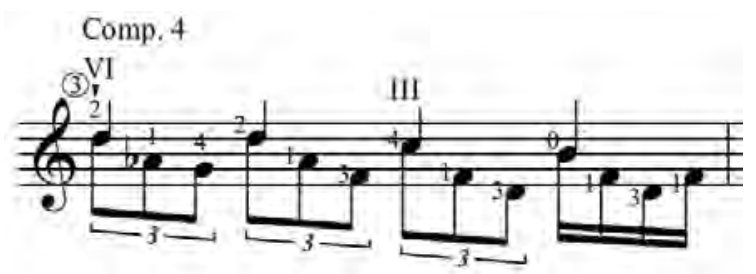

Exemplo 13: $I^{o}$ Estudo, compasso 4.

\footnotetext{
${ }^{42}$ verbo substituir do checklist de Osborn.

${ }^{43}$ verbo combinar do checklist de Osborn.
} 
O exemplo 13 explora a região central do instrumento, ainda com conexões com os compassos adjacentes e resulta em aberturas levemente menores.

O próximo exemplo oferece, através do aproveitamento de cordas soltas, um maior legato ao trecho mas com o custo de gerar maiores aberturas (principalmente no segundo tempo). Tais aberturas, embora grandes, são atenuadas pela presença de dedos fixos: o dedo 1 já vem preparado no compasso anterior, o dedo 3 fica fixo entre os dois primeiros acordes e o dedo 4 nos três últimos tempos, o que torna estas aberturas progressivas e dessa forma um pouco mais palatáveis.

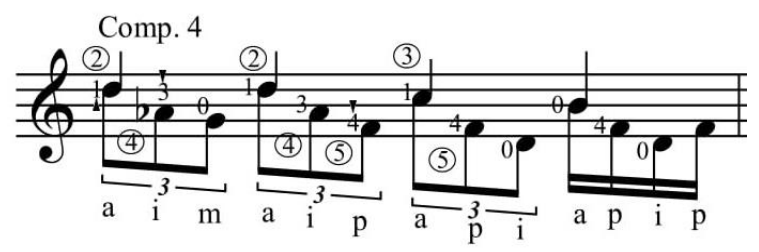

Exemplo 14: $I^{o}$ Estudo, compasso 4.

Retornando um pouco à lei Heurística da simplicidade (tópico 1.5), o exemplo 15 mantém o trecho na posição I por meio de uma combinação ${ }^{44}$ de aspectos dos exemplos 8 (dois primeiros tempos de BL), 9 (corda solta no último tempo), 12 (melodia na segunda corda) e 14 (aberturas progressivas e minimizadas/preparadas por dedos fixos). Este é um exemplo de como uso deliberado do Pensamento Divergente para gerar múltiplas soluções nos leva a lugares por vezes inesperados, criando outras possibilidades que dificilmente seriam geradas sem este processo de reflexão progressiva.

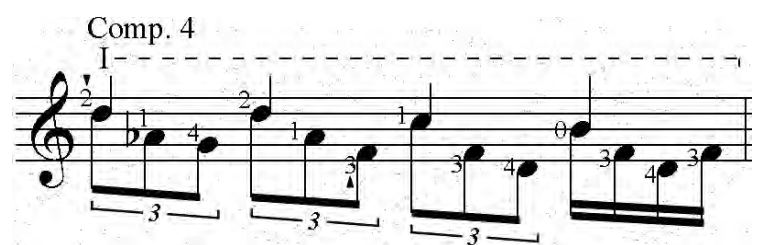

Exemplo 15: $I^{o}$ Estudo, compasso 4.

No trecho iniciado no compasso 7 a melodia fica estática, dando espaço para movimentações na voz inferior, o que gera a dupla dificuldade de manter o legato durante as mudanças dos baixos (que por vezes exige trocas de posição) e ao mesmo tempo manter o timbre da nota superior (que por vezes sofre troca de dedos e/ou cordas). Acreditamos que esta passagem é particularmente favorecida com uma execução prolongada da voz inferior que passa a ter mais destaque no trecho, aspecto que buscaremos lograr. A título de compreensão esse legato seria grafado assim:

\footnotetext{
${ }^{44}$ verbo do checklist de Osborn.
} 


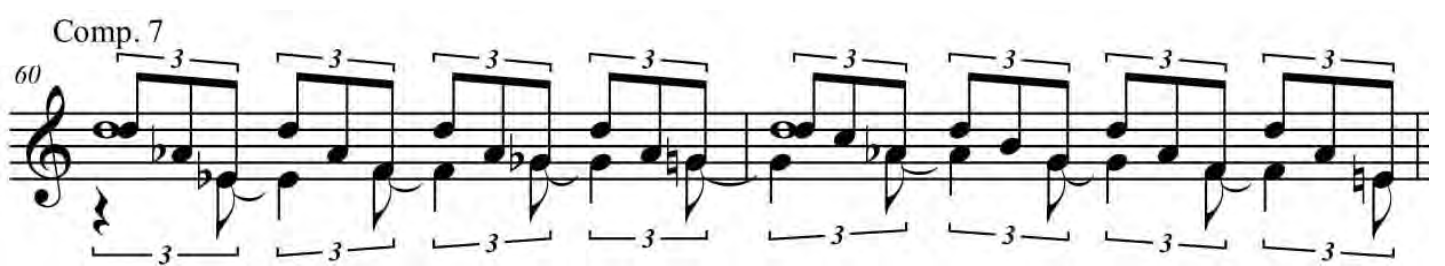

Exemplo 16: $I^{\circ}$ Estudo, compasso 7.

O Exemplo 17 mostra a digitação BL com posições e dedos guias detalhados por nós e atesta uma dubiedade no fim do compasso 9, onde a nota grafada é Sol sustenido (idem no manuscrito) e BL a digita como corda solta, o que resultaria na nota Sol natural.

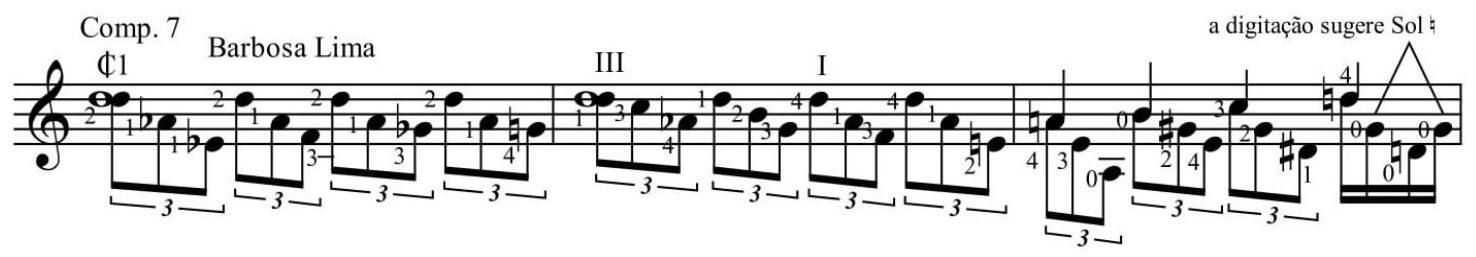

Exemplo 17: $I^{o}$ Estudo, compasso 7. Digitação BL.

Neste caso, optamos pelo Sol\# por constar no manuscrito (ex. 18, destacado por setas) e por se tratar de um acorde de dominante e esta ser a nota sensível da tonalidade.

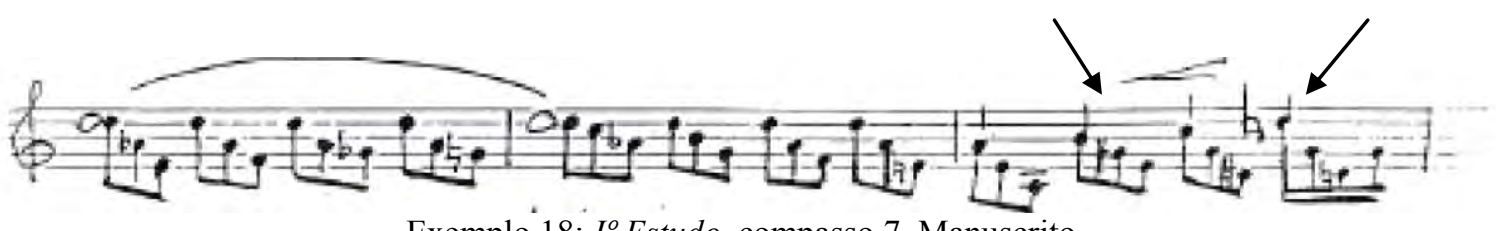

Exemplo 18: $I^{o}$ Estudo, compasso 7. Manuscrito.

Nossa primeira tentativa (ex. 19) foi aproveitar as cordas soltas do segundo tempo do compasso 8 , mas isso leva a melodia para a terceira corda o que por sua vez exige maior controle tímbrico. Por outro lado, essa opção acaba favorecendo uma melhor solução do compasso 9, trecho onde a digitação BL exige grande esforço.

Comp. 7

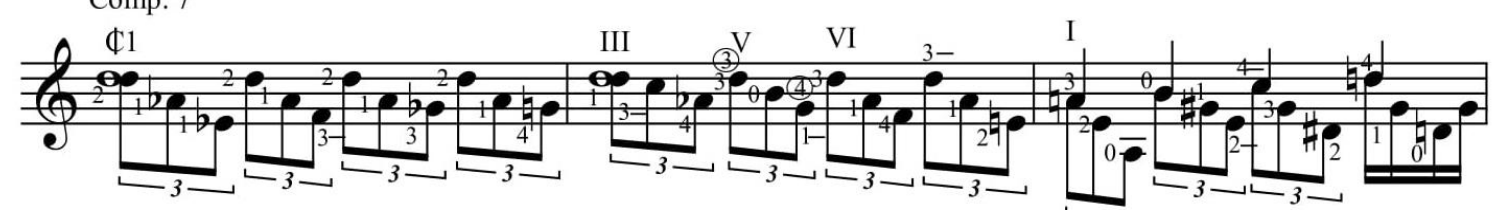

Exemplo 19: $I^{o}$ Estudo, compasso 7.

Entendendo que a pestana na primeira casa dificultava as aberturas dos exemplos anteriores, as duas próximas tentativas prescrevem o início do trecho pela posição VI, o que propicia uso de casas menos afastadas no compasso 7 gerando, todavia, uma abertura no primeiro tempo do compasso 8. A primeira delas também recorre ao uso de 3 cordas diferentes na melodia (uma delas em harmônico opcional) o que novamente favorece uma discrepância de timbre. 


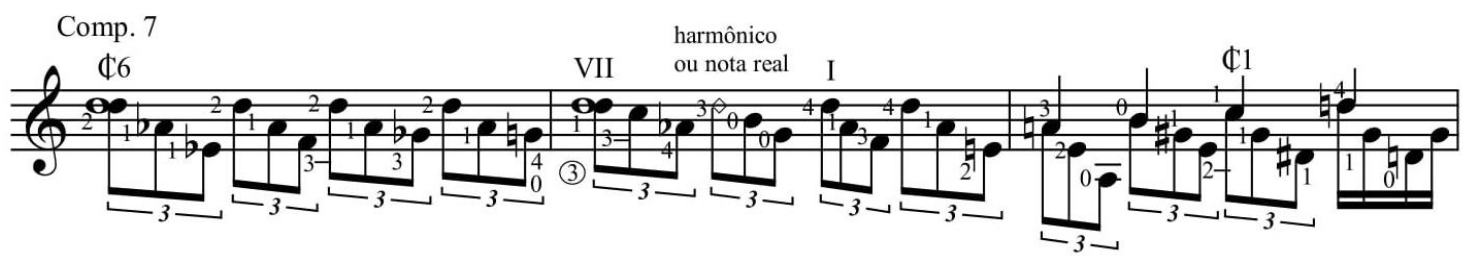

Exemplo 20: $I^{o}$ Estudo, compasso 7.

Já o exemplo 21, ainda mantém a abertura do compasso 8, mas oferece transição mais suave ao tempo seguinte ao utilizar o dedo 1 fixo na melodia, envolvendo assim menos cordas na voz superior, mas ainda com diferença tímbrica.

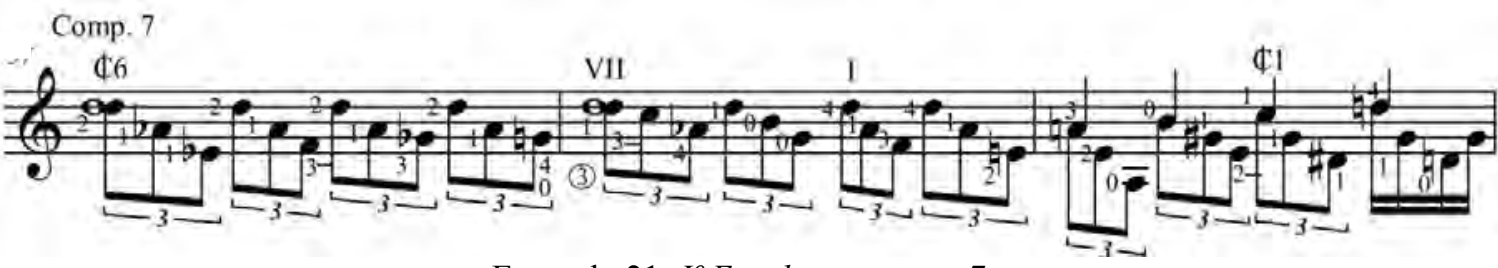

Exemplo 21: $I^{\circ}$ Estudo, compasso 7.

Outra solução válida para o compasso 7 foi oferecida por nosso orientador, Prof.

Dr. Edelton Gloeden, ainda na posição I, mas com a substituição ${ }^{45}$ dos dedos propostos por BL e assim deixando um dedo livre para cada nota do baixo (dedos 1, 2 e 4) e resolvendo o último tempo por meio de um ligado.

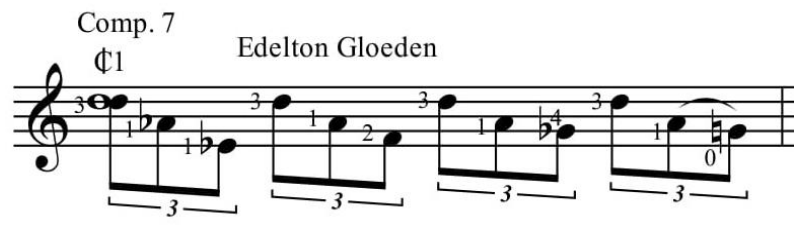

Exemplo 22: $I^{\circ}$ Estudo, compasso 7.

Nossa performance acabou se acostumando com uma união ${ }^{46}$ entre a digitação BL dos dois primeiros compassos e o último compasso do exemplo 19.

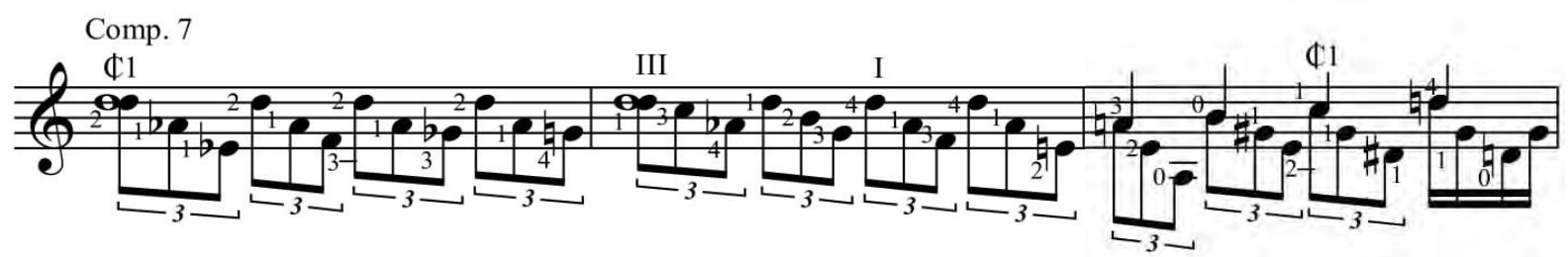

Exemplo 23: $I^{o}$ Estudo, compasso 7.

No compasso 10, a digitação BL respeita a distinção de vozes proposta pelo compositor (especialmente no segundo tempo), mas parece utilizar demasiadamente o dedo 4, incluindo um salto do mesmo no terceiro tempo, levemente desconfortável:

\footnotetext{
${ }^{45}$ verbo do checklist de Osborn

${ }^{46}$ verbo combinar do checklist de Osborn.
} 


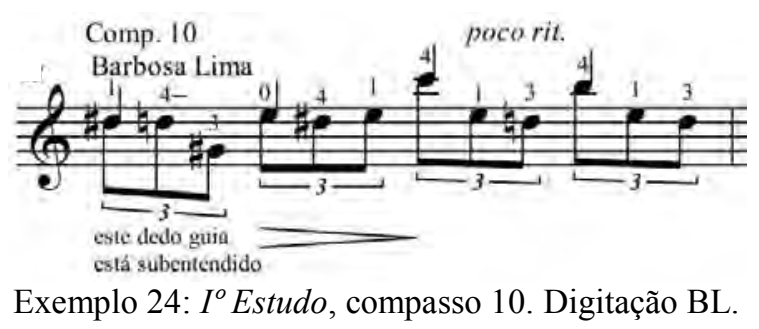

O exemplo 25 facilita a atuação do dedo 4, mas no segundo tempo cria um salto similar com o dedo 3 e não respeita a divisão de vozes do compositor:

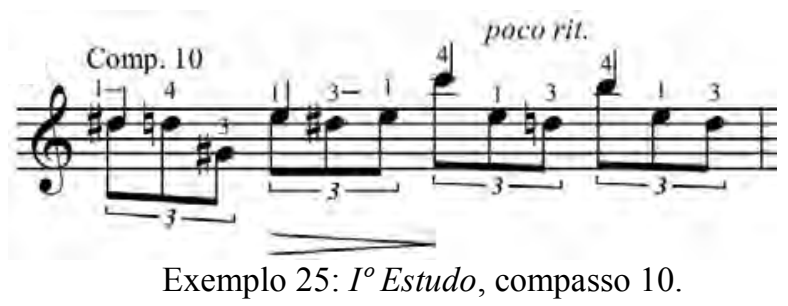

O exemplo 26 conserta este último lapso ao inserir uma corda solta em atitude similar a BL, integrando as duas versões anteriores ${ }^{47}$ :

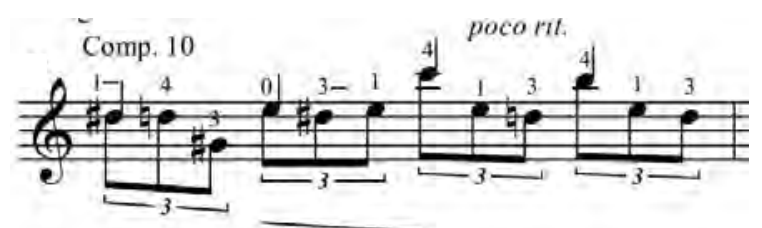

Exemplo 26: I $I^{\circ}$ Estudo, compasso 10.

Agindo por substituição ${ }^{48}$ e exacerbando o uso de cordas soltas, o próximo exemplo oferece uma maior e benéfica sustentação ao trecho (não prevista originalmente), mas novamente não discerne as vozes do segundo tempo:

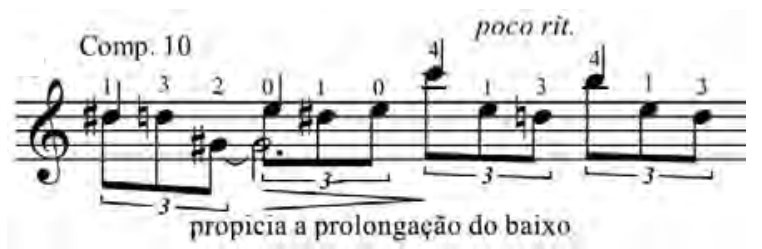

Exemplo 27: $I^{\circ}$ Estudo, compasso 10.

O exemplo 28 experimenta o uso de um ligado no segundo tempo do trecho, bastante ágil e fácil, mas de maneira um pouco "destrutiva" na distinção das vozes.

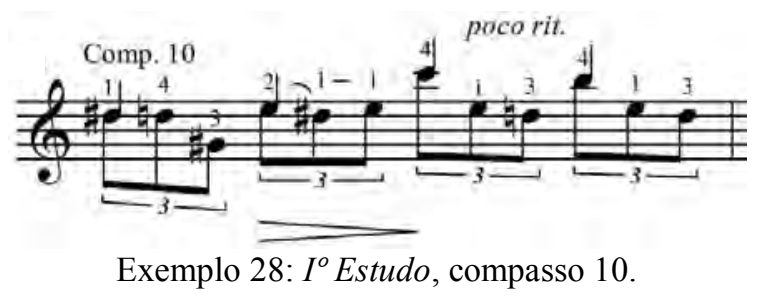

Já a inclusão de um portamento nas notas secundárias do segundo tempo confere a mesma agilidade ao trecho mas contorna o problema anterior.

\footnotetext{
${ }^{47}$ verbo combinar do checklist de Osborn.

${ }^{48}$ verbo do checklist de Osborn.
} 


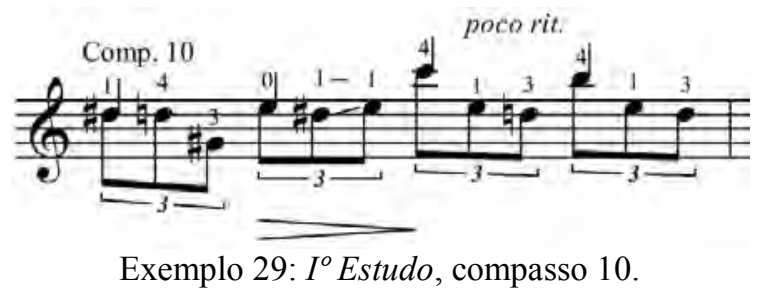

O exemplo 30 integra o uso do portamento com a mesma sustentação de notas do exemplo 27 (gerada por substituição ${ }^{49}$ de dedos), conciliando agilidade e legato na passagem.

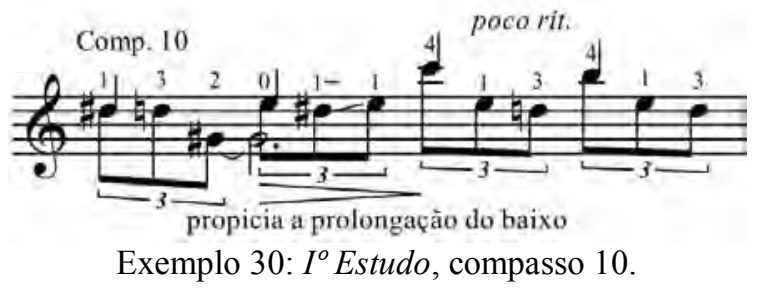

O exemplo 31 mantém $^{50}$ as características benéficas do anterior e o elabora com o critério de "originalidade" do Pensamento Divergente (ou seja, uma resposta rara e/ou inovadora) ao incluir harmônicos naturais no final da frase, flexibilizando um pouco mais a indicação de poco ritenuto.

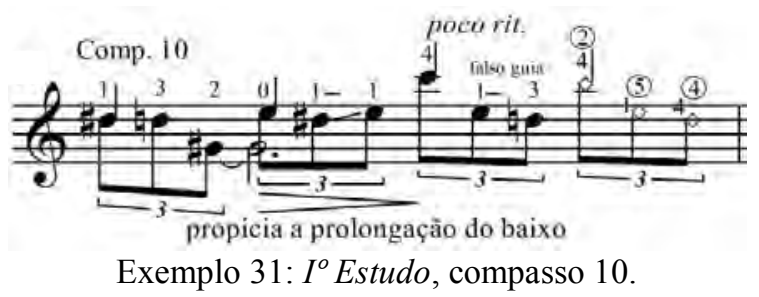

O compasso 14 oferece novo desafio: um arpejo envolvendo todas as cordas do instrumento em amplo movimento descendente e ascendente, com ritmo bem definido. A digitação BL prevê no início do arpejo uma transferência de localização vertical da $m d$ (conforme definido por Canilha, 2018, p.74-77), ou seja, inicialmente o grupo $a-m-i$ está alinhado às cordas mais agudas e o dedo $m$ tem que saltar para a quarta corda, vindo de um cruzamento e o arpejo finaliza-se com a alternância dos dedos $m$ e $a$ (e o próximo compasso se inicia com o anelar novamente). Ambas as características digitacionais não são impossíveis, mas podem ser evitadas pois geram dificuldades.

\footnotetext{
${ }^{49}$ verbo do checklist de Osborn.

50 item "deixar como está" do checklist de Osborn.
} 


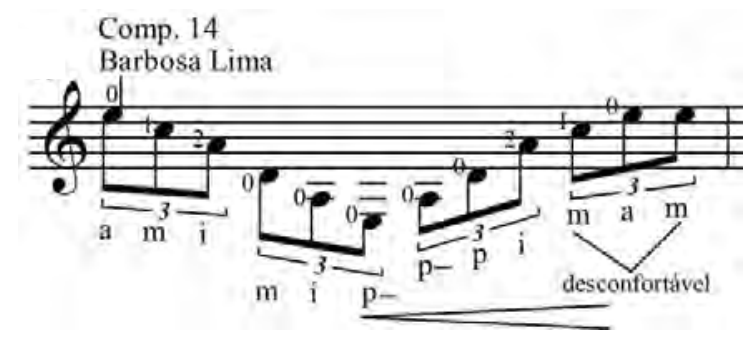

Exemplo 32: $I^{\circ}$ Estudo, compasso 14. Digitação BL.

Dividindo o problema, as primeiras versões tentam modificar ${ }^{51}$ apenas a digitação do final do arpejo. O exemplo 33 , também mantém ${ }^{52}$ o uso reincidente do polegar descendente similar a BL, mas finaliza o arpejo de duas formas distintas. Aconselha-se que o polegar descanse também em alguma corda na parte final do arpejo para dar ponto de apoio a $m d$.

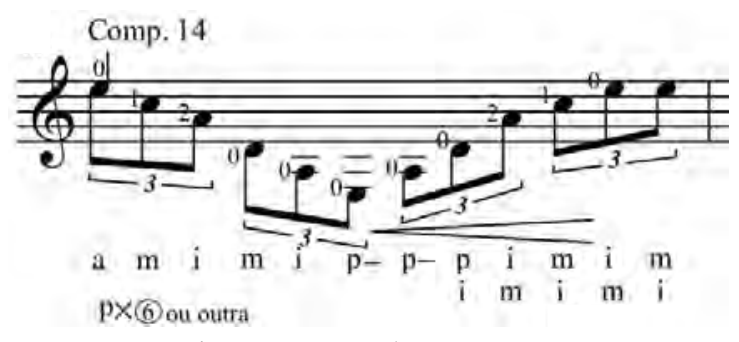

Exemplo 33: I Estudo, compasso 14.

As próximas opções também iniciam da mesma forma, mas agora abdicam da repetição do polegar. O exemplo 34 apresenta pouca estabilidade da $m d$ e muitos cruzamentos, não sendo muito satisfatório em nossa avaliação. Já o exemplo 35, apesar de partir da mesma premissa de evitar o deslizamento do polegar, oferece mais padrões na subida final (assinalados) e funciona bem, mesmo exigindo um salto considerável do polegar (que sai da sexta corda e vai para a terceira).

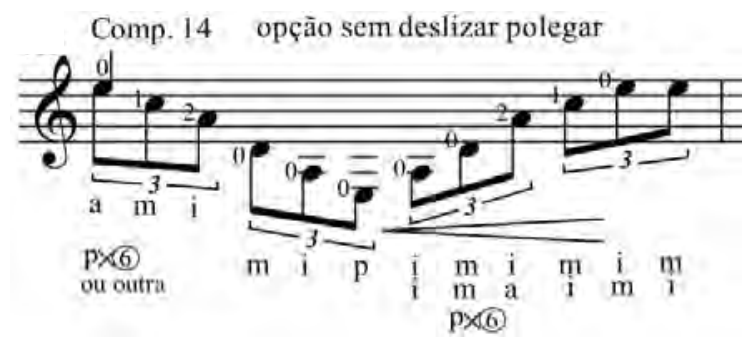

Exemplo 34: $I^{o}$ Estudo, compasso 14

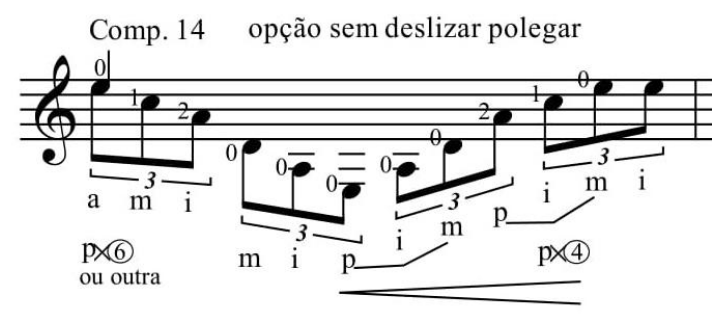

Exemplo 35: $I^{o}$ Estudo, compasso 14.

Os exemplos seguintes interferem também na digitação do início do trecho. $\mathrm{O}$ exemplo 36 aproveita o padrão $p-m-i$ do final do exemplo anterior e o aplica ao início do compasso. Novamente o polegar tem vários saltos, mas a alta ocorrência de padrões

\footnotetext{
${ }^{51}$ verbo do checklist de Osborn.

52 item "deixar como está" do checklist de Osborn.
} 
parece compensar esse aspecto. Este padrão inicial também funcionaria combinado ${ }^{53}$ com o final do exemplo 33.

Comp. 14 opção sem deslizar polegar

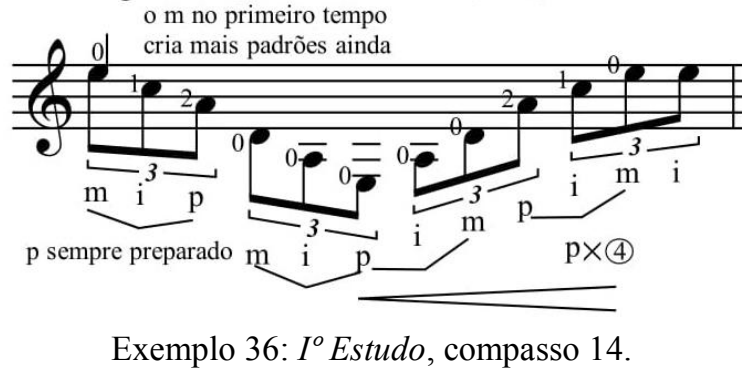

Já os exemplos 37, 38 e 39 exploram, no início do arpejo, digitações escovadas, ou seja, reiterações descendentes de um mesmo dedo. O exemplo 37 começa com duas notas tocadas pelo anelar com boa funcionalidade. Já o início com rearticulação tripla deste mesmo dedo (exemplo 38) não logra o mesmo resultado, por ocorrer um leve travamento do dedo nessa tripla repetição e haver certa dificuldade na entrada do dedo $m$, que tem de se dobrar muito para alcançar a quarta corda.

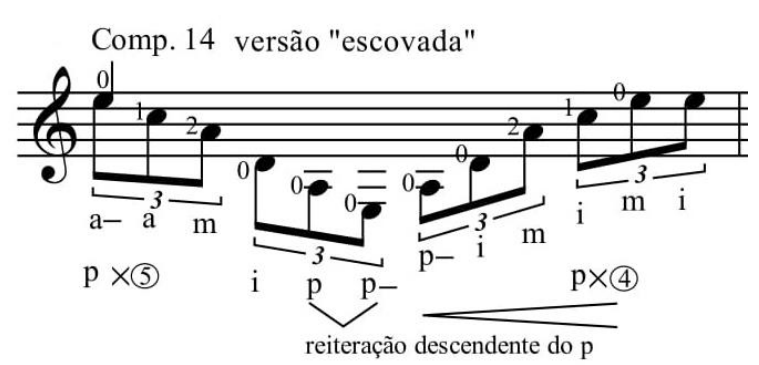

Exemplo 37: $I^{o}$ Estudo, compasso 14.

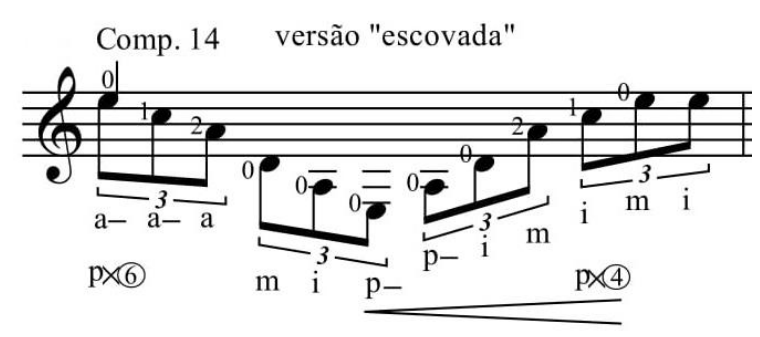

Exemplo 38: $I^{o}$ Estudo, compasso 14.

Por outro lado, repetições maiores (de três cordas) exigem maior controle rítmico mas funcionam com propriedade neste caso, podendo ser iniciadas com os dedos $m$ ou $a$ na parte descendente e com o polegar na parte ascendente do arpejo:

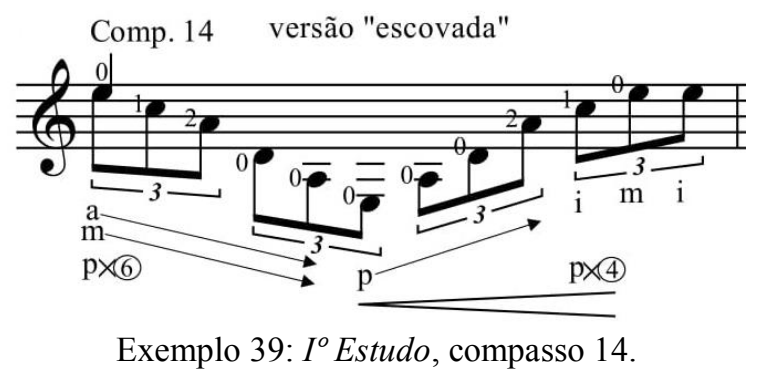

Existem opções em outras regiões do instrumento. A primeira delas nos foi sugerida pelo prof. Dr. Edelton Gloeden, nosso orientador, e aproveita, por meio de finalização na posição $\mathrm{V}$, cordas duplas nas últimas duas notas do compasso:

\footnotetext{
${ }^{53}$ verbo do checklist de Osborn.
} 


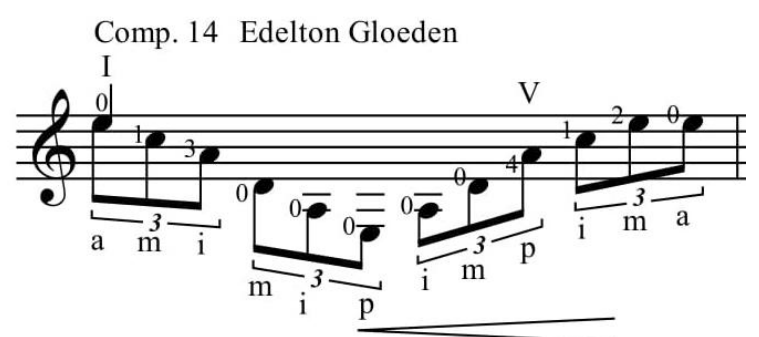

Exemplo 40: $I^{o}$ Estudo, compasso 14.

Essa digitação na posição $\mathrm{V}$ nos levou a percepção de que algumas notas poderiam ser ligadas a cordas soltas, com boa fluência, como nos exemplos 41 e 42:

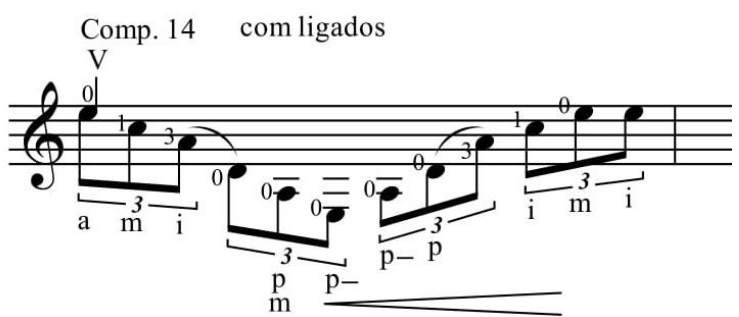

Exemplo 41: $I^{o}$ Estudo, compasso 14.

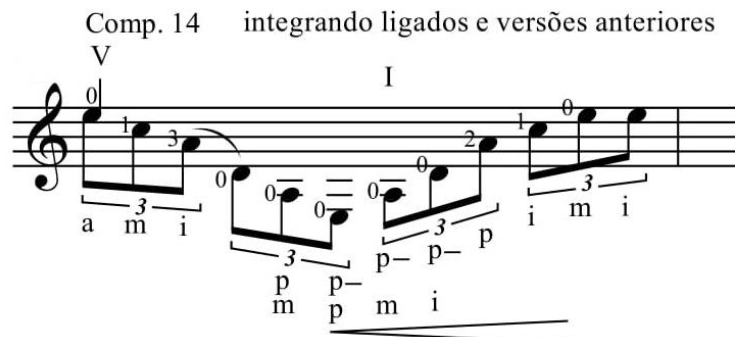

Exemplo 42: Io Estudo, compasso 14.

Levando essa ideia ainda adiante nos exemplos 43 e 44, a posição X possibilita o uso de ligados defasados (ou seja, com duas notas de diferença), técnica ágil mas de pouca ocorrência, que por sua vez demanda estudo específico para conquistar a sincronia necessária entre as mãos e igualdade de som entre notas ligadas e articuladas.

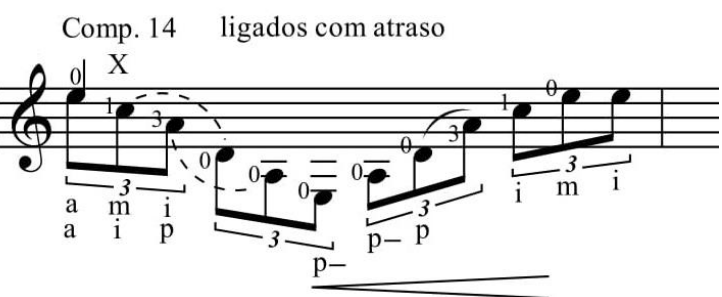

Exemplo 43: I $I^{o}$ Estudo, compasso 14.

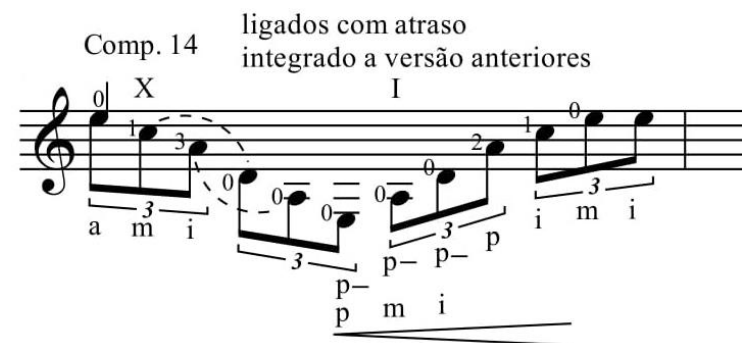

Exemplo 44: I Estudo, compasso 14.

O trecho iniciado no compasso 15 (ex. 45) gera mais uma revisão do que múltiplas versões. Optamos (no ex. 46) por inverter ${ }^{54}$ duas notas para manter o padrão de $m d$ dominante no estudo e no final do trecho, incluímos uma pestana na terceira casa, configurando nos dois casos, mudanças simples e bastante facilitadoras.

\footnotetext{
${ }^{54}$ verbo do checklist de Osborn.
} 


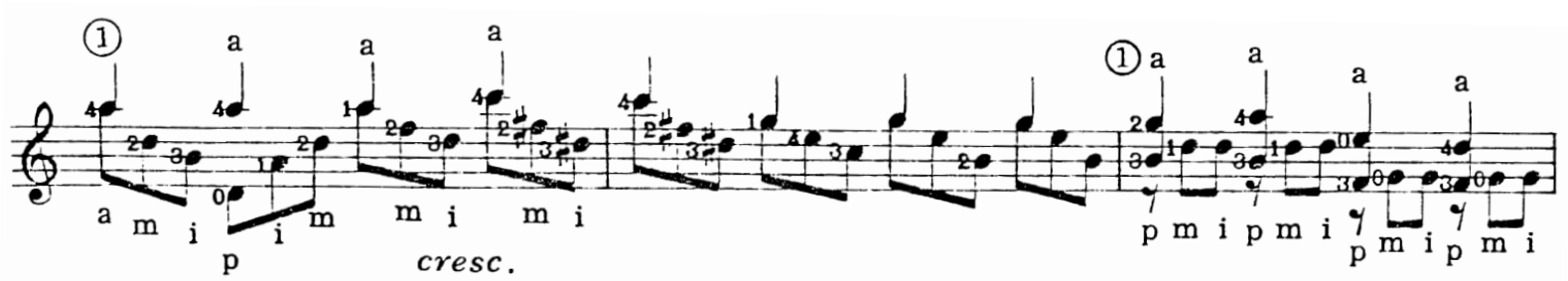

Exemplo 45: $I^{o}$ Estudo, compasso 15. Edição Columbia/Barbosa-Lima.

Comp. 15 opcional (visão pessoal do revisor)

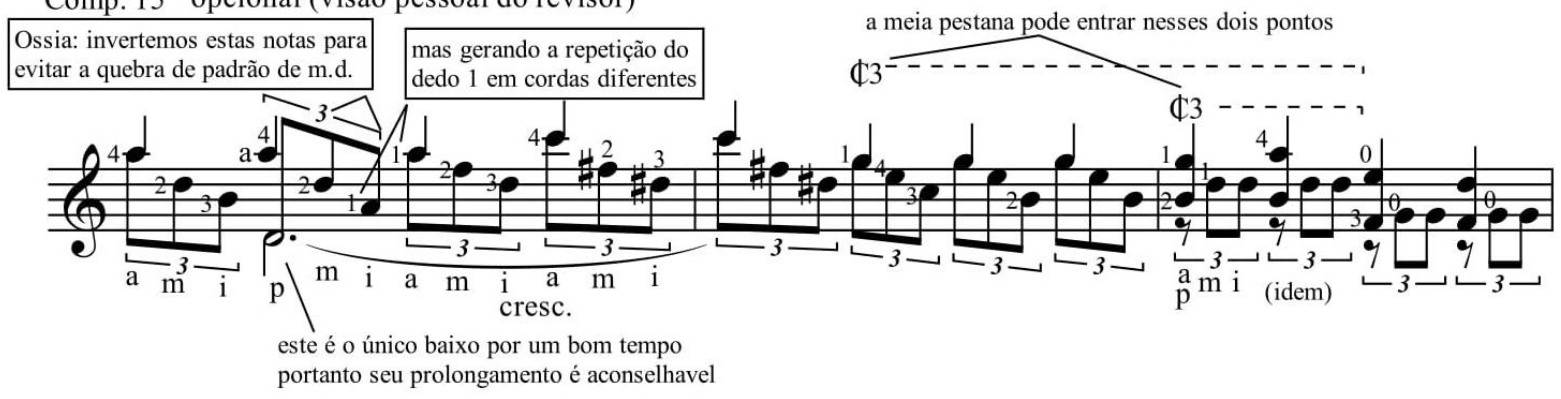

Exemplo 46: $I^{o}$ Estudo, compasso 15.

De maneira similar, o compasso 18 (versão BL no ex. 47), recebe apenas uma segunda opção de digitação de $m d$ que busca manter o polegar na quarta corda (ex. 48) e uma Ossia (versão facilitada) que evita a quebra de padrão no terceiro tempo do compasso, mas sobre o custo de perder um pouco o encaminhamento rítmico do acompanhamento original.

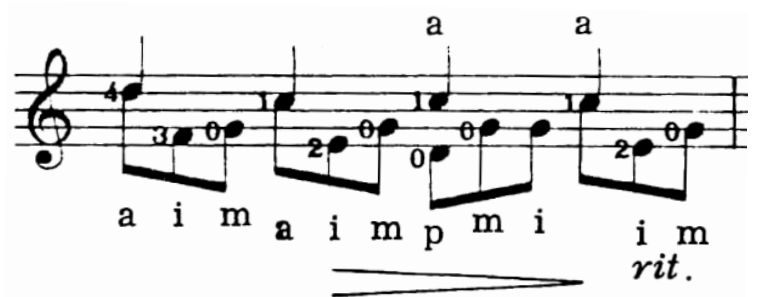

Exemplo 47: $I^{o}$ Estudo, compasso 18. Edição Columbia/Barbosa-Lima.

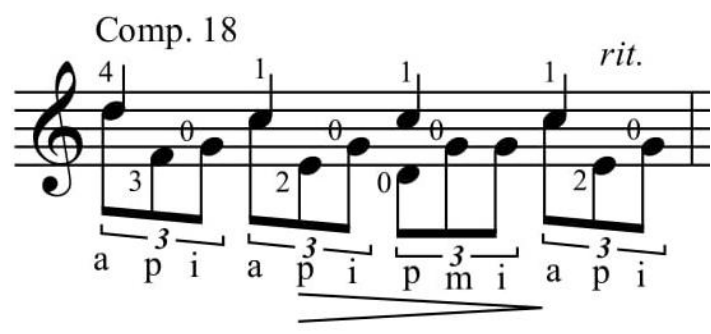

Exemplo 48: $I^{\circ}$ Estudo, compasso 18.

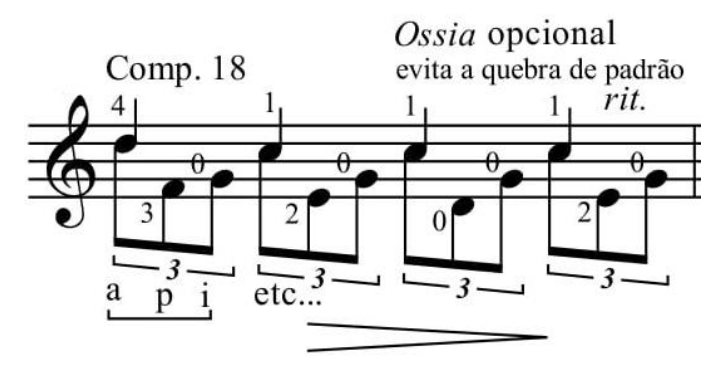

Exemplo 49: $I^{\circ}$ Estudo, compasso 18. Ossia.

O trecho iniciado no compasso 19, por envolver um acorde diminuto arpejado em paralelismo (compasso 20) gera várias resoluções. A digitação BL (exemplo 50) privilegia as cordas internas (segunda, terceira e quarta cordas) para os acordes paralelos e a chegada e a saída dos mesmos apresentam dificuldades: há um salto 
arriscado do dedo 1 no primeiro tempo do compasso 20 e o primeiro tempo do compasso seguinte carece de conexões:

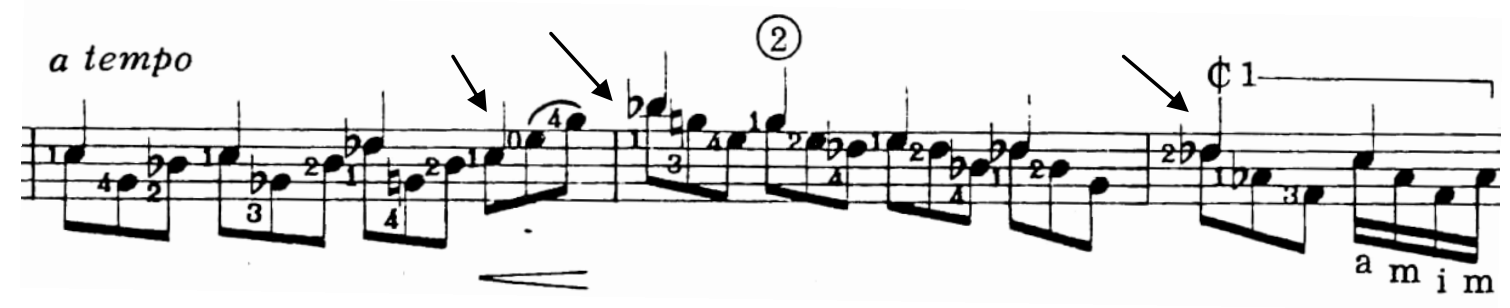

Exemplo 50: $I^{o}$ Estudo, compasso 19. Edição Columbia/Barbosa-Lima.

A primeira abordagem é aproveitar a digitação BL com ligado no último tempo do compasso 19, mas conectá-la por um translado do dedo 4 ao compasso seguinte. Isso também gera a ideia de aplicar ligados ao trecho. Embora funcional, ela ainda apresenta nenhuma conexão com o compasso final do trecho.

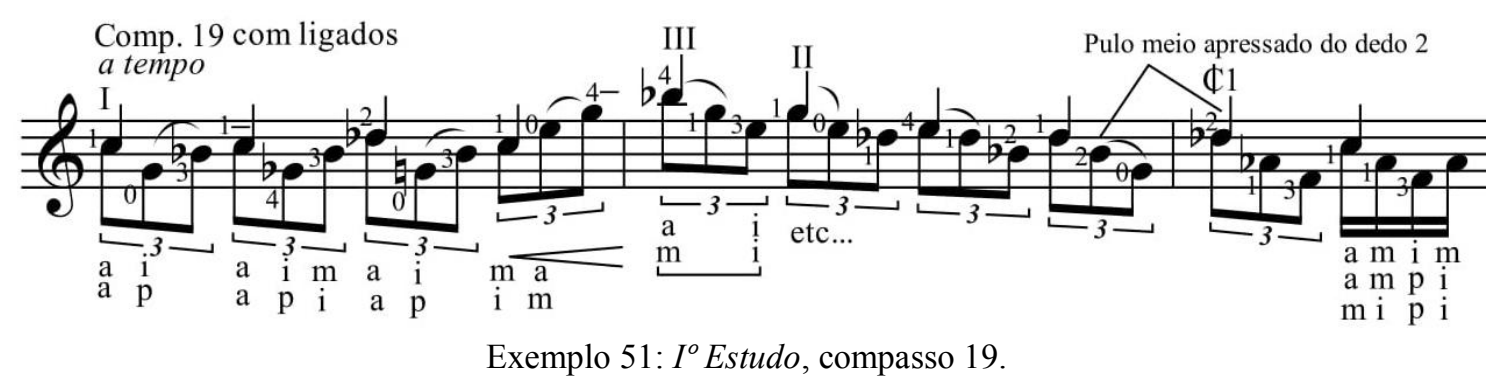

Outra abordagem diametralmente oposta a de BL para este mesmo último tempo do compasso 19 (e explorada nos exemplos 52 e 53) é digitá-lo como um acorde na terceira posição, tendo o dedo 1 como guia da transição entre compassos e deixando os acordes paralelos nas cordas agudas do instrumento. $\mathrm{O}$ exemplo 52 também propõe, sem sucesso, leves substituições ${ }^{55}$ no primeiro compasso, enquanto o exemplo 53 combina $^{56}$ diversos aspectos das opções anteriores (o início de BL, o meio do exemplo 52 e o final do exemplo 51):

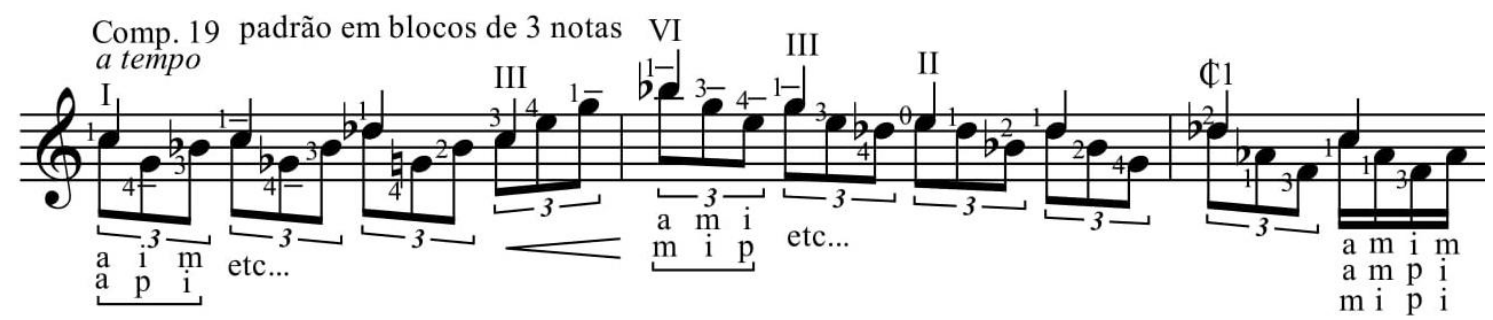

Exemplo 52: I Estudo, compasso 19.

\footnotetext{
${ }^{55}$ verbo do checklist de Osborn.

${ }^{56}$ verbo do checklist de Osborn.
} 


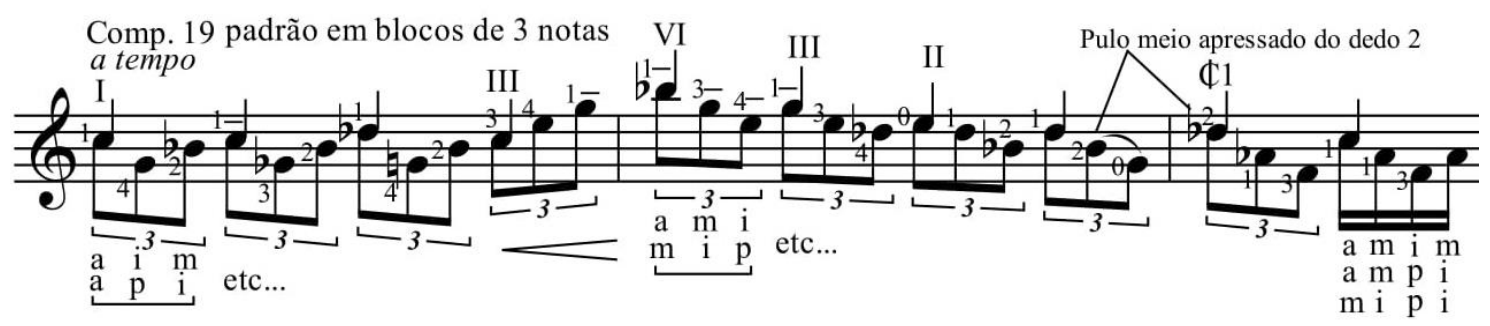

Exemplo 53: I Estudo, compasso 19.

O exemplo 54 mantém mais literalmente a ideia do paralelismo descendente pelas cordas agudas, ainda necessitando de um ligado e gerando uma conexão com o compasso seguinte (ainda delicada) por substituição (ou seja, o dedo 2 "empurra" o 3 e ocupa seu lugar):

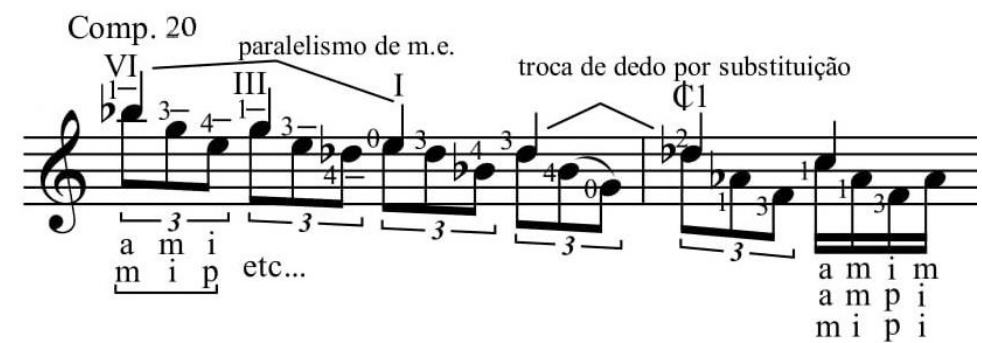

Exemplo 54: $I^{\circ}$ Estudo, anacruse do compasso 20.

Este último recurso técnico (a troca de dedo por substituição) pode ser adiantada em um tempo, deixando o dedo 2 fixo na entrada do último compasso como no exemplo 55 , talvez melhor conexão para o trecho. Este exemplo ainda aplica ao último tempo do compasso 19, o mesmo ligado proposto pela digitação BL, mas agora na posição III:

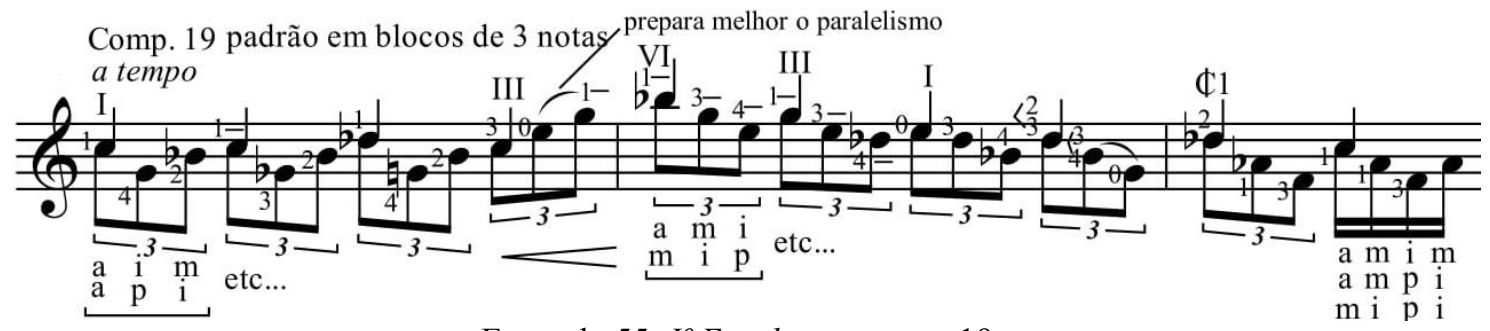

Exemplo 55: I Estudo, compasso 19.

Também partindo de uma conexão pela terceira casa, o exemplo 56 leva o dedo 1 para a sexta casa, onde poderia seguir a digitação BL, mas diferentemente criamos aqui uma versão em campanella com aproveitamento das cordas soltas (novamente sobrecarregando um pouco a $m d$ ): 


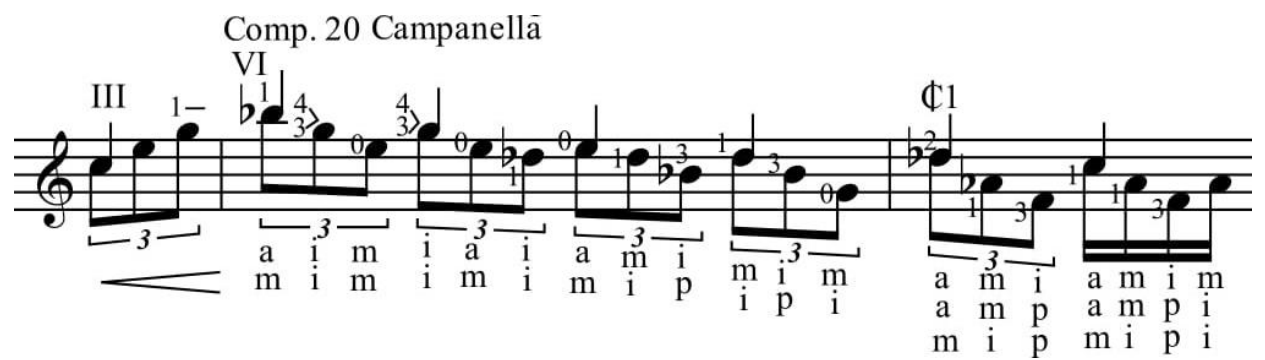

Exemplo 56: $I^{o}$ Estudo, anacruse do compasso 19 para o 20.

O próximo trecho apresenta uma dificuldade notável em como chegar ao acorde com pestana na terceira casa no compasso 23. A abordagem de BL (exemplo 57) é inteligente ao aproximá-lo no compasso anterior pela posição IV, mas o faz ao custo de algumas dificuldades: é penoso alcançar os dedos 1, 2 e 4 no terceiro tempo do compasso 21, que acabam por espremer o dedo 3 no tempo seguinte e geram aberturas no próximo compasso, sem contudo oferecer uma boa conexão dos dedos no acorde.

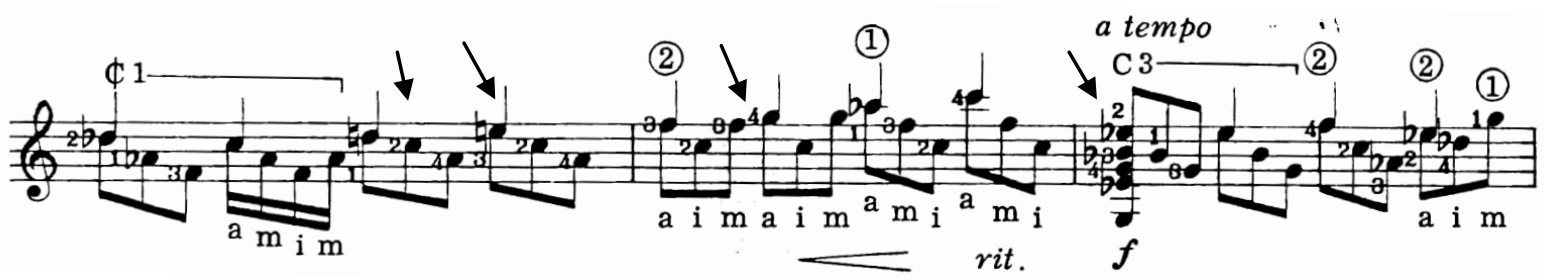

Exemplo 57: $I^{\circ}$ Estudo, compasso 21. Edição Columbia/Barbosa-Lima.

Nossas primeiras versões tentam aproveitar mais a primeira corda na subida, ainda aproximando o acorde pela posição IV como BL. No exemplo 58 o acorde é preparado por meias-pestanas progressivas: no compasso 22 a meia-pestana na casa 1 pressiona duas cordas e depois salta para a casa 4 cobrindo as seis cordas mas apenas apertando a primeira corda com a falange proximal, dessa forma preparando a pestana inteira do acorde do compasso seguinte. Lamentavelmente, essa pestana na posição IV é de acesso arriscado por conta do salto. Os dois últimos tempos do exemplo seguem a digitação BL, mas esclarecem que o dedo 3 é fixo o que facilita a colocação dos dedos seguintes. O exemplo seguinte apenas inclui um ligado no primeiro compasso, mantendo por mais tempo a meia-pestana na primeira casa.

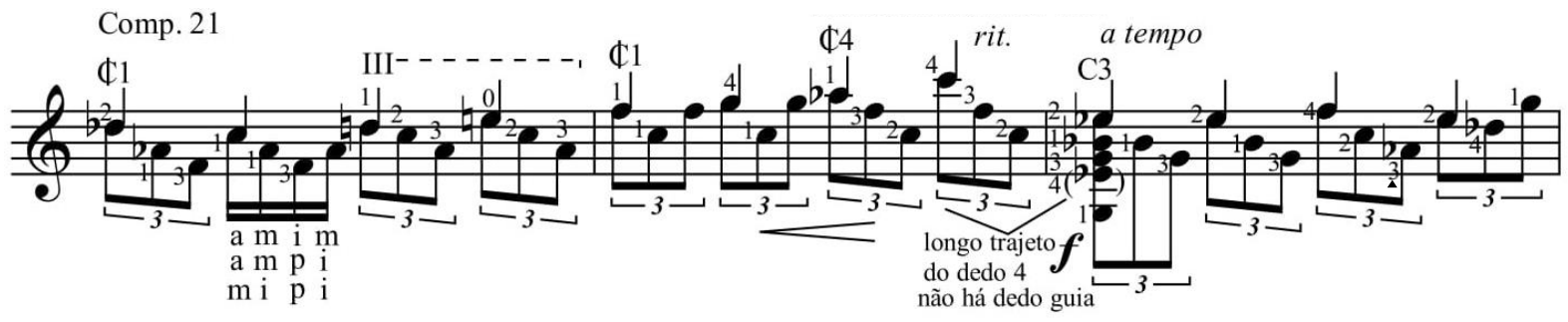

Exemplo 58: $I^{\circ}$ Estudo, compasso 21. 


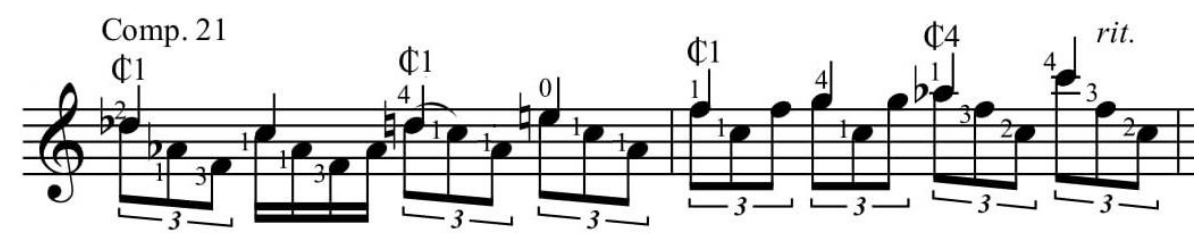

Exemplo 59: $I^{\circ}$ Estudo, compasso 21.

O exemplo 60 modifica $^{57}$ a chegada ao acorde não recorrendo à preparação da pestana na posição IV, mas colocando do dedo 1 na terceira corda (reduzindo ${ }^{58}$ levemente a duração da melodia) e fazendo do dedo 2 o guia para alcançar o acorde. Já na sequência, há uma experimentação não muito bem-sucedida, gerando a contração indicada.

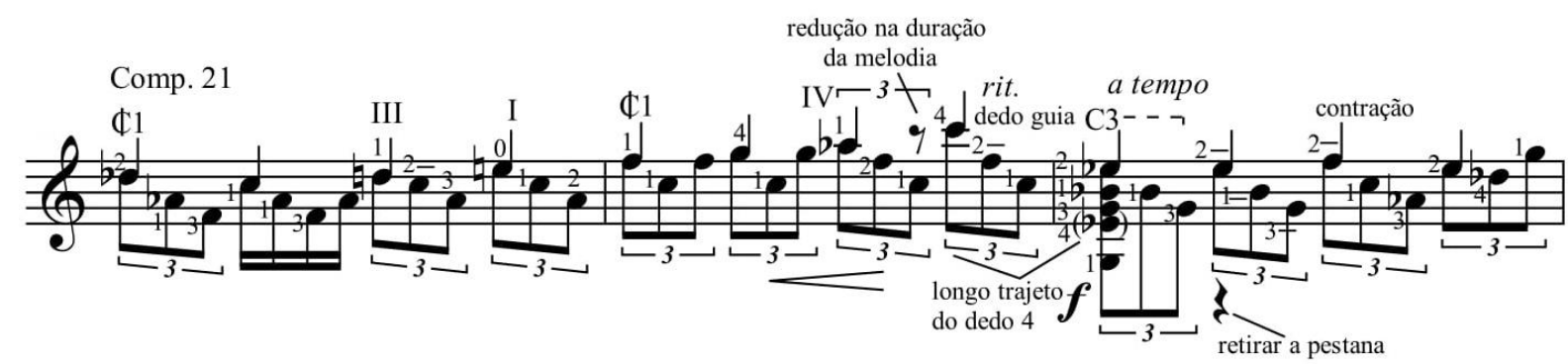

Exemplo 60: $I^{o}$ Estudo, compasso 21.

Os exemplos 61 e 62 buscam a chegada progressiva ao acorde ao manter a digitação mais ao redor das posições III e IV (na parte central do trecho). O exemplo 61 oferece meias-pestanas (de pressão apenas na falange proximal na primeira corda) de progressão mais suave que no exemplo 58 .

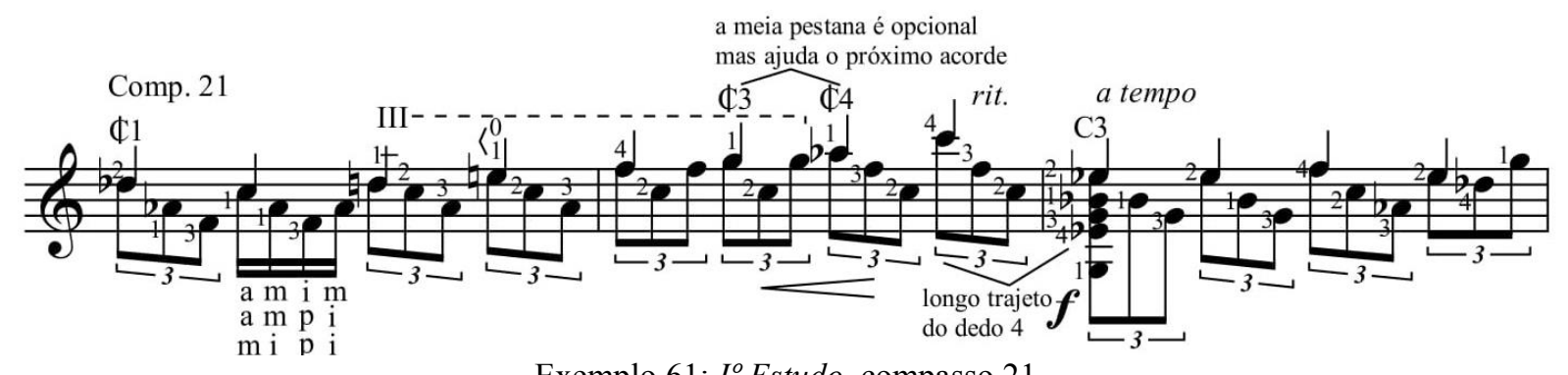

Exemplo 61: $I^{o}$ Estudo, compasso 21.

O exemplo 62 exclui as meia-pestanas e propõe dois artifícios facilitadores: uma mudança (assinalada) em um dos arpejos e uma redução ${ }^{59}$ (drástica) nas notas do acorde (curiosamente não reduzindo muito sua intensidade) levando à aplicação de ligados ao trecho final.

\footnotetext{
${ }^{57}$ verbo do checklist de Osborn.

${ }^{58}$ verbo diminuir do checklist de Osborn.

${ }^{59}$ verbo diminuir do checklist de Osborn.
} 


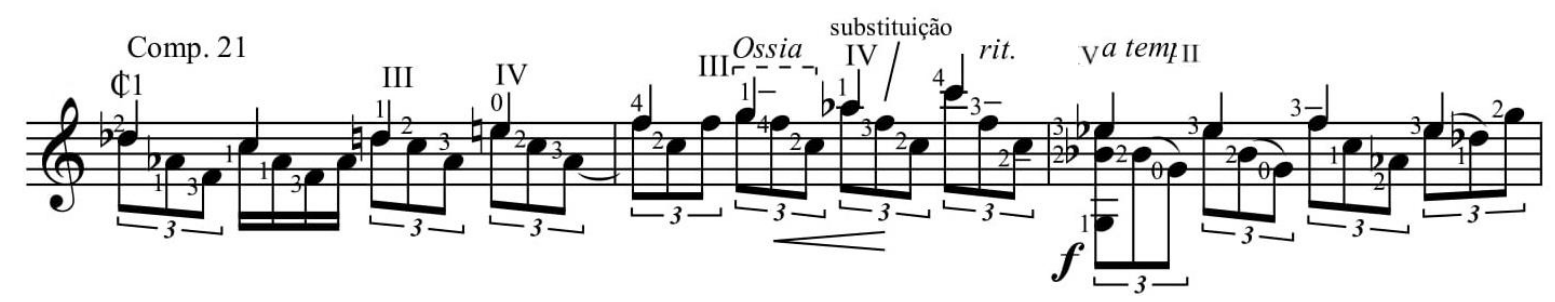

Exemplo 62: $I^{\circ}$ Estudo, compasso 21. Ossia.

As próximas tentativas (exemplos 63 e 64) alcançam regiões mais agudas do instrumento. A chegada nessas regiões (no terceiro tempo do compasso 22) não é muito bem preparada nos dois casos, mas gera dedos guias para o acorde do compasso seguinte (com supressões opcionais de notas assinaladas).

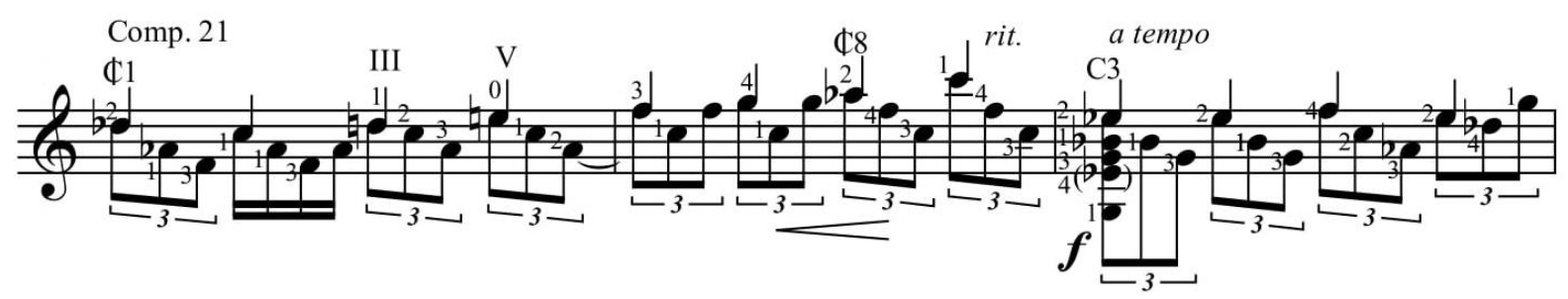

Exemplo 63: I $I^{o}$ Estudo, compasso 21.

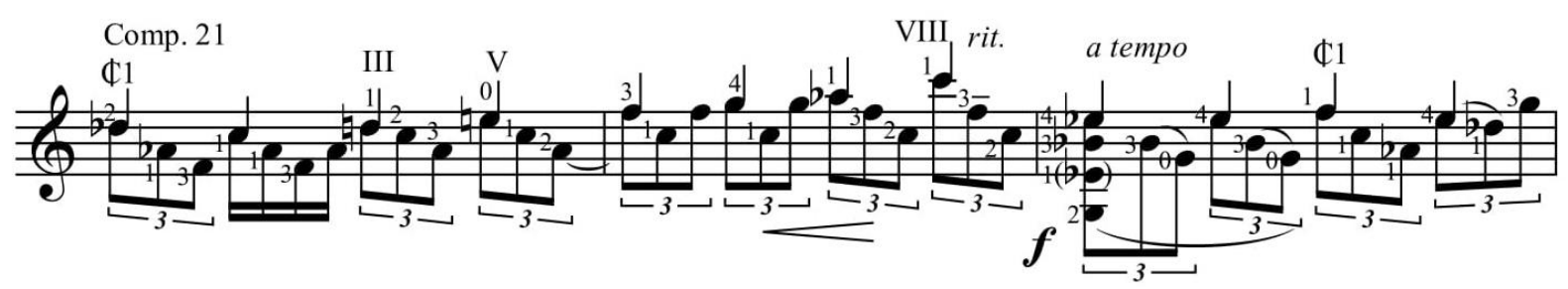

Exemplo 64: $I^{o}$ Estudo, compasso 21.

$\mathrm{O}$ exemplo 65 aproveita a chegada à posição $\mathrm{V}$ dos exemplos anteriores para propor o uso do dedo 5 (polegar da me), também proporcionando um dedo guia no encaminhamento do acorde (com supressões opcionais de notas assinaladas).

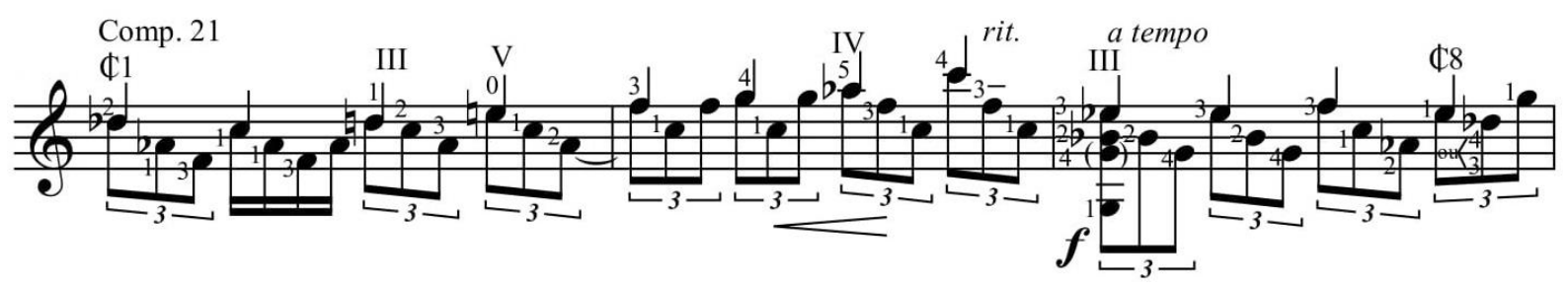

Exemplo 65: I Estudo, compasso 21.

O exemplo 66 retorna a ideia do ligado no primeiro compasso (advinda do exemplo 59) e a une com o uso de casas avançadas (exemplo 63), com conexão amarrada pelo dedo 2 como falso guia. 


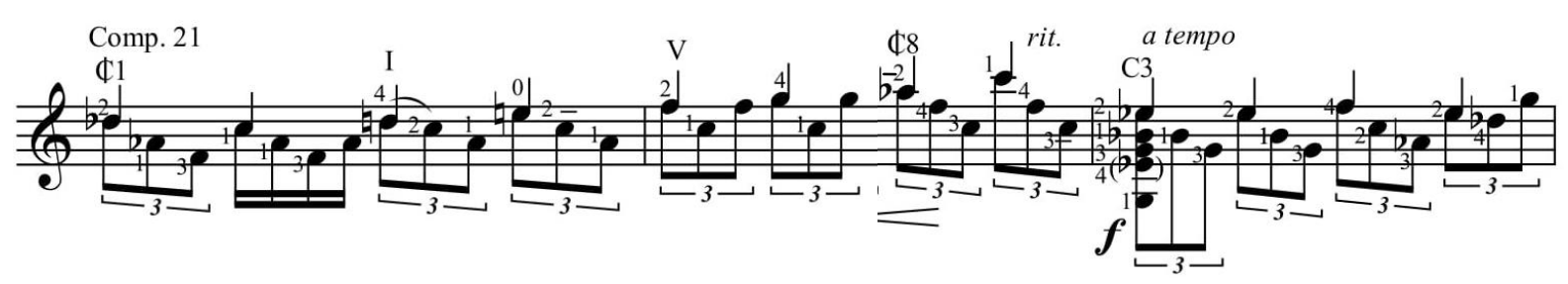

Exemplo 66: I $I^{o}$ Estudo, compasso 21.

O trecho iniciado no compasso 24 lembra os acordes diminutos paralelos do compasso 19, mas com outra disposição. A dificuldade principal diz respeito à transição entre os compassos 24 e 25 . BL opta por criar um dedo guia (dedo 2) entre os compassos, mas o alcança sem nenhuma conexão e provoca um salto de cordas arriscado do dedo 4 (assinalados por setas).

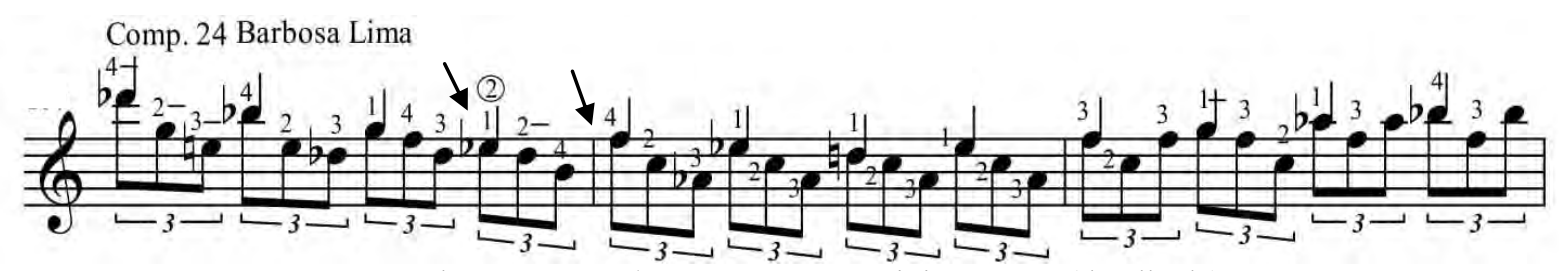

Exemplo 67: $I^{o}$ Estudo, compasso 24. Digitação BL (detalhada).

Nossa primeira estratégia foi "amarrar" melhor o final do compasso 24 por meio de um dedo fixo. No exemplo 68 o dedo fixo escolhido é o dedo 2, o que mantém ${ }^{60}$ grande parte da digitação BL mas gera uma abertura desconfortável no terceiro tempo do compasso 24 .

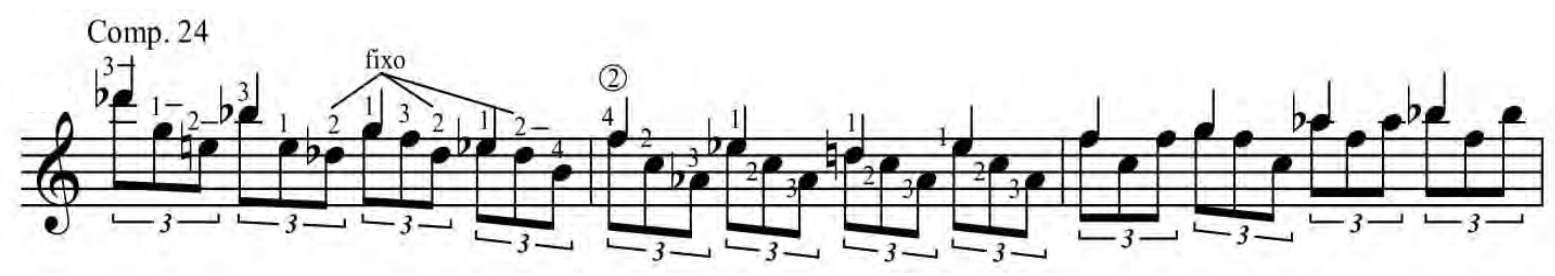

Exemplo 68: $I^{o}$ Estudo, compasso 24.

Já no exemplo 69 o dedo fixo escolhido é o dedo 3. Ele ainda poderia ser ligado à digitação $\mathrm{BL}$ do compasso seguinte pelo mesmo salto do dedo 4 , mas experimentamos uma versão alternativa, com uma contração exequível porém levemente desconfortável.

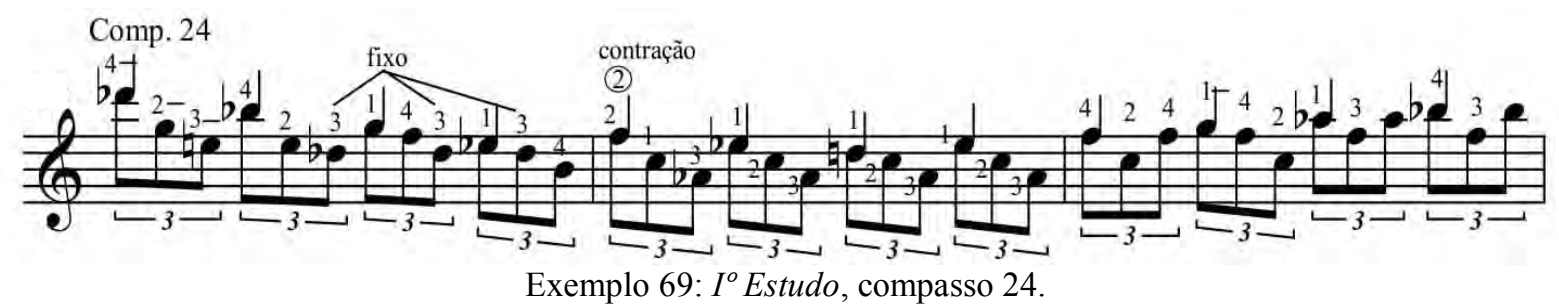

Nossas outras estratégias incluíram a aplicação de ligados facilitadores a este trecho, sob o custo de sempre reduzir ${ }^{61}$ a duração na melodia prevista na voz superior

\footnotetext{
${ }^{60}$ item "deixar como está" do checklist de Osborn.

${ }^{61}$ verbo diminuir do checklist de Osborn.
} 
original. $\mathrm{O}$ exemplo 70 conecta esta opção à digitação $\mathrm{BL}$ enquanto o exemplo 71 o conecta a mesma contração do exemplo 69. Já o exemplo 72 exacerba o uso de ligados.

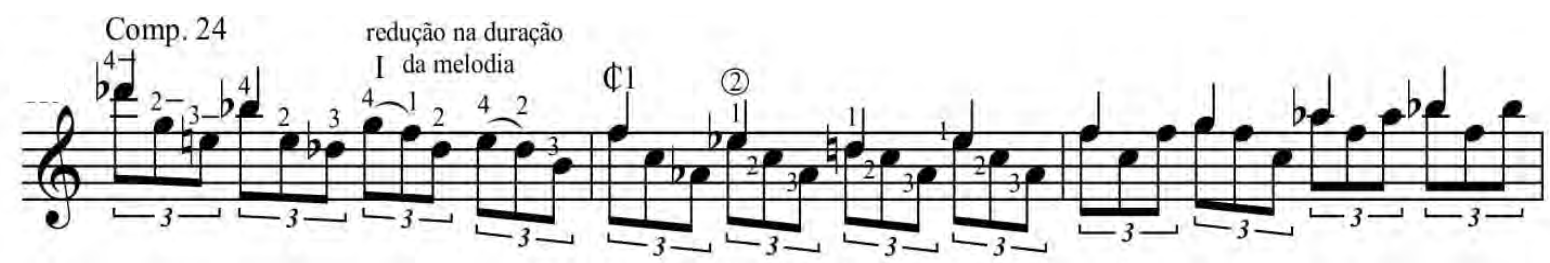

Exemplo 70: $I^{\circ}$ Estudo, compasso 24.

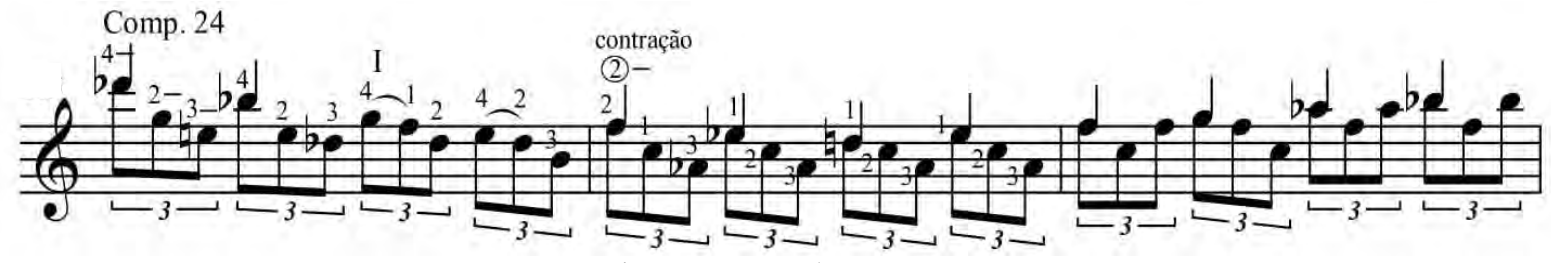

Exemplo 71: $I^{\circ}$ Estudo, compasso 24.

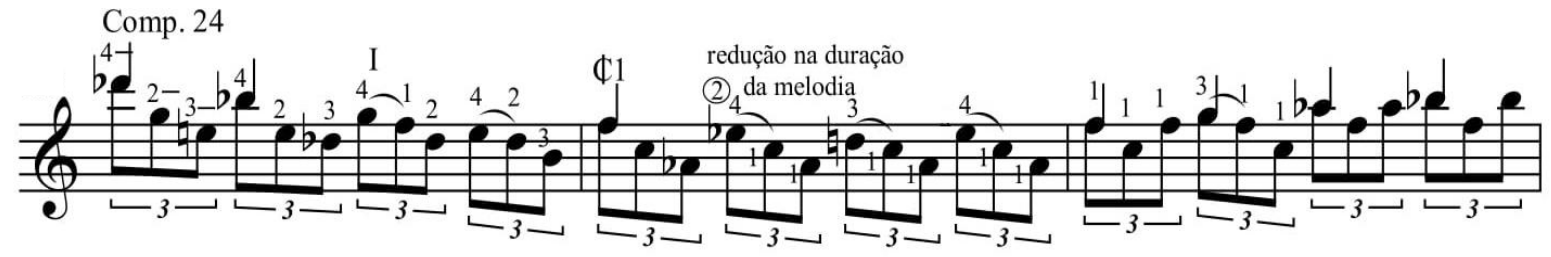

Exemplo 72: $I^{\circ}$ Estudo, compasso 24.

O compasso 27 (digitação BL no exemplo 73) apenas recebeu duas Ossias (no exemplo 74) que buscam unificar os dois tempos finais:

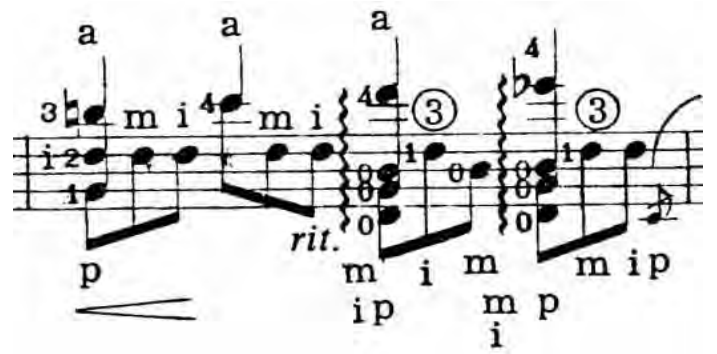

Exemplo 73: $I^{\circ}$ Estudo, compasso 27. Edição Columbia/Barbosa-Lima.
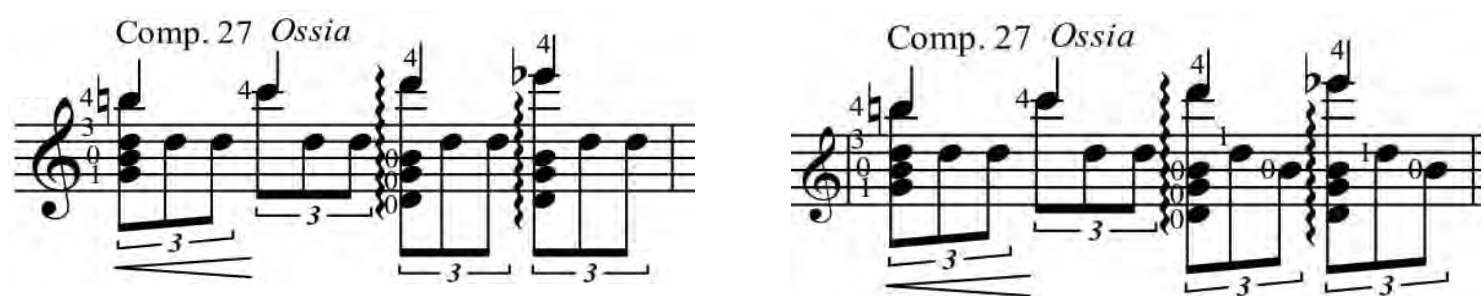

Exemplo 74: $I^{\circ}$ Estudo, compasso 27.

No próximo trecho, a digitação BL (exemplo 75) almeja manter a melodia na segunda corda na descida do compasso 31 , gerando várias trocas de posição e uma compressão no último tempo entre os dedos 3 e 4 (escolha improvável de dedos que parece até ser um erro, pois os dedos 1 e 4 seriam os mais óbvios, uma vez que seriam facilmente deslizados desde o tempo anterior). 


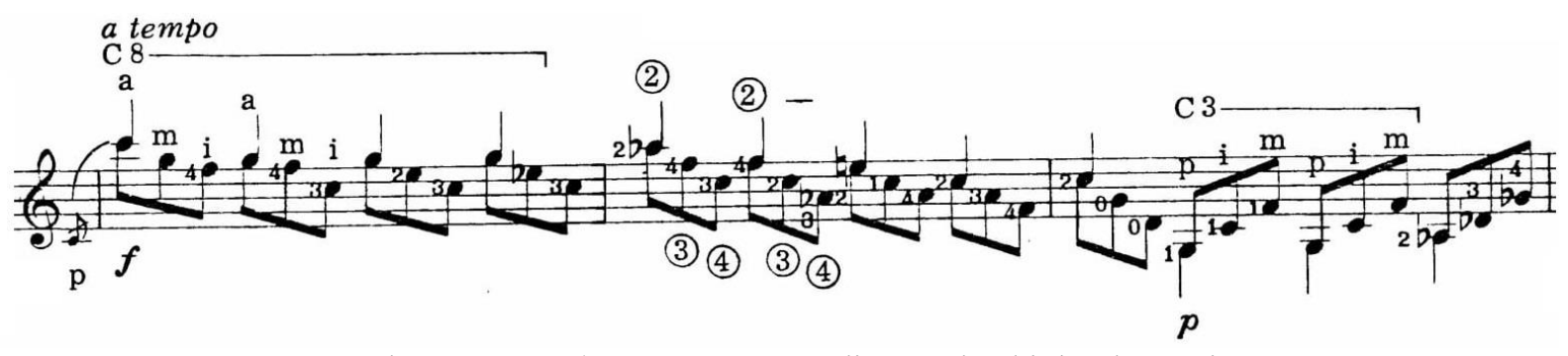

Exemplo 75: $I^{o}$ Estudo, compasso 30. Edição Columbia/Barbosa-Lima.

O exemplo 76 oferece simultaneamente duas possibilidades para esta descida (grafadas em cima e em baixo do pentagrama quebrando um pouco nossa padronização), ambas com montagens de acordes a cada dois tempos (enquanto BL muda os dedos a cada tempo). A opção superior parte de um acorde cuja digitação é levemente contraída na posição IX (que tem a vantagem de já estar próximo ao acorde anterior) enquanto a outra cria um salto para a casa 4 . Ambas as soluções seguem para a primeira posição por corda solta e tem o mesmo desfecho, distinto de BL.

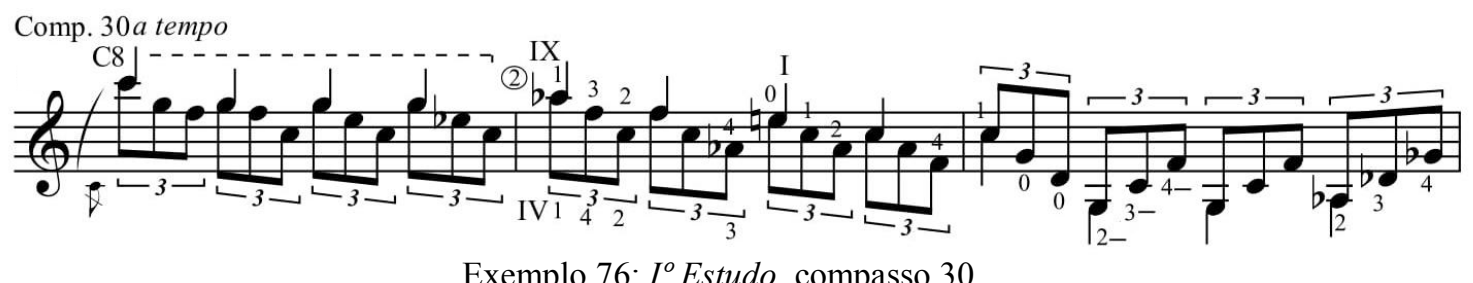

Exemplo 76: I $I^{o}$ Estudo, compasso 30.

A longa subida iniciada no compasso 37 , recebe digitação bastante intrincada por BL (exemplo 77) e alcança uma configuração de dedos pouco efetiva para os acordes na região sobreaguda do instrumento (compasso 41 e 42).

Já a nossa opção (exemplo 78), busca maior simplicidade, mantendo-se por mais tempo na primeira posição e fazendo a subida pelas cordas agudas em um padrão envolvendo os dedos 1, 2 e 3 e com isso chegando ao acorde na região sobreaguda do instrumento com digitação mais palatável com estes mesmos dedos rearranjados ${ }^{62}$. A descida (compasso 42) também é facilitada pela escolha de dedos do compasso anterior. Os dois compassos finais do trecho não sofrem mudanças relevantes.

\footnotetext{
${ }^{62}$ verbo do checklist de Osborn.
} 


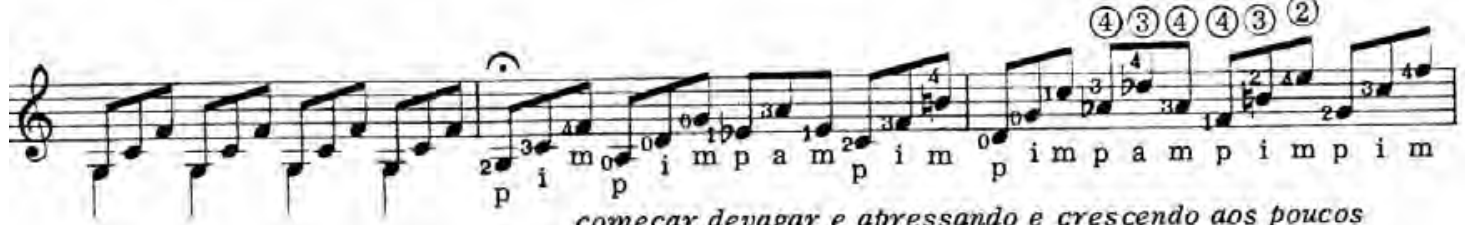
começar devagar e apressando e crescendo aos poucos
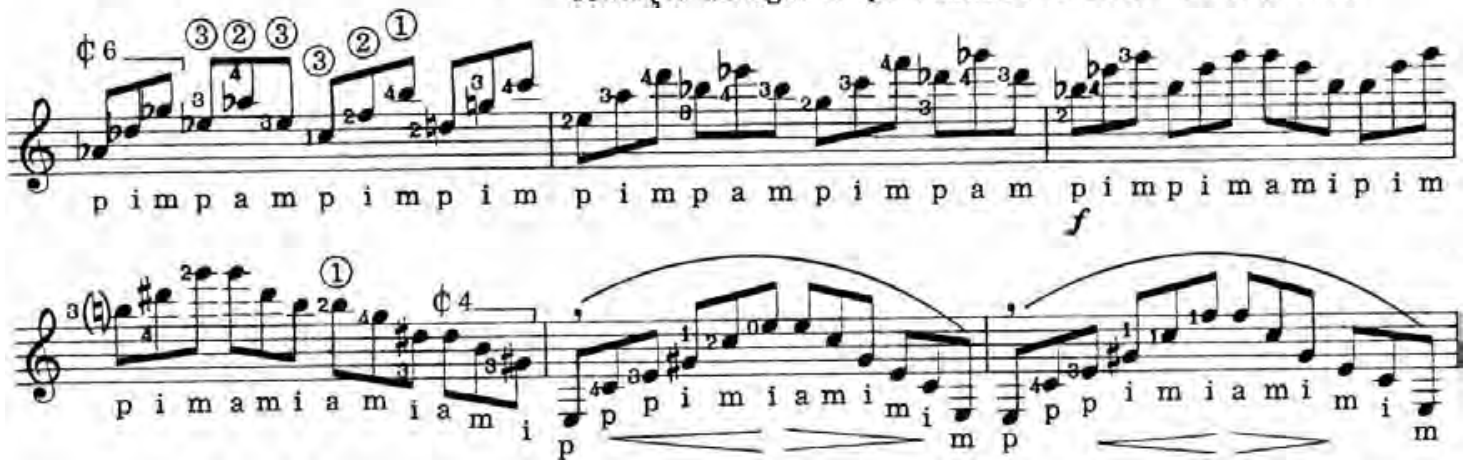

Exemplo 77: $I^{o}$ Estudo, compasso 36. Edição Columbia/Barbosa-Lima.
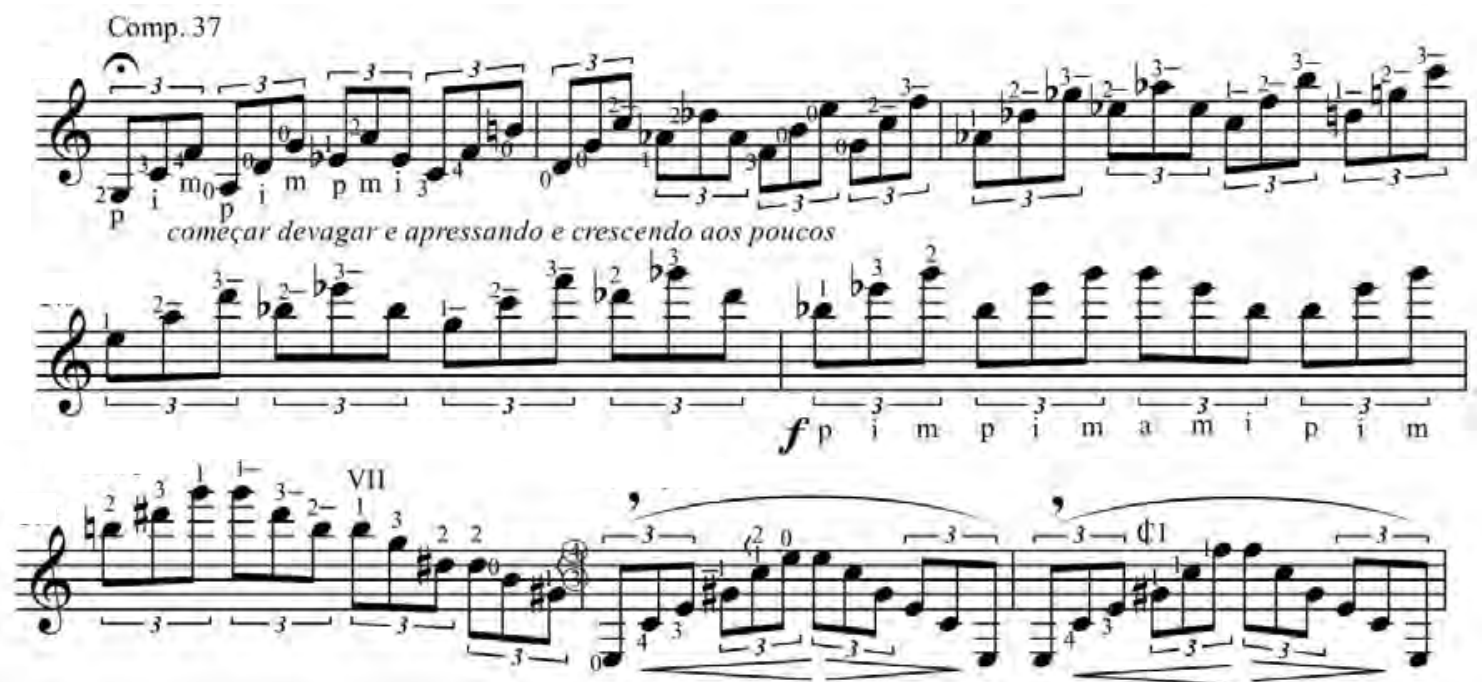

Exemplo 78: $I^{\circ}$ Estudo, compasso 37.

O trecho a partir do compasso 73 leva a uma nova subida à região sobreaguda do violão. O impasse novamente é como subir e nesse contexto parecem ser determinantes a digitação da quintina e a região escolhida para o compasso $53 \mathrm{em}$ diante. BL (no exemplo 79) oferece uma boa opção para a quintina com ligado na posição IV (deixando os dedos 1 e 3 em posição para serem arrastados para a posição VI no compasso seguinte) e para o compasso 54. No entanto, os dois compassos finais colocam o dedo 4 na quarta corda em situação espremida que gera dificuldade na entrada do dedo 3, além de ocorrer uma substituição de dedos desnecessária no penúltimo tempo do trecho.

Chegamos a duas outras soluções para quintina. A primeira delas pela posição I aproveitando o dedo 1 anteriormente preparado (ex. 79) que leva a uma subida pela cordas agudas do instrumento que por sua vez inicia os dois últimos compassos na 
posição IX, mesma de BL, mas substituindo ${ }^{63}$ o dedo 4 pelo 3 e com desfecho diferente, avançando pela segunda corda até a posição XIII.
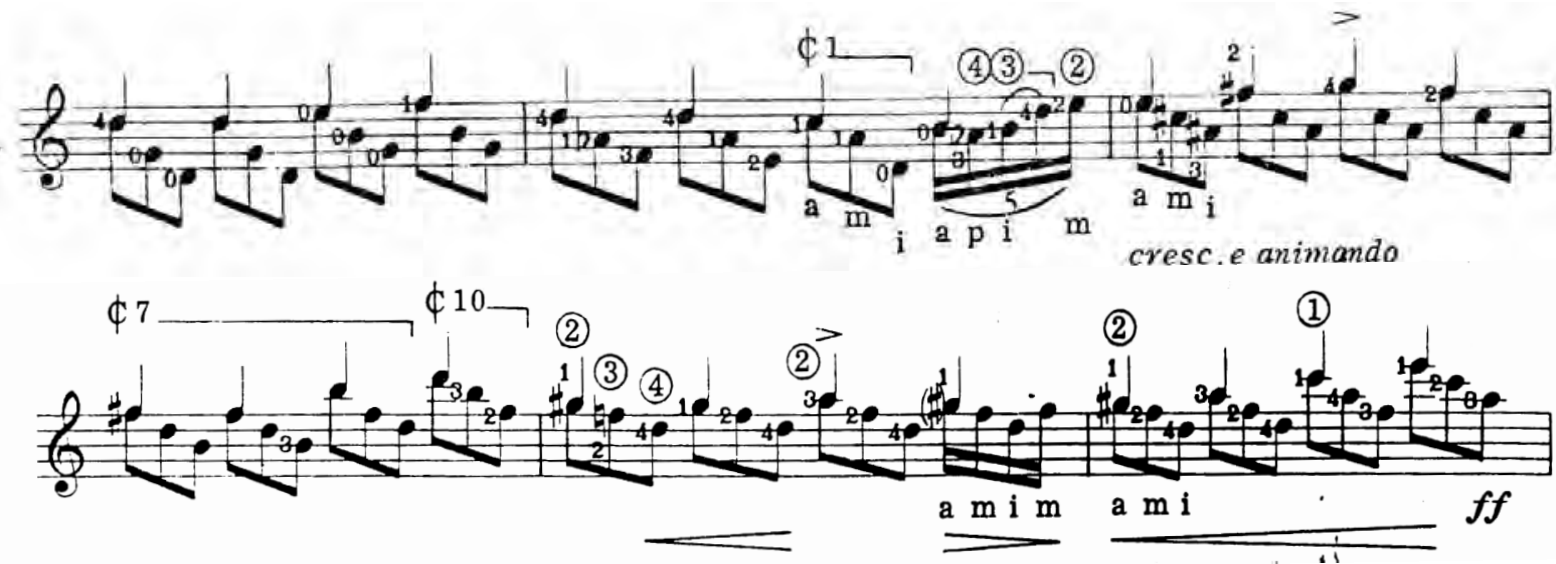

Exemplo 79: $I^{\circ}$ Estudo, compasso 51. Edição Columbia/Barbosa-Lima.
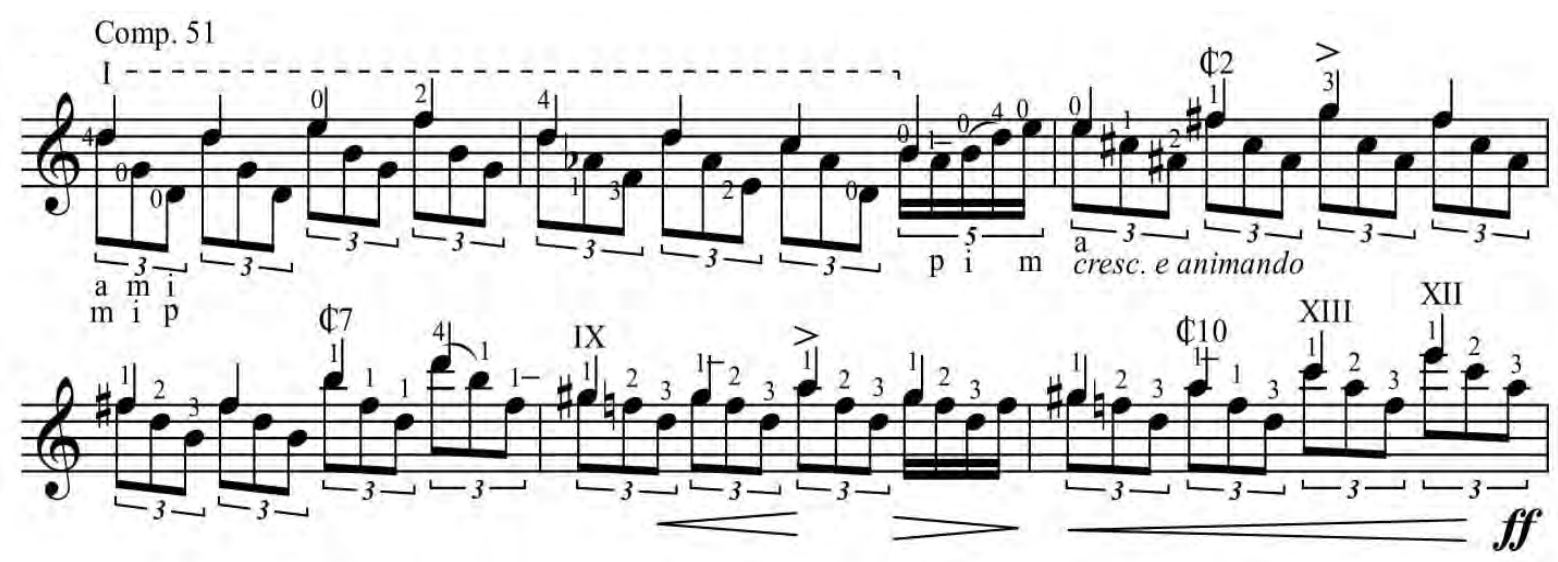

Exemplo 80: $I^{o}$ Estudo, compasso 51.

O exemplo seguinte apenas oferece uma sequência diferente a partir do compasso 54 mantendo-se ainda mais nas três cordas agudas do instrumento e colocando na posição IV o trecho anteriormente "espremido" na posição IX o que também modifica ${ }^{64}$ a ascensão final:

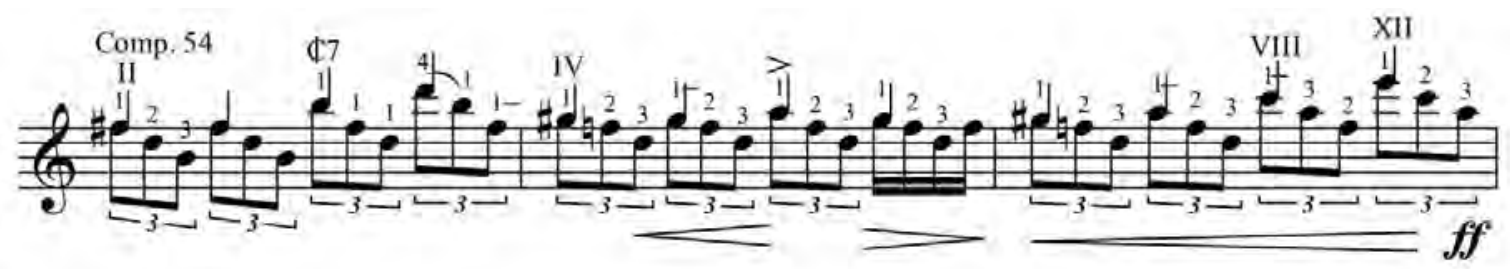

Exemplo 81: $I^{o}$ Estudo, compasso 51.

O exemplo 82 coloca a quintina na terceira casa sem ligado e segue para o mesmo desfecho do exemplo 74. Já o exemplo 83 vem apenas registrar outra possibilidade para o compasso 54, seguindo de maneira idêntica para o final.

\footnotetext{
${ }^{63}$ verbo do checklist de Osborn.

${ }^{64}$ verbo do checklist de Osborn.
} 
Comp, 51
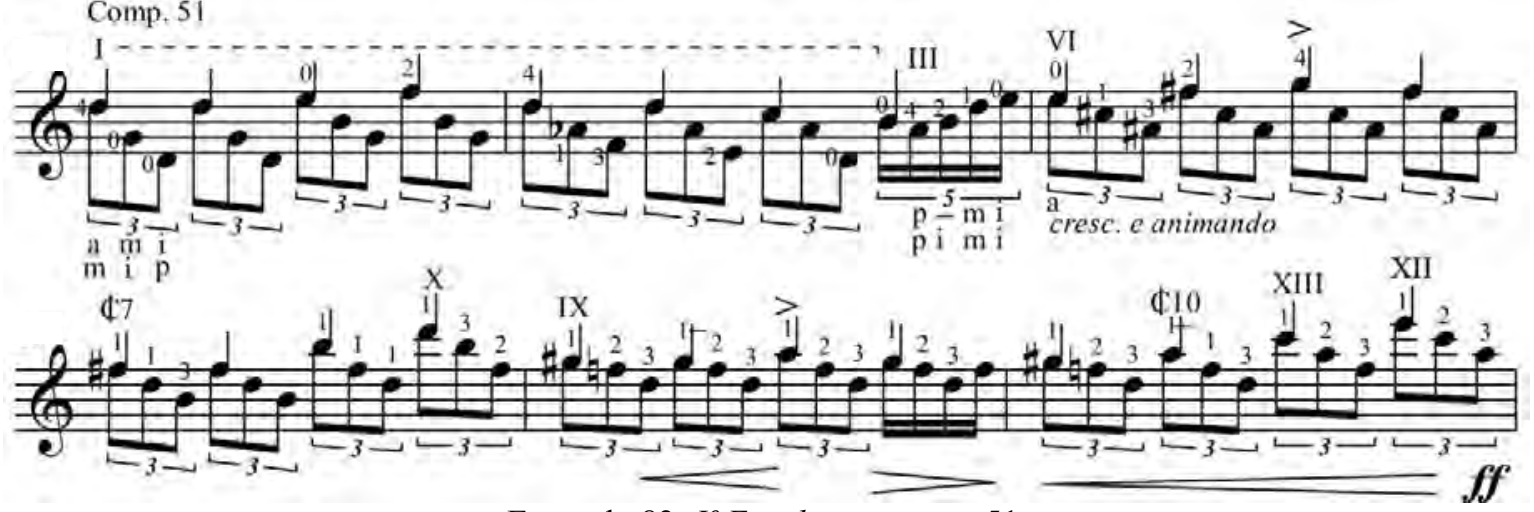

Exemplo 82: $I^{\circ}$ Estudo, compasso 51.

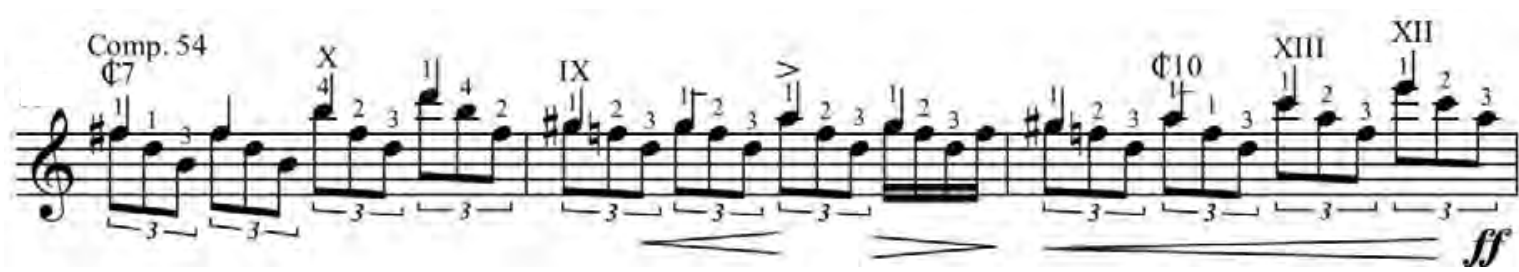

Exemplo 83: $I^{\circ}$ Estudo, compasso 54.

O ápice desta seção começa a ser construído no compasso 57 em um novo amplo arpejo de $m d$ envolvendo todas as cordas. A digitação BL (exemplo 84) é funcional, mas recebe novas versões de $m d$ no exemplo 85 , com polegar mais ativo e outra seleção de dedos da me no exemplo 86.

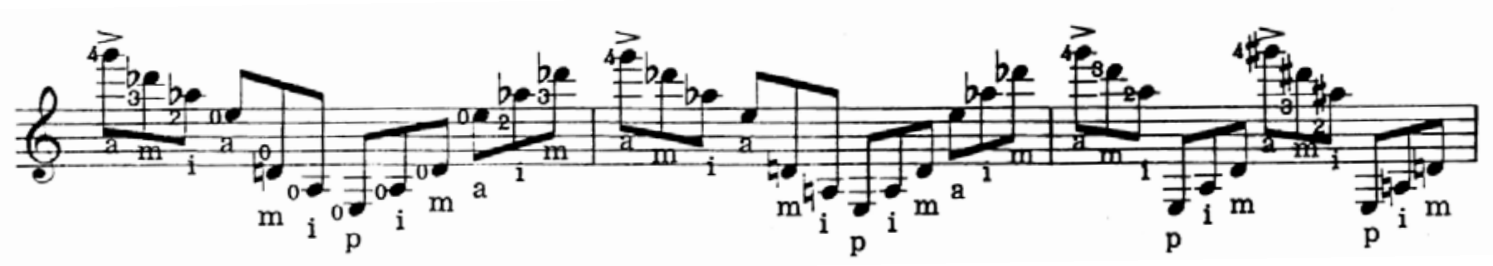

Exemplo 84: $I^{o}$ Estudo, compasso 57. Edição Columbia/Barbosa-Lima.

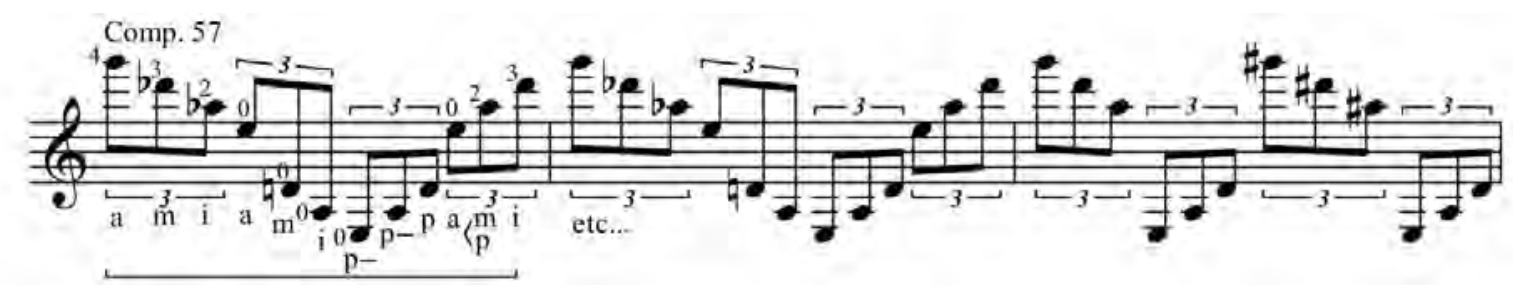

Exemplo 85: I $I^{o}$ Estudo, compasso 57.

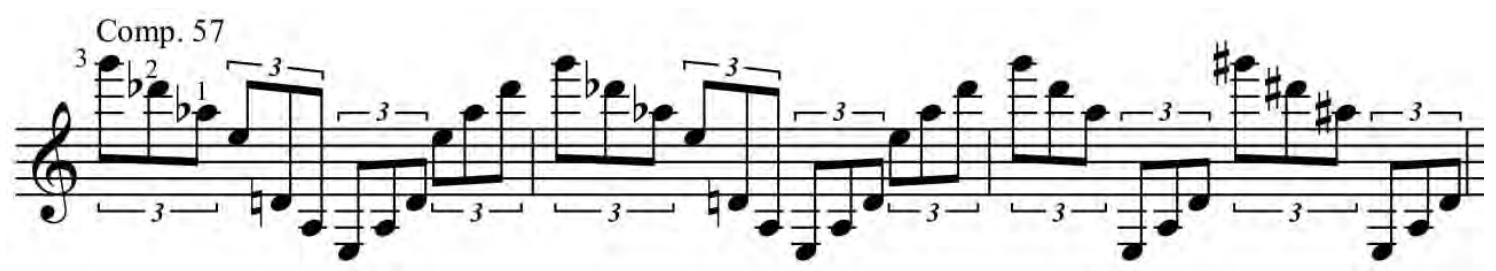

Exemplo 86: I $I^{o}$ Estudo, compasso 57.

A máxima tensão do estudo ocorre no compasso 60 onde acordes são rebatidos alternadamente nas cordas agudas e graves. BL propõe saltos verticais do grupo $a-m-i$ da $m d$ (exemplo 87), enquanto nós preferimos reservar o polegar (em toque triplo) para as cordas graves, enquanto as agudas podem ser articuladas pelo grupo $a-m-i$ ou por 
rasgueio do dedo $i$ (esta última opção foi sugerida por Turibio Santos) no intuito de lograr a dinâmica prescrita.

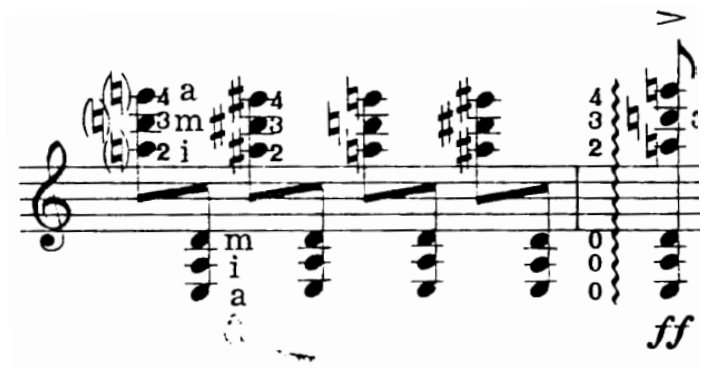

Exemplo 87: $I^{\circ}$ Estudo, compasso 60. Edição Columbia/Barbosa-Lima.

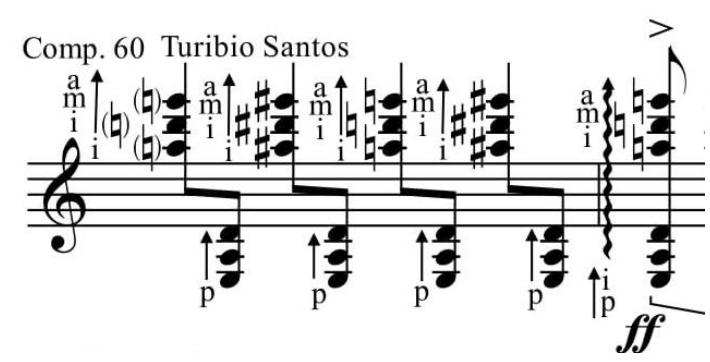

Exemplo 88: $I^{\circ}$ Estudo, compasso 60.

Já o próximo segmento (compasso 82 em diante), digitado por BL com ligados na primeira posição, recebeu outra visão (em campanella) por sugestão de Edelton Gloeden, criando uma interessante melodia na quarta corda no final do trecho.

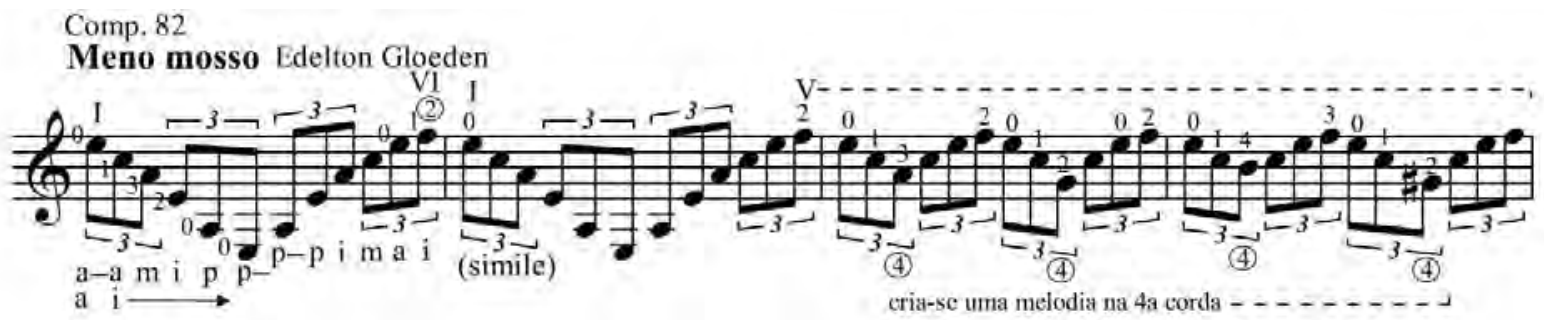

Exemplo 89: $I^{\circ}$ Estudo, compasso 82.

A criativa cadência cromática iniciada no compasso 86 recebe uma versão similar a de BL no exemplo 90, mantendo ${ }^{65}$ os mesmos ligados e cordas mas apenas substituindo $^{66}$ dedos do segundo tempo do primeiro compasso, para evitar um ligado entre os dedos 3 e 2. Já o exemplo 91 oferece digitação em campanella para o mesmo momento musical.

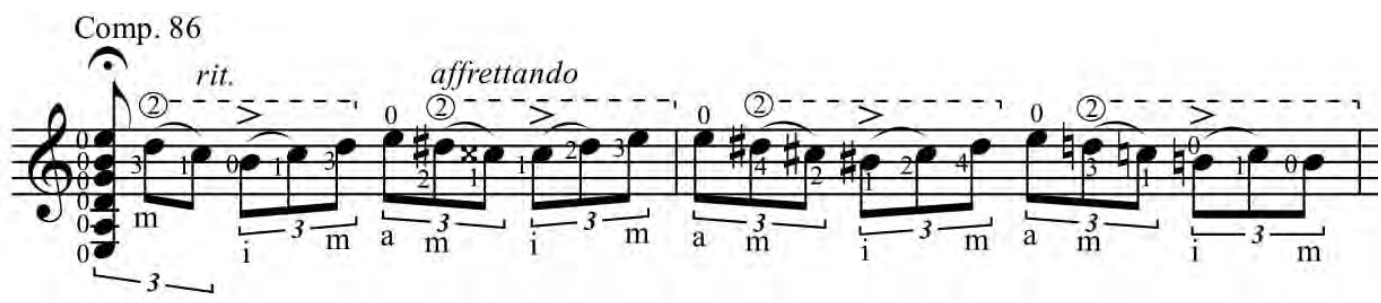

Exemplo 90: $I^{o}$ Estudo, compasso 86.

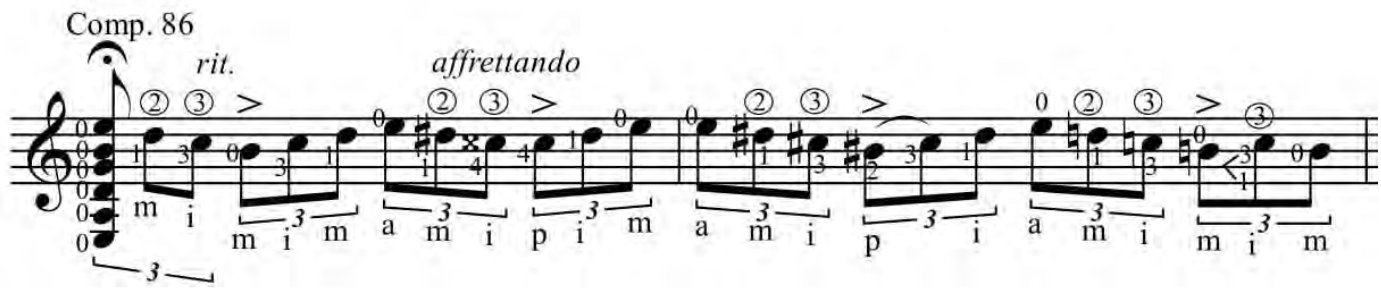

Exemplo 91: $I^{o}$ Estudo, compasso 86.

\footnotetext{
65 item "deixar como está" do checklist de Osborn.

${ }^{66}$ verbo do checklist de Osborn.
} 
Um último arpejo de grande amplitude é introduzido no compasso 88 e repetido por quatro compassos. A digitação BL (exemplo 92) apresenta muitos cruzamentos de $m d$. Outras múltiplas opções são grafadas no compasso 93, sendo as duas primeiras delas as de nossa preferência, por usarem o escovamento do anelar e do polegar como artifício de deslocamento vertical da $m d$, porém sabemos que este recurso nem sempre está plenamente absorvido por outros intérpretes.

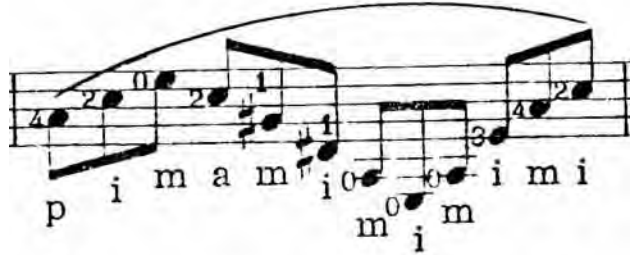

Exemplo 92: $I^{o}$ Estudo, compasso $88 \mathrm{Ed}$. CB/BL.

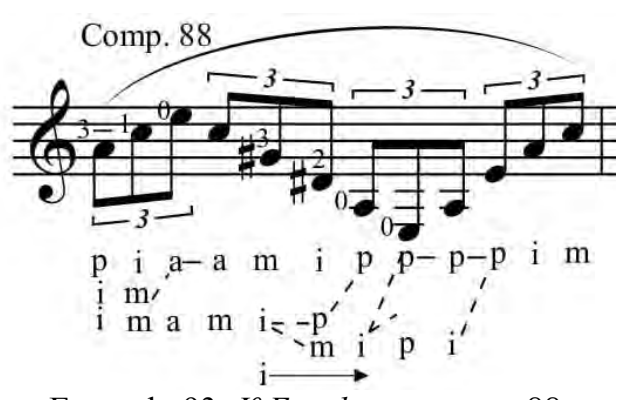

Exemplo 93: $I^{\circ}$ Estudo, compasso 88.

$\mathrm{O}$ belo e delicado desfecho do estudo recorre a harmônicos lamentavelmente não digitados por BL (exemplo 94). Nossa primeira alternativa os coloca na posição I e apresenta poucas notas sustentadas pela necessidade de avançar a posição para alcançar última nota. Já o exemplo 96 avança a posição paulatinamente e com isso consegue grande sustentação, não somente por envolver mais cordas nos harmônicos, mas também por integrar harmônicos em cordas soltas, todos tocados pela $m d$.

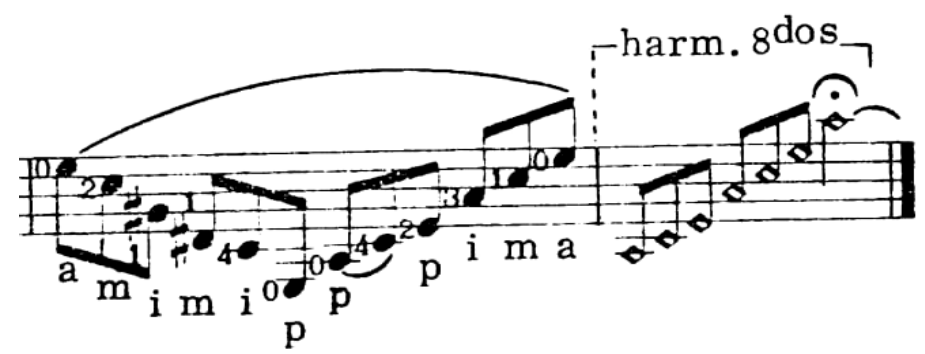

Exemplo 94: $I^{o}$ Estudo, compasso 92. Edição Columbia/Barbosa-Lima.

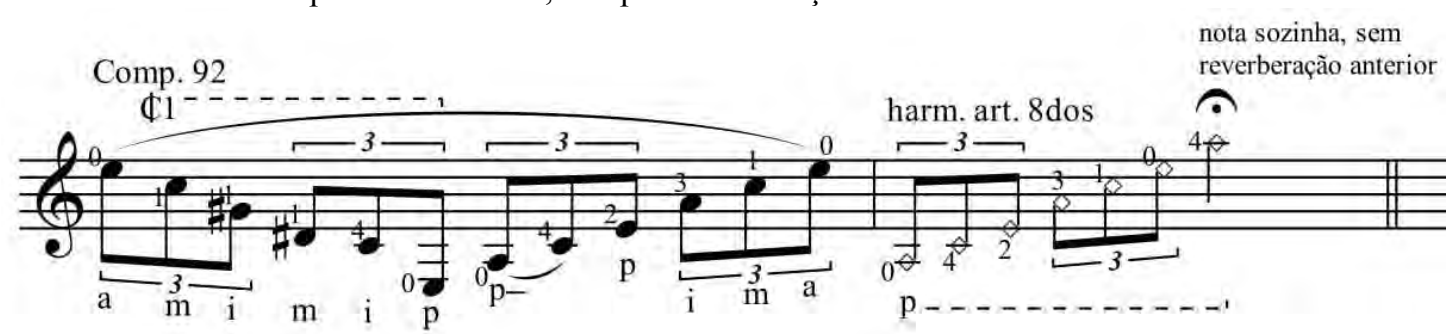

Exemplo 95: I Estudo, compasso 92.

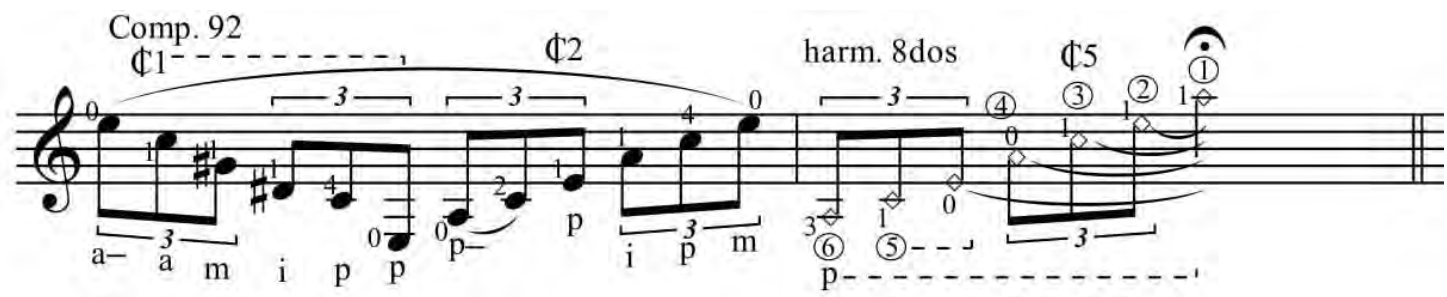

Exemplo 96: I Estudo, compasso 92. 


\section{2: II Estudo "Seresteiro"}

É talvez um dos mais executados do ciclo provavelmente por oferecer boa relação de "custo-benefício": seu caráter lânguido envolve o ouvinte (e o intérprete) ao explorar a textura de "melodia acompanhada" no violão, e seu andamento lento torna suas dificuldades bastante palatáveis. $\mathrm{O}$ aspecto interpretativo será pouco comentado, por ser muito variado, mas aconselhamos uma busca por unidade tímbrica e cantabile da melodia, bem como na igualdade na sonoridade e grau de arpejamento dos acordes.

Nossa primeira opção (ex. 97) modifica $^{67}$ alguns pequenos aspectos na versão BL: retira um ligado no segundo tempo do primeiro compasso e substitui na nota ornamental o dedo 4 pelo dedo 3, oferecendo maior firmeza ao ligado. É necessário certo cuidado com o translado do dedo 1 seguido de abertura (assinalado). Registramos também aqui duas maneiras distintas de articular os acordes e que os mesmos podem ser prolongados, embora isso não esteja indicado pelo compositor.

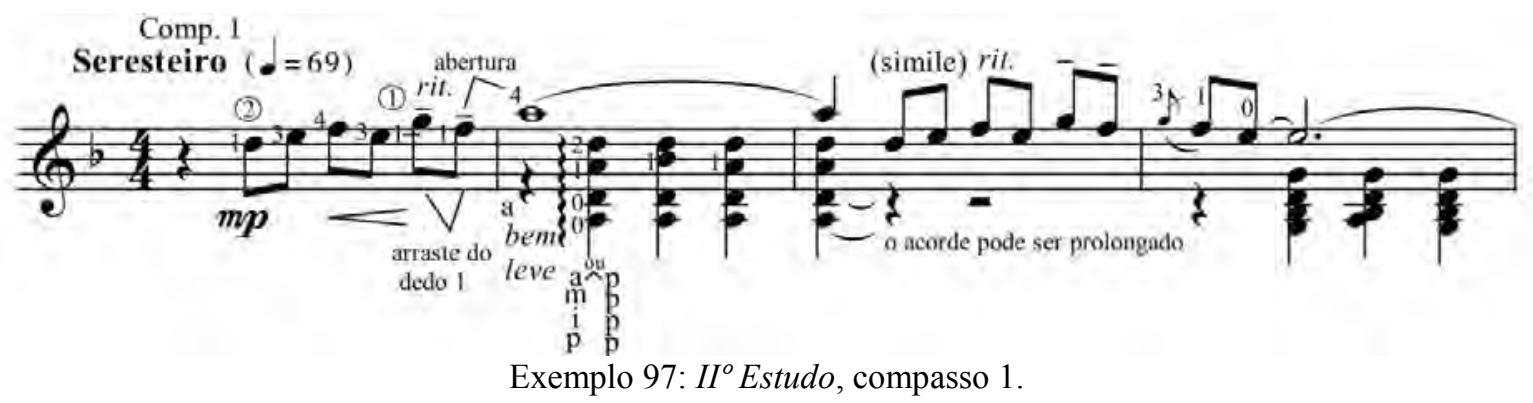

O exemplo 98 se inspira no primeiro ligado da versão BL e o aplica ao trecho todo, mantendo a melodia na segunda corda e digitando os acordes do segundo compasso em pestana na quinta casa, respeitando sua duração original (ou seja, aqui a prolongação do exemplo anterior é impossível). Esse exemplo também registra outra possibilidade de digitação para os acordes do compasso 4, substituindo o dedo 3 (previsto por BL) pelo dedo 2 para facilitar sua execução.

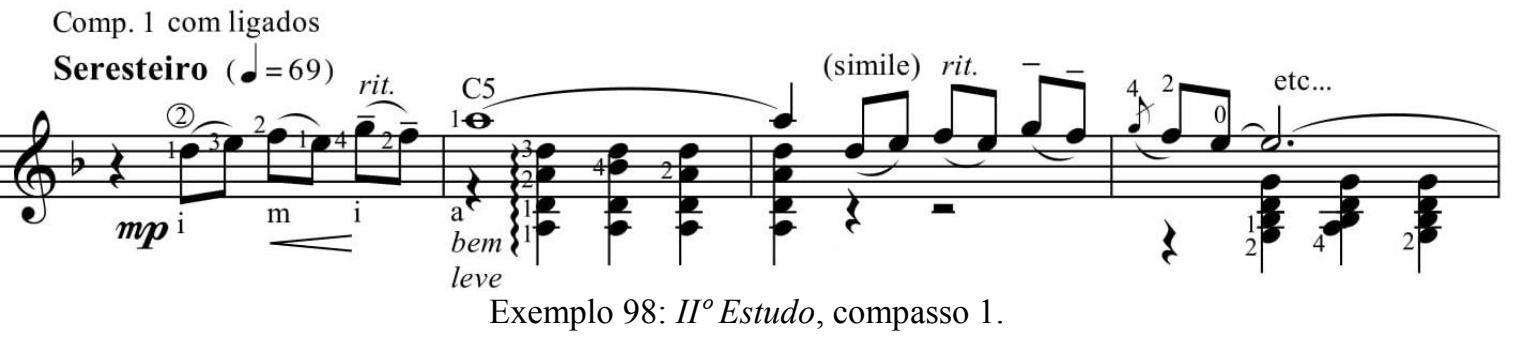

Seguem-se três versões em campanella, a primeira em duas cordas, a segunda em três cordas (ambas com o primeira acorde em pestana) e finalmente a terceira mescla

\footnotetext{
${ }^{67}$ verbo do checklist de Osborn.
} 
versões anteriores, ainda em campanella porém alcançando o acorde na posição II com baixos em cordas soltas.

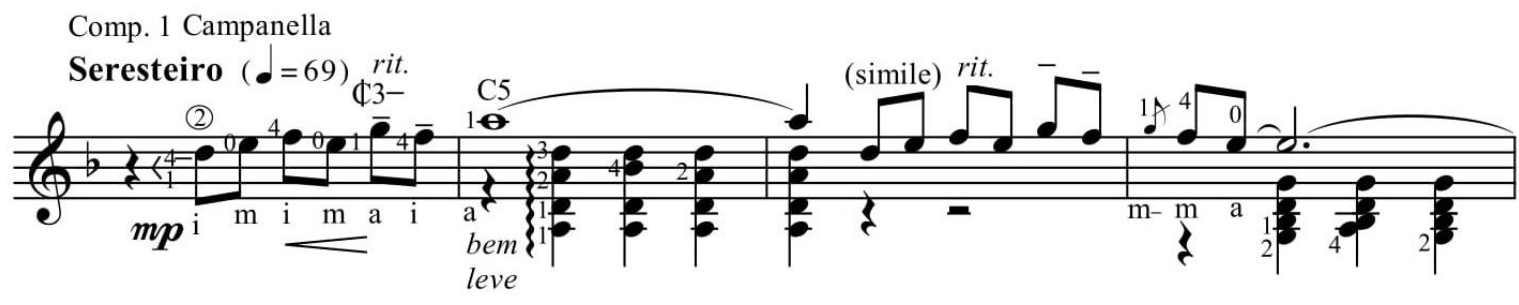

Exemplo 99: II Estudo, compasso 1.

\section{Comp. 1 Campanella}

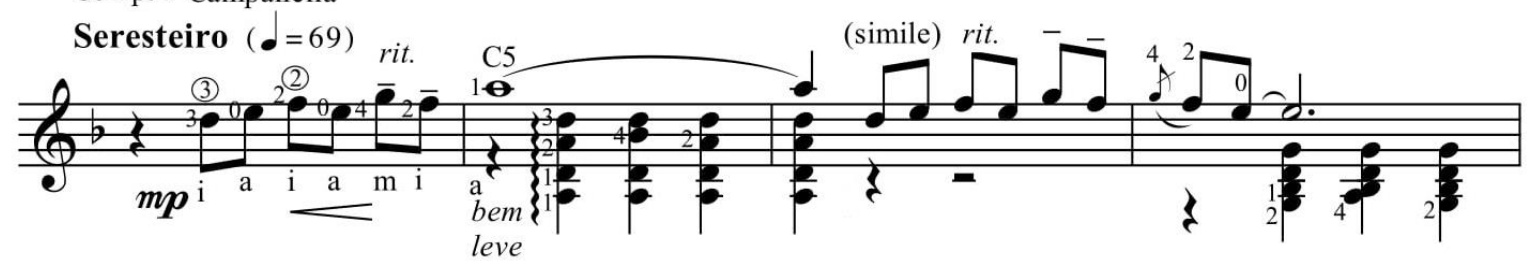

Exemplo 100: II Estudo, compasso 1.

Comp. 1 Campanella

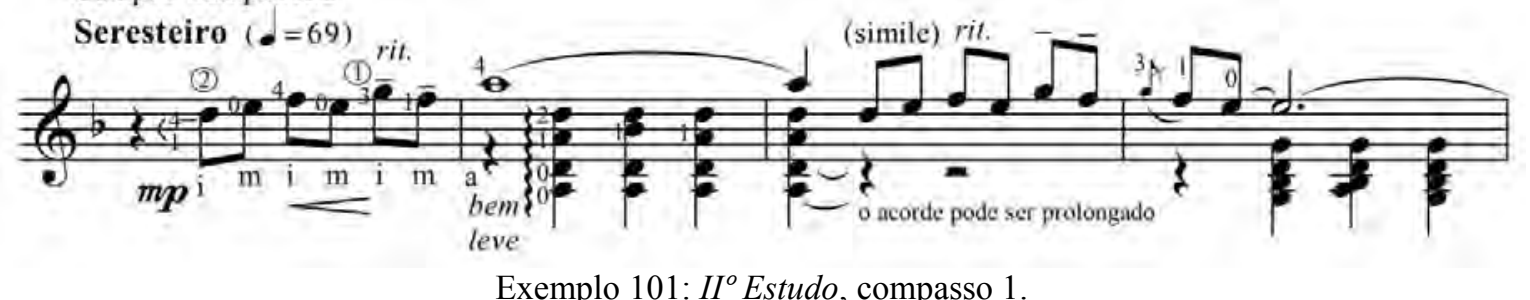

Uma última versão, por sua vez bastante experimental, coloca a melodia em harmônicos naturais alternados com notas reais, ainda em campanella. Gerando um efeito sutil e de execução avançada, ela poderia ser também utilizada com uma espécie de variação tímbrica (não prevista pelo compositor) apenas na repetição desta seção no compasso 71. A digitação proposta abarca somente seis compassos, mas ainda pode ser aplicada (com a mesma lógica) aos compassos seguintes.

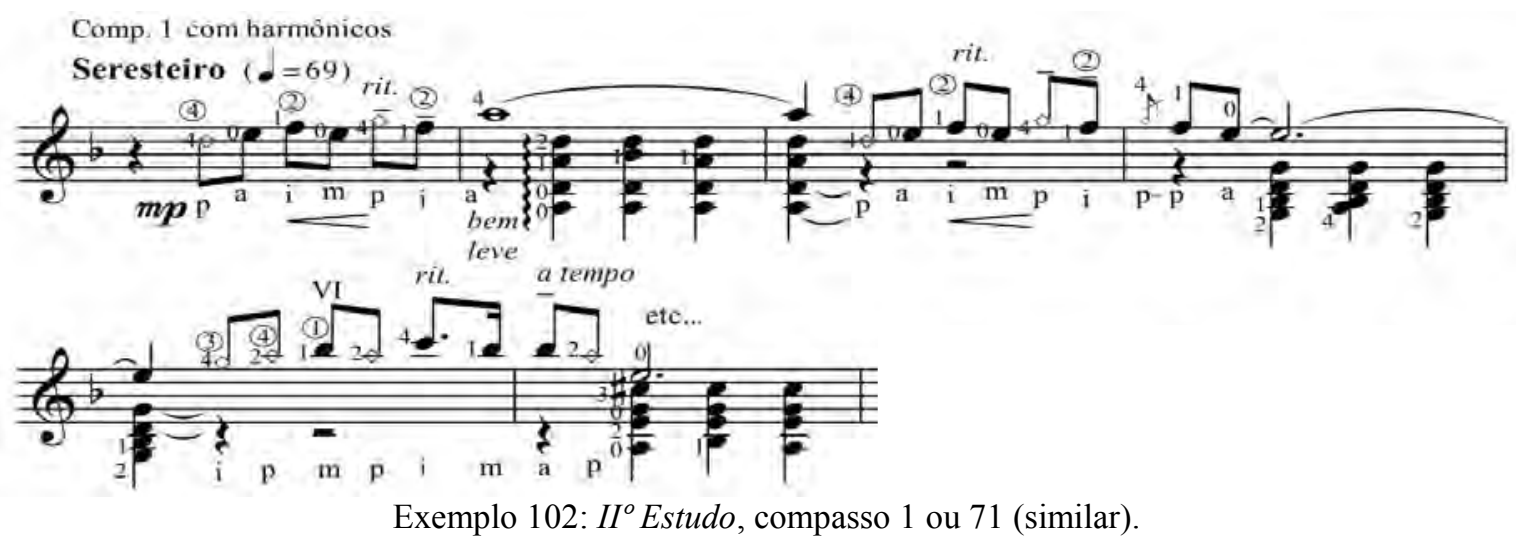

O compasso 5 tem mudanças decorrentes da substituição de dedo proposta para o acorde do compasso anterior que é o mesmo do início do presente compasso e portanto, recebe a mesma digitação. A primeira versão segue a ideia em una corda de 
BL, apenas modificando ${ }^{68}$ alguns dedos e sugerindo um portamento. Um aspecto interessante é a mudança de posição por compressão do dedo 1, substituindo o dedo 3 . Já a segunda opção experimenta o uso em duas cordas com os dedos 4 e 1 trabalhando em bloco.
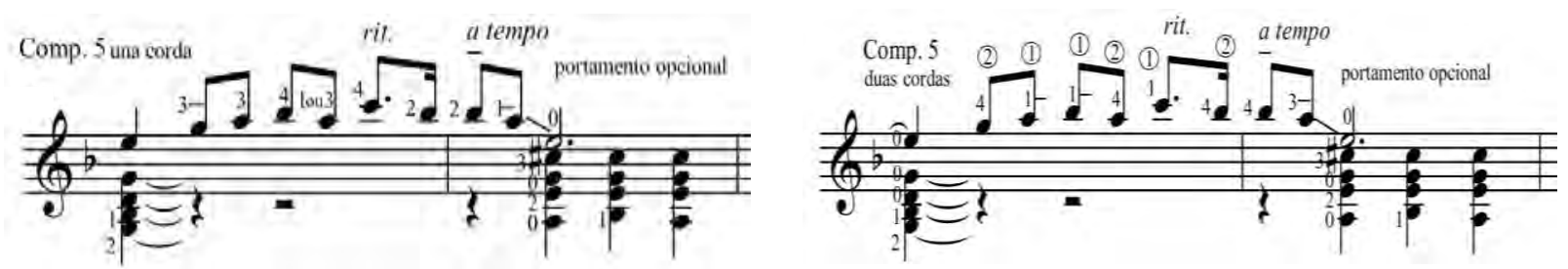

Exemplo 103: II Estudo, compasso 5.

O exemplo 104 apenas explora uma digitação do compasso 6 pela quinta casa o que coloca a melodia (com portamenti originais) circunscrita à segunda corda, enquanto a digitação BL (já satisfatória) mantinha os acordes na primeira posição e privilegiava a primeira corda para as passagens melódicas.

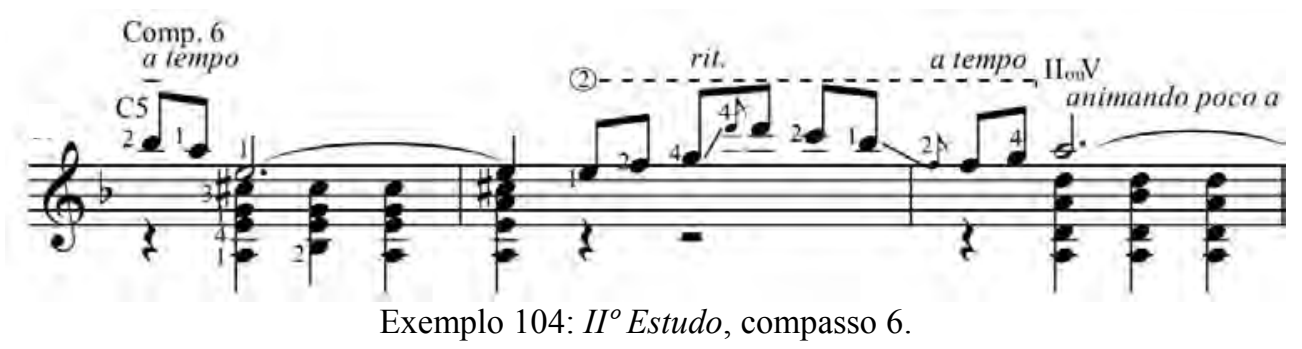

O próximo trecho oferece dificuldades na progressão de acordes iniciada no compasso 10, não somente pelos acordes envolvidos, mas por prescrever uma nota longa na melodia vinda de um amplo passeio pelo braço do instrumento. BL (exemplo 105) parece colocar esses acordes na segunda posição, embora isso não esteja claramente especificado.

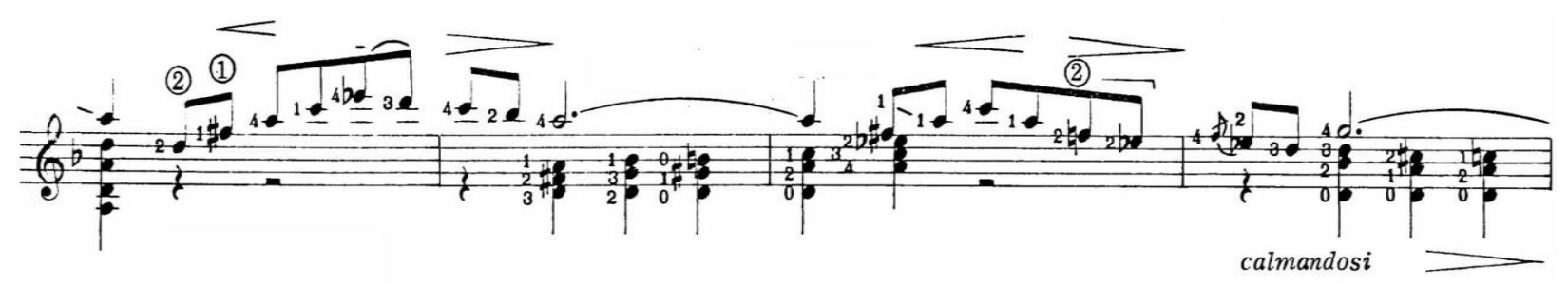

Exemplo 105: $I^{o}$ Estudo, compasso 9. Edição Columbia/Barbosa-Lima.

Nossa abordagem alternativa (nos próximos dois exemplos) é os digitar na posição VII, mais próxima da posição anterior, deixando o acorde inicial mais cômodo, aproveitamento a corda Sol solta no segundo e retomando a digitação BL no terceiro e quarto acordes, com leve prejuízo na duração da melodia.

${ }^{68}$ verbo do checklist de Osborn. 
Outro problema diz respeito ao acorde diminuto de quatro notas do segundo tempo do compasso 11 , cujo empilhamento de terças menores ${ }^{69}$ cria uma grande abertura. Os exemplos 106 e 107 diferem na exclusão de uma das notas desse acorde e na escolha dos dedos da melodia em sequência.

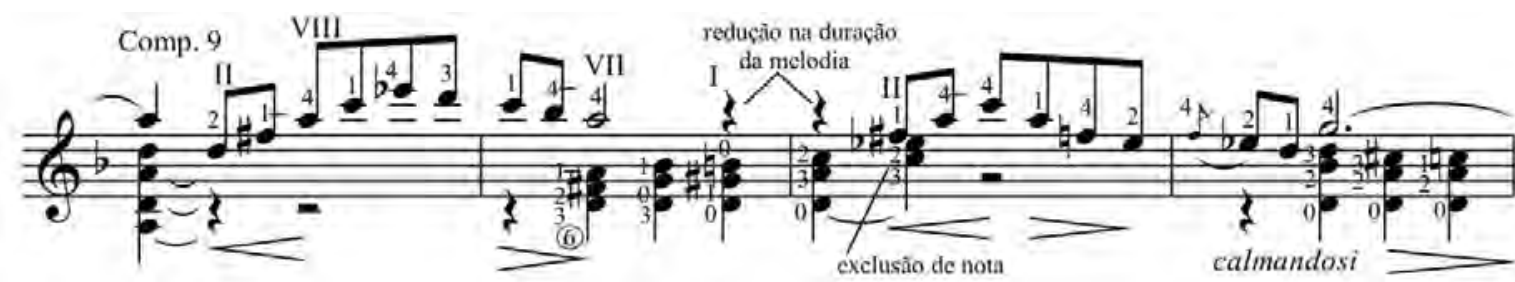

Exemplo 106: II Estudo, compasso 9.

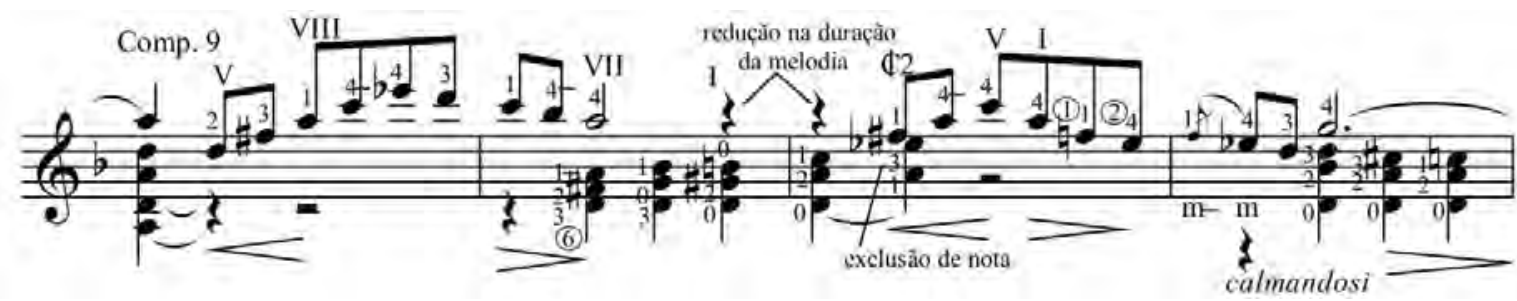

Exemplo107: II Estudo, compasso 9.

A abordagem BL para o trecho iniciado no compasso 13, privilegia o uso da terceira corda, mas abusa do uso do dedo 3 e conecta mal os compassos 15 e 16 por uma inversão completa dos dedos da me:

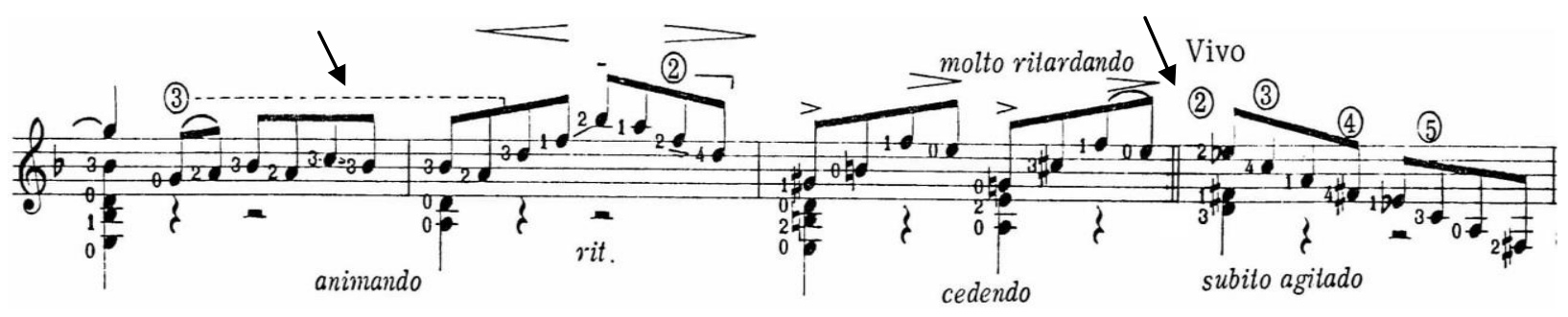

Exemplo 108: $I I^{o}$ Estudo, compasso 13. Edição Columbia/Barbosa-Lima.

Apesar de gostarmos da visão BL para o compasso 16, primeiramente gostaríamos de oferecer uma opção que melhor se conectasse à digitação BL do compasso anterior, que embora coloque o acorde inicial em posição oblíqua comprimida, atinge o mesmo pelo uso do dedo 2 como guia:

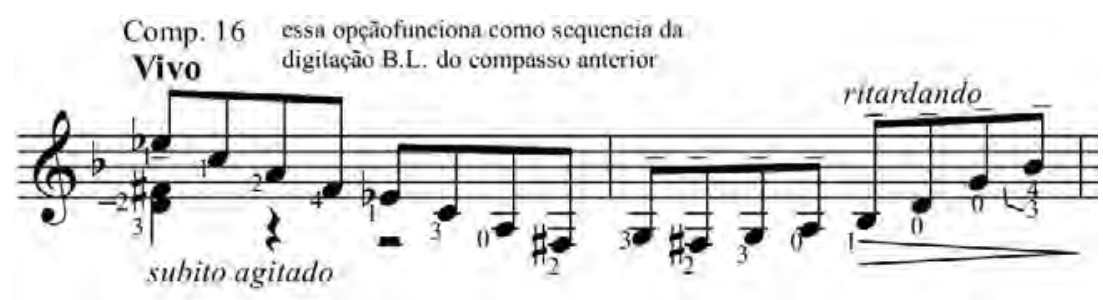

Exemplo 109: II Estudo, compasso 16.

\footnotetext{
${ }^{69}$ Pensando o F\# como Gb (em enarmonia).
} 
O exemplo 110 faz uma abordagem mais simples privilegiando a primeira posição, criando um acorde na quinta posição (alcançada por falsos guias) e resolvendo o último compasso com dedos fixos que se alternam:

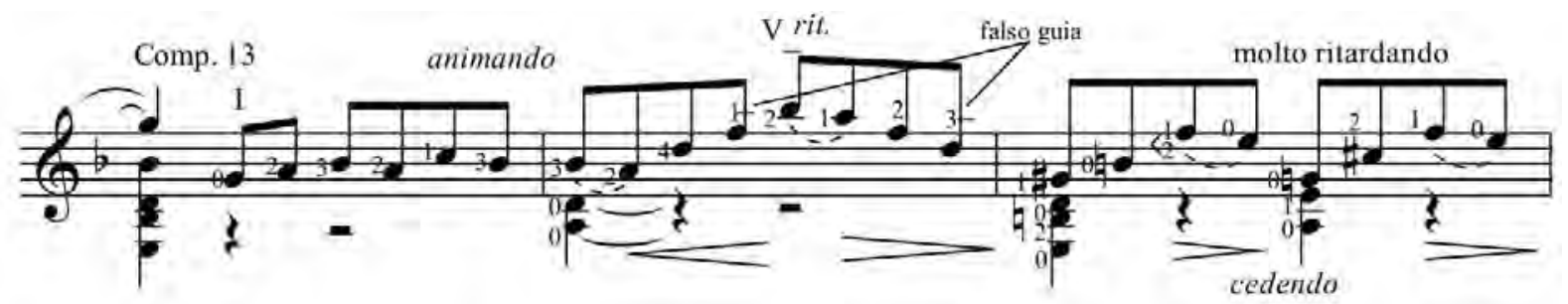

Exemplo 110: $I^{\circ}$ Estudo, compasso 13.

Outra visão possível é fazer o aproveitamento da robustez da quarta corda para a melodia inicial, consequentemente colocando todo o compasso seguinte na quinta casa e finalizando o trecho com pequenas campanellas entre a segunda e primeira cordas. $\mathrm{O}$ exemplo 112 registra um desfecho levemente similar, mas sem as campanellas. Essas nossas três versões tem ligados e portamenti opcionais e todas se ligam melhor à digitação BL do compasso 16, anteriormente exposta no exemplo 108.

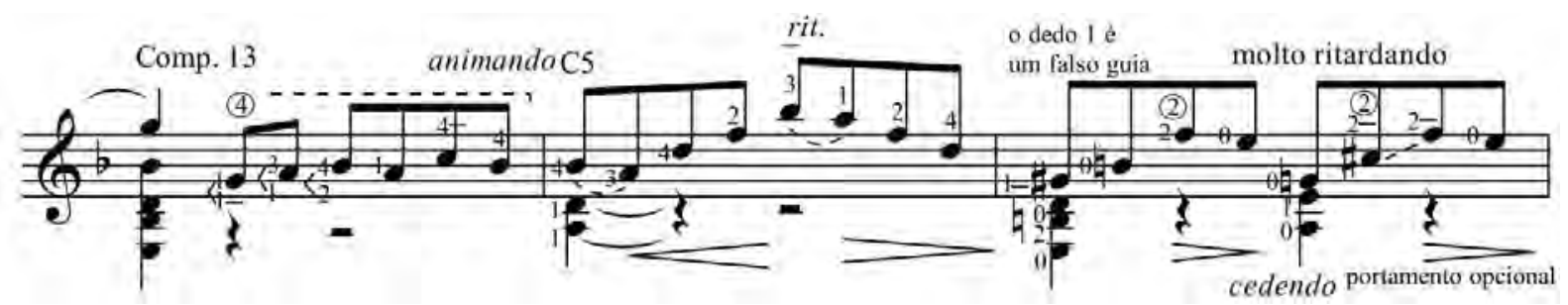

Exemplo 111: II Estudo, compasso 13.

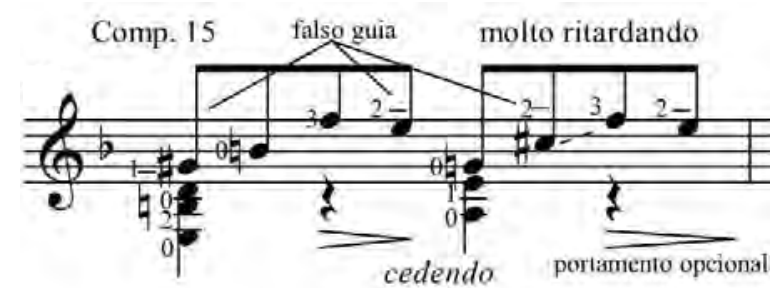

Exemplo 112: II Estudo, compasso 13.

A próxima seção, "Calmo", tem boa resolução por BL com poucos senões. Um deles diz a respeito ao compasso 23 , consideravelmente facilitado com o rearranjo ${ }^{70}$ dos dedos do primeiro tempo do compasso.

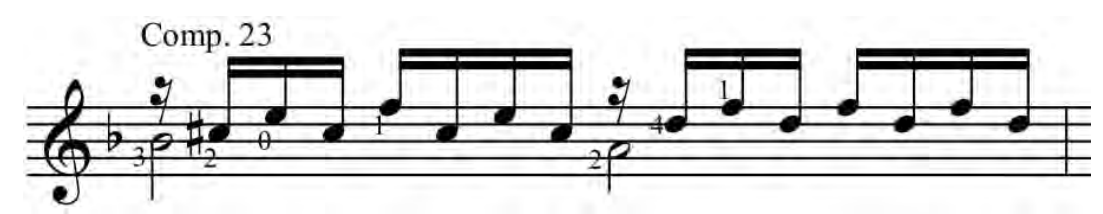

Exemplo 113: $I I^{\circ}$ Estudo, compasso 23.

A escrita cerrada das vozes partir do compasso 24 favorece a aparição de aberturas na digitação BL, especialmente nas quiálteras:

\footnotetext{
${ }^{70}$ verbo do checklist de Osborn.
} 


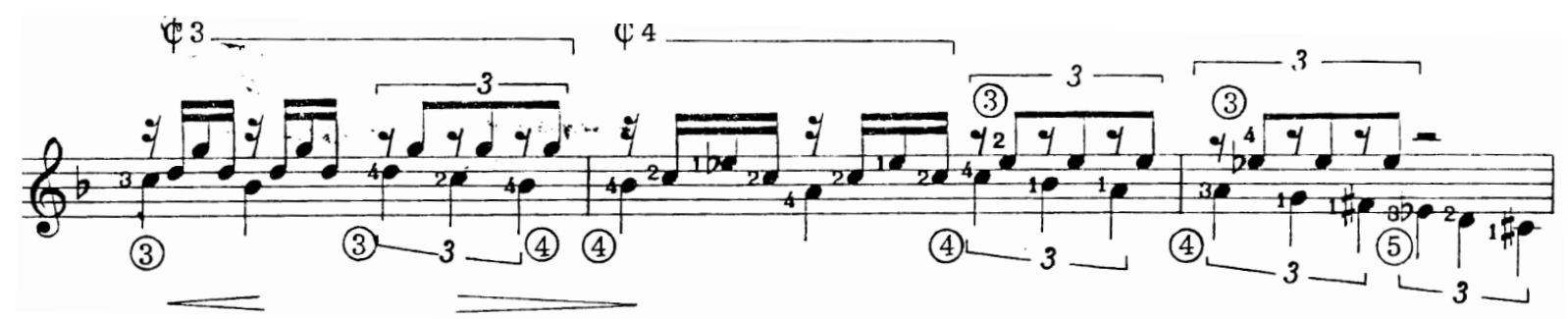

Exemplo 114: $I I^{\circ}$ Estudo, compasso 25. Edição Columbia/Barbosa-Lima.

Outra solução para o mesmo trecho reduz ${ }^{71}$ a abertura da primeira quiáltera colocando-a na quinta casa e resolve o restante fixando o dedo 1 no Mi bemol na segunda corda, ainda mantendo ${ }^{72}$ a parte inicial do compasso 26 igual à $\mathrm{BL}$.

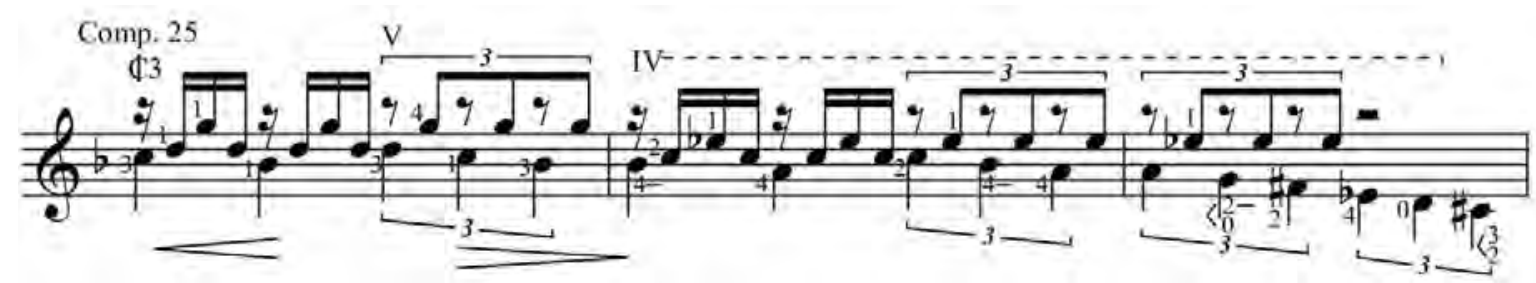

Exemplo 115: $I I^{\circ}$ Estudo, compasso 25.

O trecho estaria satisfatório, mas o Pensamento Divergente nos levou a testar outra visão, preconizando a alocação da melodia nos bordões do instrumento. Essa atitude favorece uma redução ${ }^{73}$ nas aberturas, mas por outro lado cria campanellas com alguma complexidade na $m d$ (nos compassos 21 e 23).

\footnotetext{
${ }^{71}$ verbo diminuir do checklist de Osborn.

72 item "deixar como está" do checklist de Osborn.

${ }^{73}$ verbo diminuir do checklist de Osborn.
} 

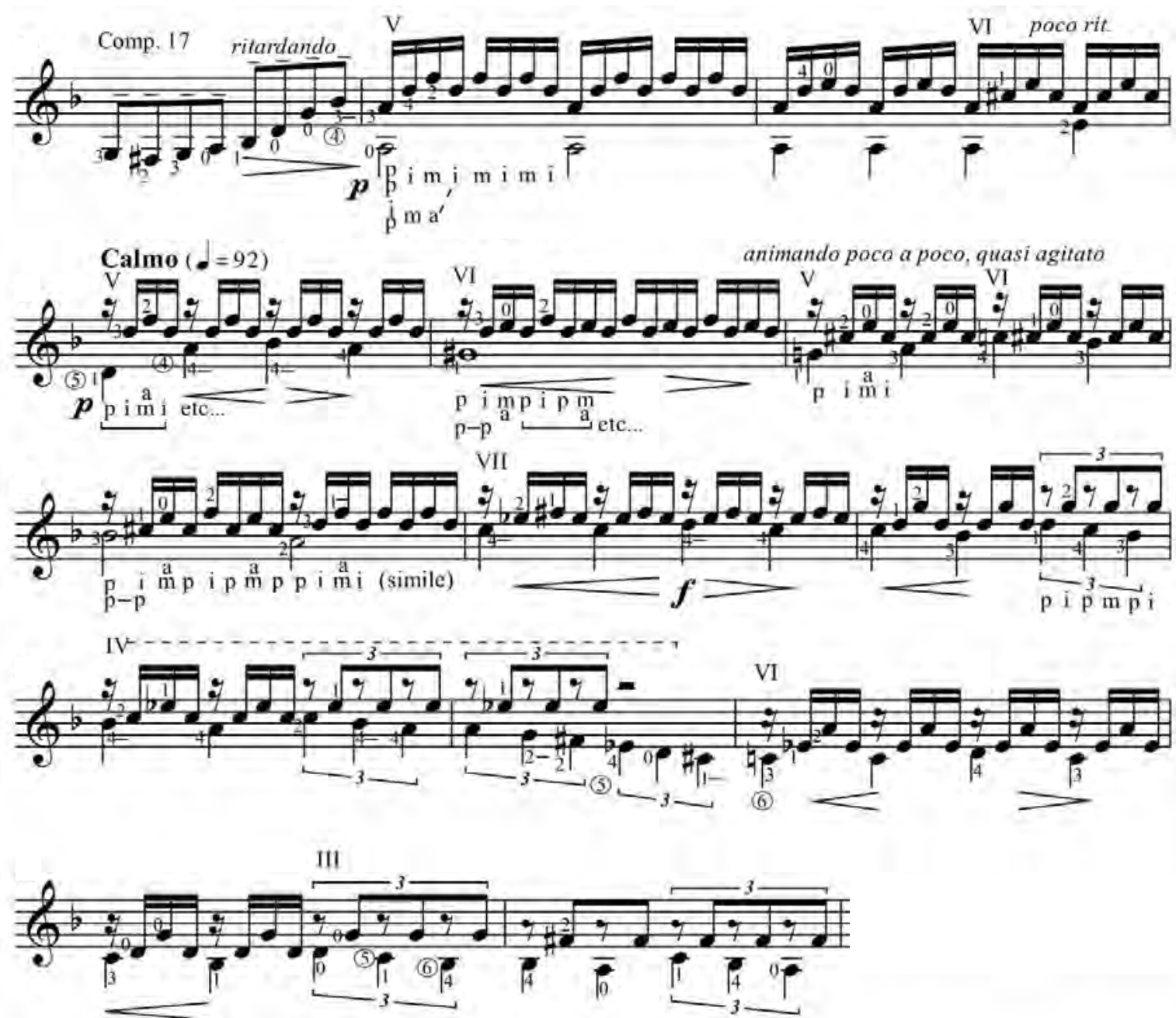

Exemplo 116: $I I^{\circ}$ Estudo, compasso 17.

A subida do compasso 31, numa textura levemente villa-lobiana em semitons (utilizada no Estudos 1 e 3 deste autor, por exemplo) também oferece várias opções não esgotadas por nós. O exemplo 117 faz a maior parte da subida pela segunda corda, enquanto os exemplos 118 e 119 aproveitam a corda solta para um único grande salto e seguem cada um a sua maneira.
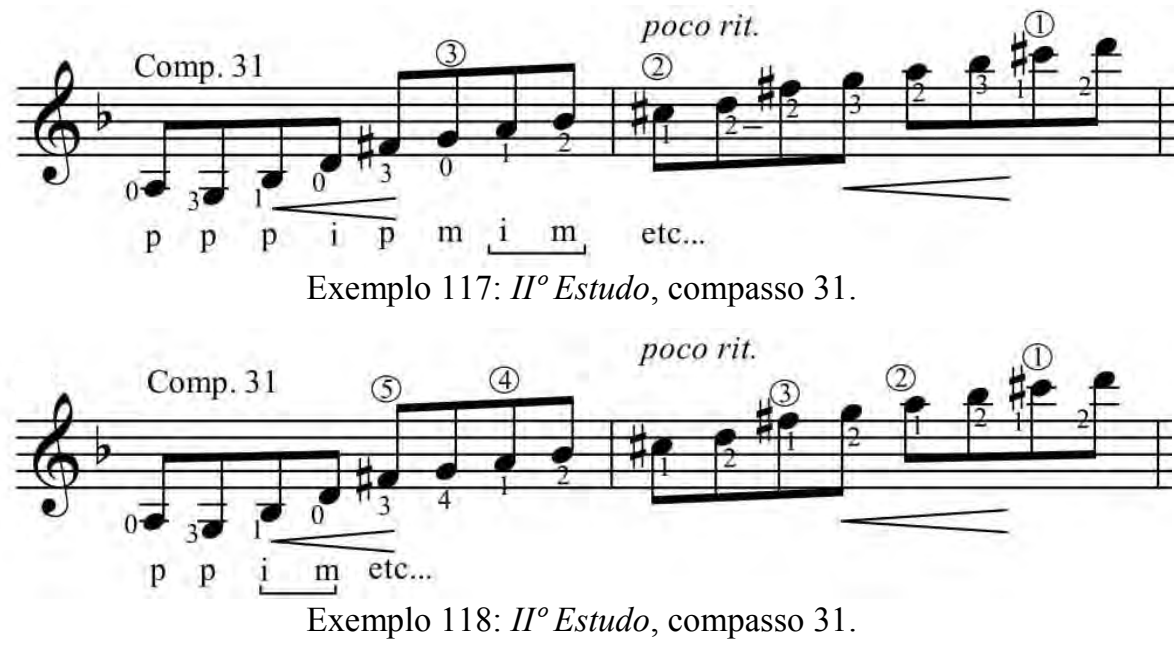


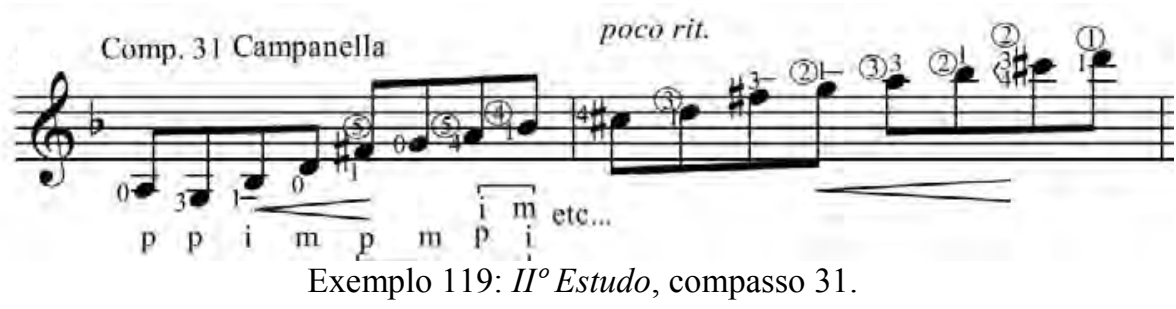

Chegamos à seção-clímax da obra no compasso 32, também bem resolvida por BL. Mesmo assim merecem maior atenção alguns pontos cadenciais, onde Mignone cria maior movimentação e com isso maiores desafios. O compasso 38 recebe uma segunda versão no exemplo 120, que abdica da meia-pestana inicial de BL, para ter o dedo 1 como guia na descida até a primeira posição.

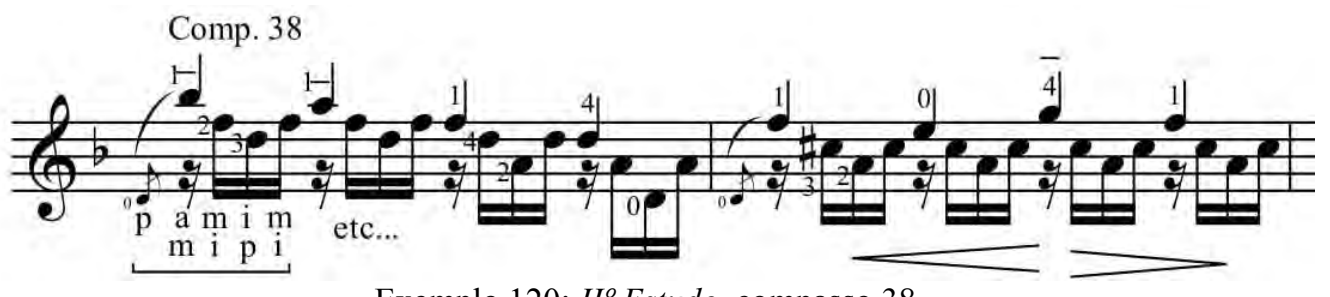

Exemplo 120: $I I^{\circ}$ Estudo, compasso 38.

Em resposta, Mignone realiza uma subida de mais de uma oitava para repetir a seção. BL propõe boa escolha de ligados mas pesa ao utilizá-los no agrupamento de dedos 4-2-3 no terceiro tempo.

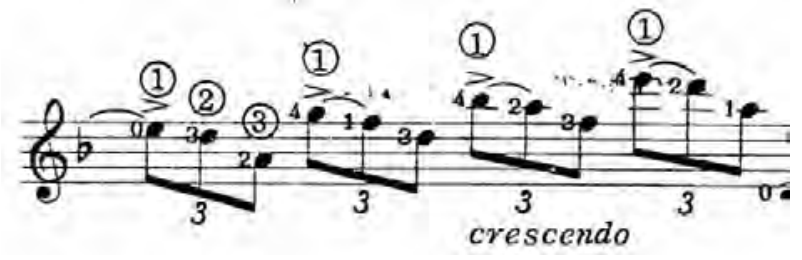

Exemplo 121: II Estudo, compasso 40. Edição Columbia/Barbosa-Lima.

Nossa primeira proposta (ex. 122) alivia este aspecto ao utilizar o agrupamento de dedos 4-1-3 no segundo e terceiro tempos e com uma meia-pestana no último. A segunda experiência (ex. 123) retira os ligados e monta blocos de acordes a cada tempo, mas com isso cria arriscadas aberturas não muito acessíveis.

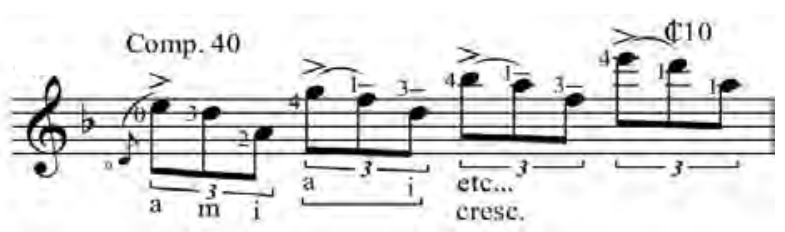

Exemplo 122: II Estudo, compasso 40.

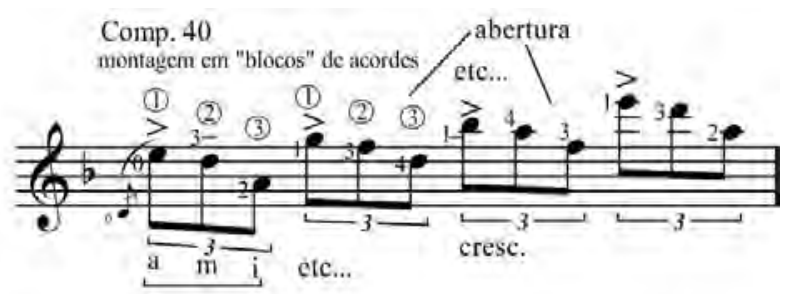

Exemplo 123: $I I^{\circ}$ Estudo, compasso 40.

A descida final da seção no compasso 46 guarda semelhança com o compasso 38 (mas agora em tercinas) e por isso ganha versão similar baseada no dedo 1 guia passando essa função para o dedo 4 logo em seguida. 


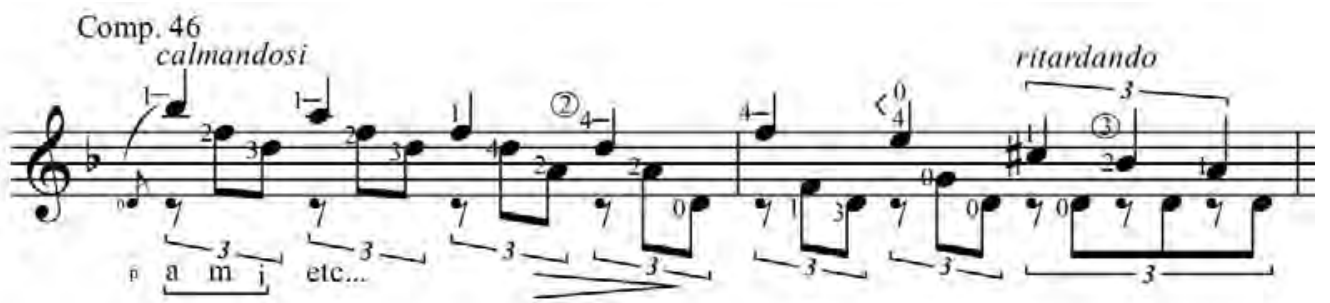

Exemplo 124: $I I^{\circ}$ Estudo, compasso 40.

Outro momento cadêncial ocorre no compasso 49, dessa vez com trabalho escalar de múltiplas digitações. O exemplo 125 o digita pela terceira posição, sempre em cordas presas; $\mathrm{O}$ exemplo 126 alcança a quinta posição através de portamento; o exemplo 127 privilegia a segunda e terceira cordas e finalmente, o exemplo 128 propõe uma digitação em campanella.

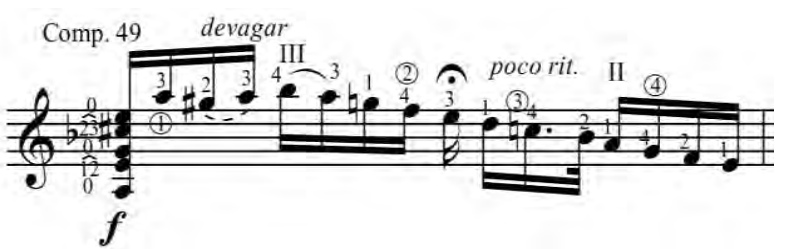

Exemplo 125: $I I^{\circ}$ Estudo, compasso 49.

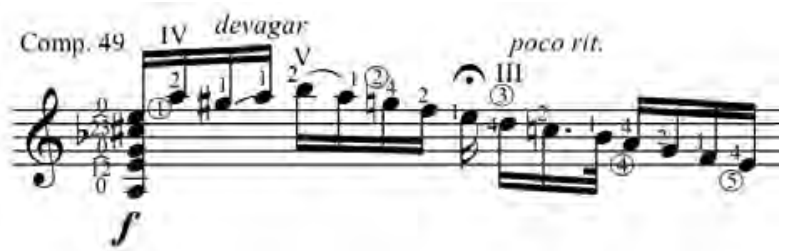

Exemplo 126: $I^{\circ}$ Estudo, compasso 49.

Comp. 49 Campanella

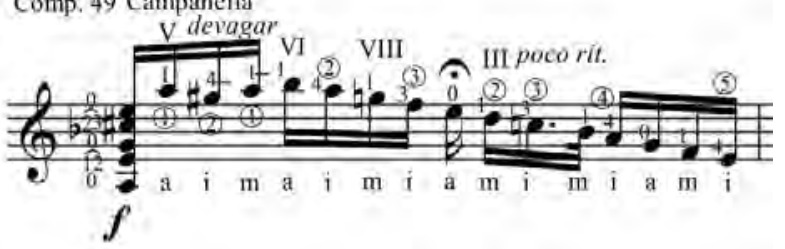

Exemplo 128: $I I^{\circ}$ Estudo, compasso 49.

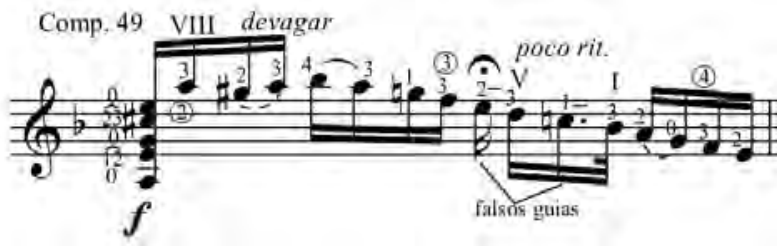

Exemplo 127: $I I^{\circ}$ Estudo, compasso 49.

O compasso 52 recebe uma versão com primeiro tempo com cordas soltas (ex. 129) e uma Ossia (ex. 130) que evita a abertura do terceiro tempo, ao trocar algumas notas do original.

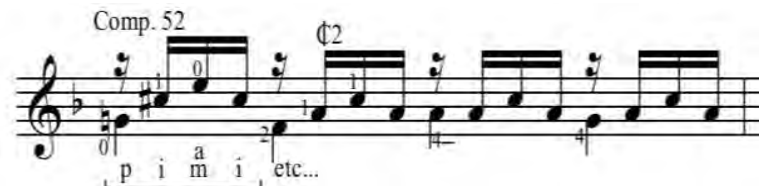

Exemplo 129: $I I^{\circ}$ Estudo, compasso 52.

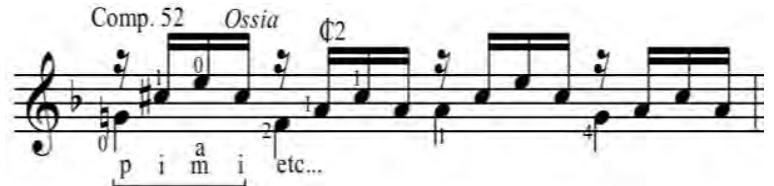

Exemplo 130: $I I^{\circ}$ Estudo, compasso 52.

O trecho iniciado no compasso 50 rememora não literalmente os compassos 2021. Dessa forma, também encontramos uma digitação similar (na região central do instrumento) que preconiza a melodia nos bordões, cria uma campanella no compasso 51 e oferece mais uma resolução ao compasso $52^{74}$.

\footnotetext{
${ }^{74}$ Como neste compasso o adiantamento do dedo 1 é opcional, ele foi grafado entre parentêsis.
} 


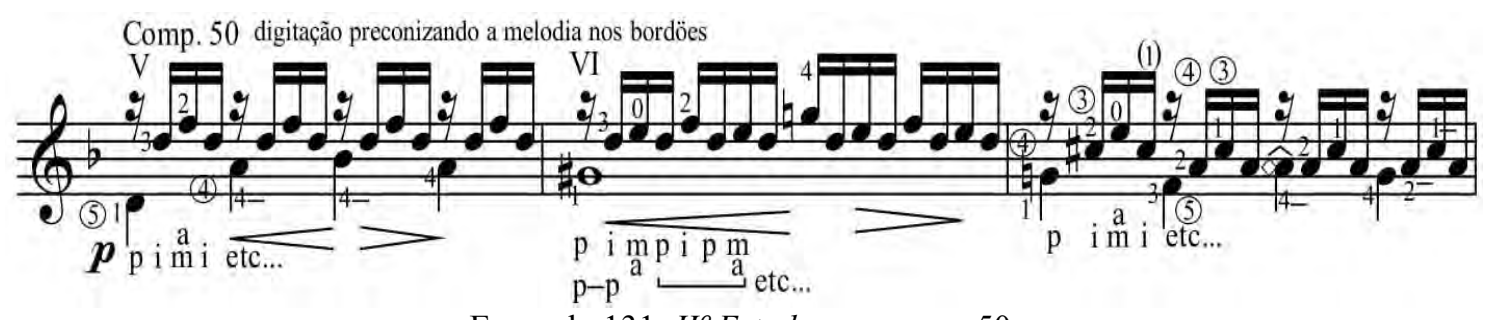

Exemplo 131: II Estudo, compasso 50.

No compasso 53 ocorre outra abertura similar ao compasso anterior. BL é sintético em sua indicação, mas prescreve uma meia-pestana na casa 2 , o que encurta $o$ alcance do dedo 4 que no compasso 55 pisará um Lá na quarta corda. Nossa opção alternativa (ex. 132) retira a meia-pestana e mantém o dedo 1 fixo na terceira corda:

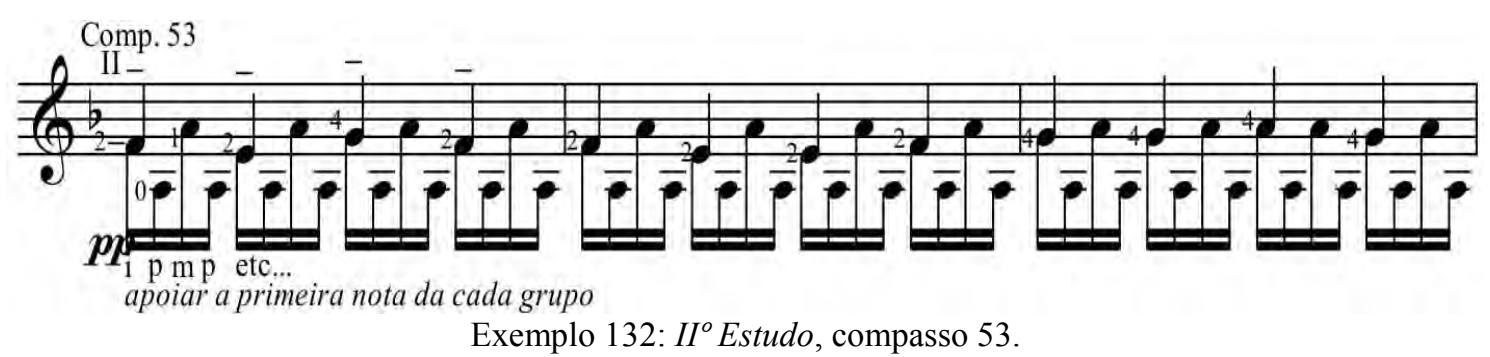

A seção de lentos arpejos (compasso 57 em diante) poderia ter a digitação BL facilitada com o uso de cordas soltas no compasso 63 (que se repete no 64), principalmente para melhor preparar os acordes seguintes como no exemplo seguinte:

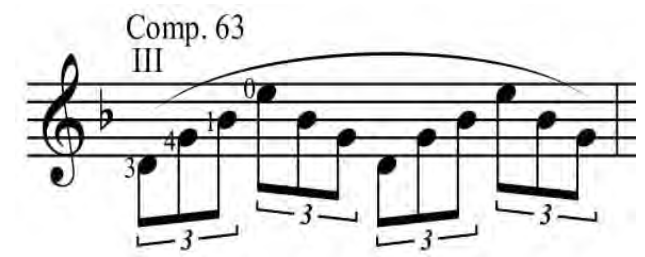

Exemplo 133: II Estudo, compasso 63.

Novamente, esses acordes também poderiam ser digitados na região central do instrumento, aspecto registrado pelo exemplo 134.

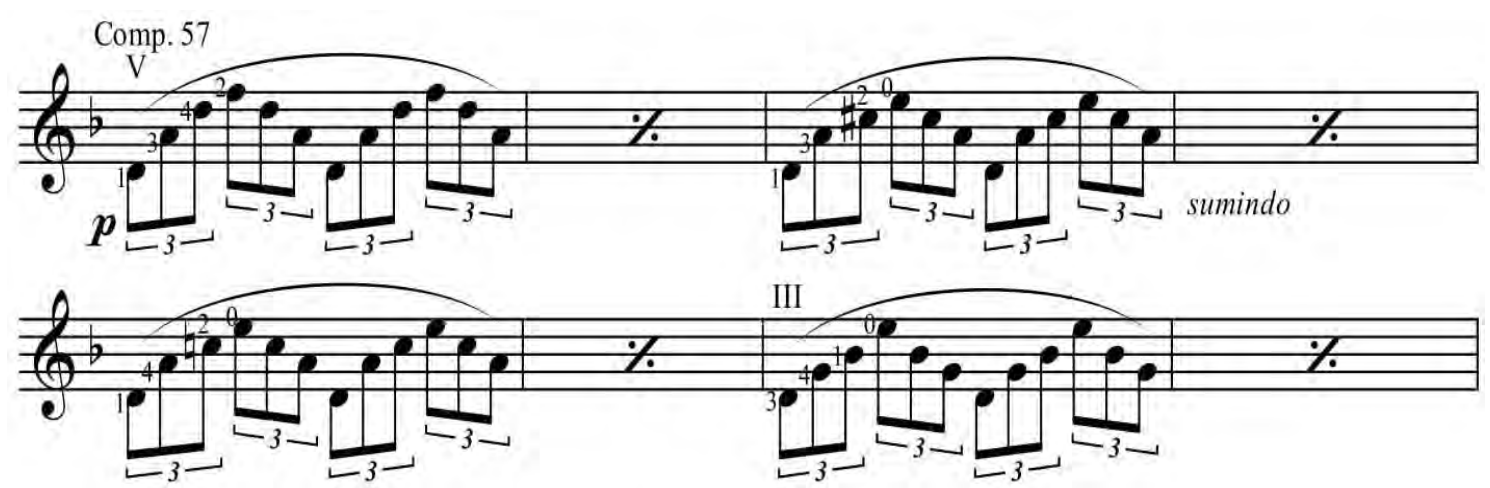

Exemplo 134: II Estudo, compasso 57.

O compasso 69 pela configuração única de seus acordes só permite a digitação BL de me, com a corda Sol solta. No entanto, no exemplo 135 ele recebe um 
detalhamento da md que pode incluir duas opções de articulação. Já o exemplo seguinte prescreve uma Ossia que exclui a nota Sol do acorde, facilitando-o.

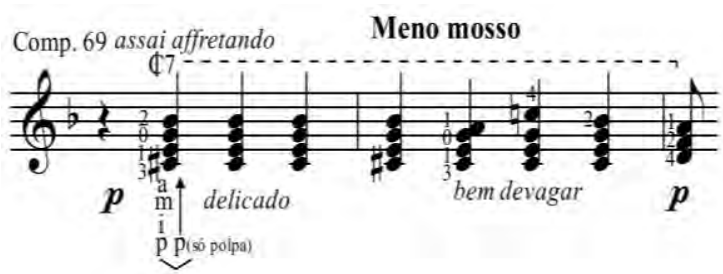

Exemplo 135: $I I^{\circ}$ Estudo, compasso 69.

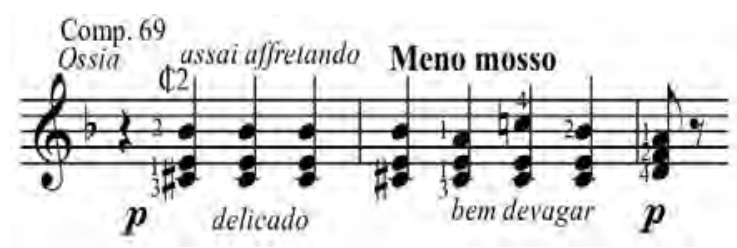

Exemplo 136: $I I^{\circ}$ Estudo, compasso 69.

O desfecho da obra recebe uma versão distinta com várias substituições de dedos em relação à $\mathrm{BL}$ e tem a duração das notas sugestionada por ligaduras nos dois primeiros compassos. No penúltimo compasso da obra, ocorre uma dubiedade de difícil esclarecimento (mesmo com consulta ao manuscrito), já que os acordes (que duram semínimas) são ligados a pausas, não definindo com clareza sua real duração.

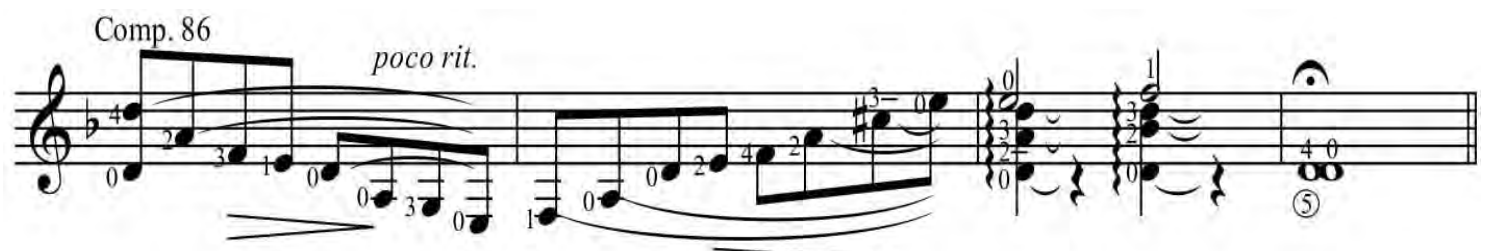

Exemplo 137: $I I^{\circ}$ Estudo, compasso 86. 


\section{3: III Estudo "Tempo de Chorinho"}

O terceiro estudo da série introduz um aspecto nacionalista relevante: a mescla entre gêneros, no caso o choro, de caráter urbano, com a música caipira, advinda do ambiente rural. Embora esta última influência não seja mencionada no título da obra, sua presença é sugerida pela presença de melodias em terças, típicas desse gênero.

\section{a Barbosa-Lima \\ $\mathrm{III}^{\circ} \mathrm{ESTUDO}$}

Fingered by

Carlos Barbosa-Lima

Tempo de chorinho $(d=72)$

FRANCISCO MIGNONE

(1970)

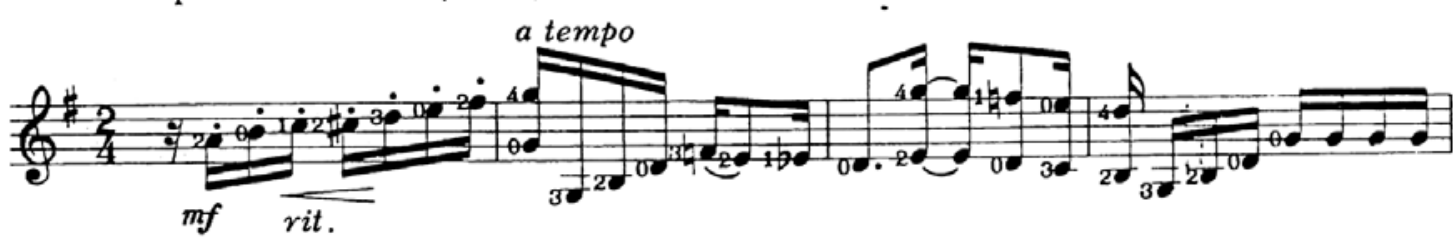

Exemplo 138: III ${ }^{o}$ Estudo, compasso 1. Edição Columbia/Barbosa-Lima.

A escala ascendente que o inicia é marcada com a indicação de staccato. Em prol de facilitar a obtenção dessa articulação, nossa única sugestão (exemplo 139) busca evitar cordas soltas (como BL de certa forma o fez). Outras opções seriam possíveis (como campanella) mas não lograriam esta articulação ou não se conectariam bem o compasso seguinte.

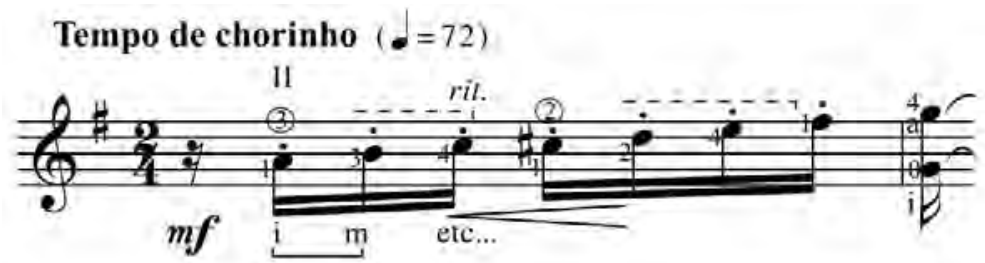

Exemplo 139: III ${ }^{\circ}$ Estudo, compasso 1.

O compasso 2, será inevitavelmente digitado pela segunda posição, permitindo apenas uma pequena substituição de dedos da me à versão BL e duas digitações de $m d$. No exemplo 140 aproveitamos para evidenciar a possibilidade da prolongação da voz superior, algo que julgamos aconselhável. O final do compasso está digitado pela quarta corda, mas também pode ser realizado na quinta, sem tanta duração da voz superior.

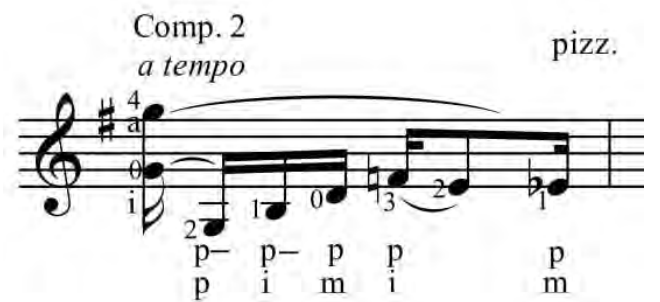

Exemplo 140: III ${ }^{\circ}$ Estudo, compasso 2. 
O compasso seguinte é bastante funcional na versão BL, havendo outras possibilidades de digitar seus intervalos de décimas envolvendo cordas mais graves e com isso produzindo mais ruídos de arraste. O exemplo 141 registra uma dessas opções ruidosas, havendo outra utilizando a terceira e sexta cordas.

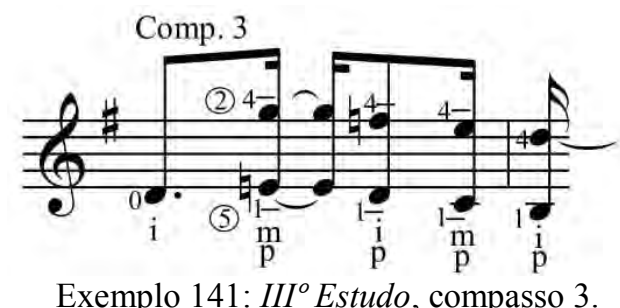

O compasso 4 também recebe uma prolongação opcional da voz superior. $\mathrm{O}$ exemplo 142 descrimina na digitação $\mathrm{BL}$ as opções de $m d$ para o trecho, todas com igual desenvoltura.

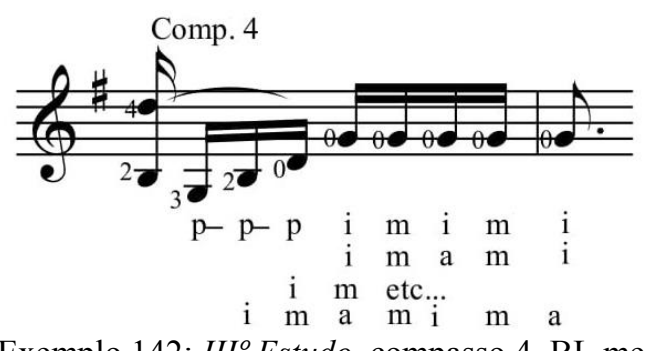

Já os exemplos 143 e 144 abdicam da voz superior prolongada para explorar o uso de duas cordas em uníssono no final do compasso, uma com alternância de cordas e outra com ligado vindo de corda solta, também com várias boas digitações de $m d$. $\mathrm{O}$ início do compasso sofre substituições mas também pode ser realizado como no exemplo anterior, por combinação ${ }^{75}$.

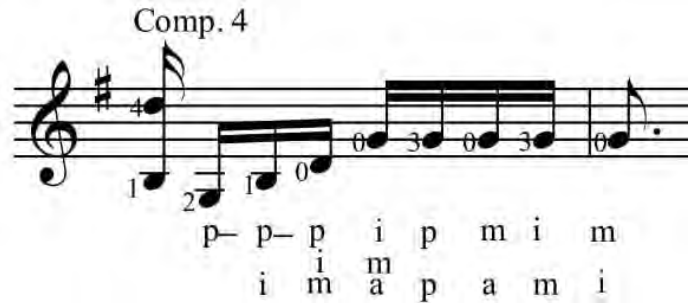

Exemplo 143: III ${ }^{\circ}$ Estudo, compasso 4.

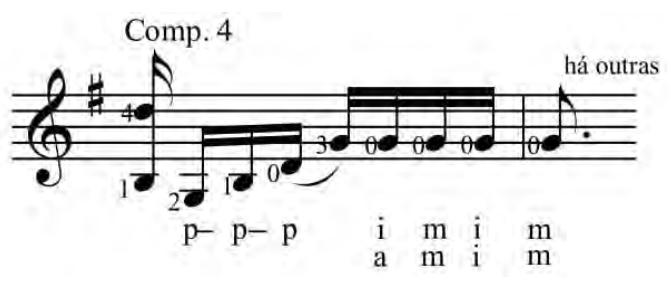

Exemplo 144: III ${ }^{\circ}$ Estudo, compasso 4.

Os compassos 6 e 8 oferecem desafios pela presença de notas repetidas em meio a arpejos amplos, textura de rara aparição na literatura e de difícil execução no violão e que pode ser considerada por nós uma característica da escrita mignoniana por ocorrer em outros estudos, configurando até um dos fatores que tem limitado sua maior acessibilidade à comunidade violonística.

\footnotetext{
${ }^{75}$ verbo do checklist de Osborn.
} 
Barbosa-Lima infelizmente não apresenta sua digitação de $m d$ neste momento mas ao menos sugere ligados bastante favoráveis. No último tempo do trecho, a digitação BL se baseia na formação de um acorde de Ré maior (completo) na segunda posição, o que requer o uso do dedo 4 na quinta corda em apresentação diagonal (ver Canilha, 2018, p. 33) o que gera mais dificuldades do que benefícios, aspecto este que pode ser bastante facilitado com o uso de uma corda solta.

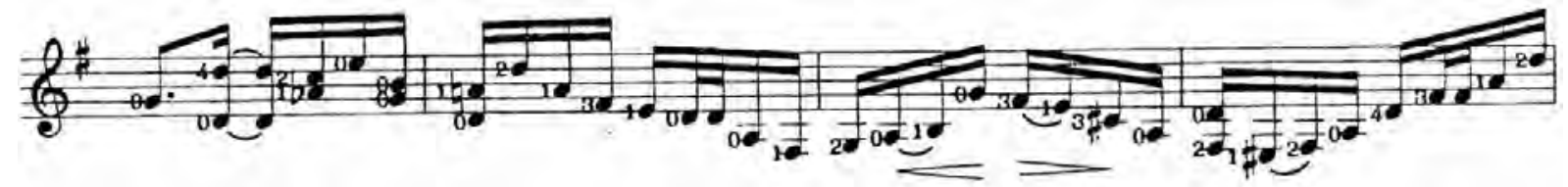

Exemplo 145: III Estudo, compasso 5. Edição Columbia/Barbosa-Lima.

Com essa modificação ${ }^{76}$, nossas opções preveem a substituição do último ligado por um portamento do dedo 1 , o que coloca a me na segunda posição, local onde executará o restante do compasso. As duas versões também sugerem um ligado opcional entre os dois primeiros compassos, mas diferem na execução das notas duplas: no exemplo 146 ambas são articuladas pela $m d$ enquanto no exemplo 147 a primeira delas recebe ligado. A digitação de $m d$ difere levemente por este mesmo motivo, sendo que o exemplo 148 ainda possibilita um escovamento do anelar no primeiro compasso.

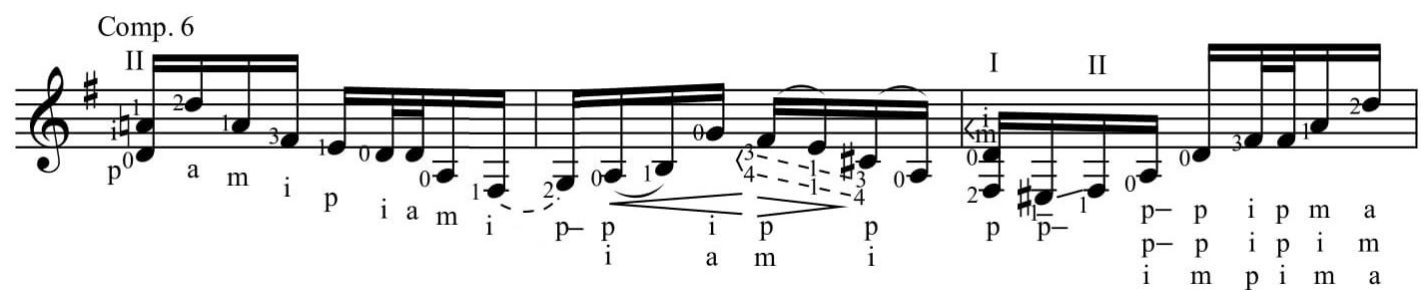

Exemplo 146: $I I^{\circ}$ Estudo, compasso 6.

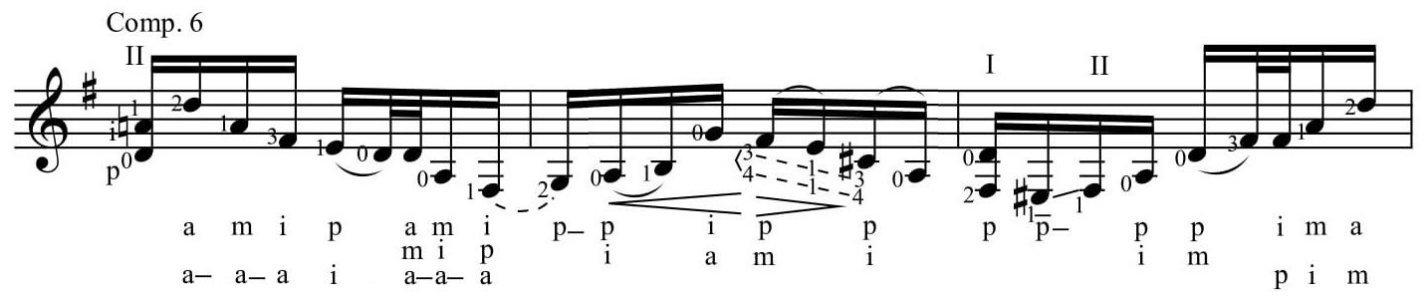

Exemplo 147: $I I I^{\circ}$ Estudo, compasso 6.

O compasso 6 ainda recebe abaixo outras duas versões, ambas com as notas duplas executadas em duas cordas distintas, diferindo na posição onde começam e no ritmo do ligado.

\footnotetext{
${ }^{76}$ verbo do checklist de Osborn.
} 


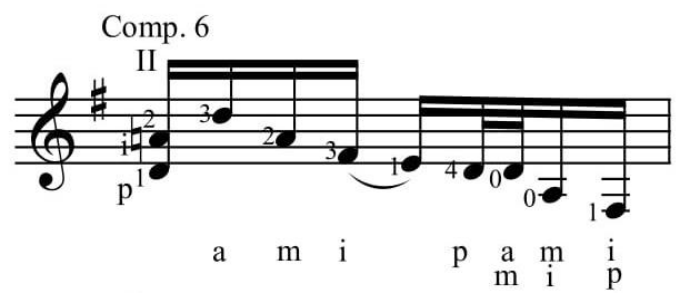

Exemplo 148: III ${ }^{\circ}$ Estudo, compasso 6.

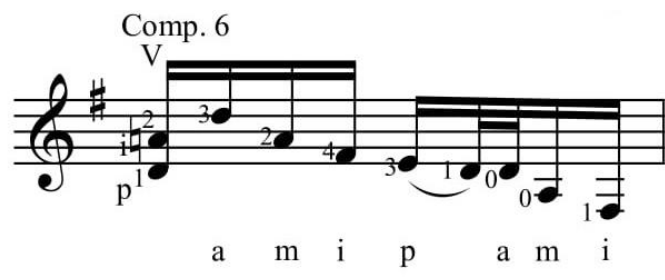

Exemplo 149: III ${ }^{\circ}$ Estudo, compasso 6.

O compasso 8 também recebe mais uma versão extra, retornando à proposta de me de BL, mas agora um portamento e um ligado, sem contudo melhorá-la absurdamente.

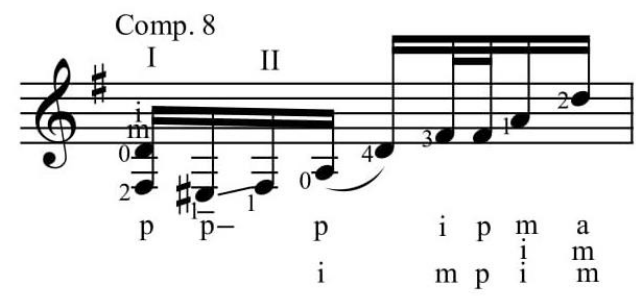

Exemplo 150: III ${ }^{\circ}$ Estudo, compasso 8.

Similar ao início da obra, o compasso 9 também recebe uma versão apenas com cordas presas para favorecer os staccati.

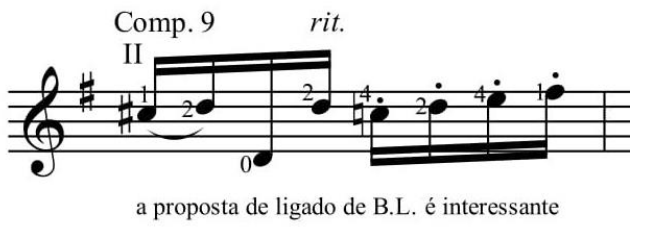

Exemplo 151: III Estudo, compasso 6.

Após uma transição com terças caipiras, uma nova seção propõe uma melodia em acordes que é respondida por uma "baixaria" chorona, criando saltos verticais e horizontais de me. No compasso 18 , a digitação BL de me é um tanto vaga ao prescrever o dedo 2 para duas notas seguidas sem maiores indicações (exemplo 152). Concluímos que a melodia era tocada por BL na quinta corda, caso contrário (ou seja, se usasse a quarta corda) necessitaria de uma pestana de dedo 2 (pisando o Si e o Mi) o que faria com o que ligado em seguida gerasse desastrosamente duas notas (o Ré\# prescrito e um Lá\# não intencional). Dessa forma, estando a melodia na quinta corda subentendemos também o uso do dedo 2 como guia (exemplo 153).

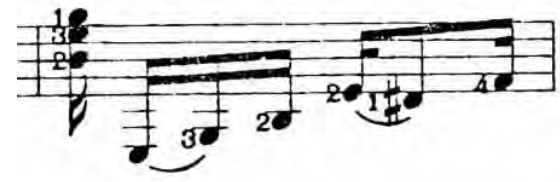

Exemplo 152: III ${ }^{\circ}$ Estudo, comp. 18. Ed. Columbia/BL.

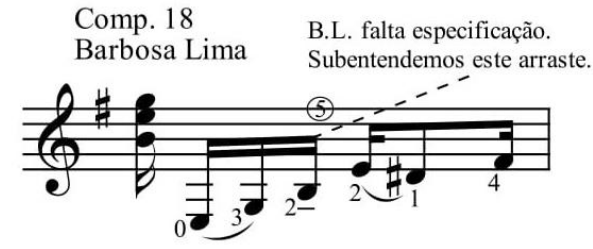

Exemplo 153: III Estudo, comp. 18.

O exemplo 154 ainda mantém a melodia na quinta corda, mas inicia a digitação pela segunda posição e coloca o dedo 1 como falso guia. Já os exemplos seguintes 
buscam manter o compasso inteiro na primeira posição utilizando também a quarta corda. O exemplo 155 inicia com o dedo 4 (mais fraco para o ligado, mas ainda funcional) por compressão para conseguir descer à quarta corda com o dedo 3. $\mathrm{O}$ exemplo 156 recorre a uma pestana com o dedo 1 na segunda casa para abarcar duas cordas, necessitando, por outro lado, de uma abertura (acessível) para alcançar o Ré\# com o dedo 4. Finalmente, o exemplo 157 modifica $^{77}$ os dedos do exemplo 155 (usando o dedo 3 no ligado) e coloca um portamento com o dedo 1 no lugar do ligado anterior. Embora possuam diferenças notáveis, os exemplos 152 a 157 tem mais ou menos igual funcionalidade, sendo decisão do intérprete qual recorrer em sua performance.

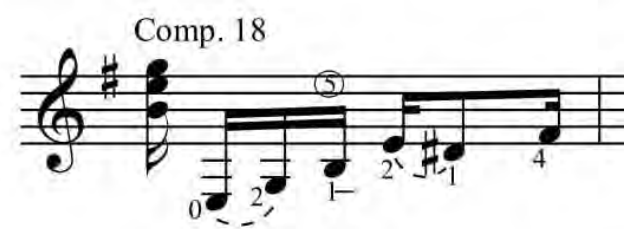

Exemplo 154: III ${ }^{\circ}$ Estudo, compasso 18.

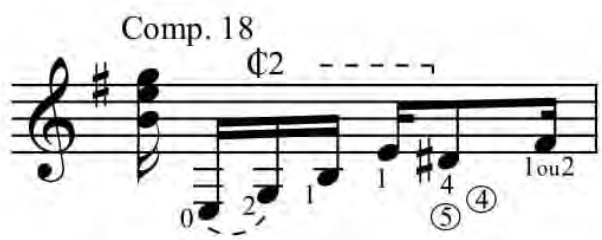

Exemplo 156: III ${ }^{\circ}$ Estudo, compasso 18.

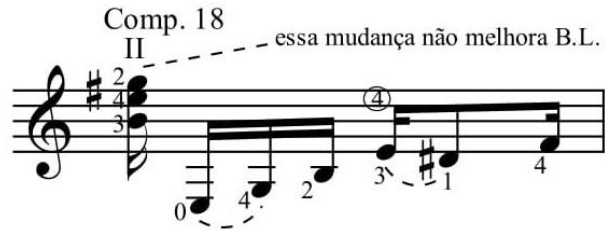

Exemplo 155: III Estudo, compasso 18.

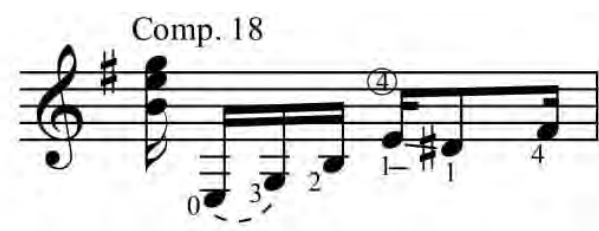

Exemplo 157: III Estudo, compasso 18.

No compasso 19, a melodia em acordes se movimenta e a chegada ao acorde de Lá menor no compasso seguinte é a maior dificuldade. A digitação BL (exemplo 158) é bastante compreensível ao utilizar o dedo 3 como guia na segunda corda, chegando ao acorde com os dedos 2, 3 e 4 em posição levemente contraída e por isso nem sempre segura dependendo do andamento da execução. O exemplo 159 modifica $^{78}$ apenas o final da versão BL, ao colocar o dedo 2 no Ré e chegar ao acorde com um rápido translado do dedo 1 em pestana de forma mais segura. Os exemplos 160 e 161 digitam o trecho a partir da sétima posição e por isso necessitam de um salto inicial para conectálos ao acorde anterior. O exemplo 160 utiliza mais pestanas mas gera a vantagem de trabalhar com dois acordes paralelos (com mesma disposição dos dedos) e já preparar a pestana na quinta casa antes do compasso seguinte. O exemplo 161 aproveita a corda Mi solta, mas gera mais ruído pelos arrastes do dedo 3 na quarta corda, podendo chegar ao acorde final com a digitação BL ou também com pestana do dedo 1 .

\footnotetext{
${ }^{77}$ verbo do checklist de Osborn.

${ }^{78}$ verbo do checklist de Osborn.
} 
$\Phi 2\urcorner$

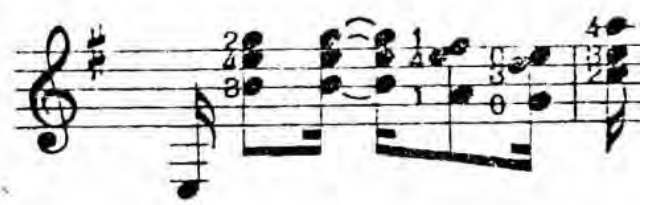

Exemplo 158: III Estudo, comp. 19. Ed. Columbia/BL.

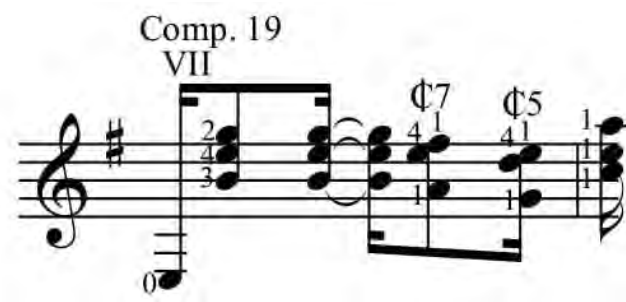

Exemplo 160: $I I I^{\circ}$ Estudo, compasso 19.

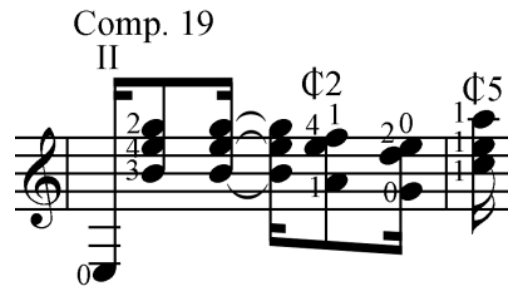

Exemplo 159: III Estudo, compasso 19.

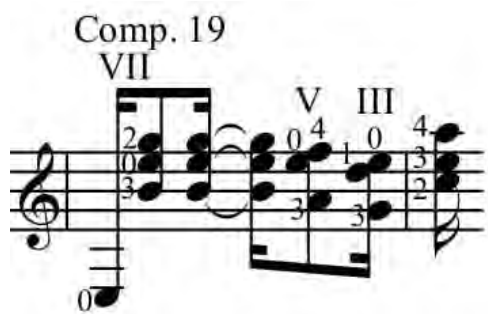

Exemplo 161: III ${ }^{\circ}$ Estudo, compasso 19.

No compasso seguinte, BL (exemplo 162) propõe um salto vertical de me onde o dedo 4 sai da primeira corda e rapidamente tem que se recolocar na quinta em um ligado, algo possível já que há uma corda solta envolvida, mas mesmo assim arriscado.

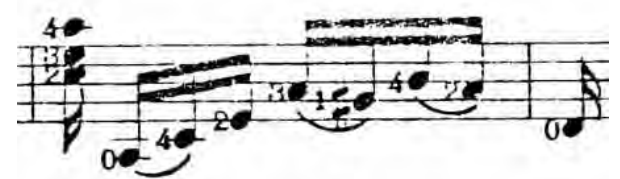

Exemplo 162: III ${ }^{\circ}$ Estudo, comp. 20. Ed. Columbia/BL.

Curiosamente a "baixaria" do trecho em muito se assemelha a do compasso 18 , transposta uma quarta acima e com leve diferença rítmica. Sendo o violão um instrumento de afinação predominantemente quartal, isso significa que as mesmas digitações do compasso 18 são aplicáveis bastando "saltar" uma corda verticalmente para se obter as alturas corretas. Dessa forma, tomamos a liberdade de apenas listar algumas das possibilidades, todas de eficácia similar.

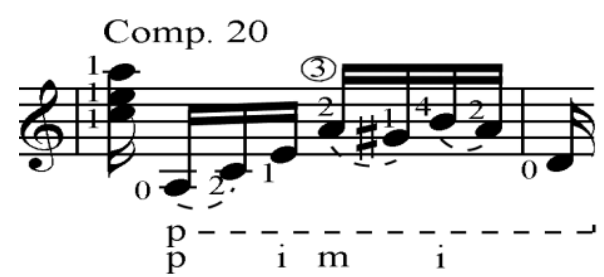

Exemplo 163: III Estudo, compasso 20.

Comp. 20

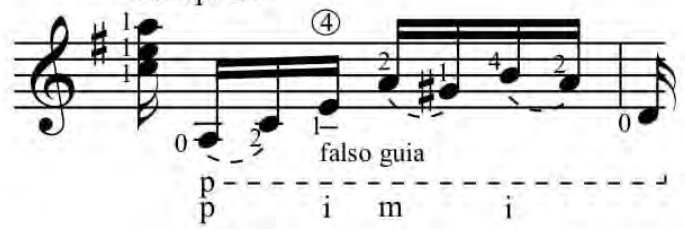

Exemplo 165: III Estudo, compasso 20.

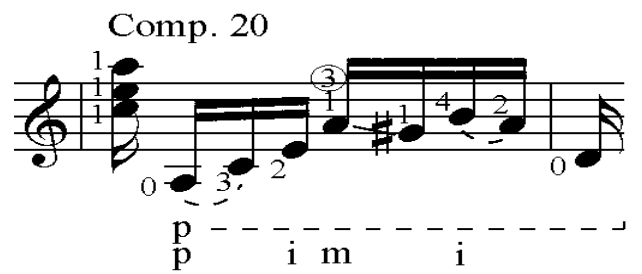

Exemplo 164: III ${ }^{\circ}$ Estudo, compasso 20.

Comp. 20

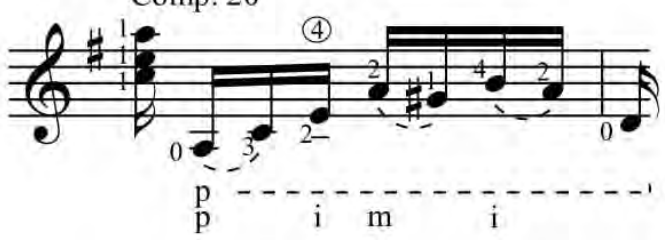

Exemplo 166: $I I I^{\circ}$ Estudo, compasso 20. 
No trecho iniciado no compasso 22 a baixaria ganha cromatismo e a melodia de acordes (agora em intervalos de sextas) chega à região aguda do instrumento, criando o desafio de como conectar esses duas texturas.

A digitação $\mathrm{BL}$ opta por realizar o baixo cromático na primeira posição, terminando com o dedo 1 e através de um grande salto (ou usando o dedo 1 como falso guia) atacar a melodia em sextas na primeira e terceira cordas.

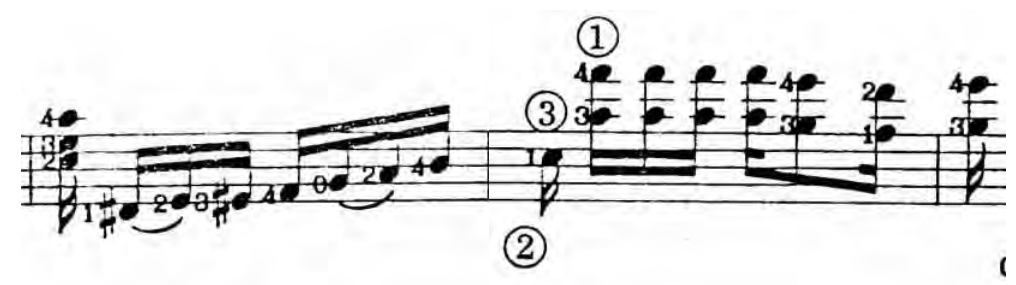

Exemplo 167: III Estudo, comp. 22. Ed. Columbia/BL.

Nossas propostas partem de uma organização diferente para o primeiro intervalo de sextas, colocando-o na primeira e segunda cordas, em uma pestana na décima casa, o que também torna possível executar a última nota do baixo (um dó) na mesma pestana, na quarta corda. Assim, as versões diferem em como atingem esse Dó na quarta corda. O exemplo 168 parte do acorde em pestana na quinta casa e realiza a subida pela quinta e quarta cordas, com falso dedo guia, mostrando também a nova digitação do compasso seguinte. As outras duas versões (que apenas focalizam o compasso 22) partem da abordagem de BL mantendo o baixo cromático na primeira posição e atingem o referido Dó na quarta corda de maneiras distintas, mas súbitas em nossa opinião.

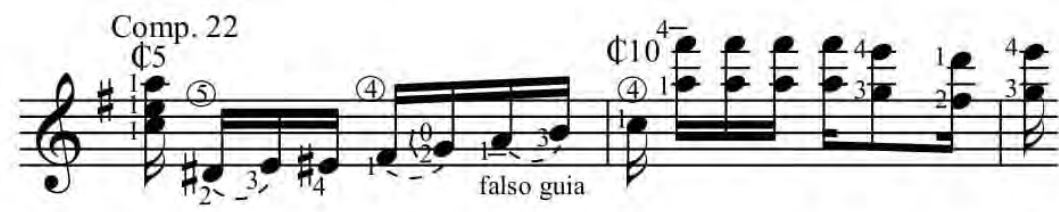

Exemplo 168: III Estudo, compasso 22.

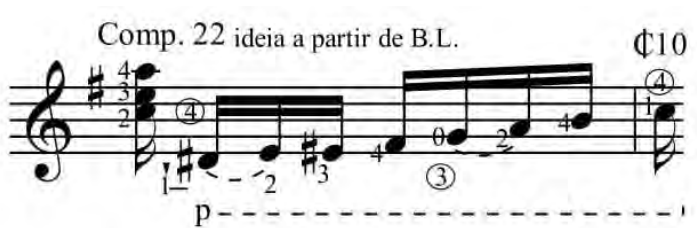

Exemplo 169: III Estudo, compasso 22.

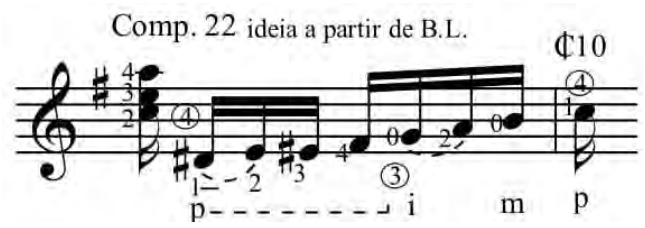

Exemplo 170: $I I I^{\circ}$ Estudo, compasso 22.

No trecho seguinte os dois gestos musicais vão gradativamente se aproximando, embora o problema de como conectá-los ainda exista. A digitação BL mantém a figuração do baixo na primeira posição (em suas duas aparições idênticas) e provavelmente usa os dedos 3 e 4 como falsos guias para atingir a primeira terça do compasso 25, mas parece usar demasiadamente o dedo 3 na melodia em terças. 


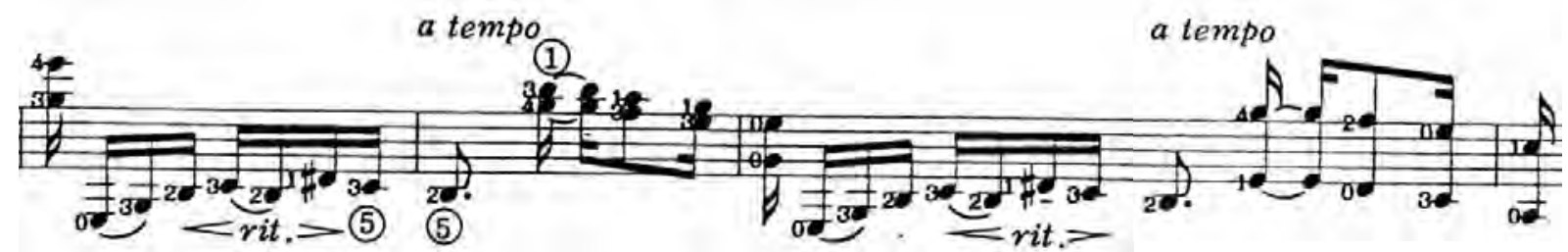

Exemplo 171: III ${ }^{\circ}$ Estudo, comp. 24. Ed. Columbia/BL.

Nossa abordagem no próximo exemplo foi tratar as duas "baixarias" com digitações diferentes, preconizando a conecção com as repostas melódicas. Dessa forma, a "baixaria" do compasso 24 leva, através do dedo 1 na quinta corda, até a região central do instrumento em tempo de executar as terças com maior legato (inclusive do baixo). Já a segunda "baixaria" se mantém ${ }^{79}$ com a mesma digitação BL na primeira posição, mas desemboca em outra alternativa para a melodia em décimas. O exemplo 173 apenas registra outra possibilidade para o compasso 27 , que peca, a nosso ver, ao usar o dedo 4 na quinta corda.

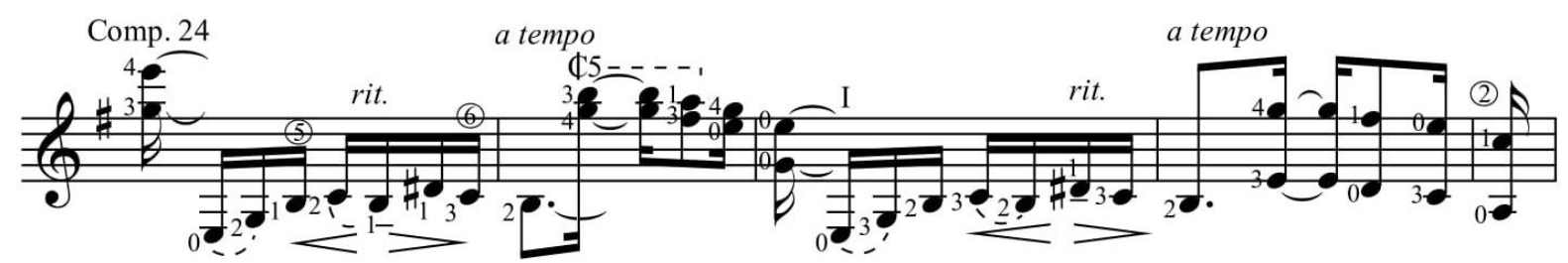

Exemplo 172: III ${ }^{\circ}$ Estudo, compasso 24.

\section{Comp. 27}

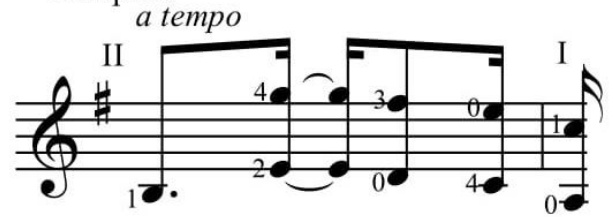

Exemplo 173: III $^{\circ}$ Estudo, compasso 27.

Já o exemplo 174 realiza ambas as "baixarias" com conexão à região central do violão (apenas com pequenas diferenças nos dedos das últimas notas), fazendo o uso eventual de harmônicos naturais nos primeiros dois compassos e digitando as décimas pela segunda e quinta cordas.

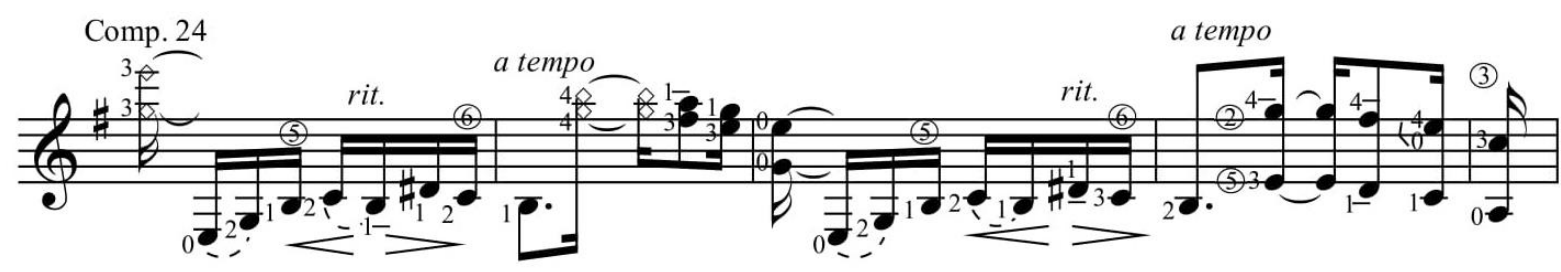

Exemplo 174: $I I^{\circ}$ Estudo, compasso 24.

O compasso 28 tem baixaria idêntica a do compasso 20, mas circundada por um contexto diferente, o que possibilita o aproveitamento das versões anteriores mas

\footnotetext{
${ }^{79}$ item "deixar como está" do checklist de Osborn.
} 
também gera novas possibilidades. A diferença mais notável diz respeito a sua sequência: a nota Dó que finaliza a baixaria será repetida logo em seguida para iniciar nova melodia com intervalos de décimas. $\mathrm{O}$ intérprete, portanto, terá dois caminhos interpretativos para seguir: ou busca unidade tímbrica entre essa repetição de notas dó, ou busca exacerbar timbricamente a diferença de funções que elas prestam. Seguindo a primeira opção, BL faz com que a baixaria culmine na segunda corda:

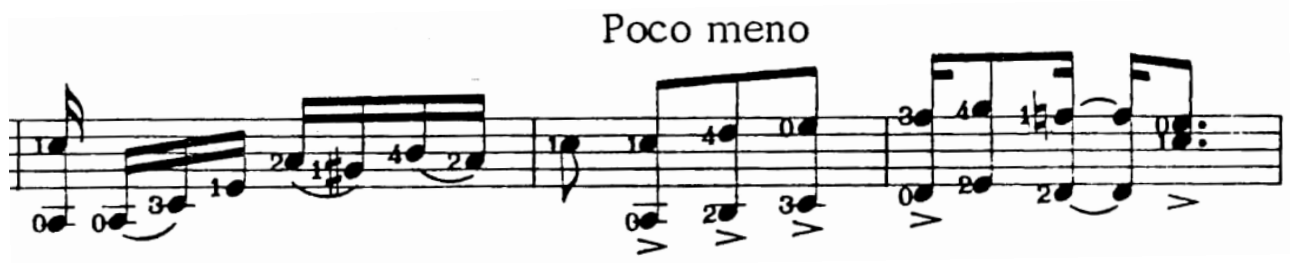

Exemplo 175: III ${ }^{\circ}$ Estudo, comp. 28. Ed. Columbia/BL.

Nosso exemplo 176 faz o mesmo, mas com uma seleção de dedos diferentes. Os exemplos 177 e 178 finalizam na terceira cordas e o 179 se mantêm pela quarta, gerando com isso a maior diferença tímbrica em relação ao trecho seguinte, que inevitavelmente ${ }^{80}$ seguirá pela segunda corda.

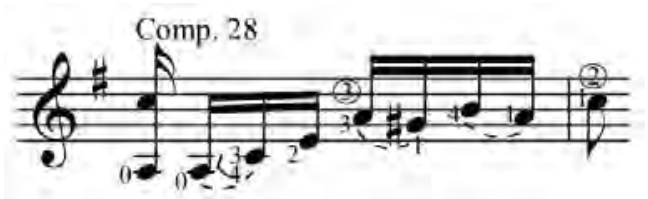

Exemplo 176: III ${ }^{\circ}$ Estudo, compasso 28.

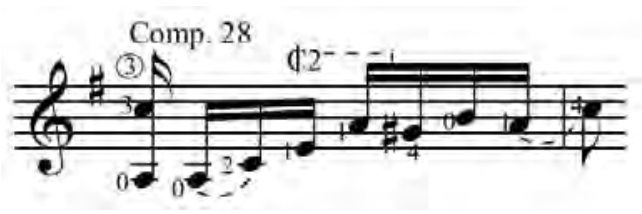

Exemplo 178: III Estudo, compasso 28.

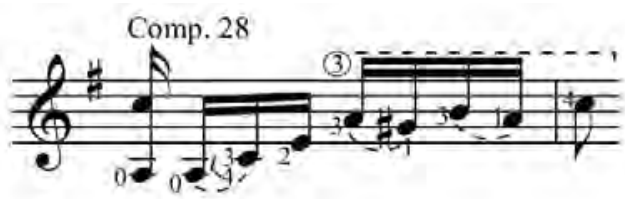

Exemplo 177: III Estudo, compasso 28.

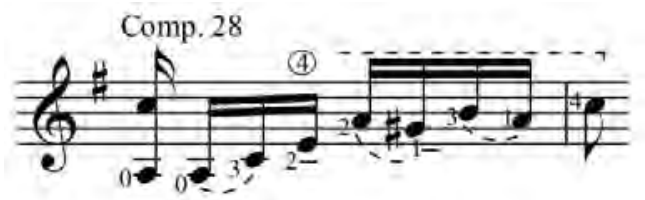

Exemplo 179: III ${ }^{\circ}$ Estudo, compasso 28.

A digitação BL para a progressão em intervalos de décimas utiliza uma repetição por salto do dedo 3 (entre os compasso 29 e 30) e do dedo 1 (final do compasso 30), primeira delas bastante arriscada, característica evitada em nossas opções. Há também uma menção ao uso (não compreensível) do dedo 2 na nota Ré que poderia ser esclarecida com uma maior indicações de cordas ou posições utilizadas.

Os exemplos 180 e 181 mantém abordagem similar, centrada nas primeiras casas do instrumento, sendo que o primeiro deles ainda mantém ${ }^{81}$ a segunda repetição de dedos da proposta de $\mathrm{BL}$, artifício normalmente desaconselhável mas que é funcional neste caso, principalmente por sua configuração rítmica. Já os exemplos 182 e 183 vão

\footnotetext{
${ }^{80}$ Existe apenas uma opção de digitação para o compasso 29 colocando as décimas na terceira e sexta cordas de forma não muito funcional e gerando muito ruído, por isso, decidimos não grafá-la.

${ }^{81}$ item "deixar como está" do checklist de Osborn.
} 
paulatinamente atingindo o centro do instrumento, o primeiro deles tendo o dedo 2 como guia na quinta corda e o segundo fazendo o mesmo com o dedo 1. Ao mesmo tempo são grafadas várias cordas soltas opcionais nos mesmos exemplos o que gera ainda outras saídas para a passagem.

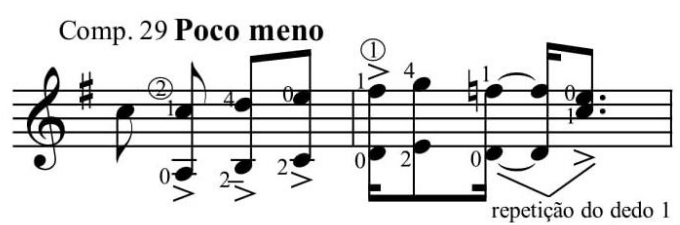

Exemplo 180: III ${ }^{\circ}$ Estudo, compasso 29.

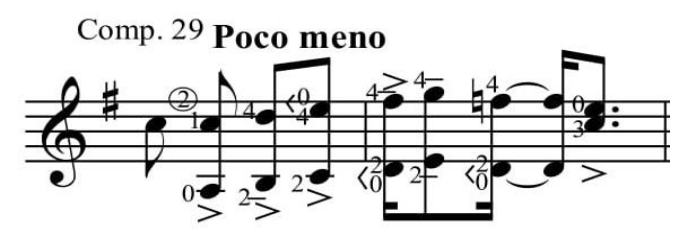

Exemplo 182: III ${ }^{o}$ Estudo, compasso 29.

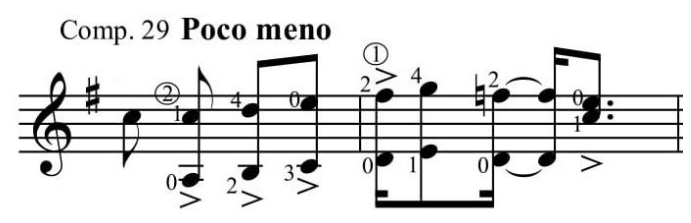

Exemplo 181: III Estudo, compasso 29.

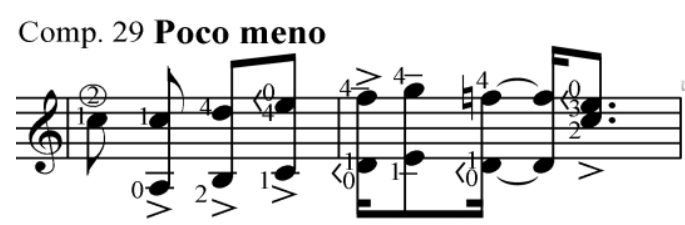

Exemplo 183: III ${ }^{\circ}$ Estudo, compasso 29.

O compasso 31 necessita primeiro de uma discussão a respeito de uma nota, com divergência entre manuscrito e edição Columbia/BL. A nota em questão é o Ré3 no final do compasso, cuja edição Columbia/BL (exemplo 184) coloca como Ré bemol e o manuscrito (exemplo 186) como Ré natural. Por outro lado, Mignone em seu manuscrito grafa, no início do novo compasso, um bequadro na mesma nota, dando a entender que ela havia sofrido alguma alteração no compasso anterior. Para isso ser verdade, a alteração feita no Ré bemol na oitava acima valeria também para as outras oitavas, protocolo este não ocorrente nos estudos. O impasse portanto, não tem resposta conclusiva e por isso trabalharemos opções com essas duas notas distintas.

O exemplo 185 mantém $^{82}$ o Ré bemol da versão BL mas substitui vários dedos, pensando em manter os dedos 1 e 3 agrupados nos deslizamentos de terças. Já os exemplos 187, 188 e 189 tratam a nota dúbia como sendo um Ré natural, o primeiro deles ainda trabalhando na primeira posição enquanto os outros dois partem da quinta casa. Todos os exemplos podem gerar maior duração do baixo $\mathrm{Si}$, caso desejado, e várias opções foram grafadas para o baixo do compasso seguinte, que pode ser iniciado com distintos dedos, como veremos a seguir.

\footnotetext{
82 item "deixar como está" do checklist de Osborn.
} 


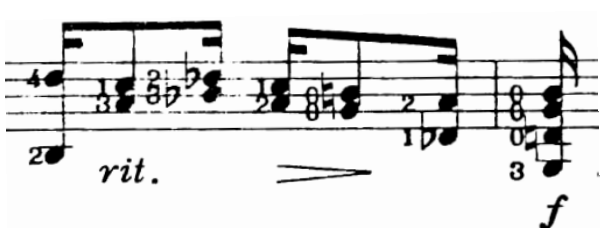

Exemplo 184: III Estudo, comp. 31. Ed. Columbia/BL.

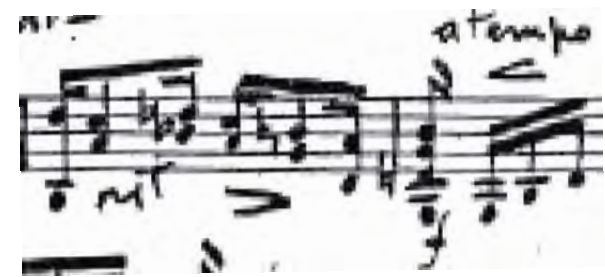

Exemplo 186: III Estudo, compasso 31. Manuscrito.

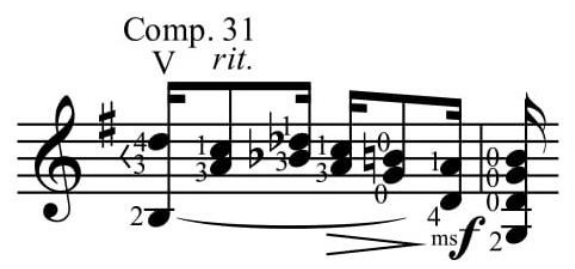

Exemplo 188: III ${ }^{\circ}$ Estudo, compasso 31.
Comp. 31

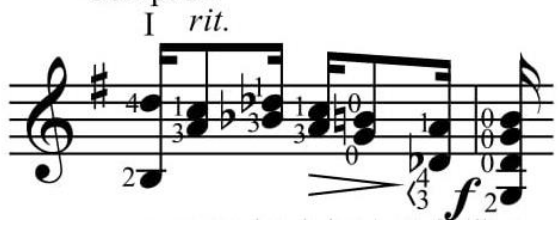

Exemplo 185: III ${ }^{\circ}$ Estudo, compasso 31.

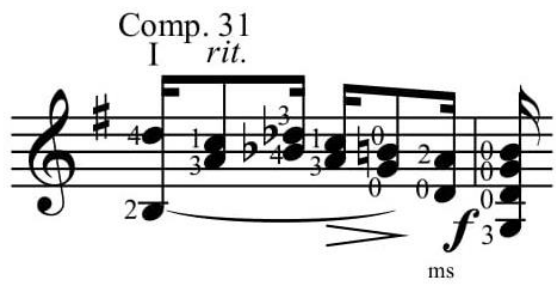

Exemplo 187: III Estudo, compasso 31

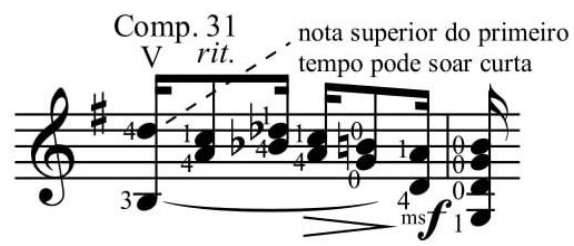

Exemplo 189: III ${ }^{\circ}$ Estudo, compasso 31.

$\mathrm{O}$ próximo trecho ainda será tratado de forma fragmentada, mas devido às semelhanças entre os compassos 32 e 36 ("baixarias"), 34 e 38 ("baixarias") e entre os compassos 33, 35, 56, 58 e 61 (acordes em rasgueios), trataremos eles em conjunto, quebrando sutilmente a ordenação natural da obra.

Esse novo padrão de baixaria possibilita a execução com ligados em diferentes posições (descriminados nos exemplos 190 e 196), ou sem ligados (descriminado pela $m d$ dos exemplos seguintes) além de possibilitar a utilização da quarta ou quinta cordas, cada qual levando para opções diferentes de posicionamento dos acordes em rasgueio que ocorrem em seguida. O compasso 32 difere do 36 apenas no acorde inicial, enquanto os compassos 34 e 38 são idênticos (embora sigam para materiais levemente diferentes). Aconselha-se o uso do mesmo padrão de ligados para todos, a fim de garantir unidade rítmica.

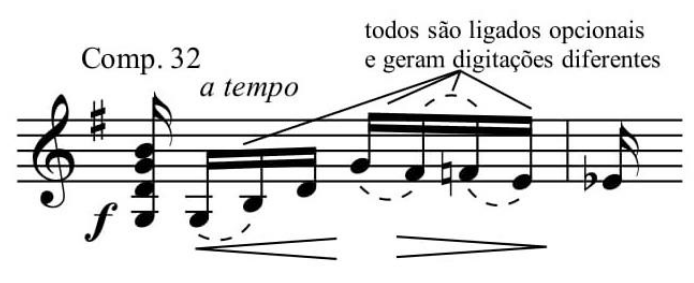

Exemplo 190: III ${ }^{o}$ Estudo, compasso 32.

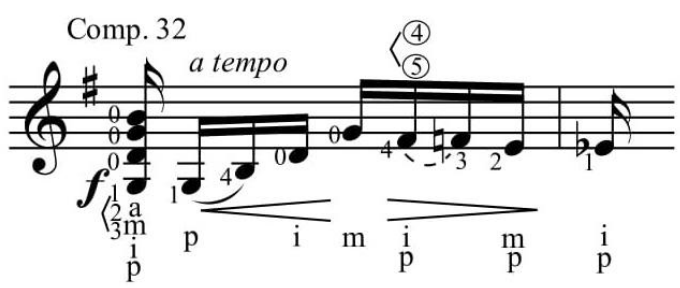

Exemplo 191: III ${ }^{\circ}$ Estudo, compasso 32. 


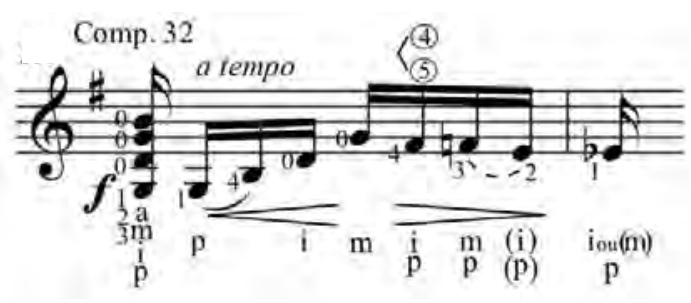

Exemplo 192: III Estudo, compasso 32.

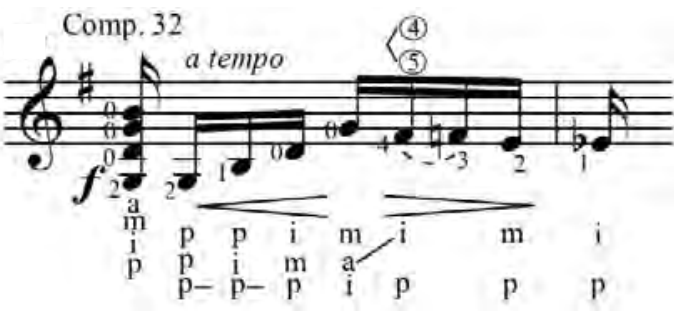

Exemplo 194: $I I^{\circ}$ Estudo, compasso 32.

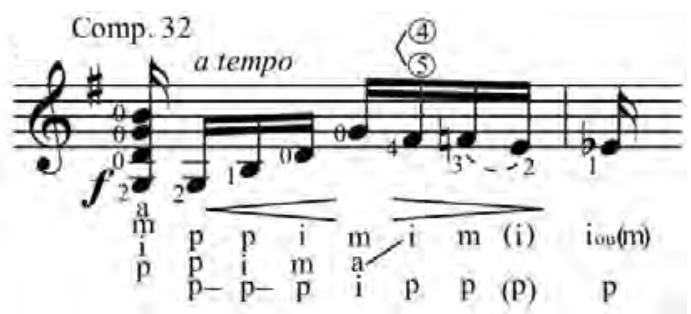

Exemplo 193: III Estudo, compasso 32.

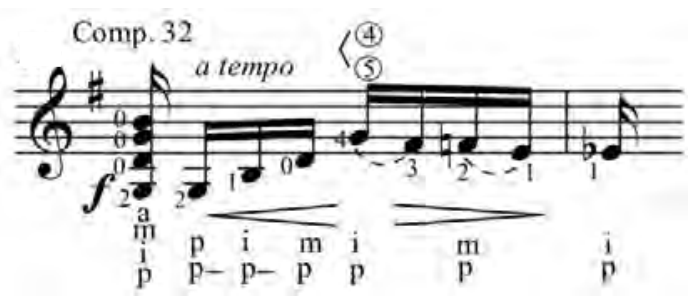

Exemplo 195: III ${ }^{\circ}$ Estudo, compasso 32.

Embora similares aos exemplos anteriores e obedecerem a mesma lógica, notese que os padrões cromáticos são diferentes nos compassos 34 e 38, levando até a nota Ré:

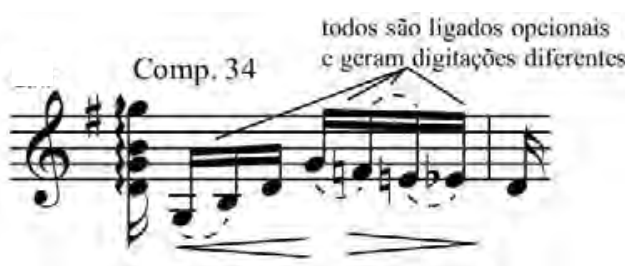

Exemplo 196: III ${ }^{\circ}$ Estudo, comp. 34 (idem 38).

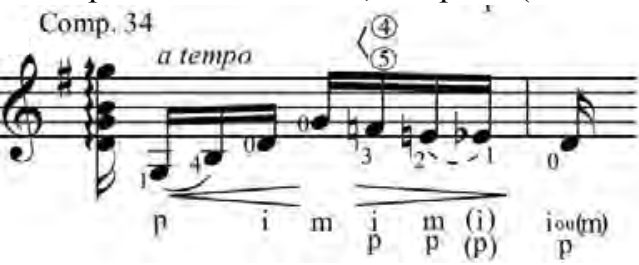

Exemplo 198: III ${ }^{\circ}$ Estudo, comp. 34 (idem 38).

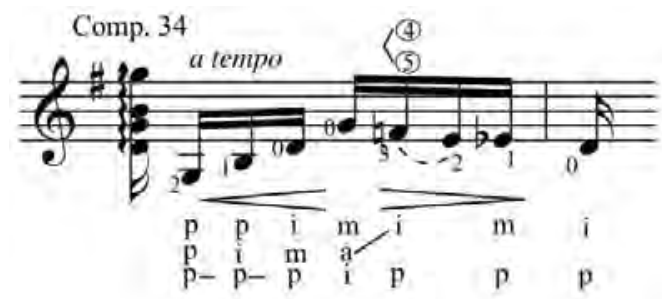

Exemplo 200: III ${ }^{o}$ Estudo, comp. 34 (idem 38).

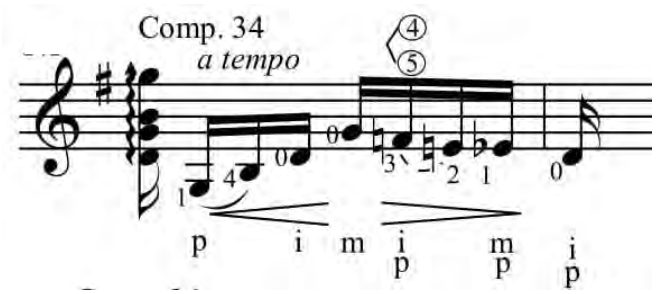

Exemplo 197: III Estudo, comp. 34 (idem 38).

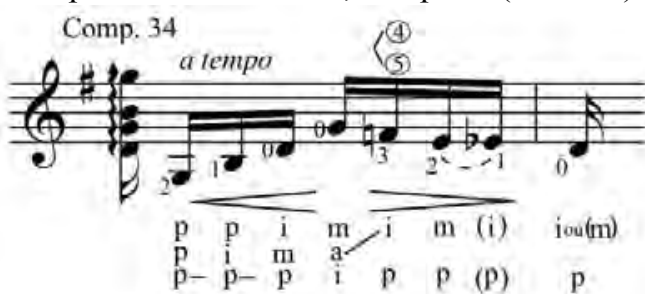

Exemplo 199: III Estudo, comp. 34 (idem 38).

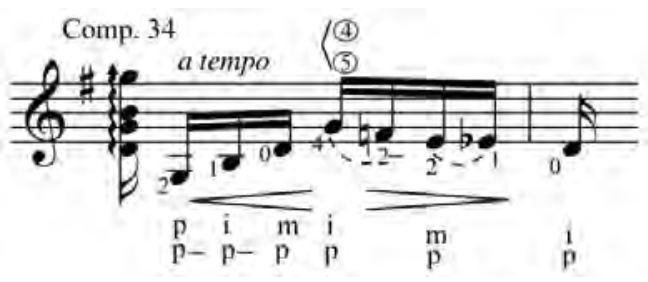

Exemplo 201: III ${ }^{\circ}$ Estudo, comp. 34 (idem 38).

Os compassos 33 e 35 (idem 58) também possuem similaridades o bastante para serem comentados em conjunto, principalmente no que tange o padrão de rasgueios embora sejam aplicados a acordes diferentes. BL (nos exemplos 202 e 205), aparentemente com intuito de ressaltar a acentuação da cabeça do segundo tempo, 
propõe um padrão com repetição de direções dos rasgueios (para que este tempo ficasse com um rasgueio para cima). Este aspecto, embora compreensível, foi evitado em nossas propostas ao contemplarem apenas padrões alternados de ragueios (entendendo como possível uma compensação da intensidade do rasgueio para baixo na cabeça do segundo tempo).

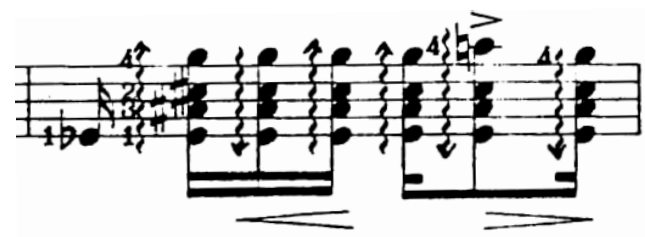

Exemplo 202: III ${ }^{\circ}$ Estudo, comp. 33. Ed. Columbia/BL.

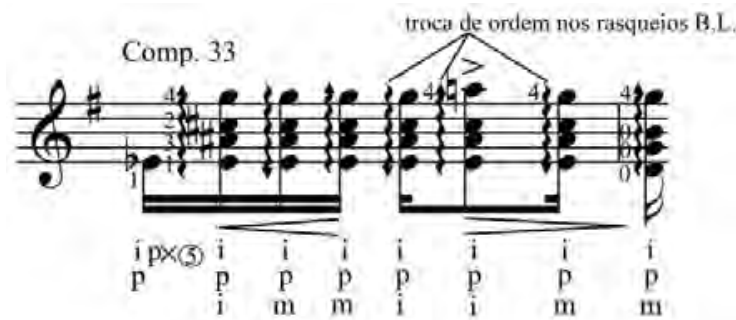

Exemplo 203: III ${ }^{\circ}$ Estudo, compasso 33.

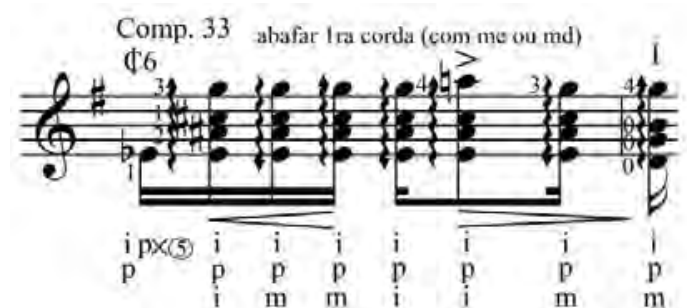

Exemplo 204: III ${ }^{o}$ Estudo, compasso 33.

Todos os padrões de ragueios são idênticos nos exemplos 202, 204, 206 e 207. Já as digitações de me focam-se na primeira posição nos exemplos 203 e 206 e na região central do instrumento nos exemplos 204 e 207.

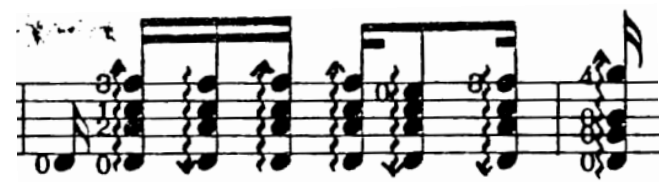

Exemplo 205: III ${ }^{o}$ Estudo, comp. 33 (idem 58). Ed. Columbia/BL.

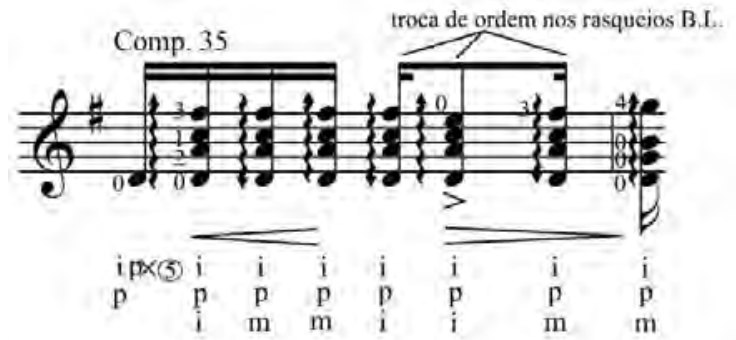

Exemplo 206: III ${ }^{\circ}$ Estudo, comp. 35 (idem 58).

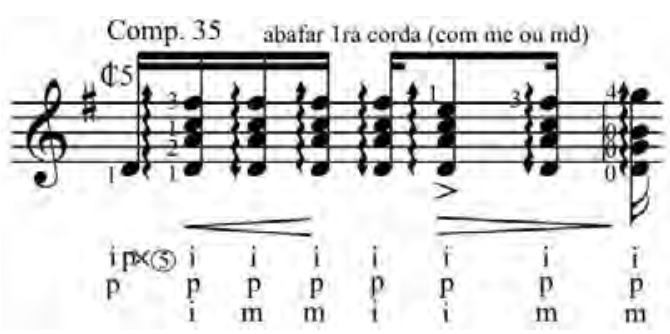

Exemplo 207: III ${ }^{o}$ Estudo, comp. 35 (idem 58).

Posteriormente (mais perto do fim da obra), Mignone reaproveita esta figuração de forma literal no compasso 58 (que é igual ao 35) e com pequenas modificações ${ }^{83}$ melódicas ou rítmicas (compassos 56 e 61). Os exemplos a seguir, seguem a mesma lógica dos anteriores em termos do funcionamento da $m d$ (buscando alternância dos rasgueios) e me (podendo trabalhar os acordes nas duas posições especificadas). 


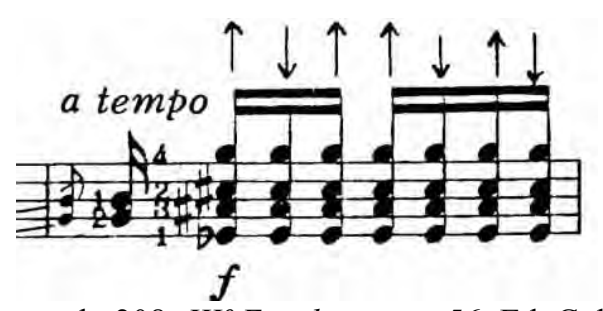

Exemplo 208: III ${ }^{\circ}$ Estudo, comp. 56. Ed. Columbia/BL.

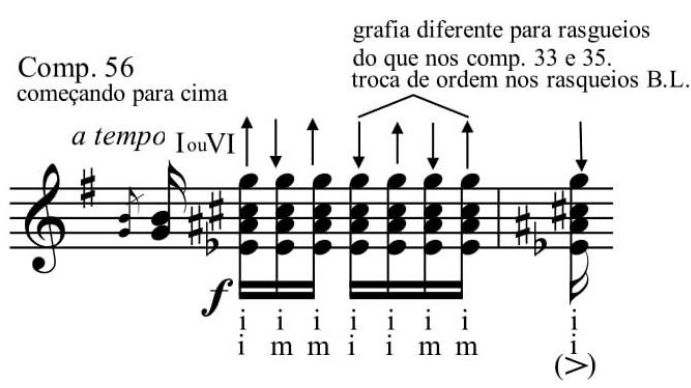

Exemplo 209: III ${ }^{\circ}$ Estudo, compasso 56.

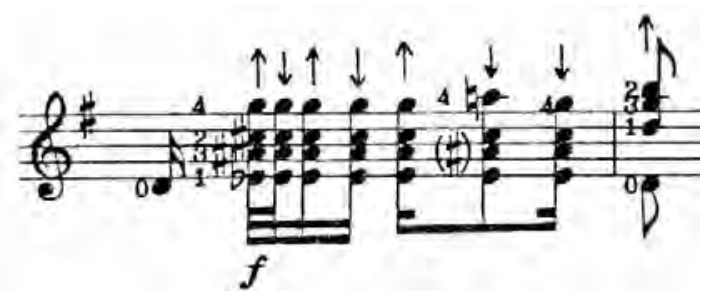

Exemplo 211: III Estudo, comp. 61. Ed. Columbia/BL.

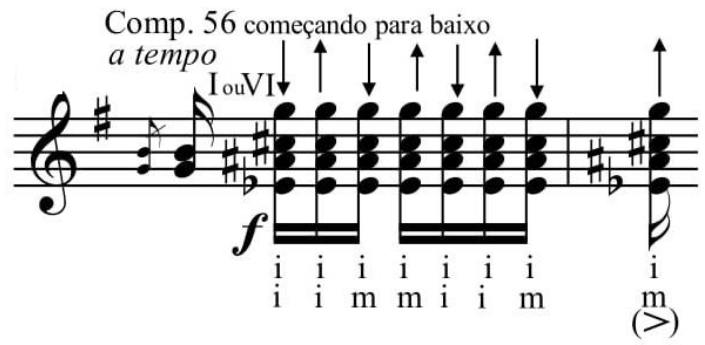

Exemplo 210: III Estudo, compasso 56.

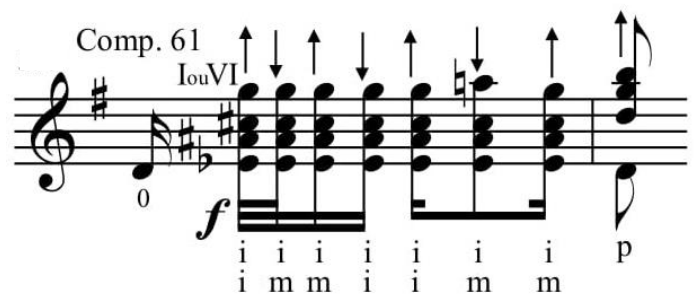

Exemplo 212: III ${ }^{\circ}$ Estudo, comp. 61.

Voltando ao compasso 37, Mignone faz uma variação em arpejos dos mesmos acordes e o uso do Pensamento Divergente se mostra novamente bastante útil. A digitação BL (exemplo 213), ainda que funcional, requer uma rápida contração do dedo 3 na terceira corda. A digitação do mesmo acorde na região central do instrumento nos proporcionou novas saídas, numa progressão de ideias. O exemplo 214 consegue dar conta do arpejo por meio de uma pestana e um ligado. O exemplo 215 coloca o acorde na sexta posição, mas numa movimentação rápida, coloca o dedo 1 na quinta casa para alcançar a nota aguda do acorde, podendo manter-se nela para ser o guia até o próximo acorde. Neste exemplo, essa mesma nota poderia ser executada com o dedo 5 (polegada da me), mas sendo muito mais difícil não foi grafada por extenso. No entanto, o posicionamento do acorde no exemplo 215 nos fez perceber que o dedo 1 apresentava uma curvatura favorável ao uso de um recurso raro: a pestana cruzada, onde o dedo 1 ocupa duas casas ao pisar uma nota com a falange distal (ponta do dedo) e outra, meia casa atrás, com a falange proximal ${ }^{84}$, resultando em um artifício facilitador muito favorável neste trecho.

\footnotetext{
${ }^{84}$ Todos os dedos das mãos são formados por três falanges (ossos), a falange proximal (que conecta o dedo à mão), a falange medial (intermediária) e a falange distal (ou seja, ponta do dedo).
} 


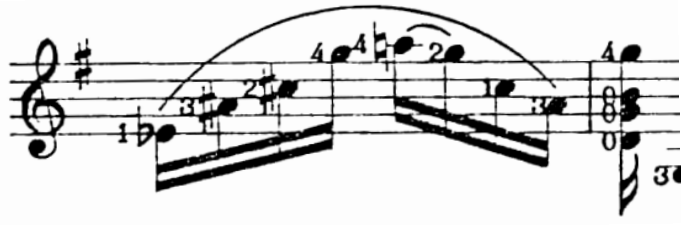

Exemplo 213: III ${ }^{o}$ Estudo, comp. 37. Ed. Columbia/BL.

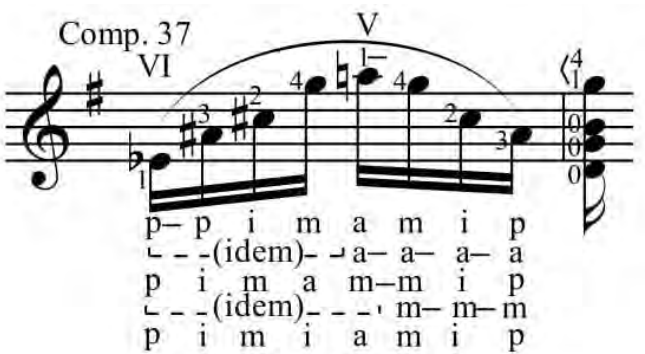

Exemplo 215: III ${ }^{\circ}$ Estudo, compasso 37.

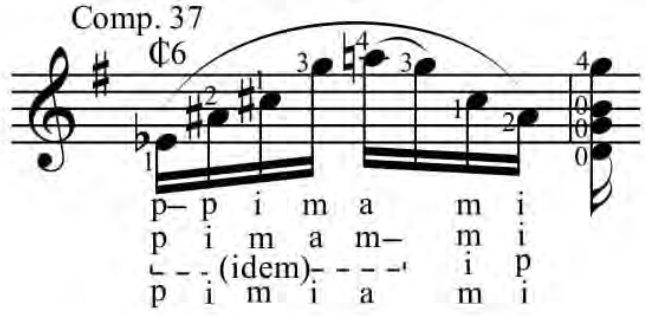

Exemplo 214: III ${ }^{\circ}$ Estudo, compasso 37.

Comp. $37 \$ 5$ pestana cruzada (entre V e VI casas)

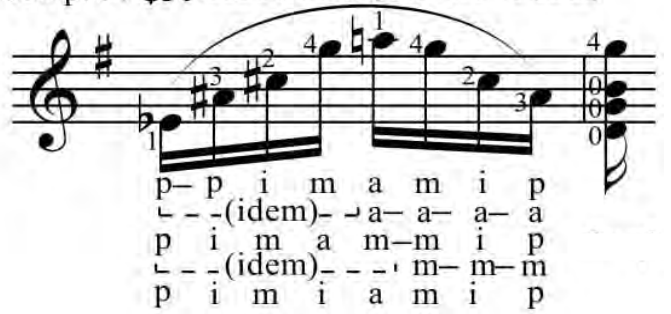

Exemplo 216: III ${ }^{o}$ Estudo, compasso 37.

No compasso 40, Mignone propõe nova melodia em terças, mas dessa vez com acentos e ligados regulares (exemplo 217) apenas parcialmente seguidos pela digitação BL, por conta do uso de uma pestana. O exemplo 219 substitui apenas a referida pestana e o exemplo 220 substitui todos os dedos e troca ligados por portamenti.

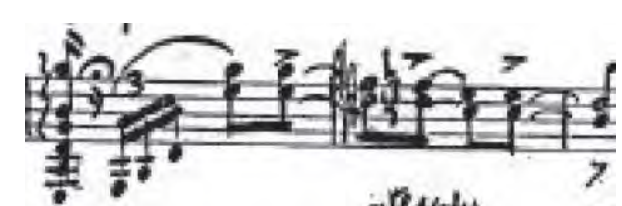

Exemplo 217: III Estudo, comp. 40. Manusc.

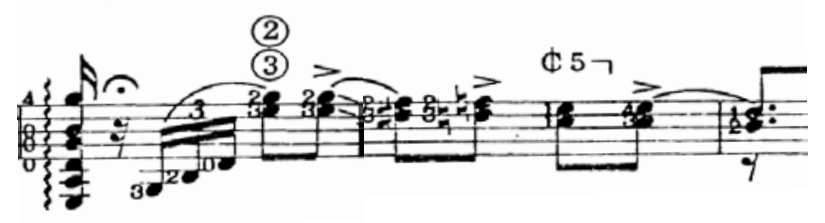

Exemplo 218: III ${ }^{\circ}$ Estudo, comp. 40. Ed. CL/BL.

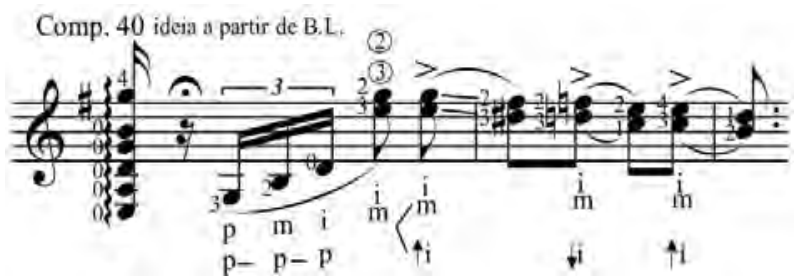

Exemplo 219: III Estudo, compasso 40.

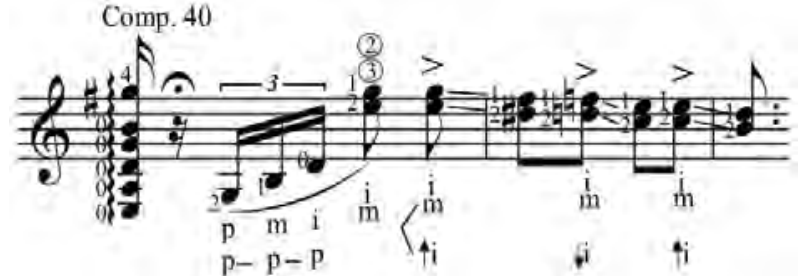

Exemplo 220: $I I I^{\circ}$ Estudo, compasso 40.

No compasso 40, BL digita a melodia em décimas com algumas cordas soltas.

Nós preferimos digitá-la em cordas "presas" para favorecer uma sonoridade caipira (exemplo 222), sendo possível ainda inserir portamenti similares ao compasso anterior (exemplo 223) e/ou tocá-la em cordas mais graves (exemplo 224).

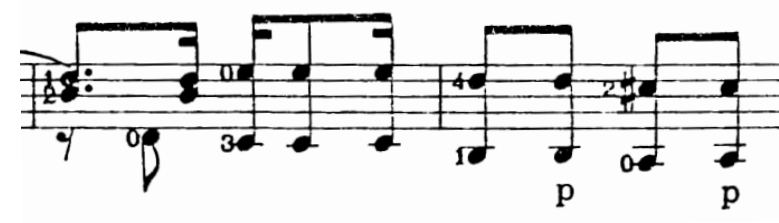

Exemplo 221: III Estudo, compasso 42. Ed. CL/BL.

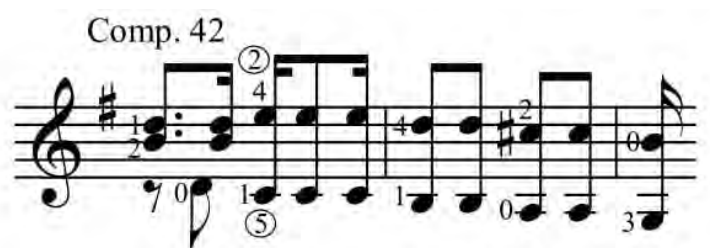

Exemplo 222: III $^{\circ}$ Estudo, compasso 42. 


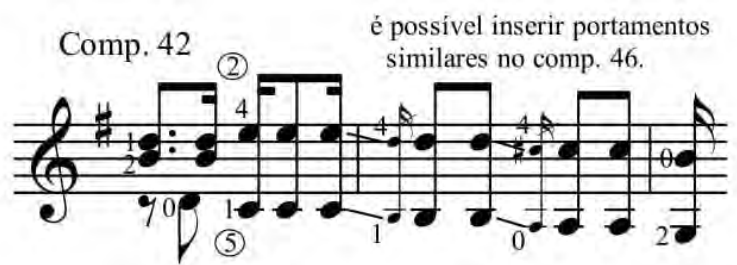

Exemplo 223: III ${ }^{\circ}$ Estudo, compasso 42.

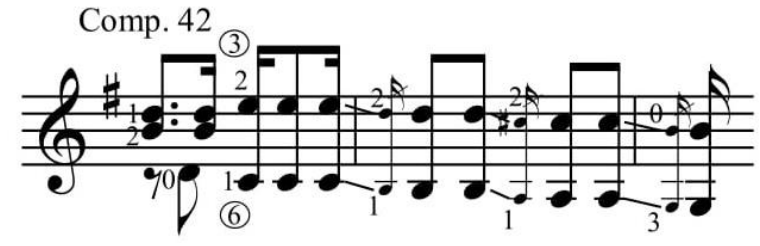

Exemplo 224: $I I I^{\circ}$ Estudo, compasso 42.

No compasso 44, nossa única sugestão à digitação BL é o uso da corda solta na última terça.

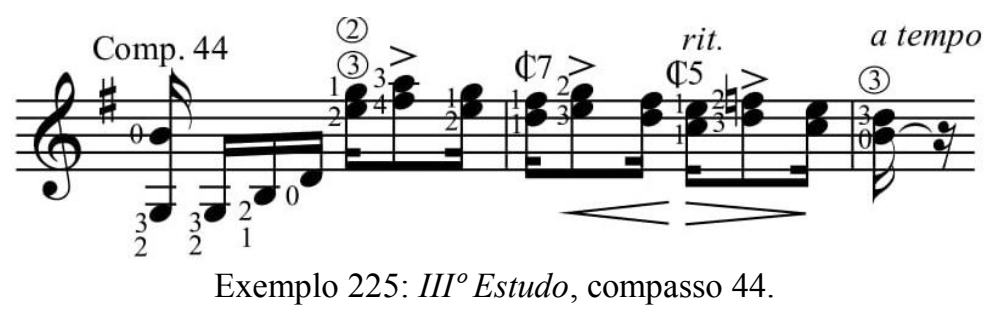

O trecho iniciado no compasso 48 recebe a seguinte digitação por BL (ex. 226), na qual se percebe um pequeno erro no primeiro compasso, se comparado ao manuscrito logo abaixo (ex. 227):

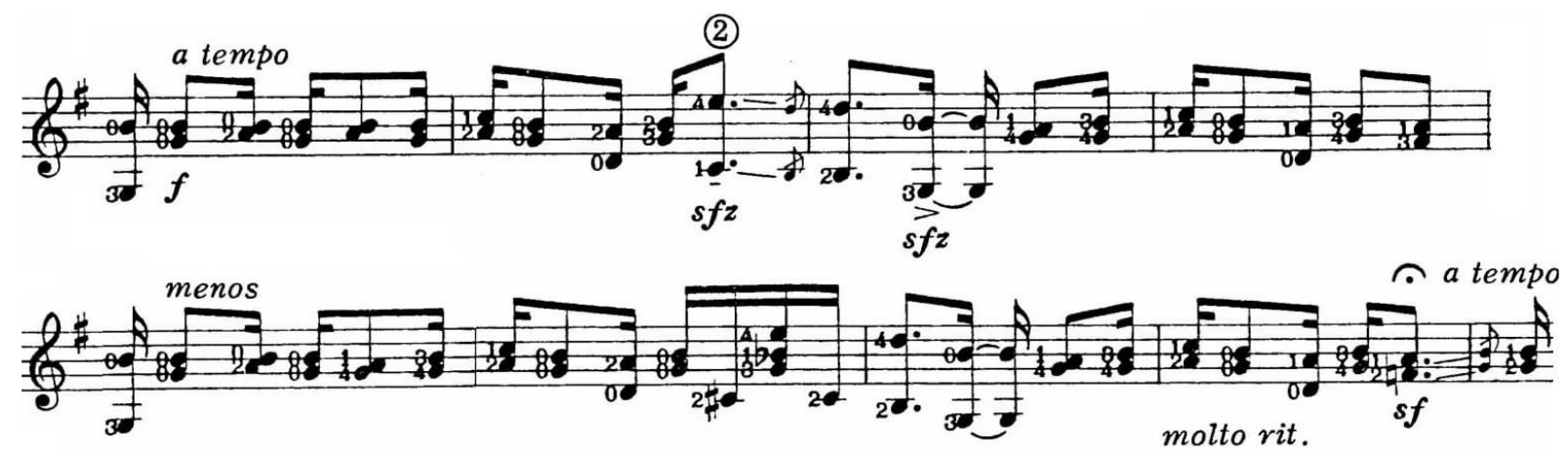

Exemplo 226: III Estudo, compasso 48. Ed. Columbia/BL.
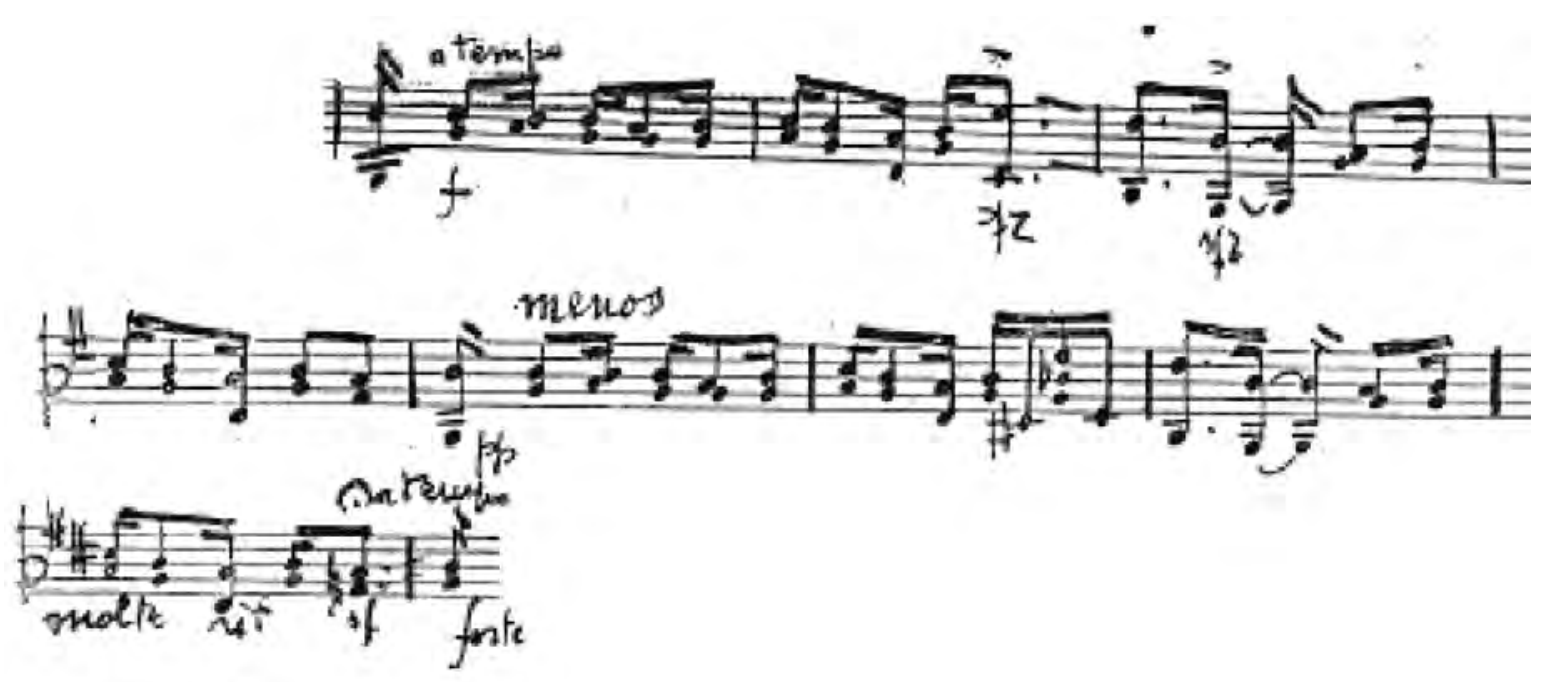

Exemplo 227: III ${ }^{\circ}$ Estudo, compasso 48. Manusc.

Nossas digitações para o trecho se focaram inicialmente em fixar um dedo no baixo Sol e apenas sair dele quando necessário, provendo maior legato. O exemplo 228 
mantém o dedo 2 sempre que possível, enquanto o exemplo 229 usa o dedo 3 como eixo fixo com maior duração.

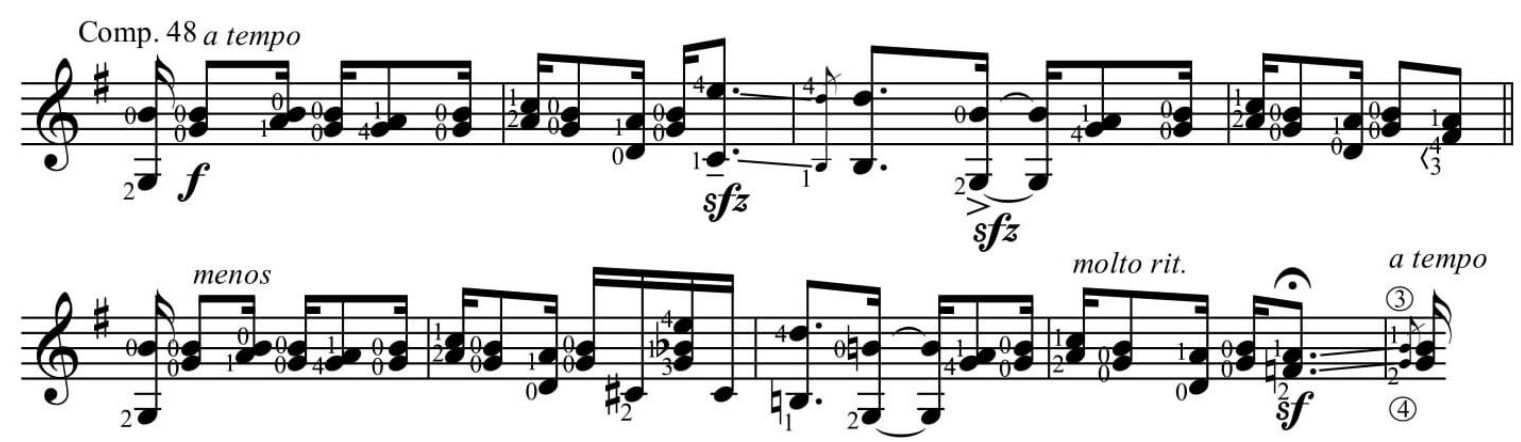

Exemplo 228: $I I I^{\circ}$ Estudo, compasso 48.
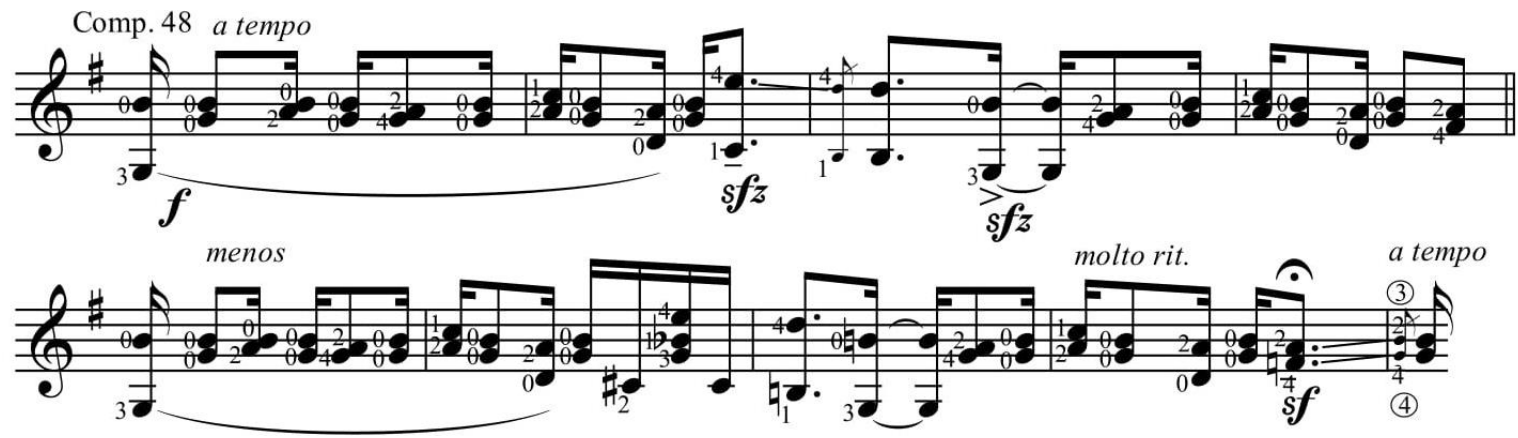

Exemplo 229: III $^{\circ}$ Estudo, compasso 48.

Já o exemplo 230 ainda fixa o dedo 2 por um compasso, mas busca criar um jogo de alternância entre as cordas soltas (Sol e $\mathrm{Si}$ ) e as notas presas, colocando-as sempre na terceira e quarta cordas. Além disso, registra também outra interessante abordagem para as décimas em sforzando, tocando-as na terceira e sexta cordas.
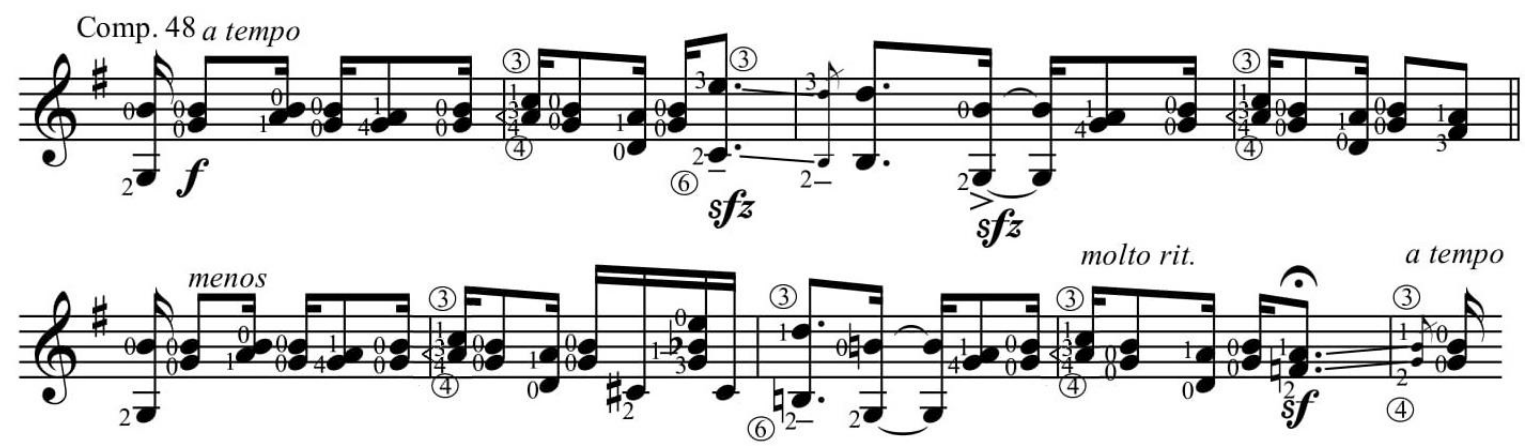

Exemplo 230: $I I I^{\circ}$ Estudo, compasso 48.

Após rememorar os acordes em rasgueio já comentados, Mignone desenvolve também a ideia da baixaria, dessa vez mais longa. O exemplo 231 parte da digitação de $m e$ de $\mathrm{BL}$ e demonstra possibilidades de $m d$. O exemplo 232 explora duas possibilidades de ligados numa mesma digitação e o exemplo 233 cria uma digitação em campanella, talvez perdendo o espírito popular do segmento. 


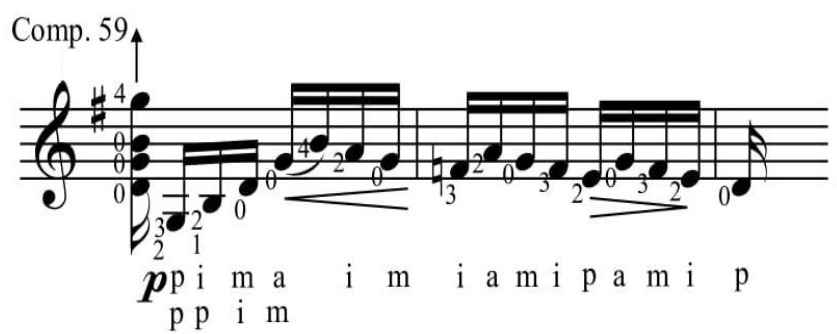

Exemplo 231: III Estudo, compasso 59.

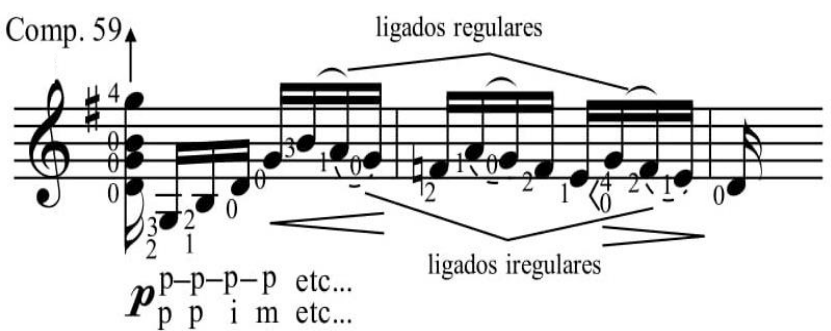

Exemplo 232: III ${ }^{\circ}$ Estudo, compasso 59.

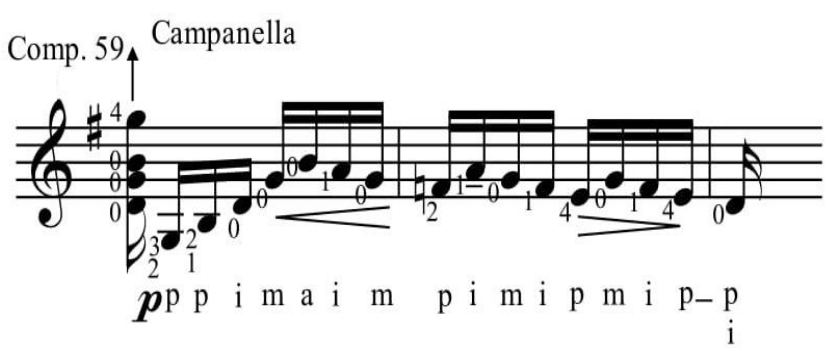

Exemplo 233: $I I I^{\circ}$ Estudo, compasso 59.

No compasso 62, enquanto BL alterna os dedos envolvidos nos acordes do trecho, mantemos fixa a digitação dos mesmos, comprimindo o dedo 4 quando o acorde é maior e expandindo-o quando o acorde é menor, de forma a conseguir executar os portamenti reais sugeridos no manuscrito.

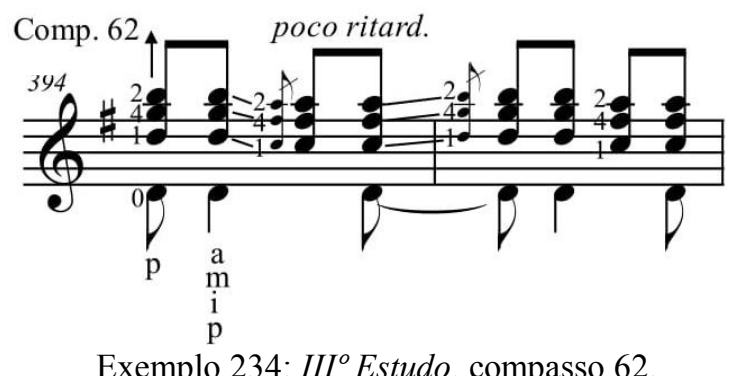

$\mathrm{Na}$ interessante e longa sequência cromática ascendente de acordes paralelos, registramos nos exemplo 235 duas possibilidades de $m d$, uma alternando o indicador em rasgueio e outra usando o conjunto $p-i-m-a$ repetidamente. Também tomamos a liberdade de simplificar a grafia dos harmônicos envolvidos. 


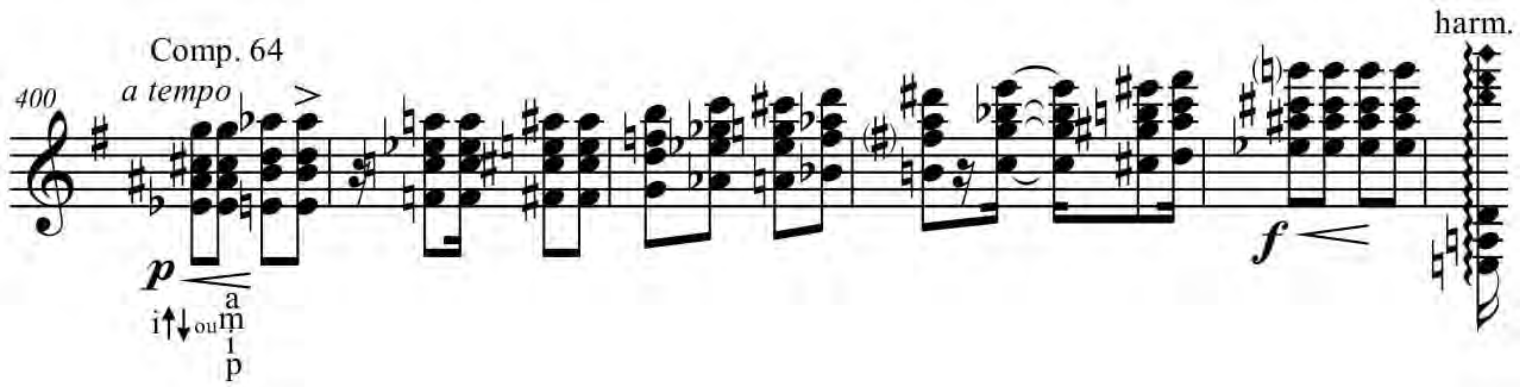

Exemplo 235: III Estudo, compasso 64.

O rasgueio final em acordes maiores paralelos também ganha várias alternativas, com $i$ - $m$ alternados no exemplo 237 e com rápidos portamenti no exemplo 238, mas ainda preferimos a versão BL (exemplo 236).

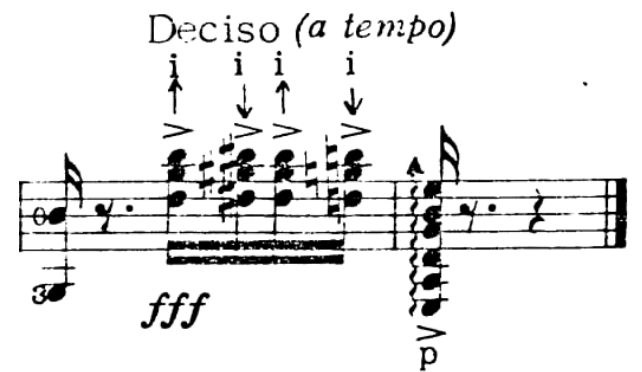

Exemplo 236: III Estudo, compasso 72. Ed. Columbia/BL.

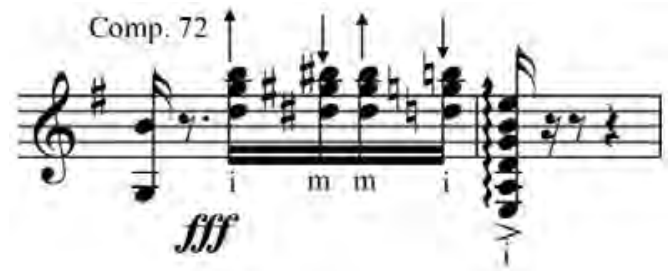

Exemplo 237: $I I I^{\circ}$ Estudo, compasso 72.

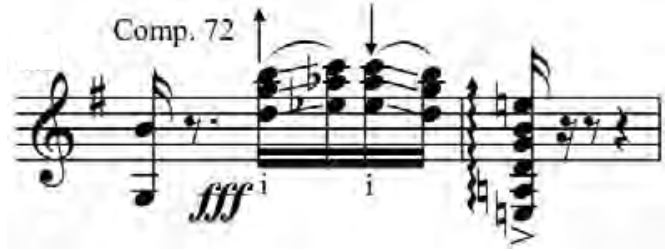

Exemplo 238: $I I I^{\circ}$ Estudo, compasso 72. 


\section{4: IV Estudo "Allegro Scherzoso"}

Em nossa opinião, essa talvez seja a peça que mais caracterize expressamente a forma estudo neste ciclo, tendo em conta que ela propõe um padrão no primeiro compasso sempre repetido duas vezes (talvez em uma herança três primeiros estudos villa-lobianos) e o vai levando a novas harmonias, "deformando-o" aos poucos e criando assim um maravilhoso exercício ao intérprete, que terá (durante seu estudo ou performance), que antecipar mentalmente as similaridades e disparidades de cada compasso e ainda realizar isso em um andamento bastante rápido, com conteúdo musical rico e tecnicamente complexo.

Diante de tal complexidade, nossa primeira atitude foi segmentar o problema em desafios menores, tratando cada compasso por vez e analisando suas possibilidades de execução, que por fim, se demonstraram bastante numerosas.

Cada trecho será tratado inicialmente sem ligados, para posteriormente os adicionar com diferentes ritmos. Várias digitações de $m e$ e principalmente de $m d$ são grafadas simultaneamente num mesmo exemplo e por isso merecem redobrada atenção.

O primeiro compasso (que é idêntico ao segundo) parte da digitação de me de BL (sem ligados e com algumas cordas soltas opcionais) que mantém o trecho na primeira posição e parece prezar por uma maior sustentação. Considerando o caminho com cordas soltas, cria-se um padrão digno de nota: o ritmo de galope (duas semicolcheias e uma colcheia) fica sempre organizado com as duas primeiras notas em uma corda e a terceira na adjacente inferior (o que chamaremos daqui para frente de padrão 2-1, em oposição ao padrão 1-2, ou seja, uma nota em uma corda, seguido de duas notas na adjacente). A observação e compreensão desse padrão parece auxiliar na resolução da $m d$. Nesse aspecto ressaltamos que: o segundo padrão, $m-i-a$, funciona como uma espécie de tremolo onde o anelar trabalha na corda inferior; O padrão $m-i$ apresenta cruzamentos, enquanto primeiro padrão, $p-i-m$, nos parece ser o mais bem resolvido para esta proposta de me.

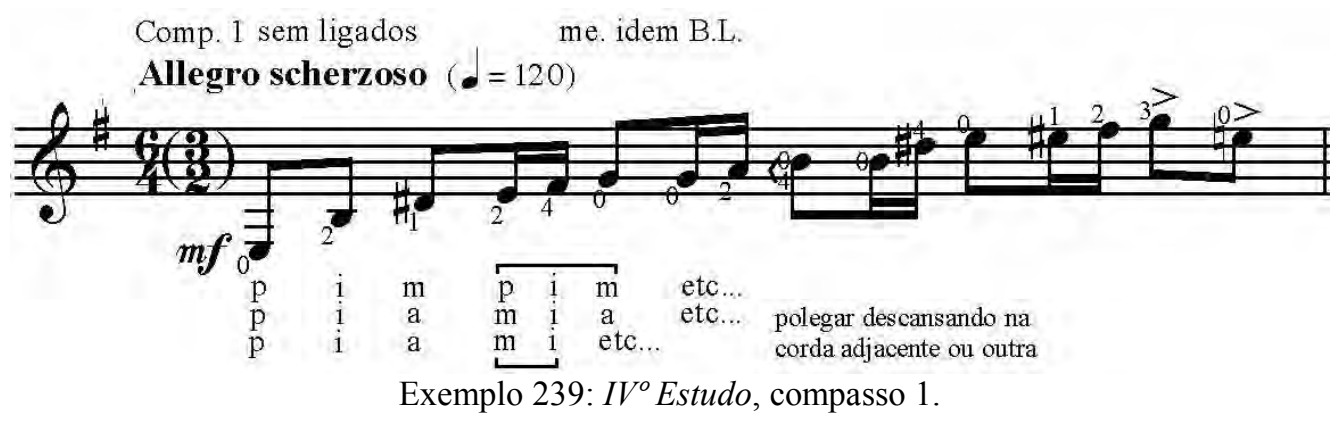


Os próximos dois exemplos exploram a distribuição oposta de cordas no ritmo de galope, ou seja o padrão 1-2. O primeiro (exemplo 240) aproveita mais as cordas graves na subida, o que pode gerar mais ruído de arraste. Ele recebe três possibilidades de $m d$, sendo a terceira delas a menos funcional e portanto descartada no exemplo seguinte. Na segunda (i-m-i) ocorre uma curiosa repetição de dedos (a cada repetição do padrão), aspecto normalmente a ser evitado mas funcional neste caso, principalmente se incluir o toque apoiado na última nota do grupo, preparando assim o indicador para a nota seguinte. A primeira digitação, $p-m-i$, novamente parece ser a mais fluída.

O exemplo 241 consegue superar consideravelmente os ruídos de arraste do exemplo anterior e pode ser concluído de três formas diferentes: a que está escrita, a do exemplo precedente e a grafada logo ao lado. As digitações de $m d$ atendem aos mesmos preceitos comentados há pouco.

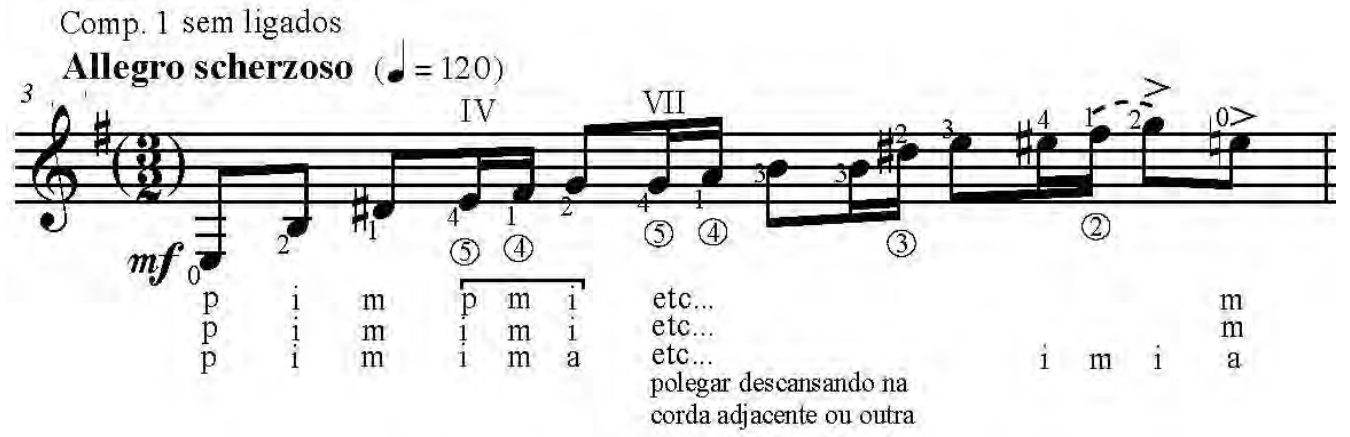

Exemplo 240: $I V^{o}$ Estudo, compasso 1.

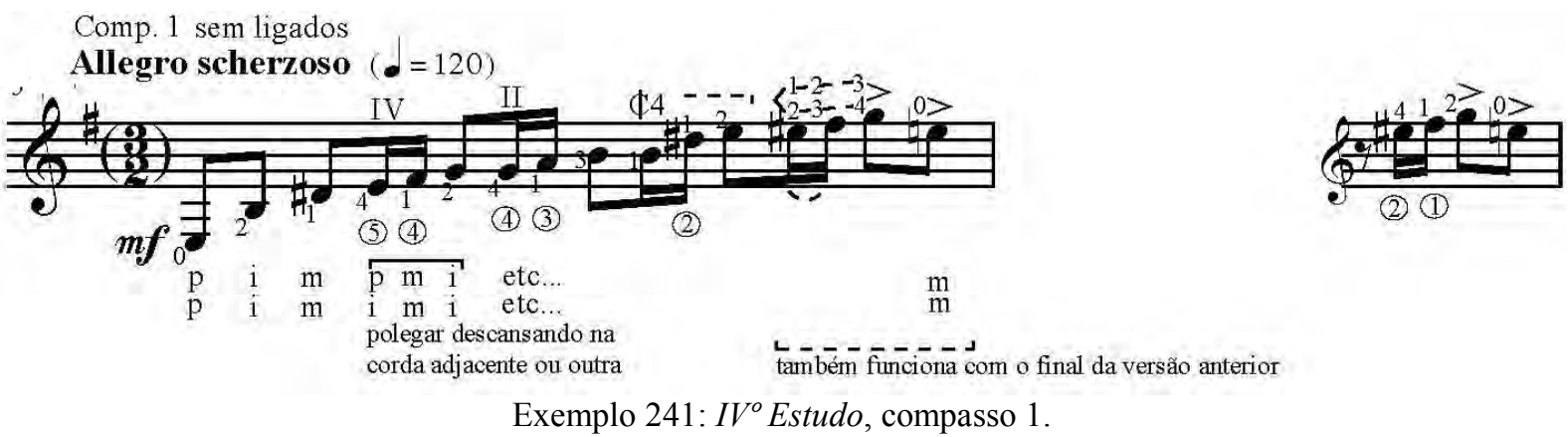

O exemplo 242 vem propor uma digitação em campanella (o que seria um padrão 1-1-1 de organização das notas nas cordas do instrumento).

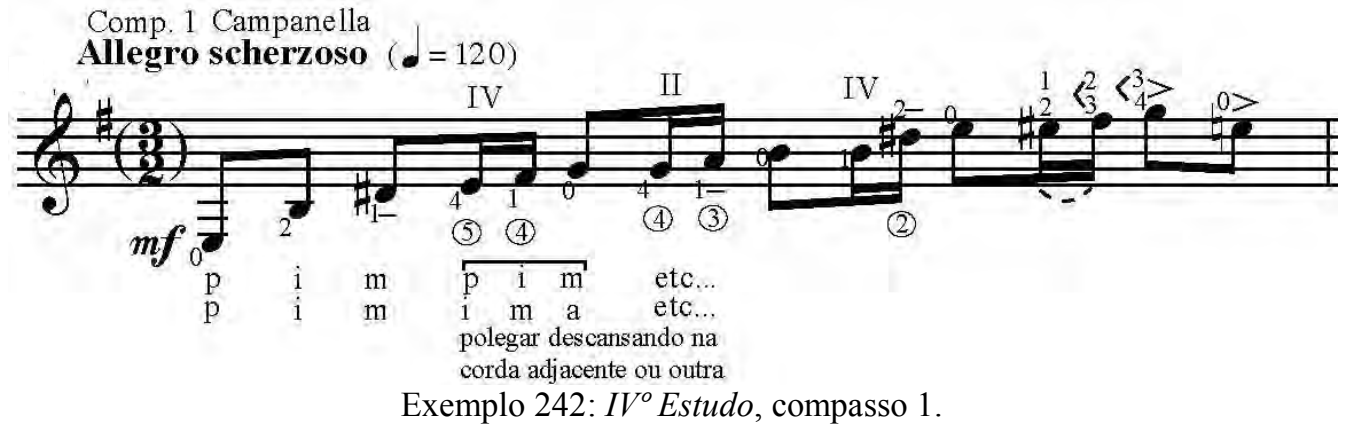


Os dois próximos exemplos seguem os ligados sugeridos por BL, que podem ser aplicados apenas nas digitações com padrão 2-1. O exemplo 243 é bastante similar à digitação BL, porém recorre a mais cordas soltas, enquanto o exemplo 244 avança casas de forma progressiva, apenas com uma abertura entre os dedos 1 e 4.
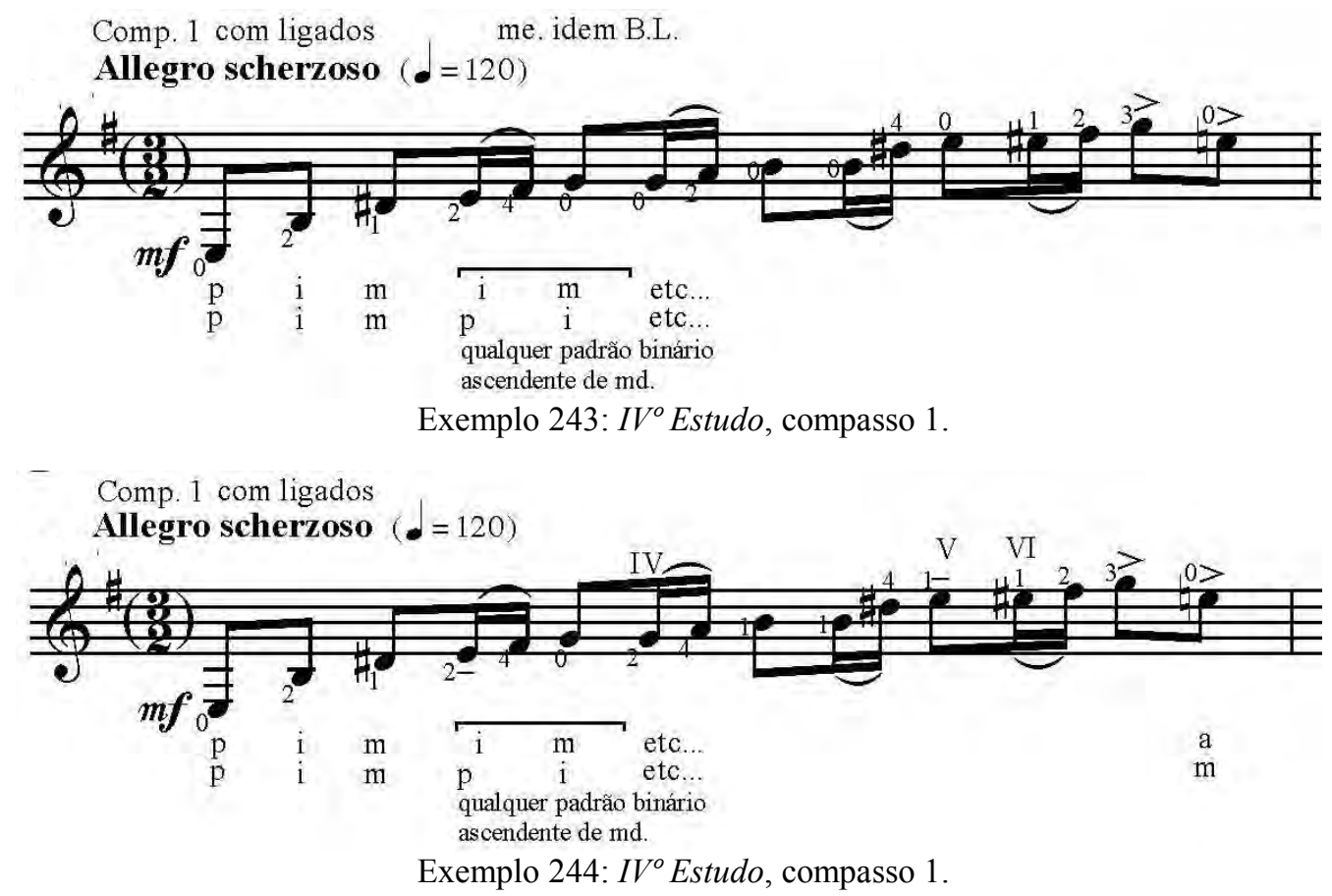

O último exemplo do compasso 1 experimenta o deslocamento da posição dos ligados, aplicando-o ao padrão 1-2 de distribuição de notas nas cordas. Esse deslocamento requer uma maior acentuação do segundo dedo do ligado, honrando sua nomenclatura americana, hammer-on (martelo adentro). $\mathrm{O}$ resultado é surpreendentemente ágil, embora musicalmente polêmico. O exemplo possui um final alternativo indicado logo em seguida.
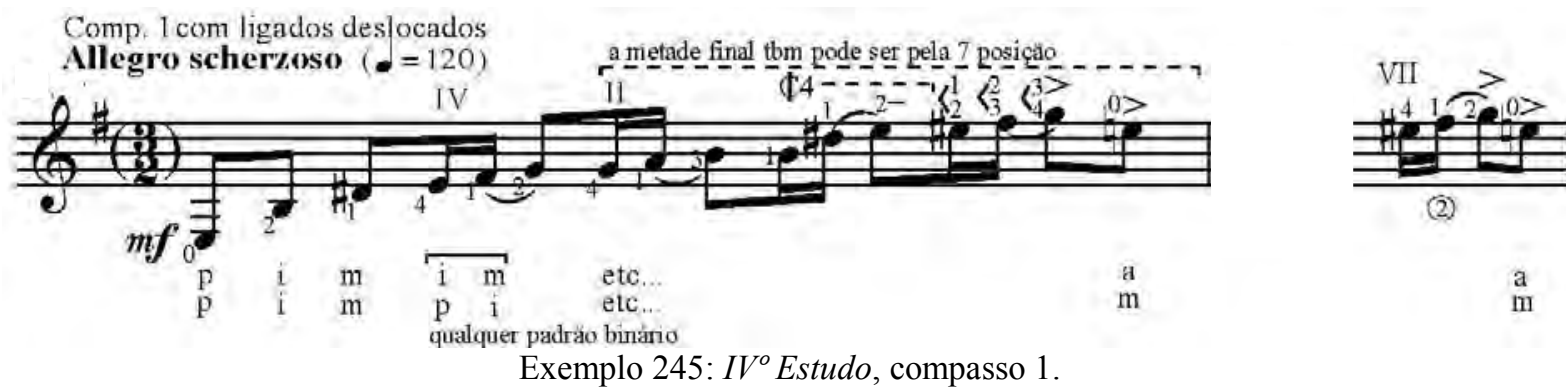

$\mathrm{Na}$ questão interpretativa cabe aqui também ressaltar dois aspectos possíveis: o primeiro diz respeito aos acentos nas duas últimas notas do compasso, previstos igualmente no manuscrito. Sua execução mereceria uso do toque apoiado em ambas as notas para obter o efeito grafado, no entanto, consideramos este um artificio um tanto “pesado" preferindo, em nossas performances, acentuar apenas a primeira nota, criando 
um leve decrescendo na segunda. O segundo aspecto diz respeito a uma visão completamente pessoal onde incluímos a possibilidade de inserir staccati em todas as colcheias dos tempos 2, 3, 4 e 5, o que a nosso ver, cria uma movimentação por diferença de articulação ressaltando os tempos do compasso (6/4) e cria um facilitador técnico já que os dedos da $m d$ que abafam as notas do staccato devem ser aqueles que vão articular a próxima nota, configurando assim o uso do que comumente se chama "toque preparado".

Para os compassos seguintes, será pertinente adotar a mesma metodologia empregada no compasso 1 , que devido à semelhança textural, seguirão o mesmo raciocínio na ordenação do exemplos: inicialmente sem ligados, trabalharemos os padrões 2-1 e 1-2, campanellas e finalmente recolocando os ligados, os experimentaremos na posição sugerida por BL e defasados em uma nota. Apesar de nossa abordagem demasiado fragmentada, aos leitores desta tese e futuros intérpretes desta obra aconselha-se, após a definição das versões de sua preferência, unir compassos com digitações que sigam critérios similares, a fim de manter a sua unidade estética.

O compasso 3, recebe no exemplo 246 versão sem ligado em padrão 2-1, seguindo a digitação de me de BL apenas com uma simplificação, a substituição do dedo 2 no Fá natural pelo dedo 1, evitando assim uma abertura. A primeira digitação de $m d$ proposta ainda é a mais funcional.

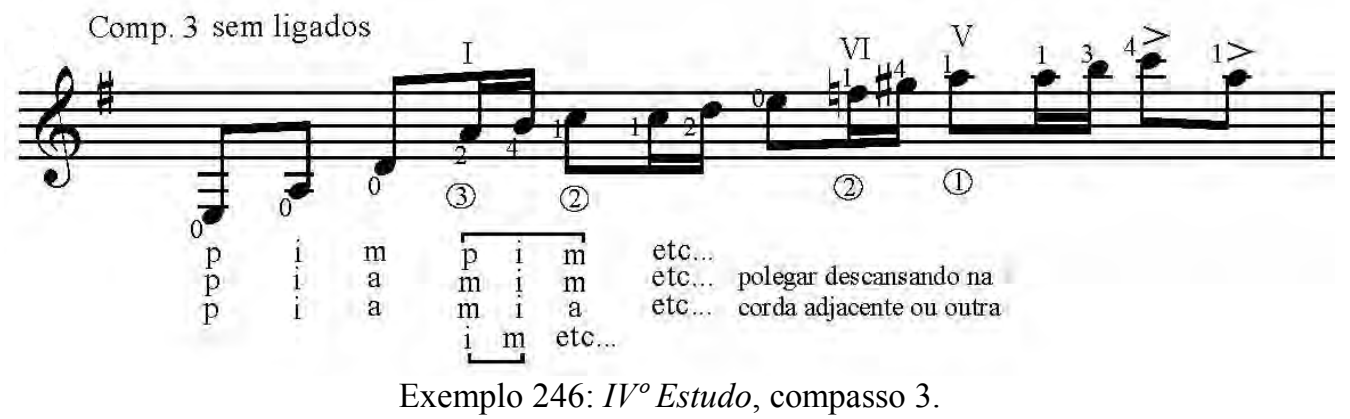

Seguem-se dois exemplos em padrão 1-2 com desfecho idêntico, mas com abordagens bastantes distintas: o primeiro (ex. 247) avança progressivamente pelo instrumento e o segundo (ex. 248) aproveita as cordas soltas iniciais para dar um grande salto para percorrer o caminho inverso, subindo à casa 10 para depois descer à casa 7 . 


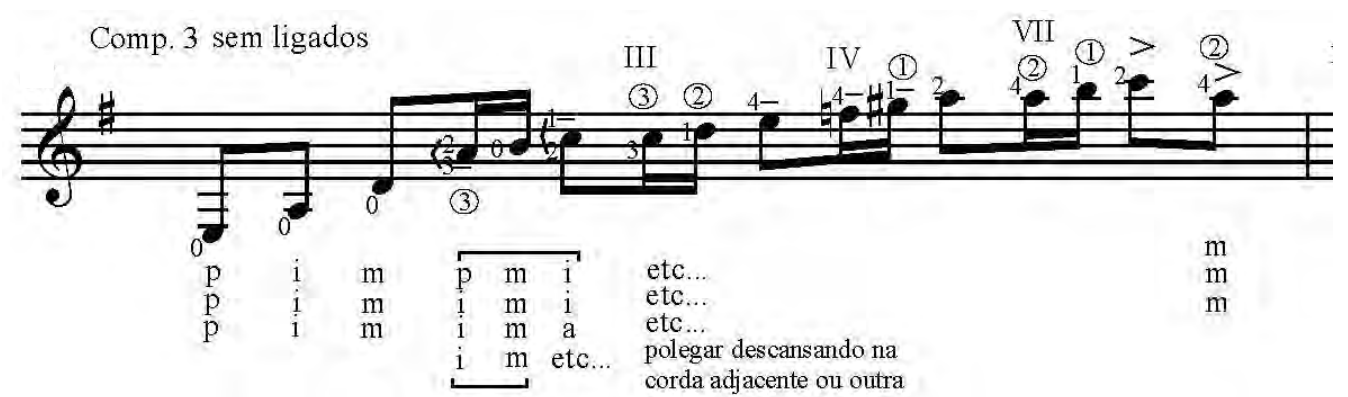

Exemplo 247: IV Estudo, compasso 3.

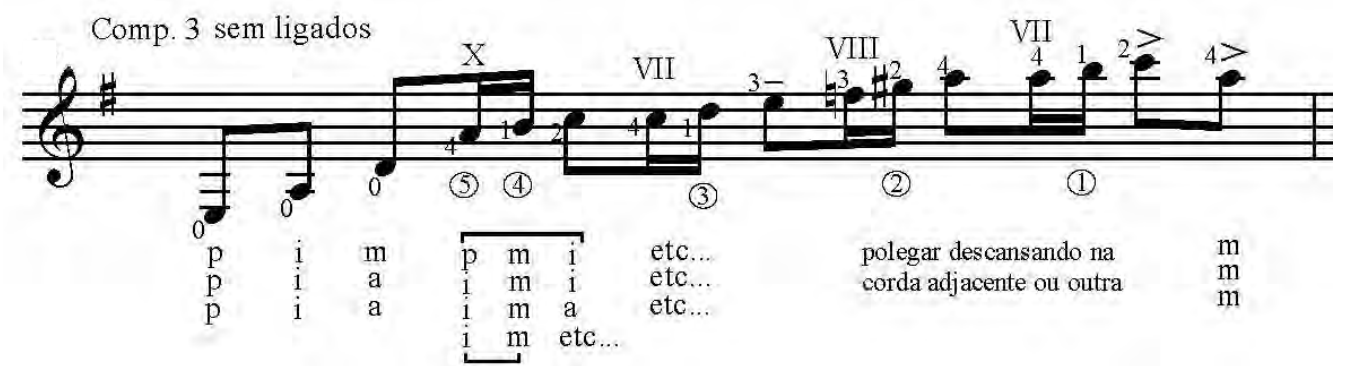

Exemplo 248: $I V^{\circ}$ Estudo, compasso 3.

As duas versões em campanella a seguir requerem uma abertura na quinta posição (factível com algum estudo) e também a atingem por regiões distintas, uma pela posição III e a outra pela VII:

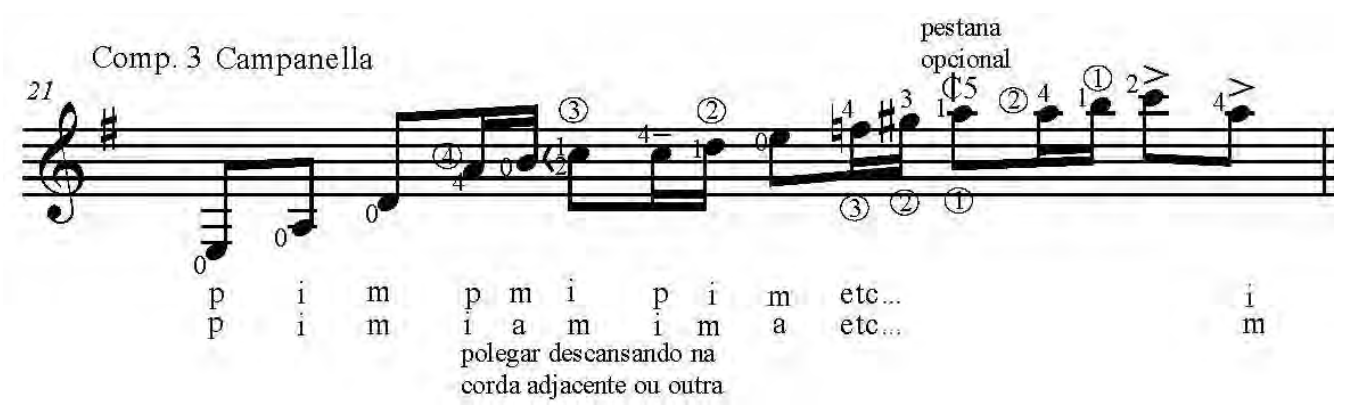

Exemplo 249: $I V^{\circ}$ Estudo, compasso 3.

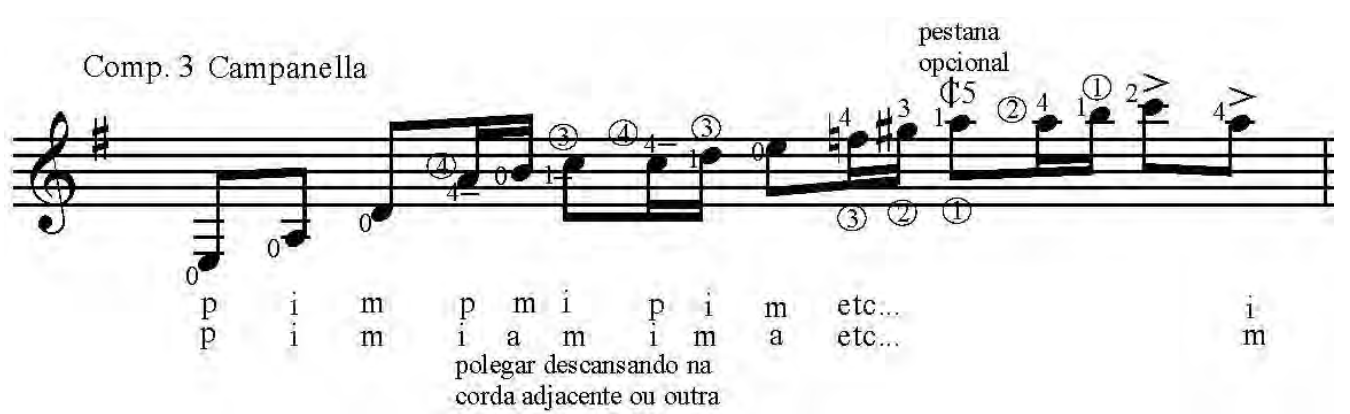

Exemplo 250: $I V^{\circ}$ Estudo, compasso 3.

Já a configuração de ligados de BL poderia ser aplicada a várias opções digitacionais normalmente no padrão 2-1, das quais duas ficam aqui registradas por envolverem regiões bem distintas do instrumento: 


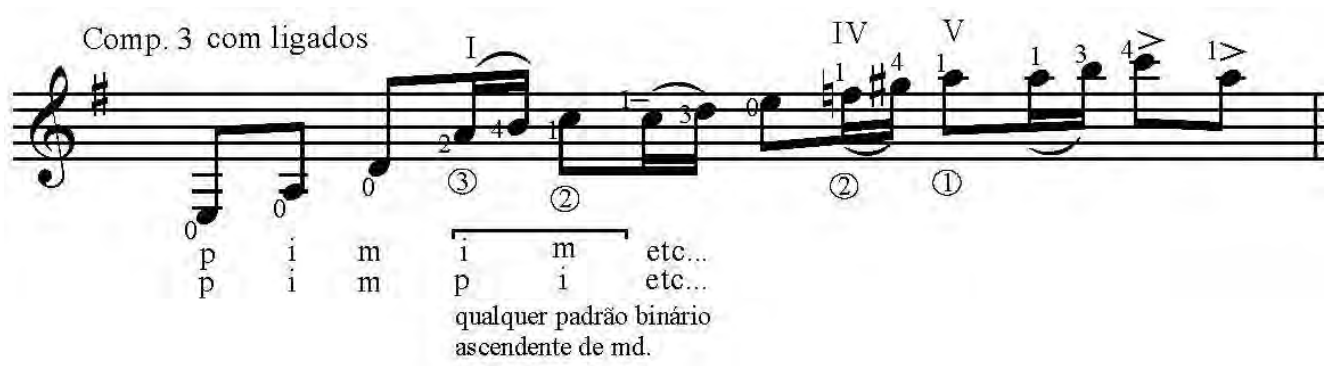

Exemplo 251: IV Estudo, compasso 3.

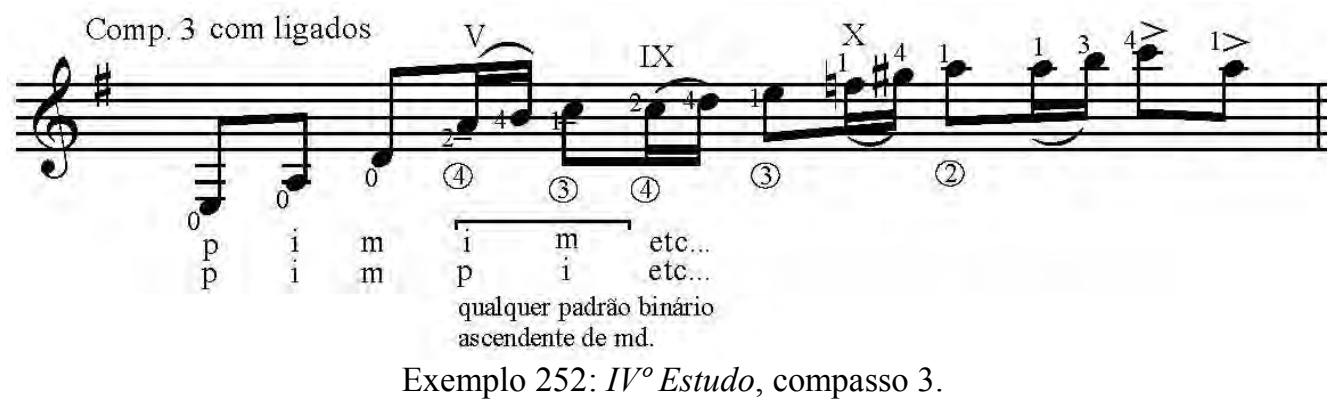

A outra posição dos ligados também pode ser aplicada a várias digitações, mas normalmente no padrão 1-2. As duas primeiras executam as notas nos exatos mesmos lugares mas com dedos distintos e também poderiam ser iniciadas na primeira posição (como no exemplo 251). Já o exemplo 255 avança para a posição VII e poderia ter o seu final combinado ${ }^{85}$ com exemplos anteriores.

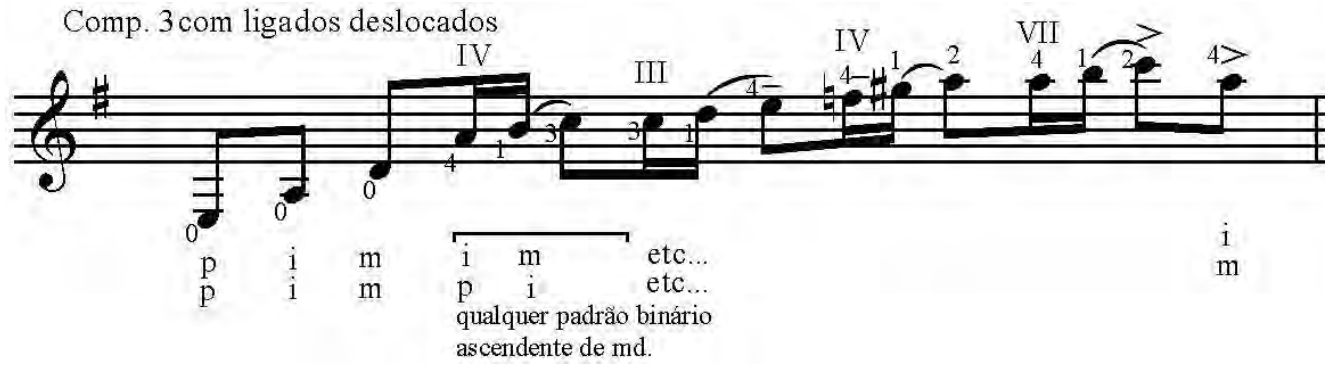

Exemplo 253: $I V^{\circ}$ Estudo, compasso 3.

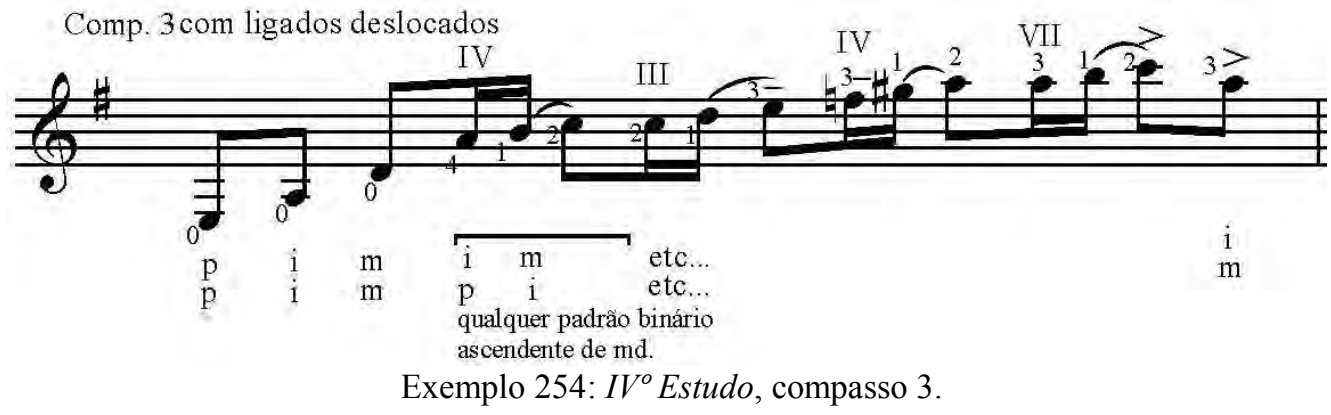

${ }^{85}$ verbo do checklist de Osborn. 


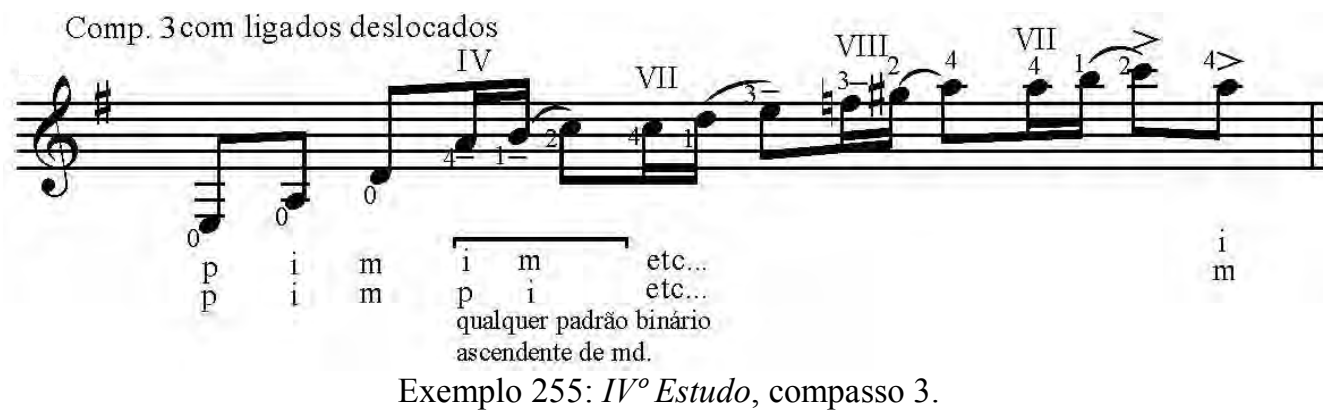

No compasso 5 o arpejo chega a sua máxima amplitude, alcançando a nota $\mathrm{Mi}$, na décima segunda casa, o que gera complicações para alcançá-la. Também há uma característica diferente na configuração intervalar do mesmo, a presença de uma terça maior (entre Mi-Sol\#) o que por vezes gera uma quebra na regularidade dos padrões de distribuição das notas nas cordas (os chamados padrões 2-1 e 1-2).

O primeiro exemplo segue o padrão 2-1 até onde consegue, passando depois para una corda e alcança a última nota pelo translado do dedo 3 ou 4, artifício que exige não somente estudo mas também acompanhamento visual para garantir que o dedo recaia na nota correta. Preferimos o uso do dedo 3 neste caso por sua maior firmeza, além do que ele alcança a casa 12 ao mesmo tempo em que a mão do intérprete se choca com o corpo do instrumento, provendo mais uma referência.

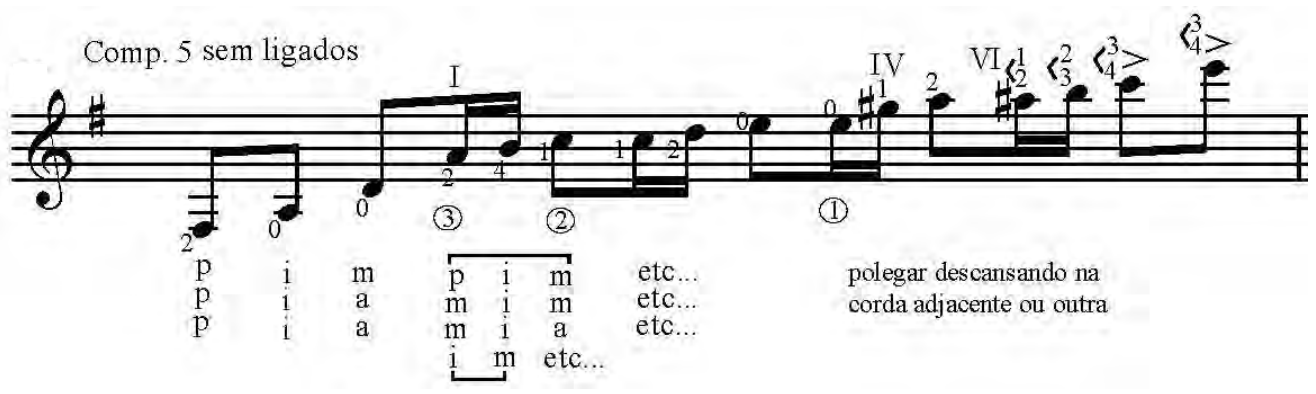

Exemplo 256: $I V^{o}$ Estudo, compasso 5.

O próximos dois exemplos seguem o padrão 1-2 em regiões diferentes. O primeiro deles ainda finaliza com o translado do dedo 3, enquanto o seguinte, ao permanecer mais tempo no padrão 1-2, alcança a nota aguda por meio de uma abertura na sétima posição.

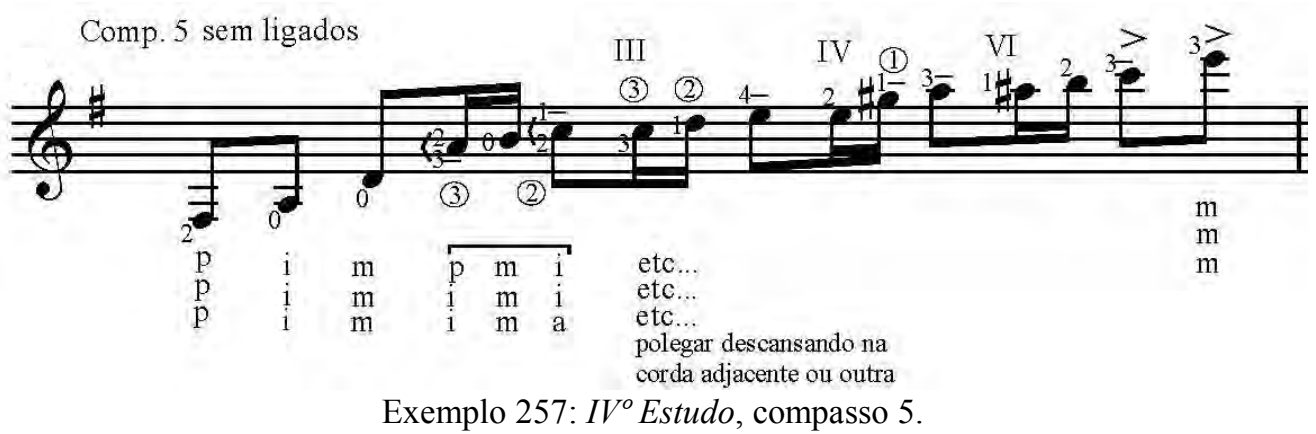




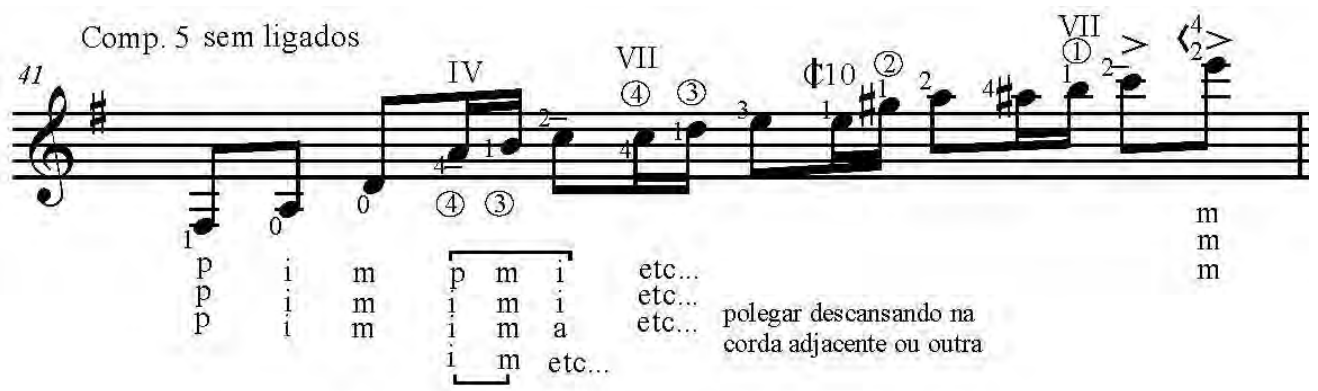

Exemplo 258: IV Estudo, compasso 5.

A única versão em campanella que registramos se baseia no alto aproveitamento dos dedos 1 e 3 que, trabalhando em bloco, "passeiam" pelo instrumento. Outras versões poderiam ser concebidas combinando ${ }^{86}$ essa versão com o final de versões anteriores, porém com menor presença do efeito de campanella.

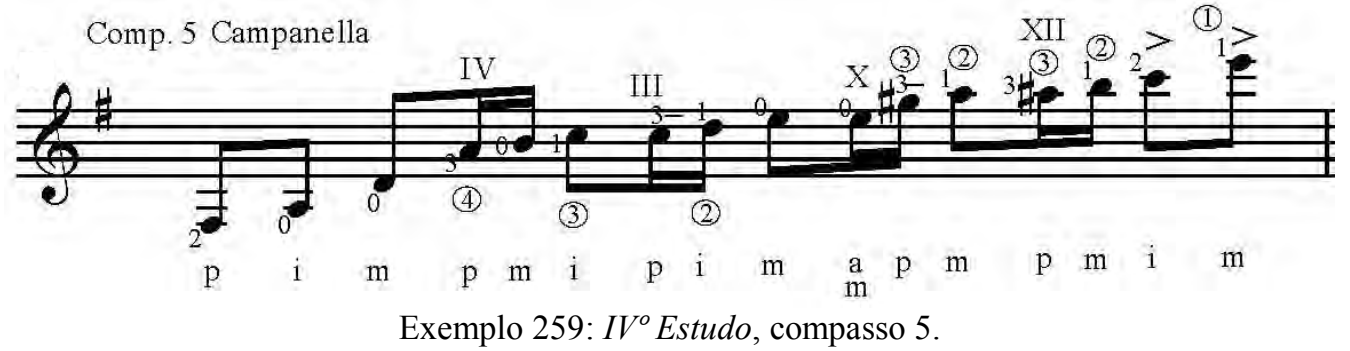

Retornando ao padrões de ligados $\mathrm{BL}$, é preciso notar sua estratégia para alcançar a nota mais aguda do compasso: ele o faz pela rápida (re)entrada do dedo 1 na primeira corda na oitava posição, alcançando a próxima nota por abertura. A ideia é muito boa, mas é dificultada por seu contexto antecedente: primeiro ao digitar a terça maior (Mi-Sol\#) na segunda corda, com abertura e ligado com o frágil dedo 4 e depois ao penalizar o translado do dedo 1 por colocar o ligado final com os dedos 2 e 3 .

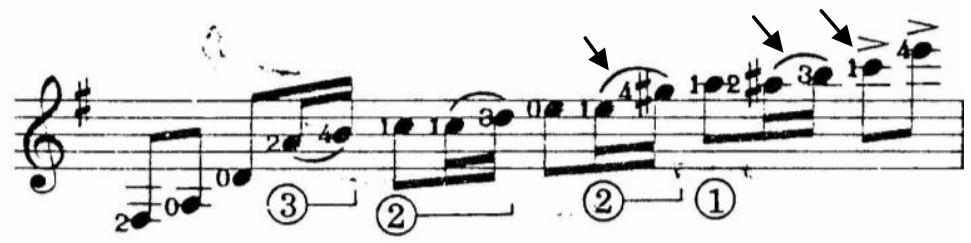

Exemplo 260: IV Estudo, compasso 5. Ed. Columbia/BL.

Nosso próximo exemplo simplifica estes dois empecilhos pelo uso maior dos dedos 1 e 2 em una corda, realizando com maior fluidez o translado final do dedo 1 para a oitava posição.

\footnotetext{
${ }^{86}$ verbo do checklist de Osborn.
} 


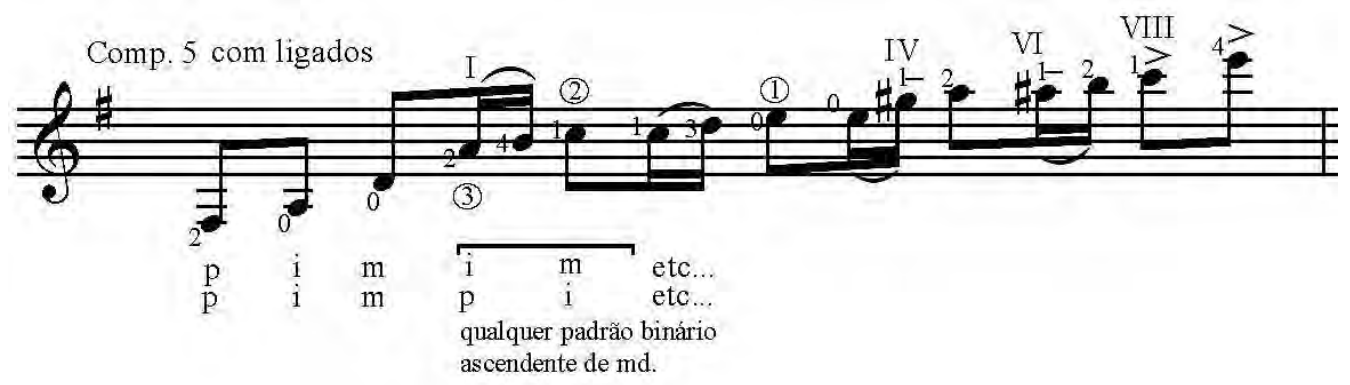

Exemplo 261: $I V^{\circ}$ Estudo, compasso 5.

O exemplo 262 é muito similar e vem apenas para registrar o final com translado do dedo 3 ou 4.

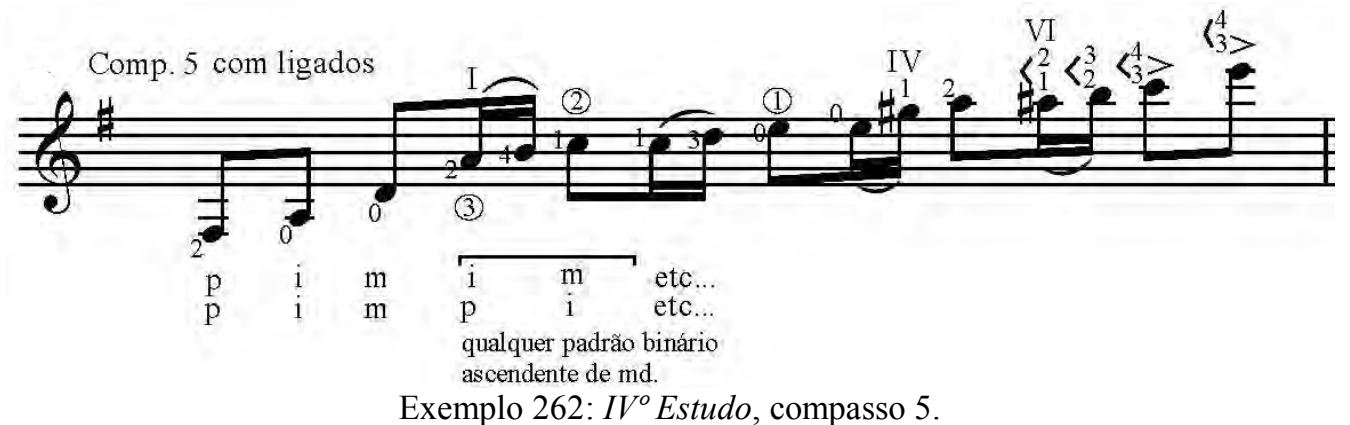

O exemplos 263 e 264 empregam os mesmos ligados em posições mais avançadas $^{87}$ do instrumento, criando uma aproximação interessante à nota aguda por meio do uso segunda corda na posição XI. Há um ligado com o dedo 4 em abertura na terça maior (Mi-Sol\#), porém esta abertura é menor do que em BL por envolver casas mais estreitas do instrumento, além do que o dedo 1 já vem preparado anteriormente. Os dois exemplos seguinte diferem apenas na digitação do primeiro ligado:

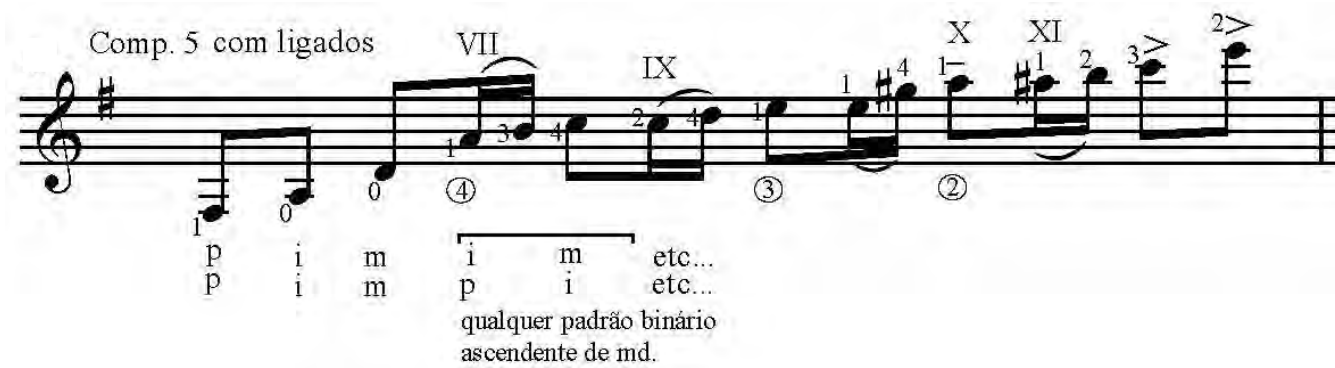

Exemplo 263: $I V^{\circ}$ Estudo, compasso 5.

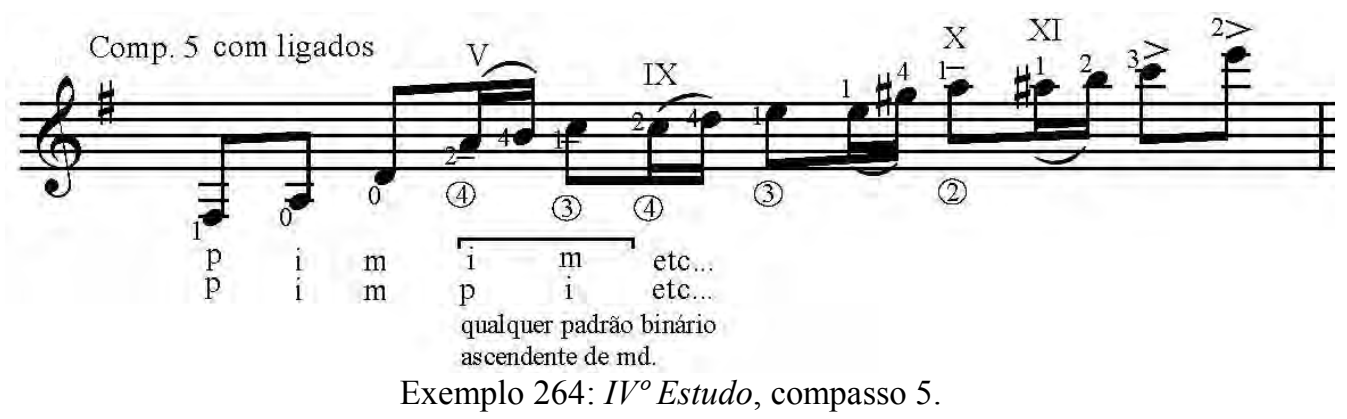

${ }^{87}$ Novamente, entenda-se "de maior valor numérico". 
A primeira e segunda versões com ligados deslocados colocam as notas nos mesmos lugares mas com dedos diferentes, havendo ainda a possibilidade de "quebrar" o padrão de ligados na condução para a nota aguda.
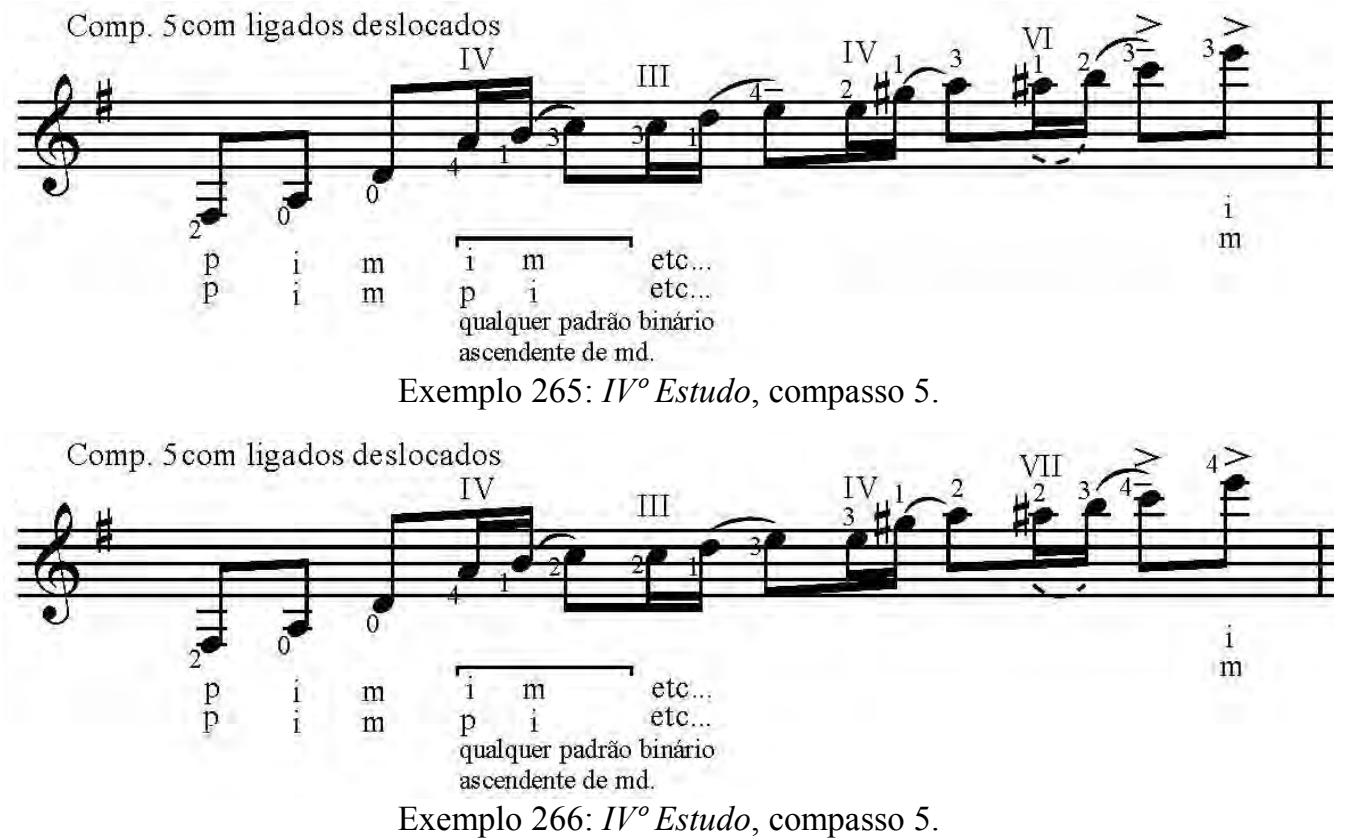

Já exemplo 267 resolve melhor a digitação da terça maior por meio de uma pestana na nona posição e desce para a sétima para alcançar a nota aguda, podendo também fazê-lo pela segunda corda na posição XI de maneira similar ao final dos exemplos 263 e 264 .

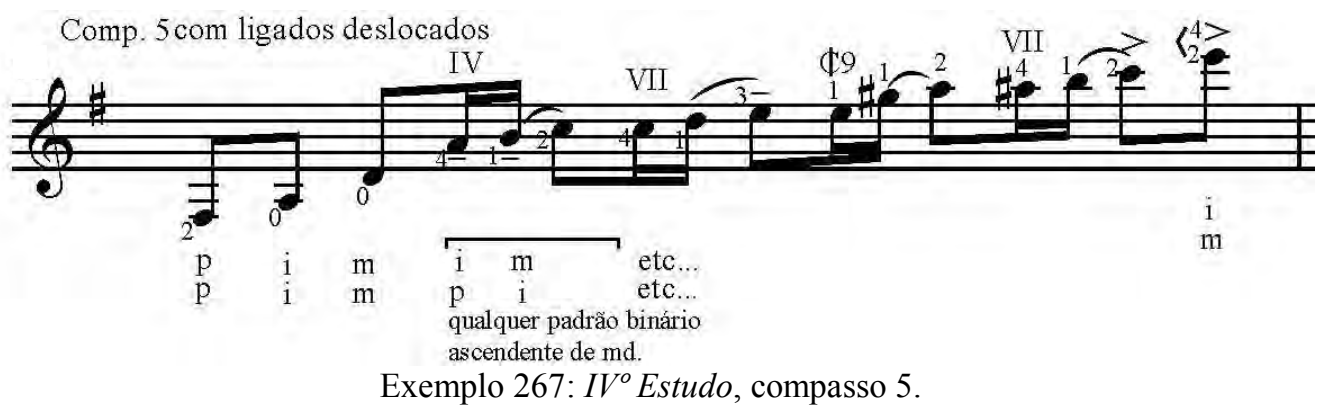

O compasso 7 também atravessa uma grande extensão, novamente com várias possibilidades de atingir seu cume (Ré\#). Este compasso apresenta grandes similaridades com os compassos 25 e 69 que serão discutidas posteriormente. A primeira versão sem ligados (ex. 268) possibilita uma construção em padrão de três notas por corda ou outra sem padrão estrito. A subida final em una corda é bastante desfavorável ao criar uma abertura na terceira posição e atingir a nota mais aguda por meio do translado por deslocamento do dedo 4. 


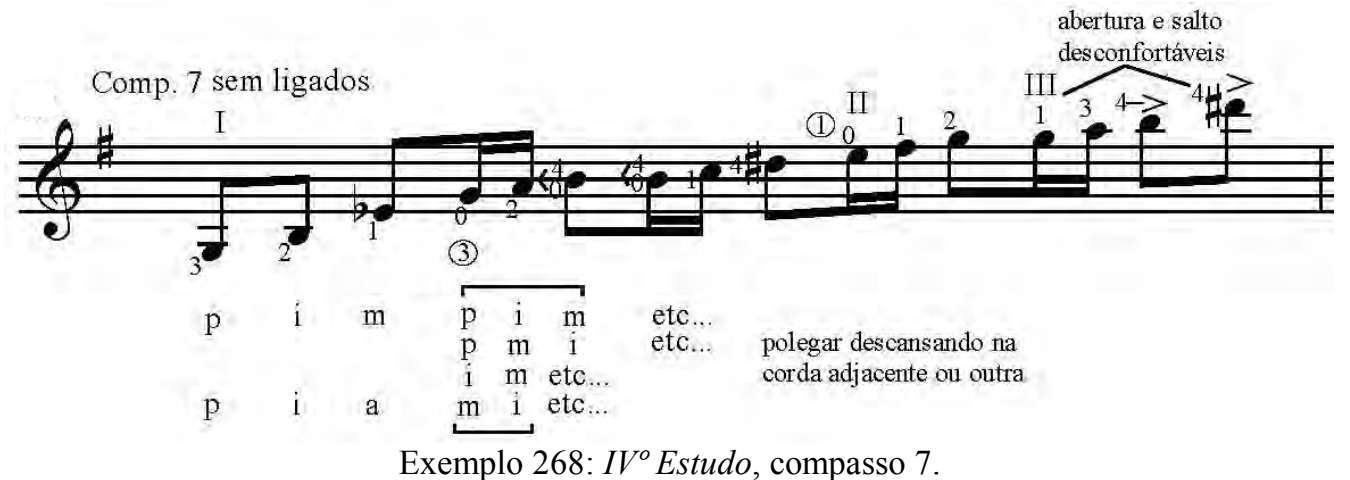

O exemplo 269 segue o padrão 1-2 e com isso talvez exagere no uso do dedo 4 , característica penosa (principalmente no início do trecho) mas por outro lado favorável ao criar uma interessante saída em duas cordas nos tempos 4 e 5 do compasso finalizada com um translado do dedo 3.

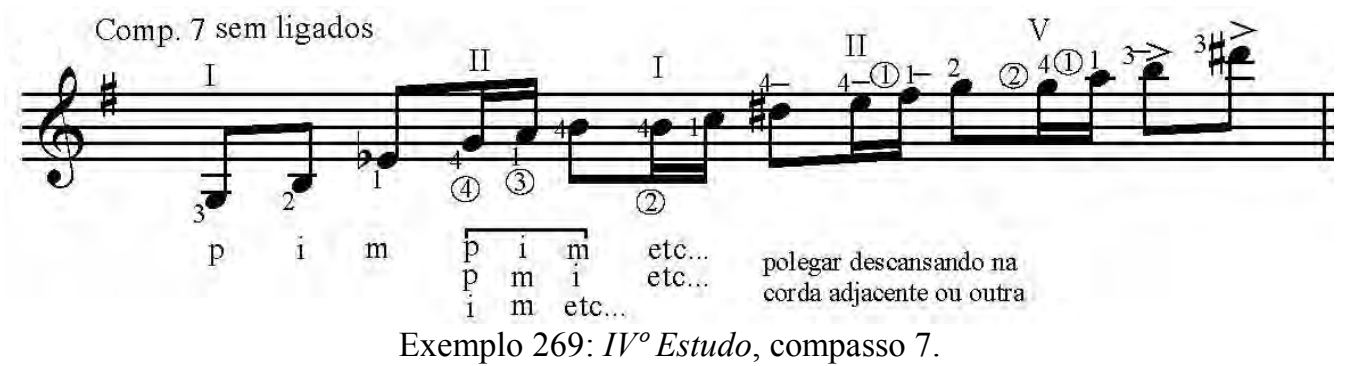

Os exemplos 270 e 271 seguem o padrão 2-1. O primeiro deles acaba apresentando duas possibilidades de subida na parte central e, apesar de necessitar de uma abertura na terceira posição, também faz uma ascensão nas duas primas pelo translado de vários dedos, em ideia vagamente semelhante ao exemplo anterior, mas com dedos e cordas completamente rearranjados ${ }^{88}$. O exemplo 271 antecipa essa ascensão por translado, colocando-a na segunda e terceira cordas.

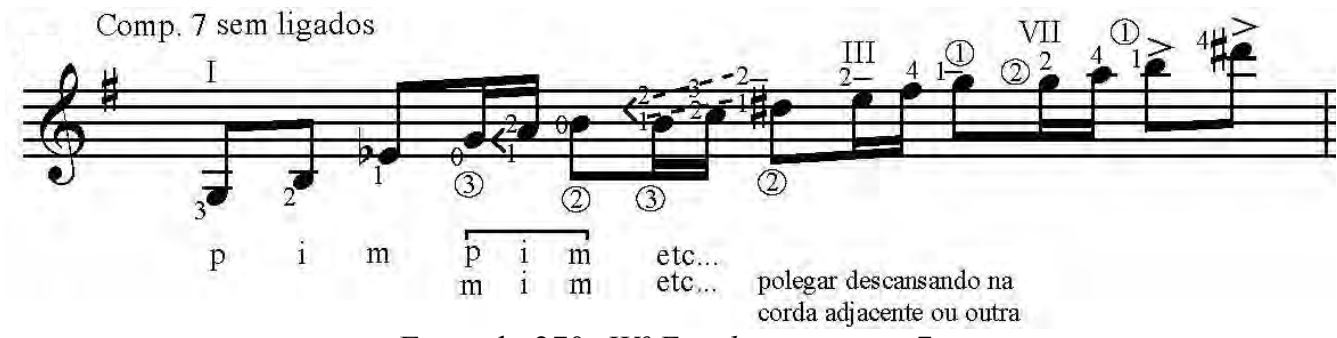

Exemplo 270: $I V^{\circ}$ Estudo, compasso 7.

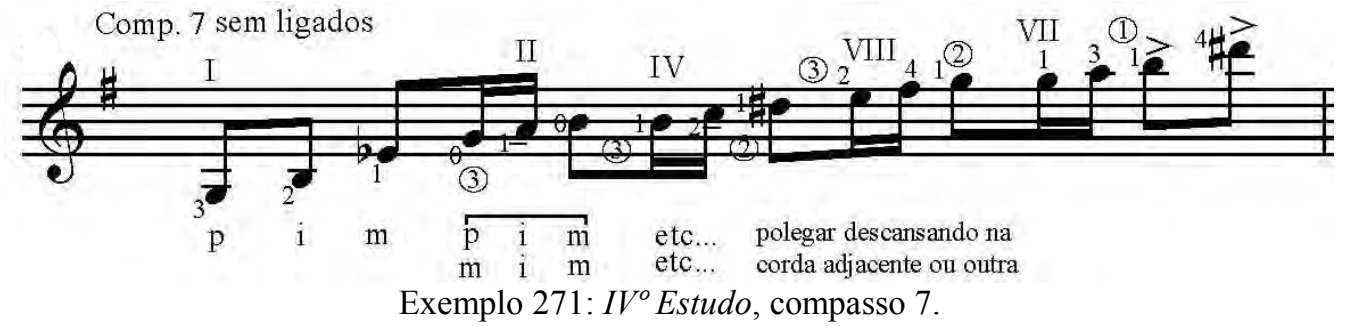

${ }^{88}$ verbo do checklist de Osborn. 
As duas versões em campanella a seguir guardam muitas semelhanças, sendo que a primeira delas faz uma subida progressiva, enquanto a outra aproveita a segunda corda solta para o traslado até a oitava posição.

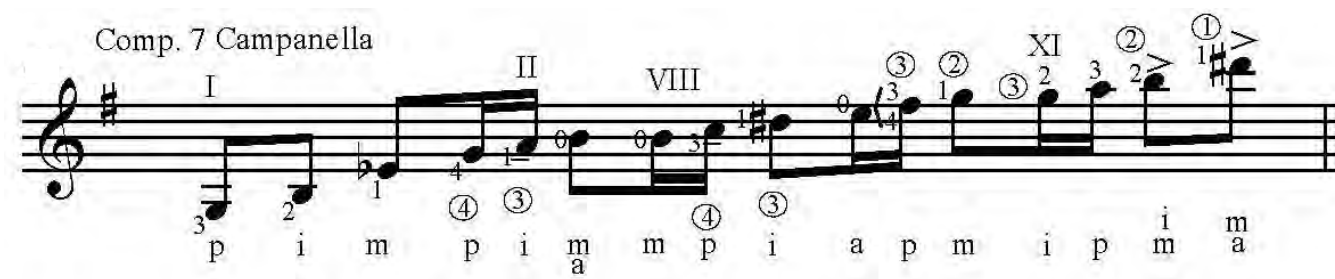

Exemplo 272: $I V^{\circ}$ Estudo, compasso 7.

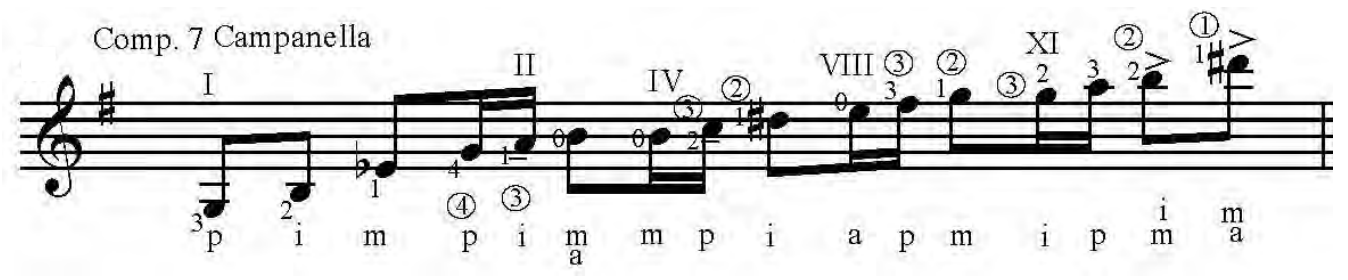

Exemplo 273: IV Estudo, compasso 7.

Os exemplos 274 e 275 apenas aplicam os ligados sugeridos por BL aos exemplos 270 e 271 anteriormente expostos. Já os exemplos 276 e 277 iniciam o padrão 2-1 com um deslocamento em cordas graves gerando inevitável ruído, sendo que no último mencionado o translado pela quinta corda é demasiado grande.
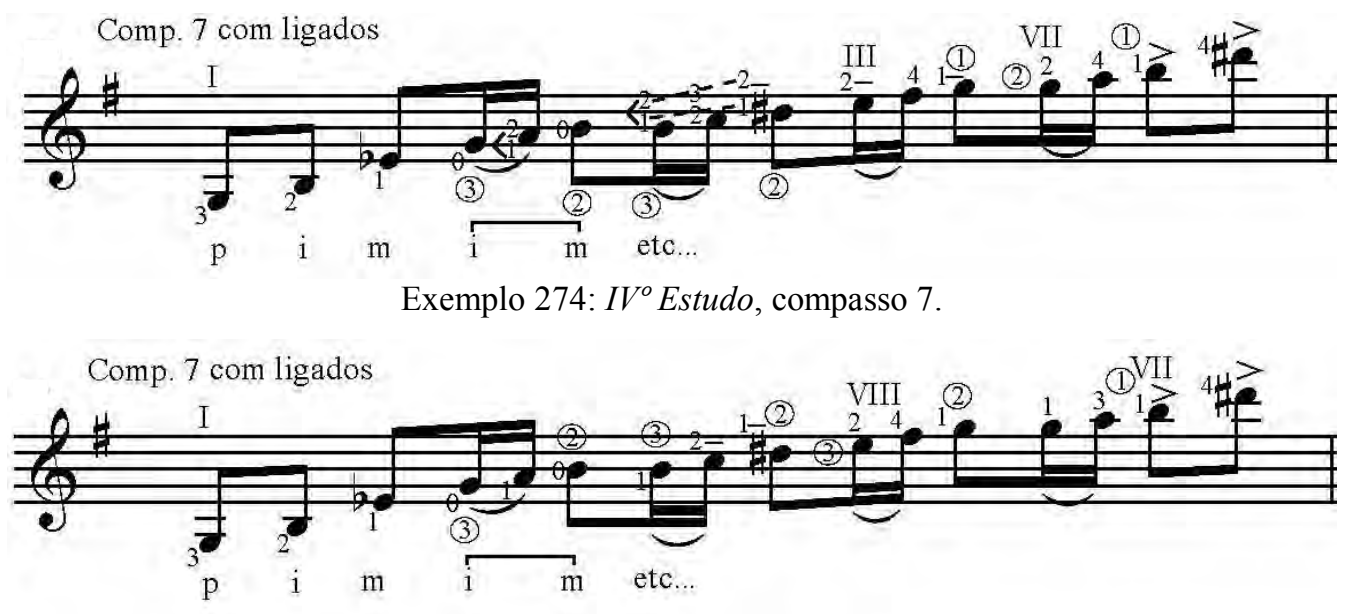

Exemplo 275: $I V^{\circ}$ Estudo, compasso 7.

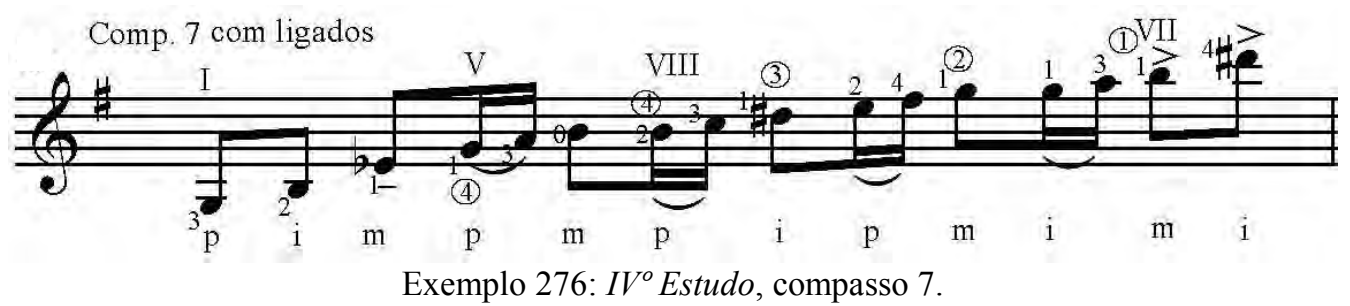




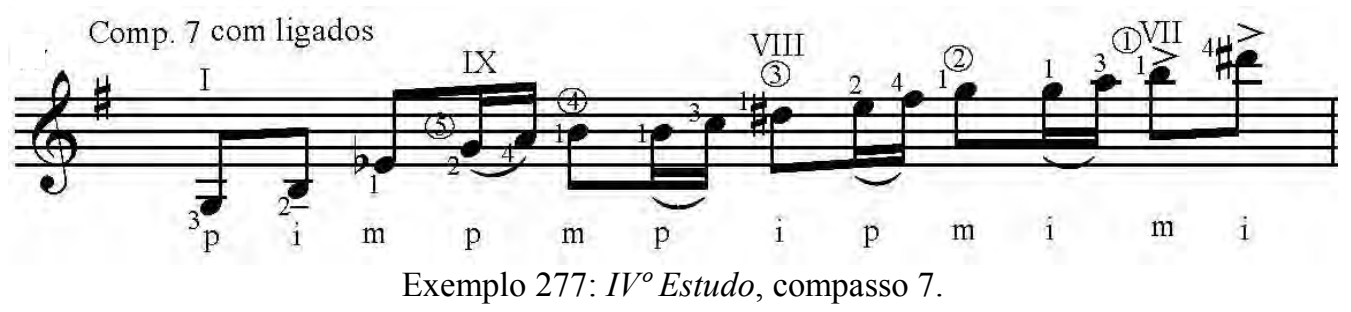

As versões com ligados deslocados também partem de opções pregressas, de forma que o exemplo 278 é idêntico ao 269 , mas com os referidos ligados.

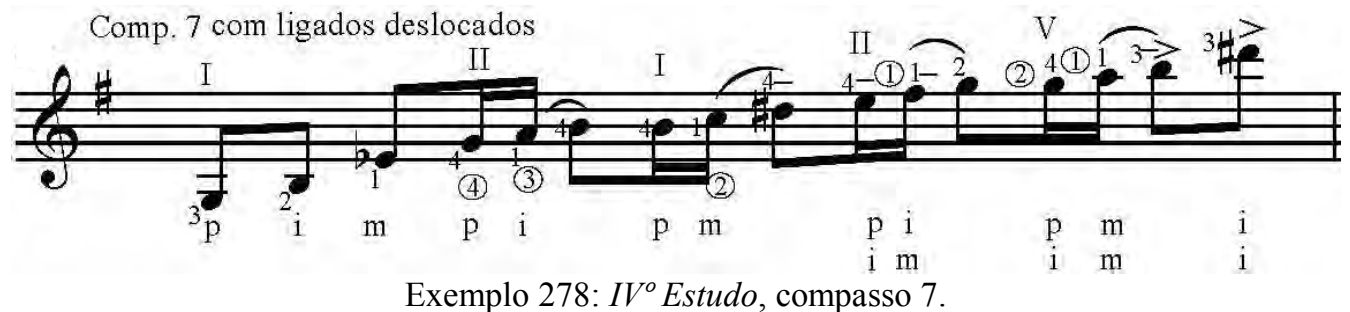

Mas a presença dos ligados deslocados permite um efeito interessante nesse trecho: o do aproveitamento de uma corda solta para iniciar o padrão 1-2 aplicado três vezes consecutivas, aspecto demonstrado nos exemplos 279 e 280. Ascendendo de maneiras distintas seu final é idêntico e apresenta uma interessante distribuição em três cordas. Já o exemplo 281 vem mesclar aspectos do exemplo 278 com este mesmo final em três cordas, atingindo-o por meio de um deslocamento em bloco dos dedos 1 e 3 .

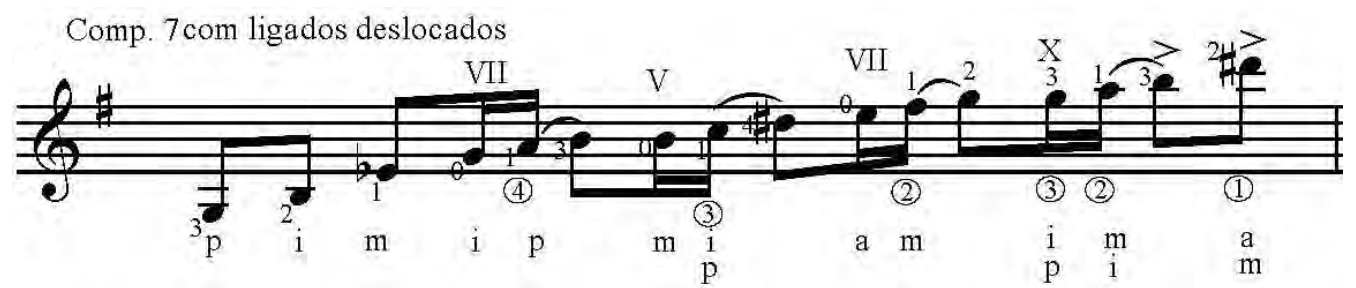

Exemplo 279: $I V^{\circ}$ Estudo, compasso 7.

Comp. 7 com ligados deslocados

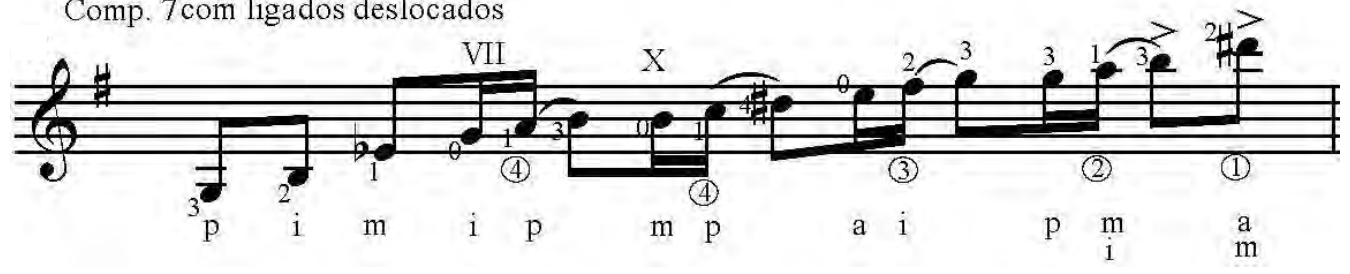

Exemplo 280: $I V^{\circ}$ Estudo, compasso 7.

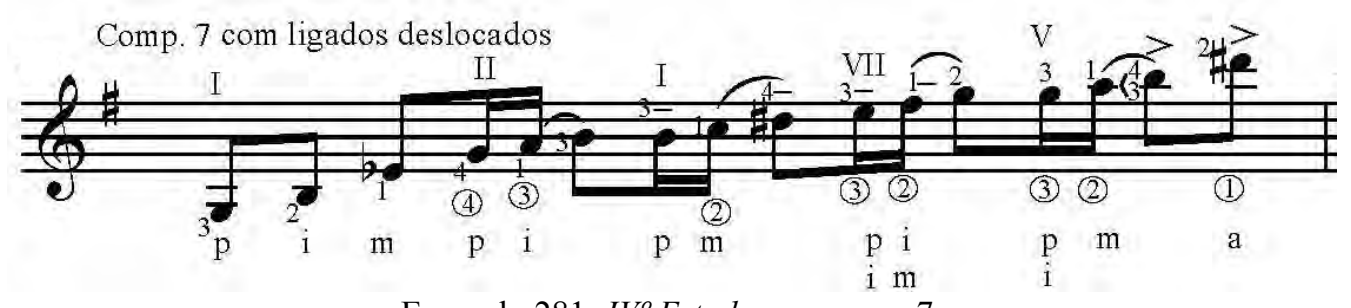

Exemplo 281: $I V^{\circ}$ Estudo, compasso 7.

Um tema contrastante é introduzido no compasso 9, com melodia na primeira corda que rememora o ritmo de galope e é acompanhada por acordes reiterados a cada tempo. A digitação BL (exemplo 282) para o primeiro compasso do trecho pauta-se no 
translado do dedo 1, enquanto nossa única alternativa (exemplo 283) usa o dedo 4 para o mesmo fim. Nossa versão também inclui três possibilidades de articulação de $m d$, também aplicáveis aos outros compassos da seção (às vezes com adaptações ${ }^{89}$, como veremos a seguir).

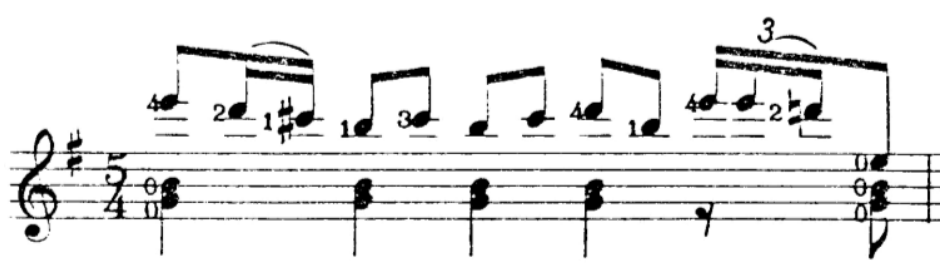

Exemplo 282: $I V^{o}$ Estudo, compasso 9. Ed. Columbia/BL.

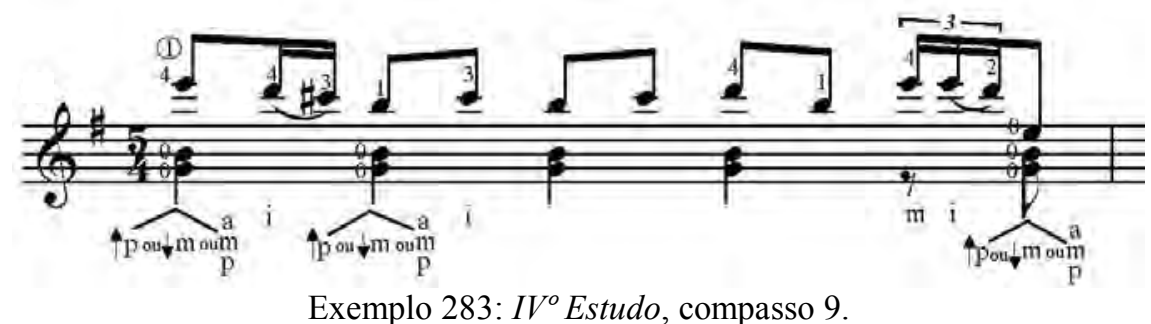

O exemplo 284 demonstra digitação BL para o compasso 11, mas com $m d$ especificada. Para padrões com reiteração do polegar ou escovamento do dedo $m$, será necessário abafar a segunda corda com a própria pestana (ver exemplo 285).

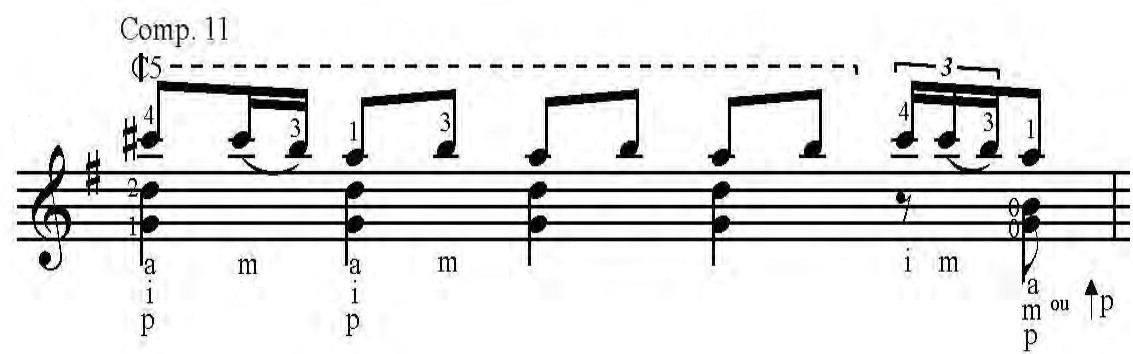

Exemplo 284: $I V^{\circ}$ Estudo, compasso 11.

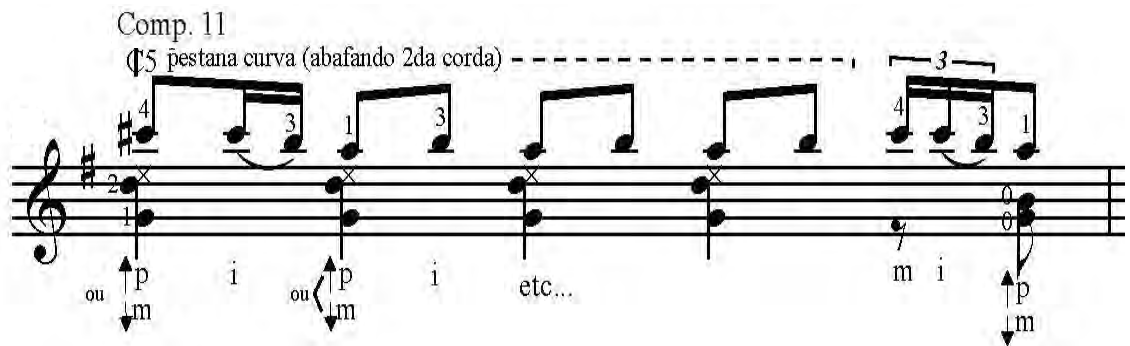

Exemplo 285: $I V^{\circ}$ Estudo, compasso 11.

O exemplo seguinte, de número 286 , embora possa parecer muito similar, vem demonstrar uma nova articulação de $m d$, que integra os dois gestos recém-descritos: a cada acorde o polegar articula as duas notas inferiores (harmonia) enquanto o $m$ se ocupa da voz superior, também aplicável à seção inteira.

\footnotetext{
${ }^{89}$ verbo do checklist de Osborn.
} 


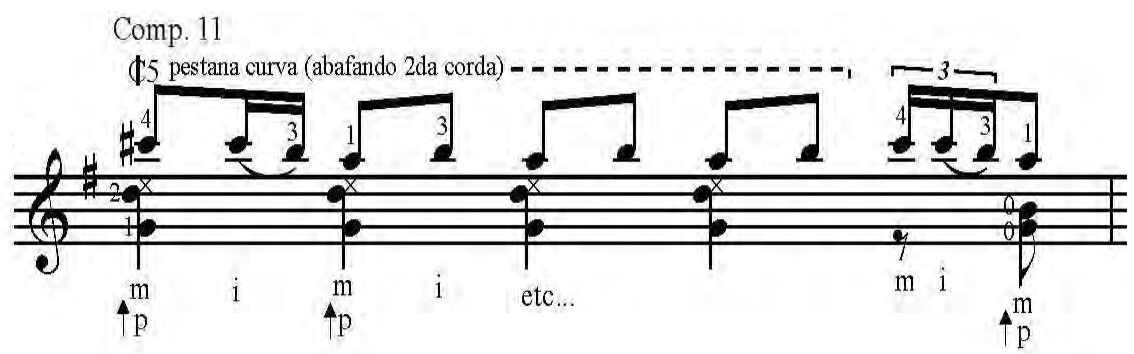

Exemplo 286: IV Estudo, compasso 11.

O exemplo 287 busca outra digitação de me para o mesmo compasso, passando o acorde para a terceira posição quando possível, mas com o custo de gerar uma abertura, ainda que factível.

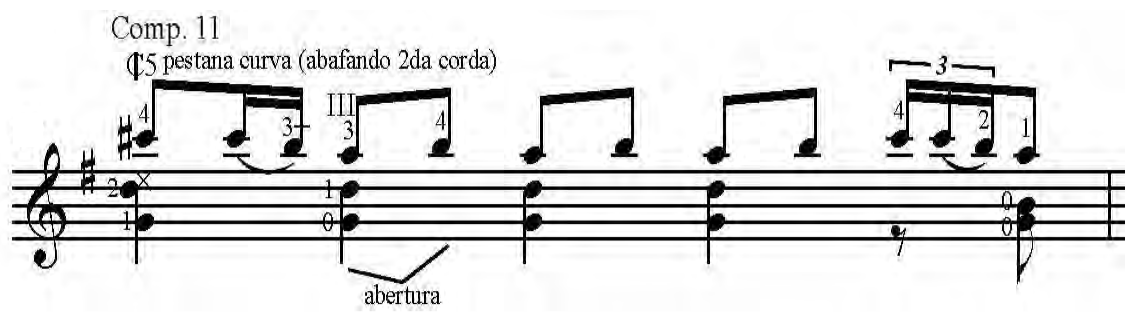

Exemplo 287: $I V^{\circ}$ Estudo, compasso 11.

O compasso 13 é bastante exequível com a digitação BL, mas mesmo assim recebe outra versão que evita a troca de posição por meio de abertura e inclui uma nota opcional.

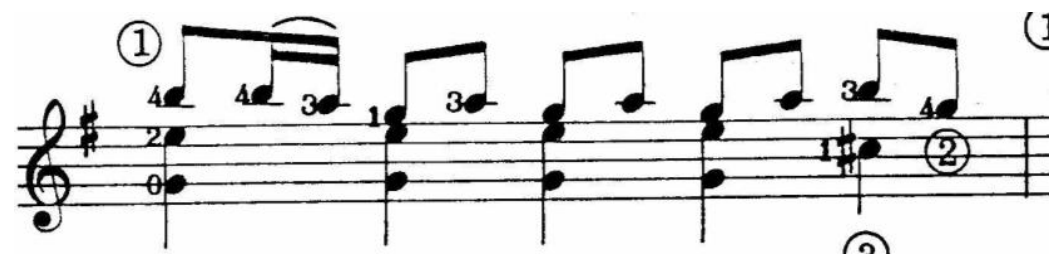

Exemplo 288: IV Estudo, compasso 13. Ed. Columbia/BL.

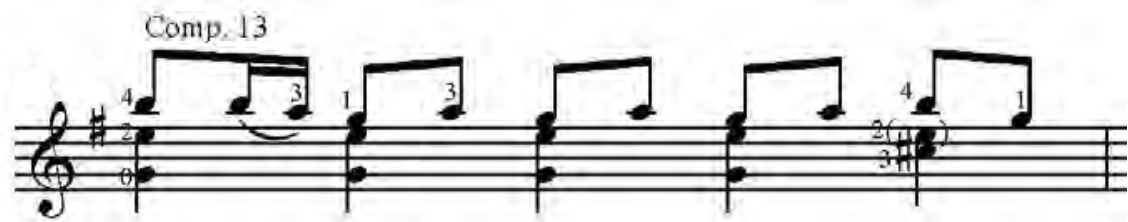

Exemplo 289: $I V^{\circ}$ Estudo, compasso 13.

Repetindo a seção inicial, Mignone propõe variações a alguns dos compassos existentes e também alarga o trecho. O compasso 23 nada mais é do que uma variação bastante modificada ${ }^{90}$ do compasso 5 , que recebe notas repetidas e alcança menor extensão que seu antecessor. Por este motivo, propusemos apenas três versões, cobrindo as diferentes abordagens anteriores, sendo que o exemplo em campanella (ex. 292) parece resolver melhor a nota repetida, solução esta que pode ser integrada às outras versões.

\footnotetext{
${ }^{90}$ verbo do checklist de Osborn.
} 

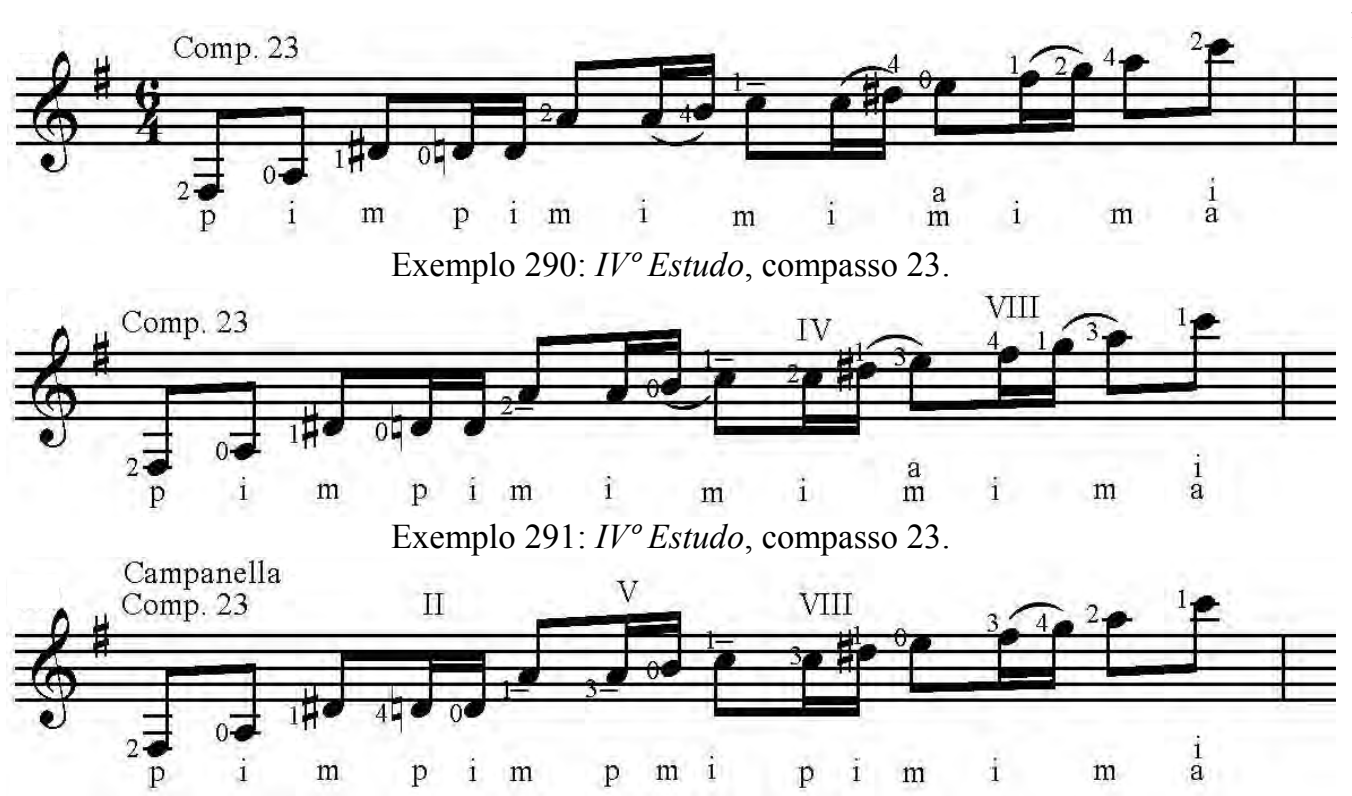

Exemplo 292: IV Estudo, compasso 23.

O compasso 25 é uma variação muito sutil do compasso 7, trocando apenas duas de suas notas: o Dó passa a ser sustenido e o cume sobe meio tom atingindo o Mi natural. Essa pequena divergência de poucas notas também ocorre no compasso 69, modificando novamente poucas notas do compasso. Curiosamente esta obra possui dois manuscritos, um com três páginas (MS A) e outro, com duas (MS B), onde novamente ocorrem divergências, não apenas entre os referidos compassos na mesma fonte, mas entre as fontes também, resultando em uma confusão considerável.

Seguem as versões de todas as aparições dos compassos 7, 25 e 69 nas três fontes primárias ${ }^{91}$ existentes, colocadas lado a lado para propiciar melhor comparação. Favor lembrar que todos os excertos estão em clave de Sol e possuem um Fá\# na armaduras de clave, embora isso nem sempre esteja visível.

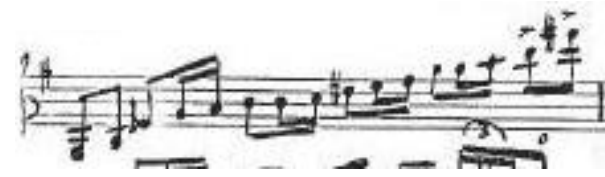

Ex. 293: IV Est., comp. 7 MS A.

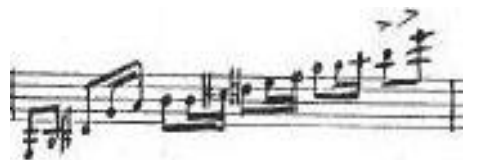

IV Est., comp. $25 \mathrm{MS} \mathrm{A.}$

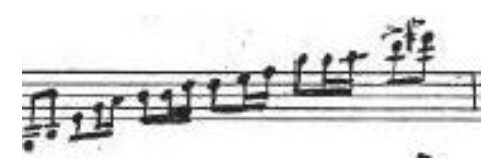

IV Est., comp. 69 MS A.
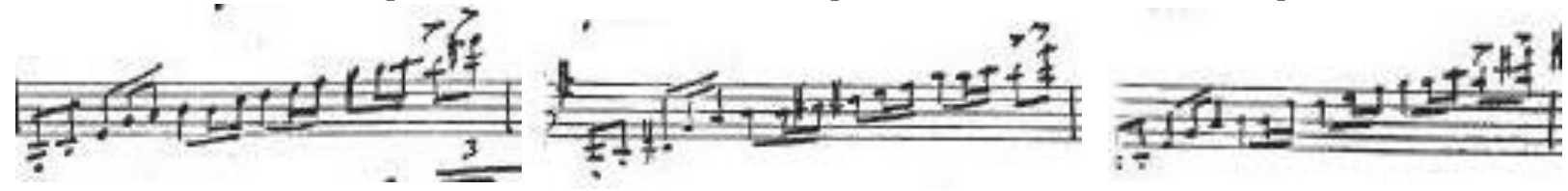

Ex. 294: $I V^{o}$ Est., comp. 7 MS B.

IV Est., comp. $25 \mathrm{MS}$ B.

IV Est., comp. 69 MS B.
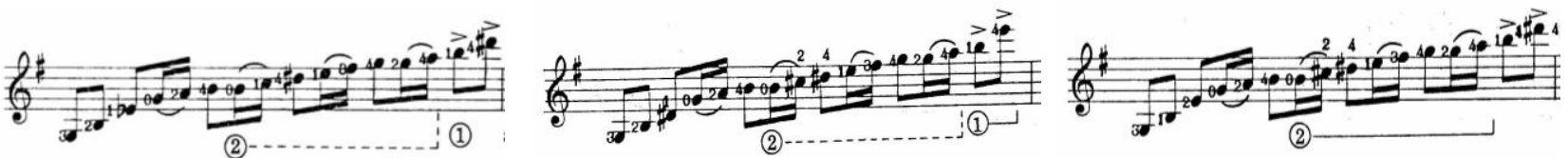

Ex. 295: IV $V^{o}$ Est., comp. 7. CB/BL ${ }^{92}$. IV $\quad I V^{o}$ Est., comp. 25. CB/BL.

IV $V^{o}$ Est., comp. 69.CB/BL.

\footnotetext{
${ }^{91}$ Também consideramos a edição Columbia/BL como primária por julgar que as modificações nela apresentadas podem ter passado pelo crivo do compositor, embora isso não seja confirmado.

${ }^{92}$ Aqui tivemos de abreviar Ed. Columbia/BL para $\mathrm{CB} / \mathrm{BL}$.
} 
As gravações disponíveis (comerciais ou não) do trecho são igualmente divergentes neste aspecto. Registramos aqui as opções dos intérpretes em relação às três notas mais conflituosas a saber: 1) primeira nota do segundo tempo, 2) terceira nota do terceiro tempo e 3) última nota do compasso:

Barbosa-Lima (Philips Polygram, 1978): compasso 7 (Ré\#, Dó nat., Ré\#), compasso 25 (Mi nat., Dó nat., Mi nat.) e compasso 69 (Mi nat., Dó nat., Ré\#).

Flávio Apro (Tempus Clasico, 2013) ${ }^{93}$ : compasso 7 (Ré\#, Dó\#, Ré\#), compasso 25 (Ré\#, Dó\#, Mi nat.) e compasso 69 (Mi nat., Ré nat., Ré\#).

Consideramos que essas divergências não criam mudanças harmônicas muito consideráveis e que, se tratando de obra em andamento rápido com amplos translados de me, a troca de algumas notas a cada aparição representa, sob a perspectiva do intérprete, um momento muito propício ao erro. Em outras palavras, estamos dizendo que seguir literalmente todas essas pequenas divergências apresenta, sob a ótica do performer, pouca relação custo-benefício já que este tipo de pequena variação é um dos pontos frágeis do instrumento.

Dessa forma, em nossa performance pessoal, adotamos o conselho que informalmente nos foi passado por Luís Carlos Barbieri de unificar todas as aparições desses compassos, exigindo assim uma única memória muscular para o trecho.

Tendo em conta todos estes aspectos, nos absteremos de apresentar novas opções para estes compassos, entendendo que o leitor pode se servir das digitações ofertadas para o compasso 7 para construir as digitações dos outros compassos similares, bastando realizar as pequenas alterações de notas e readequar os dedos utilizados para as mesmas.

Antes de seguir à diante é preciso registrar que algo semelhante ocorre entre os compassos de número 5 e 67 que apresentam apenas uma nota diferente em seu quarto tempo (no primeiro um Mi natural se transforma em Fá\# no segundo), divergência simples que também não exemplificaremos.

Encerrado estes esclarecimentos, seguimos para o compasso 27 onde Mignone leva o padrão a novas harmonias, fazendo com que novas digitações sejam necessárias. Iniciando com os ligados BL, o primeiro exemplo privilegia as primeiras posições e atinge à nota aguda por translado de dedo guia, enquanto o segundo avança pela quarta corda. O exemplo 298 explora os ligados deslocados e atinge o cume com uma

\footnotetext{
${ }^{93}$ Disponível em www.tempusclasico.com/Catalogo/doce_estudios.html, acesso em 13/12/2018, às 14hs.
} 
interessante pestana na nona casa, enquanto o último exemplo do trecho registra uma opção em campanella, existindo ainda outras digitações viáveis.

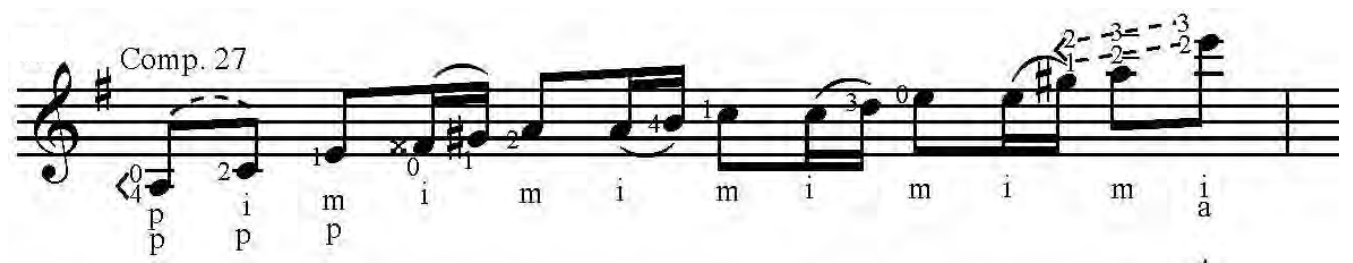

Exemplo 296: IV Estudo, compasso 27.

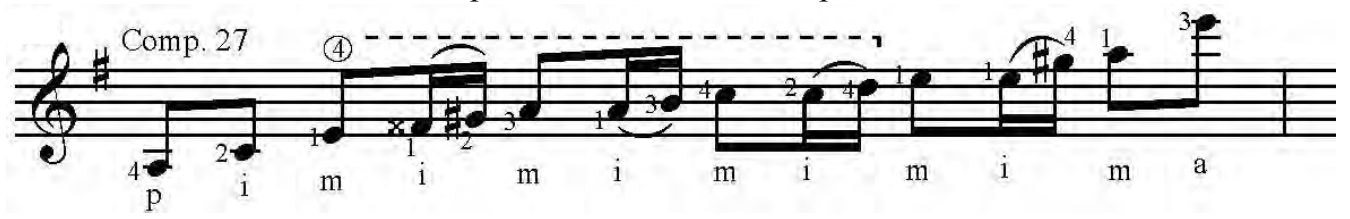

Exemplo 297: IV Estudo, compasso 27.

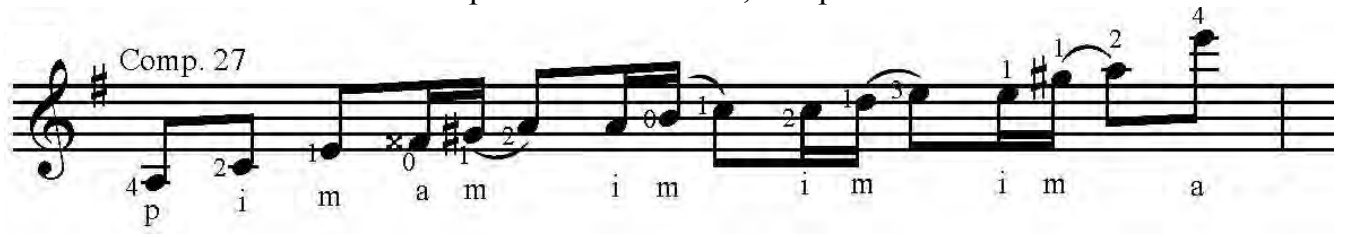

Exemplo 298: $I V^{\circ}$ Estudo, compasso 27.

Comp. 27 Campanella

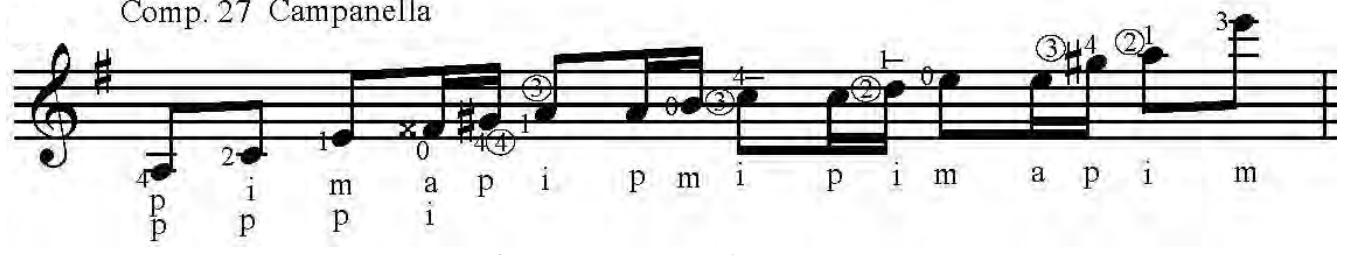

Exemplo 299: $I V^{\circ}$ Estudo, compasso 27

O compasso 28 é preferencialmente iniciado na primeira posição com ligado, mas também tem início possível em três cordas, embora com abertura considerável por se tratar da região grave do violão. Os exemplos seguem lógica semelhante ao trecho anterior: seguindo os ligados BL, o exemplo 300 utiliza posições iniciais e o 301 sobe pela quarta corda, enquanto o exemplo 302 desloca os ligados e o 303 apresenta uma campanella, ambos com desfechos similares pela quinta casa em duas cordas envolvendo diferentes dedos.

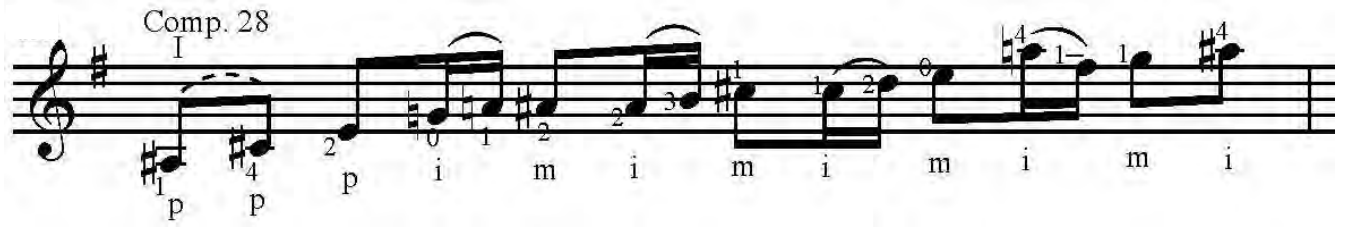

Exemplo 300: $I V^{\circ}$ Estudo, compasso 28.

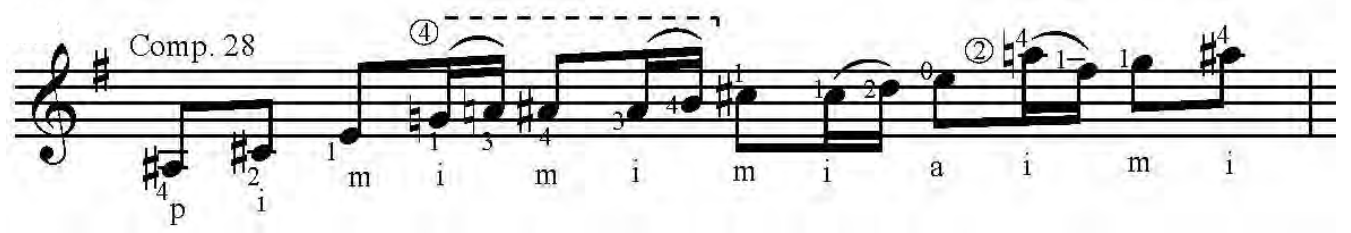

Exemplo 301: $I V^{\circ}$ Estudo, compasso 28. 


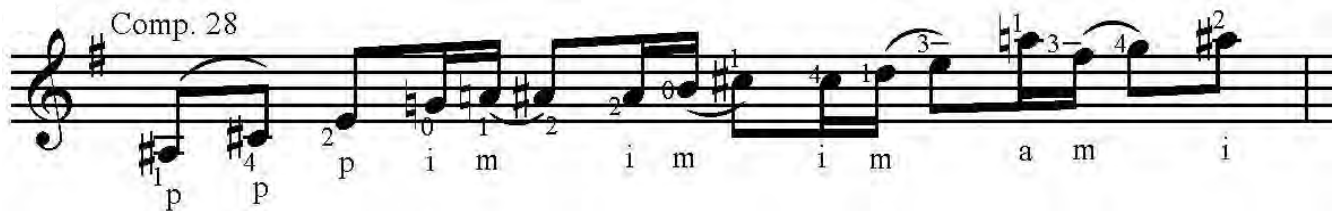

Exemplo 302: IV Estudo, compasso 28.

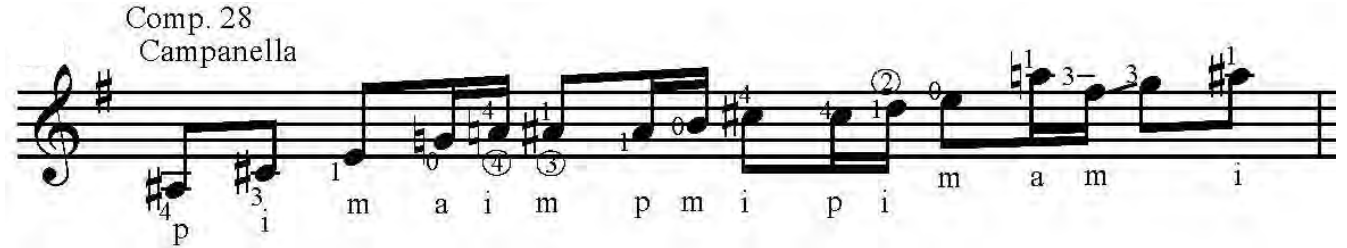

Exemplo 303: IV Estudo, compasso 28.

No compasso 29 a digitação BL (exemplo 304) ascende por meio de um padrão 2-1 nas duas primas, gerando uma abertura levemente desconfortável entre o quarto e quinto tempos. Nosso exemplo 305 propõe uma simplificação com subida em una corda e o 306 aproveita a primeira corda solta para saltar para a nona posição. O exemplo 307 em ligados deslocados faz novamente grande uso das cordas soltas e o 308 oferece uma campanella com os dedos 1 e 3 sendo arrastados pela segunda e terceira cordas.

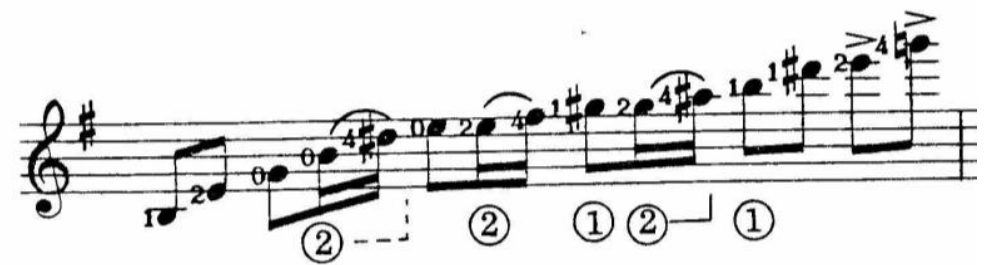

Exemplo 304: $I V^{o}$ Estudo, compasso 29. Ed. Columbia/BL.

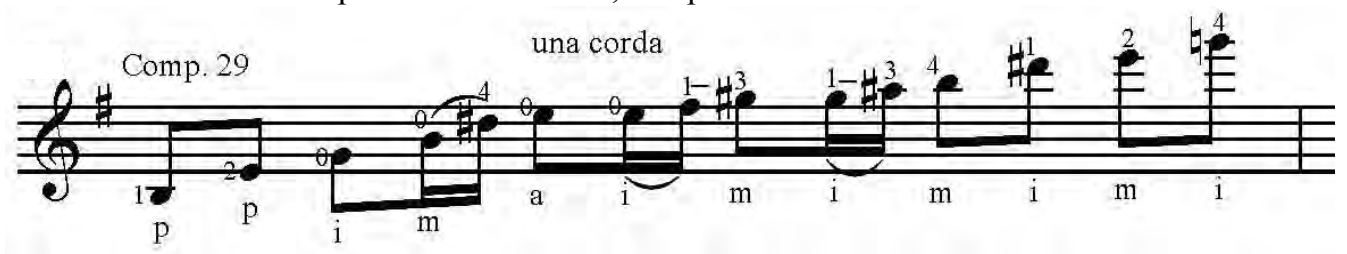

Exemplo 305: IV Estudo, compasso 29.

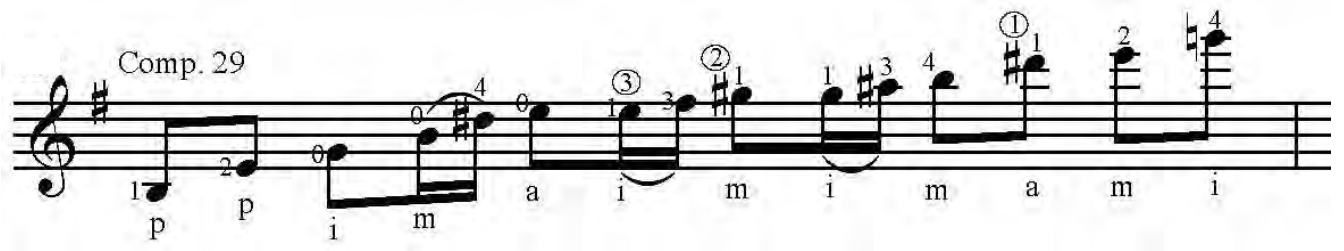

Exemplo 306: IV Estudo, compasso 29.

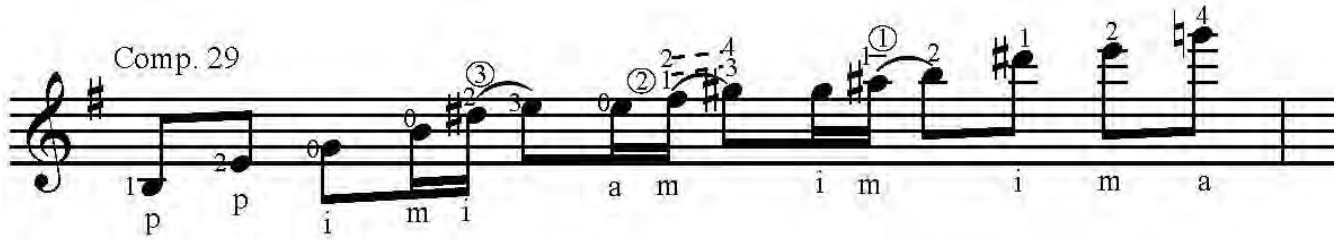

Exemplo 307: IV Estudo, compasso 29

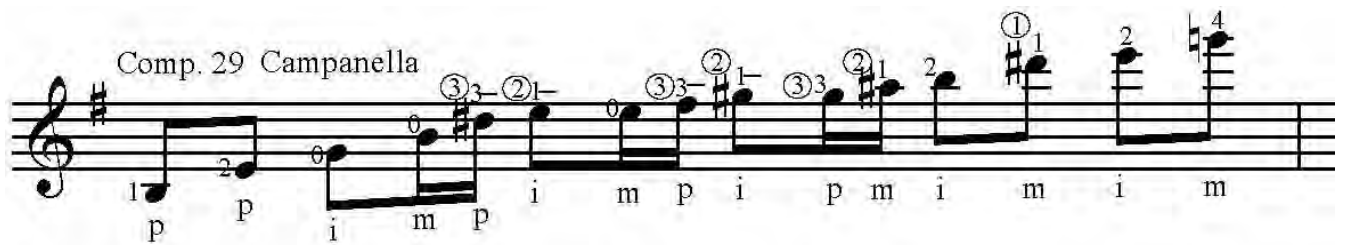

Exemplo 308: IV Estudo, compasso 29 
Inicia-se uma transição onde várias articulações de $m d$ são possíveis, com pequenas implicações na me. O primeiro exemplo tem mesma abordagem de $\mathrm{BL}^{94}$, mas apenas mantém por mais tempo o padrão inicial de $m d$.

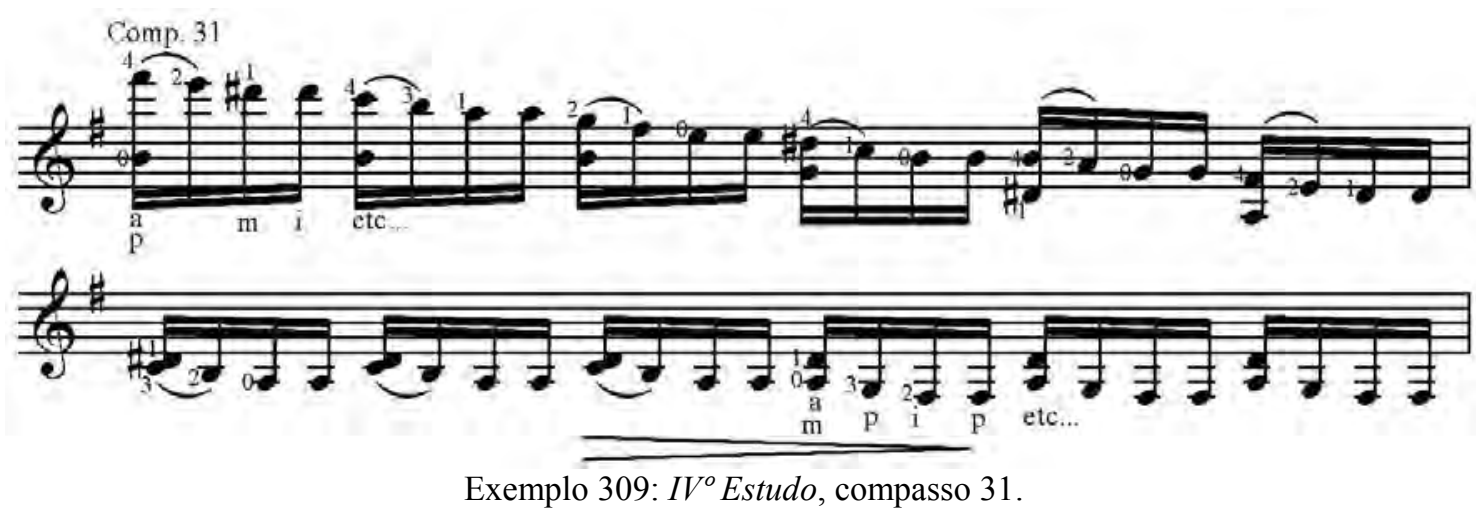

O exemplo 310 explora o uso da articulação dupla do polegar a cada tempo, com algumas implicações: conforme ela progride cordas "adentro" é exigido maior controle do polegar para não atingir cordas desnecessárias, algo auxiliado pelo apoio do anelar em algumas cordas sugeridas. Quando trecho atinge os bordões é necessário um salto arriscado da me para quinta posição. Neste momento o uso dos dedos 2, 3 e 4 é apenas um primeiro experimento, no qual se concluiu que o ligado entre os dedo 3 e 4 é um tanto penoso, o que nos levou a apresentar no próximo exemplo uma segunda proposta.
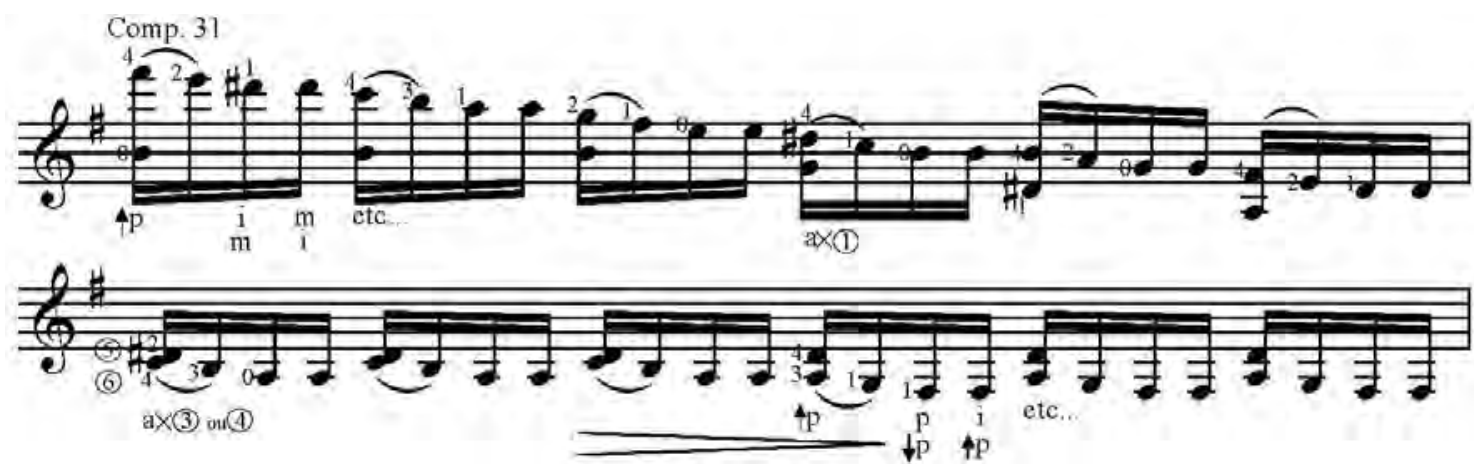

Exemplo 310: IV Estudo, compasso 31.

O exemplo 311 vem demonstrar o uso do indicador como principal articulador do trecho, o que também requer controle deste dedo quando o padrão descende e abafamentos mais numerosos de cordas indesejadas. Segue-se uma proposta melhor para o compasso 32, que pode ser aplicada ao exemplo anterior.

94 item "deixar como está" do checklist de Osborn. 


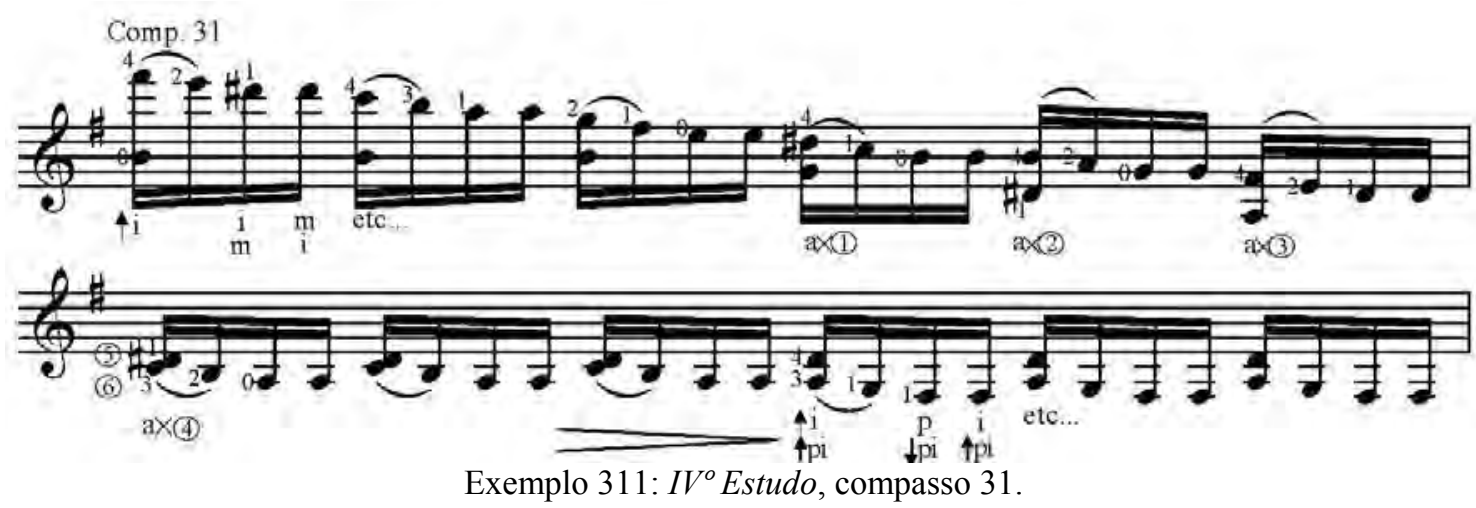

Um último padrão de articulação utiliza o anelar escovado, utilizando agora o polegar como meio abafador.

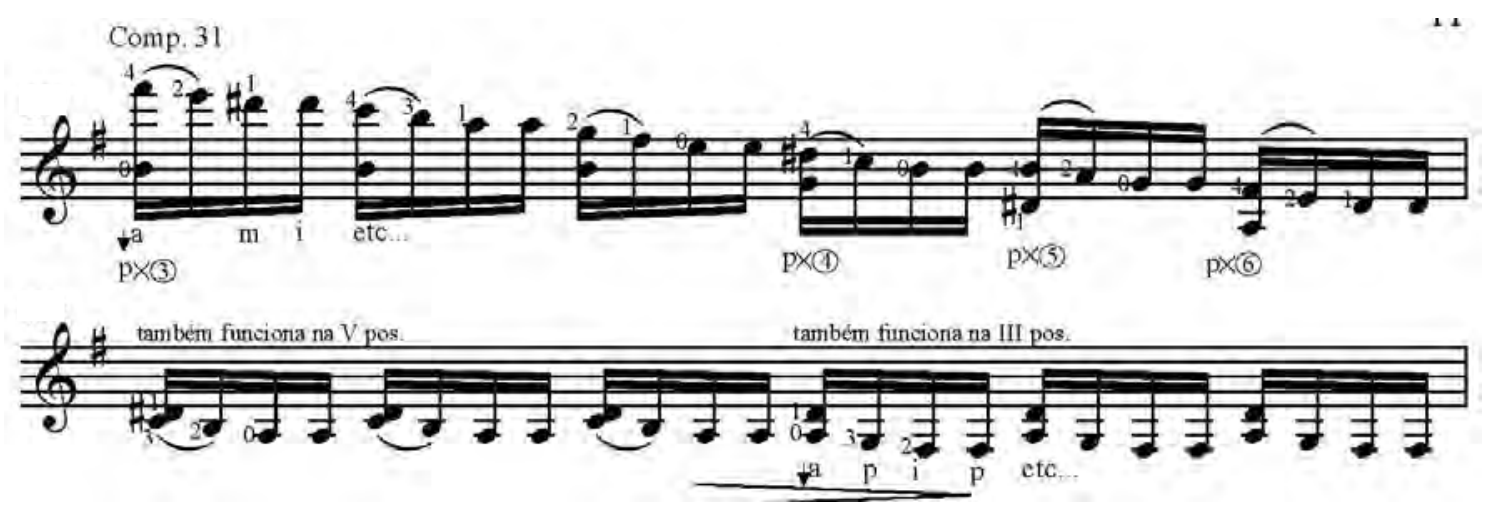

Exemplo 312: $I V^{\circ}$ Estudo, compasso 31.

Outro assunto que resolvermos grafar isoladamente para este trecho foram outras propostas de ligados: neste caso, o deslocamento demonstrado no exemplo 313 é infrutífero assim como os ligados triplos do exemplo 314, que sobrecarregam a me e criam difícil sincronização com a $m d$.

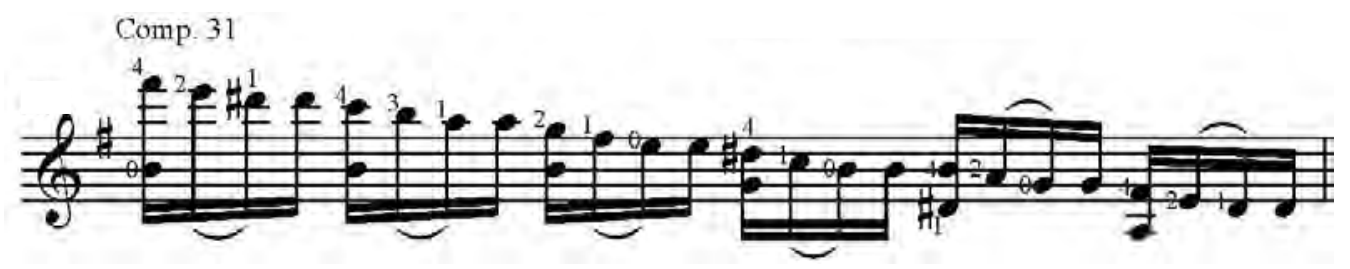

Comp. 31

Exemplo 313: $I V^{\circ}$ Estudo, compasso 31.

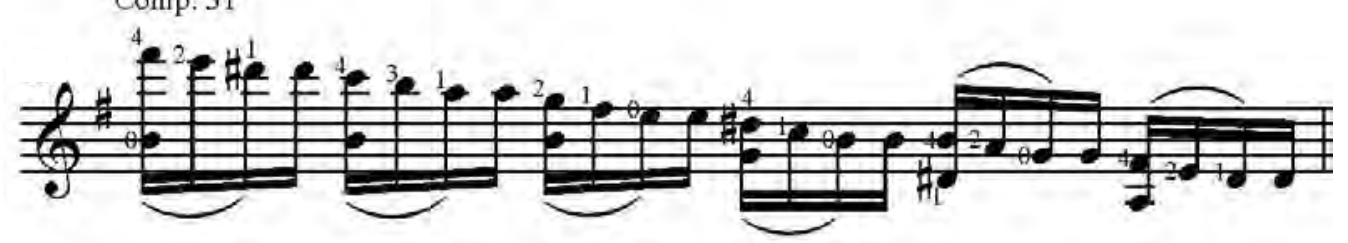

Exemplo 314: $I V^{o}$ Estudo, compasso 31.

De maneira contrária, o compasso final da transição aceita várias opções de ligados igualmente funcionais, mas com resultado musicalmente distintos. O primeiro deles é de caráter descendente com considerável utilização do polegar, enquanto o segundo e terceiro exemplos utilizam os ligados ascendentes e tem apenas desfecho 
distinto. Finalmente, o exemplo 318 abdica dos ligados para oferecer uma versão mais $\underline{\text { tradicional, }}$ onde todas as notas são articuladas pelos dedos $i$ e $m$.

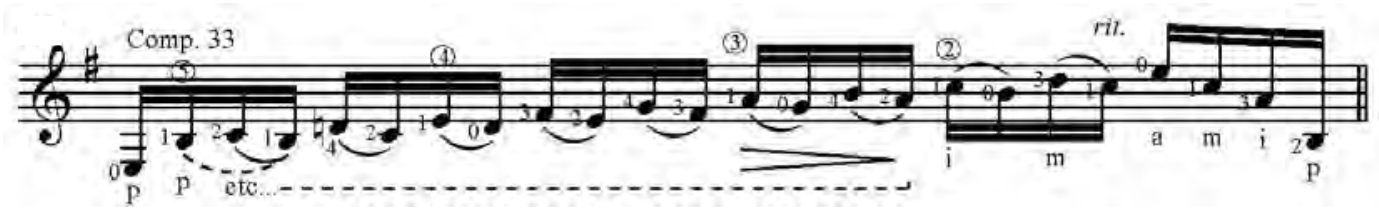

Exemplo 315: IV Estudo, compasso 33.

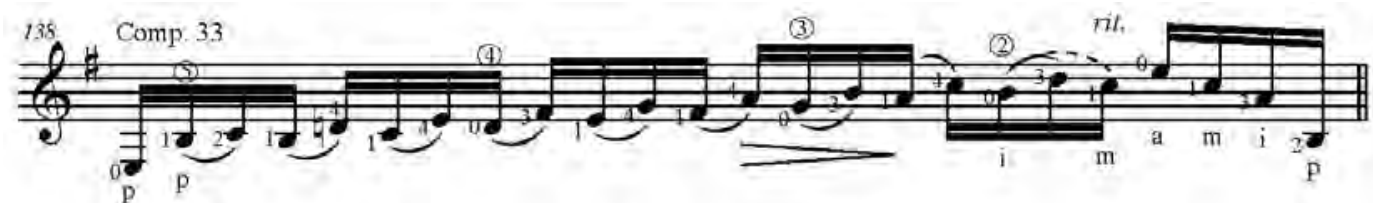

Exemplo 316: IV Estudo, compasso 33.

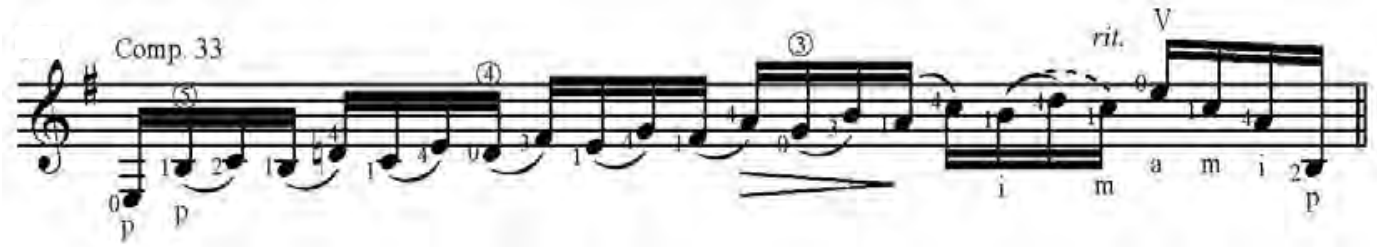

Exemplo 317: IV Estudo, compasso 33.

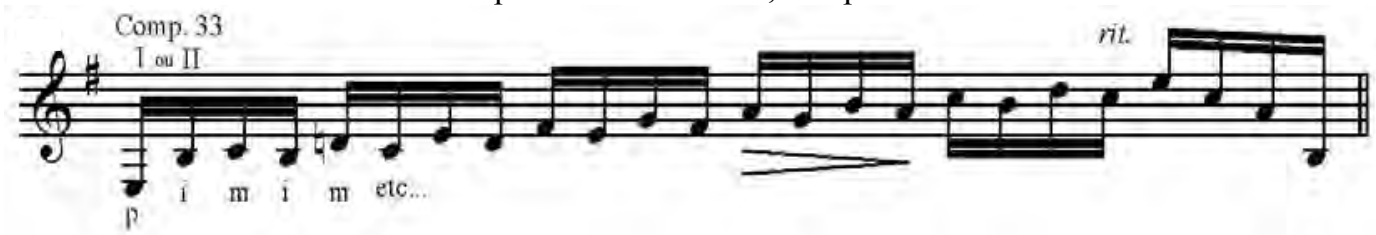

Exemplo 318: IV Estudo, compasso 33.

A primeira parte da seção lenta será tratada de forma menos fragmentada. Nos três primeiros compassos pares, BL preconiza o uso da terceira corda para alocar a melodia, mas nos compassos adjacentes ela também passeia pela quarta e segunda cordas, criando inevitável diferença tímbrica. Os dois primeiros compassos ímpares (que diferem apenas em uma nota) exigem uma abertura considerável (nos dois primeiros tempos) e uma entrada espremida do dedo 3 (no terceiro tempo) nem sempre acessível a todos os violonistas enquanto a descida cromática (a partir do compasso 42) carrega a melodia na quarta corda em pestanas consecutivas que resolvem em acorde nas três cordas primas soltas, criando nova diferença timbral. 

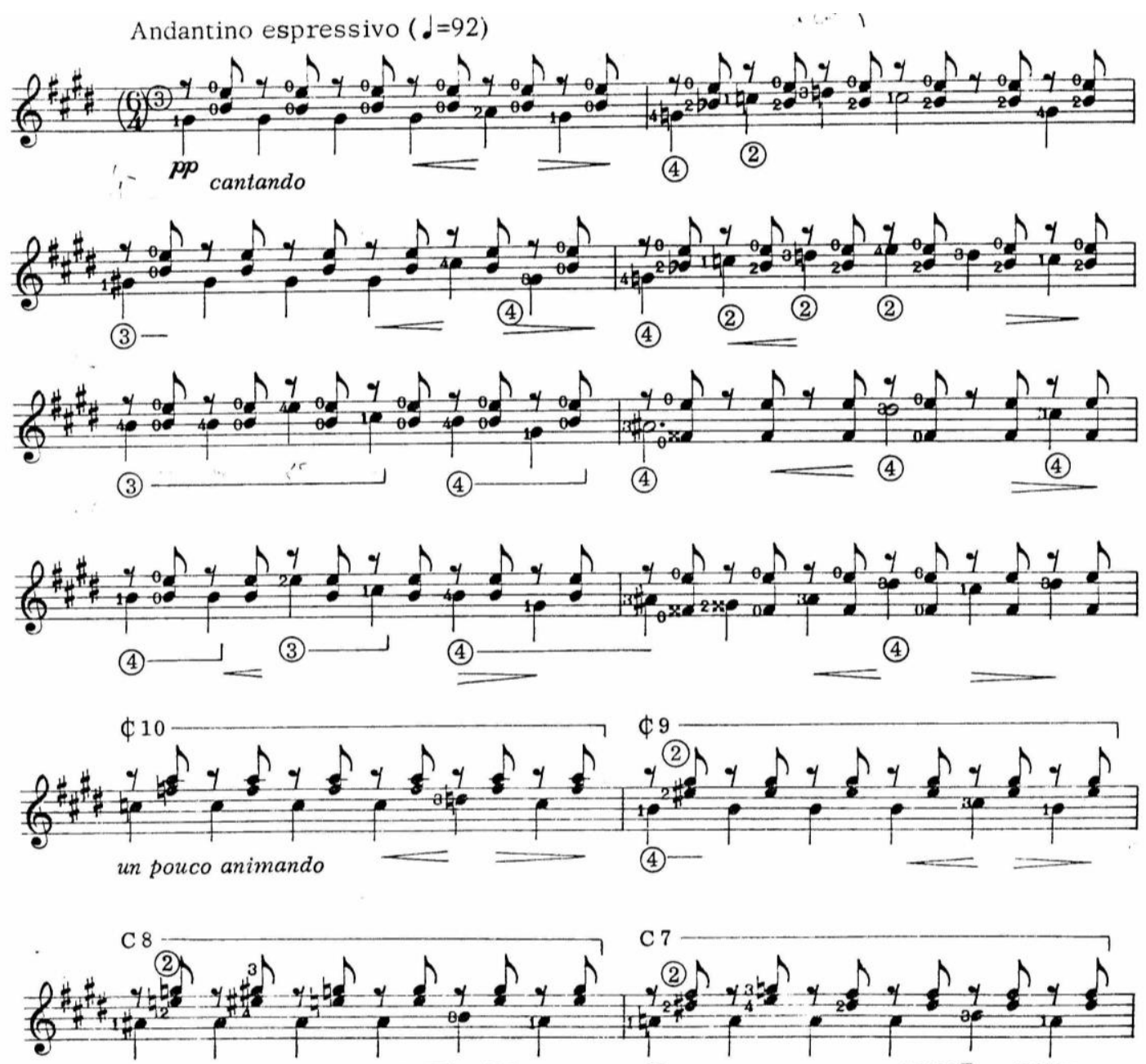

(4)
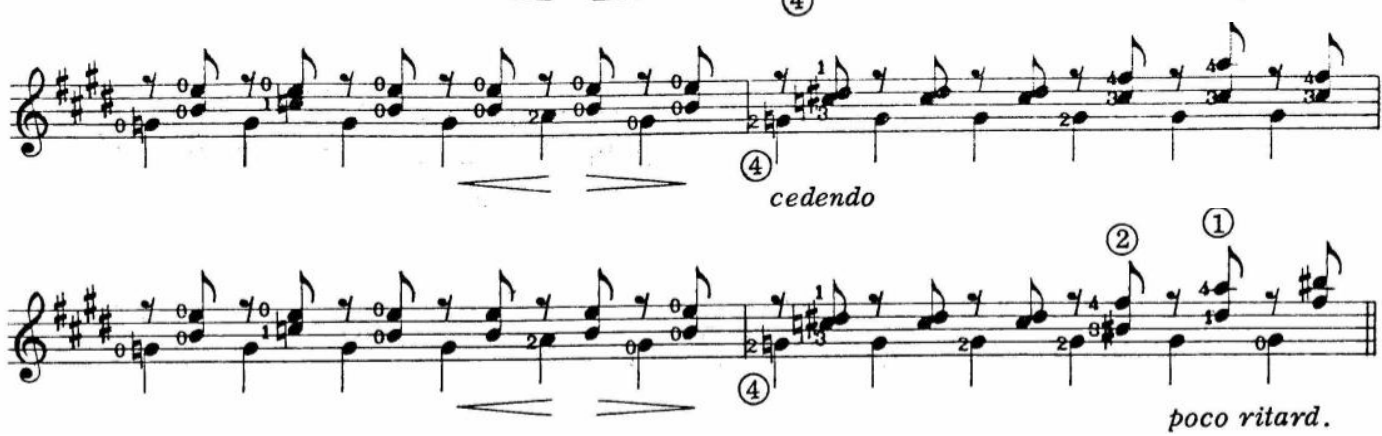

Exemplo 319: IV Estudo, compasso 34. Ed. Columbia/BL.

Nossa única alternativa buscou manter a melodia ao máximo na quarta corda, excetuando os dois primeiros compassos ímpares que alocam na terceira corda uma espécie de resposta melódica. A descida utiliza apenas uma pestana e os últimos compassos recorrem mais parcimoniosamente às primas soltas, com intuito de manter a mesma paleta sonora. Também há a sugestão de baixos adicionais opcionais nos primeiros compassos, a fim de prover maior sustentação harmônica. 

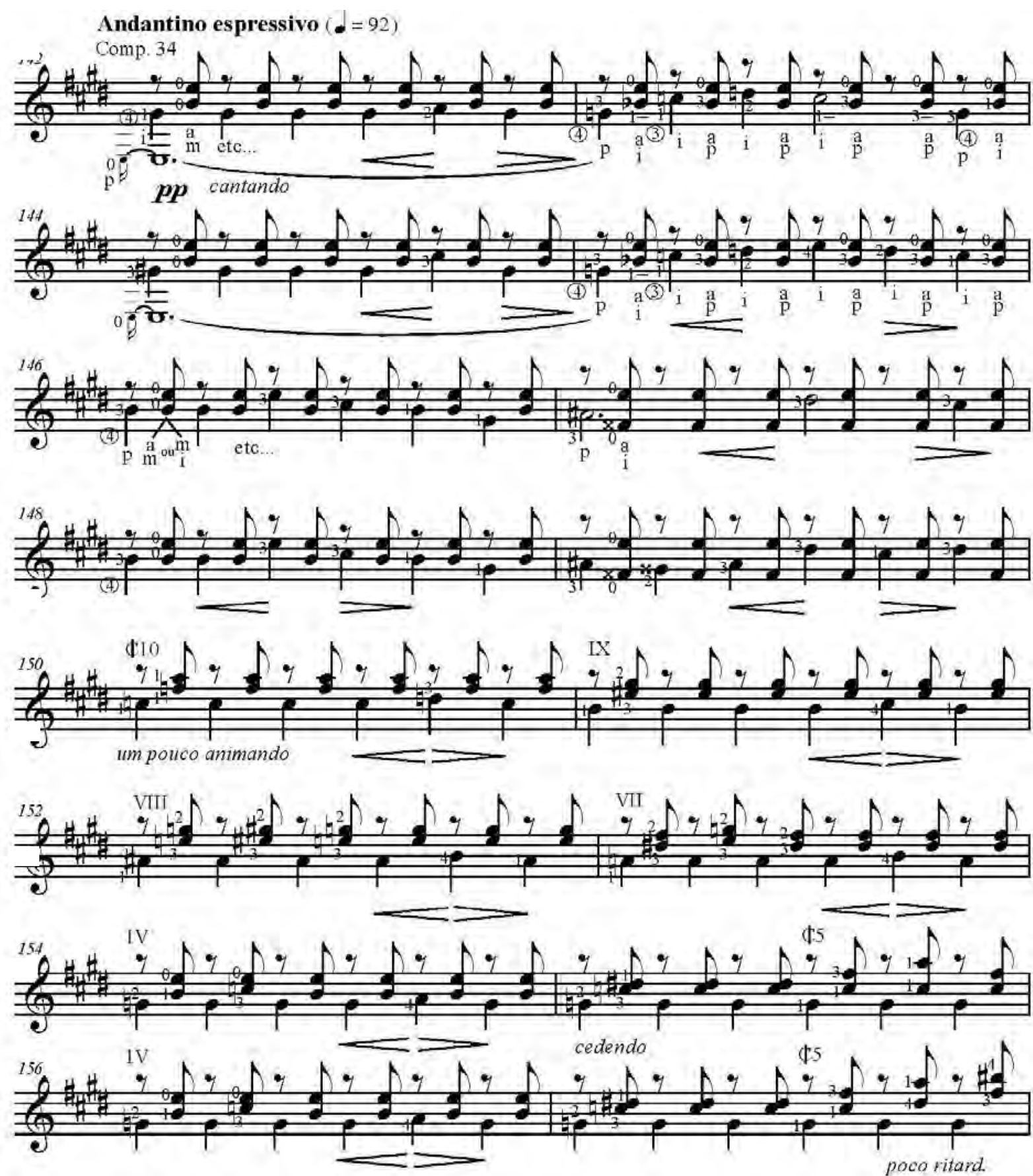

Exemplo 320: IV Estudo, compasso 34.

A mesma melodia recebe então uma variação em arpejos, onde a ocorrência única de notas repetidas (quinto tempo do exemplo 321) quebra desnecessariamente o padrão da $m d$, aspecto unificado no exemplo seguinte. A sequência em oitavas também têm a digitação de me unificada ao adotar-se os dedos 1 e 4 para as mesmas, na quinta e terceira cordas respectivamente, seguindo assim até o fim do trecho no compasso 58. 


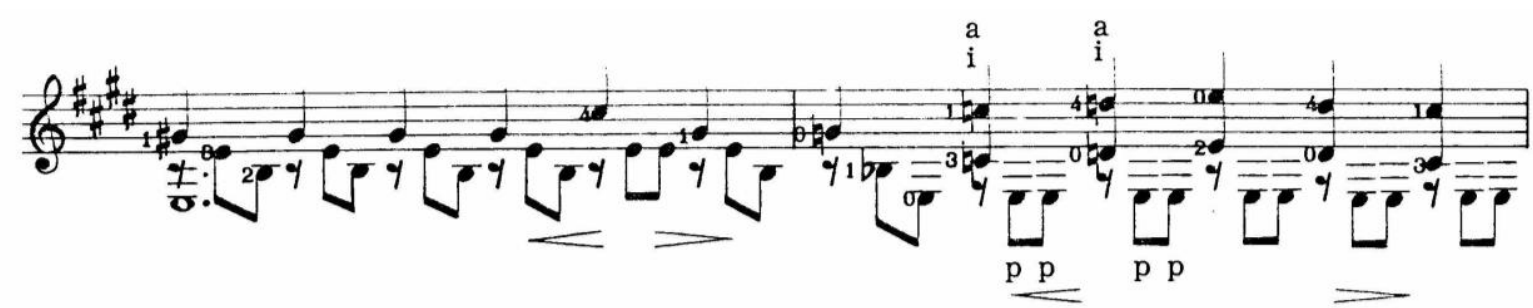

Exemplo 321: $I V^{o}$ Estudo, compasso 51. Ed. Columbia/BL.

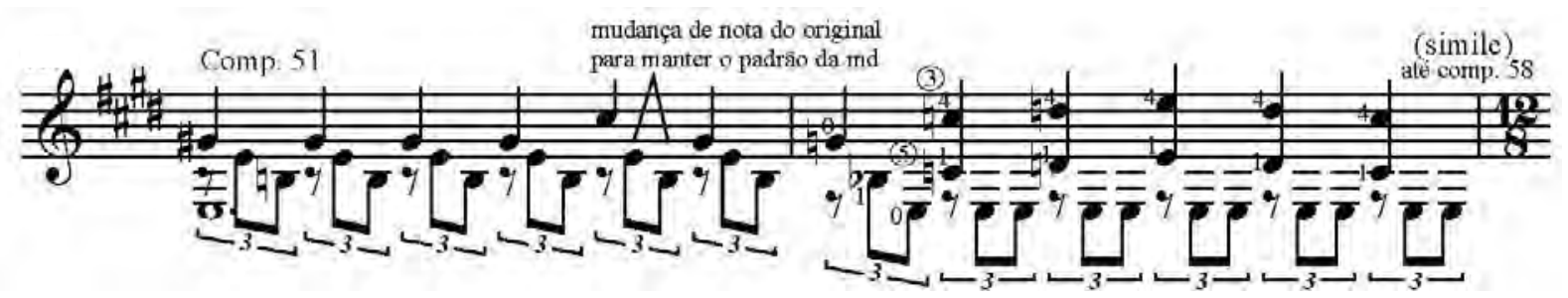

Exemplo 322: $I V^{o}$ Estudo, compasso 51.

A transição para o retorno da primeira seção, iniciada no compasso 59 é funcional na versão $\mathrm{BL}$, mas recebe também uma opção em campanella para o compasso 62 no exemplo 324:

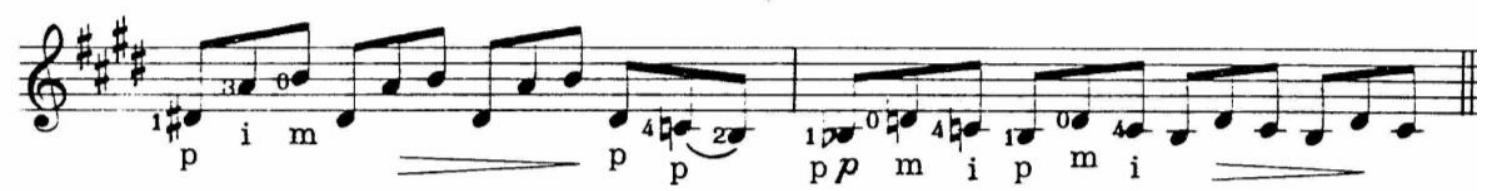

Exemplo 323: $I V^{o}$ Estudo, compasso 61. Ed. Columbia/BL.

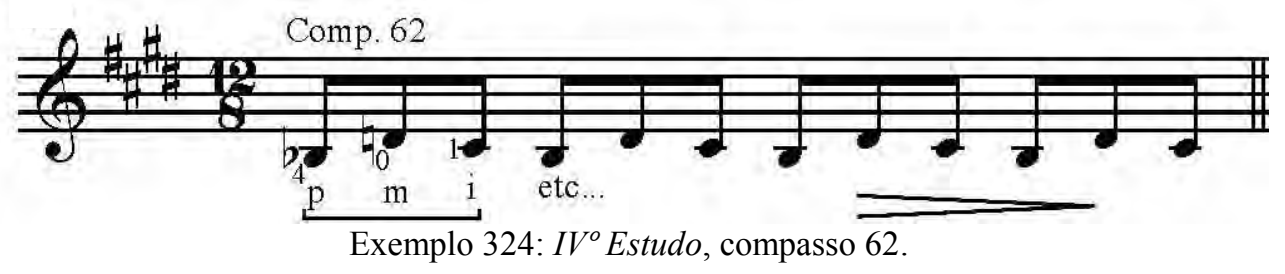

$\mathrm{Na}$ derradeira repetição da seção inicial temos novas ocorrência de divergências em pequenas notas nos compassos 67 e 69 (já comentadas). Apenas no segundo deles será necessário contrariar nossa decisão de não analisá-los digitalmente, devido ao fato de que este compasso é respondido por um padrão descendente, este sim, de nosso maior interesse. As notas grafadas aqui são as da edição Columbia que divergem levemente dos manuscritos (já demonstrados em exemplos anteriores).

Na subida, o exemplo 326 privilegia a segunda corda e apenas simplifica alguns dedos da digitação BL. A figuração descendente, em caminho distinto a BL, é realizada pela primeira corda em boa parcela, havendo contudo repetições cautelosas do dedo 3 (no quarto tempo) e do dedo 1 (no quinto), factíveis por serem intermediadas por cordas soltas. 

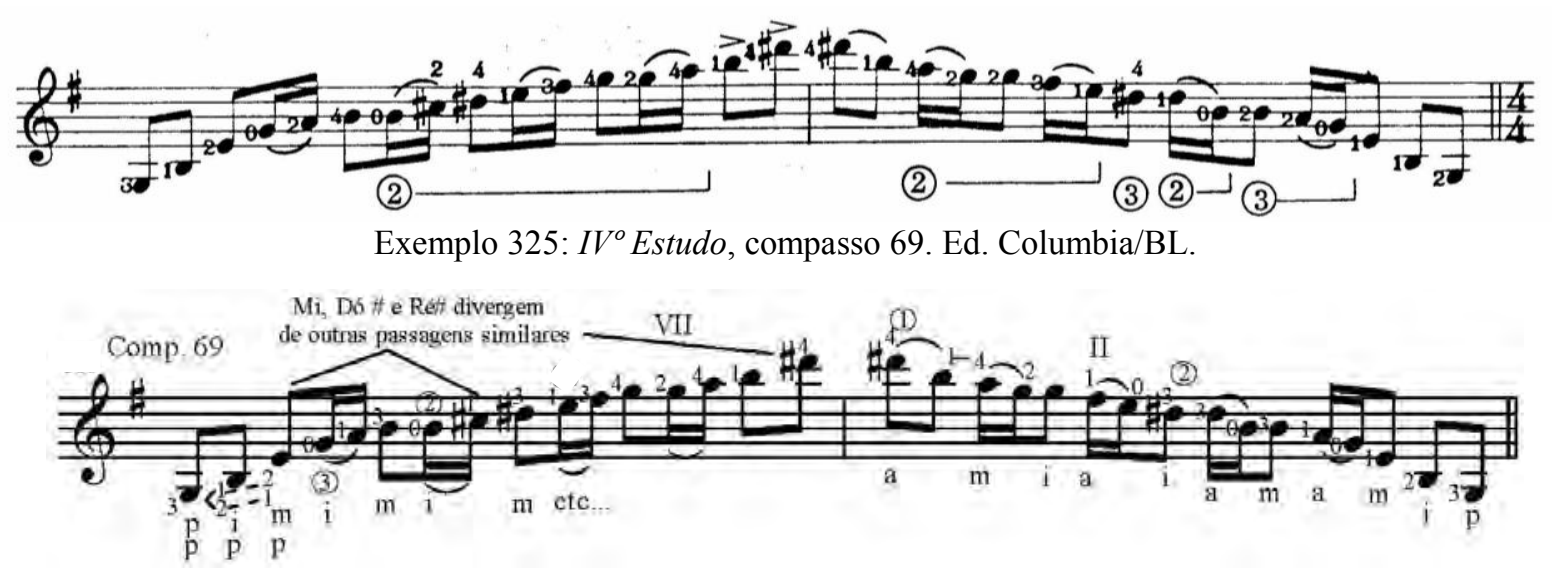

Exemplo 326: $I V^{\circ}$ Estudo, compasso 69.

O exemplo 327 sobe em padrão 2-1 e desce (nos tempos 2 e 3) pela segunda corda, havendo sobrecarga no uso do dedo 1 (nos tempos 4 e 5) em novas repetições intercaladas por cordas soltas (excetuando uma).

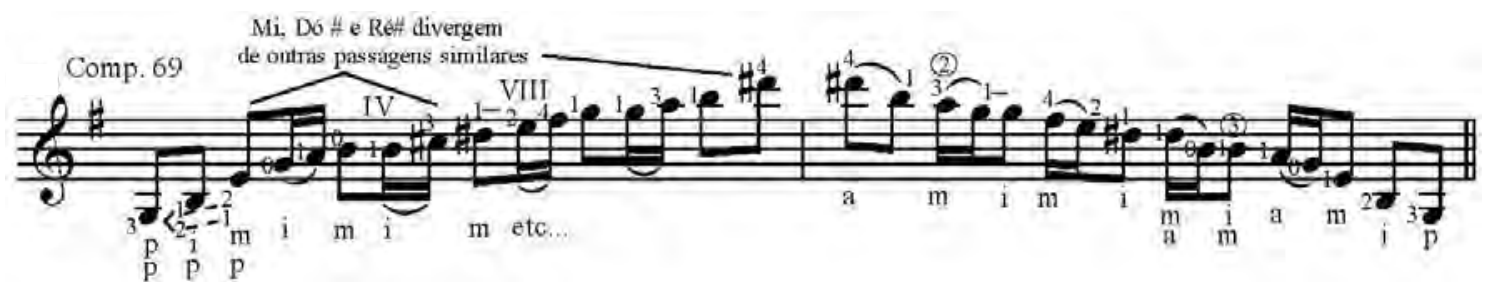

Exemplo 327: $I V^{\circ}$ Estudo, compasso 69.

O exemplo 328 aproveita cordas soltas para subir pela oitava posição, descendo pela mesma, havendo porém uma abertura no quarto tempo e uma leve sobrecarga do dedo 1 , repetido sempre intercalado com cordas soltas.

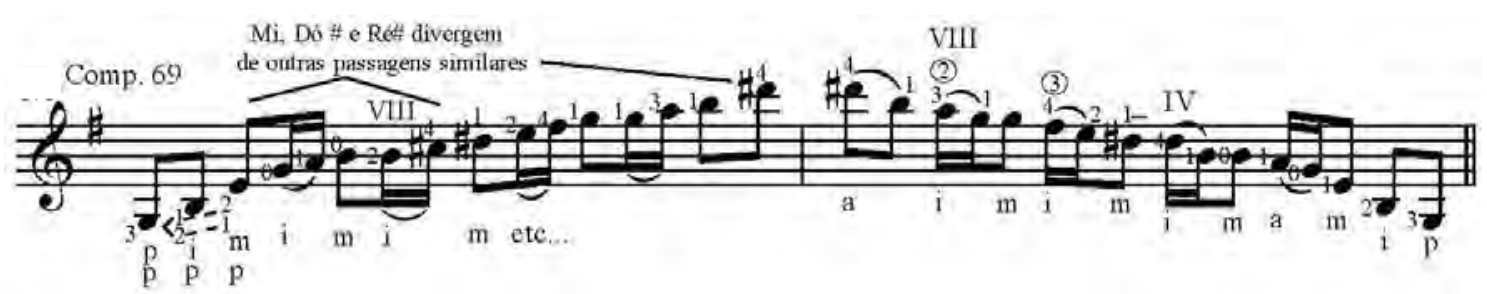

Exemplo 328: Estudo 4, compasso 69.

E para finalizar: duas versões em campanella. A primeira sobe paulatinamente pelo translado em bloco dos dedos 1 e 3 e descende principalmente pela sétima posição, havendo um translado digno de atenção do dedo 1 pela quarta corda no quinto tempo. A segunda versão sobe principalmente pela oitava posição e realiza o segundo compasso mais na parte central do instrumento evitando as repetições de dedos das versões anteriores porém criando uma abertura na quinta posição. 


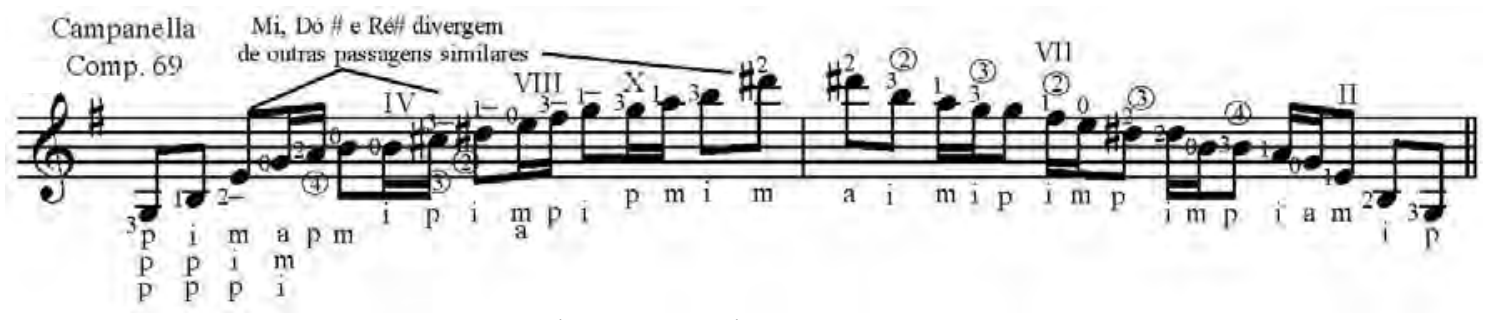

Exemplo 329: Estudo 4, compasso 69.

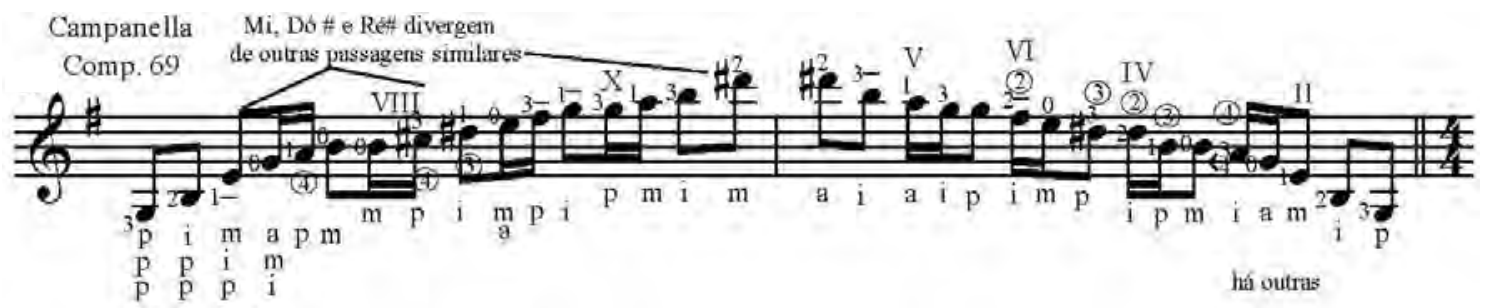

Exemplo 330: IV Estudo, compasso 69.

$\mathrm{O}$ compasso 71 ganha versões com menos ligados em relação à digitação BL (exemplo 331), com mais especificações de $m d$ e com uma sugestão de adição de um baixo, visando concluir a frase anterior.

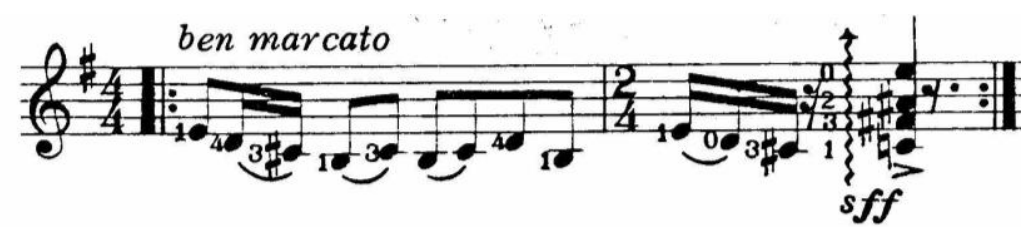

Exemplo 331: IV Estudo, compasso 71. Ed. Columbia/BL.

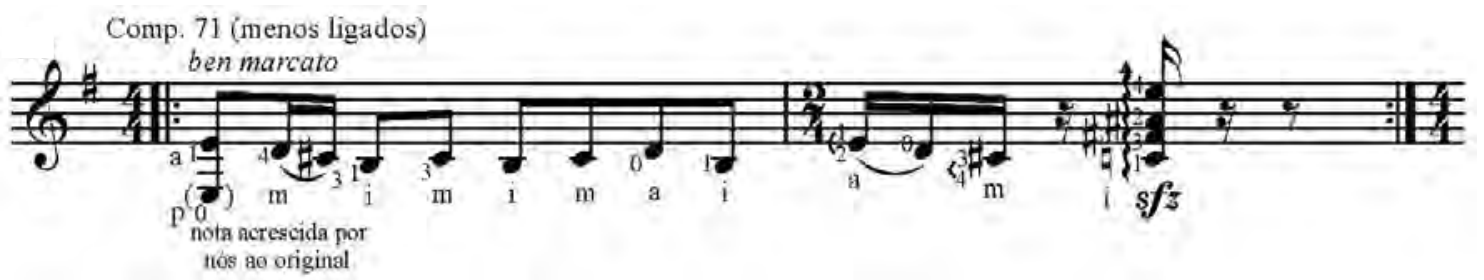

Exemplo 332: IV Estudo, compasso 71.

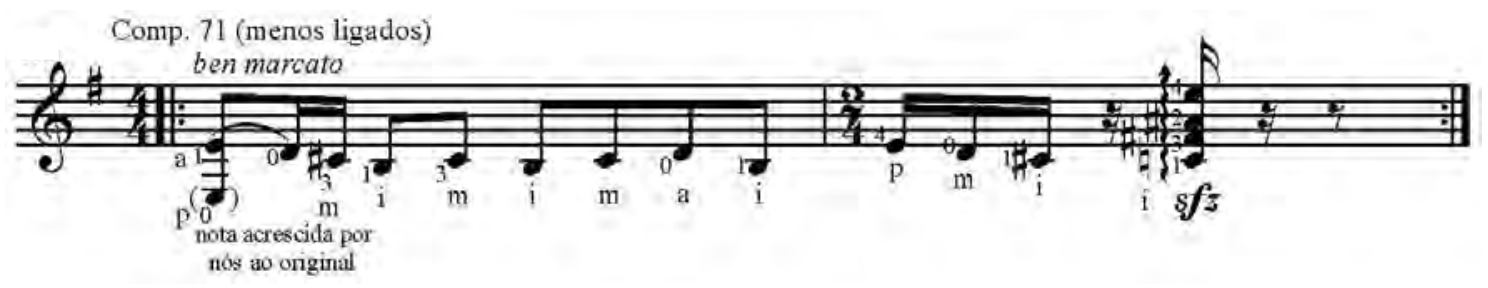

Exemplo 333: IV Estudo, compasso 71.

O compasso 77 rememora o motivo inicial do estudo, mas em uma nova transposição (meio tom acima da tonalidade da música). A subida proposta por BL parece ter como principal característica reconhecível o maior uso da terceira corda.

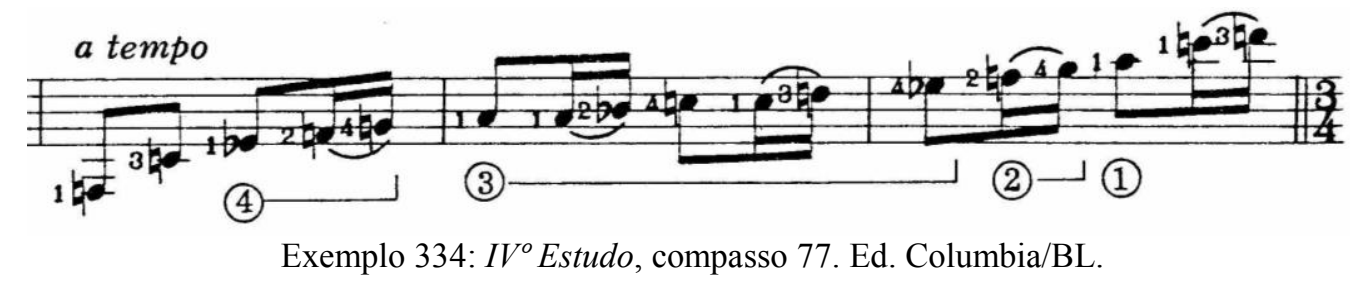


Os exemplos 335, 336 e 237 mantém $^{95}$ algumas ideias de BL mas conseguem criar um padrão mais reconhecível com os dedos 2, 4 e 1 que se repetem três vezes em diferentes posições e cordas.

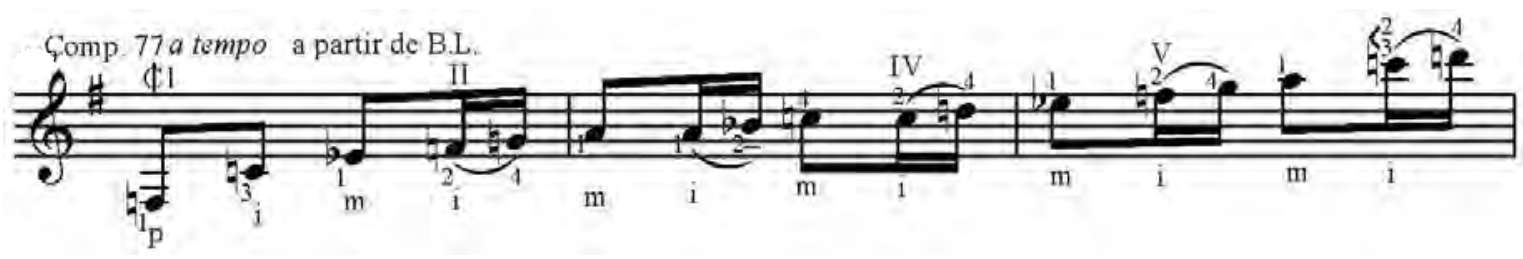

Exemplo 335: IV Estudo, compasso 77.

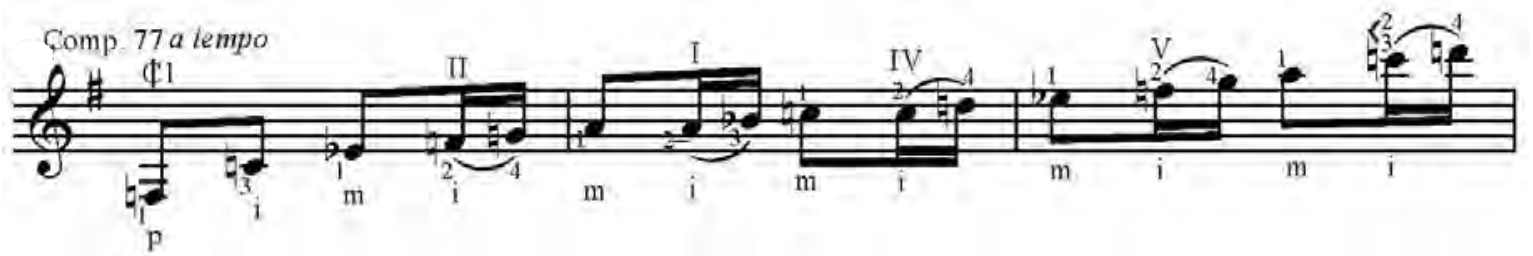

Exemplo 336: $I V^{\circ}$ Estudo, compasso 77.

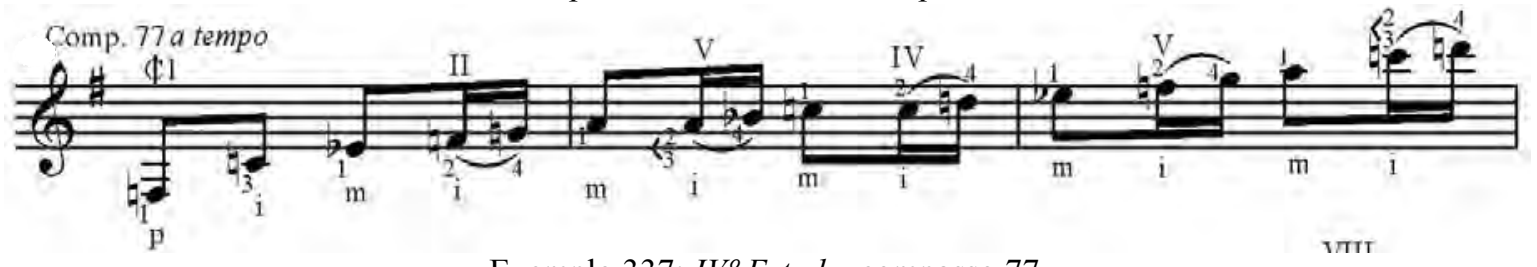

Exemplo 337: IV Estudo, compasso 77.

O exemplo 338 retira completamente os ligados para trabalhar em padrão 1-2 principalmente pela terceira casa, sendo possível acrescentar ligados como em exemplos pregressos.

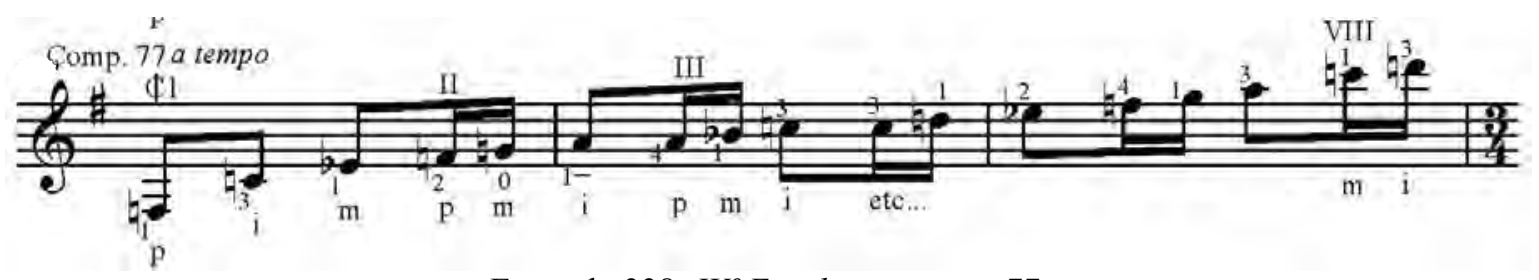

Exemplo 338: $I V^{\circ}$ Estudo, compasso 77.

O momento mais intenso da obra é certamente o trecho a seguir. Embora BL lamentavelmente não especifique muito a $m d$, imaginamos que o primeiro compasso deva trabalhar com $p-p-i-m-a$ reiterado em todos os acordes. $\mathrm{Na} m e$, o primeiro compasso trabalha com um salto vertical do dedo 2 que merece cuidado.

\footnotetext{
95 item "deixar como está" do checklist de Osborn.
} 

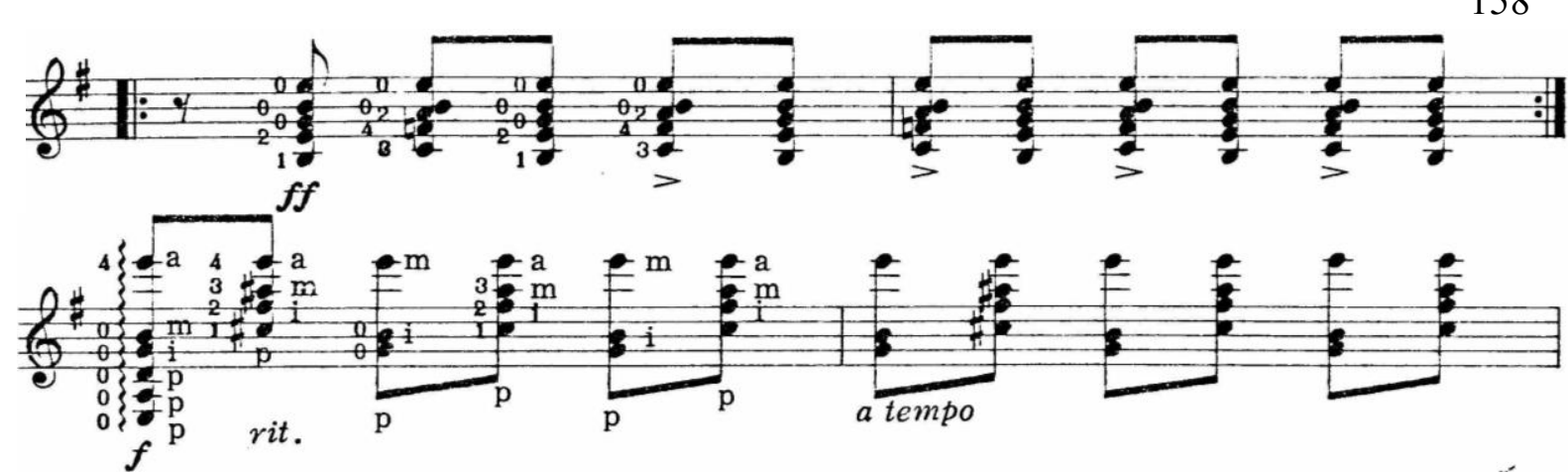

Exemplo 339: IV Estudo, compasso 80. Ed. Columbia/BL.

Nossa única versão alternativa sugere articulação mais robusta (mas também mais ruidosa) de $m d$ com o indicador alternado (com polegar dando ponto de apoio na sexta corda) enquanto a me apenas arrasta dedos 3 e 4 em grupo, inserindo o dedo 1 no segundo acorde. Já o compasso 81 recebe a sugestão de acréscimo de uma nota, que facilita e unifica consideravelmente o trabalho da $m d$ e provêm maior coesão aos acordes, sem descaracterizar a harmonia original.
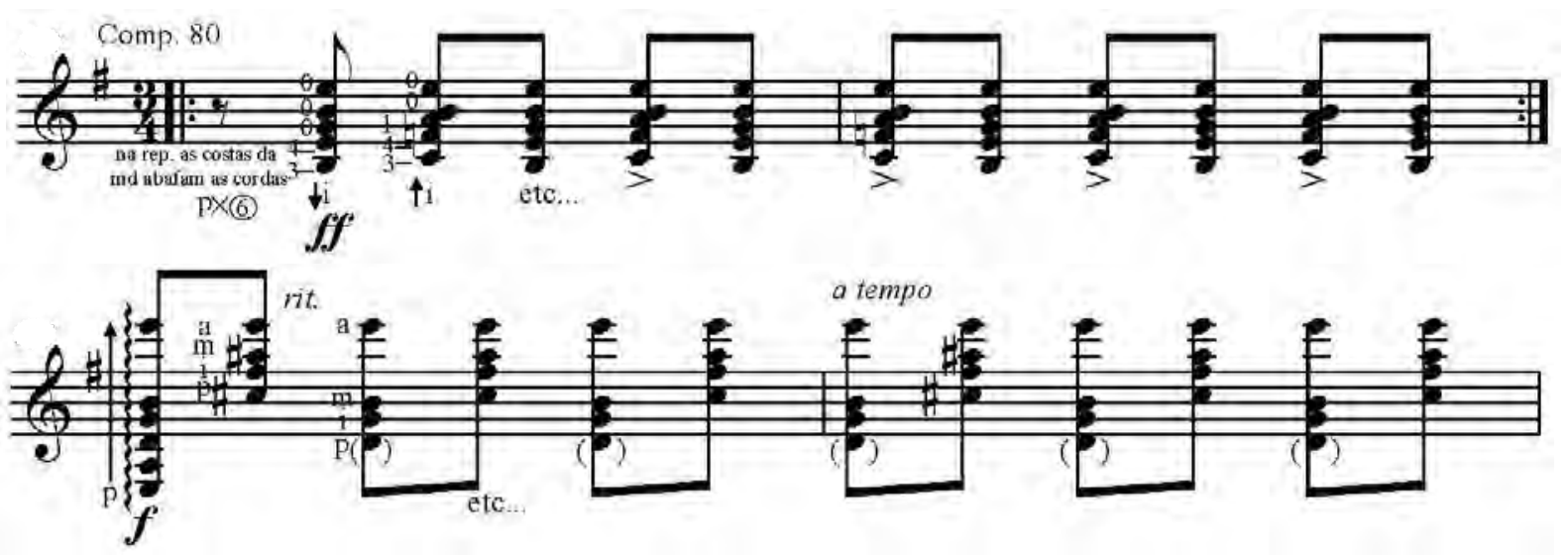

Exemplo 340: $I V^{o}$ Estudo, compasso 80.

Para o desfecho da obra, o motivo do galope é invertido em sua direção, agora descendente. O exemplo 341 usa a digitação de me de BL e apenas especifica o que imaginamos ser a $m d$ do trecho enquanto o exemplo 342 cria uma pequena campanella na quinta posição. No aspecto interpretativo, vale à pena ressaltar o Ré\# (a sensível da tonalidade) por meio de leve rubato.

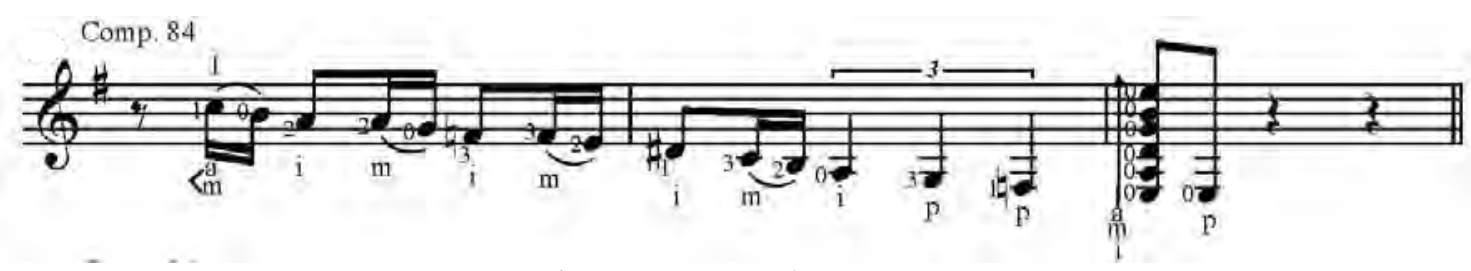

Exemplo 341: IV Estudo, compasso 34.

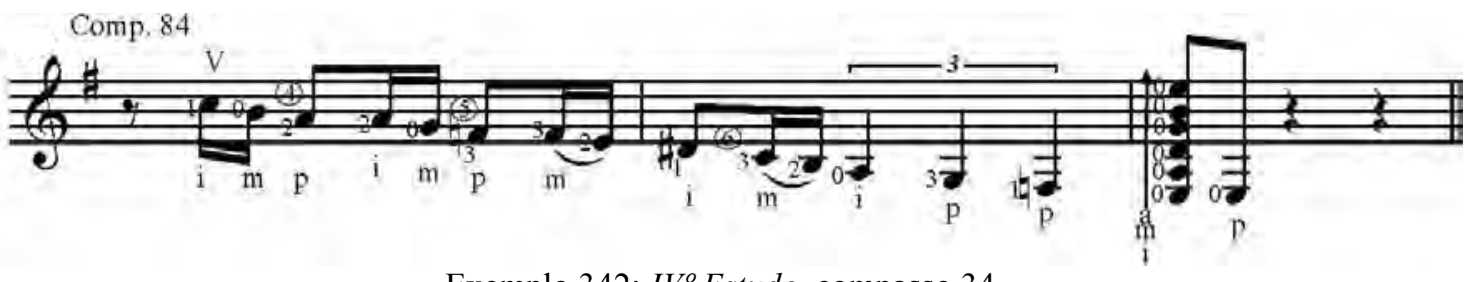

Exemplo 342: IV Estudo, compasso 34. 


\section{5: V Estudo "Vagaroso"}

O quinto estudo da série apresenta caráter mais introspectivo e tem certa predominância acordal em sua primeira seção.

Fingered $b y$

Carlos Barbosa-Lima

\section{a Barbosa-Lima \\ $\mathrm{V}^{\circ} \mathrm{ESTUDO}$}

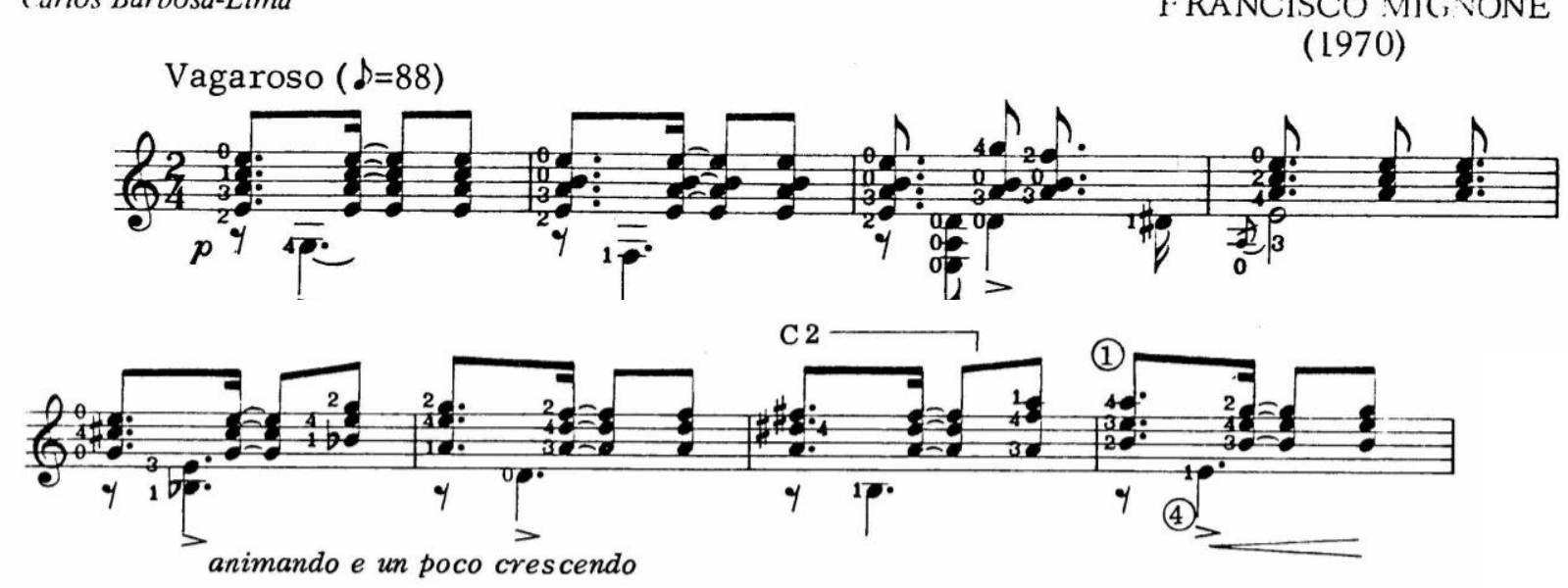

Exemplo 343: $V^{o}$ Estudo, compasso 1. Ed. Columbia/BL.

O exemplo 344 apenas toma caminho diferente de BL a partir do quarto compasso, no entanto, especifica melhor as opções de $m d$ para os compassos anteriores e para o trecho em geral (onde registra uma opção com uso do dedo mínimo da $m d$ ) e também apresenta uma proposta de grafia rítmica mais clara para o terceiro compasso.

No compasso seguinte (quarto), BL opta pelo uso dos dedos 3, 4 e 2 no acorde de Lá menor para que seja possível tornar o dedo 4 o guia no próximo compasso. Nossa primeira versão alternativa prevê os dedos 2, 3 e 1 no mesmo acorde, dando ao dedo 3 a função de guia na sequência e recorre à meias-pestanas para a resolução dos compassos 5 e 6.

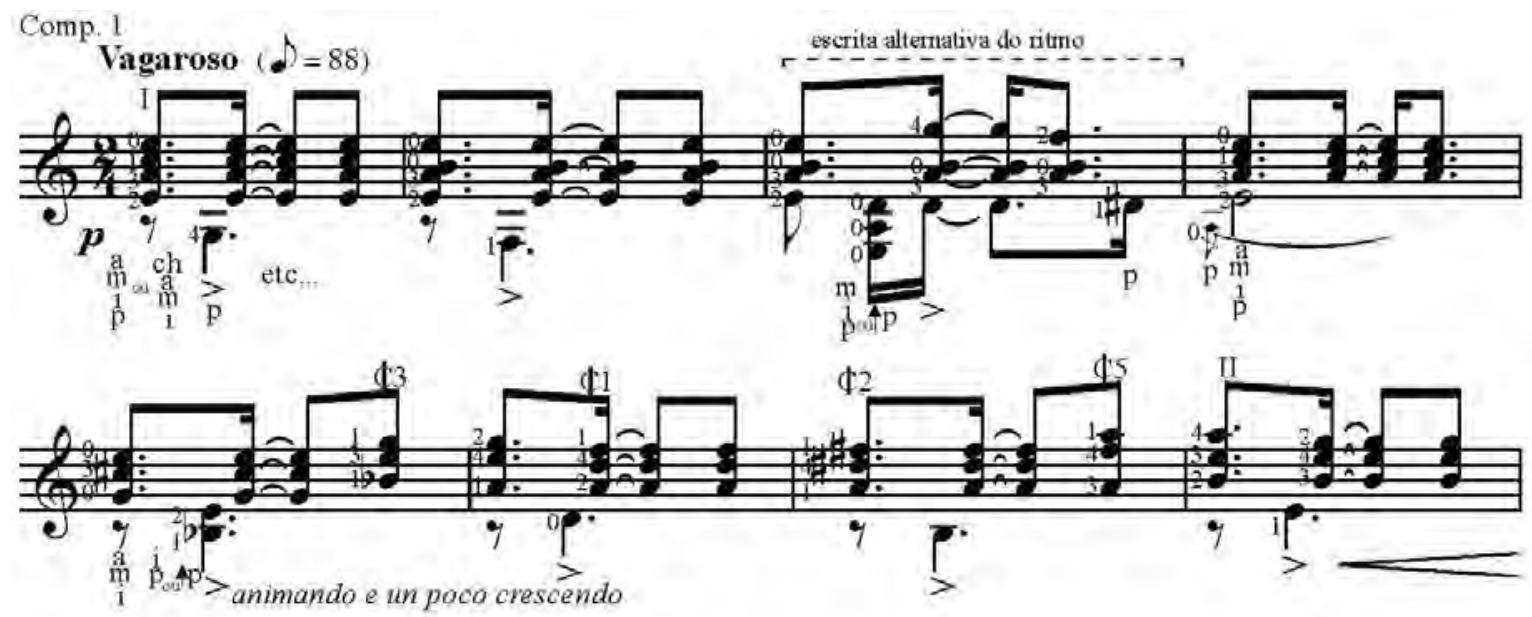

Exemplo 344: $V^{o}$ Estudo, compasso 1. 
O exemplo 345 propõe uma sequência distinta para a digitação BL a partir do compasso 5, fazendo uma experimentação com cordas soltas nos acordes, recorrendo também ao uso do polegar da $m d$ na frente do espelho (dedo 5) e a um harmônico em um dos baixos.

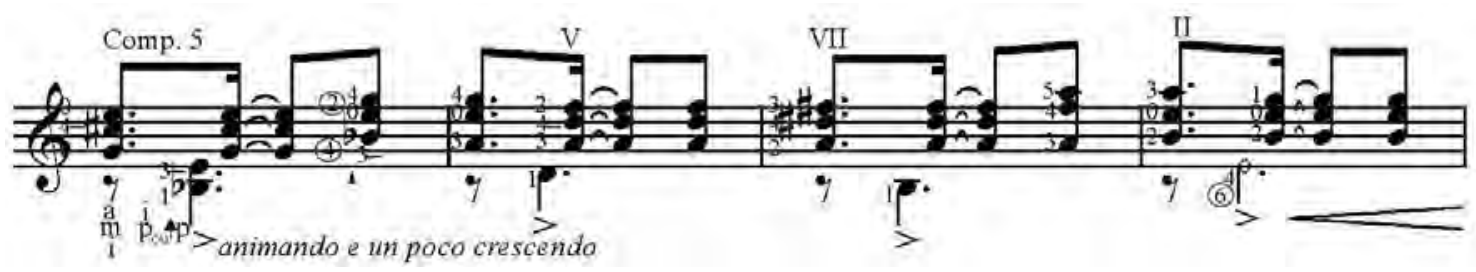

Exemplo 345: $V^{o}$ Estudo, compasso 5.

Nos compassos 13 e 14, Mignone alcança acordes em posição fechada na região aguda do instrumento. BL propõe uma boa digitação para os mesmos, mas economiza na grafia das posições e cordas, o que poderia ter facilitado uma melhor compreensão de sua proposta, aspecto então reparado no exemplo 346. Nele, vemos que BL fixa o dedo 3 na passagem entre os referidos compassos, colocando uma pestana no último acorde do compasso 13 e retirando a mesma no acorde seguinte, mas ainda mantendo-se na mesma posição. Outra saída criativa é o uso da corda solta no penúltimo acorde do compasso 14, também alcançado por dedos fixos (2 e 3) e translado do dedo 1 (nossa grafia talvez não tenha dado conta de registrar tudo isso com clareza).

A única saída alternativa para estes mesmos acordes está proposta no exemplo 347 , onde o retirou-se a pestana do último acorde do compasso 13 para se alcançar o acorde seguinte tendo o dedo 2 como guia, mas com o custo de uma reconfiguração abrupta dos outros dedos (o dedo 4 inclusive salta da primeira para a quarta corda). Já o penúltimo acorde do compasso 14 é realocado em meia-pestana na quinta casa, com dedos 2 e 4 em posições desconfortáveis, mas exequíveis que ao menos facilitam o acorde seguinte.
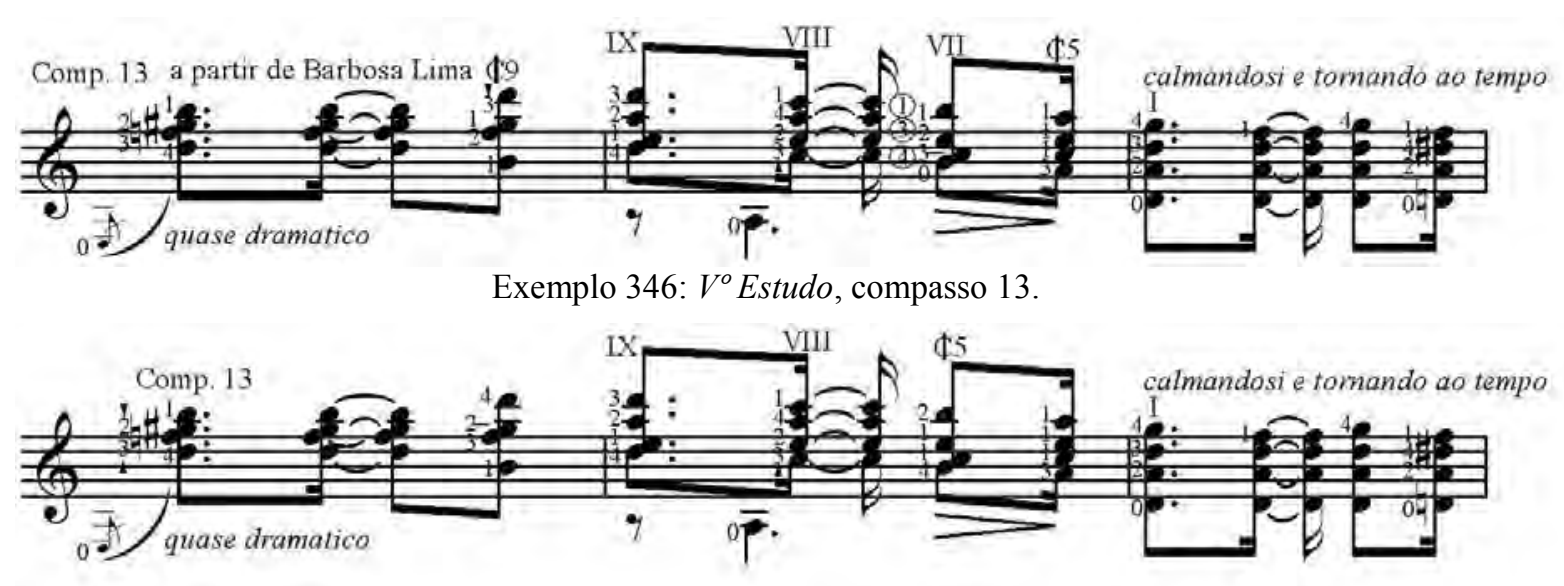

Exemplo 347: $V^{o}$ Estudo, compasso 13. 
O compasso 16 recebe não uma mudança de digitação (em relação a BL), mas apenas duas propostas de retirada de notas para aliviar a concomitância de notas entre a voz superior e inferior (sempre na quarta corda). Nesse sentido, o exemplo 348 sugere a retirada de notas da voz inferior, enquanto o seguinte faz o mesmo na voz superior.

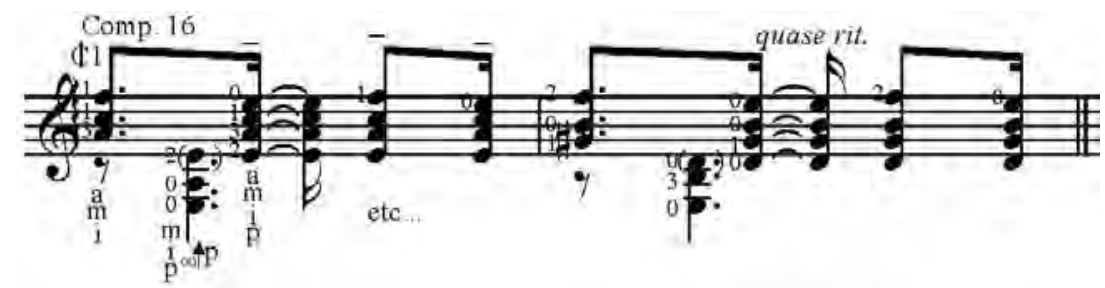

Exemplo 348: $V^{o}$ Estudo, compasso 16.

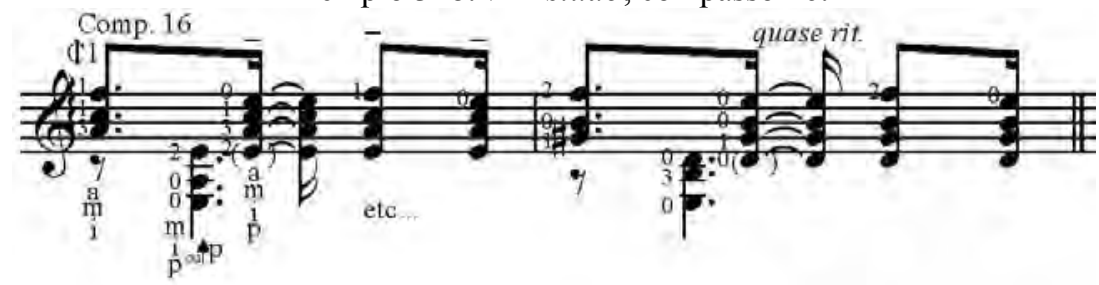

Exemplo 349: $V^{o}$ Estudo, compasso 16.

A seção "Calmo e Sereno" (iniciada no compasso 18) também privilegia acordes (ao menos em seu início) dessa vez arpejados e com movimentação melódica na voz central que, associada à ligados, oferece dificuldade ao intérprete para destacá-la. Nos compassos 20 e 22, a digitação BL (exemplo 350 e 352) coloca os ligados entre os dedos 4 e 1 seguidos pela segunda corda solta, havendo a possibilidade de fazê-los também com os dedos 3 e 1 realocando a nota Si para a terceira corda com o dedo 4 (exemplo 351 e 353). Já na $m d$, registramos dois arpejos com efeitos distintos, que podem inclusive ser revezados, reservando o arpejo com o polegar para ressaltar alguma mudança harmônica. Todas essas possibilidades (de me e $m d$ ) oferecem mesma dificuldade, cabendo ao intérprete definir sua preferência.

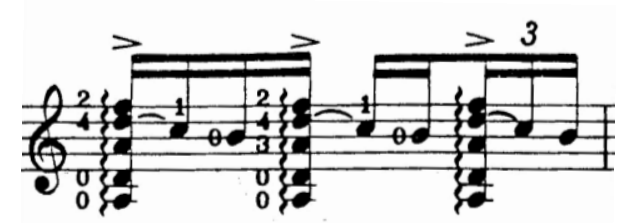

Exemplo 350: $V^{o}$ Estudo, comp. 20. Ed. Columbia/BL.

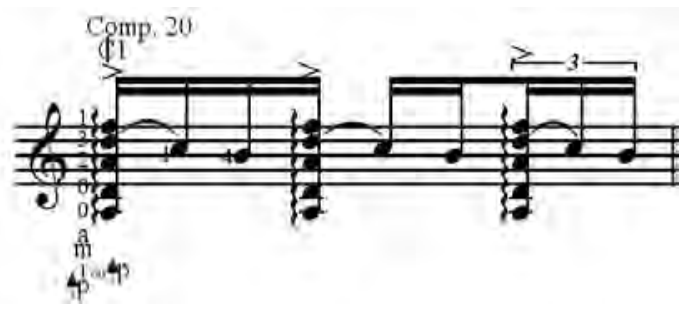

Exemplo 351: $V^{o}$ Estudo, comp. 20.

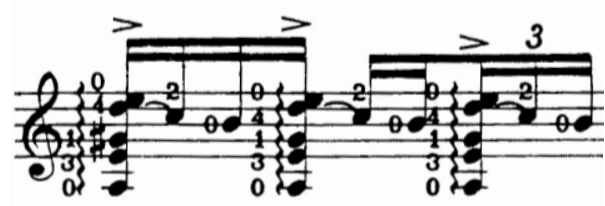

Exemplo 352: $V^{o}$ Estudo, comp. 22. Ed. Columbia/BL.

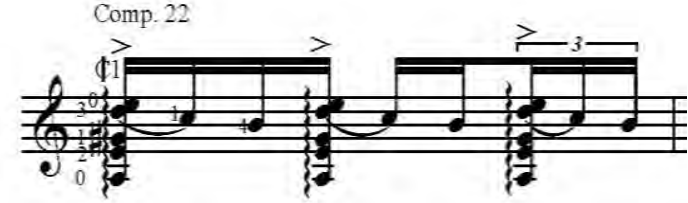

Exemplo 353: $V^{o}$ Estudo, comp. 22. 
O compasso 31 inclui um uníssono $(\mathrm{Si})$ provavelmente porque $\mathrm{BL}$ articulava este acorde com o polegar. Uma das notas recebe ligado descendente com dedo 4 na terceira corda, o que pode ocasionar um choque ruidoso com a segunda corda solta. Por este motivo o exemplo 355 exclui a segunda corda solta e coloca o dedo 3 para realizar o ligado com maior firmeza.

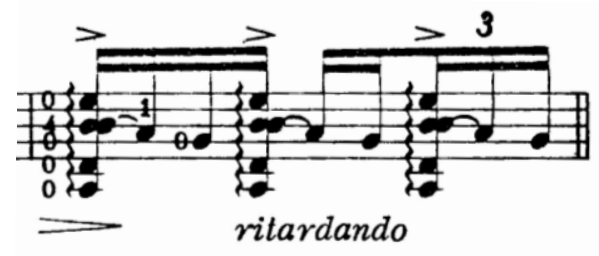

Exemplo 354: $V^{o}$ Est., comp. 31. Ed. Columbia/BL.

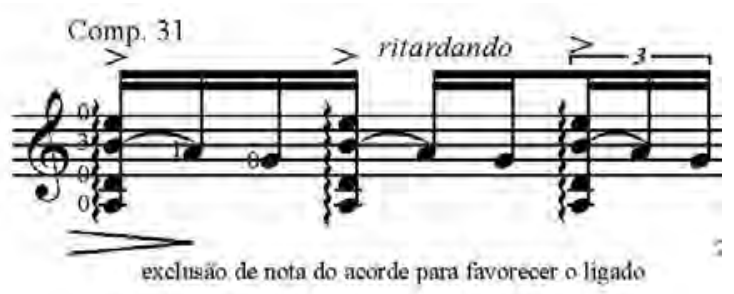

Exemplo 355: $V^{o}$ Est., comp. 31, idem 102.

O compasso 32 recebe apenas a possibilidade de substituir um dedo para se obter um guia ao trecho:

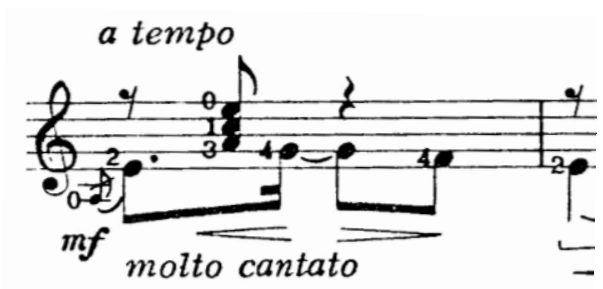

Exemplo 356: $V^{o}$ Est., comp. 20. Ed. Columbia/BL.

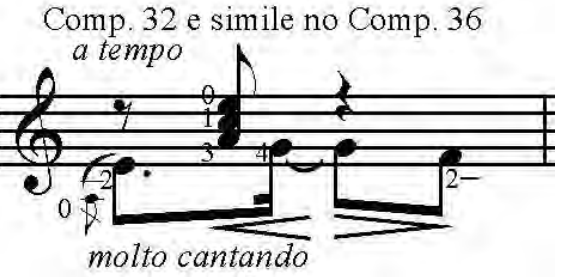

Exemplo 357: $V^{o}$ Est., comp. 32 e símile 36.

No compasso 50 a melodia no baixo se confronta com um complexo arpejo em tercinas que fatalmente quebra o legato da melodia (grafado com pausas em nossas versões). O exemplo 359 segue a digitação BL com abertura na primeira posição e apenas modifica ${ }^{96}$ os compassos seguintes especificando também a $m d$ do trecho.

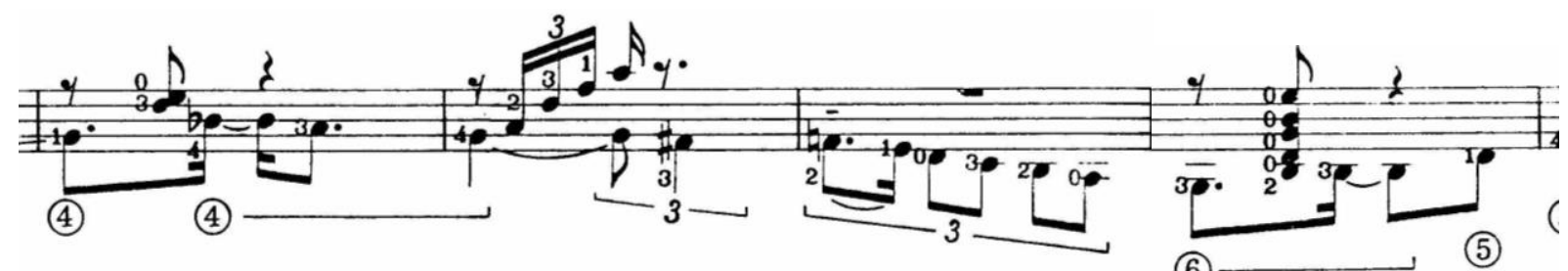

Exemplo 358: $V^{o}$ Estudo, comp. 49. Ed. Columbia/BL

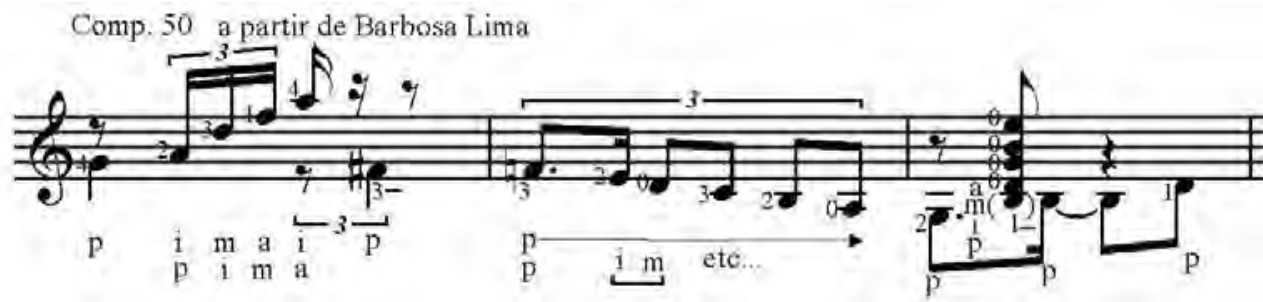

Exemplo 359: $V^{o}$ Estudo, compasso 50.

\footnotetext{
${ }^{96}$ verbo do checklist de Osborn.
} 
Os exemplos seguintes tentam contornar essa abertura, porém reduzem ${ }^{97}$ ainda mais a duração da melodia, aspecto que pode ser disfarçado por meio de rubato. $\mathrm{O}$ exemplo 360 digita o arpejo na quinta posição, enquanto os seguintes experimentam inserir harmônicos naturais no mesmo, obrigando a "baixaria" em sequência a trilhar caminhos distintos, sendo a última delas em campanella.

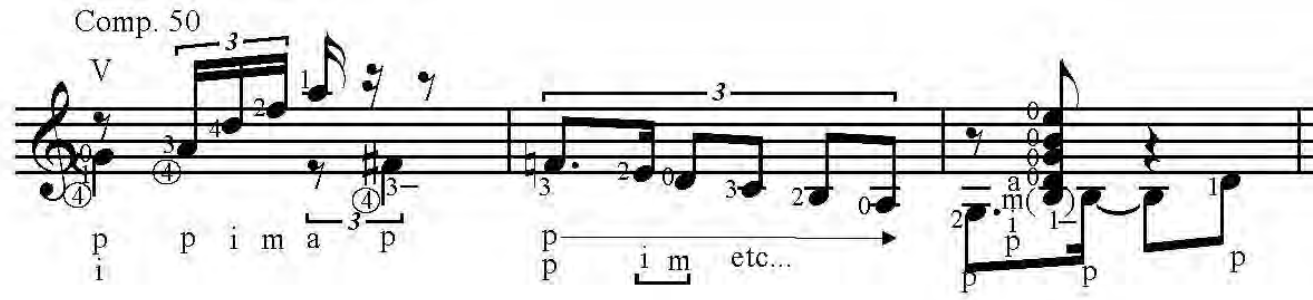

Exemplo 360: $V^{o}$ Estudo, compasso 50.

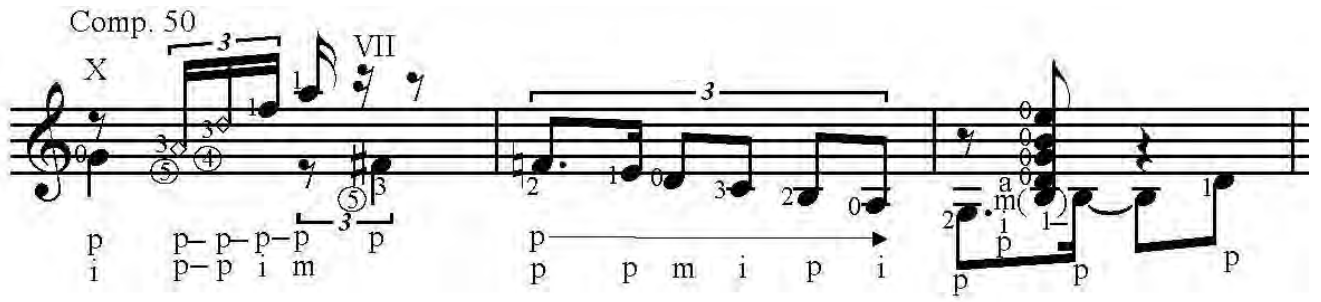

Exemplo 361: $V^{o}$ Estudo, compasso 50.

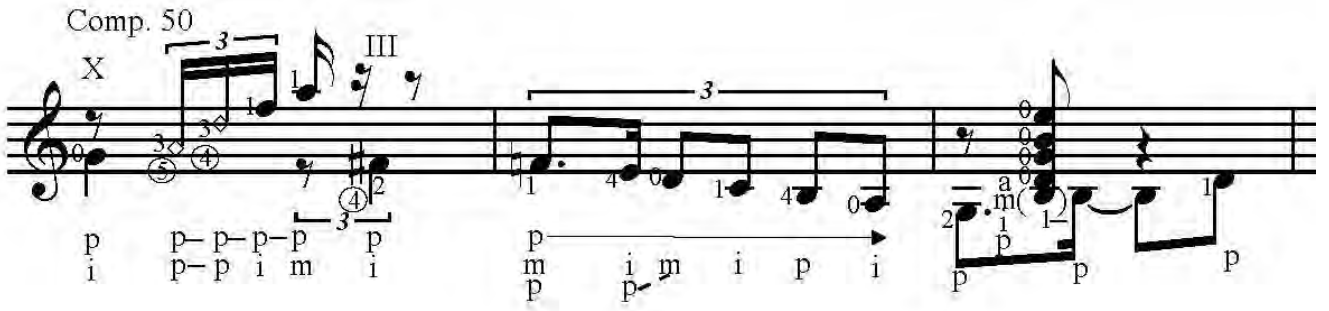

Exemplo 362: $V^{o}$ Estudo, compasso 50.

No compasso 54 a intervenção em arpejo reincide de forma simplificada (com menos notas e com corda solta), também possibilitando uma digitação pela quinta casa (exemplo 364) onde aproveitamos para grafar a nova "baixaria" em campanella, mesmo não sendo esta a digitação mais tradicional para este gesto musical.

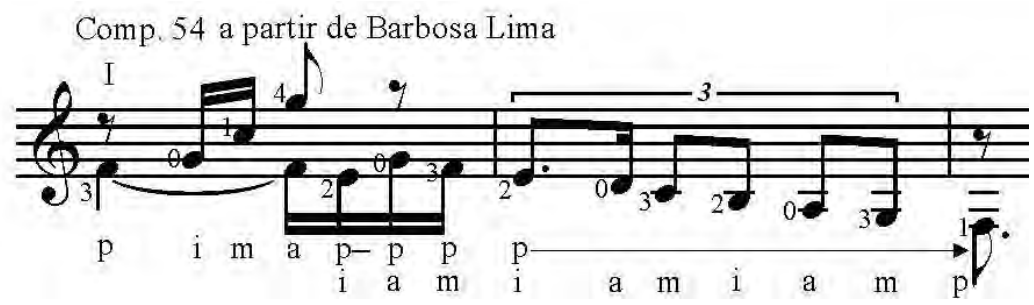

Exemplo 363: $V^{o}$ Estudo, compasso 54.

\footnotetext{
${ }^{97}$ verbo diminuir do checklist de Osborn.
} 


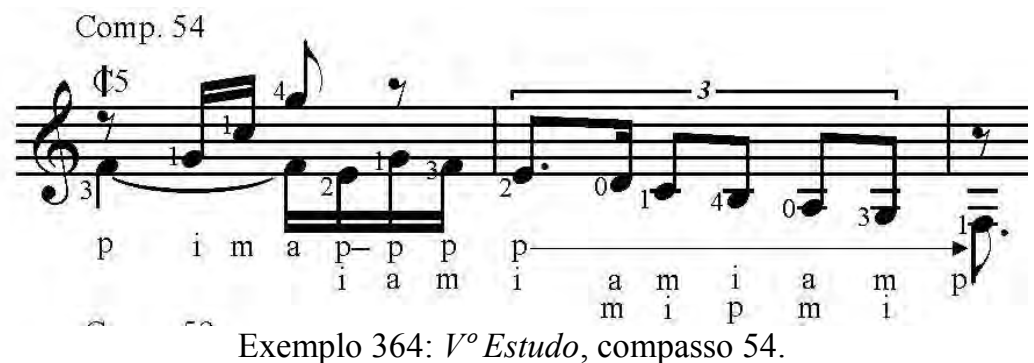

O compasso 59 pode ganhar expressividade (exemplo 366) por meio de translado em oitavas com aproveitamento de corda solta:

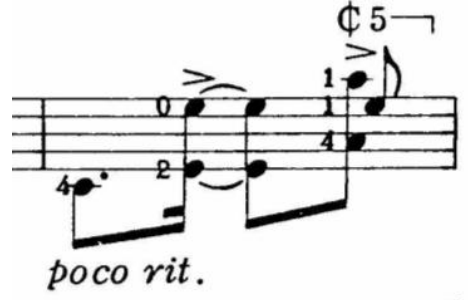

Exemplo 365: $V^{o}$ Est., comp. 59. Ed. Columbia/BL.

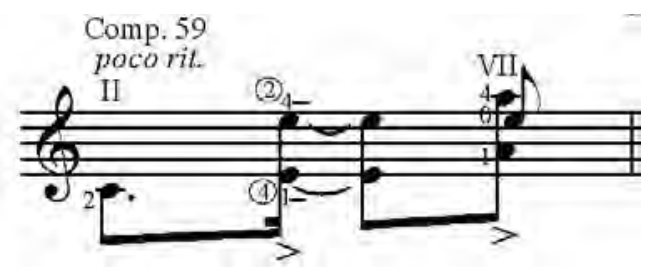

Exemplo 366: $V^{o}$ Est., compasso 59.

Uma pequena dubiedade de grafia ocorre no compasso 62 onde, em um momento cadencial, Mignone sustenta um Dó e o solicita novamente para os acordes a seguir, não havendo possibilidade de alcançar a duração completa da melodia em nota longa. No entanto, essa grafia se justifica por buscar um registro mais da intenção musical do que da exatidão técnica do trecho. Coincidentemente, o local onde digitar este acorde climático bem como suas cercanias (ou seja, compassos 61-63), estão abertos a várias possibilidades.

A digitação BL digita o compasso 62 pela segunda posição e alcança o ápice da melodia na segunda corda e com isso os acordes recaem na primeira posição e a escala cromática final descende pela terceira e quarta cordas em uma abordagem bastante compreensível já que a próxima seção também se iniciará pelas primeiras posições.

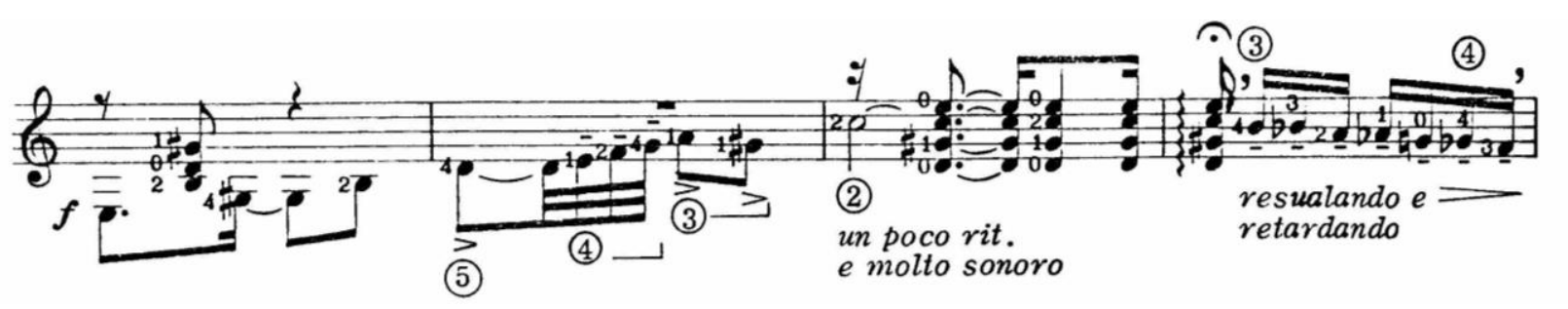

Exemplo 367: $V^{o}$ Estudo, comp.60. Ed. Columbia/BL.

O exemplo 368, busca explorar o efeito expressivo da quarta corda para esta passagem cadencial tanto na subida quanto na descida e com isso coloca os acordes nos bordões na décima posição. $\mathrm{O}$ exemplo seguinte apenas propõe uma descida ainda mais audaciosa e experimental com campanella cromática que envolve um harmônico natural. 


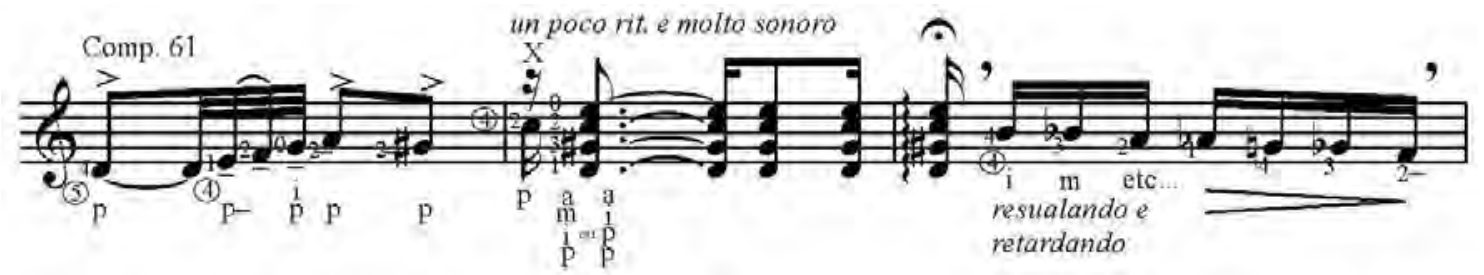

Exemplo 368: $V^{o}$ Estudo, compasso 61.

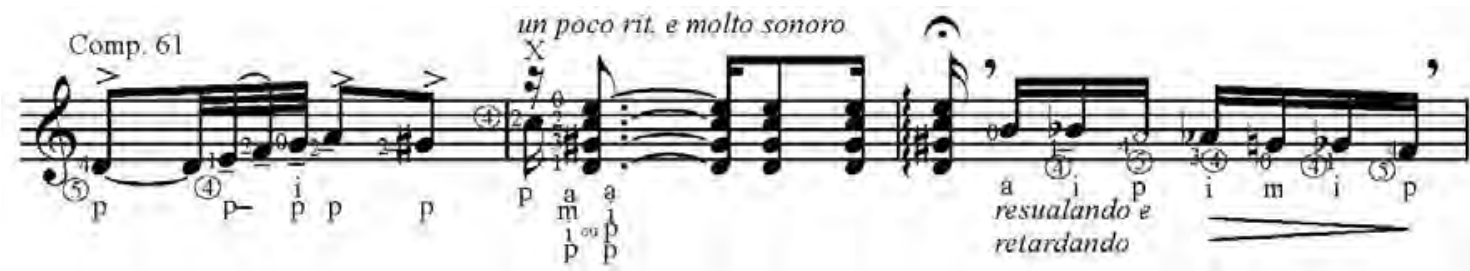

Exemplo 369: $V^{o}$ Estudo, compasso 61.

No compasso 64 há um retorno da melodia do compasso 32, mas agora na voz superior quando antes havia sido apresentada na inferior.

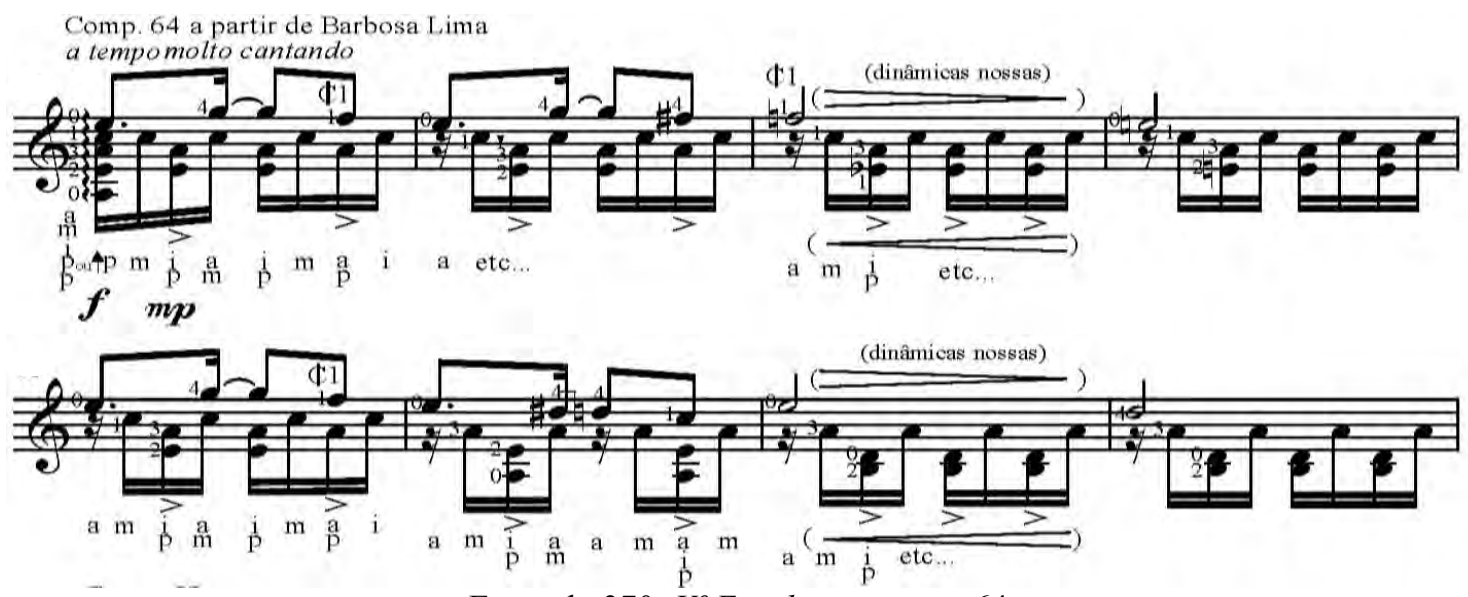

Exemplo 370: $V^{o}$ Estudo, compasso 64.

O exemplo 370 apresenta a digitação de $m e$ de BL e detalha a digitação de $m d$ ainda com sugestões de dinâmica, onde a melodia decresce e o acompanhamento se intensifica levemente.

Há momentos, como no compasso 68 , no qual a melodia se aproxima do acompanhamento adentrando a segunda corda e criando dificuldades para a $m d$. Os exemplos 371 e 372 registram outras possibilidades de $m d$ para o referido compasso.

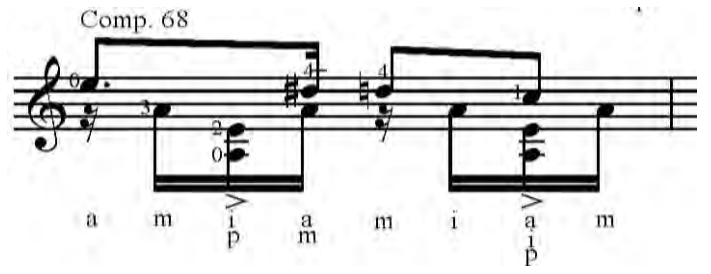

Exemplo 371: $V^{o}$ Estudo, compasso 59.

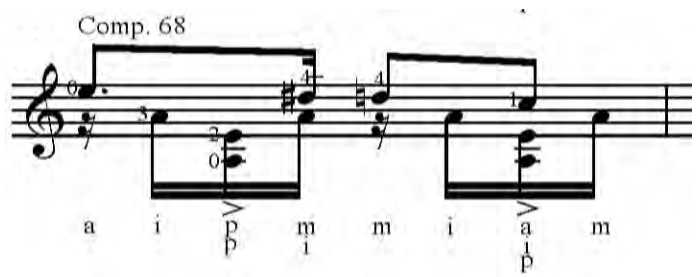

Exemplo 372: $V^{o}$ Estudo, compasso 59.

O último exemplo com sua articulação do acompanhamento pelo polegar duplo, gerou a ideia de aplicá-lo ao trecho como um todo (exemplo 373), podendo com isso, haver o acréscimo opcional de notas para unificar o funcionamento da $m d$. Dessa forma 
o padrão de $m d$ fica mais previsível, porém deve-se tomar cuidado pois o polegar, com seu maior peso, tem tendência de destacar demasiadamente o acompanhamento.

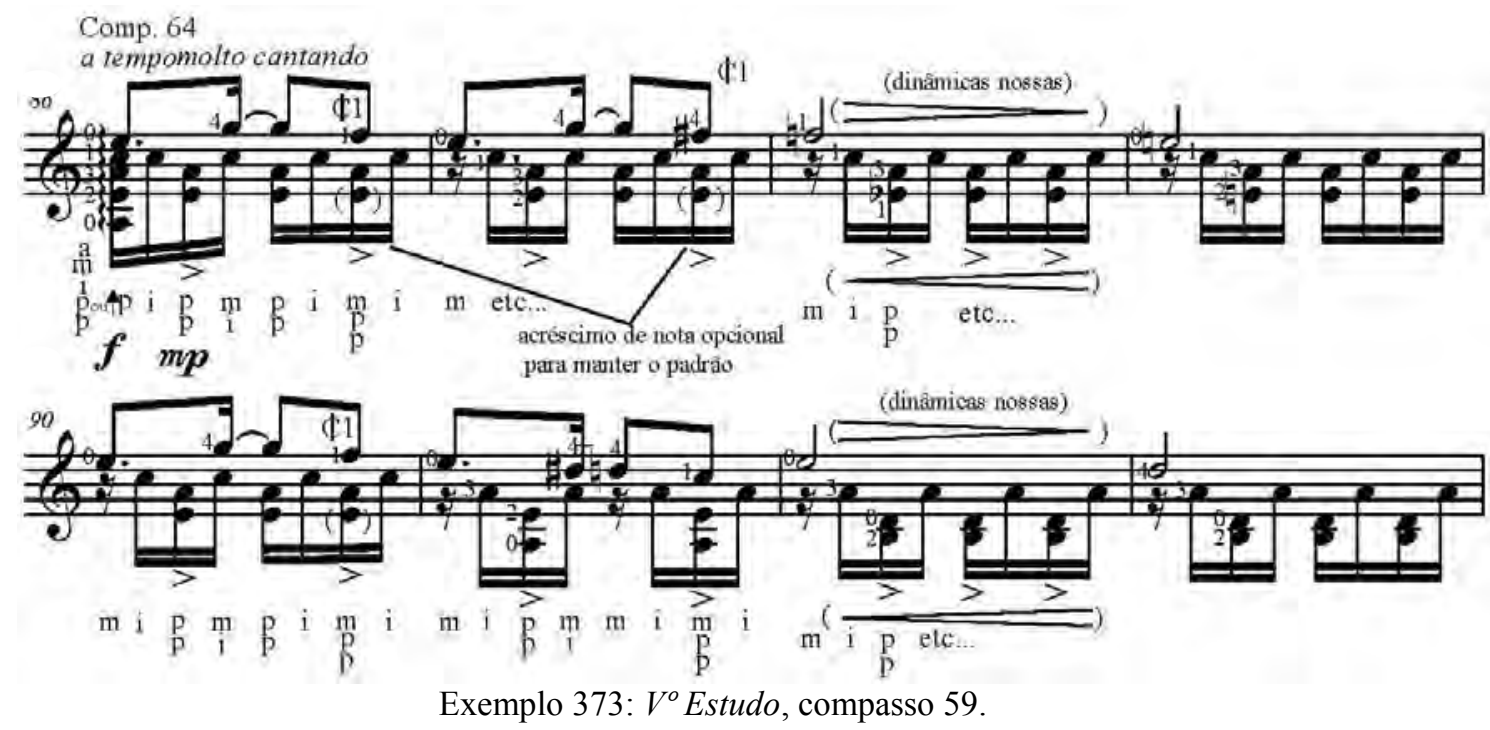

No compasso 72, a digitação BL foca-se na região central do instrumento, sem muita conexão com os compassos adjacentes.

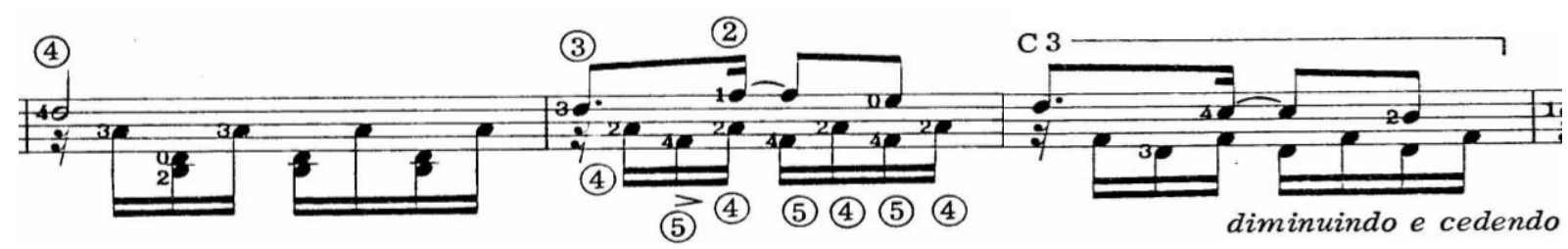

Exemplo 374: $V^{o}$ Estudo, comp.71. Ed. Columbia/BL.

O exemplo 375 imita a digitação BL do referido compasso mas mantém o compasso seguinte em posição próxima. Já o exemplo 376 faz o inverso adotando estratégia mais simples na primeira posição no compasso 72 e simplificando a proposta BL para o próximo compasso com uma corda solta.

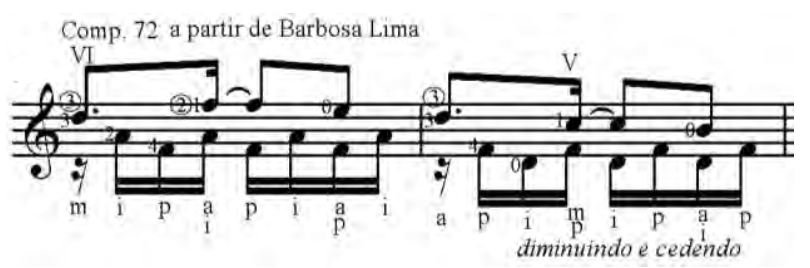

Exemplo 375: $V^{o}$ Estudo, compasso 72.

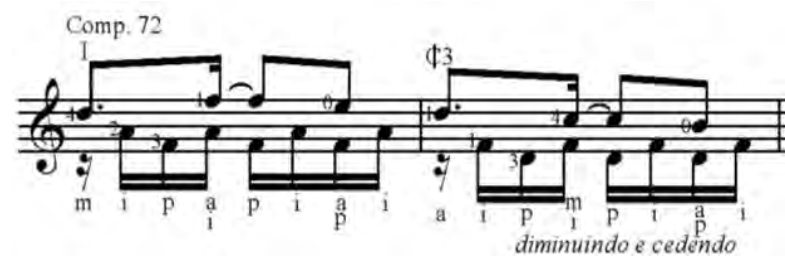

Exemplo 376: $V^{o}$ Estudo, compasso 72.

A partir do compasso 72 há novo movimento descendente da melodia em direção às cordas internas. BL opta por fixar-se no acorde de Lá menor na primeira posição e "deformá-lo" conforme a melodia de movimenta e usando o dedo 3 como guia para conectá-lo com o compasso 76 na segunda posição. O exemplo 377 registra a digitação BL de $m e$ e introduz a primeira possibilidade de execução de $m d$, enquanto o 
378 apresenta a opção com articulação dupla do polegar da $m d$ e modifica ${ }^{98}$ poucos dedos da me do compasso 76. Finalmente, o exemplo 379 apresenta nova visão de me privilegiando a segunda posição ainda com articulação dupla de polegar.

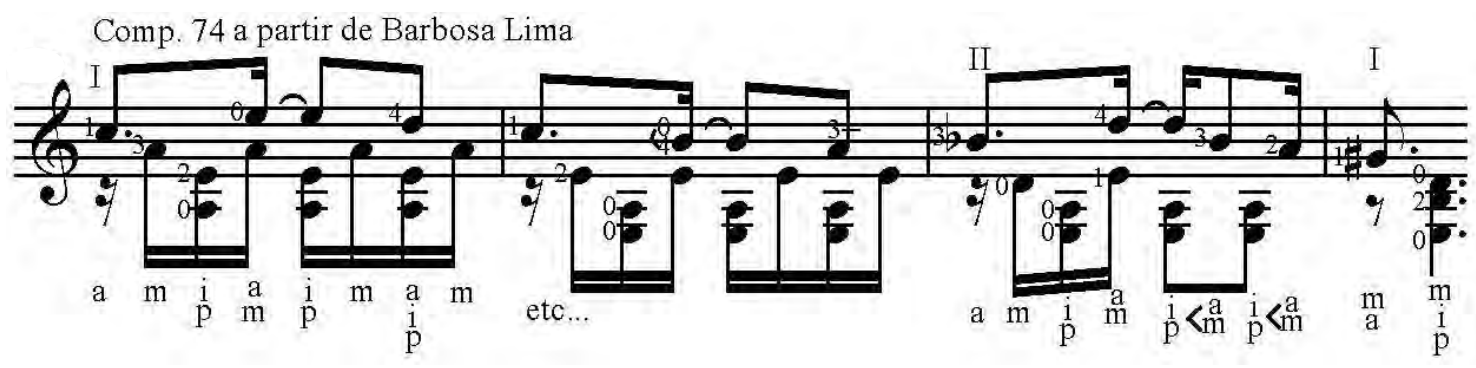

Exemplo 377: $V^{o}$ Estudo, compasso 74.

Comp. 74

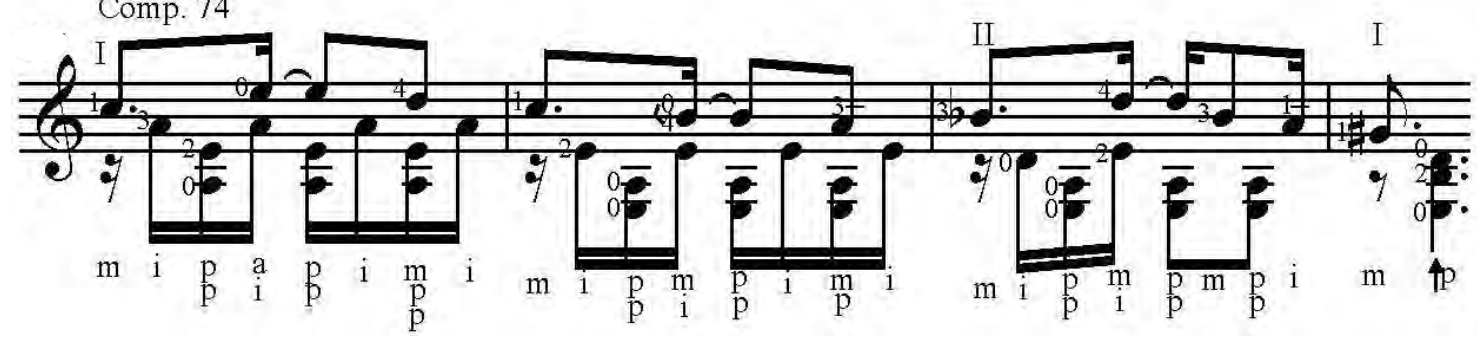

Exemplo 378: $V^{o}$ Estudo, compasso 74.

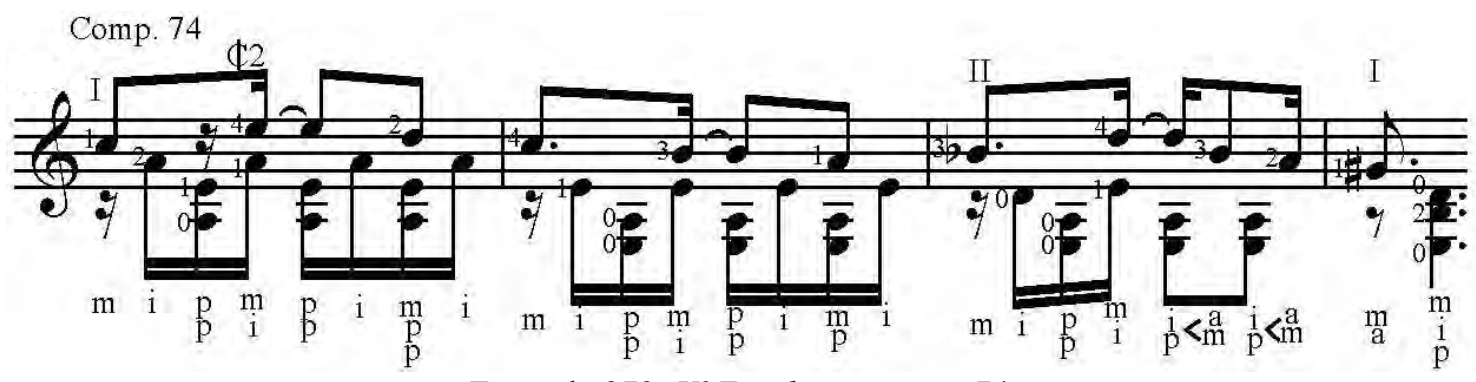

Exemplo 379: $V^{o}$ Estudo, compasso 74.

Uma nova e pequena cadência se inicia no compasso 77. O exemplo 381 aproveita a quarta corda com portamento opcional no primeiro compasso e simplifica com cordas soltas a digitação BL do compasso seguinte. Já o exemplo 382 simplifica o primeiro compasso na primeira posição, mas elabora os seguintes com campanellas.

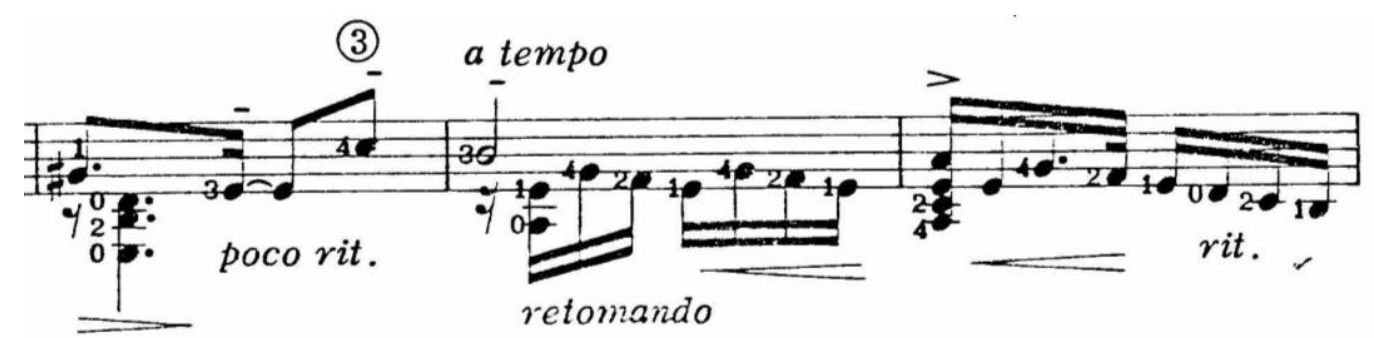

Exemplo 380: $V^{o}$ Estudo, comp.77. Ed. Columbia/BL

\footnotetext{
${ }^{98}$ verbo do checklist de Osborn.
} 


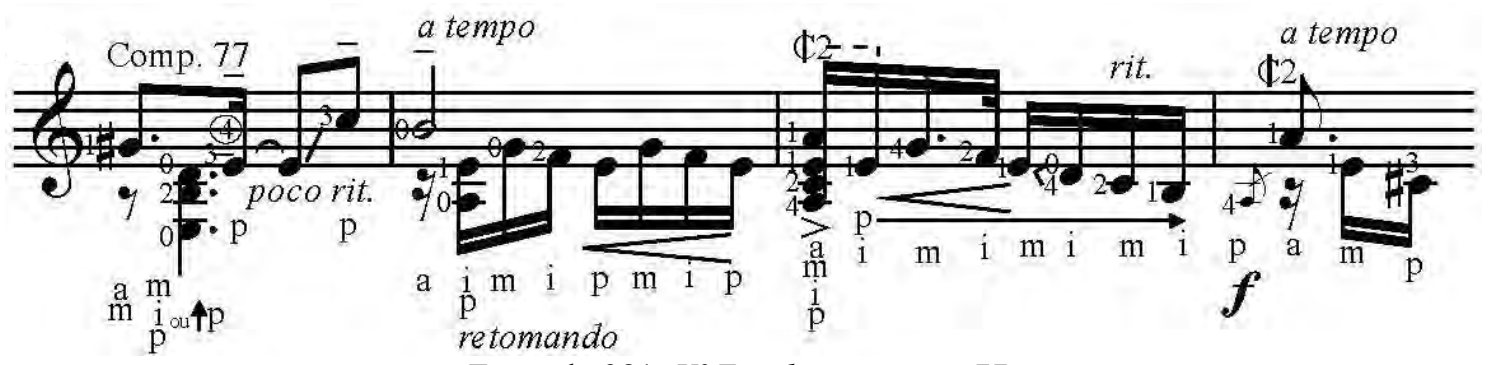

Exemplo 381: $V^{o}$ Estudo, compasso 77.

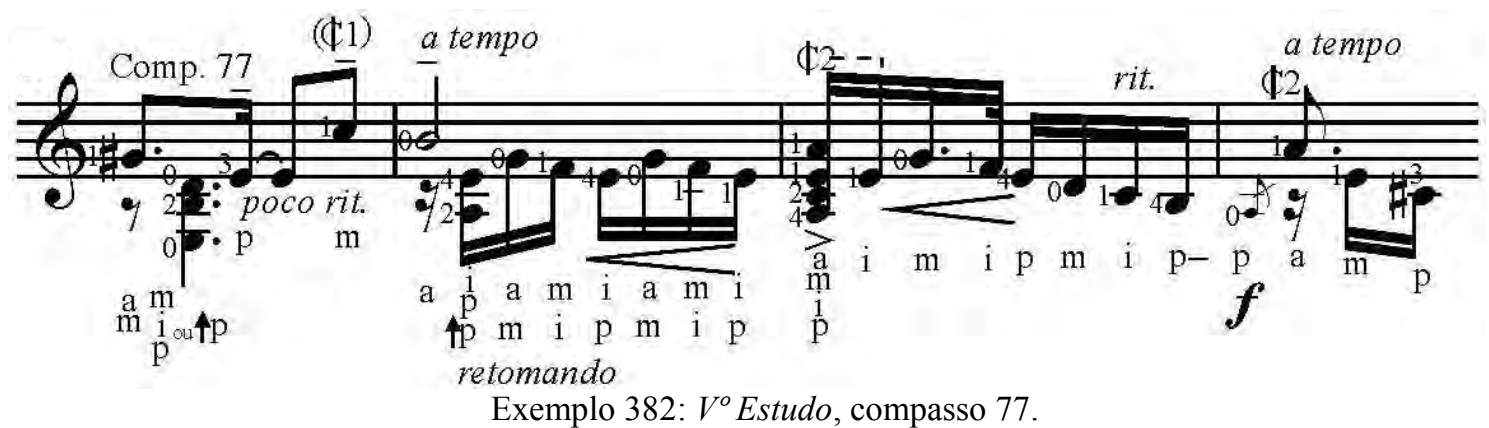

A partir do compasso 80, Mignone ascende com a melodia e harmonia conjuntamente, mas com uma nota repetida no acompanhamento, criando complicações. O exemplo 384 tenta aproveitar-se por mais tempo da pestana na segunda casa proposta por BL mas ocasiona pequeno prejuízo no legato melódico e no compasso seguinte, apenas experimenta a inversão de alguns dedos.

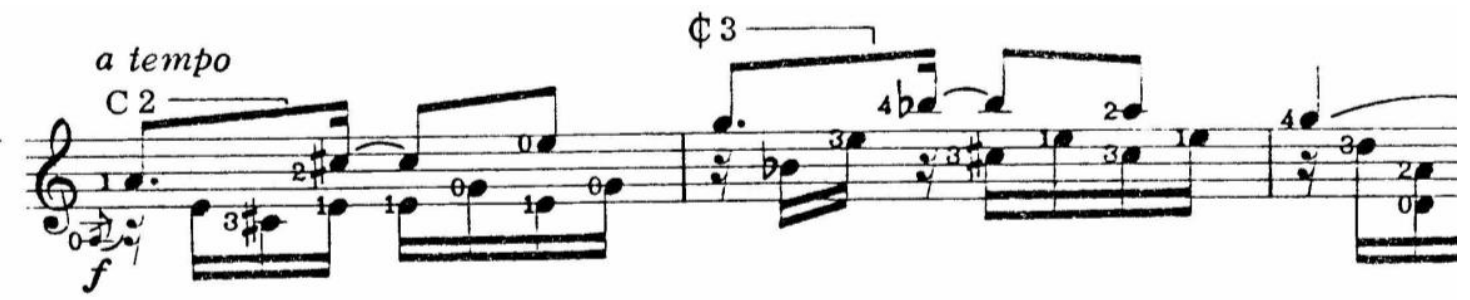

\section{Exemplo 383: $V^{o}$ Estudo, comp. 80. Ed. Columbia/BL.}

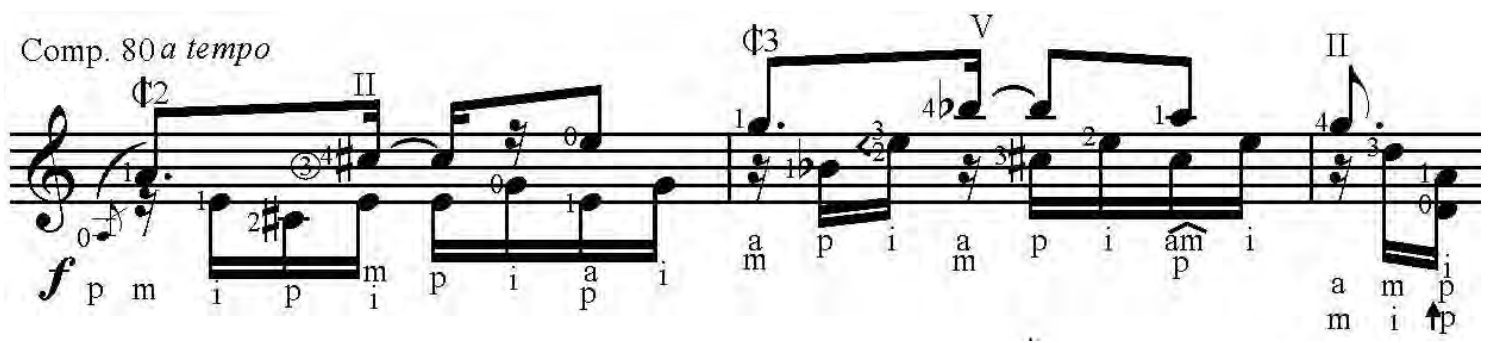

Exemplo 384: $V^{o}$ Estudo, compasso 80.

Os exemplos 385 e 386 abdicam da pestana inicial e substituem alguns dedos obtendo melhor solução para o primeiro compasso. No seguinte, ambos transladam pela segunda corda com o dedo 2 até as casas avançadas, mas somente o segundo utiliza cordas soltas a partir de então, criando um padrão interessante de sextas paralelas mas com necessidade de compensação tímbrica pelo intérprete nas cordas soltas. 


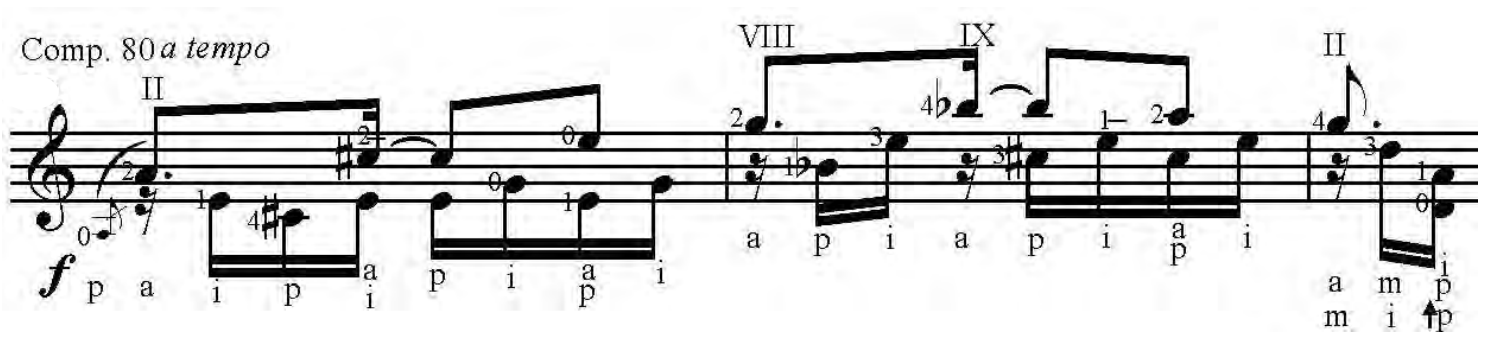

Exemplo 385: $V^{o}$ Estudo, compasso 80.

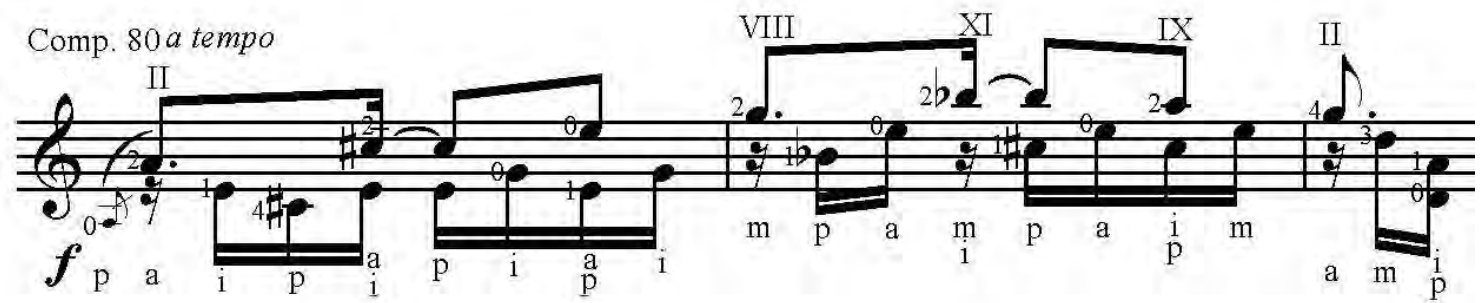

Exemplo 386: $V^{o}$ Estudo, compasso 80.

O último exemplo do trecho retira a nota dupla por substituição (em Ossia facilitadora) e também adota a estratégia de manter a pestana da segunda casa por maior tempo, agora sem prejuízo na melodia. $\mathrm{O}$ compasso seguinte faz um novo experimento de rearranjo ${ }^{99}$ de dedos.

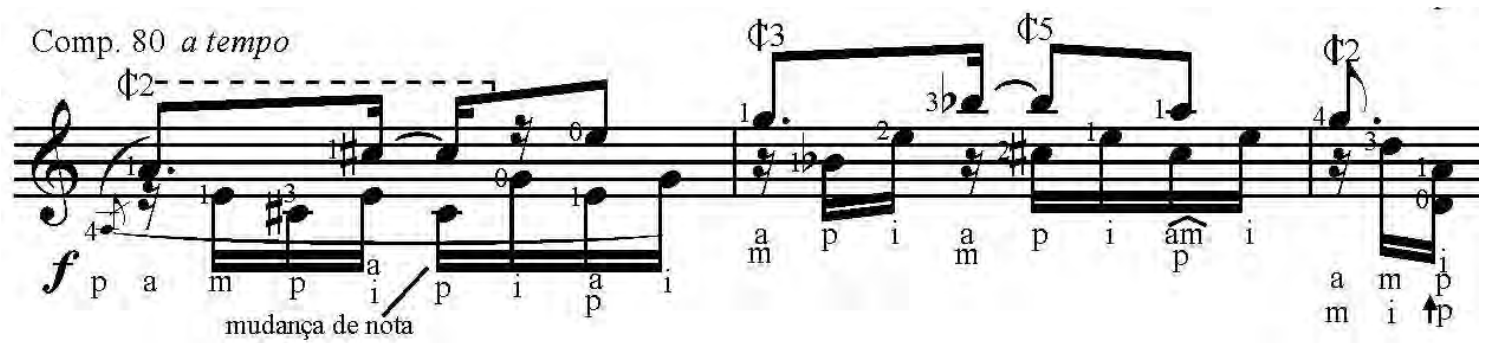

Exemplo 387: $V^{o}$ Estudo, compasso 80.

O exemplo 388 inclui digitação de me idêntica a BL para o trecho seguinte, mas com indicação da $m d$. Alternativamente, o exemplo 389 fixa o dedo 3, obtendo outra configuração para o último compasso.

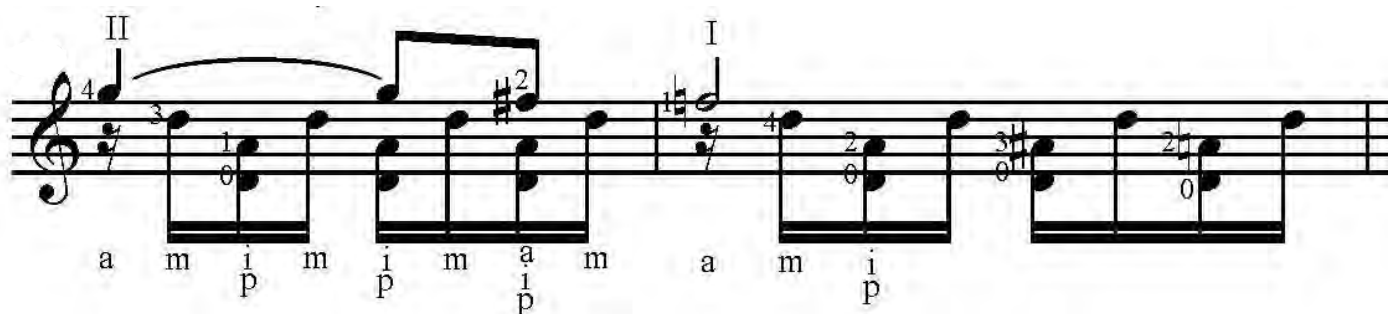

Exemplo 388: $V^{o}$ Estudo, compasso 82.

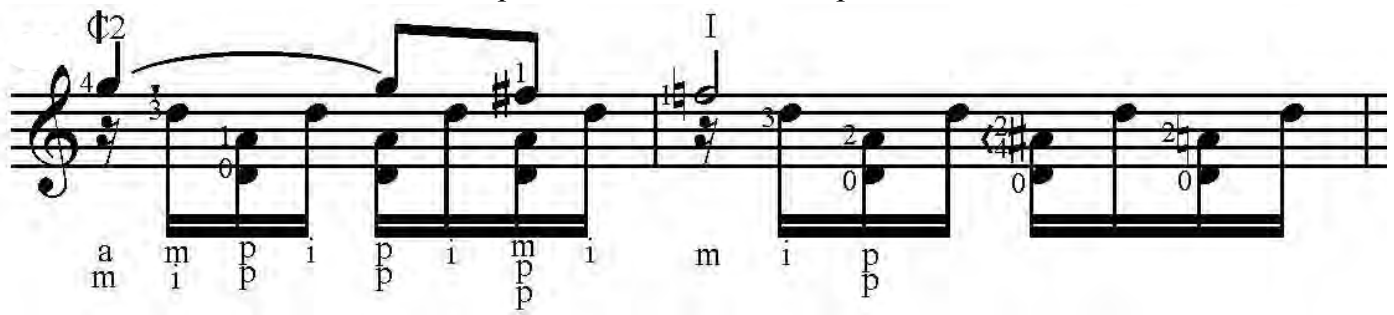

Exemplo 389: $V^{o}$ Estudo, compasso 82.

\footnotetext{
${ }^{99}$ verbo do checklist de Osborn.
} 
No compasso 84 inicia-se nova subida harmônica e melódica com ocorrência de notas repetidas. BL sugere o uso inteligente de cordas duplas para a rearticulação do Ré, mas opta pelo uso do dedo 4 na quinta corda. Em nossas versões, optamos pelo dedo 3 na mesma função. O exemplo 391 também realiza o último compasso na primeira posição, mas com pestana (ao contrário de BL) o que modifica ${ }^{100}$ o compasso anterior para prover melhor encaminhamento.

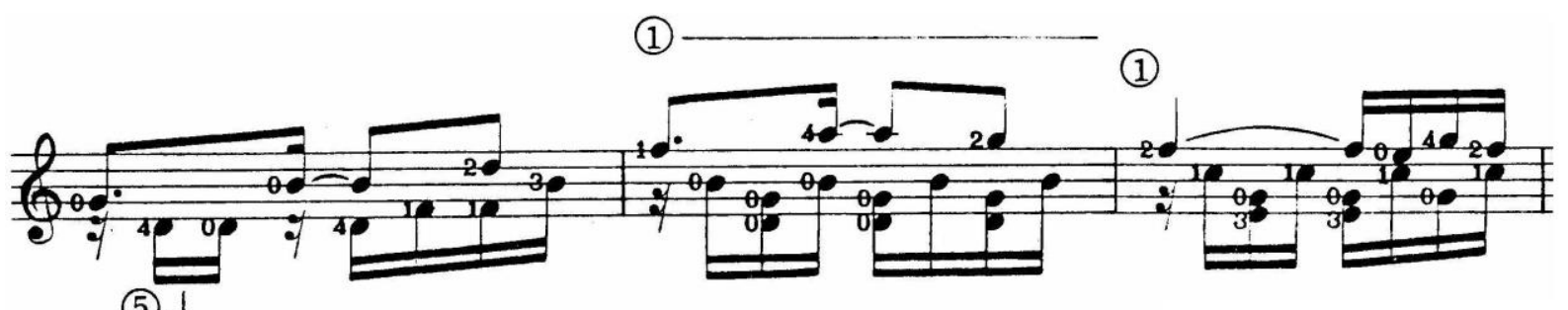

(5) $\lrcorner$

Exemplo 390: $V^{o}$ Estudo, comp. 84. Ed. Columbia/BL.

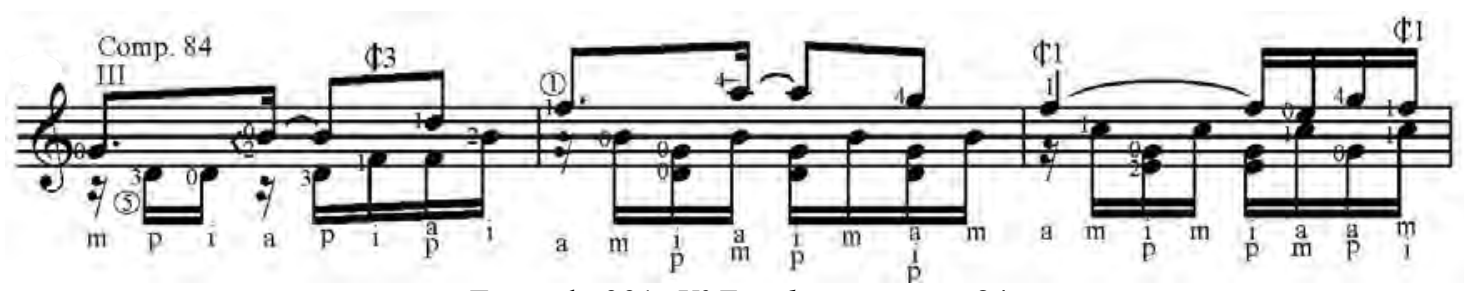

Exemplo 391: $V^{o}$ Estudo, compasso 84.

Os dois exemplos seguintes excluem a dupla incidência da nota Fá, trocando-a por Ré já que esta nota está disponível em duas cordas, simplificando a $m d$ do trecho e atrasando a entrada da pestana na terceira casa. O exemplo 392 experimenta colocar o compasso seguinte na quarta posição quase que plenamente realizado por notas presas mas ainda encaminhando o final para a primeira posição em pestana, enquanto o exemplo 393 difere neste momento ao levar para quinta posição, também em pestana.

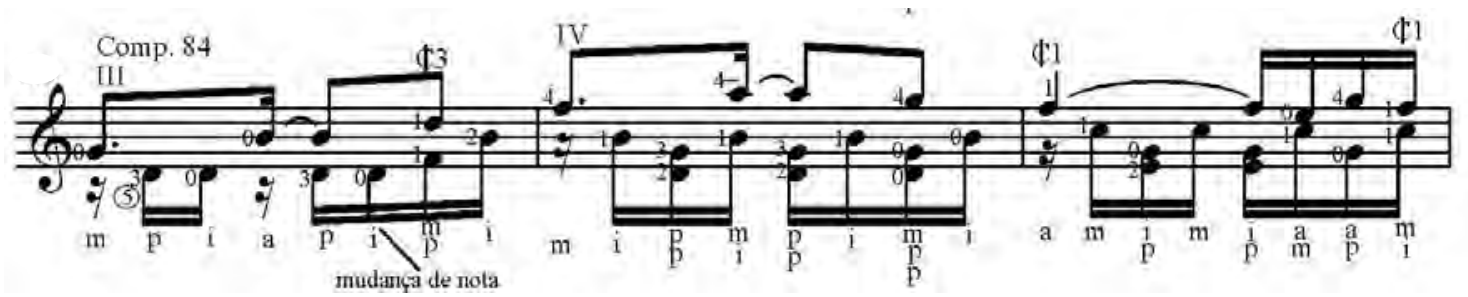

Exemplo 392: $V^{o}$ Estudo, compasso 84.

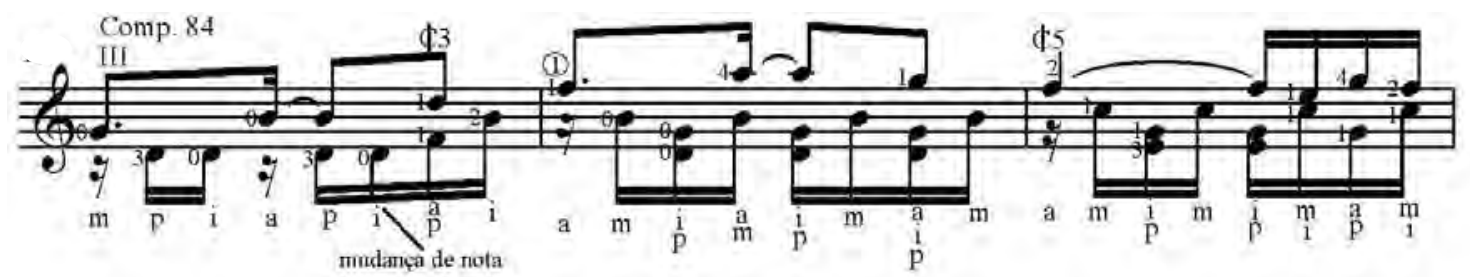

Exemplo 393: $V^{o}$ Estudo, compasso 84.

${ }^{100}$ verbo do checklist de Osborn. 
Os próximos exemplos ainda tentam outros recursos. O exemplo 394 recorre a ligado na execução da nota dupla e o exemplo 395 retrabalha a mudança de nota anteriormente proposta, criando um translado pela quinta corda.

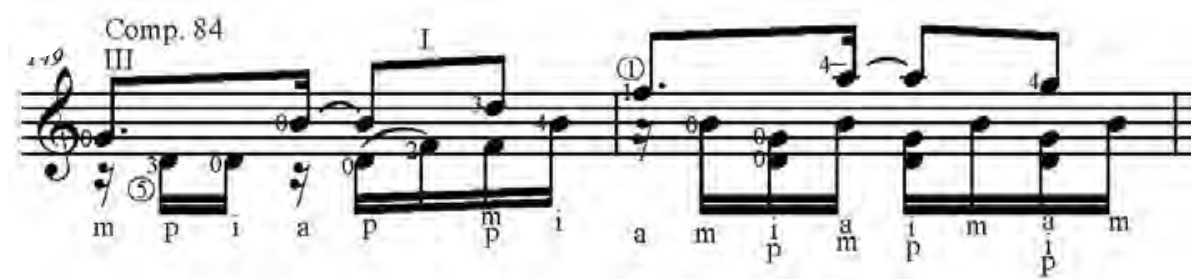

Exemplo 394: $V^{o}$ Estudo, compasso 84.

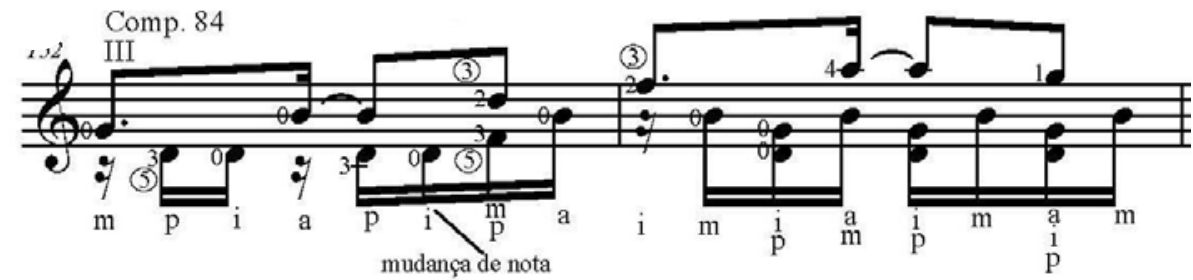

Exemplo 395: $V^{o}$ Estudo, compasso 84.

No compasso 87 há uma longa e criativa tirata $^{101}$ cromática que ao final descende também por quartas paralelas. O exemplo 397 se inspira no padrão BL, mas atinge as quartas com os dedos 1 e 2 e os utiliza para todas, em arraste, encaminhando melhor para o próximo compasso. O exemplo 398 parte da sexta posição e atinge as quartas com os dedos 3 e 4 na sexta e quinta cordas enquanto o exemplo 399 integra o início desta versão com o final da anterior.

\section{ad libitum}

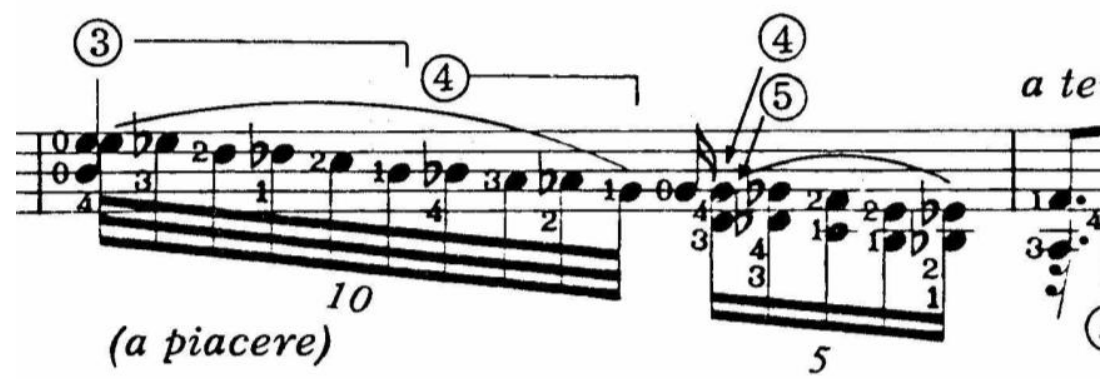

Exemplo 396: $V^{o}$ Estudo, comp. 87. Ed. Columbia/BL.

Comp. 87a partir de Barbosa Lima

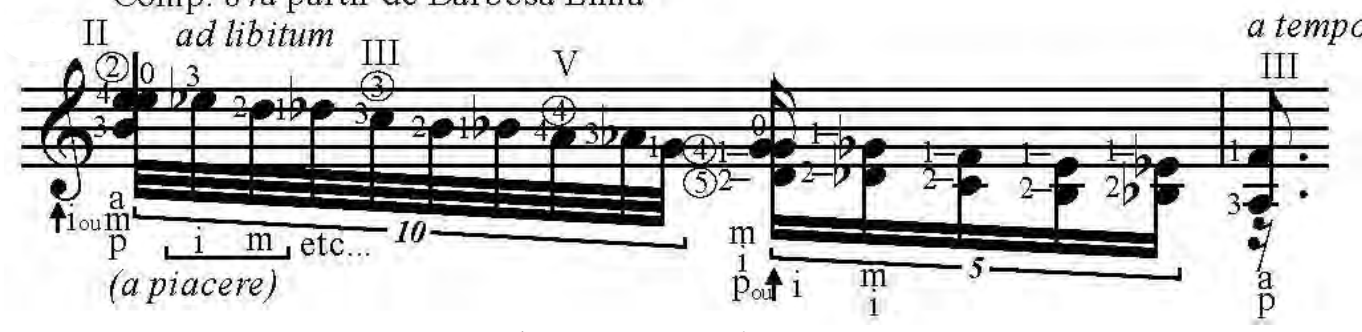

Exemplo 397: $V^{o}$ Estudo, compasso 87.

${ }^{101}$ Ornamentação Barroca baseada em rápidas escalas conectivas. 
Comp. 87

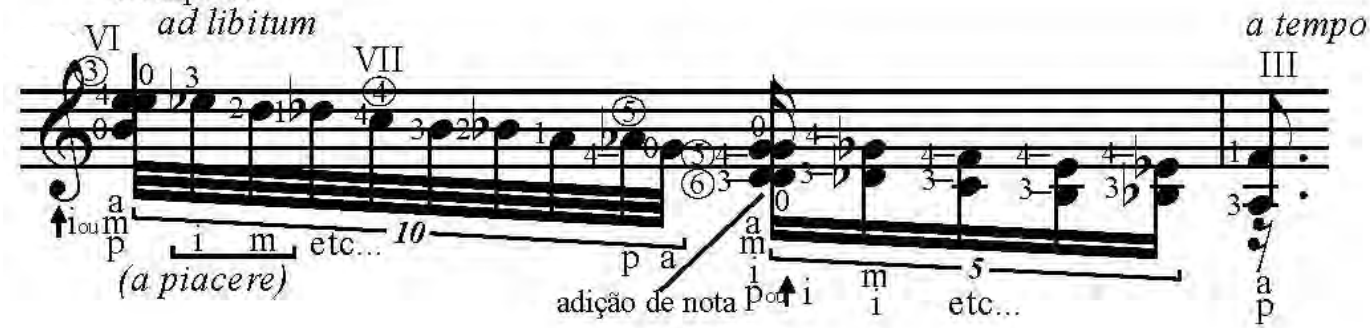

Exemplo 398: $V^{o}$ Estudo, compasso 87.

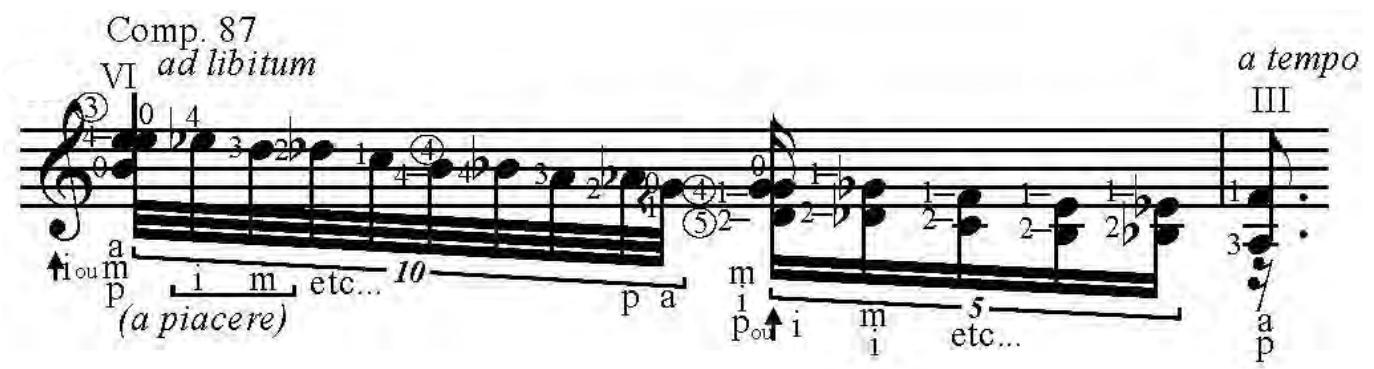

Exemplo 399: $V^{o}$ Estudo, compasso 87.

O trecho imediatamente seguinte também faz uso reiterado da nota Ré no acompanhamento, disposta por BL em cordas duplas. Nossas versões aproveitam mais a alternâncias das cordas duplas, mas com isso reduzem ${ }^{102}$ de forma imperceptível a duração de algumas notas da voz superior (a primeira de cada compasso, mais precisamente). O exemplo 401 e 402 são muito similares, apresentando diferenças na alternância do pedal Ré no primeiro compasso e na redução ${ }^{103}$ de notas do último acorde no compasso seguinte.

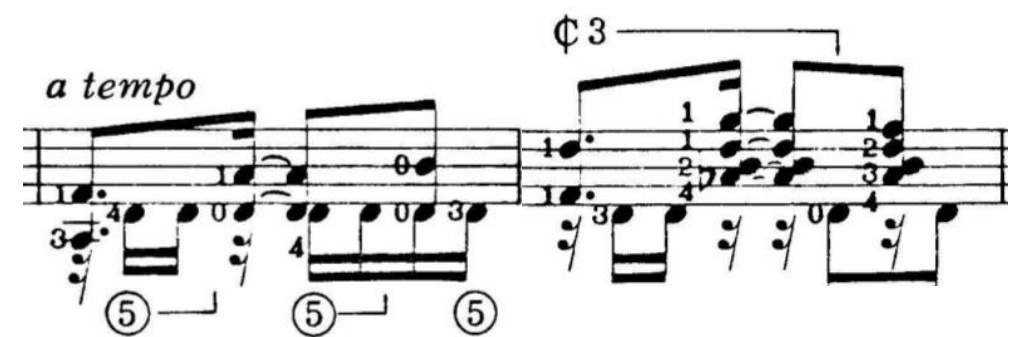

Exemplo 400: $V^{o}$ Estudo, comp. 88. Ed. Columbia/BL.

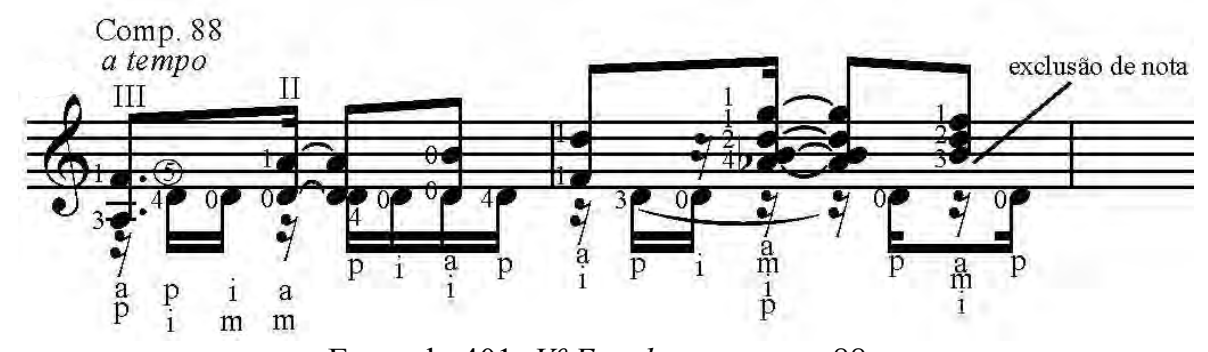

Exemplo 401: $V^{o}$ Estudo, compasso 88.

\footnotetext{
${ }^{102}$ verbo diminuir do checklist de Osborn.

${ }^{103}$ verbo diminuir do checklist de Osborn.
} 


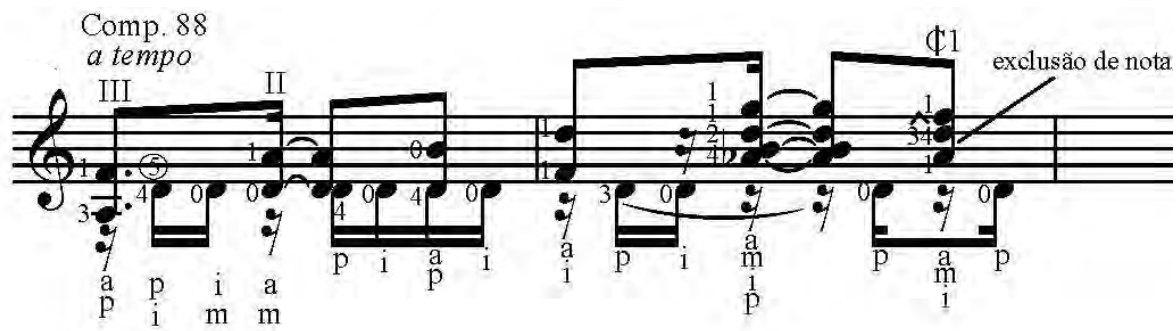

Exemplo 402: $V^{o}$ Estudo, compasso 88.

O exemplo 403 adota estratégia completamente distinta ao digitar a melodia superior na sexta e quinta cordas para incumbir apenas a quarta corda na execução do pedal. No compasso seguinte, a melodia excede a tessitura dos bordões e passa para a incluir a terceira corda, ainda deixando a quarta livre. Os dois últimos acordes também recebem outra digitação, agora pela décima posição aproveitando a segunda corda solta e conseguindo assim executar o acorde completo. Essa versão, embora interessante, pode resultar em mais ruídos pelo uso dos bordões, contornáveis por saltos ao invés de arrastes.

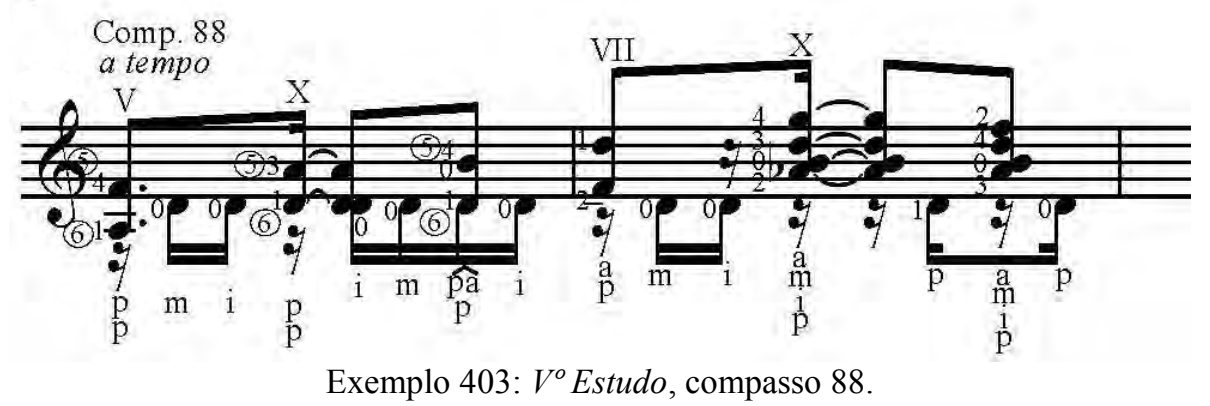

Os amplos acordes do compasso 90 incluem uma movimentação em oitavas entre as vozes extremas, exigindo inevitável contorcionismo. BL usa o dedo 3 como guia inicial e executa as oitavas do acorde mais problemático com os dedos 2 e 4 e rapidamente retira a pestana para articular o baixo com o dedo 1 . O exemplo 405 troca os dedos envolvidos nessa transação conseguindo maior duração do acorde problemático do primeiro compasso. Nos compassos seguintes também há uma troca geral nos dedos selecionados para tocar as oitavas paralelas e acordes, havendo várias opções de articulação de $m d$ para o trecho.

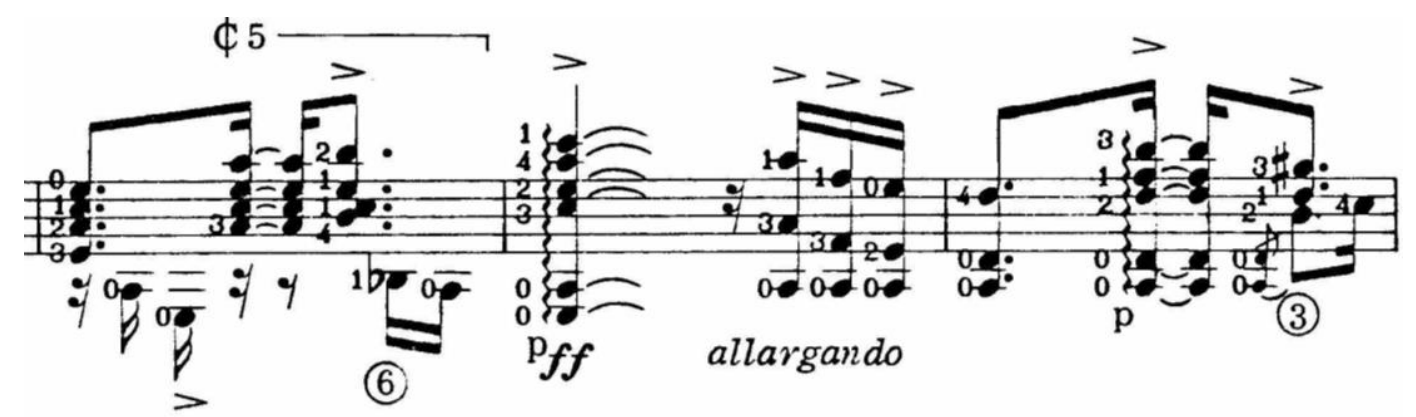

Exemplo 404: $V^{o}$ Estudo, comp. 88. Ed. Columbia/BL. 


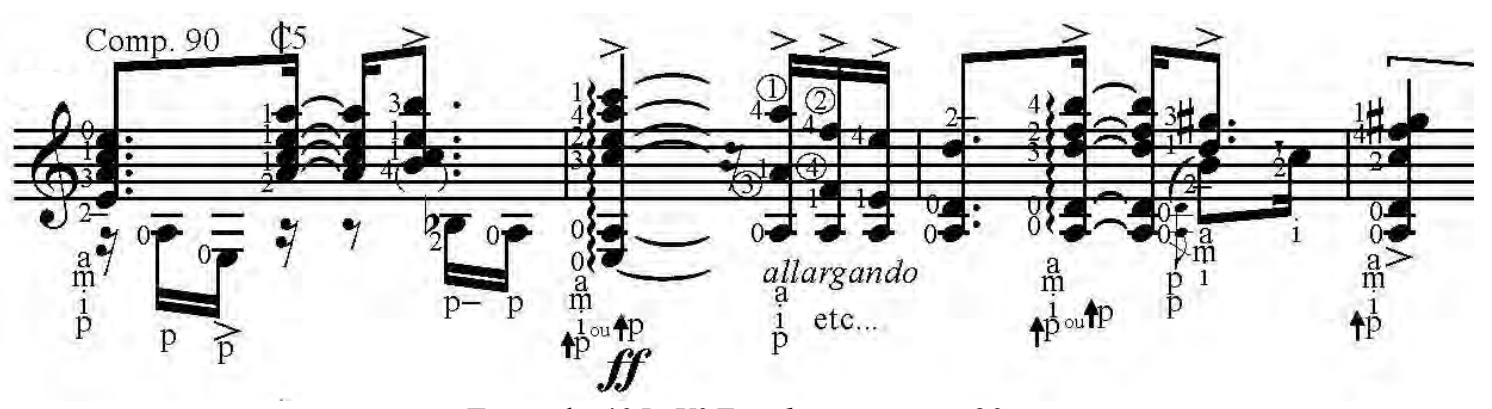

Exemplo 405: $V^{o}$ Estudo, compasso 90.

O exemplo 406 apresenta uma Ossia facilitadora do terceiro acorde do primeiro compasso e aproveita para demonstrar outra visão para as oitavas e acordes do compasso seguinte.

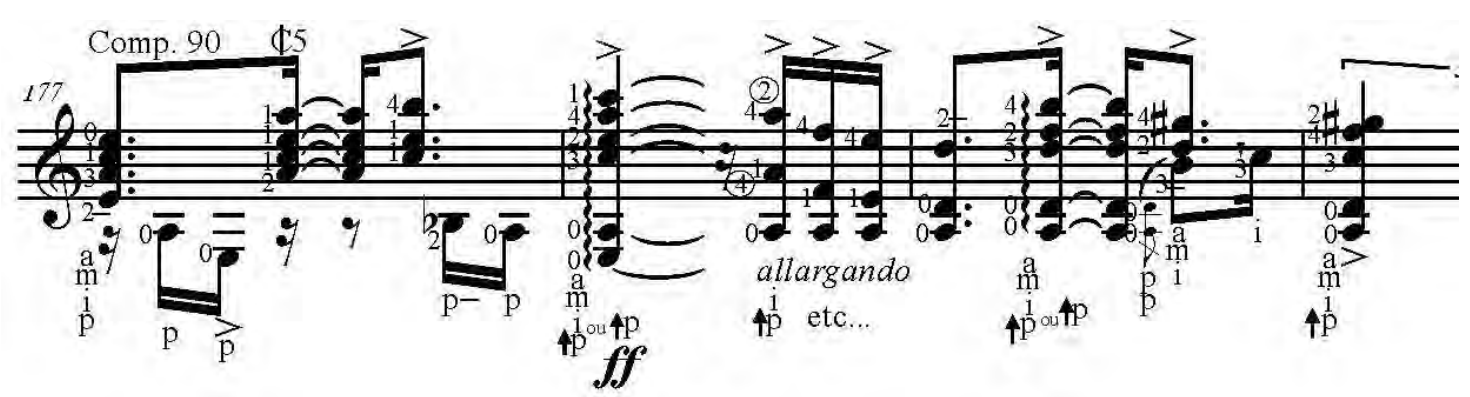

Exemplo 406: $V^{o}$ Estudo, compasso 90. Ossia.

O compasso 99 recebe não apenas outra opção digital no exemplo 407, mas também uma grafia rítmica mais esclarecedora.

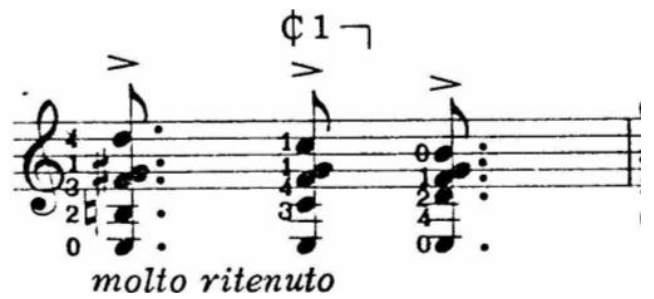

Exemplo 407: $V^{o}$ Estudo, comp. 99. Ed. CL/BL.

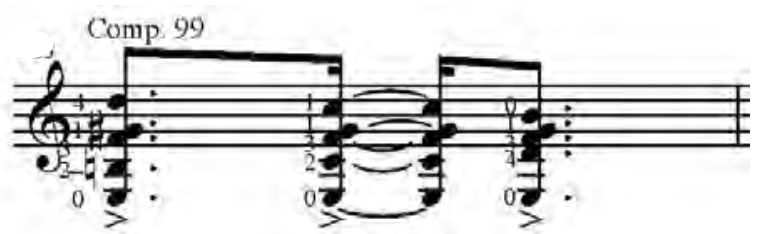

Exemplo 408: $V^{o}$ Estudo, comp. 99.

Mignone rememora no compasso 100, os acordes levemente arpejados anteriormente apresentados no compasso 18, mas agora de forma mais sintética e que por outro lado leva a outros dois acordes novos, dos quais apenas o primeiro demanda reflexões. Na digitação BL (exemplo 409), o mesmo é colocado em pestana na terceira posição com grande abertura e ligado partindo do dedo 4, gerando uma opção acessível a poucos. O exemplo 410 propõem uma meia-pestana na quinta casa, com ligado desconfortável do dedo 2 que encontra-se comprimido pelo dedo 3 , ainda não configurando solução muito acessível. Resta-nos apenas propor uma Ossia (no ex. 411) retirando uma das notas do acorde e com isso logrando saída simples e sem grande perda musical. 


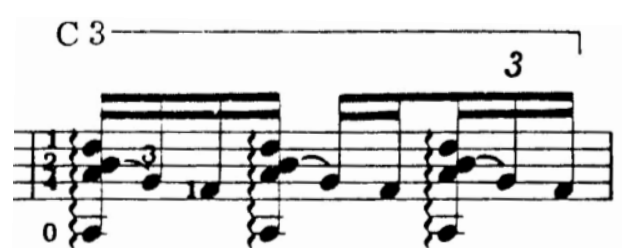

Exemplo 409: $V^{o}$ Est., comp. 104. Ed. CL/BL.

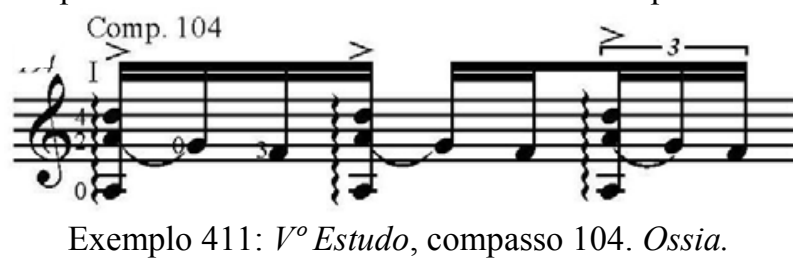

Um amplo arpejo descendente ocorre apenas uma vez no compasso 113, no qual BL prevê apenas o uso dos dedos $m-i$ caminhando verticalmente. O exemplo 413 é ainda tradicional mas reduz ${ }^{104}$ a incidência dos dedos $m-i$ ao inserir o anelar na primeira corda e o polegar na sexta. Já o exemplo seguinte, prevê três possibilidades de escovamento total do arpejo, com $\operatorname{dedos} a, m$ ou $i$ e ainda uma versão com escovamento parcial do anelar nas duas primeiras cordas, sempre com ligado entre os dois baixos. Ambos os exemplos trocam a digitação de me fixando o dedo 4 na terceira corda e liberando o dedo para o baixo em Fá.

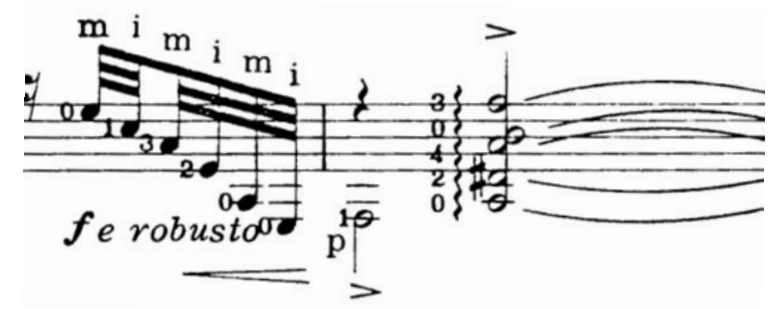

Exemplo 412: $V^{o}$ Estudo, comp. 113. Ed. Columbia/BL.

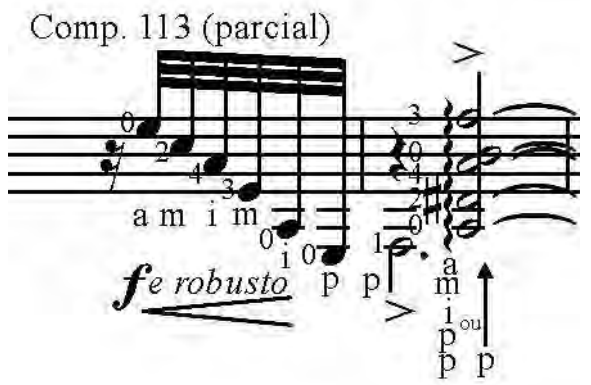

Exemplo 413: $V^{o}$ Estudo, comp. 113.

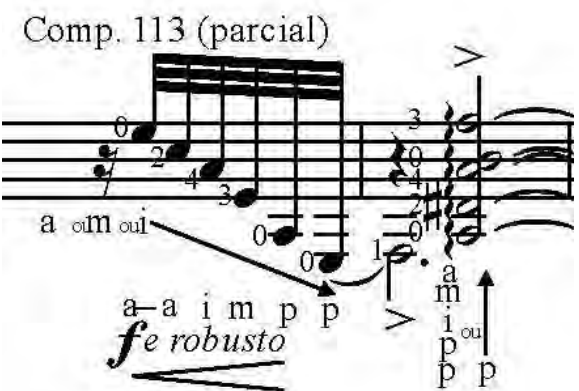

Exemplo 414: $V^{o}$ Estudo, comp. 113.

Perto do fim, Mignone escreve três acordes com a antecipação em uma de suas notas com uma pausa entre o ornamento e o acorde acompanhados de uma seta não esclarecedora (exemplo 415). Imaginando que ela significa o mesmo que um ligado, cria-se uma dualidade: ou se garante a continuidade da nota ou se segue a pausa. Nossa pesquisa apenas vislumbrou uma solução a esta dicotomia quando observou que tanto

\footnotetext{
${ }^{104}$ verbo diminuir do checklist de Osborn.
} 
no manuscrito, quanto na edição Columbia, todos os ornamentos da obra são escritos antes da barra de compasso quando aparecem no primeiro tempo de um compasso. Nesse caso específico, essa grafia estaria gerando uma confusão por se tratar de compasso acéfalo. Nossa performance passou a adotar a grafia habitual de ornamentos onde o mesmo aparece próximo às notas reais como no exemplo 406. Esta versão também sugere reconfigurações na digitação BL no segundo acorde e nos harmônicos artificiais finais.

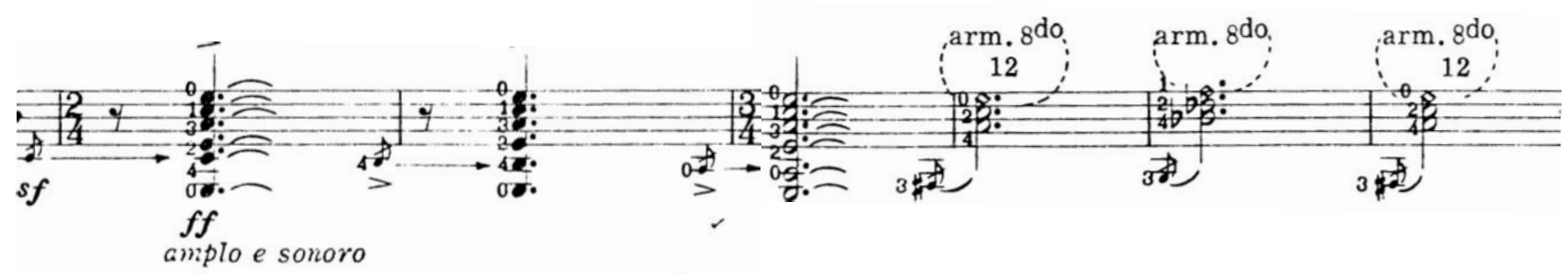

Exemplo 415: $V^{o}$ Estudo, comp. 117. Ed. Columbia/BL.

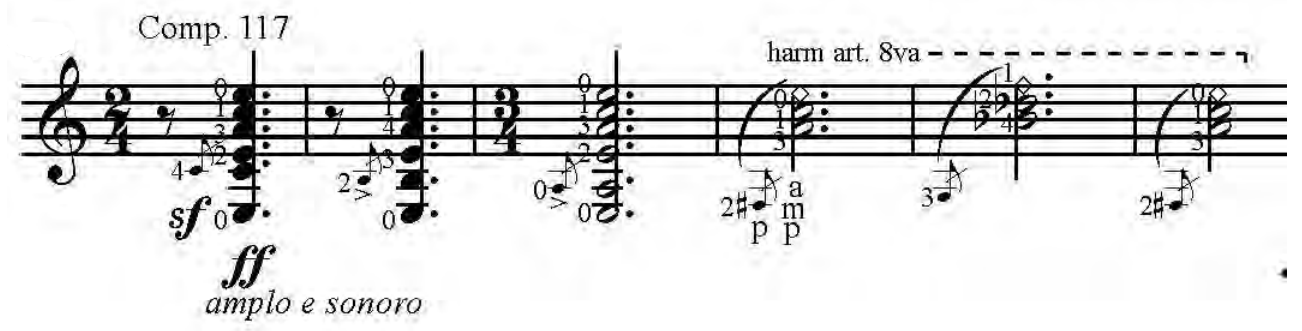

Exemplo 416: $V^{o}$ Estudo, compasso 117.

O brusco encerramento da obra também propicia várias visões, representadas lado a lado no exemplo 417. A da esquerda segue a me de BL mas especifica a $m d$, a central inclui um ligado na segunda corda e a terceira parte da quinta casa, colocando o último acorde nos bordões. A articulação do mesmo é factível de ser realizada de diferentes maneiras: pelo grupo $m-i-p$, pelo indicador ou polegar totalmente escovados ou pelo escovamento parcial do anelar nas duas notas agudas junto ao polegar cuidando da nota grave.
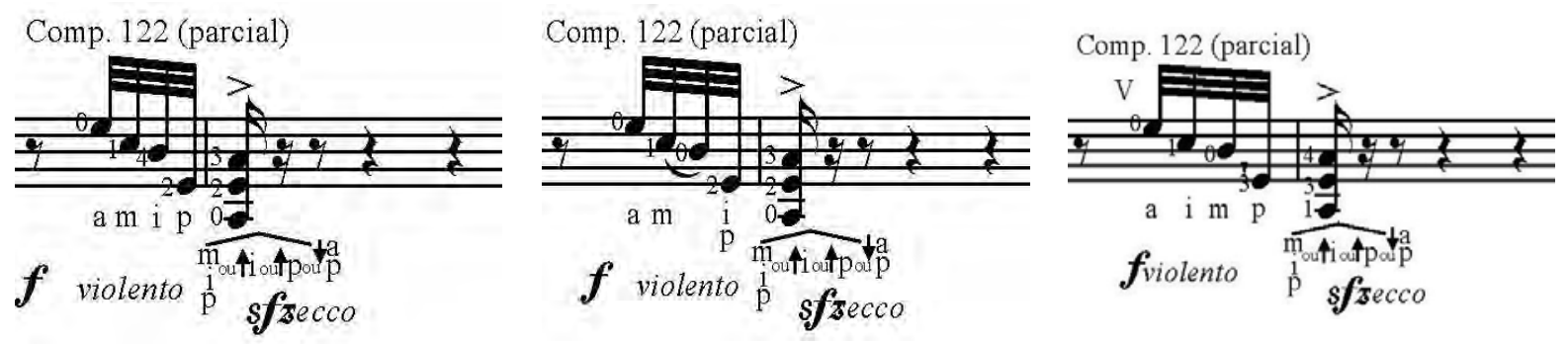

Exemplo 417: $V^{o}$ Estudo, compasso 122. 


\section{6: VI Estudo "Assai vivo"}

Talvez um dos estudos de maior "sabor" popular e festivo da série (juntamente aos $I I^{\circ}$ e $I X^{o}$ Estudos) também se destaca pelo tratamento inteligente dado ao tema principal, que reaparece várias vezes sempre com textura distinta. $\mathrm{Na}$ primeira exposição, ele aparece em arpejo com nota grave fixa a cada dois compassos. Sua longa progressão harmônica descendente associada a natureza de seu perfil melódico cria dificuldades para se estabelecer padrões que funcionem como um todo para o trecho. É natural portanto, que os arpejos acabem sendo distribuídos ora em três e ora em quatro cordas.

A digitação BL não é uma exceção a esta regra e embora possua qualidades, recorre a alguns recursos avançados (e até arriscados) como pestana com dedo 4 (compasso 2), trocas súbitas de corda com o dedo 2 (compassos 3 e 4) e abertura sem preparação (compasso 4).

\section{$\mathrm{VI}^{\circ}$ ESTUDO}

Fingered he Carlos Barbosu-Lima Assai vivo $(d=92)$
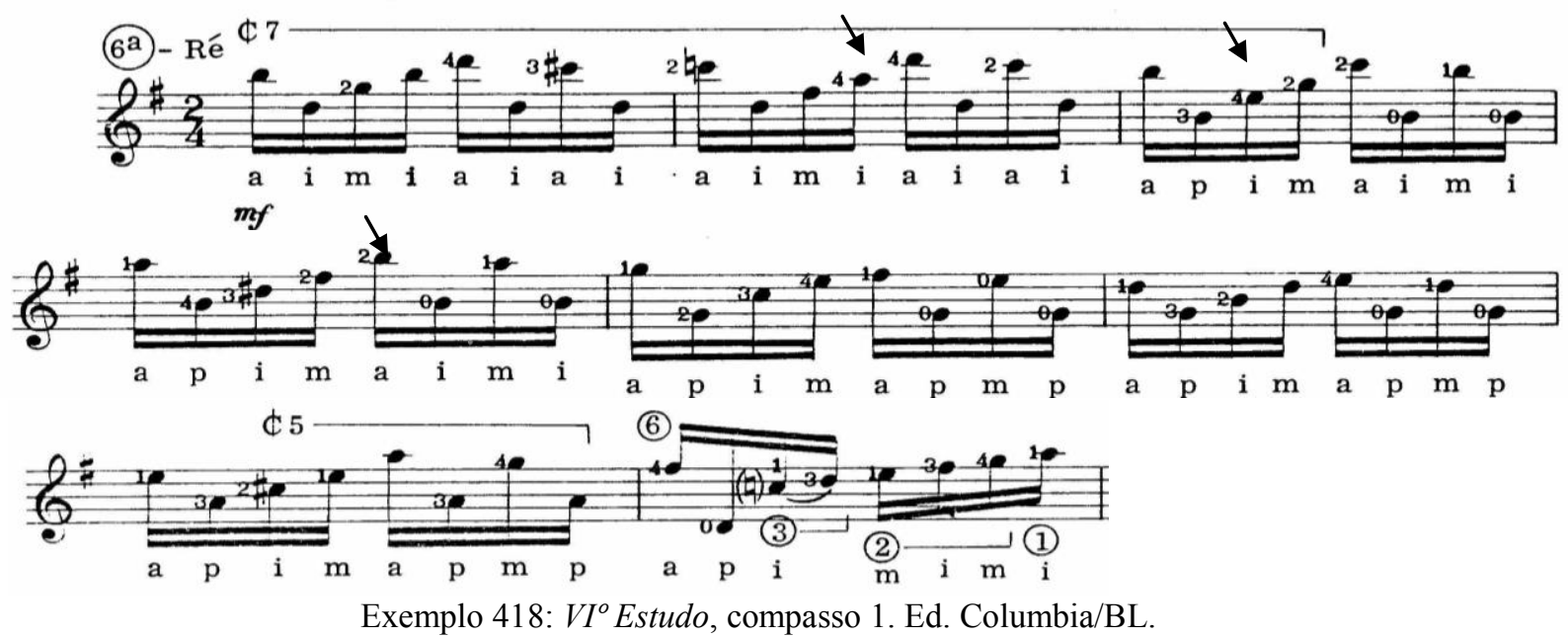

Nossa primeira tentativa de unificação adota o padrão $\mathrm{BL}$ em três cordas (compasso 1) criando uma troca de posição por tempo (nos compassos 2 a 4) e aberturas e saltos (compassos 2, 3 e 4), havendo um final alternativo no exemplo seguinte. 


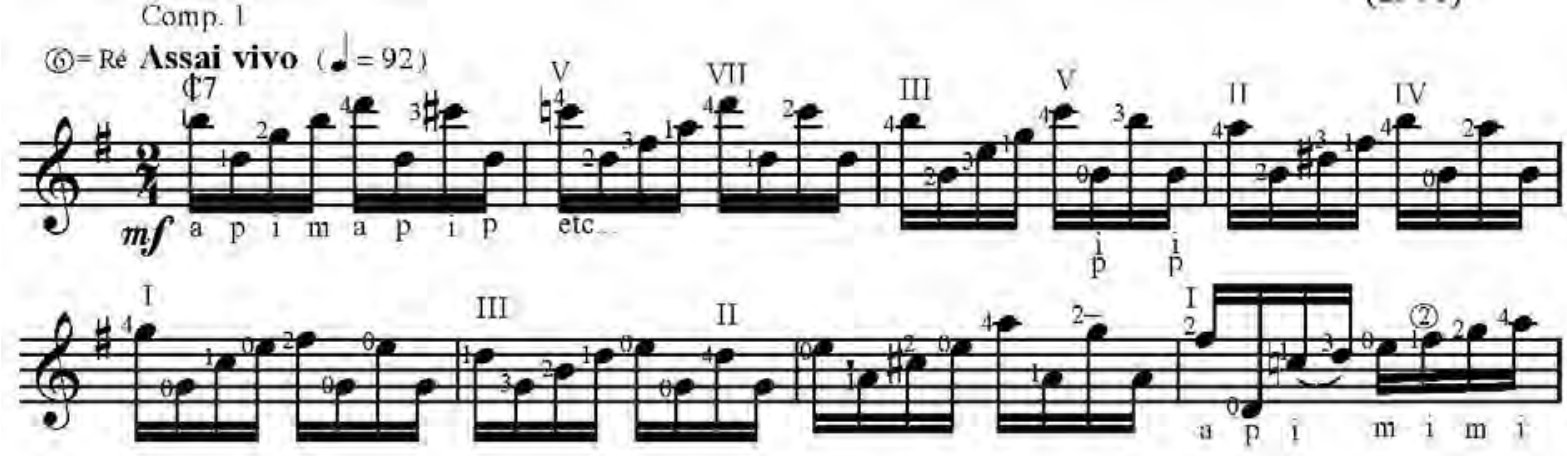

Exemplo 419: VI Estudo, compasso 1.

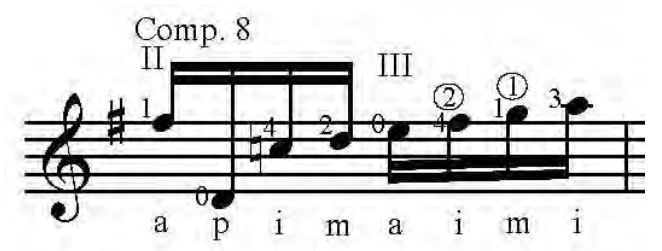

Exemplo 420: $V I^{\circ}$ Estudo, compasso 1.

A outra estratégia ainda em três cordas foi manter ${ }^{105}$ a digitação BL até o segundo compasso, mas com inserção experimental de ligados, que se revelaram sem muito custo-benefício por gerar grandes aberturas (compassos 3 e 5) e ampliar o uso da pestana de dedo 4 (compassos 2, 5 e 7).
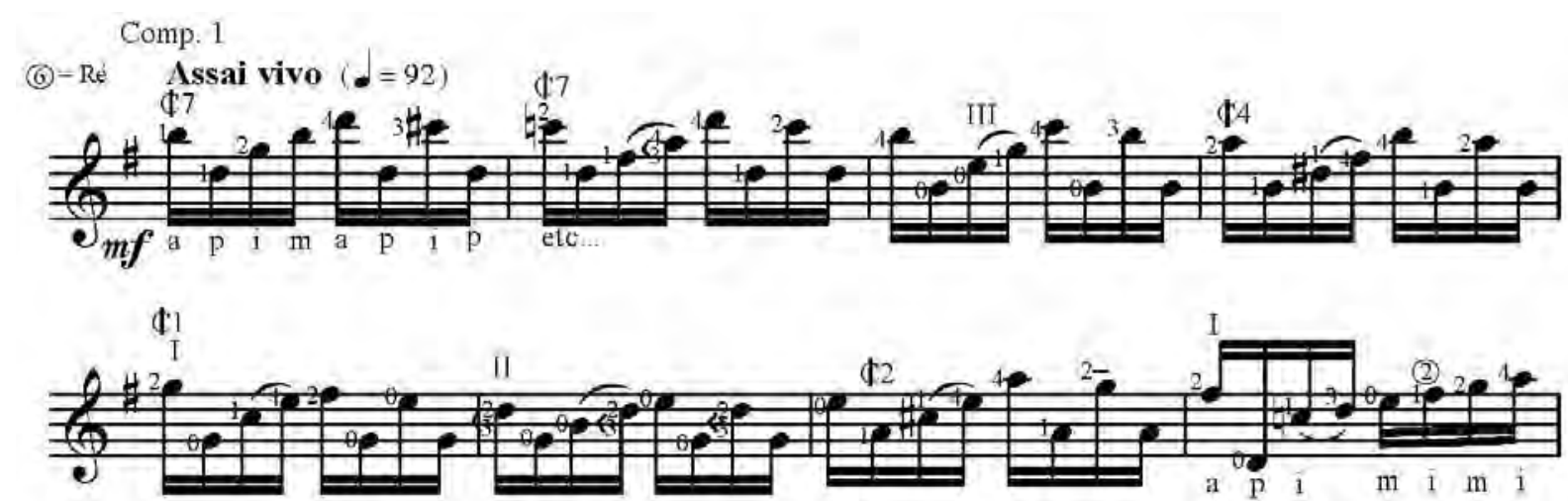

Exemplo 421: VI Estudo, compasso 1.

Abdicando de uma padronização severa, o exemplo seguinte busca outra região para o início (apertada porém factível) e distribuí os primeiros quatro arpejos em quatro cordas com pestanas eventuais. Com isso, a melodia não reside sempre na primeira corda, passando por vezes para a segunda, permitindo dessa forma a repetição por deslizamento (indicado por seta) de alguns dedos aproveitando que o toque apoiado (indicado em sublinhado) já o coloca na próxima corda alvo.

105 item "deixar como está" do checklist de Osborn. 

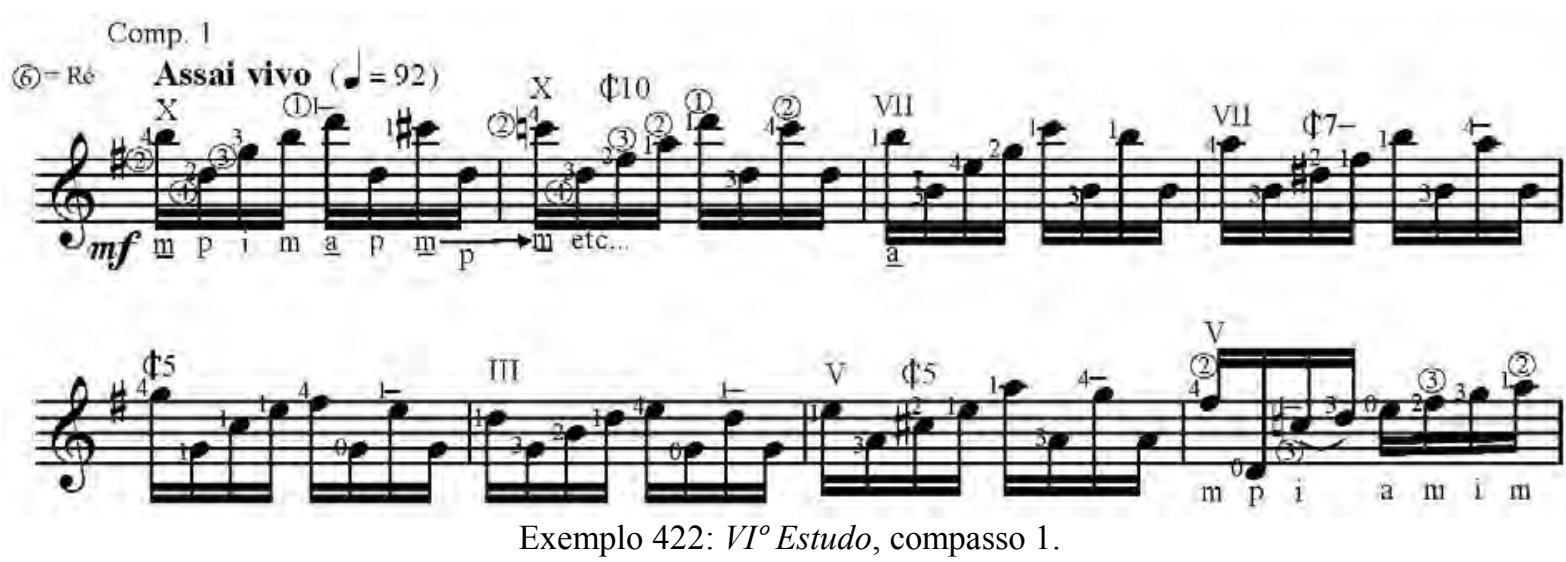

$\mathrm{O}$ último exemplo do trecho retorna à digitação BL como fonte de inspiração e a une com compassos dos exemplos anteriores, retocando dessa forma alguns de seus problemas mas exigindo em troca o uso reincidente do dedo 1 (compassos 3 a 7), um pequeno e sobreponível desafio.

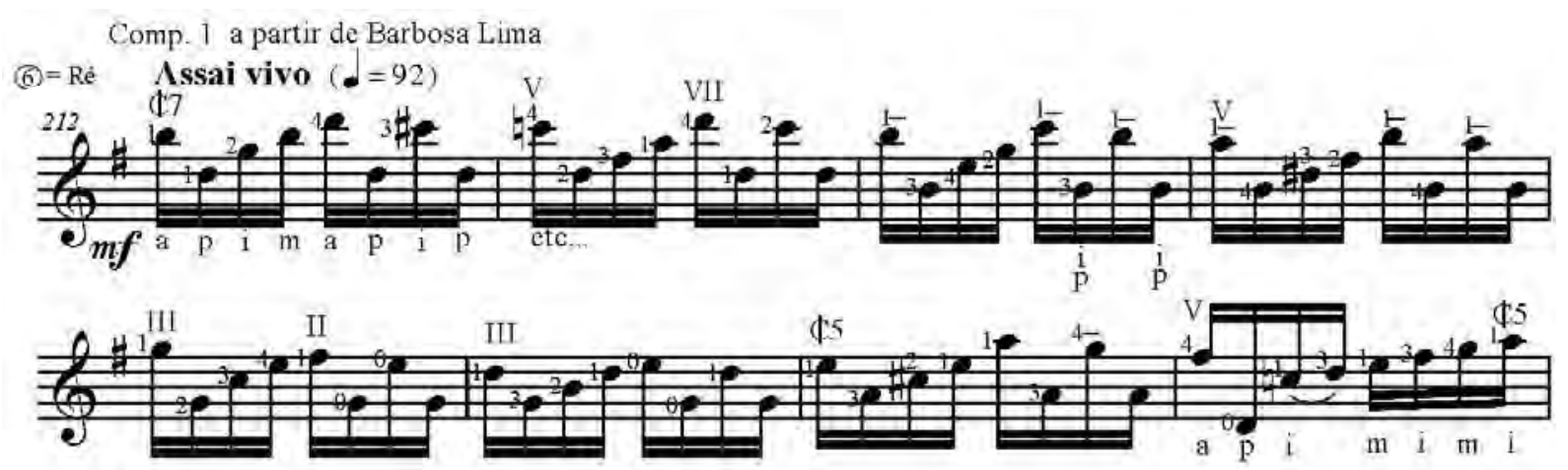

Exemplo 423: VI Estudo, compasso 1.

Este tema recebe, a partir do compasso 9, uma repetição levemente variada. Levemente se aplica apenas a questões composicionais, já que os acordes e notas são exatamente os mesmos. Do ponto de vista do intérprete, a variação rítmica por meio de inserção de nota dupla dentro do arpejo (que já dissemos tratar-se de reincidente na obra violonística de Mignone) configura aspecto bastante complicador da $m d$, necessitando de dedicado estudo. Do ponto de vista do Pensamento Divergente, encontramos apenas uma segunda digitação funcional ao trecho, a qual demonstramos apenas em sua primeira aparição, assim como a de BL:

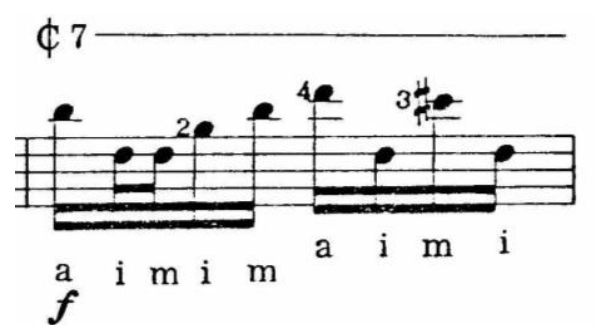

Exemplo 424: VI ${ }^{\circ}$ Est. 6, comp. 9. Ed. Columbia/BL.

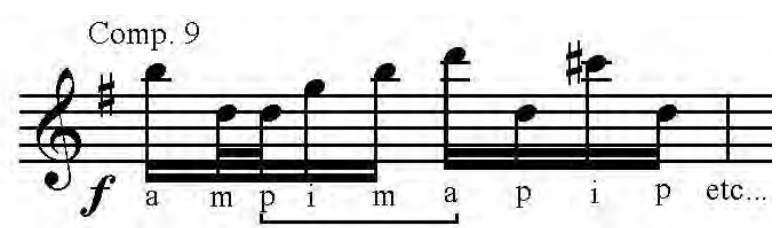

Exemplo 425: VI ${ }^{o}$ Est. 6, comp. 9. 
Os dois últimos compassos da seção são modificados ${ }^{106}$ para encaminhá-la a uma nova textura, recebendo versões que realizam diferentemente essa transição e entre regiões distintas do instrumento. Nesse sentido a abordagem de BL liga a quinta posição à segunda, com boa sugestão de ligados mas com abertura na primeira corda. $\mathrm{O}$ exemplo 427 se inicia e finaliza na segunda posição, ainda com mesma abertura de BL, mas envolvendo outros dedos e aproveitando corda solta. $\mathrm{O}$ exemplo final liga a quinta posição à quarta, sem aberturas, mas com uma compressão. É preciso também ressaltar a maior a incidência de notas repetidas no compasso 15 configurando aspecto dificultante.
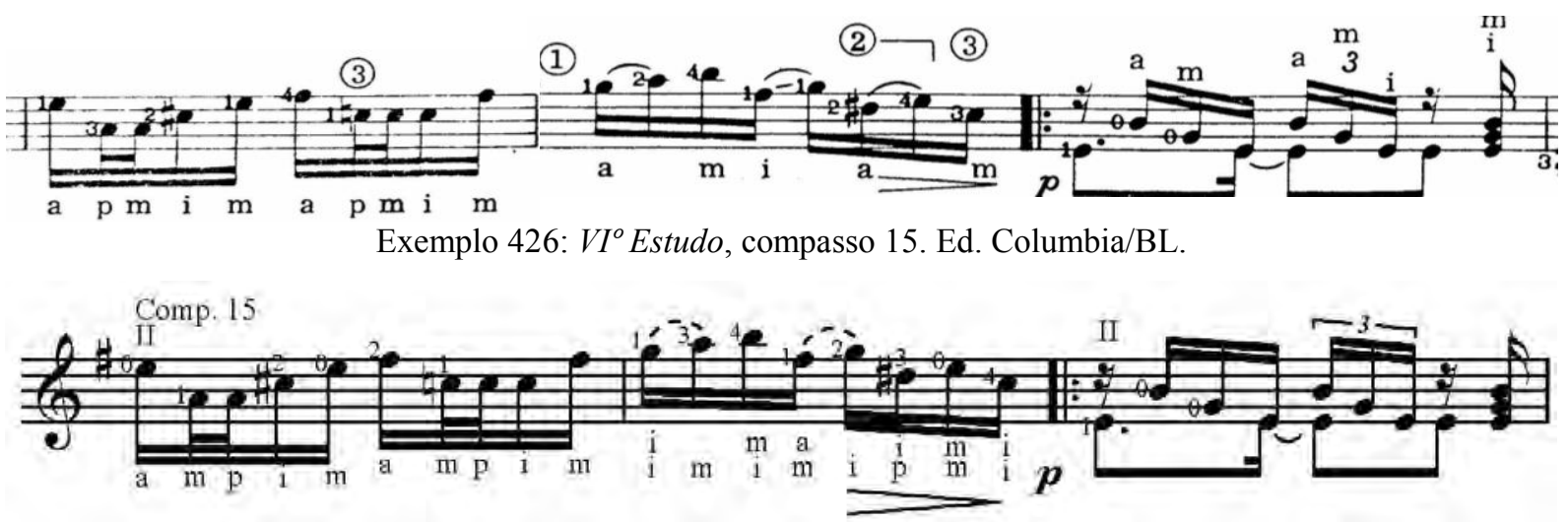

Exemplo 427: VI $I^{\circ}$ Estudo, compasso 15.

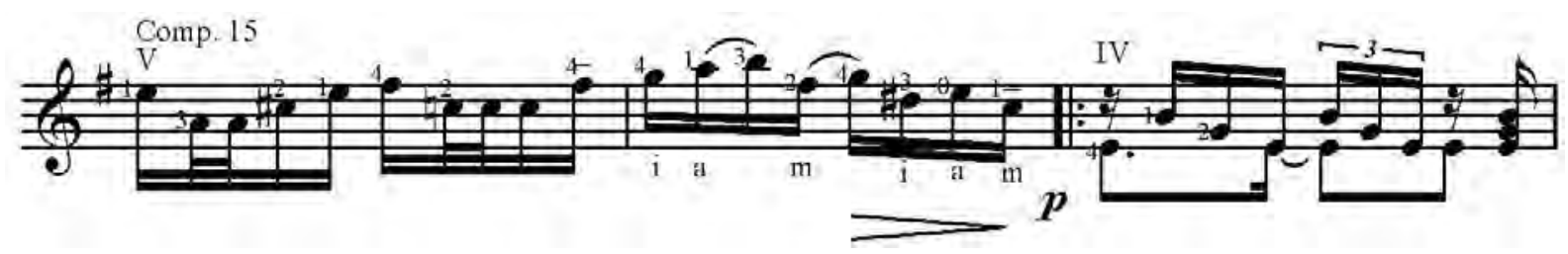

Exemplo 428: $V I^{\circ}$ Estudo, compasso 15.

A segunda seção trabalha com novo padrão de arpejos também com ocorrência de notas duplas e onde os quatro dedos da $m d$ trabalham em apenas três cordas. Este tipo de compressão de $m d$ reincidente em Mignone não é muito usual na literatura violonística e não está muito bem absorvido pelos intérpretes configurando assim um dos possíveis entraves à maior disseminação do ciclo de estudos ora analisado.

A digitação de BL se inicia na segunda posição e privilegia o uso de pestanas (exemplo 429), aspecto que é modificado ${ }^{107}$ no exemplo 430. Já o exemplo 431 se inicia pela quarta posição, mas segue a maior parte da digitação BL com suas pestanas. $\mathrm{O}$ últimos dois compassos das versões oferecem diferenças relevantes na utilização a $m d$, ainda que usando os mesmos ligados.

\footnotetext{
${ }^{106}$ verbo do checklist de Osborn.

${ }^{107}$ verbo do checklist de Osborn.
} 
No aspecto interpretativo esta seção permite um destaque da voz inferior do arpejo com o polegar ou da voz superior com o anelar, ou até mesmo uma alternância dessas ênfases acompanhando as trocas de harmonia, a fim de as sublinhar.

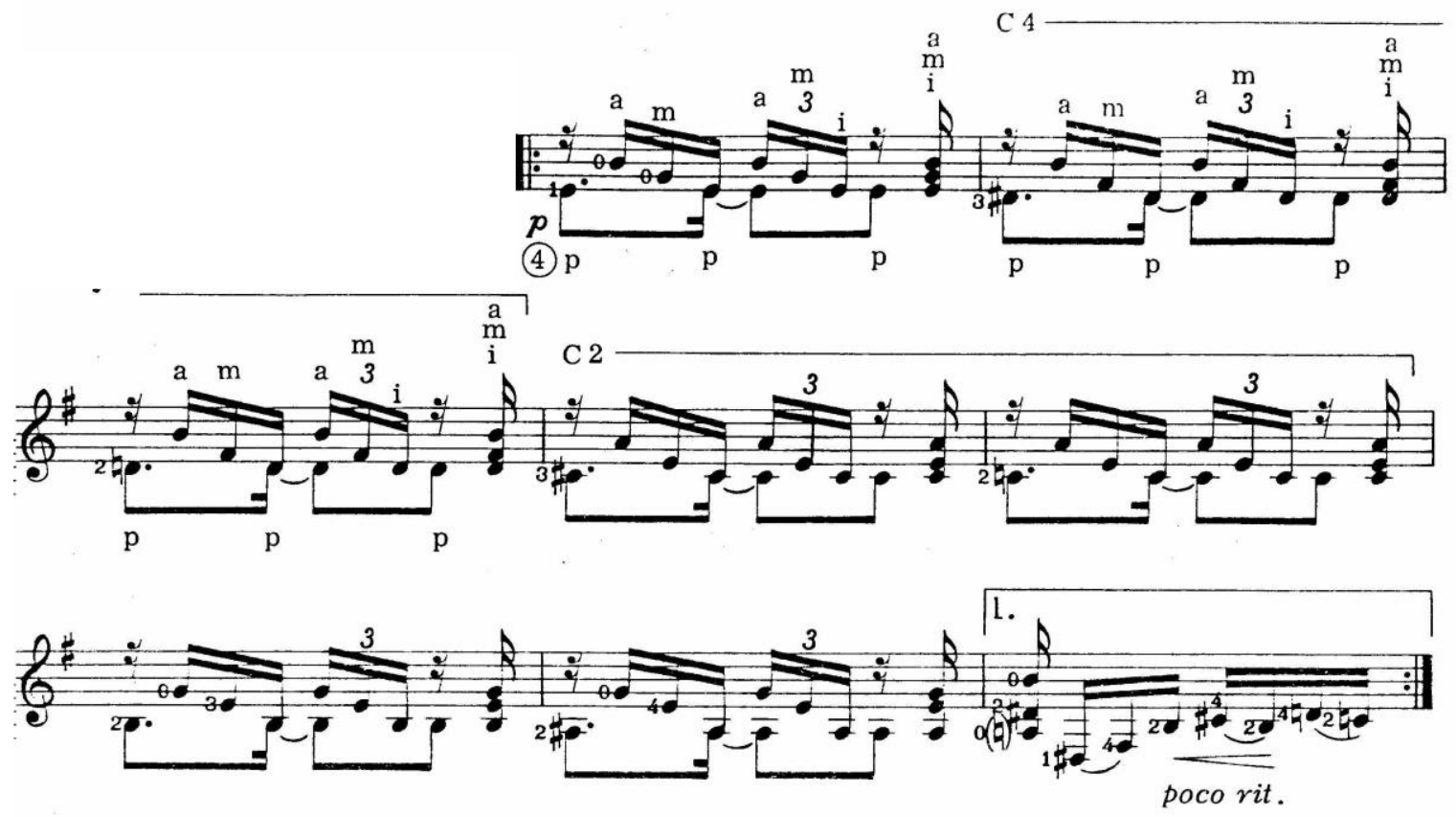

Exemplo 429: VI Estudo, compasso 17. Ed. Columbia/BL.

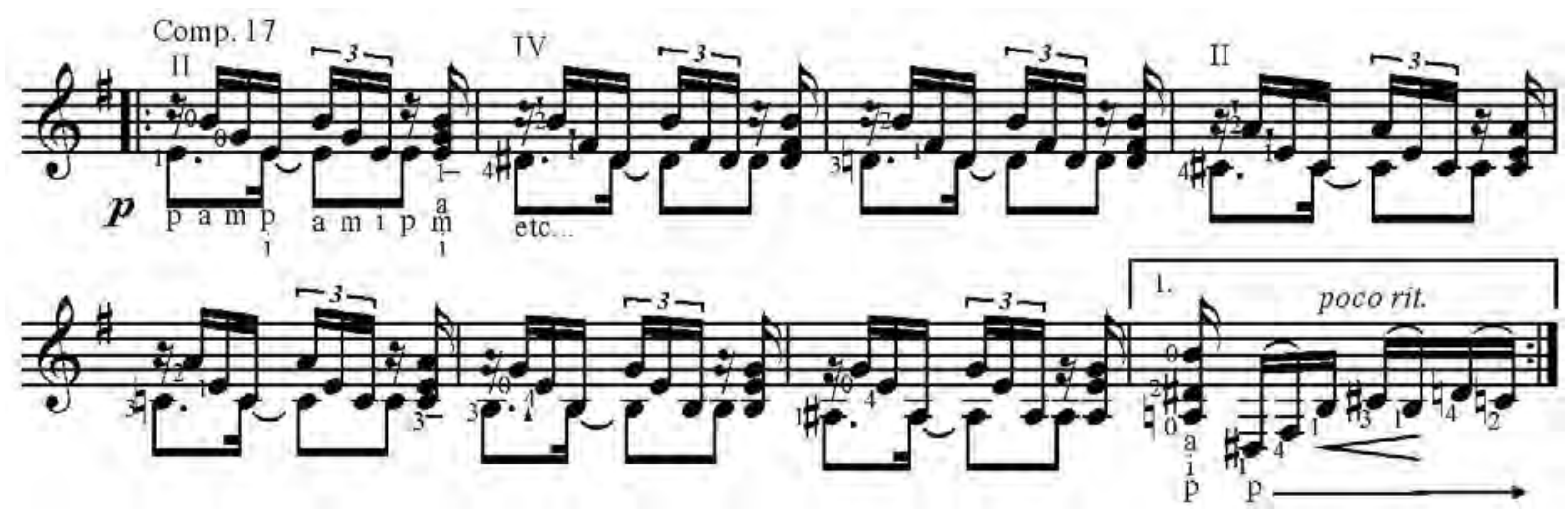

Exemplo 430: VI Estudo, compasso 17.

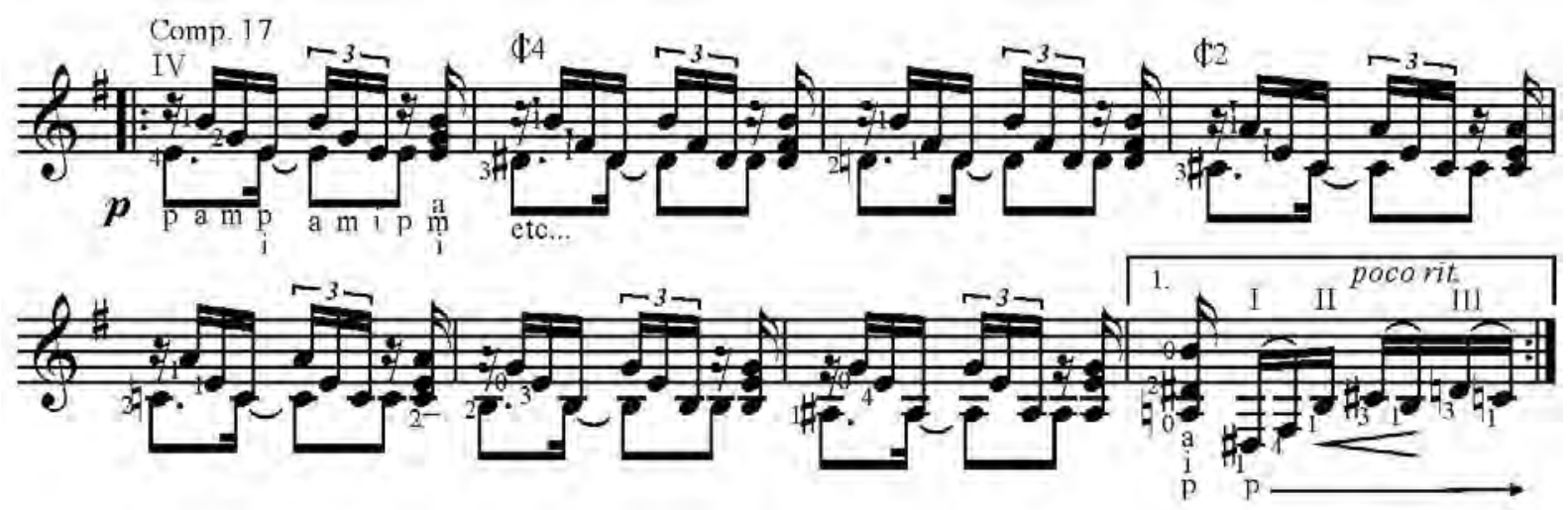

Exemplo 431: VI Estudo, compasso 17.

Alguns poucos compassos merecem um acréscimo opcional de notas a fim de garantir uma padronização da $m d$ e prover assim maior conforto ao intérprete. Esse tipo 
de acréscimo é tão lógico que o próprio Barbosa-Lima assim o faz no compasso 25 , se compararmos o manuscrito à edição Columbia.

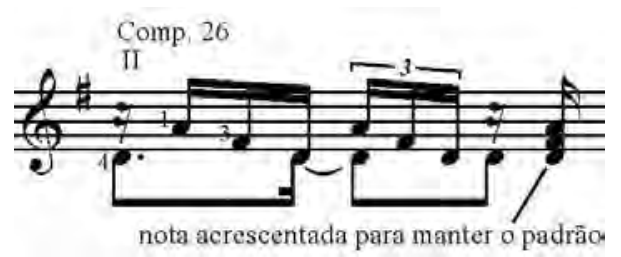

Exemplo 432: VI Estudo, compasso 26.

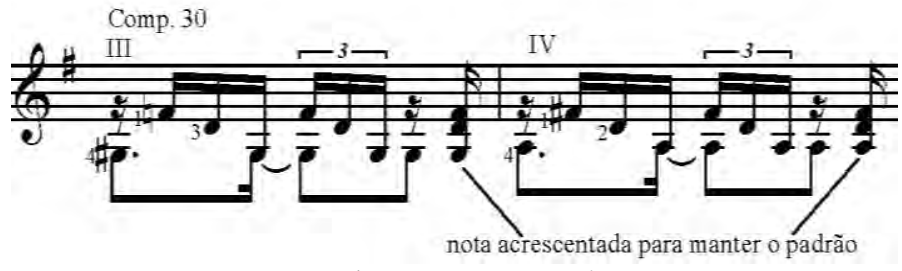

Exemplo 433: VI Estudo, compasso 30.

A sequência desta seção acaba por fim aplicando o mesmo padrão de arpejo à quatro cordas do instrumento, intensificando a textura. Há presença de vários acordes paralelos no trecho para os quais apresentamos apenas uma única versão alternativa que os aproveita com translados de dedos eventuais, mas mais que isso, mantém todos os acordes nas quatro cordas graves do instrumento, com o objetivo de fixar e unificar o funcionamento da $m d$ para o trecho e não necessitar de aberturas nesta mão como na digitação BL. O último compasso da casa 1 aproveita as cordas duplas sugeridas por BL mas sofre uma pequena mas transformadora mudança: a simples inversão das cordas envolvidas no uníssono propicia um padrão mais confortável de $m d$ que age em movimento contrário ao resto da seção e sem recorrer ao dedo anelar, provendo um rápido descanso antes do ritornello. Outros compassos recebem uma pequena simplificação de dedos evitando o uso do dedo 4 nos bordões.
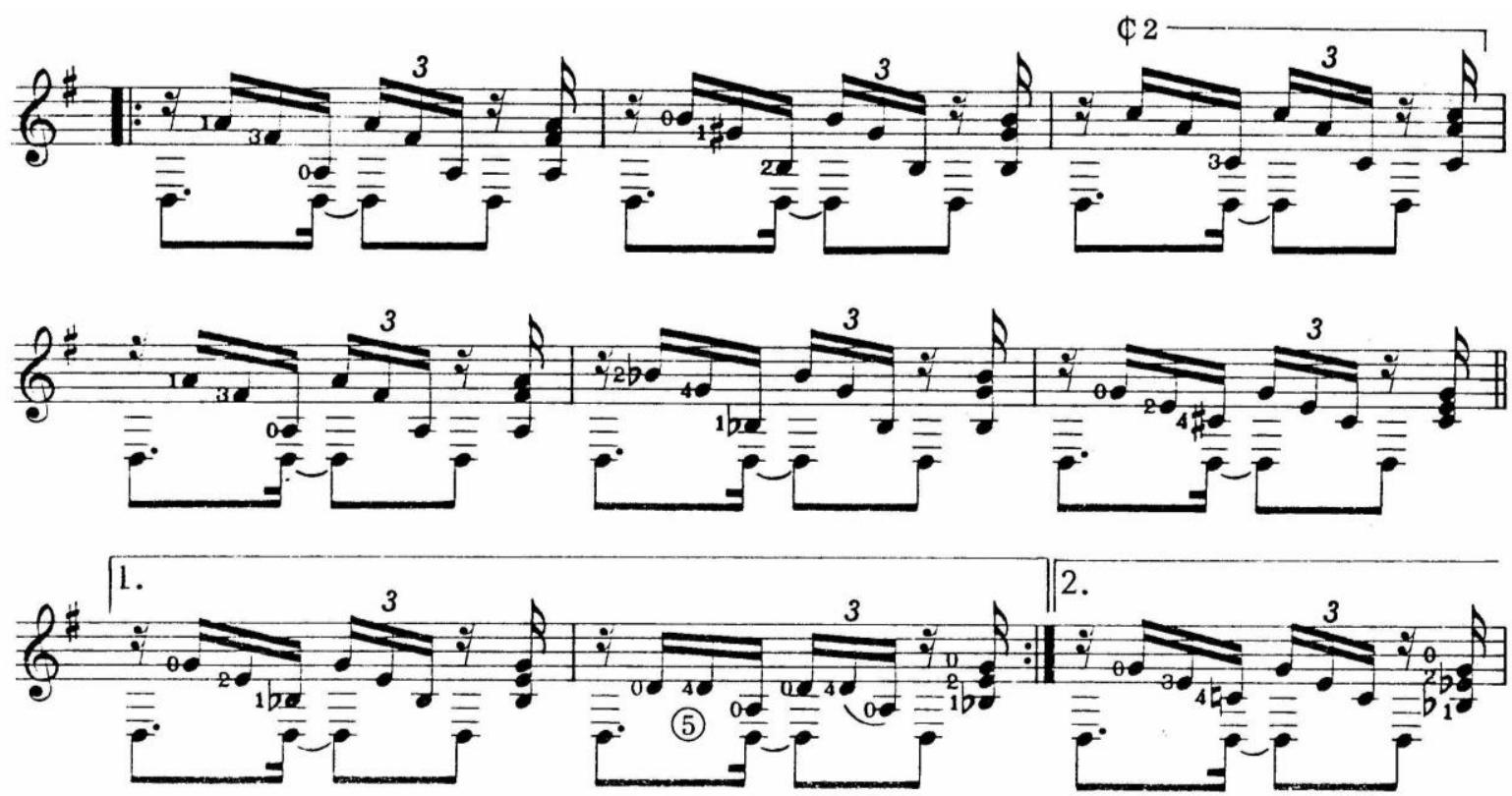

Exemplo 434: VI Estudo, compasso 34. Ed. Columbia/BL. 

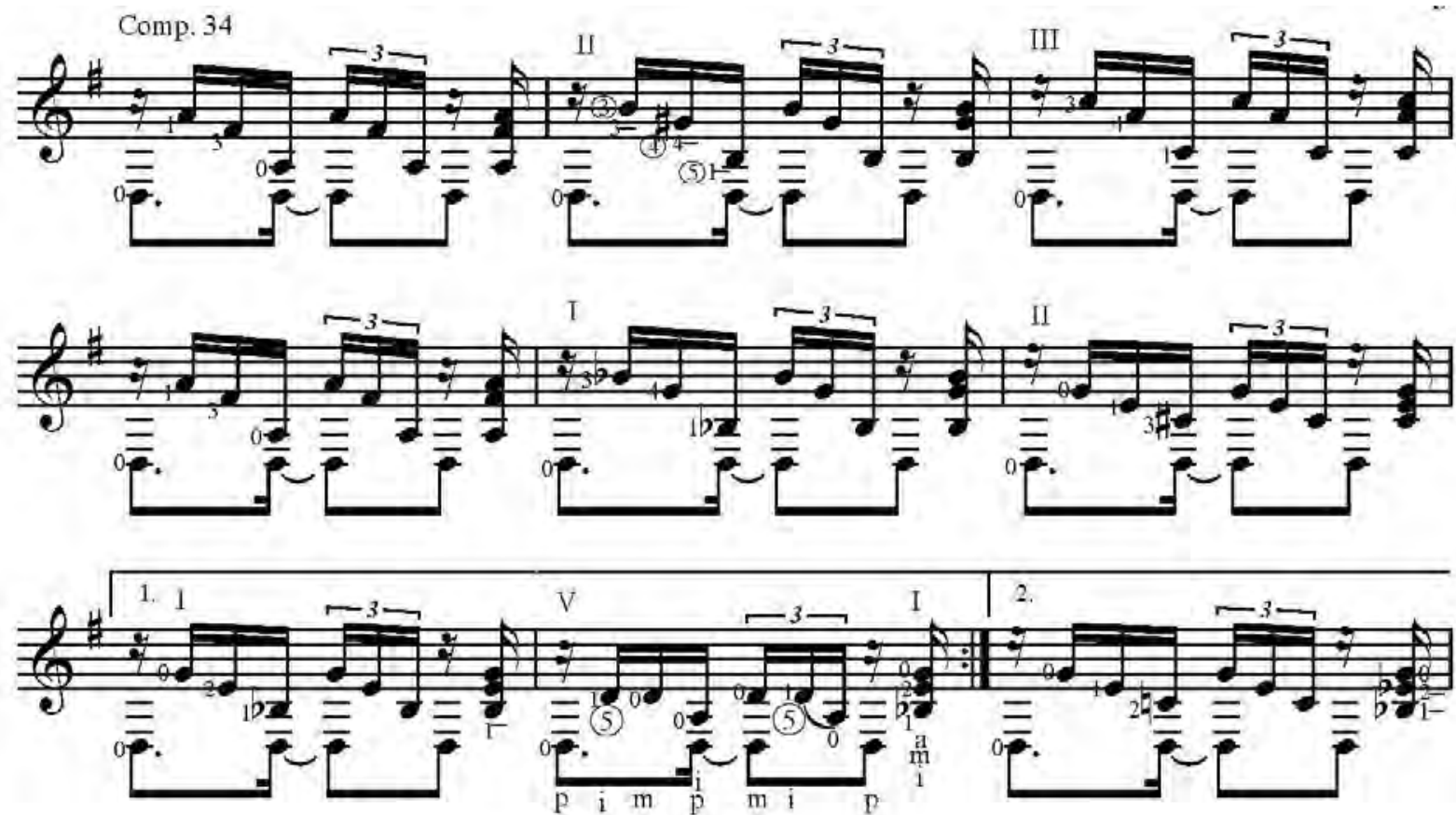

Exemplo 435: VI $I^{\circ}$ Estudo, compasso 34.

Segue-se um momento cadencial inicialmente ascendente em arpejos que subitamente mudam de padrão. BL privilegia os dedos 2, 3 e 4 no início do trecho e posteriormente ascende principalmente pelas cordas internas (segunda, terceira e quarta) valendo-se das cordas soltas para o salto à quinta casa. $\mathrm{O}$ exemplo 437 substitui alguns dedos do início e após as cordas soltas, segue subindo pelas mesmas até o desfecho. Os exemplos 438 e 439 antecipam em alguns tempos o salto por cordas soltas seguindo por caminhos distintos, o primeiro com final igual a BL e o último aproveitando-se de cordas soltas em posições avançadas.

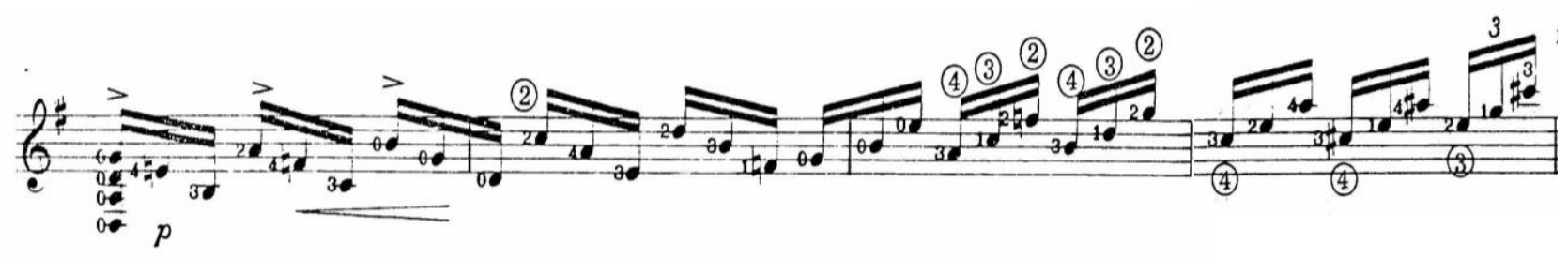

Exemplo 436: VI Estudo, compasso 43. Ed. Columbia/BL.

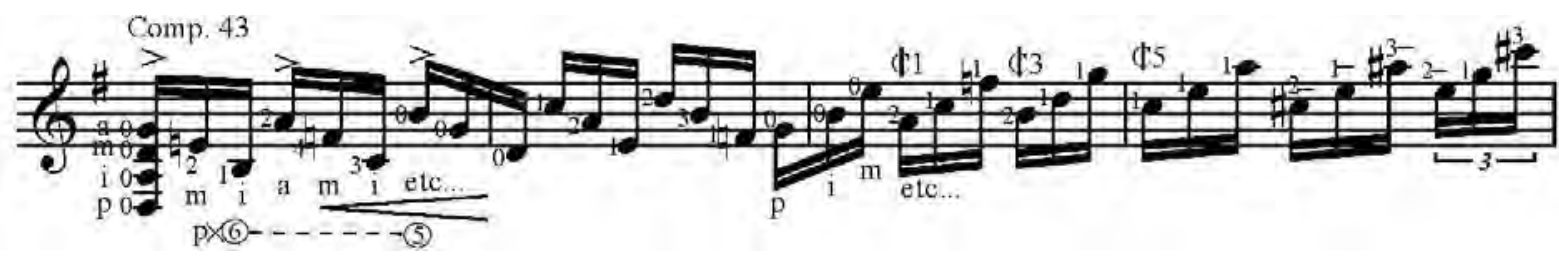

Exemplo 437: VI Estudo, compasso 43.

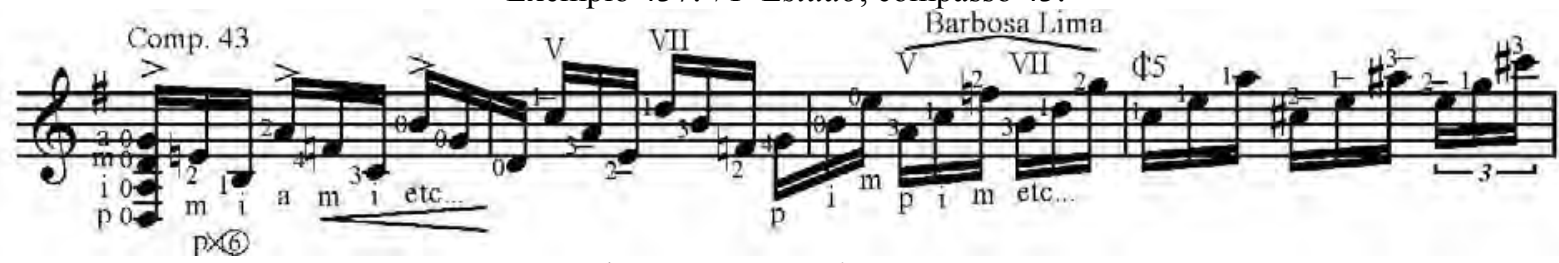

Exemplo 438: $V I^{\circ}$ Estudo, compasso 43. 


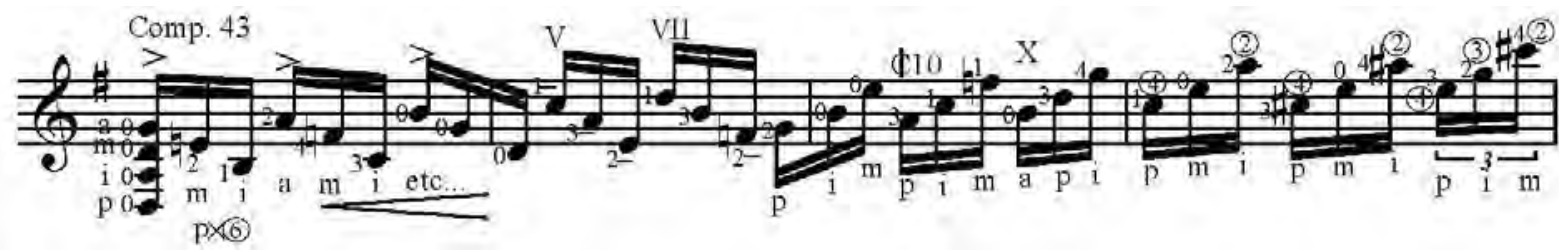

Exemplo 439: $V I^{\circ}$ Estudo, compasso 43.

$\mathrm{O}$ ápice dessa cadência permanece ${ }^{108}$ com me idêntica à de $\mathrm{BL}$, mas recebe várias possibilidades de $m d$, a mais tradicional no exemplo 440, com rasgueios no $441 \mathrm{e}$ com escovamento do anelar no 442.

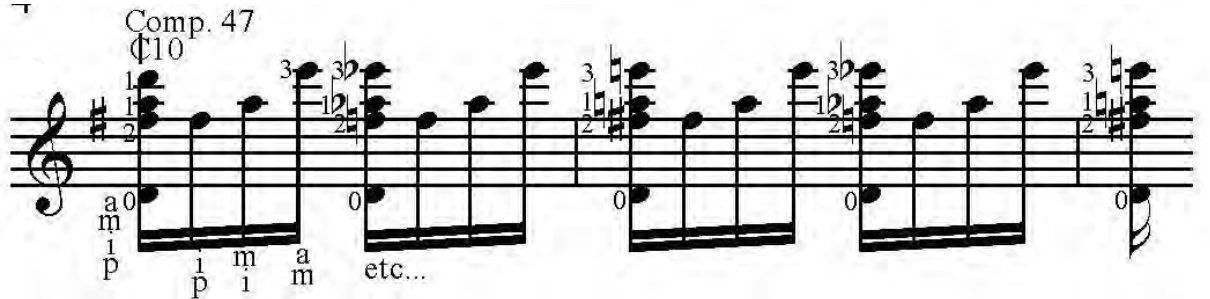

Exemplo 440: $V I^{\circ}$ Estudo, compasso 47.

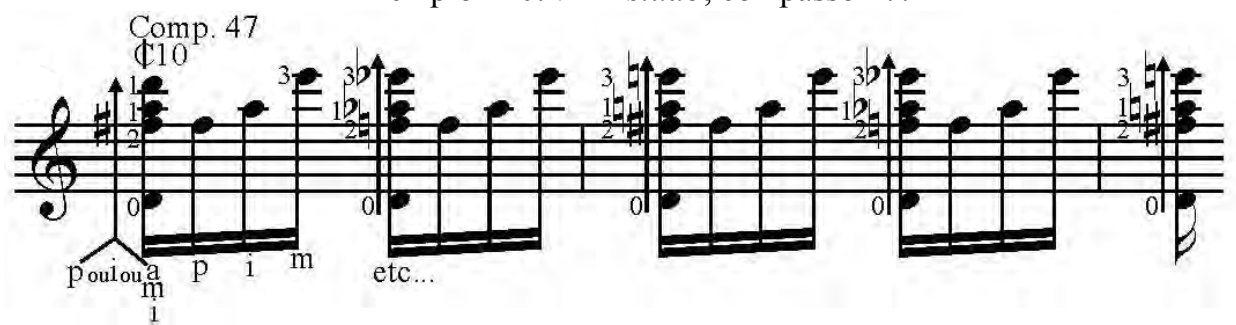

Exemplo 441: VI Estudo, compasso 47.

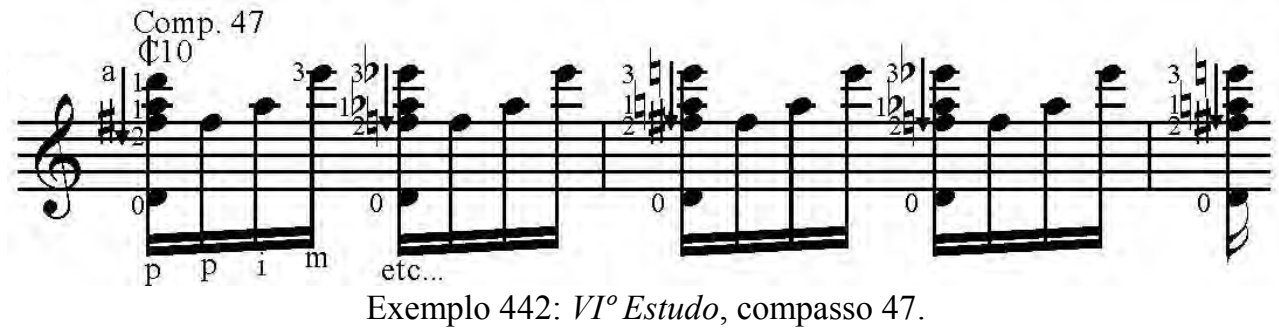

Uma pequena escala conectora, ainda na cadência, recebe uma versão com um único dedo diferente de BL e outra descendo pela primeira corda, ambas com intuito de ligar-se melhor às versões do próximo trecho a ser discutido.

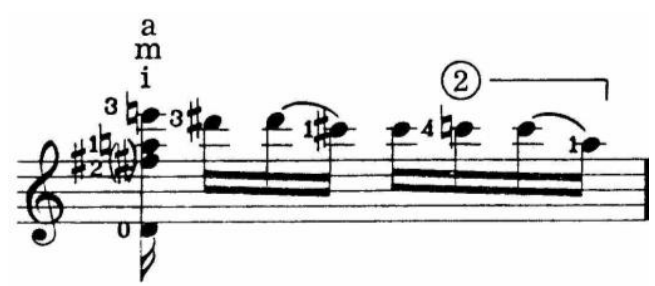

Exemplo 443: VI Estudo, compasso 49. Ed. Columbia/BL.

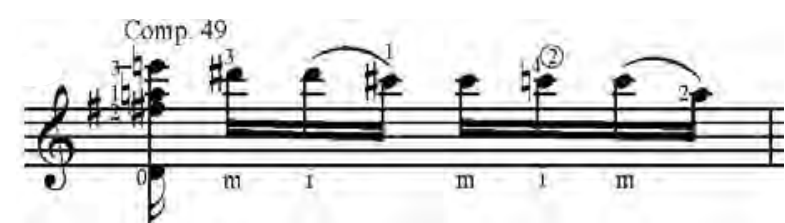

Exemplo 444: VI ${ }^{o}$ Estudo, compasso 49.

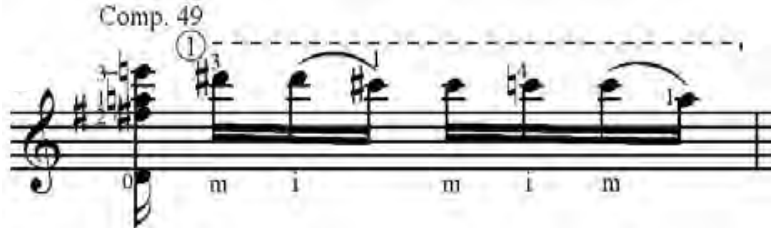

Exemplo 445: VI Estudo, compasso 49.

108 item "deixar como está" do checklist de Osborn. 
Esta pequena progressão em ritornello não tem solução tão simples quanto sua aparência. BL opta sabiamente por manter o dedo 2 como guia na segunda corda, auxiliado pelo dedo 4 no primeiro compasso e pelo dedo 3 no último, porém com uma custosa compressão em um dos acordes.

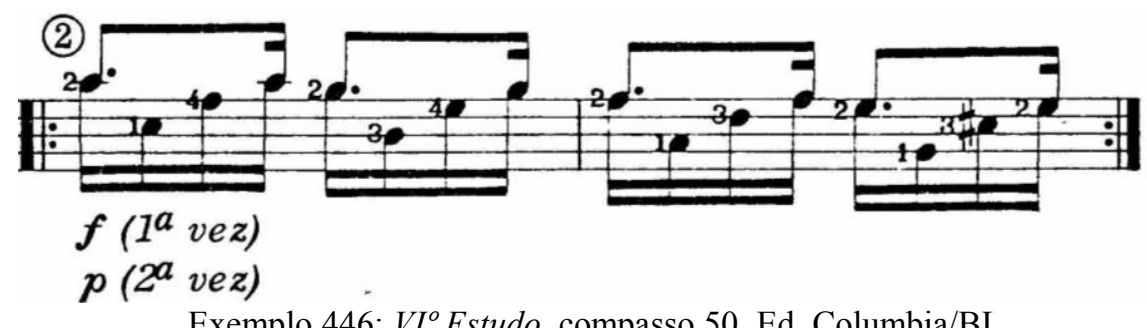

Exemplo 446: VI ${ }^{o}$ Estudo, compasso 50. Ed. Columbia/BL.

A nossa primeira abordagem mantém somente o dedo 2 como guia exigindo maiores mudanças dos outros dedos, mas com mais conforto, embora ainda prescreva uma meia-pestana na sétima casa por cima do dedo 2 , em compressão menor que a anterior. Essa versão pode incluir um portamento anacrústico antes de cada translado do dedo 2 em efeito humorístico, mas julgamos não ser necessário grafá-lo. Ainda na mesma posição, o exemplo 348 coloca pestanas em todos os acordes e as arrasta progressivamente enquanto o exemplo 349 parte de abordagem diferente na quinta posição para utilizar somente as primas nesse trecho, mas com translados de pestana similares auxiliados pelo dedo 3 como guia.

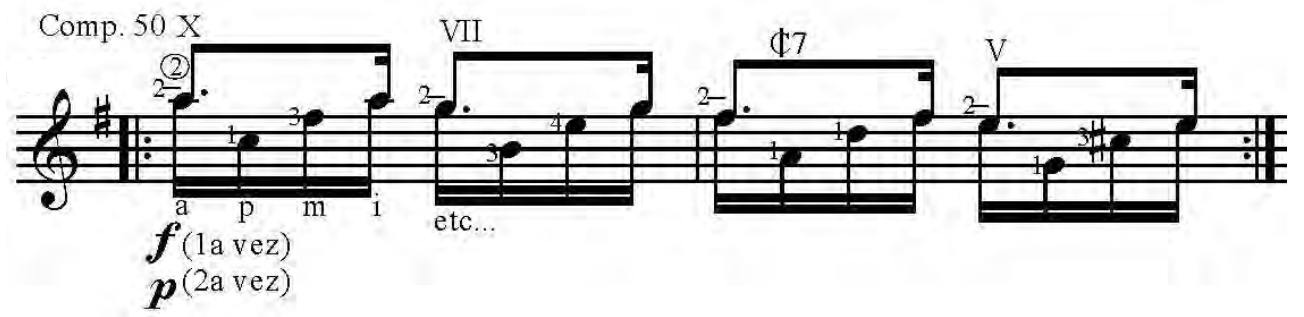

Exemplo 447: VI Estudo, compasso 50.

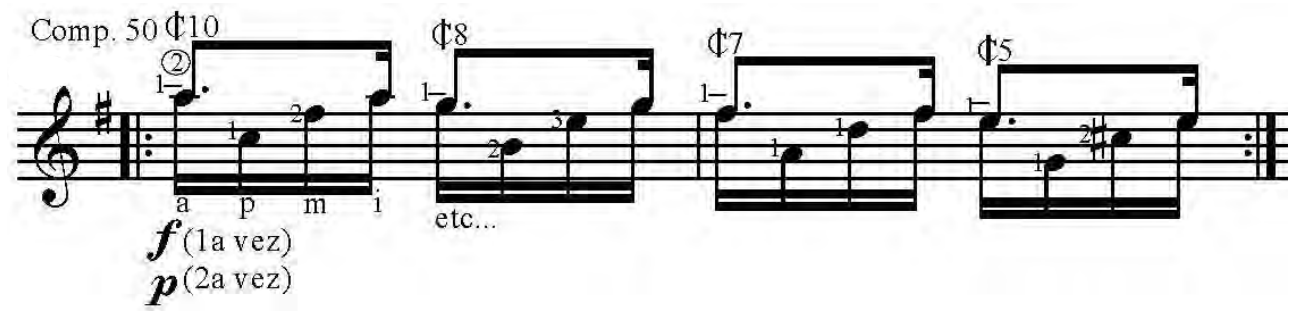

Exemplo 448: VI Estudo, compasso 50.

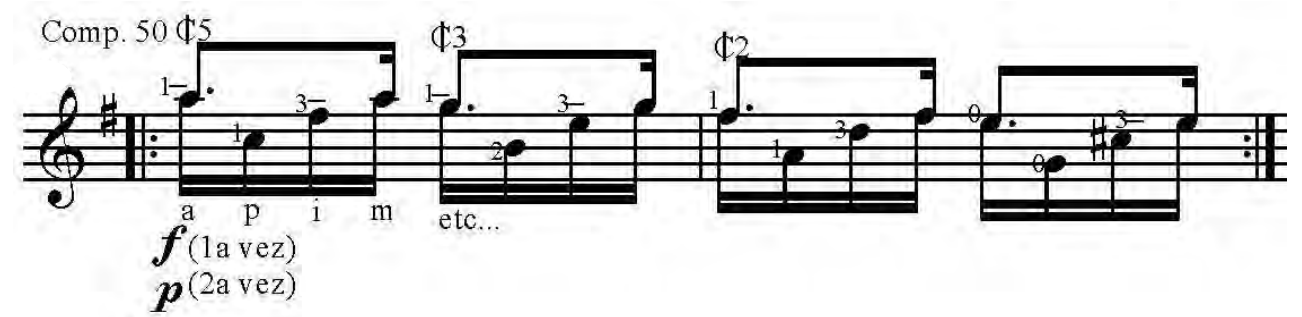

Exemplo 449: VI Estudo, compasso 50. 
Após alguns compassos Mignone retoma o tema inicial com configuração completamente diferente provendo-lhe maior caráter "amaxixado" ao colocar a melodia no baixo acompanhado por acordes secos em figuração bastante brasileira e violonística. Os trechos passíveis de aplicação do Pensamento Divergente começam a partir do compasso 59, onde o padrão alcança a tessitura grave o instrumento com abertura e ainda arpeja o acorde no compasso seguinte. $\mathrm{O}$ exemplo 451 apenas substitui um dedo do primeiro compasso e especifica as várias opções de $m d$ para o arpejo, enquanto o exemplo 452 cria um dedo guia no primeiro compasso para levar a um ligado na cabeça do arpejo na quinta posição. Já o exemplo 453 oferece uma versão facilitada do compasso 59 ao excluir uma nota do acompanhamento que se ligaria ao exemplo anterior.

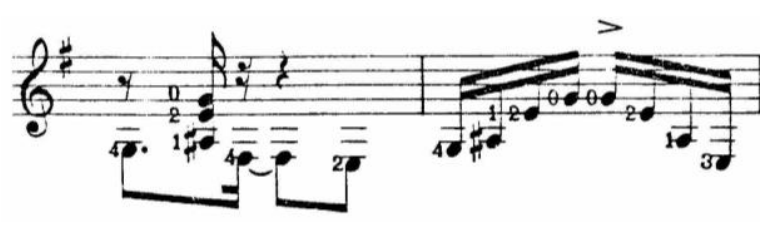

Exemplo 450: VI Est., comp. 59 Ed. Columbia/BL.

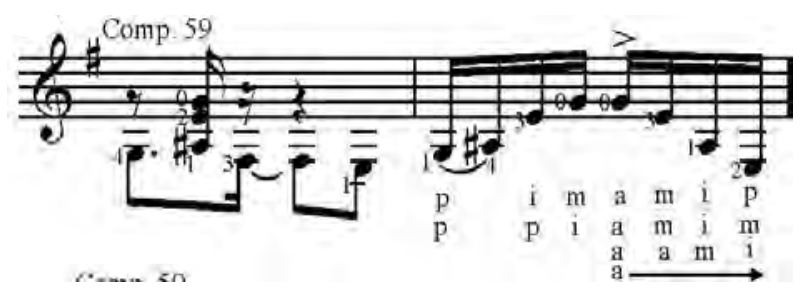

Exemplo 452: $V I^{\circ}$ Est., compasso 59.

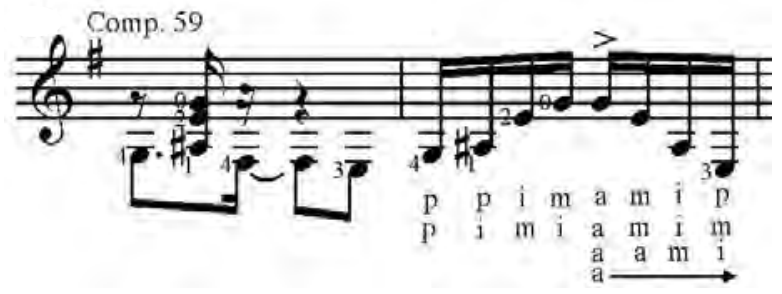

Exemplo 451: VI Est., comp. 59.

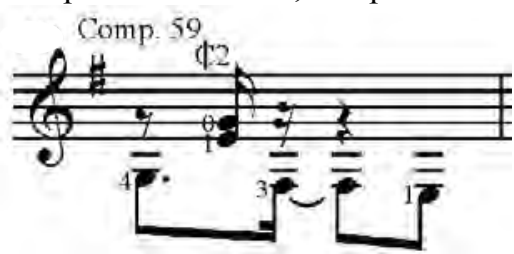

Exemplo 453: VI ${ }^{o}$ Est., comp. 59. Ossia.

Segue-se, no compasso 63, uma repetição com baixo ornamentado e ritmo diferente do acompanhamento. Nossa versão alternativa (ex. 455) insere ligados regulares no baixo para deixá-lo factível de ser executado apenas com o polegar para sublinhar seu caráter deveras chorão.

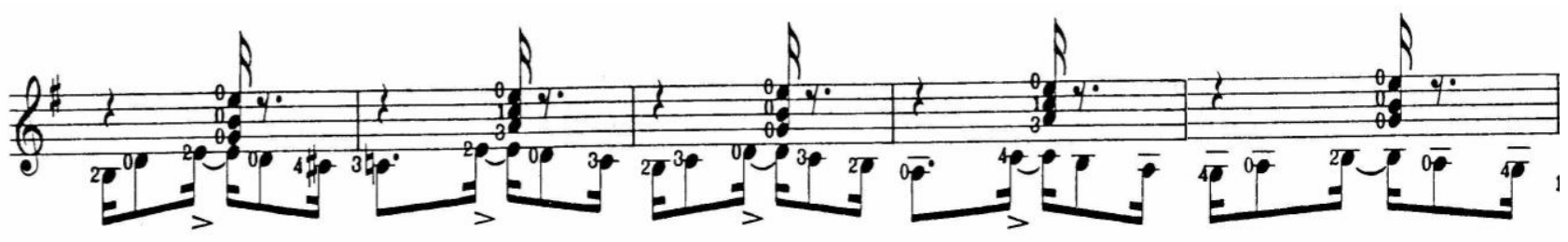

Exemplo 454: VI Estudo, compasso 63. Ed. Columbia/BL.

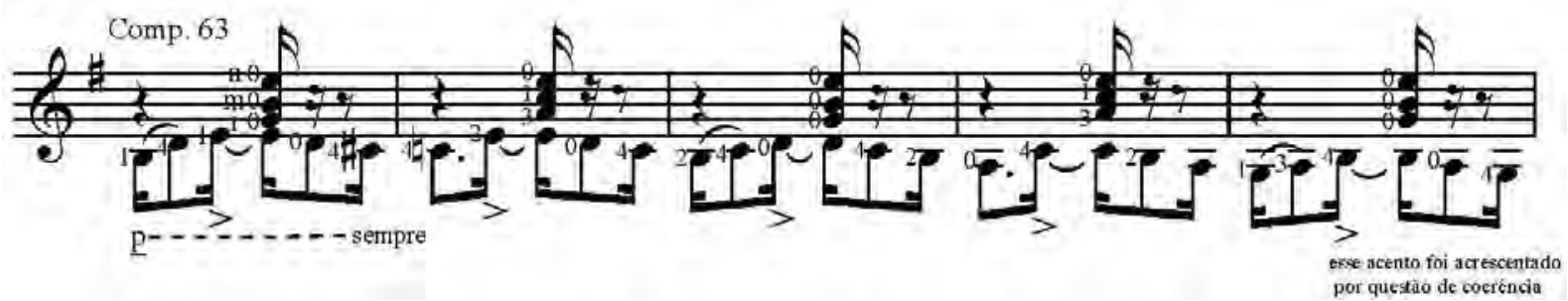

Exemplo 455: VI Estudo, compasso 63. 
Uma nova cadência inicia-se com o arpejo de Lá meio-diminuto, começado por sua quinta, Mi bemol, passível de ser digitado de várias maneiras interessantes. BL nitidamente o mantém na primeira posição com boa opção de ligados, mas sem especificar sua $m d$, fato reparado pelo exemplo 457. O seguinte, apenas insere mais um ligado, a fim de manter apenas um dedo da $m d$ em cada corda (e o polegar cuidado de várias).
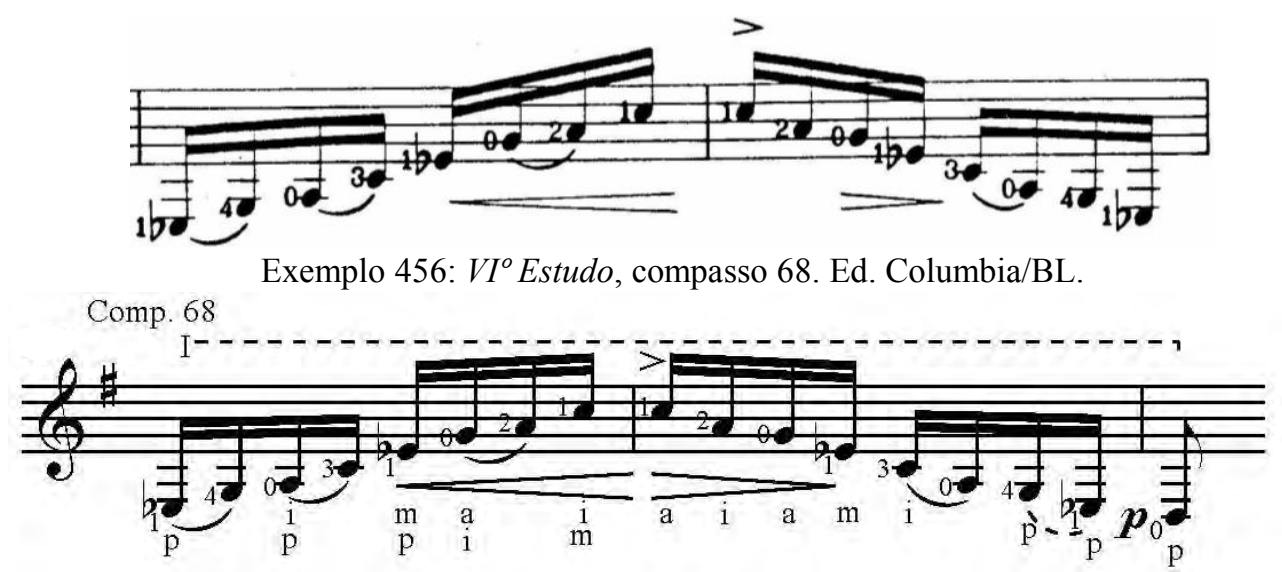

Exemplo 457: VI Estudo, compasso 68.

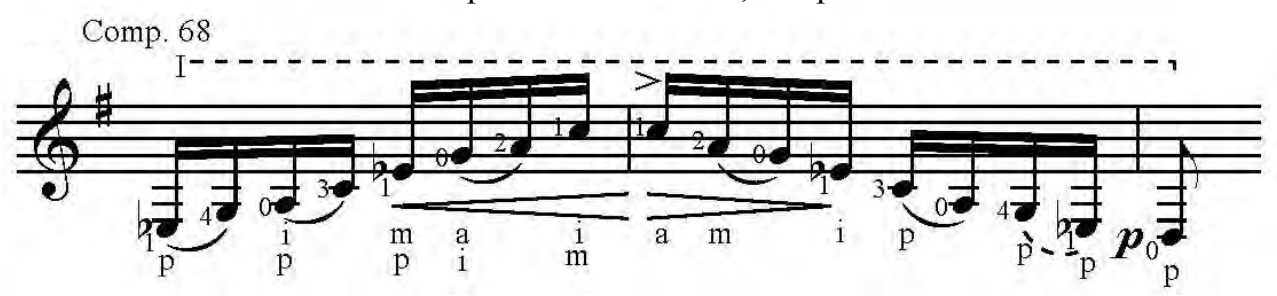

Exemplo 458: $V I^{\circ}$ Estudo, compasso 68.

Os próximos exemplos testam a inclusão de ligados triplos e posições mais à frente. O exemplo 460 tem ápice na terceira corda e está construído em forma espelhada, ou seja, ele sobe e desce pelo mesmo caminho, enquanto o exemplo seguinte desce pela primeira posição, como nas versões anteriores. $O$ último, também espelhado, utiliza apenas os bordões e com isso requer maior número de ligados para sua fluência.

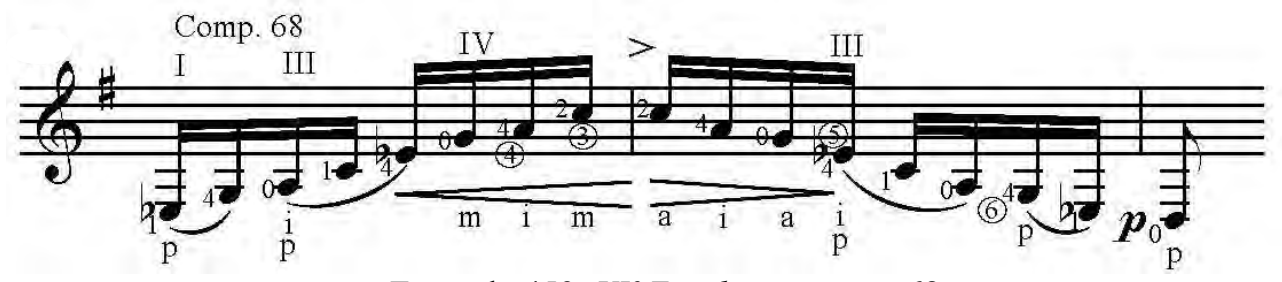

Exemplo 459: $V I^{\circ}$ Estudo, compasso 68.

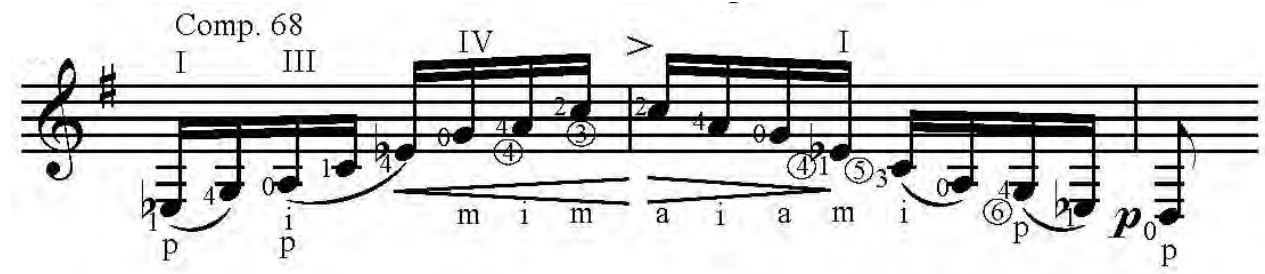

Exemplo 460: VI Estudo, compasso 68. 


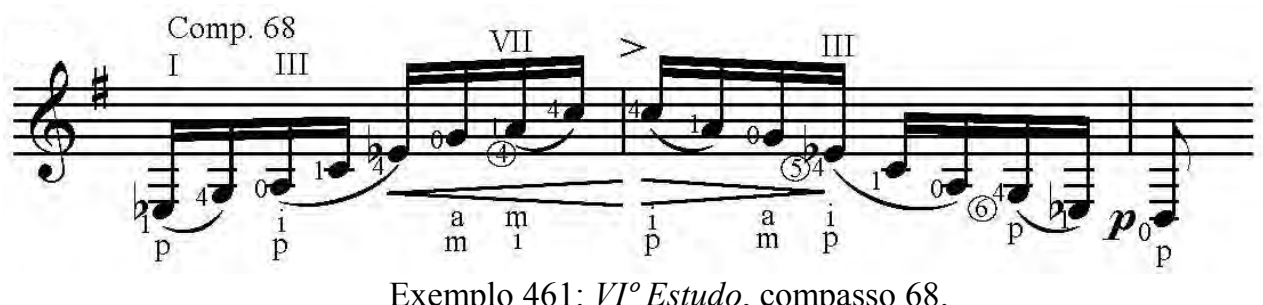

Exemplo 461: VI Estudo, compasso 68.

Ainda dentro da cadência, uma longa passagem liga a nota mais grave do instrumento ao retorno do tema no registro agudo. Ela conforma-se primeiro por escala e depois por arpejos ascendentes com baixo pedal e por isso essas texturas serão tratadas isoladamente.

A escala digitada por BL é bastante funcional mas não possui regularidade nos ligados (que poderiam ser melhor compreendidos se houvesse digitação de $m d$ ). Nossa abordagem inicial (ex. 463) foi colocá-los em todos os tempos e contratempos, o que talvez possa parecer um exagero, mas possibilita uma execução integral do trecho com o polegar, algo típico do gênero, enquanto gera cruzamentos com $i-m$ ou $m-i$. Ao contrário da digitação $\mathrm{BL}$, ocorre a criação de um padrão sonoro que é repetido a cada corda (embora os dedos possam ser diferentes) algo que também é empregado nas demais versões. O exemplo 464 coloca ligados apenas a cada tempo com boa fluência tanto em padrões binários $(m-i)$ quanto ternários $(m-i-p)$ de $m d$ e o exemplo 465 privilegia os semitons em cordas duplas, embora seus ligados percam regularidade para se tornarem funcionais com padrão $i-m$ de $m d$.

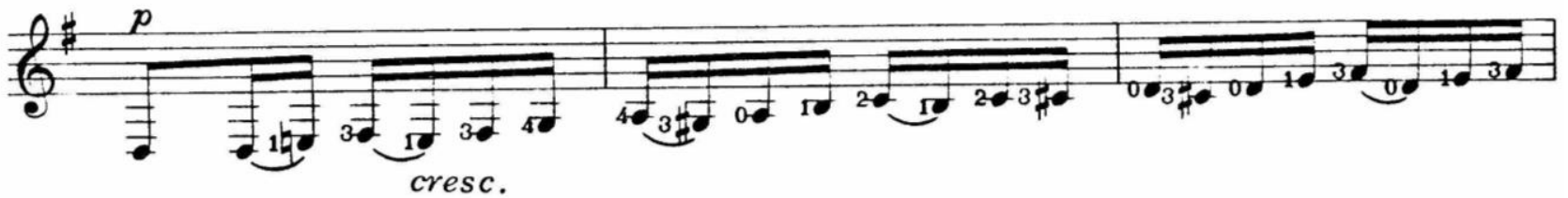

Exemplo 462: VI Estudo, compasso 70. Ed. Columbia/BL.

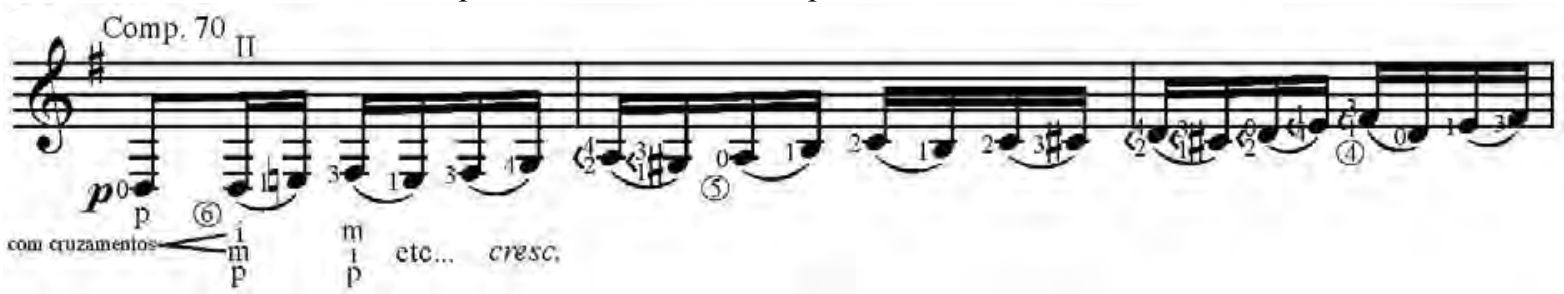

Exemplo 463: VI Estudo, compasso 70.

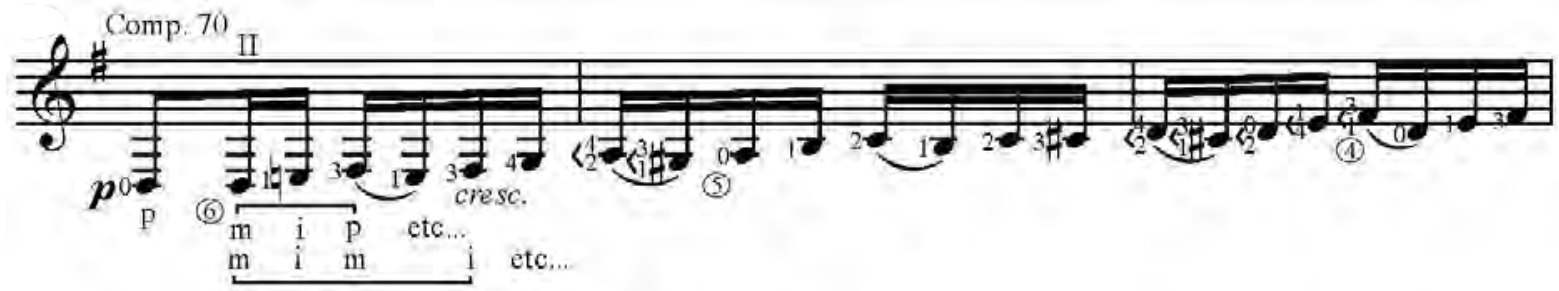

Exemplo 464: VI Estudo, compasso 70. 


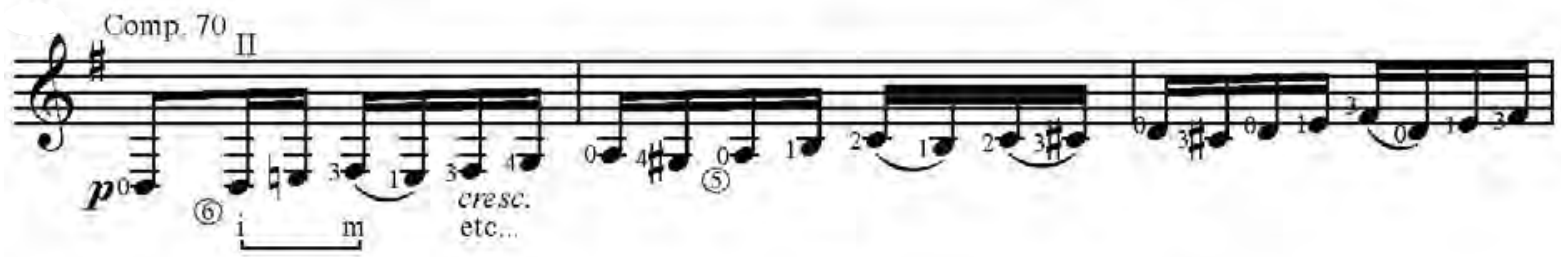

Exemplo 465: VI Estudo, compasso 70.

$\mathrm{O}$ arpejo ascendente que levará ao retorno do tema tem baixo pedal na nota Sol, onde são empilhadas terças (sequenciadas por grau conjunto) cada vez mais distantes. $\mathrm{O}$ baixo em questão, na maior parte das digitações, aparece preso nos acordes iniciais e solto conforme as terças vão ascendendo, algo não muito problemático que pode ser disfarçado pelo crescendo natural do trecho. Outro aspecto relevante é que a escolha dos dedos deste trecho dependerá de como será iniciado o próximo. Dessa forma $\mathrm{BL}$ finaliza com os dedos 4 e 2 para deixar o dedo 1 livre para iniciar o segmento seguinte na sétima posição. Nosso exemplos (excetuando o último) encerram com os dedos 3 e 1 encaminhando a próxima frase para décima posição com os mesmos dedos arrastados meio tom acima.

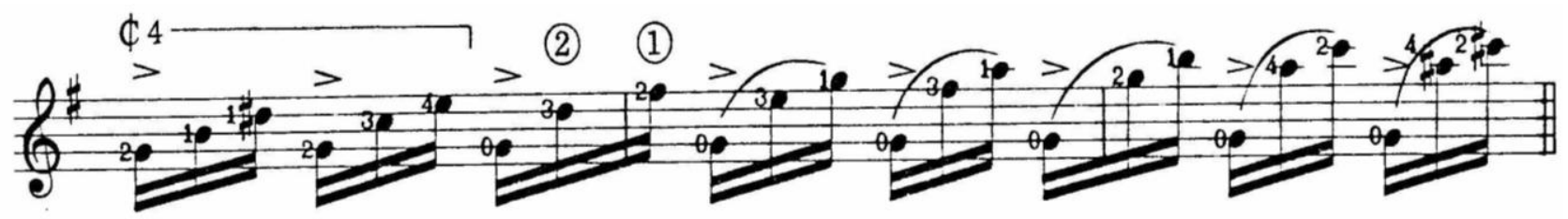

Exemplo 466: VI Estudo, compasso 73. Ed. Columbia/BL.

Os próximos dois exemplos inserem uma pestana no segundo acorde. O primeiro executa as notas nos mesmos locais que BL, mas com outros dedos, padronizando melhor as terças (maiores com dedos 2 e 1 e menores com 3 e 1). O segundo atrasa um pouco a entrada da corda solta no baixo alcançando configuração levemente diferente para as terças.

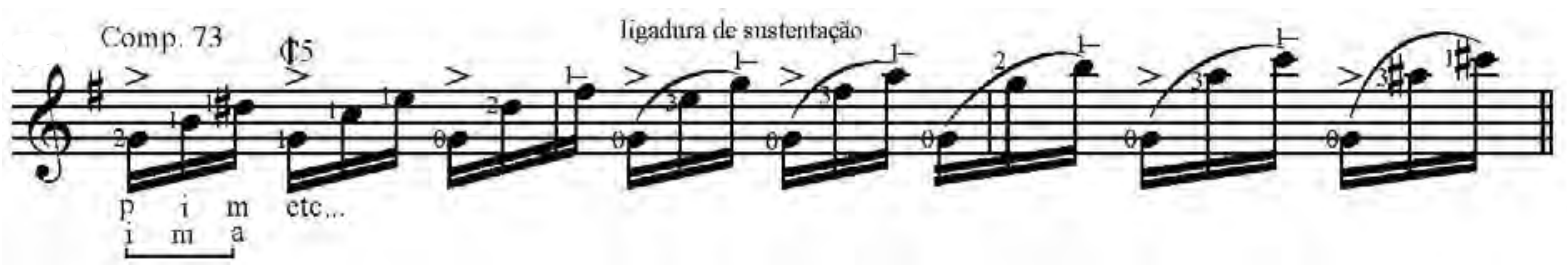

Exemplo 467: VI Estudo, compasso 73.

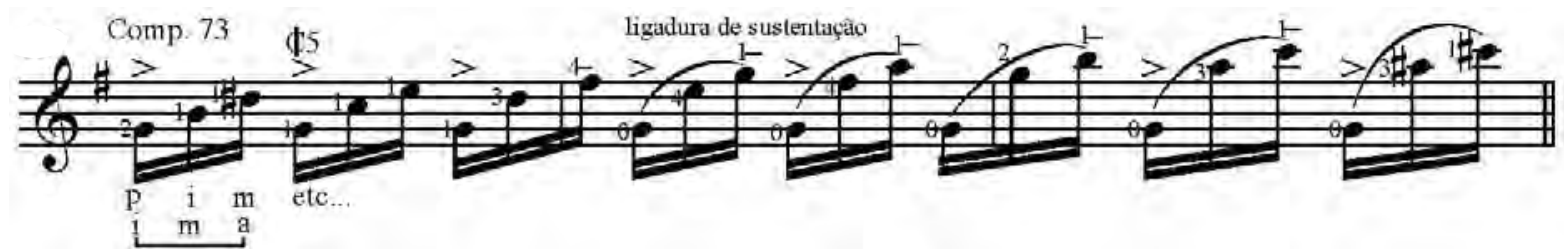

Exemplo 468: VI Estudo, compasso 73.

Os últimos dois exemplos do segmento incluem a utilização de ligados. Eles aparecem apenas no primeiro tempo no exemplo 469 (talvez prejudicando sua unidade) 
e em todos os tempos no exemplo 470 possibilitando o uso do baixo solto em todos os acordes em ambos os casos ${ }^{109}$. No último exemplo eles agregam certa conotação caipira ao trecho, mas sob o custo de colocar as duas terças finais no registro superagudo das cordas 2 e 3. Para contornar este problema, pode-se utilizar versões anteriores nesses dois acordes, cuja mudança de sonoridade pode ser aliviada por um leve rallentando.

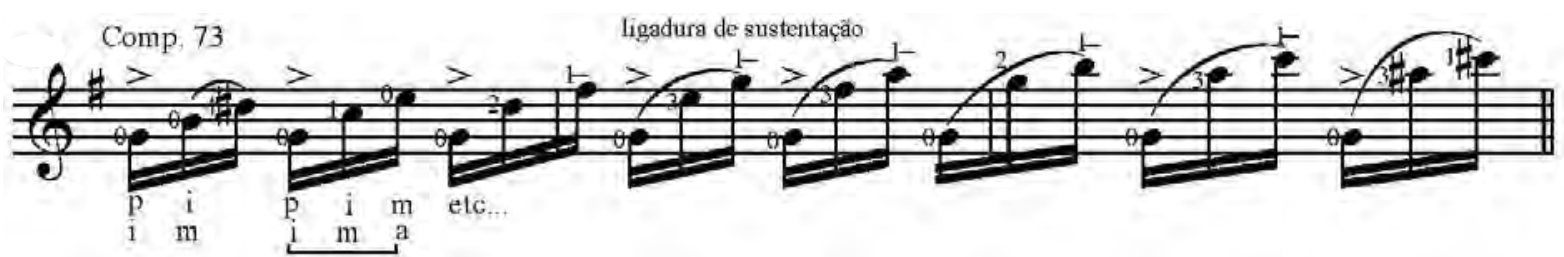

Exemplo 469: VI $I^{\circ}$ Estudo, compasso 73.

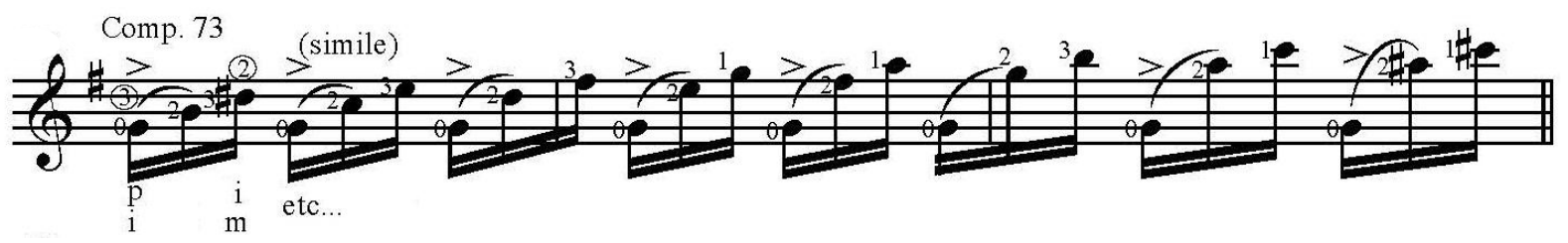

Exemplo 470: $V I^{\circ}$ Estudo, compasso 73.

O tema tem sua aparição final com nova "orquestração" em sequência de terças com baixo pedal em andamento "Mais Vivo", criando passagem extremamente virtuosística, mas de grande dificuldade. Diferentemente de BL, nossa primeira digitação (exemplo 472) fixa e arrasta os dedos 1 e 3 nos quatro primeiros compassos, comprimindo-os quando tratam-se de terças maiores e alargando-os nas terças menores, possuindo um final alternativo no exemplo 473.
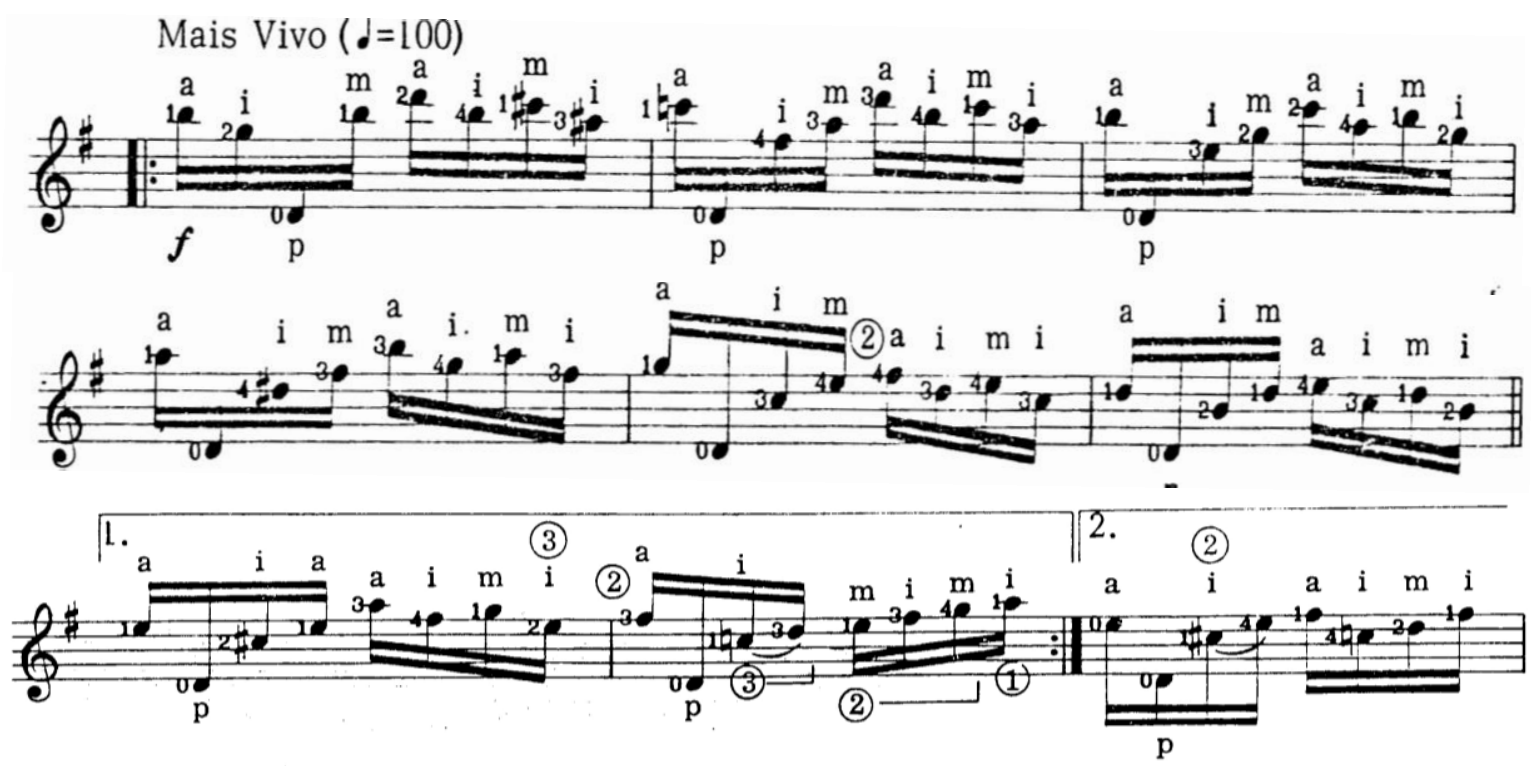

Exemplo 471: VI Estudo, compasso 76. Ed. Columbia/BL.

\footnotetext{
${ }^{109}$ lembrado que a ligadura de sustentação está assinalada nos exemplos anteriores e advém do manuscrito do compositor. No último exemplo as excluímos para não se confundirem com os ligados.
} 

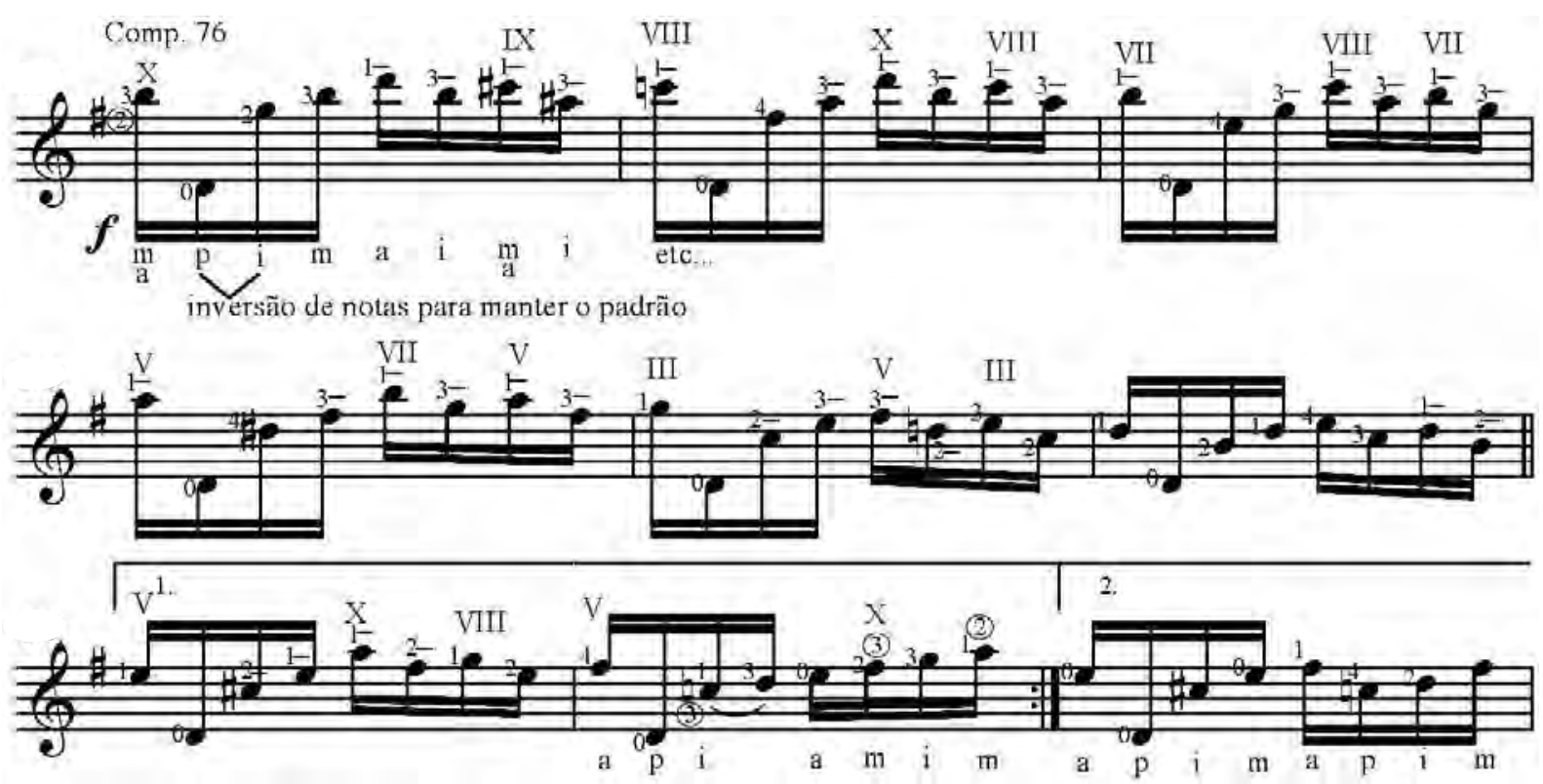

Exemplo 472: $V I^{\circ}$ Estudo, compasso 76.

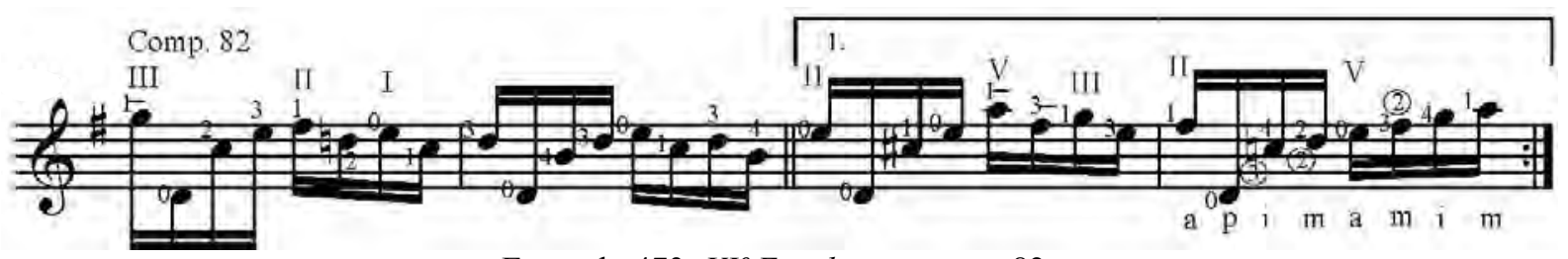

Exemplo 473: $V I^{\circ}$ Estudo, compasso 82.

Outra abordagem é a da inserção de ligados no segundo tempo, criando com isso várias aberturas (severas a partir do quarto compasso) mas menos trocas de posição.
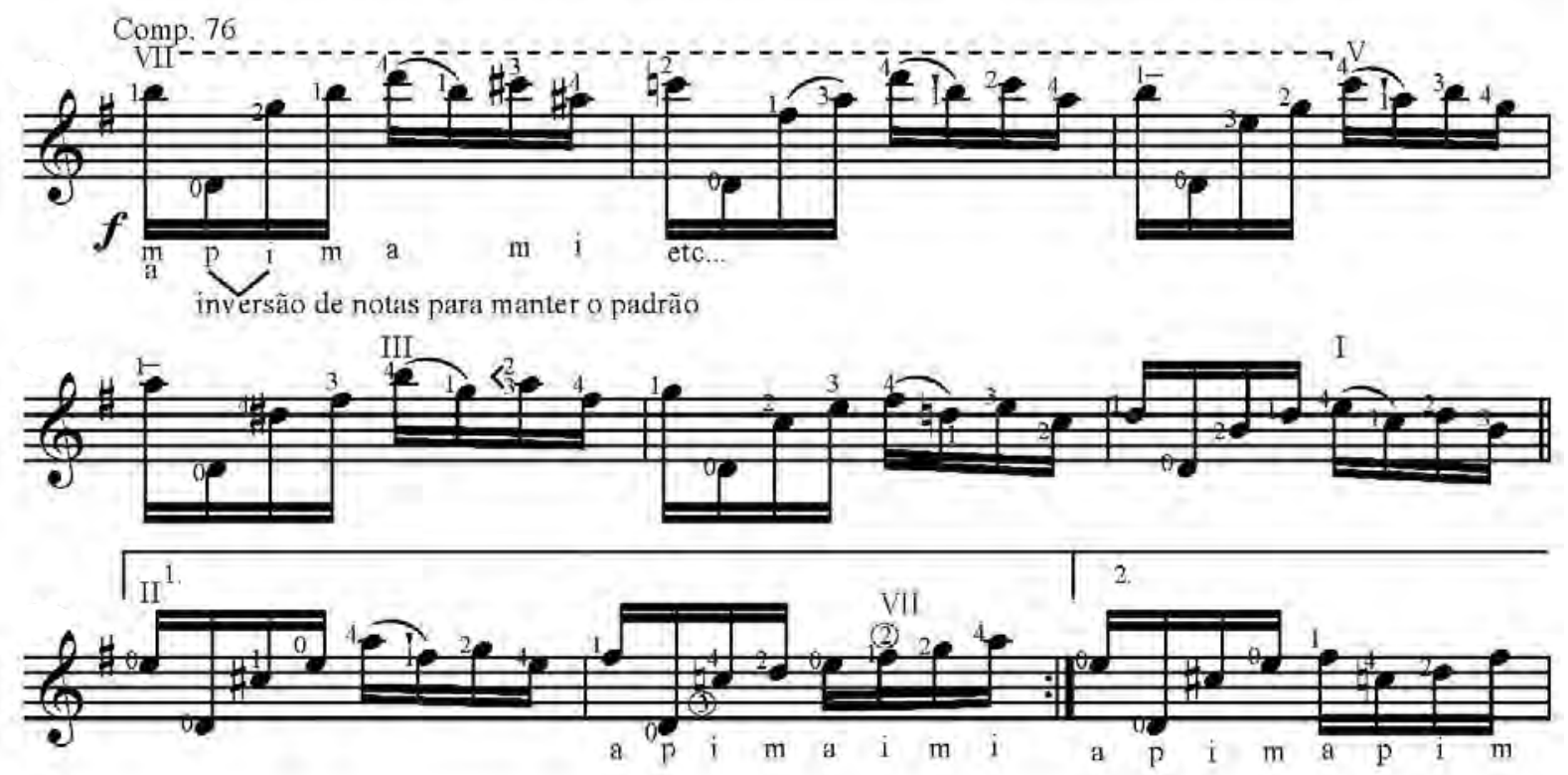

Exemplo 474: $V I^{\circ}$ Estudo, compasso 82.

Consideramos que essas versões possuem igual grau de dificuldade, cabendo ao intérprete julgar seu costume ou familiaridade com as técnicas exigidas nas mesmas e assim avaliar qual se demonstra mais promissora para seu estudo. 
Segue-se uma passagem de arpejos graves com pedal na voz superior sem muitas possibilidades de me, onde somente especificamos opções de articulação de $m d$ inclusive para o acorde inicial (que caso for rasgueado, necessitará de abafamento da quarta corda, assinalado com um X).

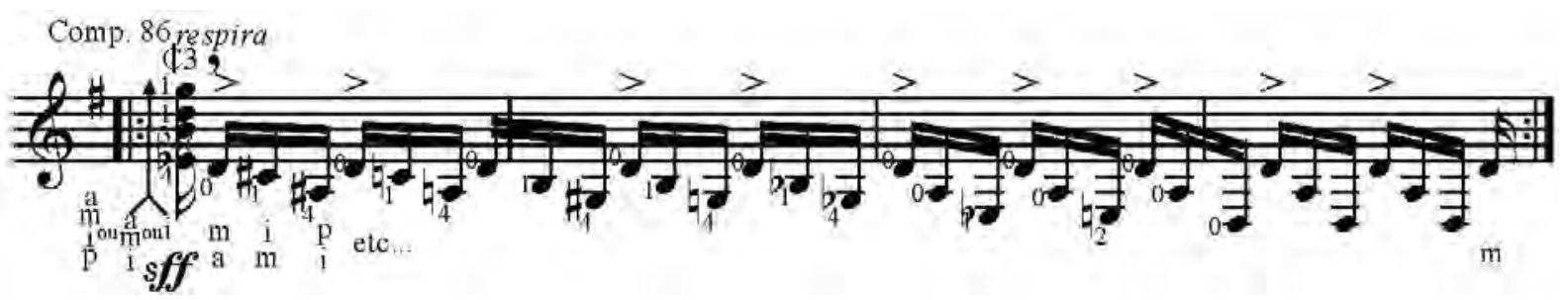

Exemplo 475: $V I^{\circ}$ Estudo, compasso 86.

A interessante escala final repete-se não literalmente em três oitavas, modificando seu modo na segunda aparição. Note-se que há um erro na última nota da edição Columbia (conferido a partir do manuscrito) e que BL utiliza-se bastante da segunda corda.

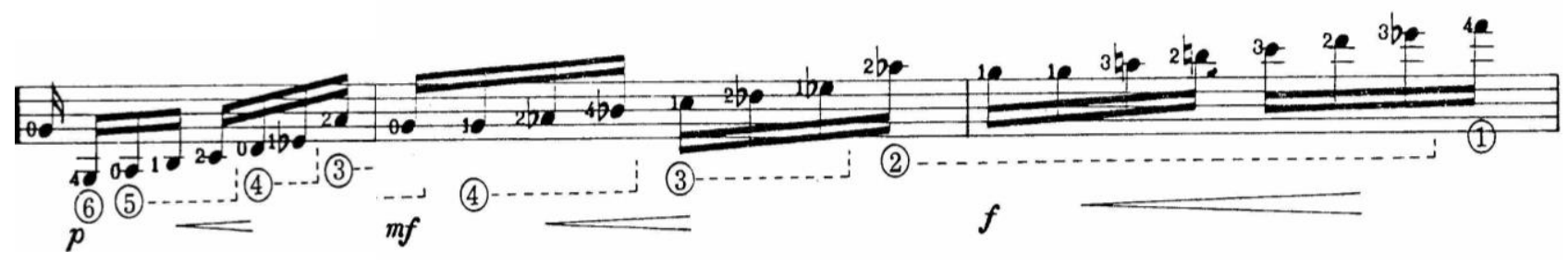

Exemplo 476: VI ${ }^{\circ}$ Estudo, compasso 90. Ed. Columbia/BL.

Nosso exemplos comumente seguem o primeiro compasso da digitação BL. O exemplo 477, também inicia o padrão central pela quarta corda na quinta posição, mas o modifica $^{110}$ a partir de um translado do dedo 1 , também leva a um padrão mais confortável na sexta posição e posteriormente uma finalização toda a partir da décima segunda posição.

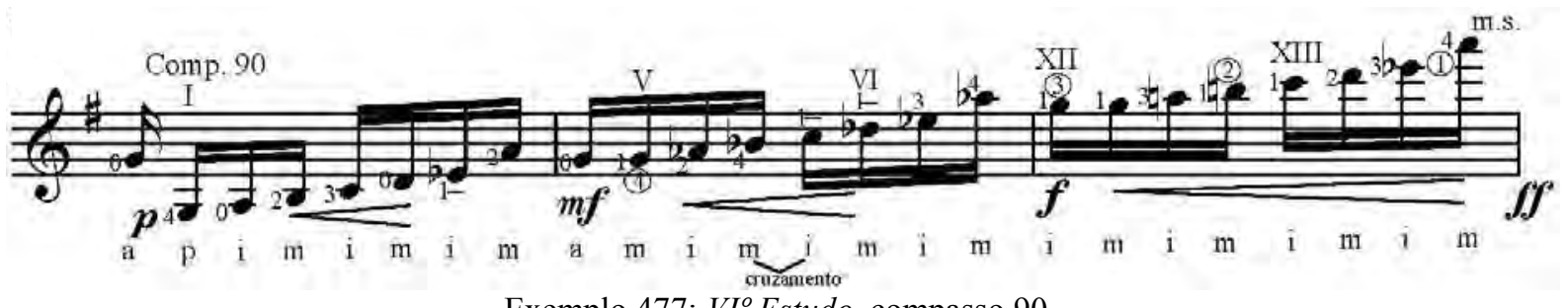

Exemplo 477: VI Estudo, compasso 90.

O exemplo 478 usa a terceira corda solta para um salto, colocando todo o segundo compasso na oitava posição e concluindo de maneira igual ao exemplo pregresso.

${ }^{110}$ verbo do checklist de Osborn. 


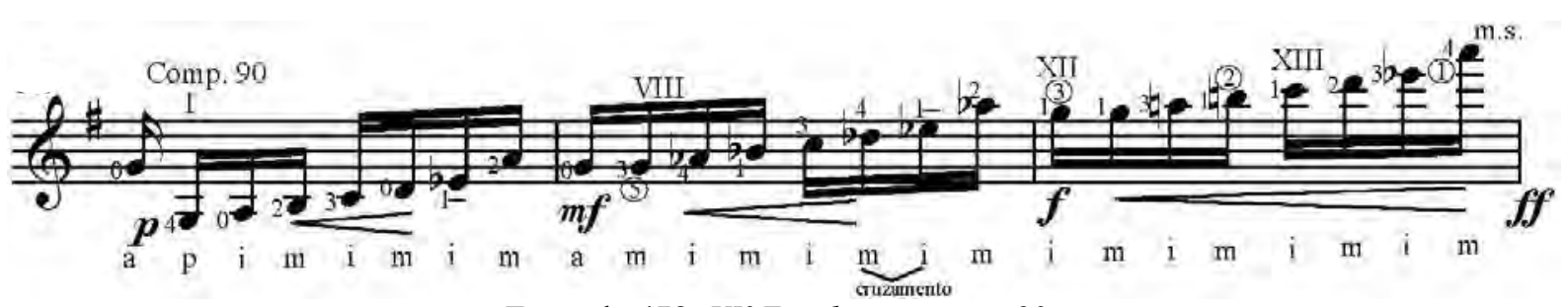

Exemplo 478: $V I^{\circ}$ Estudo, compasso 90.

O exemplo 479 coloca o trecho central na terceira e quarta posições e conclui com maior utilização da segunda corda. $\mathrm{O}$ aspecto crucial desse exemplo a maior utilização de padrões $m d$ iniciados com o polegar.

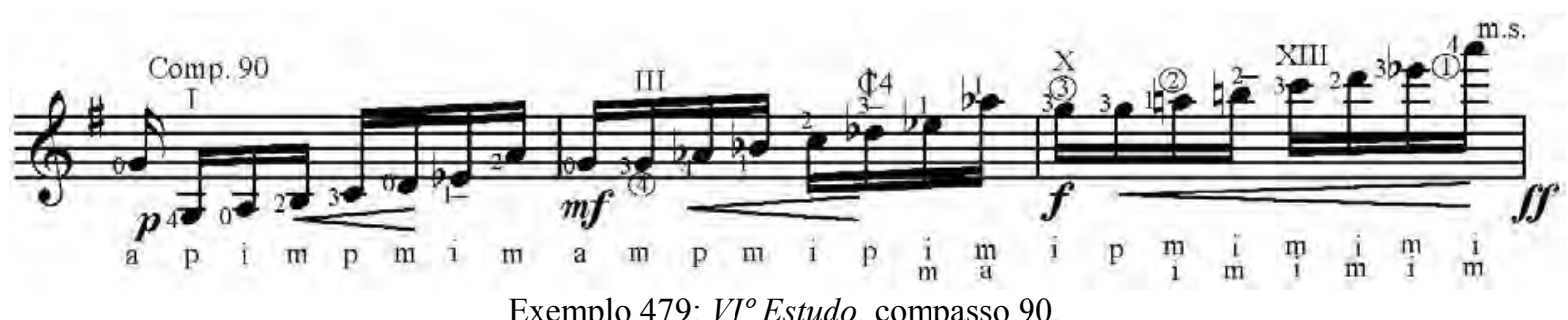

Os três exemplos finais testam o uso de ligados nesse trecho. Os dois primeiros exemplos obedecem a mesma lógica de ligados apenas usando posições levemente distintas na parte central.

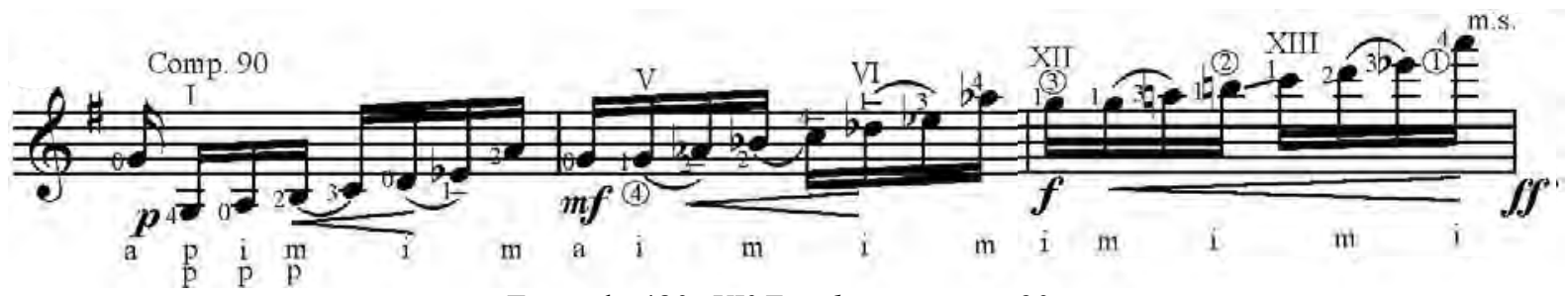

Exemplo 480: $V I^{\circ}$ Estudo, compasso 90.

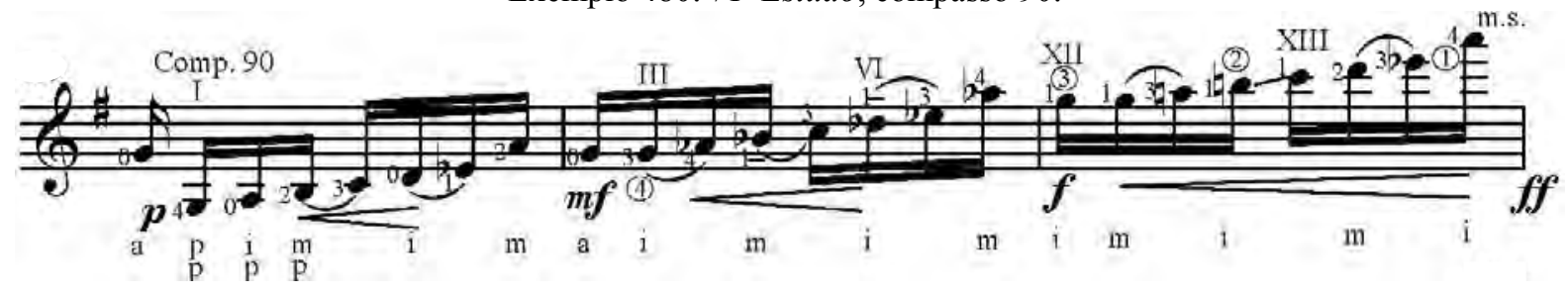

Exemplo 481: VI Estudo, compasso 90.

O último ainda insere ligados triplos para garantir uma $m d$ similar a padrões de arpejo nos dois primeiros compassos, onde cada dedo cuida de uma corda.

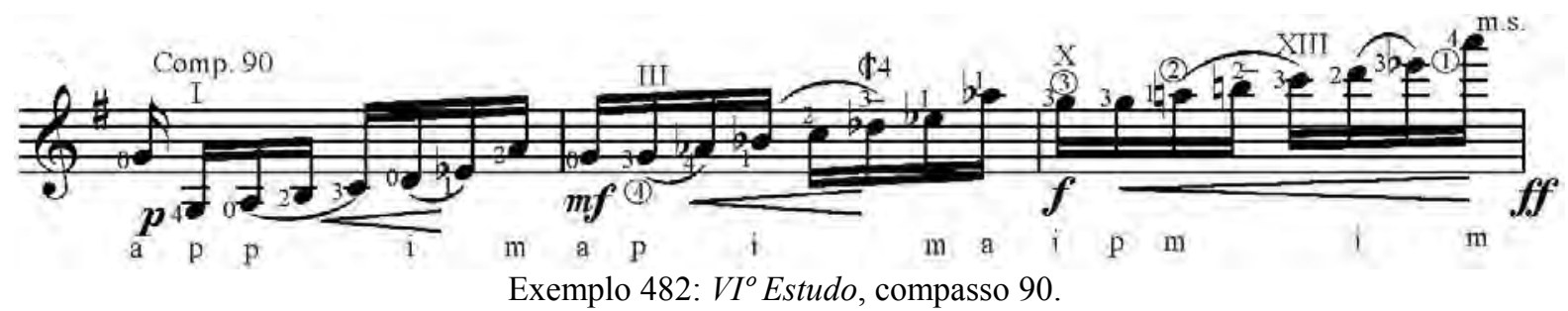

Todos os padrões em ligado até resultam em boa funcionalidade no início, mas possuem pouca emissão quando o trecho atinge o registro sobreagudo do instrumento, 
algo que pode ser contornado com a retirada dos ligados no último compasso ou pelo uso de versões anteriores do mesmo.

Outro aspecto relevante é que todos os nossos exemplos, assim como BL, finalizaram o trecho anterior com os dedos 2, 3 e 4 definindo os mesmos para o trecho seguinte, ainda na região sobreaguda do violão.

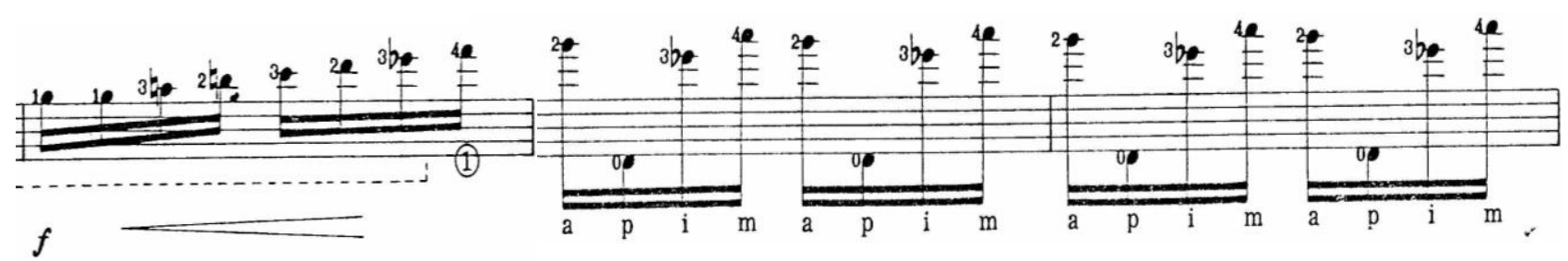

Exemplo 483: VI Estudo, compasso 92. Ed. Columbia/BL.

É necessário registrar outra abordagem, que possibilita a chegada com os dedos

1,2 e 3 , podendo a mesma ser integrada aos exemplos anteriores.

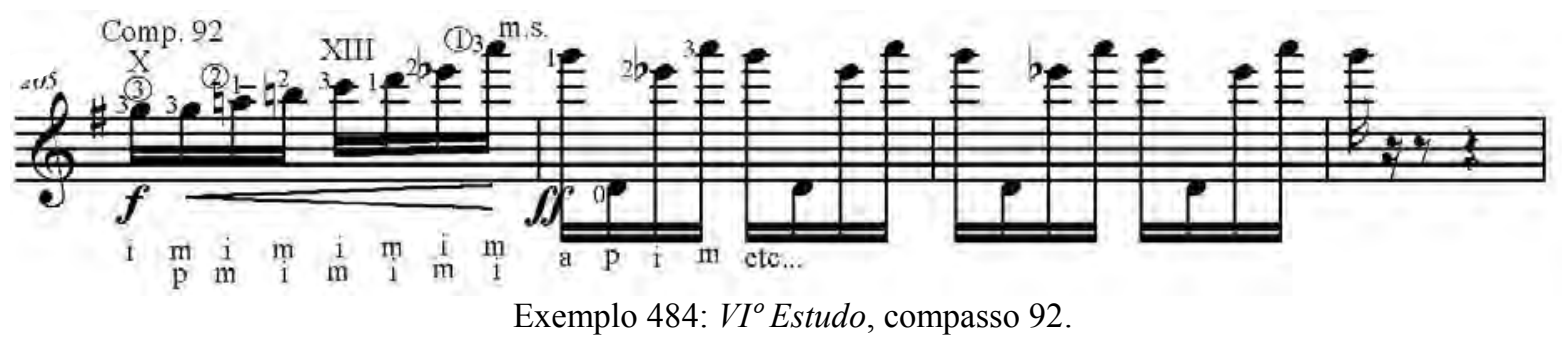

$\mathrm{O}$ compasso final, com mesma digitação $\mathrm{BL}$ de $m e$, recebe apenas algumas possibilidades de emissão, no primeiro e último acordes.

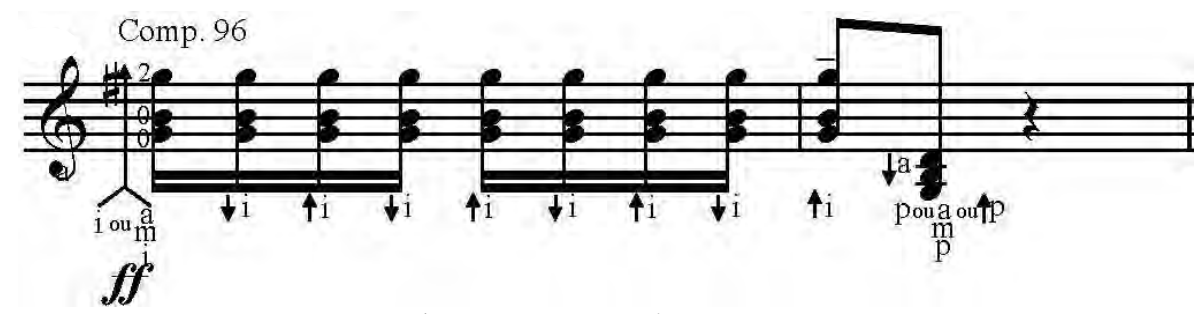

Exemplo 485: VI Estudo, compasso 96. 


\section{7: VII ${ }^{\circ}$ Estudo "Cantiga de ninar"}

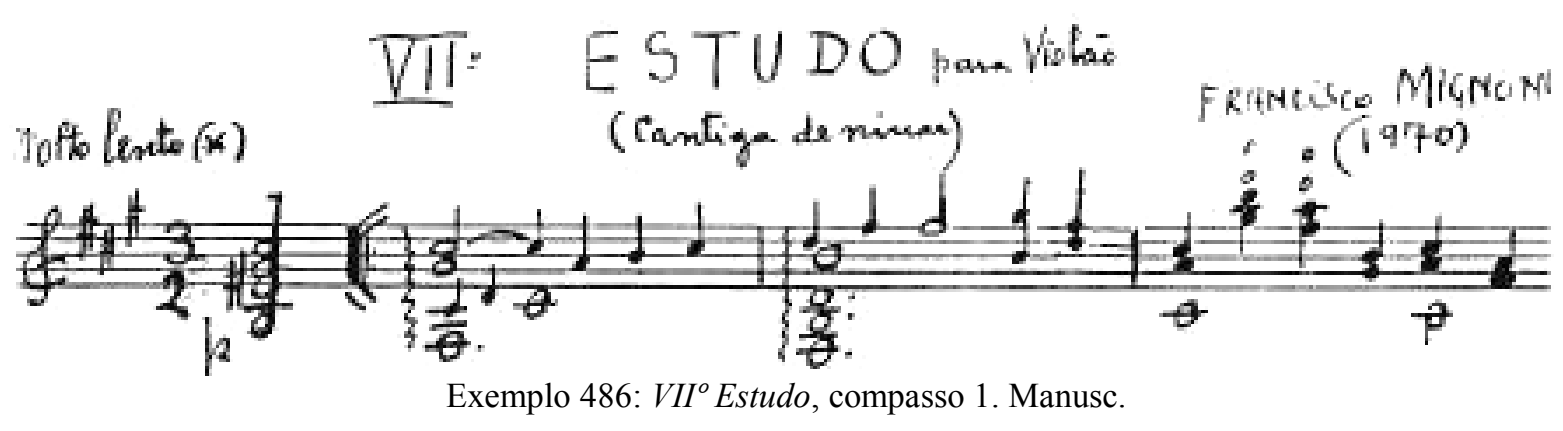

O sétimo estudo da série ganha o subtítulo de "cantiga de ninar" apenas em seu manuscrito (exemplo 486), não se sabendo exatamente o motivo de sua exclusão na edição Columbia, talvez por uma divergência entre os manuscritos entregues à editora ou por ter sido um nome dado a posteriori, já que havia a ideia não concretizada de dar subtítulos a todos os estudos:

Barbosa Lima nos revelou ainda que nas últimas ocasiões em que esteve com Mignone, surgiu a ideia de se atribuir subtítulos a cada Estudo, em vista do forte gosto do compositor pela literatura e poesia. Os títulos seriam descritivos $-\mathrm{o} N^{o} 1$, por exemplo, chamaria-se Homenagem a Tárrega, mas infelizmente o projeto ficou na ideia inicial. Apenas dois estudos possuem subtítulo: $\mathrm{N}^{\mathrm{0}} 7$, Cantiga de Ninar, e No11, Spleen (Apro, 2004, p. 69).

No entanto, Apro baseado no aspecto harmônico a obra, pergunta: "como uma berceuse pode ser tão sombria?" para então buscar a resposta "nos trabalhos de Carlos del Nero (1965), específico no que tange à temática do 'folclore tenebroso' de Gilberto Freyre (1996)" (Apro, 2004, p. 102-103) de onde conjectura a possível inspiração (não confirmada) de Mignone:

A cantiga de ninar brasileira está associada ao ancestral hábito profiláticopedagógico dos pais e educadores de incutir o medo nas crianças, com o fito de protegê-las de influências malignas (superstições) e de orientá-las na educação e obediência às autoridades e membros mais velhos da comunidade (Apro, 2004, p. 103).

$\mathrm{Na}$ questão técnica este estudo trabalha principalmente a textura de melodia (às vezes em terças e mais raramente em outros intervalos) acompanhada por acordes de longa duração cuja notação é flexibilizada pela seguinte indicação do compositor:

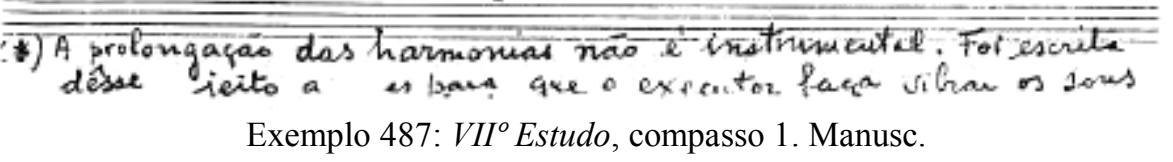

*A prolongação das harmonias não é instrumental. Foi escrita dêsse jeito apenas para que o executor faça vibrar os sons o mais que fôr possivel. 
Em outras palavras Mignone esclarece que a grafia não é literal no que diz respeito às durações, mas por outro lado, relega ao intérprete a missão de sustentá-las o máximo possível. Com isso, a escolha de digitação deve primar pela obtenção de um legato consistente, já que a música de esvaziaria sem o mesmo.

Nossa análise digitacional se focará mais nesse aspecto de me do que na $m d$ que será raramente grafada por ter funcionamento mais ou menos óbvio. No entanto, adiantamos que nossa performance privilegia o uso de polegares múltiplos nos acordes provendo-lhes maior robustez.

No compasso 1 (contado após a anacruse) a digitação BL é bastante lógica ao utilizar apenas cordas presas com pestana na segunda casa, no entanto, nossa única opção alternativa ao trecho modifica ${ }^{111}$ esses critérios para propor uma digitação com cordas soltas, sem necessariamente superar a anterior.

Registra-se também outra opção para o acorde anacrústico, colocando-o na sexta posição nas cordas graves o que gera ruído de arraste para se alcançar o acorde seguinte. Por este motivo, preferimos a digitação BL para este acorde inicial.

\section{VII $^{\circ}$ ESTUDO}
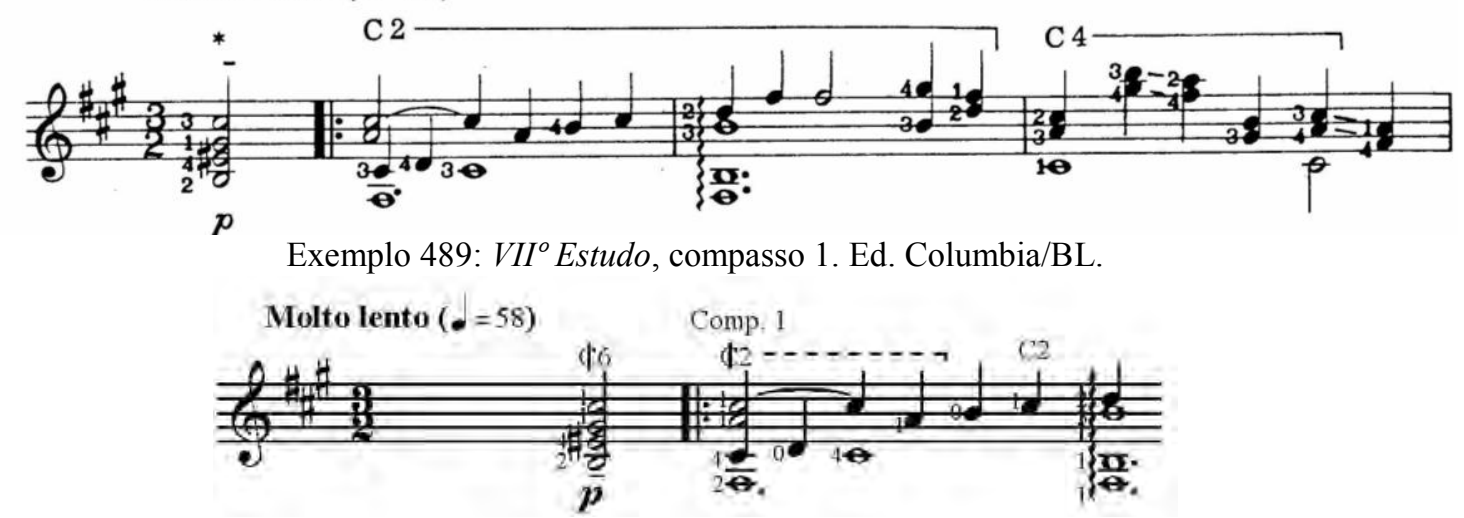

Exemplo 490: VII Estudo, compasso 1.

A decisão da digitação do compasso 2 dependerá de onde será executado o compasso seguinte, situação "em cascata" que ocorrerá recorrentemente nesse estudo. O exemplo 481 e 482 encaminham para a quarta posição assim como BL, mas de formas diferentes.

${ }^{111}$ verbo do checklist de Osborn. 


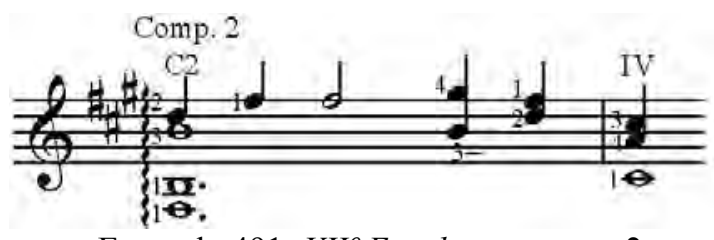

Exemplo 491: VII ${ }^{\circ}$ Estudo, compasso 2.

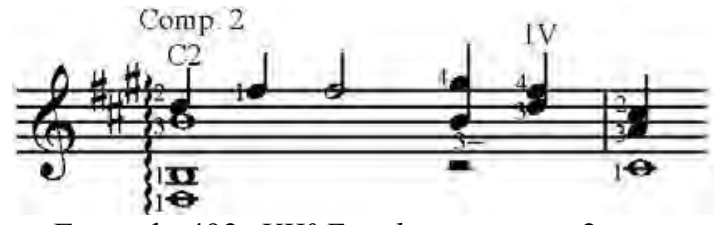

Exemplo 492: $V I I^{\circ}$ Estudo, compasso 2.

Os exemplos 493 e 494 abdicam da sustentação do acorde para criar um portamento expressivo pela segunda corda, alcançado outras posições. É possível atingir as mesmas posições avançadas por meio de salto a partir das versões anteriores.

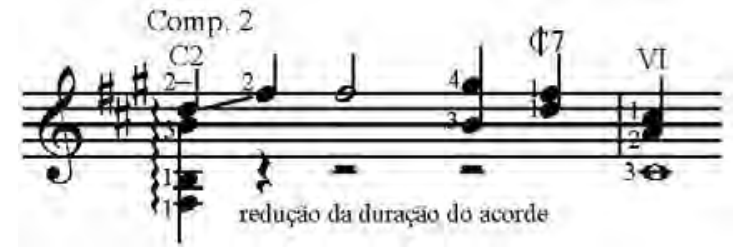

Exemplo 493: VII Estudo, compasso 2.

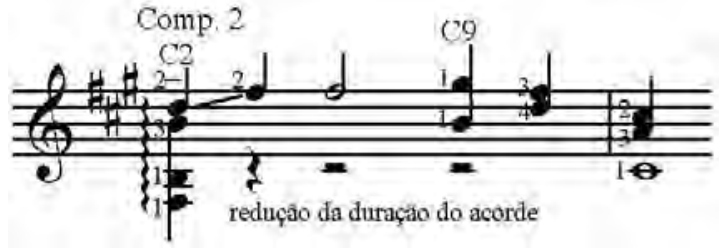

Exemplo 494: VII Estudo, compasso 2.

O compasso 3 inicia movimentações em terças paralelas que eventualmente possuem indicação de harmônicos duplos no manuscrito (ver primeiro exemplo do presente tópico) os quais são excluídos na edição Columbia (ver exemplo 489), fato que ocorre também nos compassos 4, 26, 28, 31 e 33. Não sabemos exatamente por qual motivo ou por quem (pelo compositor, por BL ou ambos) e ressaltamos que BL é conhecido por integrar harmônicos (normalmente simples) em seus arranjos e possui habilidade em realizá-los, mas ao mesmo tempo a decisão de retirá-los é compreensível já que harmônicos duplos são de execução pouco confiável e de pequena projeção. Tendo em conta estes aspectos, o campo do Pensamento Divergente nos leva a três tratamentos: sem harmônicos, com harmônicos duplos e com harmônicos somente na voz superior, grafando-os com durações mais literais do baixo e com eventuais portamenti sugeridos BL ou outros adicionados por nós.

Iniciando sem harmônicos, detalhamos a digitação BL no primeiro exemplo já com uma corda solta opcional e ressaltamos a existência de uma abertura desconfortável para manter o primeiro baixo. O segundo exemplo mantém as notas nos mesmos lugares mas alivia levemente essa abertura com a substituição de alguns dedos e o exemplo seguinte (497) apenas adiciona harmônicos artificiais na voz superior.

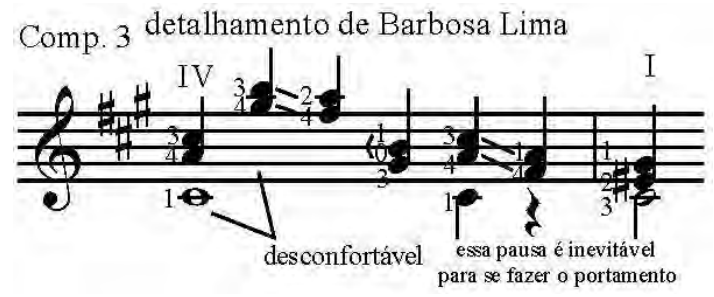

Exemplo 495: VII Estudo, compasso 3.

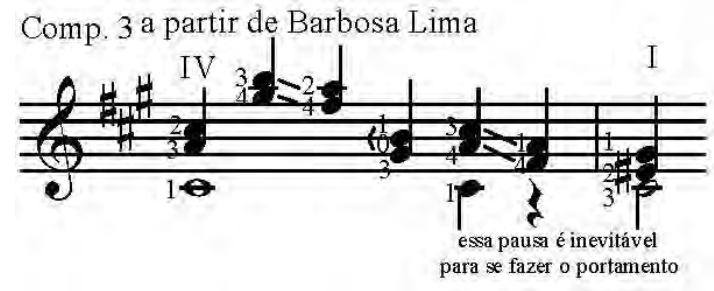

Exemplo 496: VII Estudo, compasso 3. 


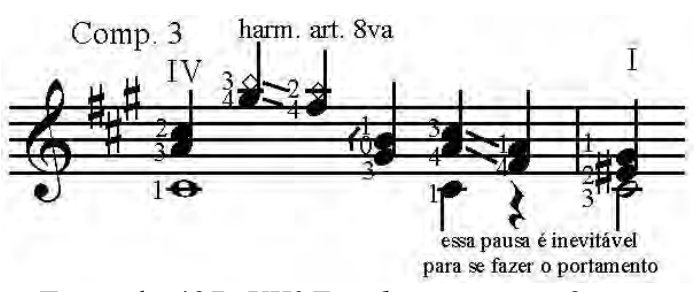

Exemplo 497: VII Estudo, compasso 3.

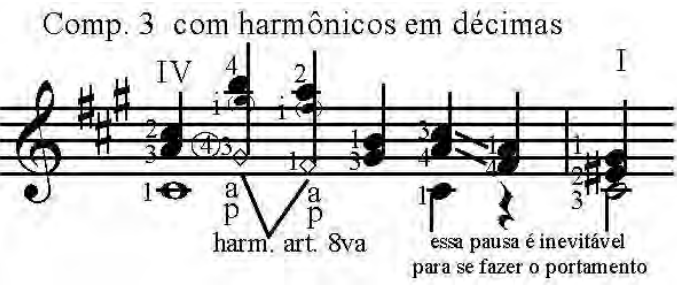

Exemplo 498: VII ${ }^{o}$ Estudo, compasso 3.

Os exemplos 498, 499 e 500 transformam duas terças em décimas, com harmônicos de oitava na voz inferior (a nota real está entre parêntesis) e assim conseguem evitar as aberturas anteriores. O exemplo 499 adiciona portamenti ao anterior e o 500 finalmente realiza os harmônicos duplos. Para executá-los é necessário uma técnica específica: o polegar e anelar articulam as notas presas pela me, enquanto o indicador e médio da $m d$ sobrepõem as oitavas artificiais (grafadas em parêntesis) em cima do espelho. Esse expediente requer independência da $m d$ já que apenas os dedos $p$ e $a$ se movem enquanto o $i$ e $m$ permanecem esticados e rígidos.

Comp. 3 com harmônicos em décimas

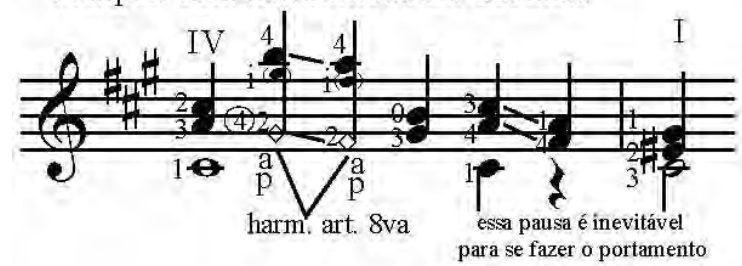

Exemplo 499: VII Estudo, compasso 3.
Comp. 3 com harmônicos duplos em décimas

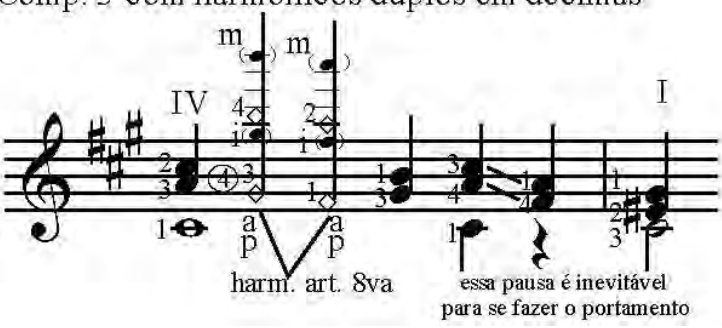

Exemplo 500: VII Estudo, compasso 3.

A próxima abordagem é colocar as terças agudas na segunda e terceira cordas, como no exemplo 501, o que demanda a interrupção do primeiro baixo. O final do compasso também é modificado ${ }^{112}$ e ganha legato por meia-pestana na segunda posição. O exemplo 502 insere harmônico artificial na voz superior e o 503 realiza os harmônicos duplos, agora em terças (e com sonoridade mais próxima do manuscrito) articuladas pelo anelar e polegar e com o indicador inclinado sobre duas cordas sobrepondo as duas notas artificiais (em parêntesis) sobre a boca do instrumento, requerendo muita precisão e com projeção limitada.

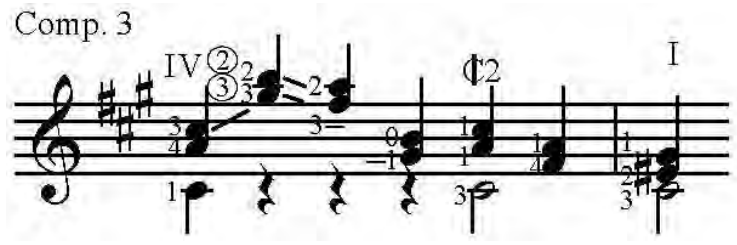

Exemplo 501: VII Estudo, compasso 3.

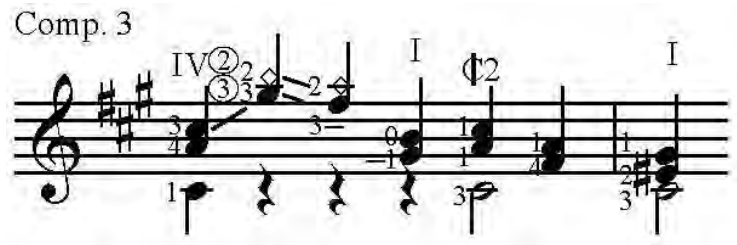

Exemplo 502: VII ${ }^{o}$ Estudo, compasso 3.

112 verbo do checklist de Osborn. 
Comp. 3 com harmônicos duplos em terças

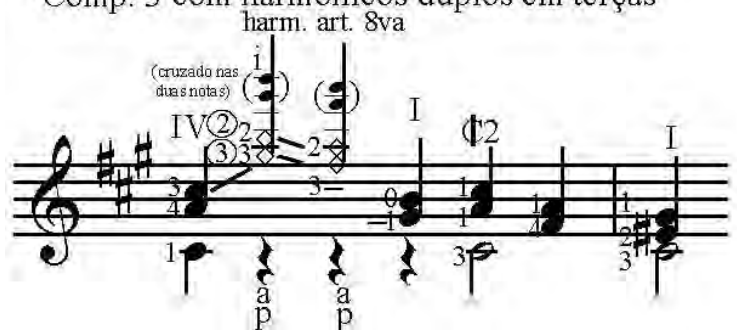

Exemplo 503: VII ${ }^{\circ}$ Estudo, compasso 3.

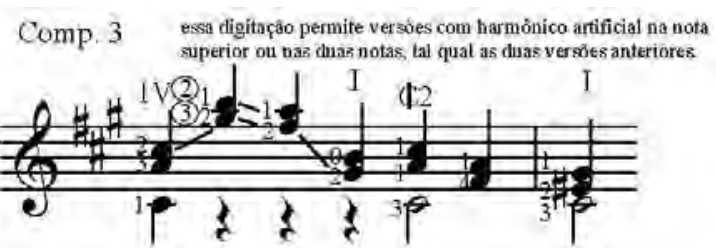

Exemplo 504: VII ${ }^{o}$ Estudo, compasso 3.

O exemplo 504 apenas substitui alguns dedos às versões anteriores, permitindo as exatas mesmas abordagens com harmônicos na voz superior e harmônicos duplos.

O exemplo 505 tenta aplicar na digitação do exemplo 496 a mesma abordagem de harmônicos duplos em terças sem muito sucesso pois o indicador tem de se inclinar demasiadamente para "abafar" as terças menores nas duas primas.

Harmônicos duplos em terças não funcionam muito bem Comp. 3 na lrá corda, pois o indicador fica muito inclinado

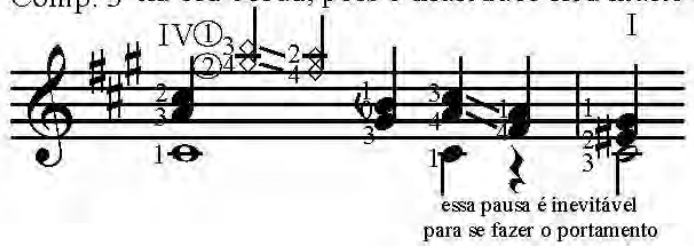

Exemplo 505: VII Estudo, compasso 3.

Experimentou-se, nos exemplos 506 e 507 o uso de outras posições, o primeiro partindo da sexta (permitindo harmônico na voz superior) e o outro da nona (permitindo harmônicos simples e duplos em terças, como em versões anteriores).

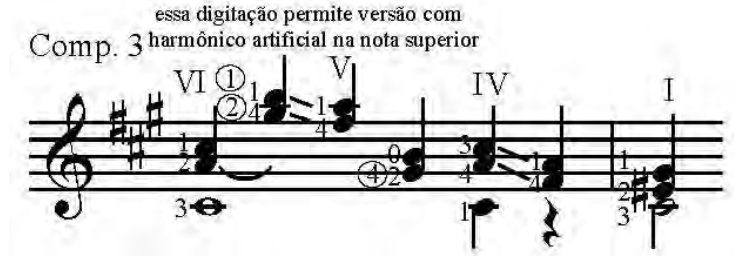

Exemplo 506: VII ${ }^{\circ}$ Estudo, compasso 3.

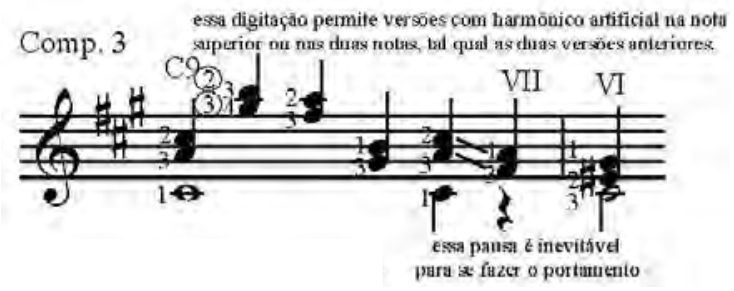

Exemplo 507: VII Estudo, compasso 3.

A abordagem dos próximos dois exemplos foi unificar as oitavas do compasso e usar harmônicos na voz superior das terças paralelas do segundo e terceiro tempos, recolocando-as parcialmente na oitava prescrita na edição Columbia.

Comp. 3versão com mudança de 8 vas

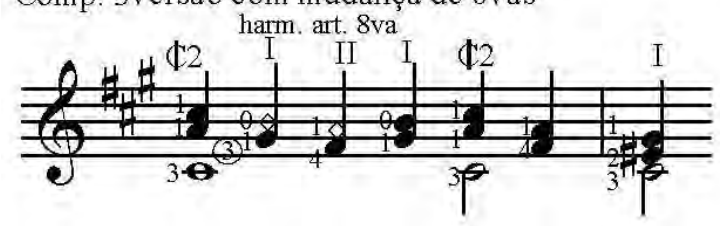

Exemplo 508: VII Estudo, compasso 3.
Comp. 3versão com mudança de 8vas

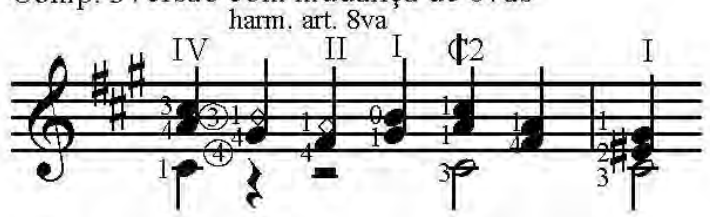

Exemplo 509: VII Estudo, compasso 3. 
A última estratégia foi integrar harmônicos naturais e artificiais ao trecho gerando uma grafia possivelmente confusa, onde não estão grafadas as notas resultantes.

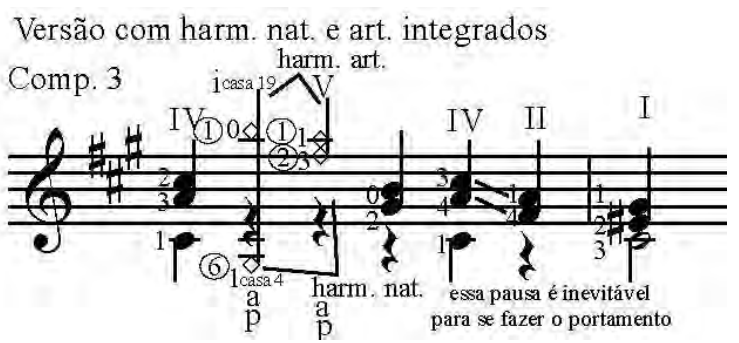

Exemplo 510: VII Estudo, compasso 3.

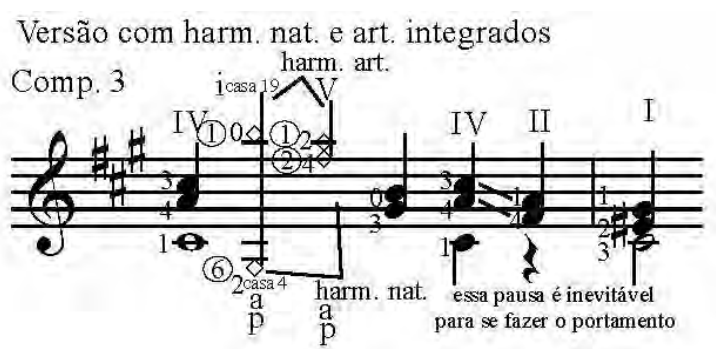

Exemplo 511: VII ${ }^{\circ}$ Estudo, compasso 3.

A mesma divergência de harmônicos entre edição Columbia (ex. 512) e manuscrito (ex. 513) ocorre no compasso seguinte, que recebe portanto, metodologia similar. Os exemplos 514 e 515 apenas unificam os dedos da digitação BL relativos às terças paralelas a fim de facilitar o portamento e o exemplo 516 adiciona harmônicos na voz superior.

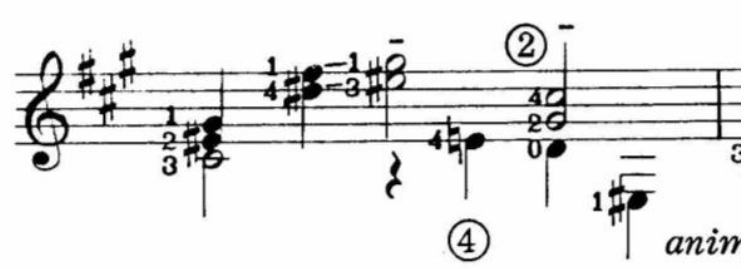

Exemplo 512: Est. 7, comp. 4. Ed. Columbia/BL.

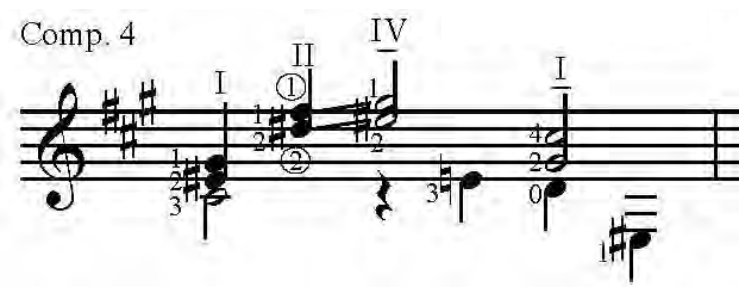

Exemplo 514: VII ${ }^{\circ}$ Estudo, compasso 4

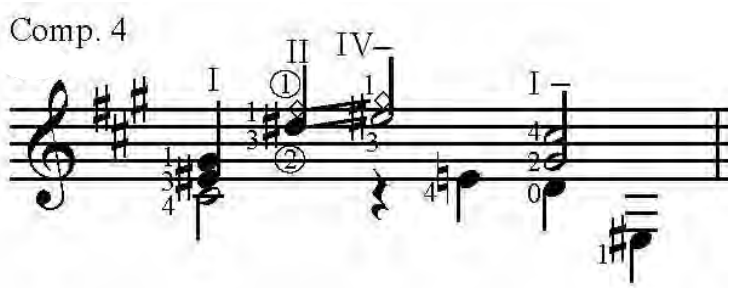

Exemplo 516: VII ${ }^{\circ}$ Estudo, compasso 4.

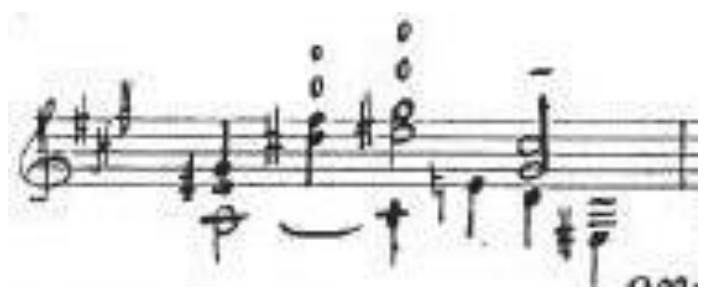

Exemplo 513: Est. 7, comp. 4. Manusc.

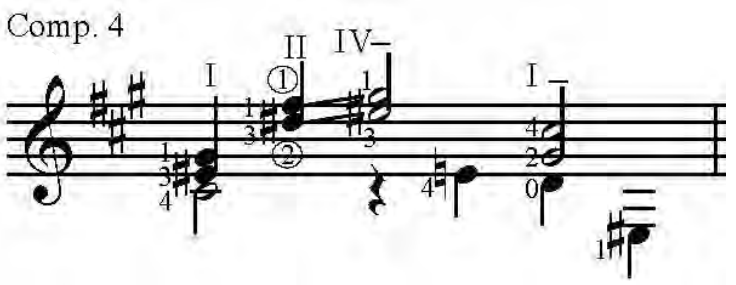

Exemplo 515: VII Estudo, compasso 4. Comp. 4 com harmônicos em décimas

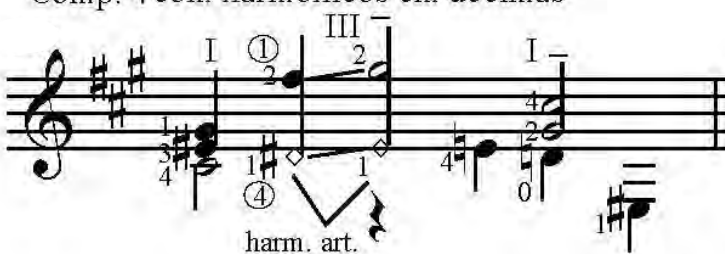

Exemplo 517: VII ${ }^{\circ}$ Estudo, compasso 4.

O exemplo 517, 518 e 519 trabalham com harmônicos artificiais na voz intermediária recolocada em posição de décimas, para gerar a terça intencionada. Usando diferentes dedos, os dois primeiros mantém ${ }^{113}$ o portamento de BL enquanto terceiro o exclui, logrando maior legato. O exemplo 520 demonstra a aplicação harmônicos duplos ao exemplo 517 em lógica que também poderia ser similarmente

113 item "deixar como está" do checklist de Osborn. 
empregada aos exemplos 518 e 519. Ele também experimenta a possibilidade do uso de um harmônico na nota Mi da voz inferior, neste caso sem muito equilíbrio por se tratar de harmônico artificial e por isso débil em relação a nota seguinte.

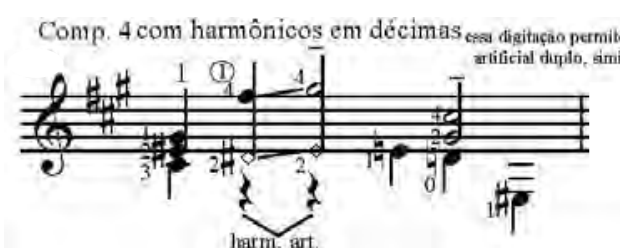

Exemplo 518: VII ${ }^{\circ}$ Estudo, compasso 4.

Comp. 4 com harmônicos duplos em décimas

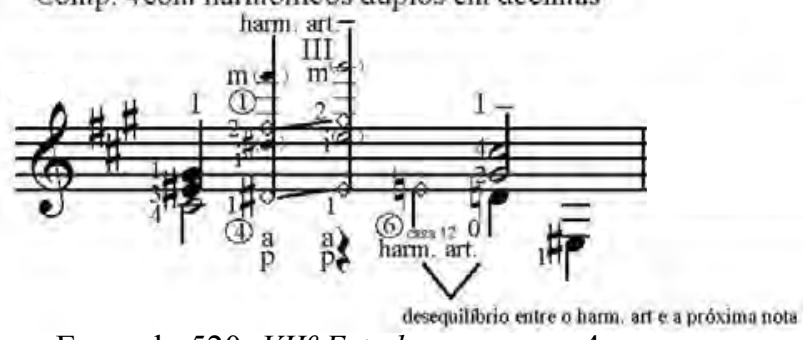

Exemplo 520: VII Estudo, compasso 4.

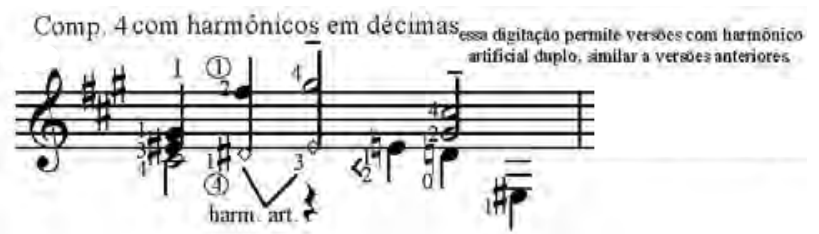

Exemplo 519: VII Estudo, compasso 4.

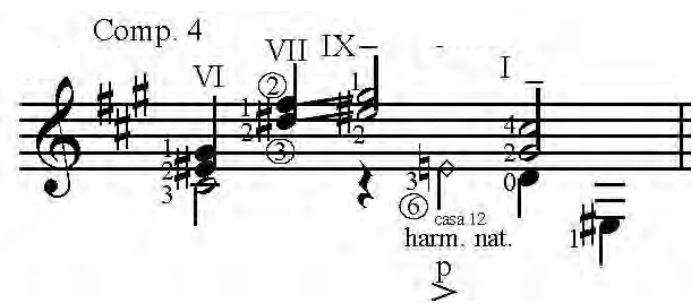

Exemplo 521: VII Estudo, compasso 4.

O exemplo 521 é o único iniciado pela sexta posição e também permite harmônicos artificiais na voz superior, embora não grafados. Para realizar o salto à primeira posição e aproveitando-se de sua proximidade à casa 12 ele recorre à mesma nota Mi em harmônico na sexta corda do exemplo anterior, mas dessa vez com melhor sonoridade por se tratar de harmônico natural passível de ser reforçado por articulação apoiada do polegar.

A abordagem de BL (ex. 522) para o compasso 6 encaminha o compasso seguinte à primeira posição, dificultando a execução de seu segundo acorde por requerer um grande salto vertical do dedo 4 o que também facilmente cria corte na duração da nota Sol. O exemplo 523 conserta isso por meio de um portamento na segunda corda com o dedo 3 , que passa a ser o guia na chegada deste acorde mas reduzindo ${ }^{114}$ a duração do anterior.

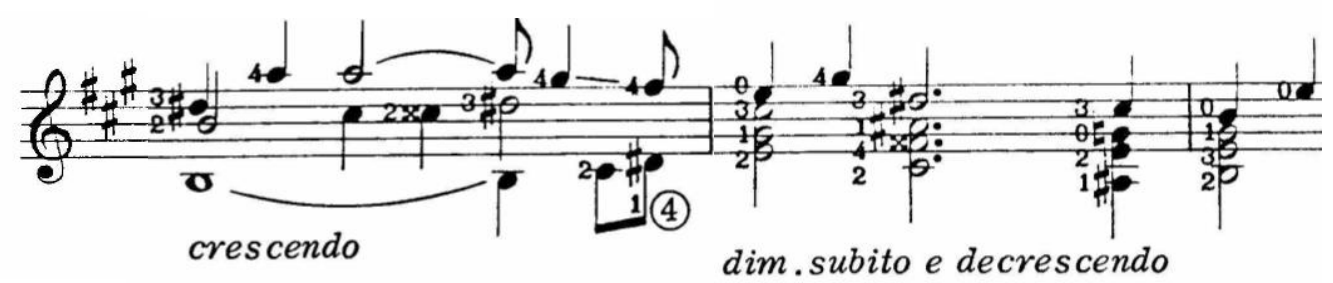

Exemplo 522: VII ${ }^{o}$ Estudo, compasso 6. Ed. Columbia/BL.

\footnotetext{
${ }^{114}$ verbo diminuir do checklist de Osborn.
} 


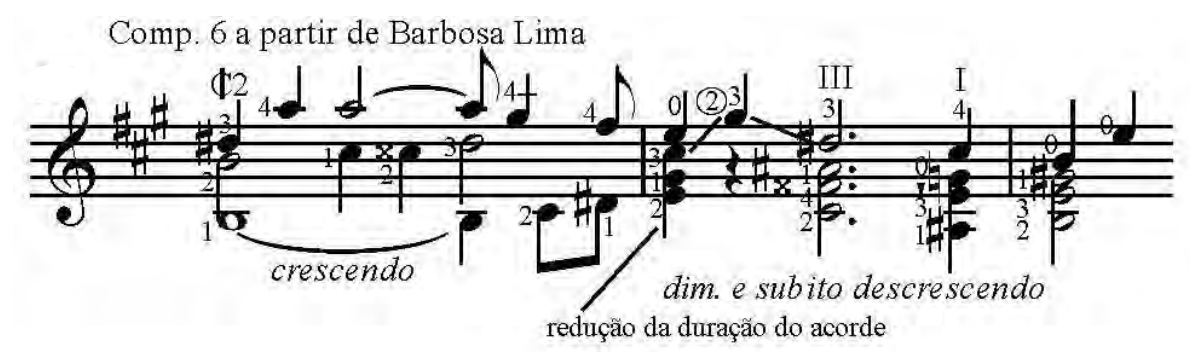

Exemplo 523: VII Estudo, compasso 6.

Todos os exemplos seguintes alcançam o segundo compasso na sexta posição por diferentes expedientes. A primeira parte da digitação BL enquanto o segundo usa pestana na quarta casa, reduzindo ${ }^{115}$ um pouco o baixo.

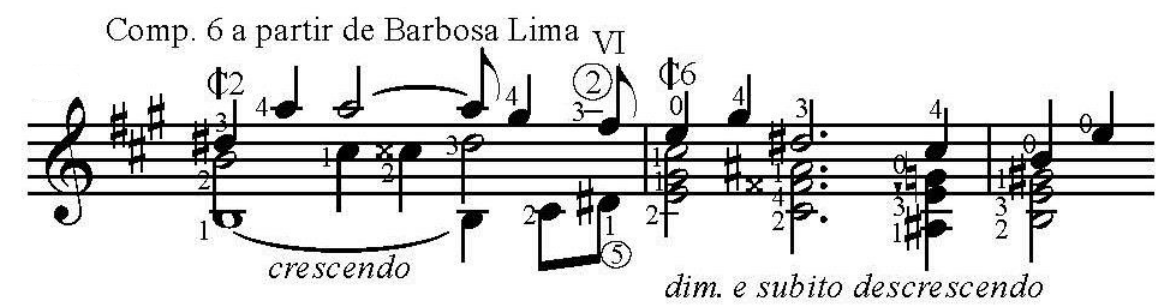

Exemplo 524: VII ${ }^{\circ}$ Estudo, compasso 6.

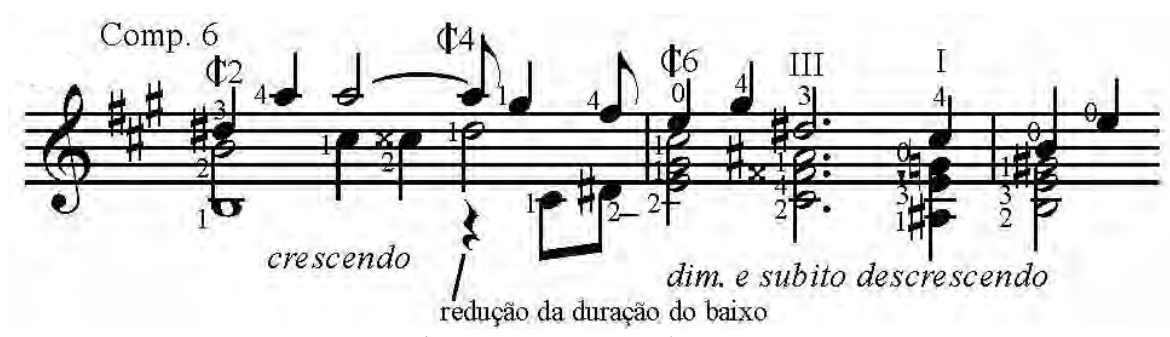

Exemplo 525: VII Estudo, compasso 6.

Já os dois exemplos finais do trecho se iniciam pela quinta posição fazendo uso da segunda corda solta. Apesar de também se iniciar pela sexta posição, o segundo compasso, recebe digitação que favorece os bordões, mas com mais ruídos.

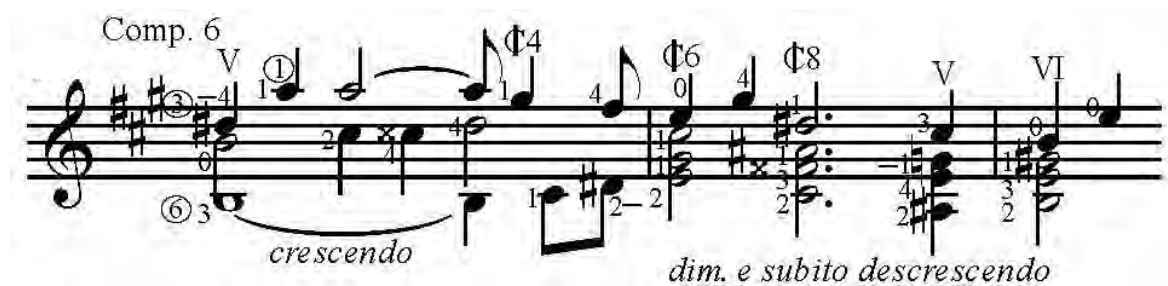

Exemplo 526: VII ${ }^{\circ}$ Estudo, compasso 6.

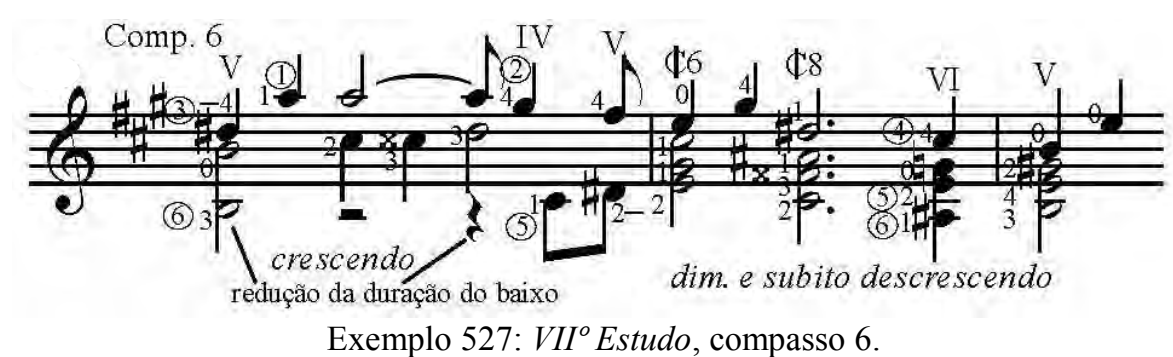

${ }^{115}$ verbo diminuir do checklist de Osborn. 
O compasso 7 ainda recebe um último experimento, também ruidoso, que consiste no aproveitamento da terceira corda solta no último acorde, que é rodeado por dedos guias.

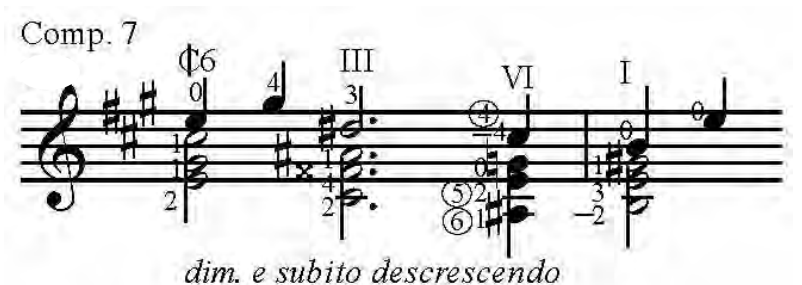

Exemplo 528: VII ${ }^{\circ}$ Estudo, compasso 7.

Os compassos 8 e 9 recebem solução racional por BL (ex. 529) enquanto o 10 permite abordagem mais pessoal. O exemplo 530 especifica melhor os dois primeiros compassos de BL, modificando-o ${ }^{116}$ sutilmente e levando a cadência final a passar pela quarta posição para culminar na quinta, em campanella.

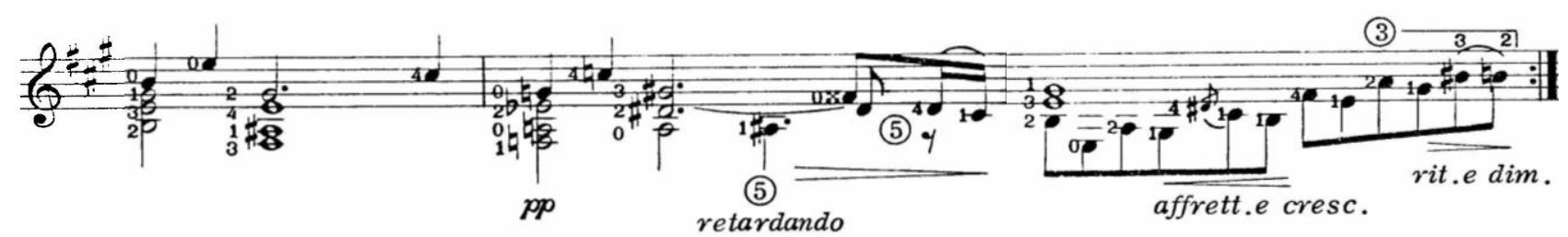

Exemplo 529: VII ${ }^{\circ}$ Estudo, compasso 8. Ed. Columbia/BL.

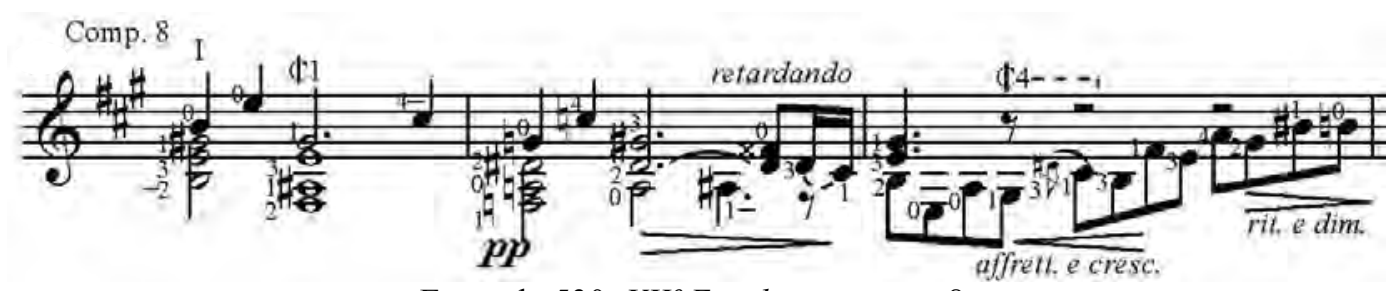

Exemplo 530: VII ${ }^{\circ}$ Estudo, compasso 8.

O exemplo 531 modifica $^{117}$ mais o segundo compasso (com resultado similar) e pauta o último pela segunda posição.

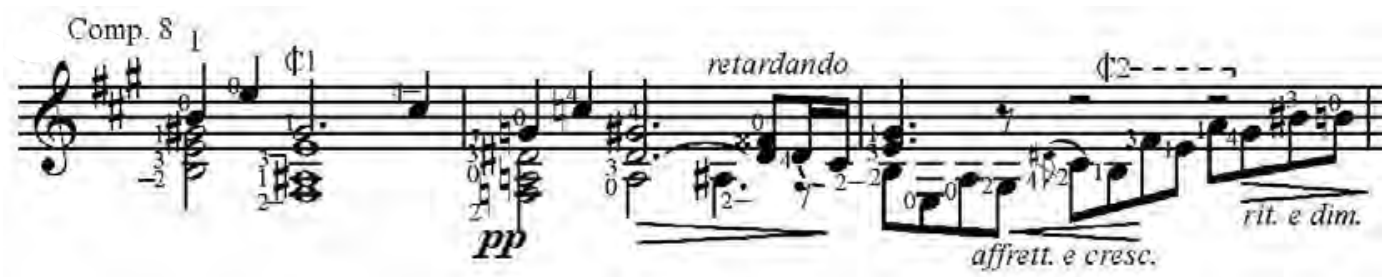

Exemplo 531: VII Estudo, compasso 8.

O trecho cadêncial ainda possui mais versões apresentadas a seguir. As duas primeiras (ex. 532 e 533) ainda privilegiam a segunda posição mas finalizam com portamento pela quarta corda com diferentes dedos. O exemplo 534 avança mais pelos bordões aproveitando os intervalos de quintas para alcançar harmônicos naturais na casa

\footnotetext{
116 verbo do checklist de Osborn.

${ }^{117}$ verbo do checklist de Osborn.
} 
12 e retornando à quinta posição com grande sustentação. $\mathrm{O}$ último exemplo do trecho testa a inserção de mais ligados girando em torno da porção inicial do instrumento.

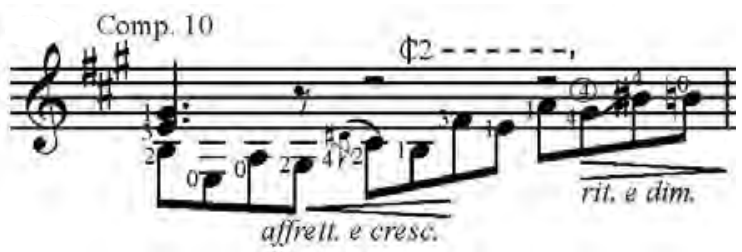

Exemplo 532: VII ${ }^{\circ}$ Estudo, compasso 10.

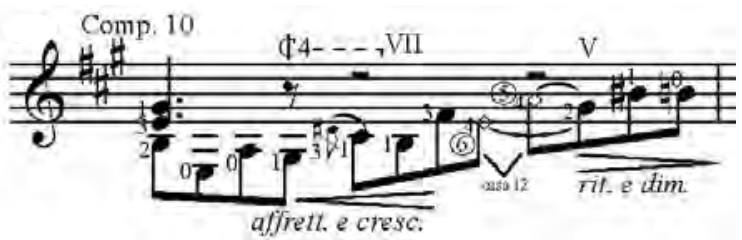

Exemplo 534: VII ${ }^{\circ}$ Estudo, compasso 10.

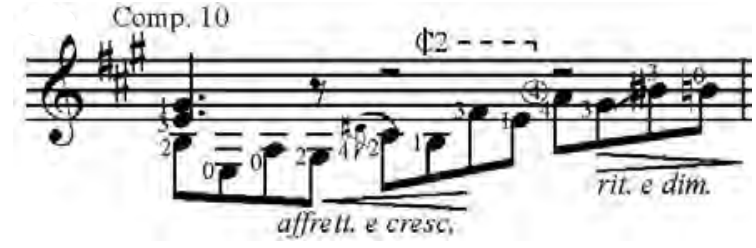

Exemplo 533: VII ${ }^{\circ}$ Estudo, compasso 10.

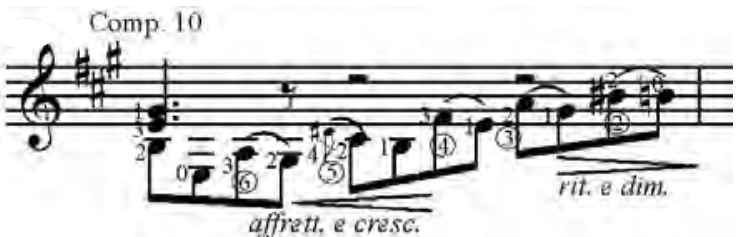

Exemplo 535: VII ${ }^{\circ}$ Estudo, compasso 10.

O compasso 11 recebe cordas soltas por BL (ex. 536), mas pode ser executado com cordas presas como no exemplo 537.

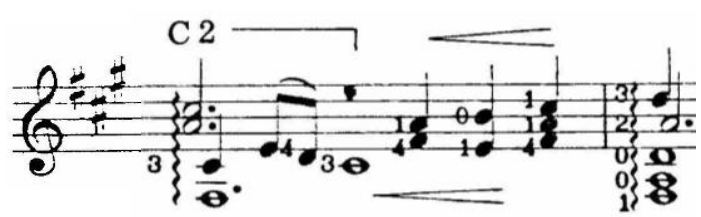

movimentando

Exemplo 536: VII ${ }^{\circ}$ Est. comp. 11. Ed. Columbia/BL.

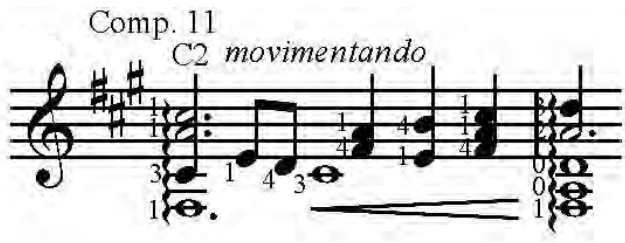

Exemplo 537: VII ${ }^{\circ}$ Est., comp. 11.

O trecho iniciado no compasso 12 novamente depende da posição que se almeja no compasso seguinte e se inicia por um acorde com sustentação plena impossível devido ao ornamento na primeira corda. O exemplo 539 difere levemente da digitação BL ao usar a segunda posição para chegar à terceira no compasso 13.

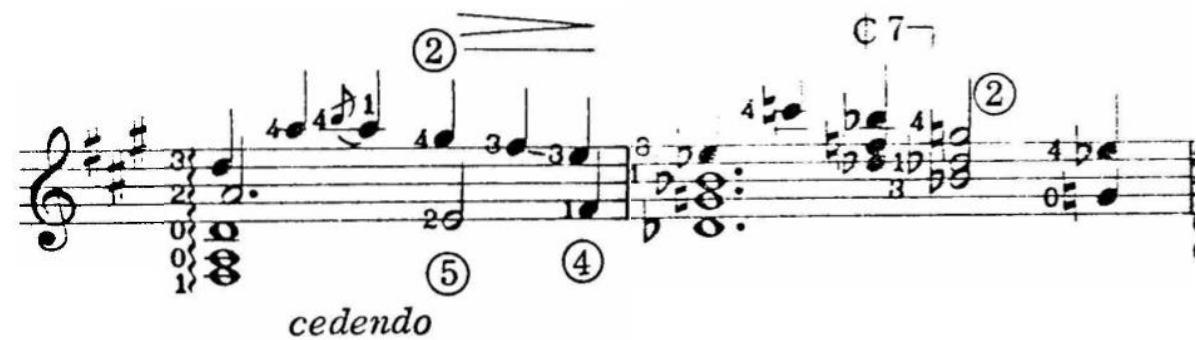

Exemplo 538: VII $^{\circ}$ Estudo compasso 12. Ed. Columbia/BL.

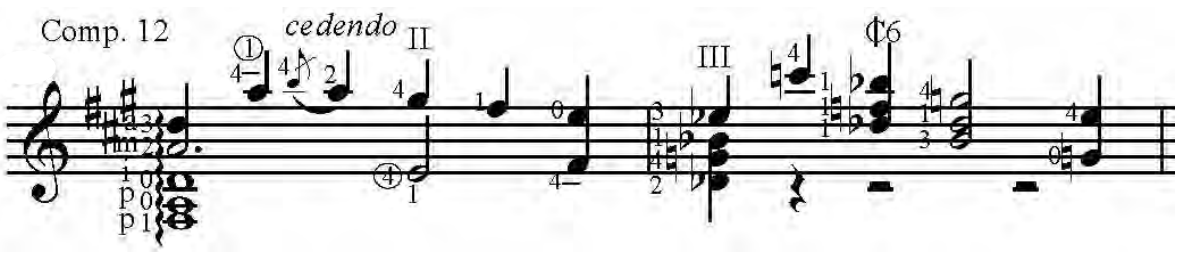

Exemplo 539: VII Estudo, compasso 12.

Já os exemplos 540 e 541 almejam chegar ao compasso 13 na oitava posição por expedientes distintos: o primeiro usando a quinta corda com o dedo 3 como guia e o 
segundo ascendendo à sétima posição pela segunda corda (com ornamento em corda dupla).

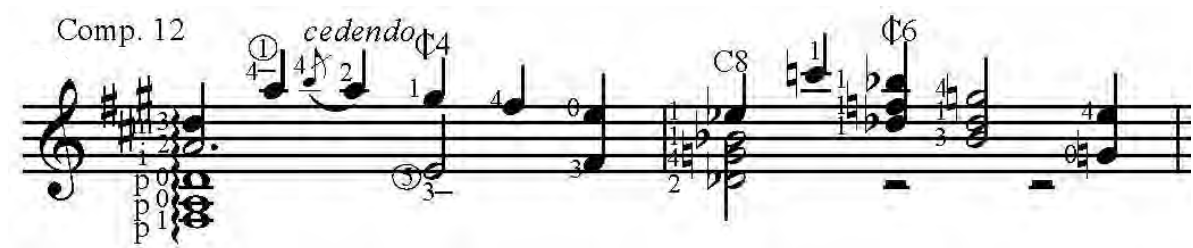

Exemplo 540: VII Estudo, compasso 12.

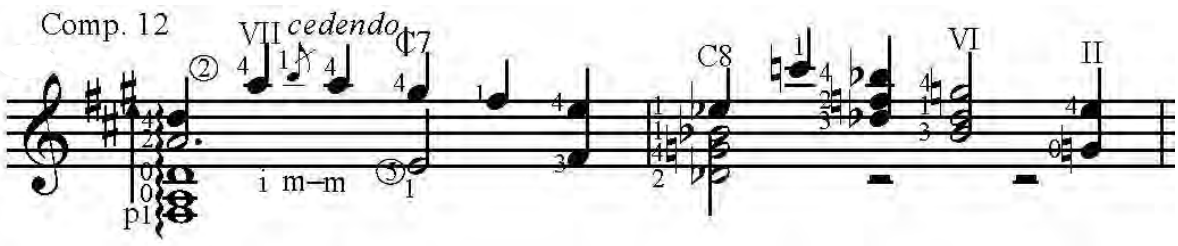

Exemplo 541: VII ${ }^{\circ}$ Estudo, compasso 12.

O compasso 14 parte do mesmo acorde de duração plena impossível e recebe boa resolução por BL. O exemplo 543 “desliza” pelas duas primas alcançando o último acorde com o dedo 3 .
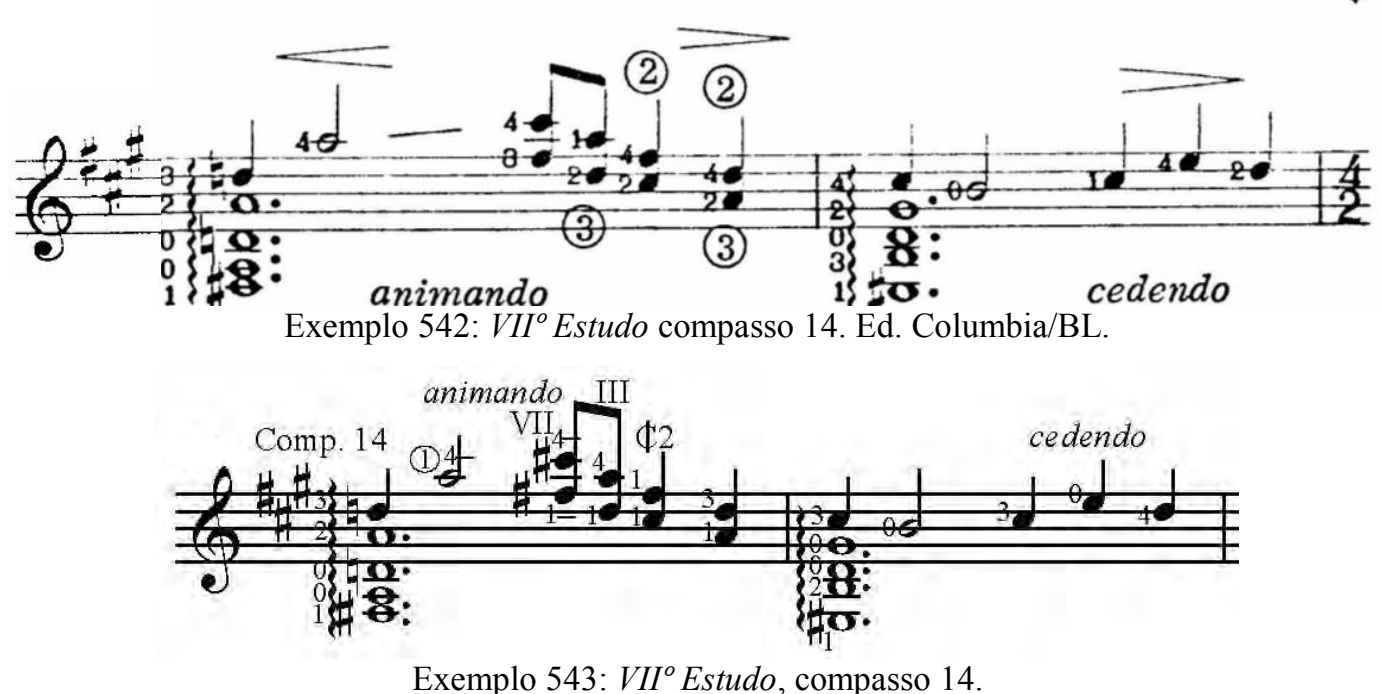

Todos os exemplos seguintes se unificam pela presença de pestana na sétima casa, mas diferem em como a atingem: o primeiro por falso guia na primeira corda, o segundo ascendendo pela segunda corda e o terceiro por uso de harmônico artificial, que possibilita o salto de $m e$.

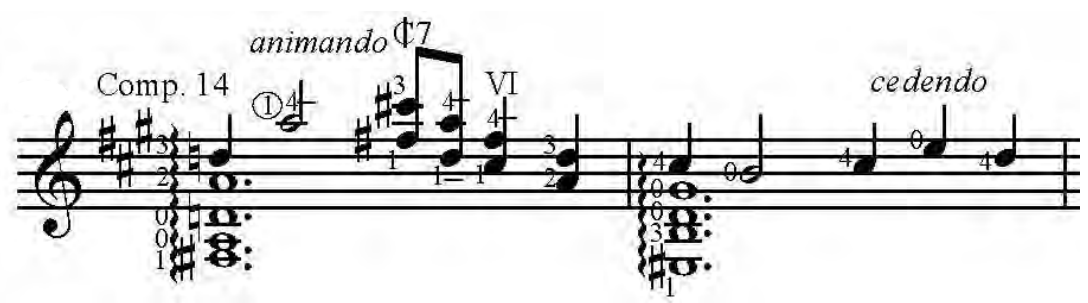

Exemplo 544: VII Estudo, compasso 14. 


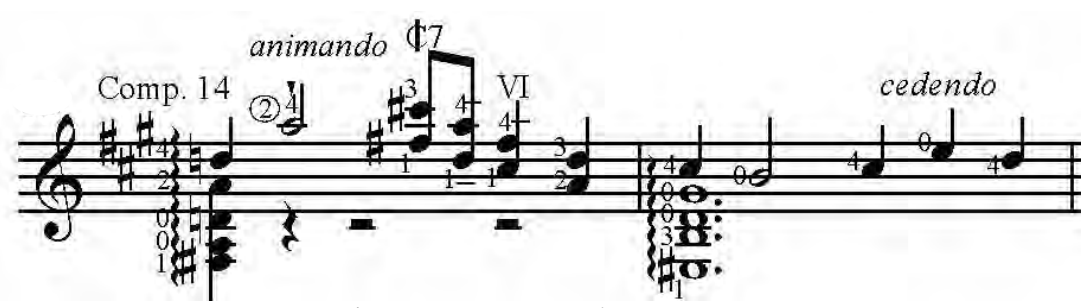

Exemplo 545: VII Estudo, compasso 14.

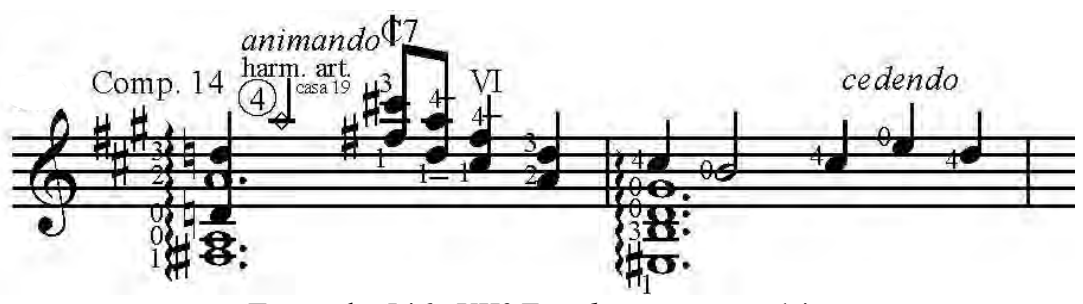

Exemplo 546: VII Estudo, compasso 14.

O compasso 16 consegue no exemplo 548 maior sustentação harmônica do que na digitação BL (ex. 547) mantendo-se na primeira posição, com algum malabarismo.

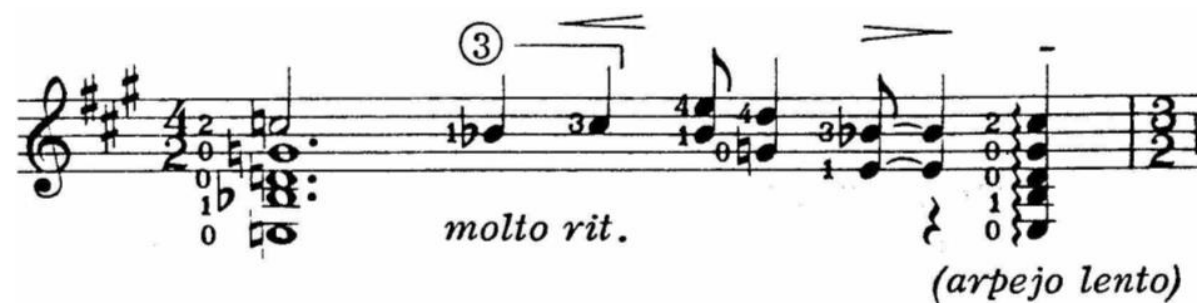

Exemplo 547: VII Estudo, compasso 16. Ed. Columbia/BL.

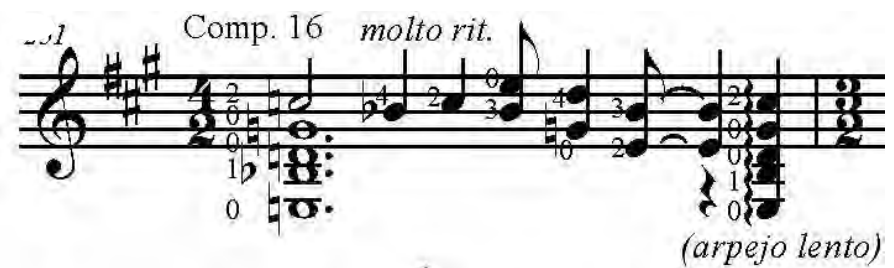

Exemplo 548: $V I I^{\circ}$ Estudo, compasso 16.

O inverso ocorre no compasso 18 , onde a digitação BL permanece na primeira posição e oferece maior prolongação porém com maior dificuldade do que as nossas que por sua vez resolvem as tercinas com pestana na terceira casa usando diferentes dedos. A última delas, abdica da sustentação para inserir um portamento na segunda corda.

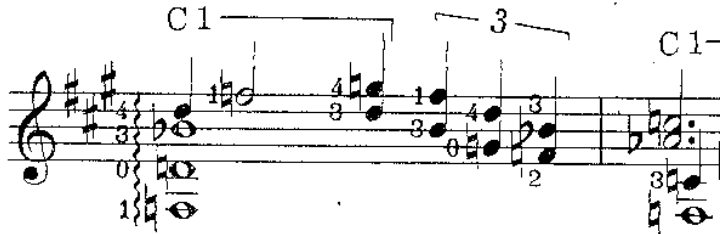

Exemplo 549: VII ${ }^{\circ}$ Estudo, comp. 18. Ed. Columbia/BL.

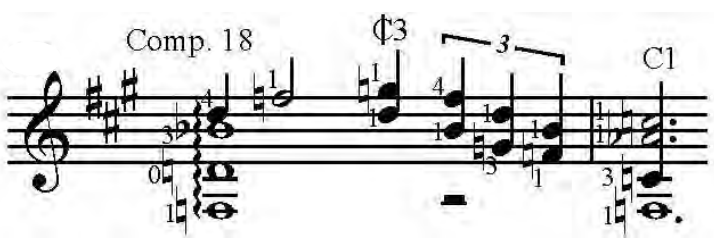

Exemplo 550: VII ${ }^{\circ}$ Estudo, comp. 18.

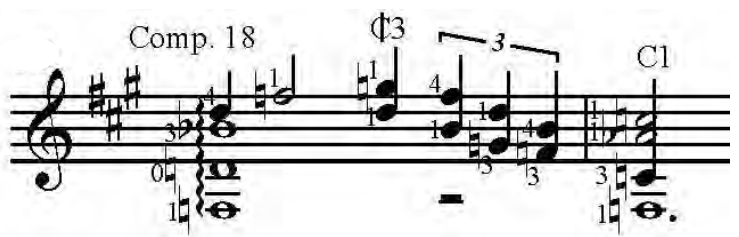

Exemplo 551: VII ${ }^{\circ}$ Estudo, compasso 18.

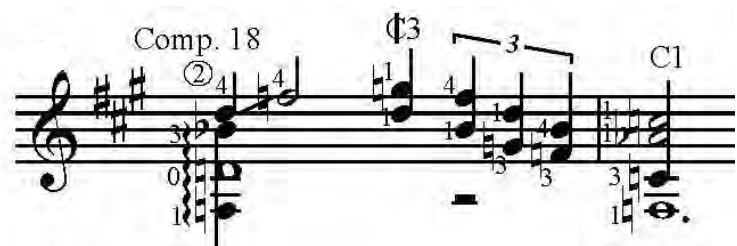

Exemplo 552: VII ${ }^{\circ}$ Estudo, compasso 18. 
O mesmo ocorre com o compasso 20, onde nossa única outra opção versão também recebe portamento e com isso reduz ${ }^{118}$ a duração do acorde.

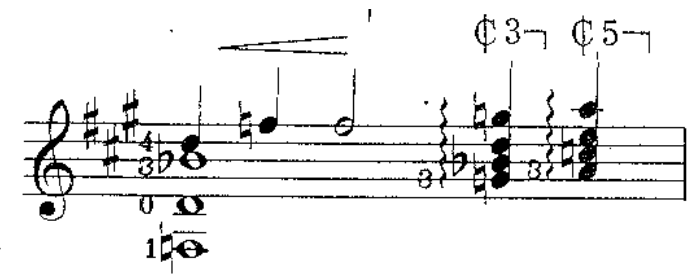

Exemplo 553: VII ${ }^{\circ}$ Estudo, comp. 20. Ed. Columbia/BL.

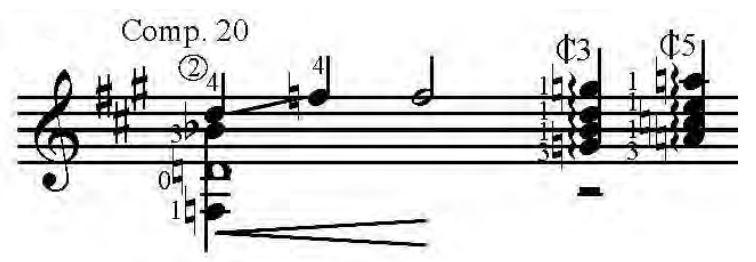

Exemplo 554: VII Estudo, comp. 20.

O clímax do estudo é alcançado por acorde de seis notas no manuscrito, lamentavelmente impossível de ser realizado com tantas vozes. Ele recebe uma redução ${ }^{119}$ considerável por BL a quatro notas possivelmente para tornar possível o uso do toque apoiado no polegar e anelar nas vozes extremas e assim conseguir maior intensidade. Nossa sugestão (ex. 557) consegue abarcar seis vozes, mas modifica ${ }^{120}$ uma nota, ainda respeitando obviamente a harmonia. Essa utilização das seis cordas do instrumento comporta vários padrões de $m d$, dos quais destacamos o uso do polegar triplo nos bordões e $i-m-a$ nas primas ou apenas polegar deslizando por todas as notas. O trecho final do compasso também outra recebe resolução por pestana na oitava casa e deslizamento do dedo 4 pela segunda corda.

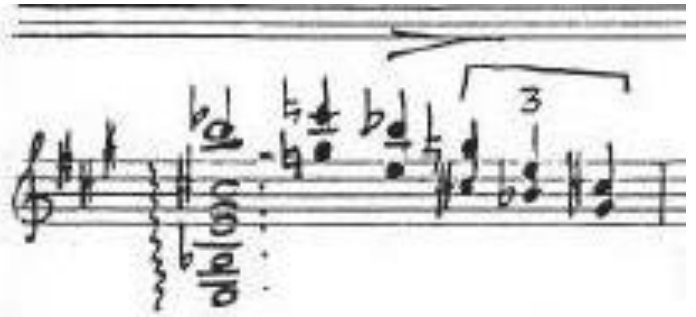

Exemplo 555: VII Estudo, compasso 21. Manusc.

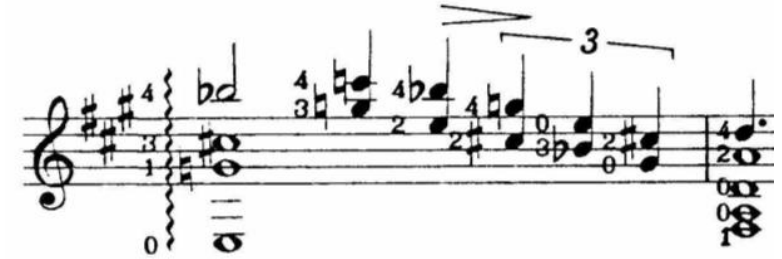

Exemplo 556: Est. 7, comp. 21. Ed. Columbia/BL.

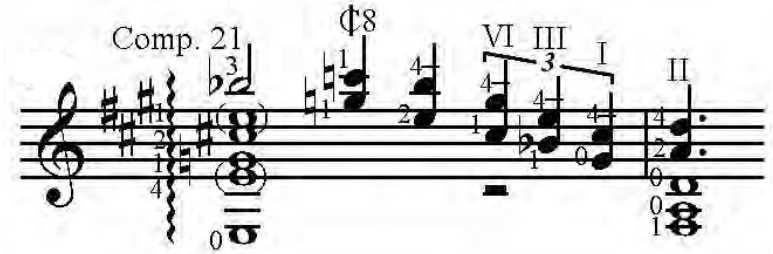

Exemplo 557: Est. 7, comp. 21.

De forma contrária o compasso 22 recebe apenas uma sugestão de supressão ${ }^{121}$ de nota (entre parêntesis) para evitar sua redundância e facilitar a $m d$.

\footnotetext{
118 verbo diminuir do checklist de Osborn.

${ }^{119}$ verbo diminuir do checklist de Osborn.

${ }^{120}$ verbo do checklist de Osborn.

${ }^{121}$ verbo diminuir do checklist de Osborn.
} 


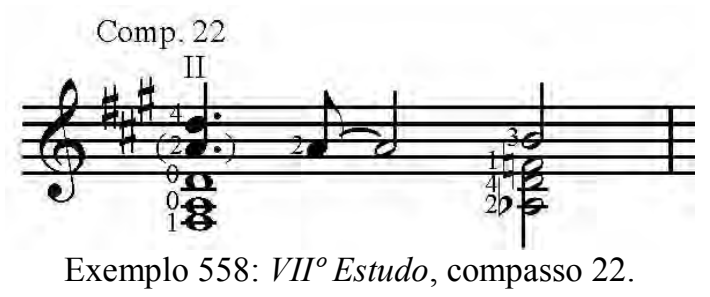

O mesmo ocorre no compasso 23, pelo mesmo motivo, o qual também recebe nova digitação de oitavas e uma correção de bequadros no Fá.

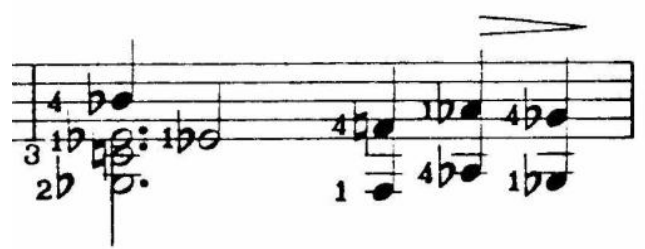

Exemplo 559: VII ${ }^{o}$ Est., comp. 23. Ed. Columbia/BL.

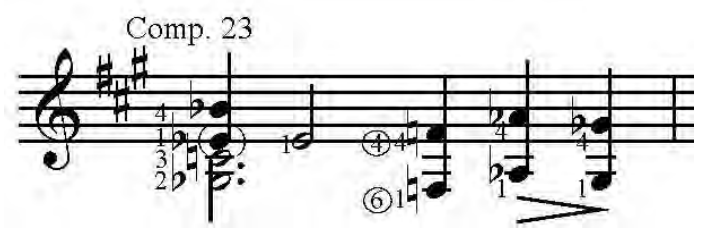

Exemplo 560: VII Est., comp. 23.

O compasso 24 apresenta bastante cromatismo na região grave do instrumento característica que favorece a aparição de ruídos de arraste. A única mudança em nossa digitação é a redução ${ }^{122}$ do uso triplo do dedo 4 por BL na voz interna, substituindo-o pelo dedo 1 em compressão.

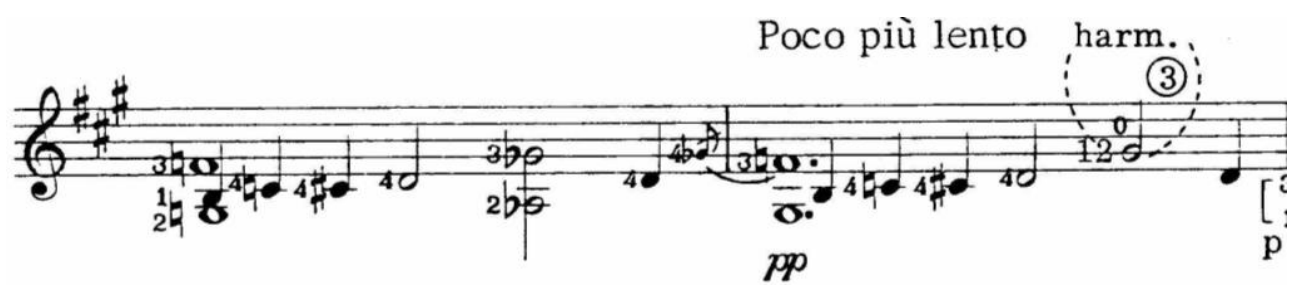

Exemplo 561: VII ${ }^{o}$ Estudo, compasso 24. Ed. Columbia/BL.

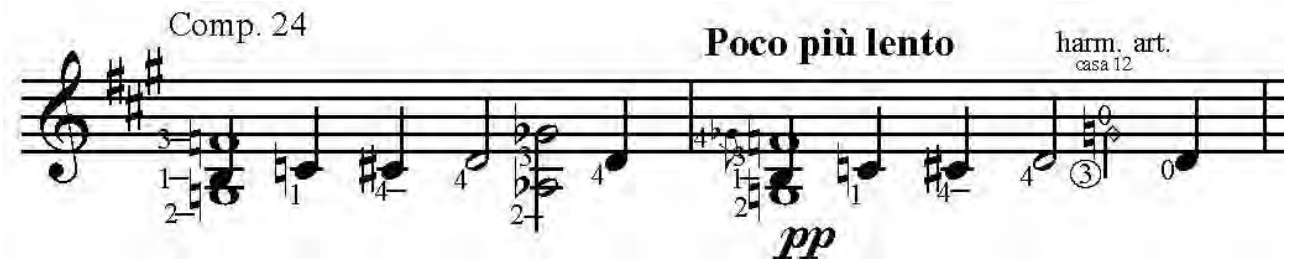

Exemplo 562: VII Estudo, compasso 24.

Uma nova passagem recebe harmônicos duplos no manuscrito (ex. 563) que são aplicados coerentemente apenas à voz superior por BL (ex. 26). Ele também exclui um ornamento duplo em intervalo de quintas no baixo de pouco resultado violonístico por envolver as cordas graves em arraste muito ruidoso, num trecho muito sutil.

${ }^{122}$ verbo diminuir do checklist de Osborn. 


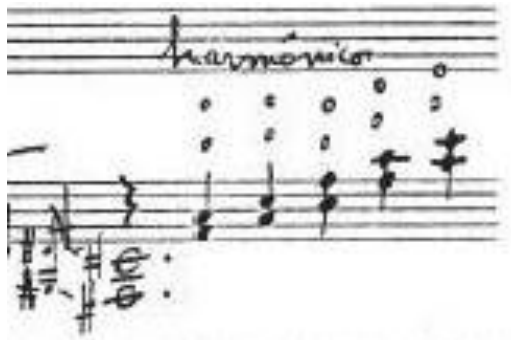

Exemplo 563: VII ${ }^{\circ}$ Estudo, compasso 26. Manusc.

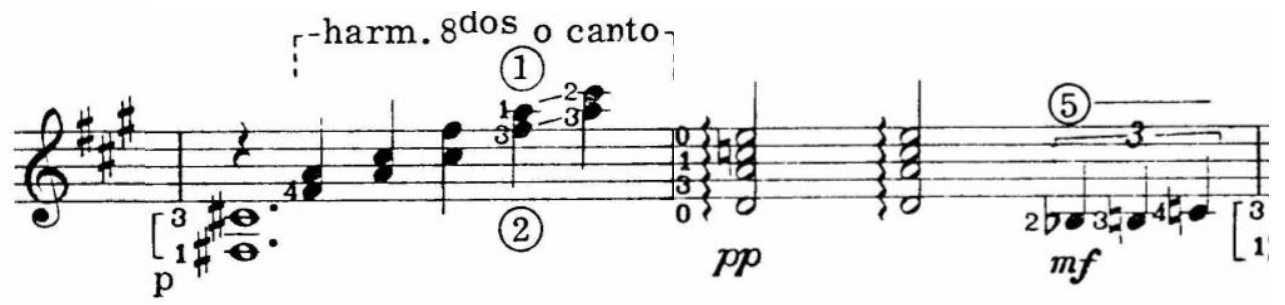

Exemplo 564: VII Estudo, compasso 26. Ed. Columbia/BL.

$\mathrm{O}$ exemplo 565 possui digitação muito similar à $\mathrm{BL}$, com exceção dos baixos cromáticos finais e da reinserção das quintas paralelas iniciais (apenas a título de teste para o leitor). A grafia dos harmônicos também é esclarecida com losangos e a $m d$ melhor especificada. Lamentavelmente os dois harmônicos finais soam demasiadamente vazios tanto pela redução ${ }^{123}$ na duração do baixo quanto pelo corte de legato nas trocas de posição.

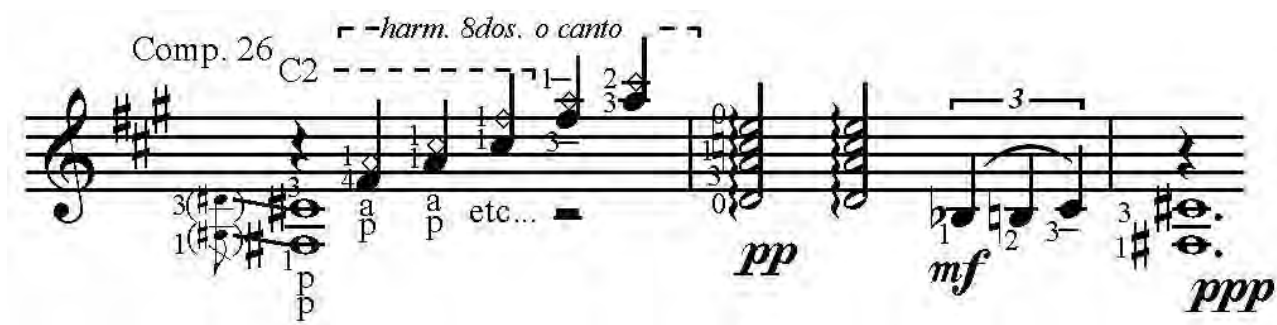

Exemplo 565: VII Estudo, compasso 26.

A execução dos harmônicos duplos seria possível nessa digitação usando-se o indicador curvo sobre duas cordas para firmar as oitavas artificiais dos harmônicos e o polegar e anelar como articuladores das notas. No entanto, ela logra pouco resultado em nossa opinião, devido à dificuldade de emissão do primeiro e dos últimos dois harmônicos e principalmente porque sua pouca sonoridade exacerba o vazio gerado nos dois últimos tempos.

A primeira estratégia foi tentar maior sobreposição dos harmônicos finais do compasso 26, como nos exemplos 566 e 567 mas isso sacrifica consideravelmente a duração do baixo. O primeiro deles utiliza a nona posição com um salto mal resolvido que gera um corte de legato abrupto na mudança de posições. $\mathrm{O}$ seguinte salta para quinta posição, fazendo uso engenhoso da terceira corda no último harmônico e obtém

\footnotetext{
${ }^{123}$ verbo diminuir do checklist de Osborn.
} 
um melhor resultado geral por apresentar um salto consideravelmente menor. Embora também prejudique a duração do baixo isso não é sentido como um problema grande por não haver corte no legato na troca de posições.

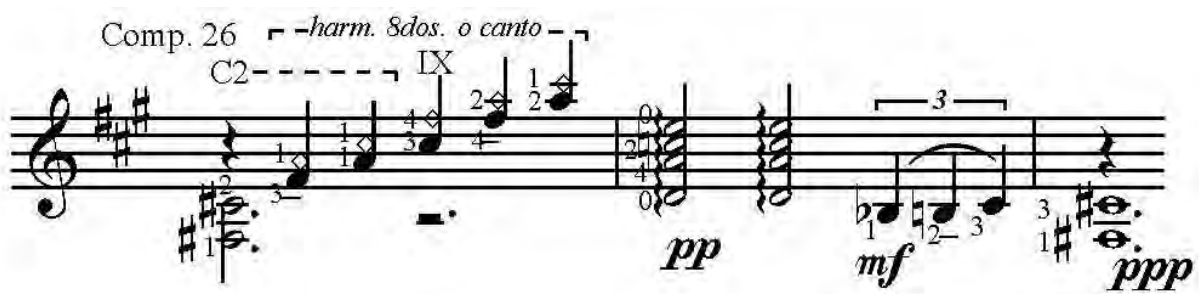

Exemplo 566: VII ${ }^{\circ}$ Estudo, compasso 26.

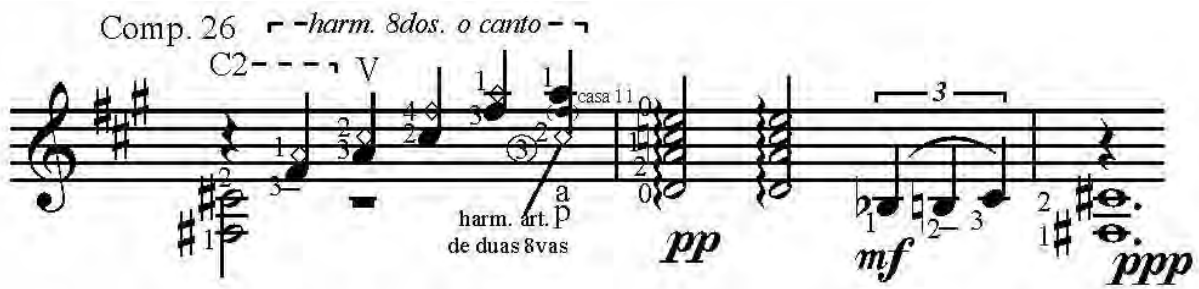

Exemplo 567: VII ${ }^{\circ}$ Estudo, compasso 26.

Essa ideia do uso de harmônicos em sextas leva a seu extrapolamento no exemplo 568, finalmente conseguindo manter todos os harmônicos na mesma posição e com isso executando a duração plena dos baixos. Novamente uma ideia que não teria sido gerada por nós sem o processo de busca por várias soluções estimulado por nosso referencial teórico.

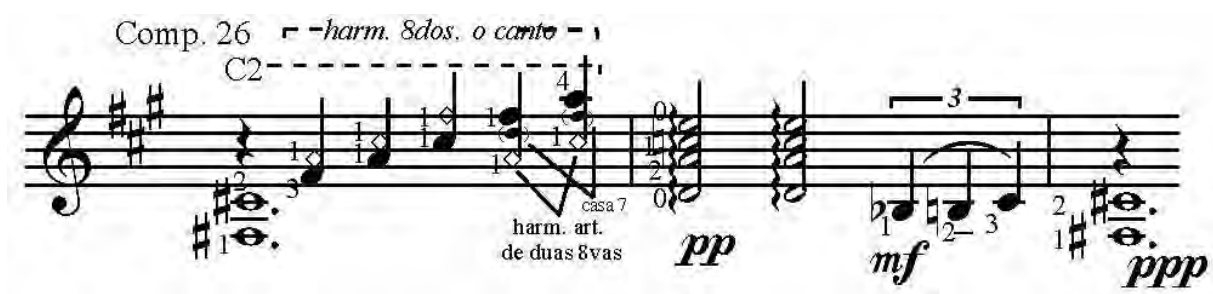

Exemplo 568: VII Estudo, compasso 26.

Outra ideia que gera a duração integral dos baixos é a reescrita da voz intermediária da seguinte forma:

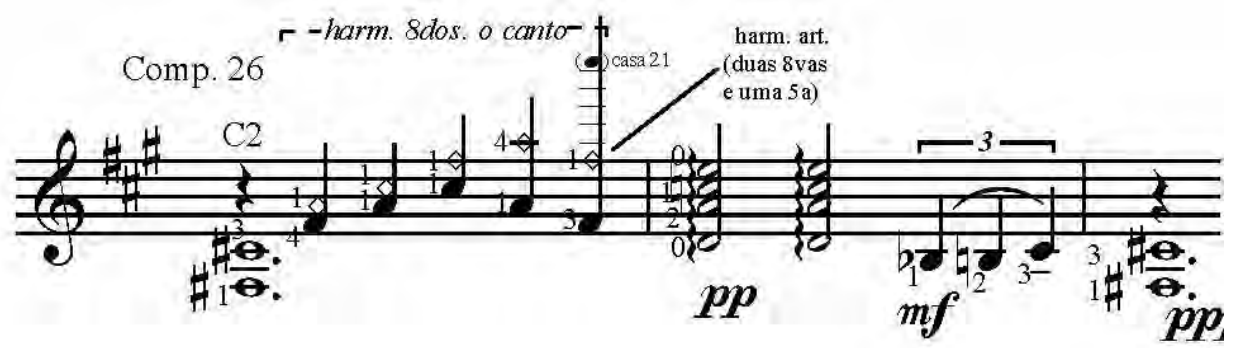

Exemplo 569: VII ${ }^{\circ}$ Estudo, compasso 26.

Lembrando que o trecho ainda pode ser tocado com bom resultado da maneira mas simples, ou seja, sem harmônicos, e ainda pode ganhar potencial dramático e maior reverberação através de vibrato nas duas últimas notas: 


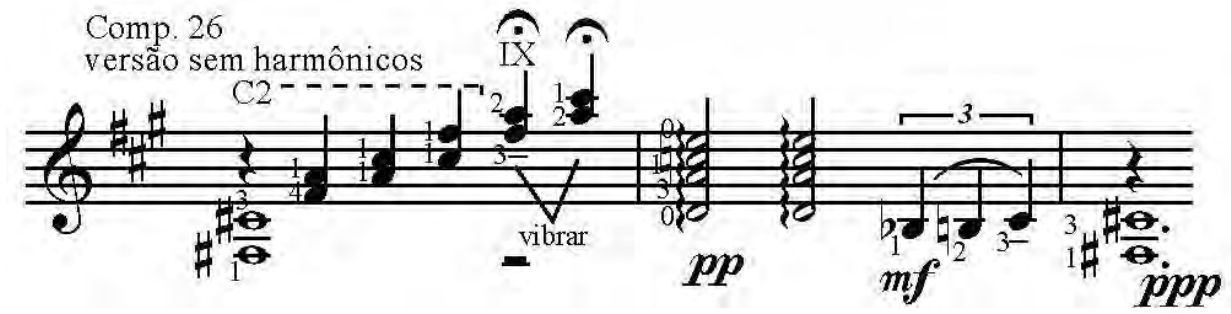

Exemplo 570: $V I I^{\circ}$ Estudo, compasso 26.

O compasso 29, bem resolvido por BL, ganha duas versões experimentais na quinta posição sem melhora substancial.

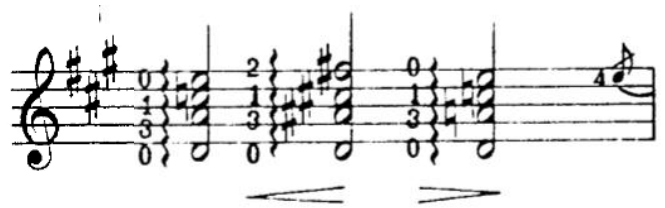

Exemplo 571: VII ${ }^{o}$ Estudo, compasso 29. Ed. Columbia/BL.

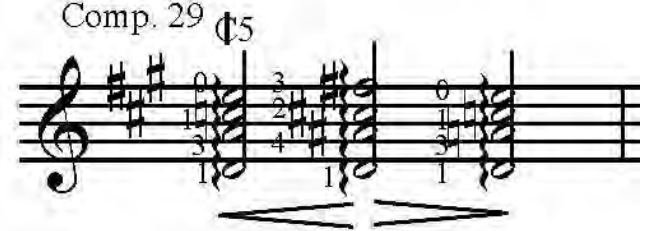

Exemplo 572: VII ${ }^{\circ}$ Estudo, compasso 29.

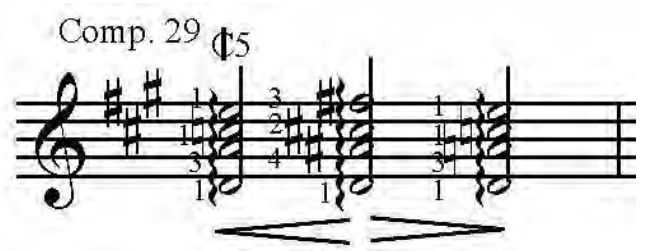

Exemplo 573: VII Estudo, compasso 29.

O segmento final tem novos harmônicos duplos o primeiro deles factível pelo expediente do dedo $i$ novamente cobrindo duas cordas em cima da oitava desejada (neste caso, na $22^{\mathrm{a}}$ casa) enquanto o $p$ e $a$ articulam as notas. Mesmo assim ainda preferimos a sonoridade e segurança dos harmônicos simples.

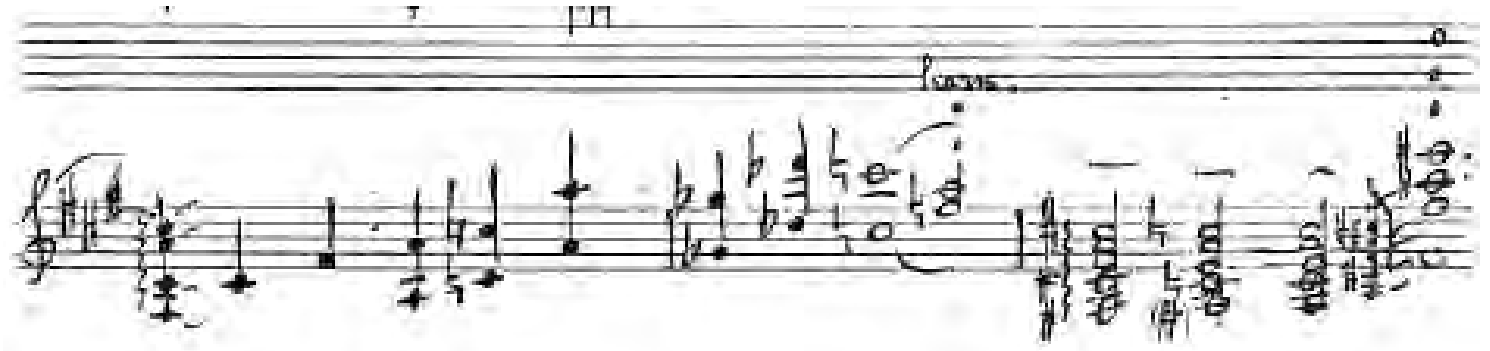

Exemplo 574: VII ${ }^{o}$ Estudo, compasso 30. Manusc.

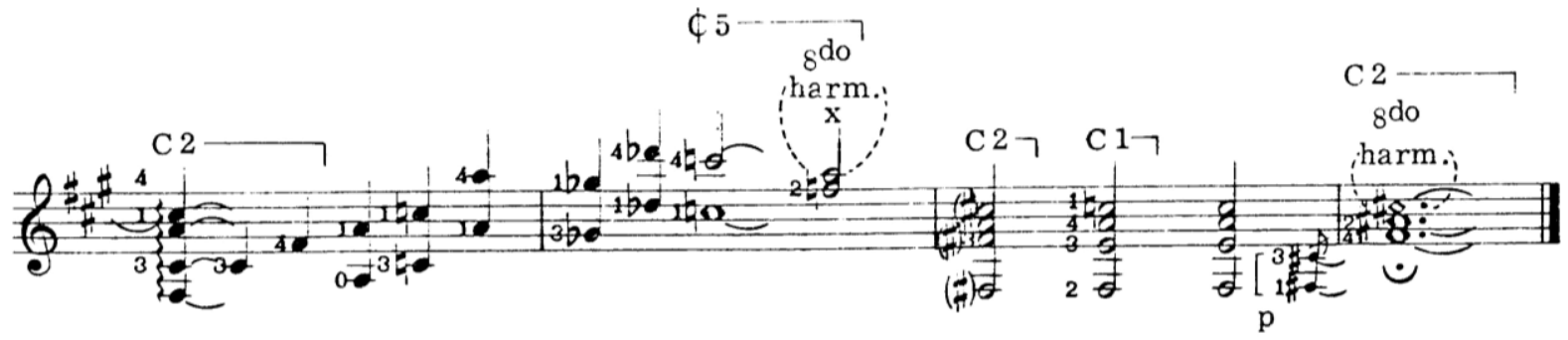

Exemplo 575: VII ${ }^{o}$ Estudo, compasso 30. Ed. Columbia/BL.

Na digitação BL (ex. 565) o compasso 31 almeja alcançar a quinta casa em seu ápice, porém o compasso anterior parece exagerar em saltos verticais do dedo 1 .

De maneira distinta, nossos exemplos sempre buscaram alcançar os harmônicos na oitava posição, para com isso conseguir duração plena da oitava que os circunda. 


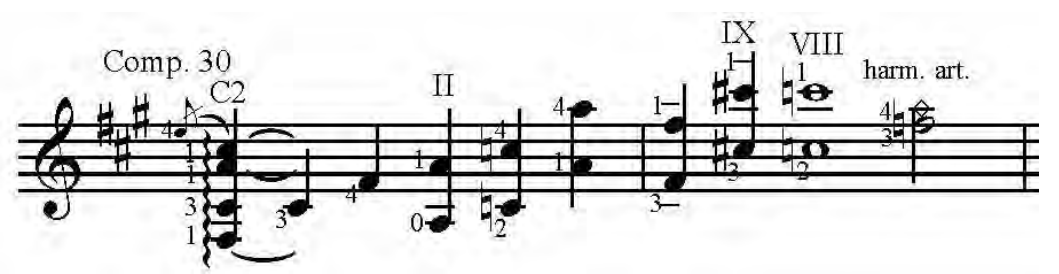

Exemplo 576: VII Estudo, compasso 30.

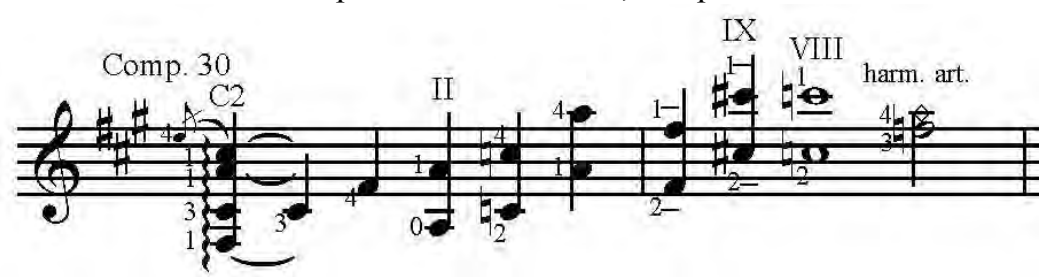

Exemplo 577: VII ${ }^{\circ}$ Estudo, compasso 30.

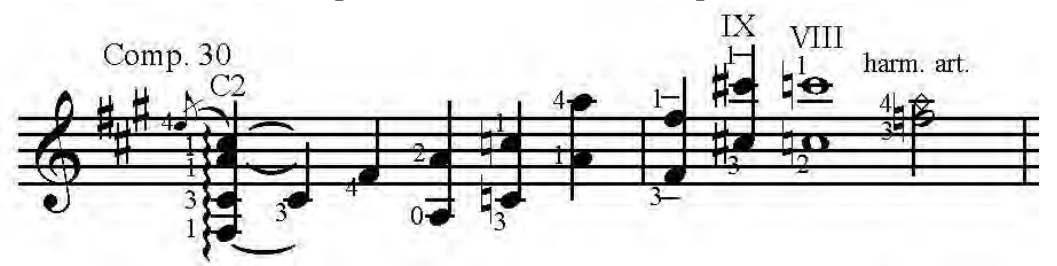

Exemplo 578: VII ${ }^{\circ}$ Estudo, compasso 30.

Os acordes da progressão final também podem receber digitação diferente da de BL. O primeiro exemplo fixa o dedo 2 no baixo para garantir ligação entre os acordes, mas tem de recorrer a uma meia-pestana não usual da falange distal do dedo 1 nas cordas centrais, movimento às vezes impossível para alguns violonistas por depender da fisiologia de seus dedos e por isso não absorvível por estudo. Já o exemplo 577 adota os acordes de cinco notas do manuscrito original (ver ex. 574) e detalha sua execução.

Lamentavelmente, o compasso final é impossível de ser realizado conforme o manuscrito (ver ex. 574), mas consideramos que a solução de BL cortou demasiadas notas e colocou o harmônico na segunda corda, em região mais "escura". Nossa única alternativa prevê maior tessitura do acorde (que utiliza praticamente a extensão total do instrumento), contando com mais bordões e com harmônico artificial de $12^{\mathrm{a}}$ (ou seja, soando uma oitava mais uma quinta acima).

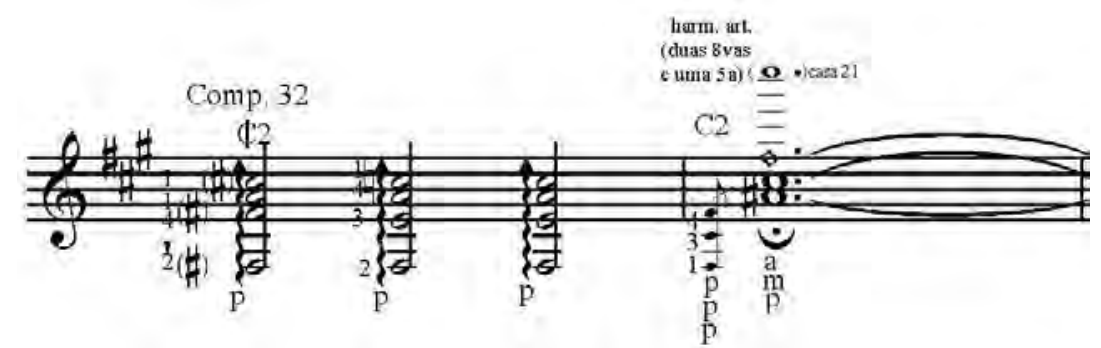

Exemplo 579: VII ${ }^{\circ}$ Estudo, compasso 32.

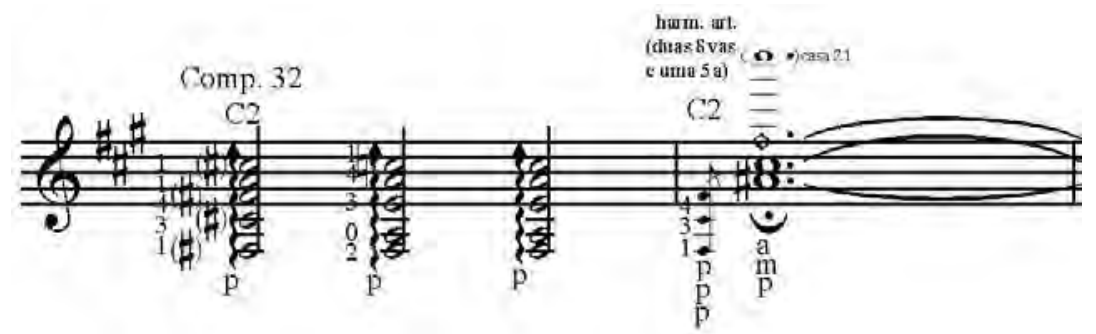

Exemplo 580: VII ${ }^{\circ}$ Estudo, compasso 32. 


\section{8: VIII Estudo "Allegro"}

Neste estudo de grande dificuldade as notas repetidas aparecem com ainda maior frequência dentro de arpejos ascendentes e descendentes, articuladas duplamente à cada acorde em praticamente toda a obra. O padrão rítmico, segundo Apro "situa-se entre o paso doble hispânico e o frevo pernambucano" (Apro, 2004, p.105), justificando que "existe, efetivamente, uma influência da música espanhola (especialmente o paso doble das touradas e o zapateado flamenco) sobre o frevo". Pessoalmente, sentimos mais a influência do ritmo pernambucano, mas devemos frisar que ele não aparece literalmente na obra, sendo esta possível influência mais subjetiva do que textual.

O primeiro exemplo segue a digitação BL de me (apenas substituindo o dedo 3 pelo 2 no baixo Sol) e recebe especificação variada de $m d$ (que é favorecida com toques repetidos de polegar). No segundo compasso as notas marcadas com $x$ não devem ser tocadas pois apenas buscam representar adiantamentos de dedos guias com o intuito de evitar saltos, artifício também utilizado nos exemplos seguintes. No aspecto interpretativo pode-se incluir um staccato no segundo tempo de cada acorde ternário, o que exacerba o seu aspecto frevístico.

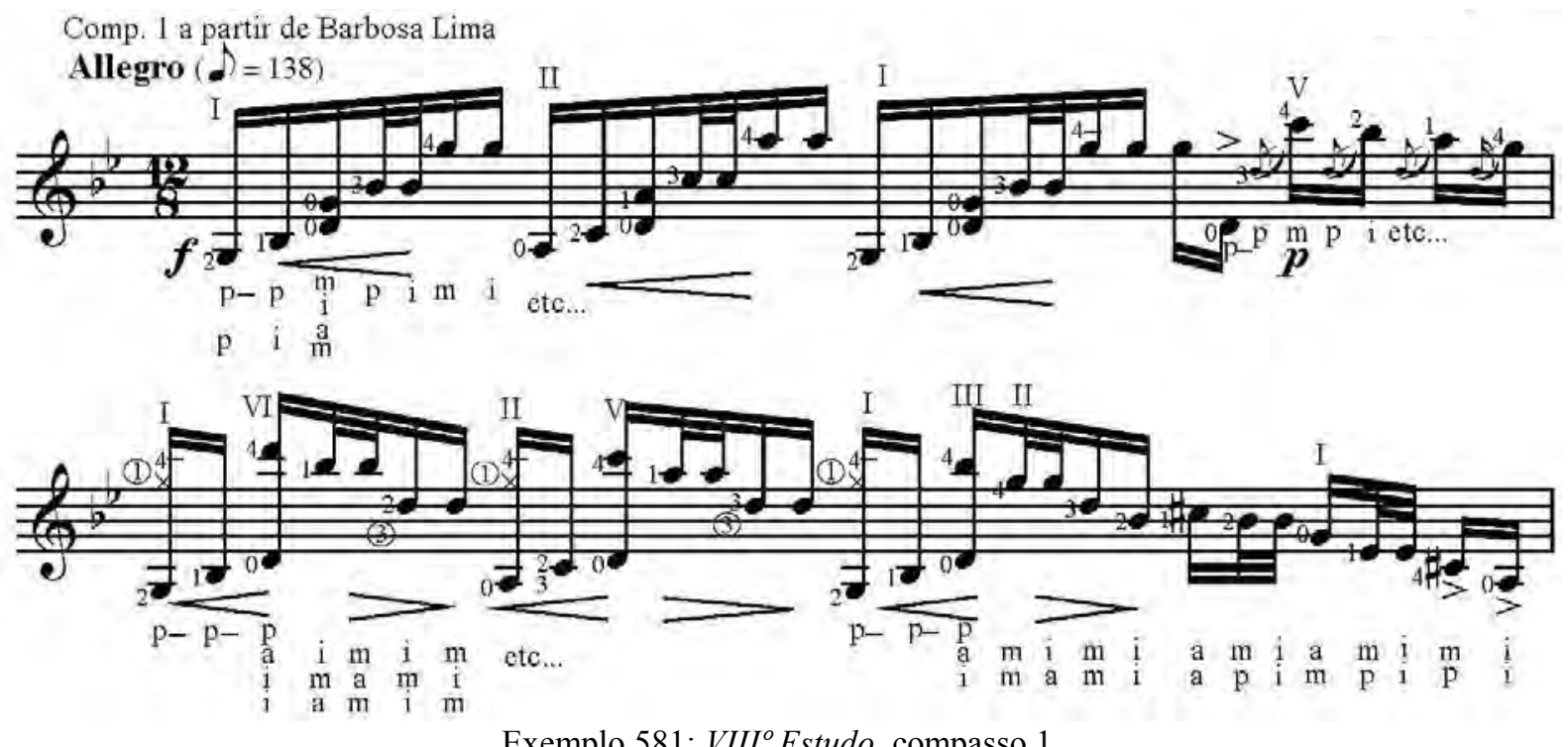

Exemplo 581: VIII $^{\circ}$ Estudo, compasso 1.

Um recurso bastante facilitador é a inclusão de um ligado nas notas graves. No exemplo 582 ele é aplicado em acordes presos por pestana no primeiro compasso, algo que sobrecarrega um pouco a me e que portanto é acessibilizado no exemplo seguinte com cordas soltas. O segundo compasso também sofre modificações ${ }^{124}$ de posições por essa inclusão de ligados (em relação a BL) e recebe uma pestana na casa 3 que melhora

\footnotetext{
${ }^{124}$ verbo do checklist de Osborn.
} 
substancialmente o translado de dedo 4 antes previsto por BL. Neste ponto a versão seguinte também apresenta um desfecho levemente diferente.

Comp. 1 com ligados

Allegro $(-138)$
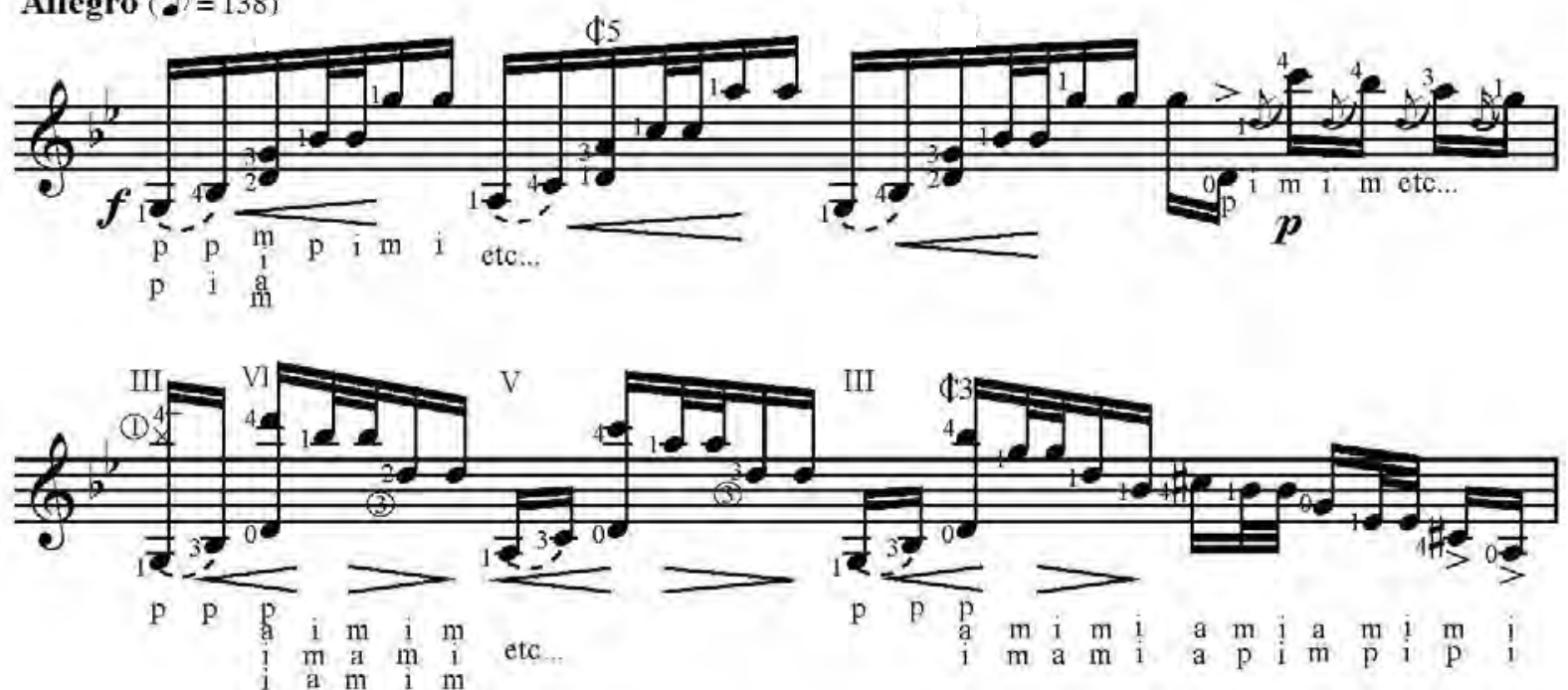

Exemplo 582: VIII $^{\circ}$ Estudo, compasso 1.

Comp. 1 com ligados

Allegro $(-138)$
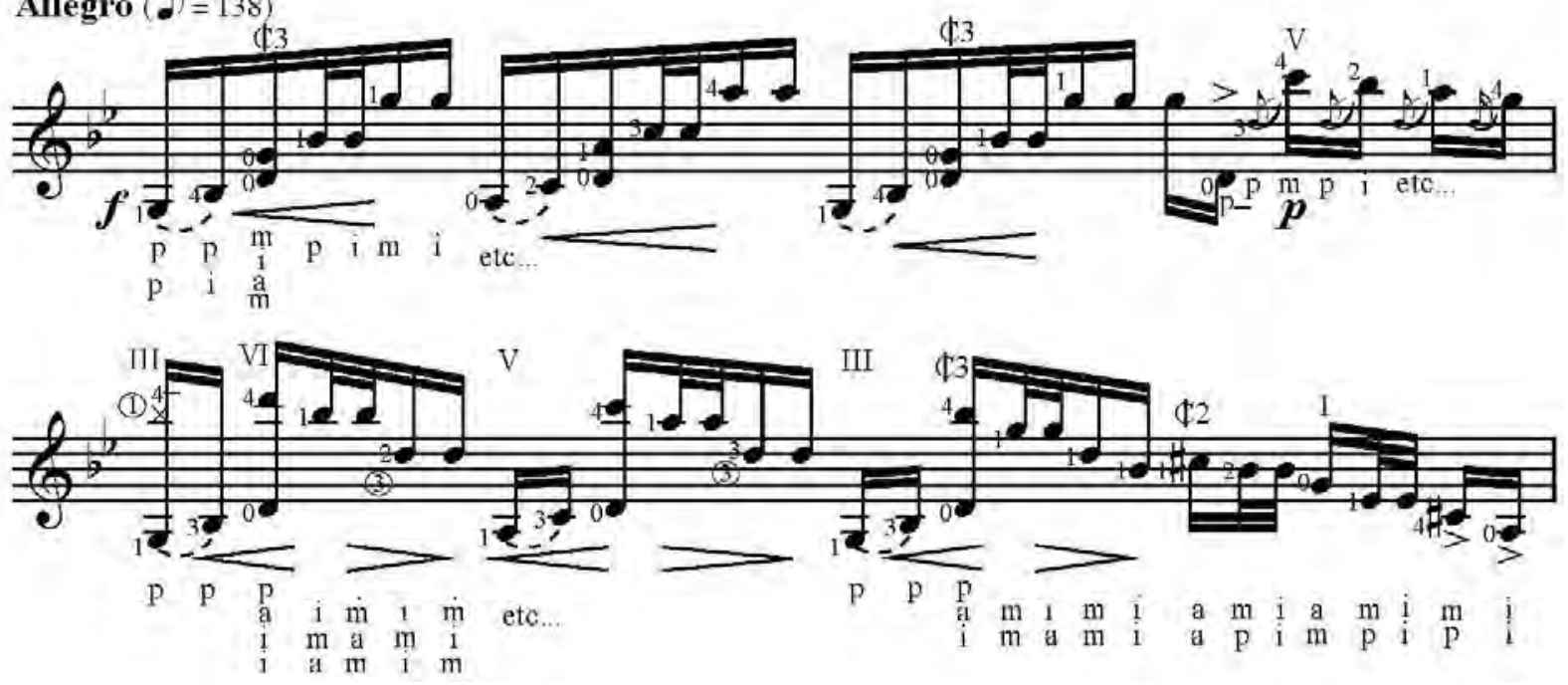

Exemplo 583: VIII $^{\circ}$ Estudo, compasso 1.

Os exemplos 584 e 585 têm a inclusão de portamenti que dão ar bufão ao trecho e que podem servir como variações em repetições do trecho. 
Comp. 1 com portamentos
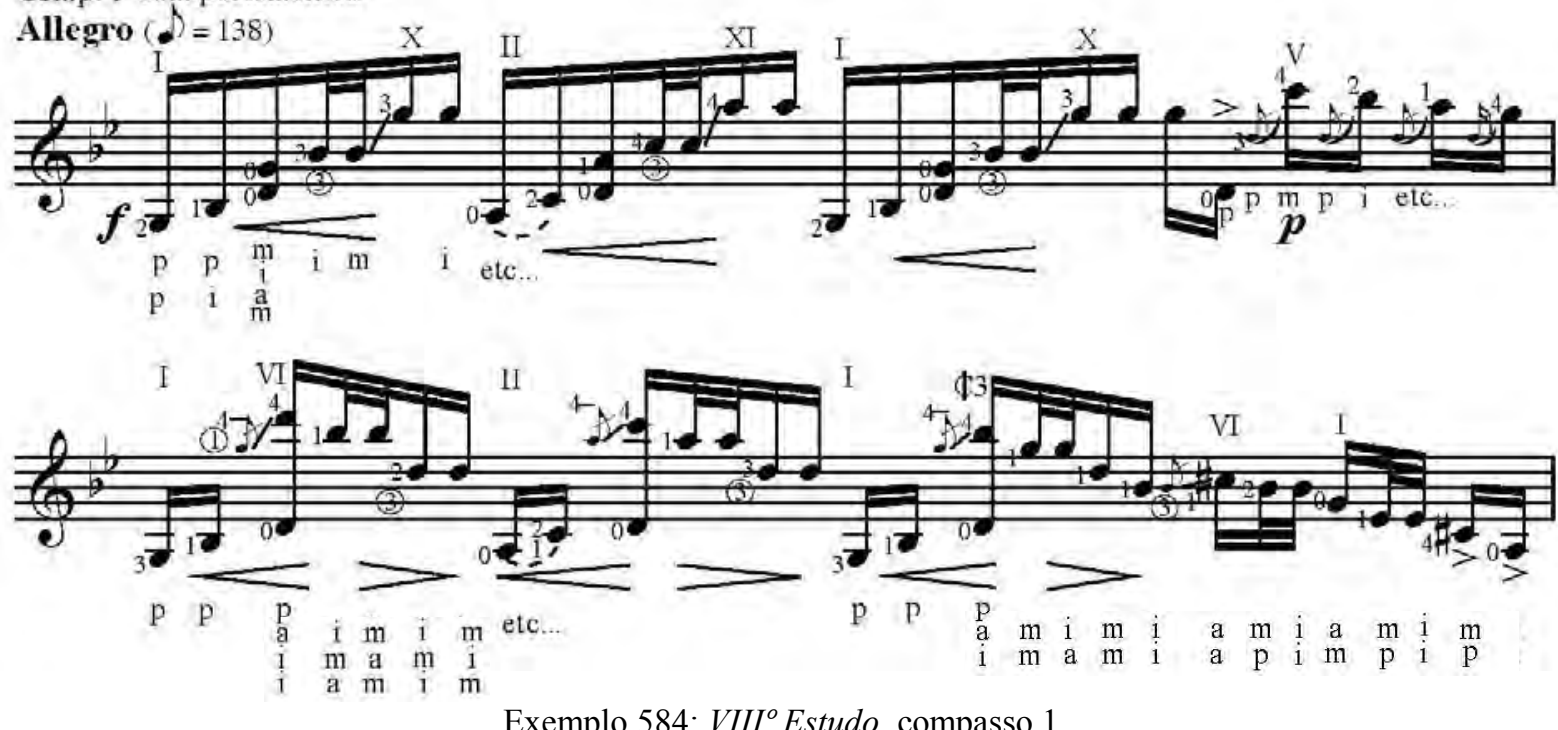

Exemplo 584: VIII $^{\circ}$ Estudo, compasso 1.

Comp. 1 com portamentos
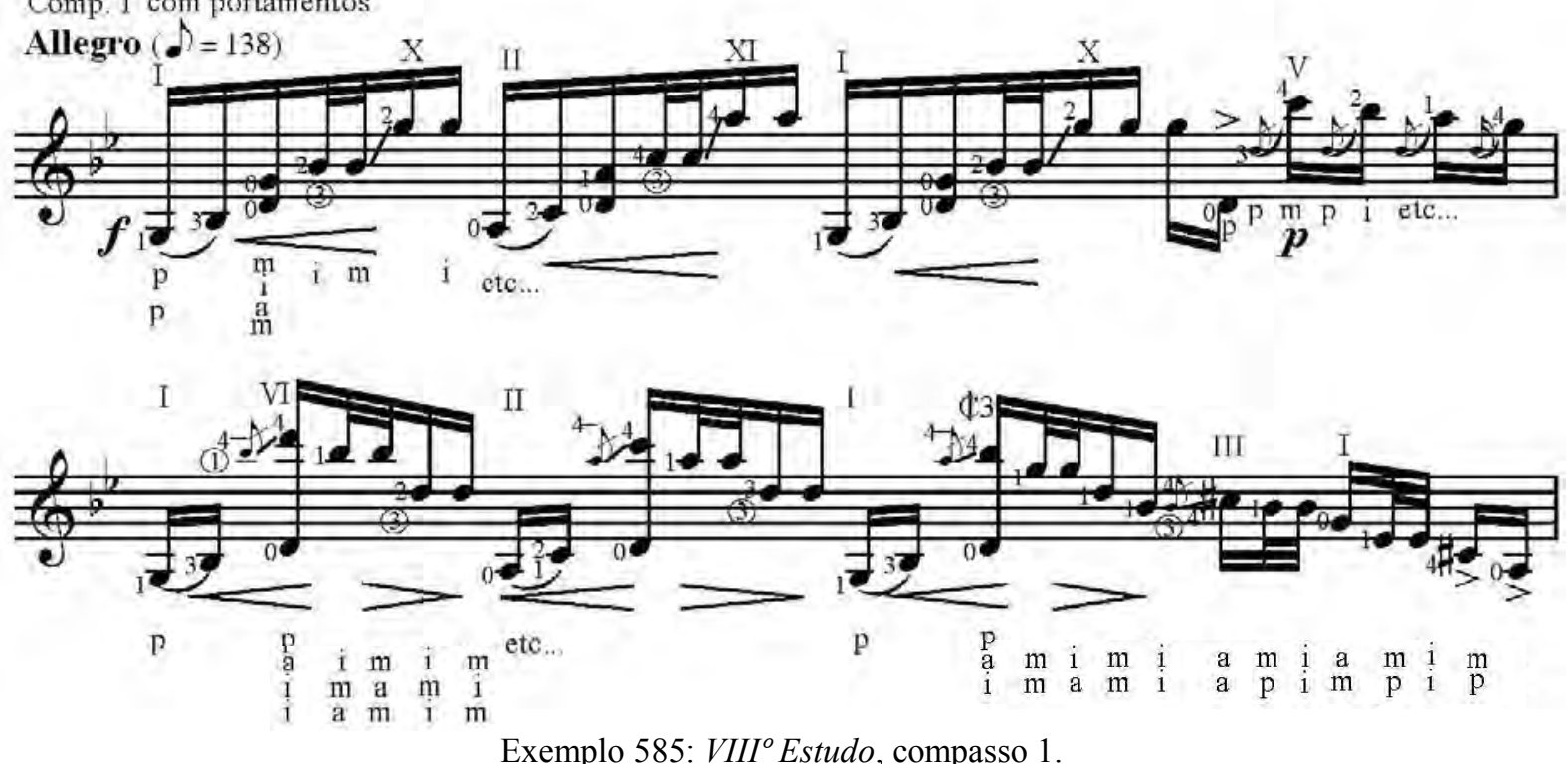

O compasso 3 apresenta acordes cuja redução ${ }^{125}$ de uma nota (ex. 587) é muito

facilitadora, sem contudo oferecer, a nosso ver, prejuízo musical.

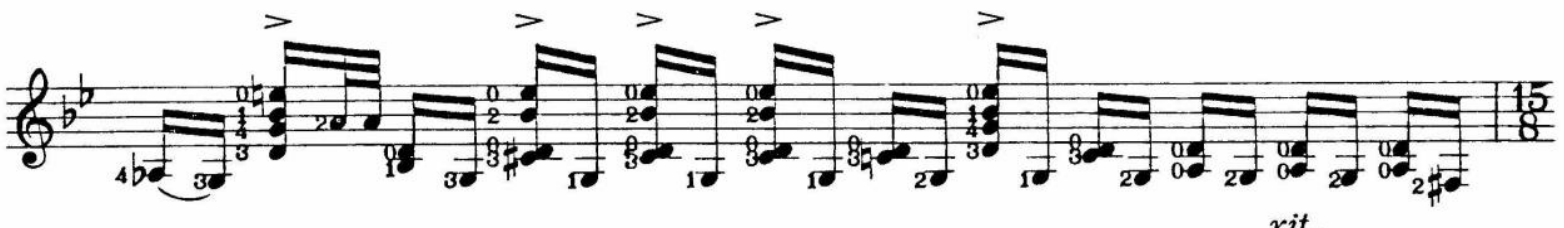

Exemplo 586: VIII ${ }^{\circ}$ Estudo, compasso 3. Ed. Columbia/BL.

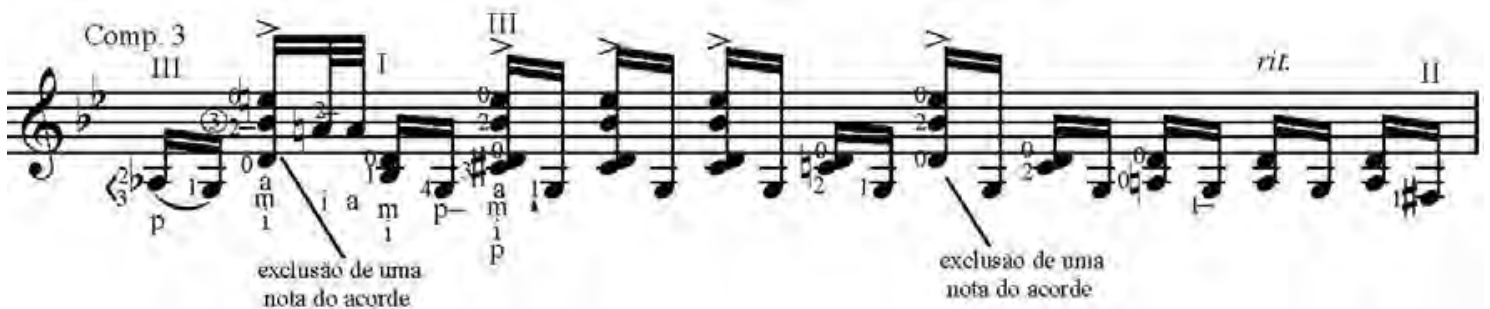

Exemplo 587: VIII $^{\circ}$ Estudo, compasso 3.

${ }^{125}$ verbo diminuir do checklist de Osborn. 
No compasso 4, sugerimos o oposto: a inclusão de uma nota para padronizar técnica de $m d$ e sonoridade do trecho, presente em todas as nossas versões. O exemplo 591 é o único a incluir ligados e a apresentar final alternativo à digitação BL, permanecendo mais tempo na mesma posição no acorde diminuto final.

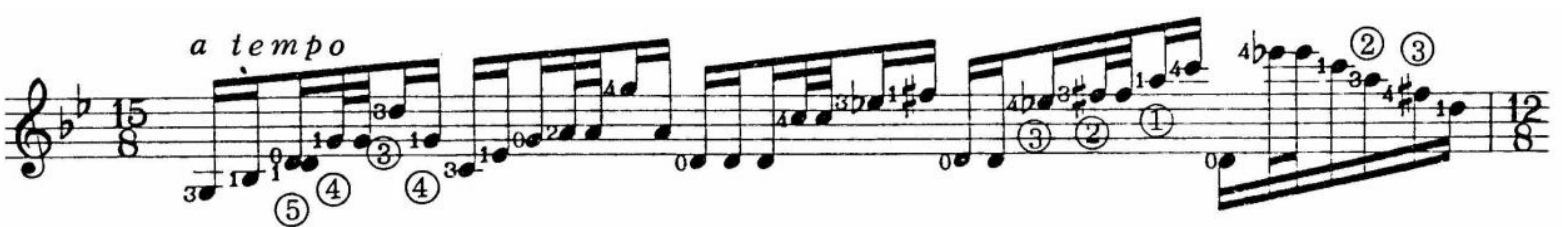

(5)
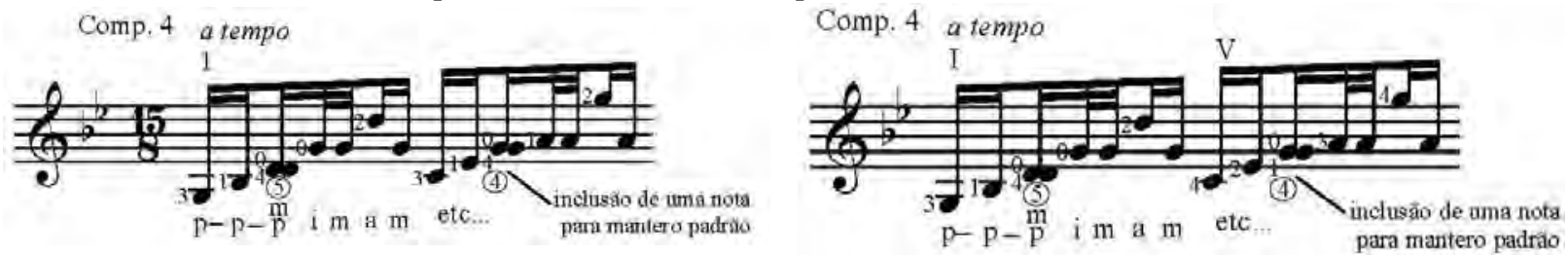

Exemplo 589: VIII $^{\circ}$ Estudo, compasso 4.

Exemplo 590: VIII $^{\circ}$ Estudo, compasso 4.

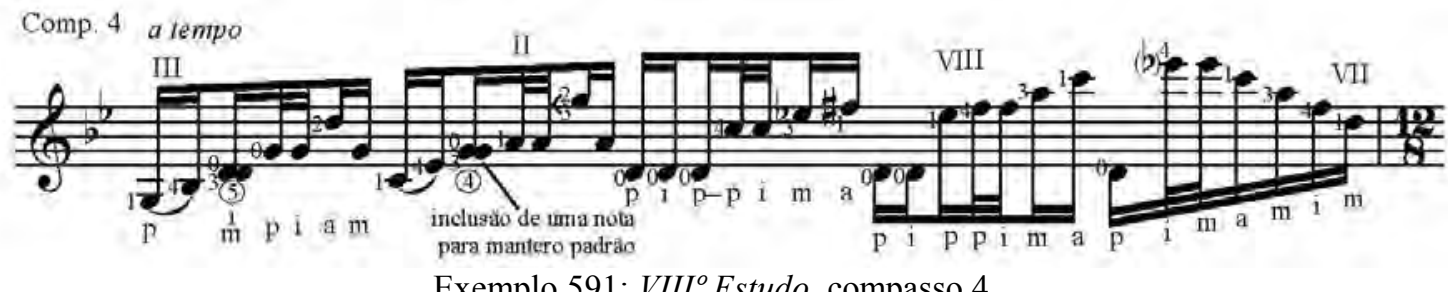

Exemplo 591: VIII ${ }^{\circ}$ Estudo, compasso 4.

O compasso 5 tem nova aparição de acordes diminutos (em sua parte central), que recebem em nossas versões digitações pela segunda e pela sétima posições com igual funcionalidade.

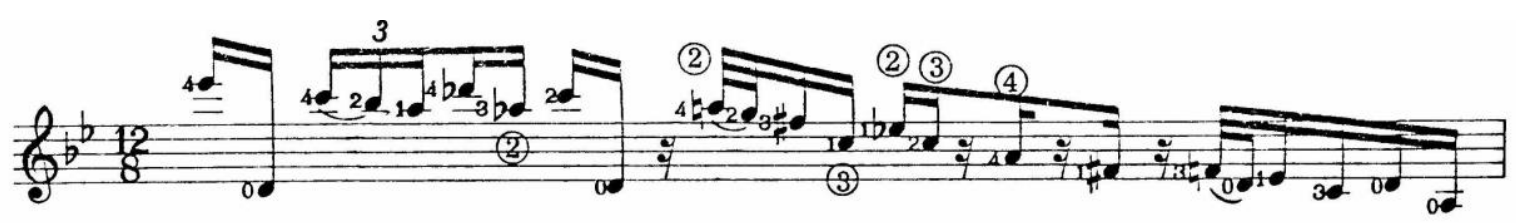

Exemplo 592: VIII ${ }^{\circ}$ Estudo, compasso 5. Ed. Columbia/BL.

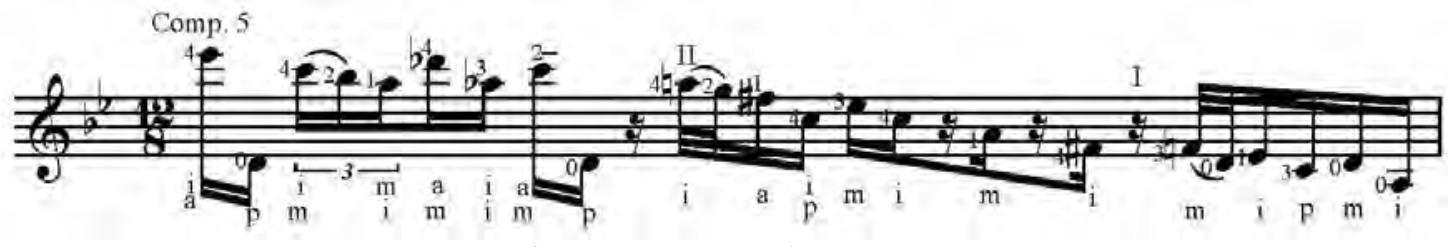

Exemplo 593: VIII $^{\circ}$ Estudo, compasso 5.

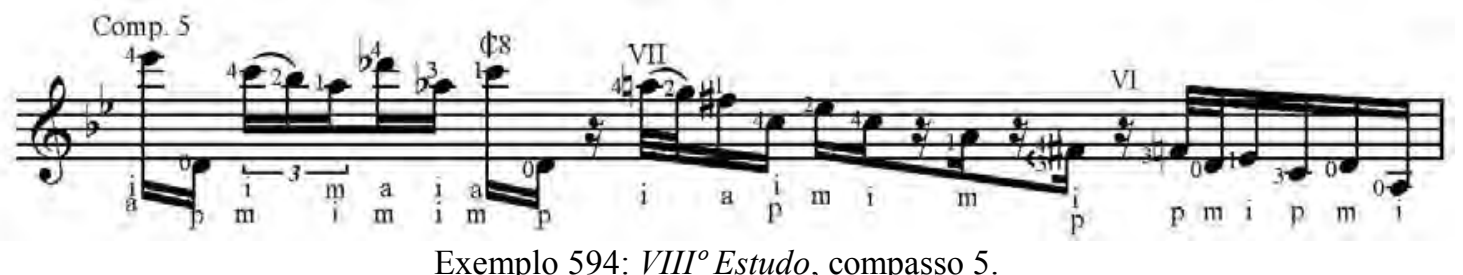

Exemplo 594: VIII ${ }^{\circ}$ Estudo, compasso 5. 
Após repetição do compasso inicial, Mignone desenvolve a figuração levando-a a outras tonalidades a partir do compasso 7. O exemplo 596 modifica $^{126}$ alguns pequenos aspectos da digitação BL e especifica sua $m d$. Dessas diferenças ressalta-se o último grupo ternário do primeiro compasso e início do compasso seguinte que são facilitados por meio de meias-pestana. Outra sugestão relevante ocorre no final do trecho, colocando em duas cordas a pequena e rápida figuração cromática, facilitando-a.

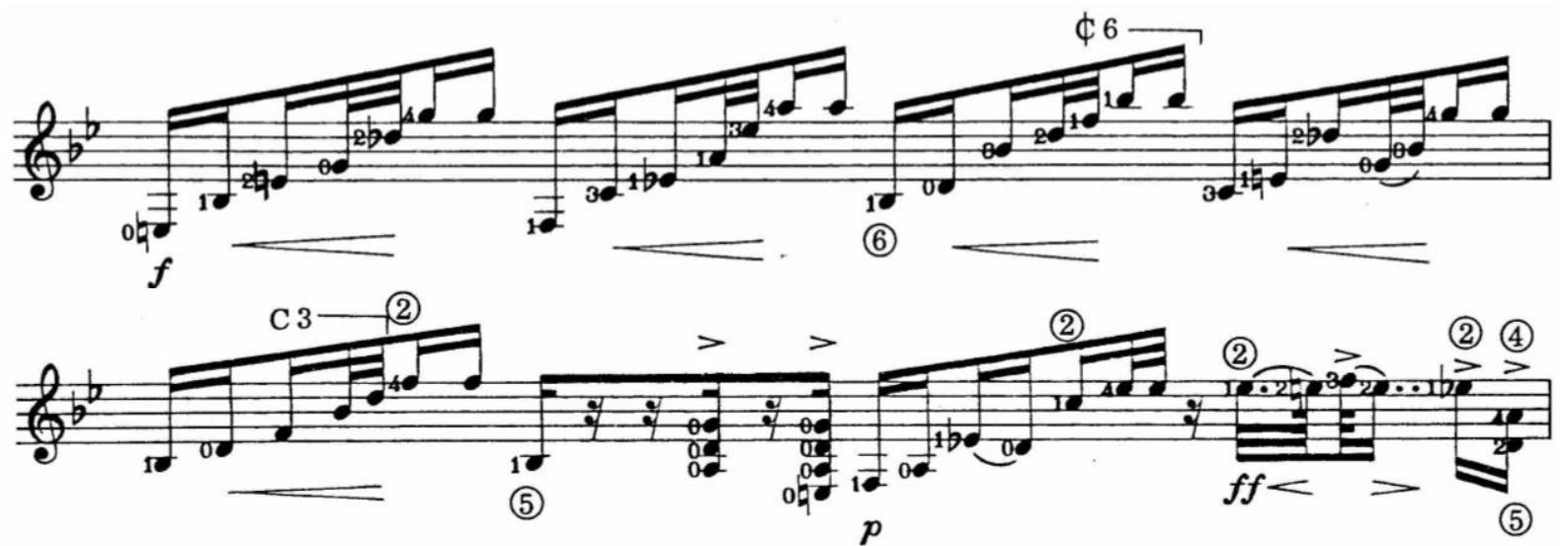

Exemplo 595: VIII $^{\circ}$ Estudo, compasso 7. Ed. Columbia/BL.
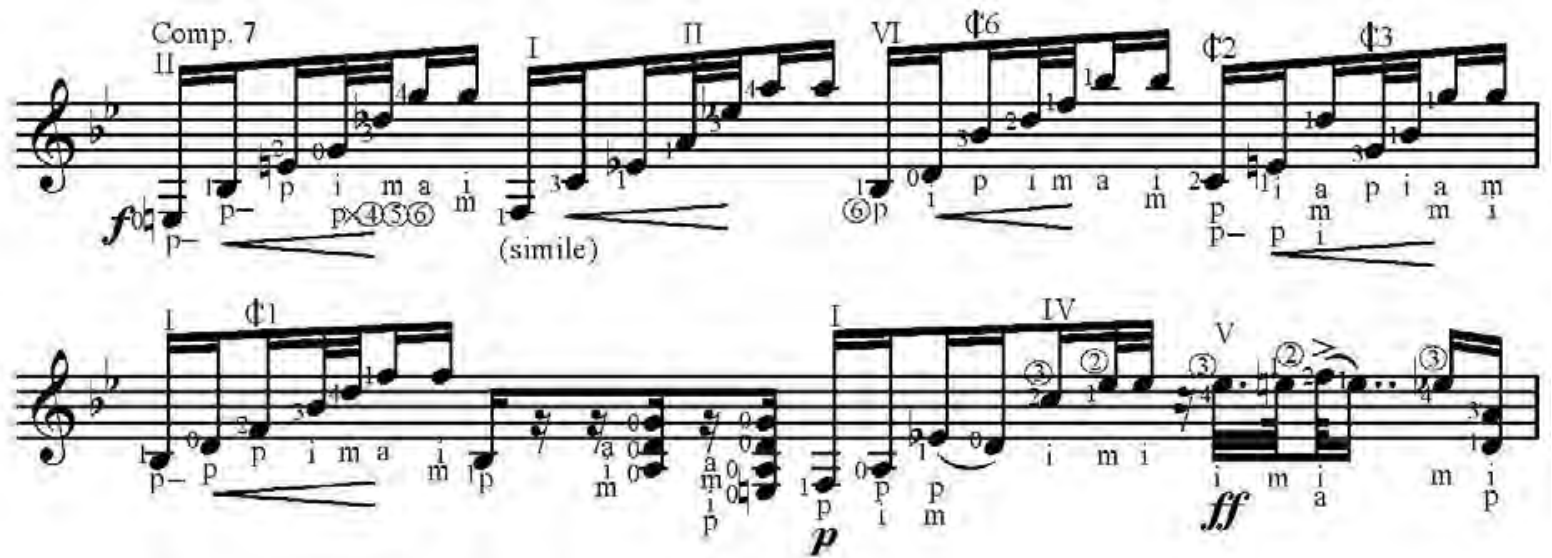

Exemplo 596: VIII $^{\circ}$ Estudo, compasso 7.

O exemplo 597 vem registrar outras opções para o compasso 8, colocando o primeiro acorde na sexta posição, sugerindo o uso do polegar alternado nos acordes centrais e também modificando ${ }^{127} \mathrm{o}$ final do trecho.

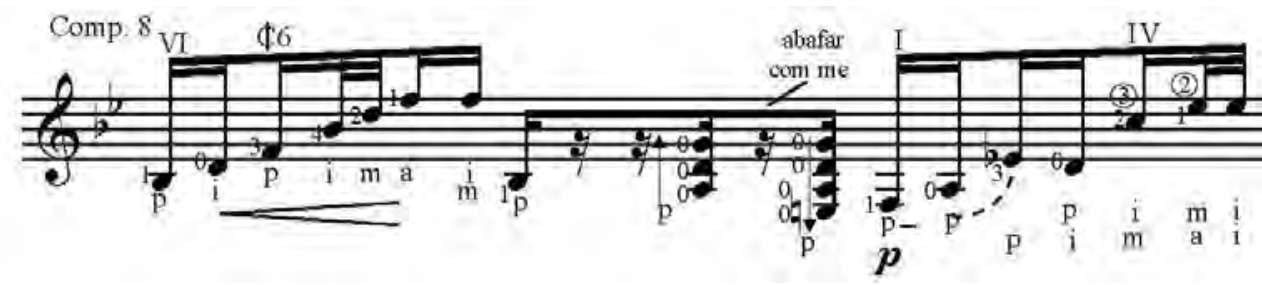

Exemplo 597: VIII $^{\circ}$ Estudo, compasso 8 (parcial).

\footnotetext{
${ }^{126}$ verbo do checklist de Osborn.

${ }^{127}$ verbo do checklist de Osborn.
} 
O exemplo 598 retorna ao compasso 7 para oferecer uma digitação com ligados, inspirada pelo último tempo da digitação BL, mas aplicando este artifício a todos os acordes (excetuando um portamento na mesma posição).
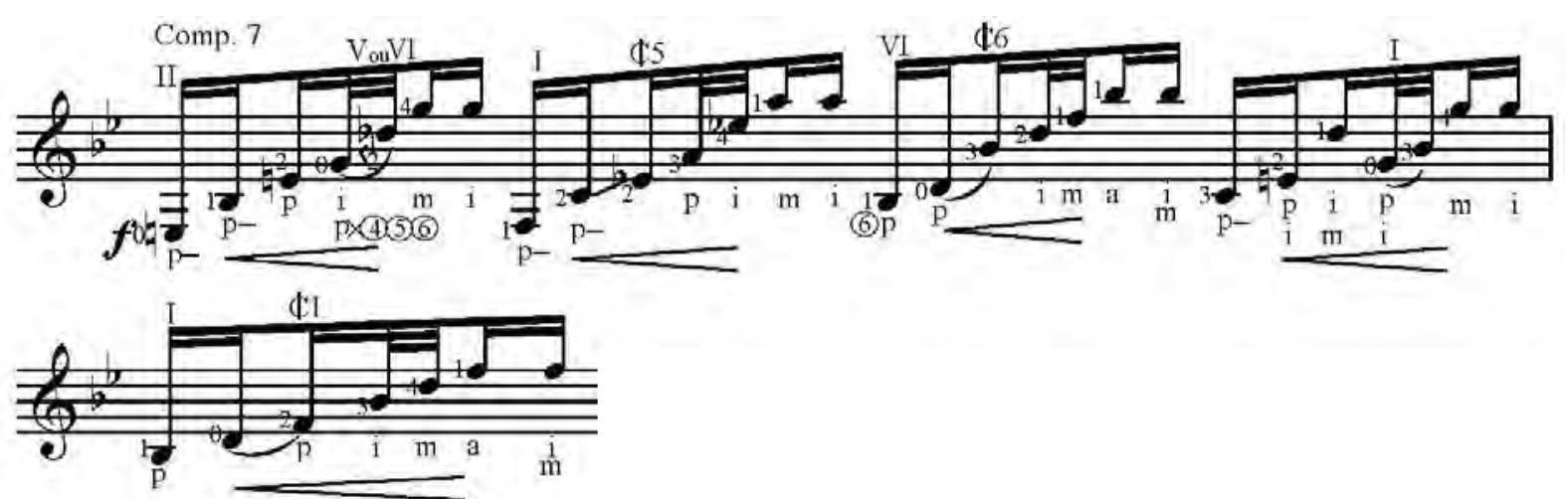

Exemplo 598: VIII $^{\circ}$ Estudo, compasso 7.

O exemplo 600 modifica ${ }^{128}$ principalmente os dedos envolvidos no cromatismo na terceira corda para com isso resolver diferentemente a ascensão até o Si agudo e também faz o trecho final girar em torno da quarta posição com uso duplo do polegar.
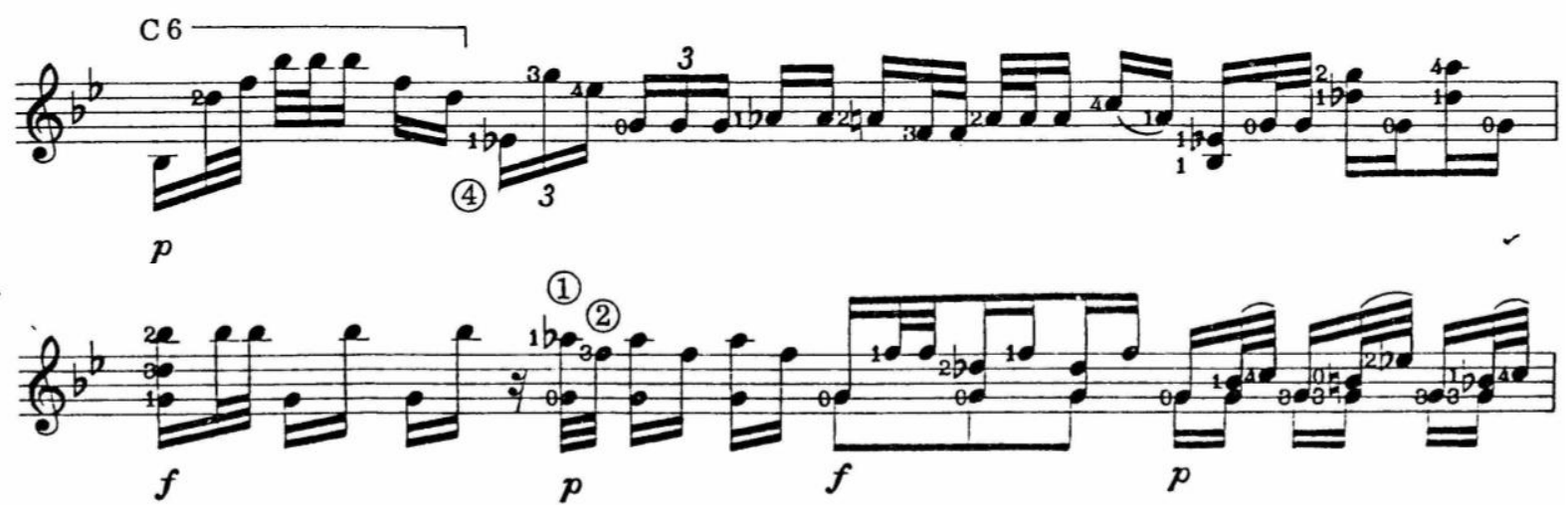

Exemplo 599: VIII ${ }^{\circ}$ Estudo, compasso 7. Ed. Columbia/BL.
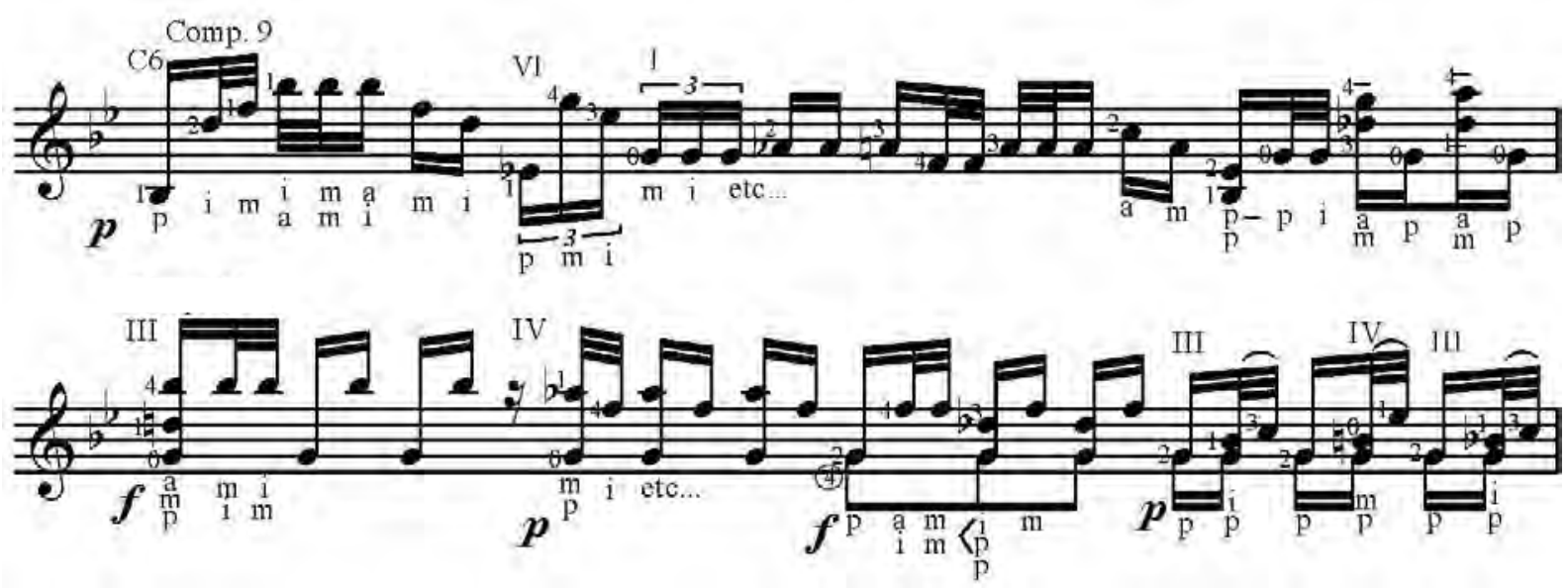

Exemplo 600: VIII $^{\circ}$ Estudo, compasso 9.

\footnotetext{
${ }^{128}$ verbo do checklist de Osborn.
} 
O final deste trecho também recebe uma versão com ligados que também fixa o baixo na terceira corda solta por todo o compasso o que gera um interessante efeito de saltos (entremeados com cordas soltas) em sua última porção.

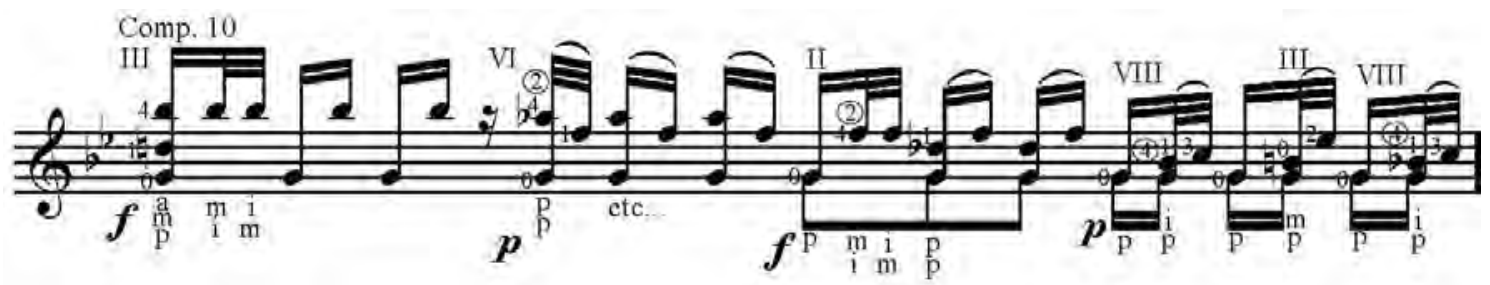

Exemplo 601: VIII ${ }^{\circ}$ Estudo, compasso 10.

O compasso 11 talvez seja um dos que mais oferece diferentes versões nessa obra. BL o aborda centrado na primeira posição, com destaque para o uso de um ligado triplo na terceira corda.

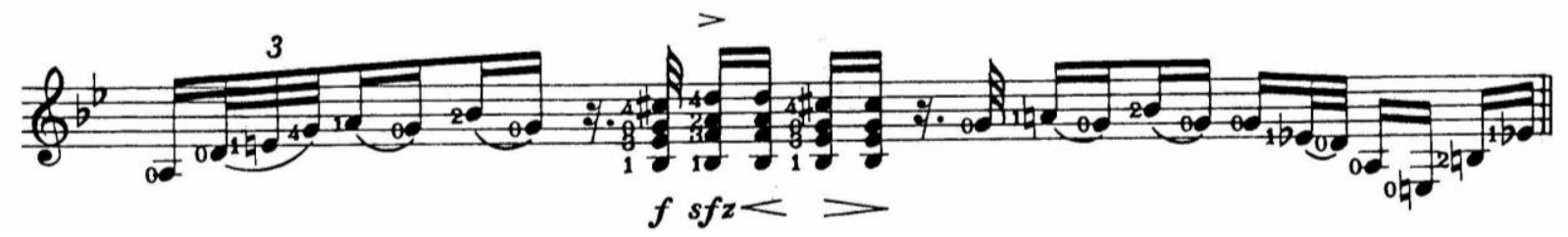

Exemplo 602: VIII ${ }^{\circ}$ Estudo, compasso 11. Ed. Columbia/BL.

Nosso exemplo 603 é bem próximo a BL em sua porção final, mas é bastante antagônico no trecho inicial ao transformá-lo em um acorde em campanella com necessidade de abertura.

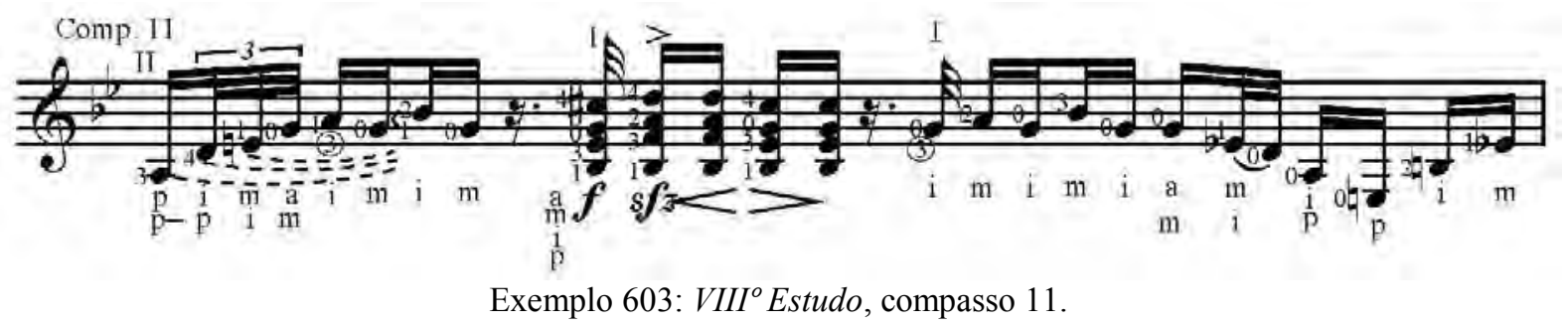

O exemplo 604 oferece uma distribuição de ligados com uso da terceira corda solta (mais ou menos inspirado pelo exemplo 602) e demonstra pela primeira vez várias articulações de $m d$ para os acordes centrais. Nesse aspecto os rasgueios podem ser todos para baixo ou com direção alternada, sendo que o primeiro propicia uma unidade entre os acordes e o segundo favorece o acento e contorno dinâmico proposto pelo compositor.

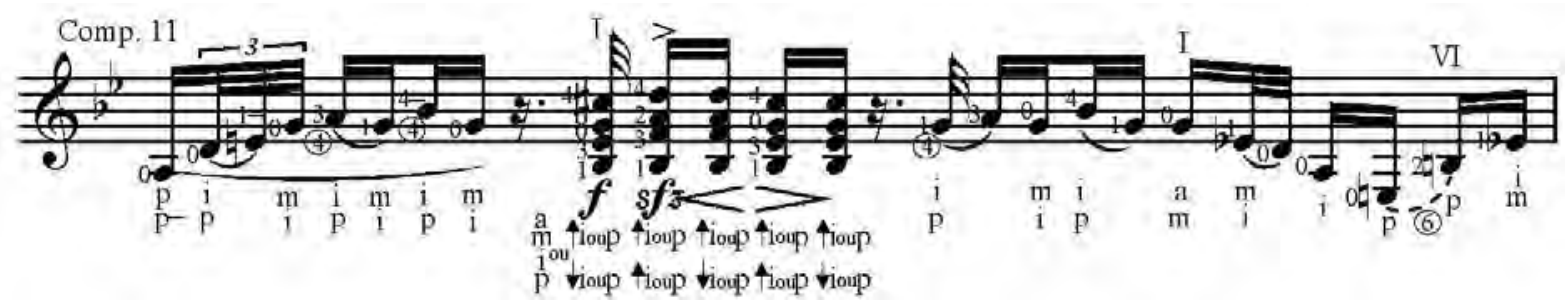

Exemplo 604: VIII $^{\circ}$ Estudo, compasso 11. 
Os exemplos 605, 606 e 607 alternam as passagens melódicas entre terceira e quarta cordas (com apenas um ligado inicial) de diferentes maneiras e possuem desfechos também distintos, sendo que os dois últimos se iniciam pela quinta posição.

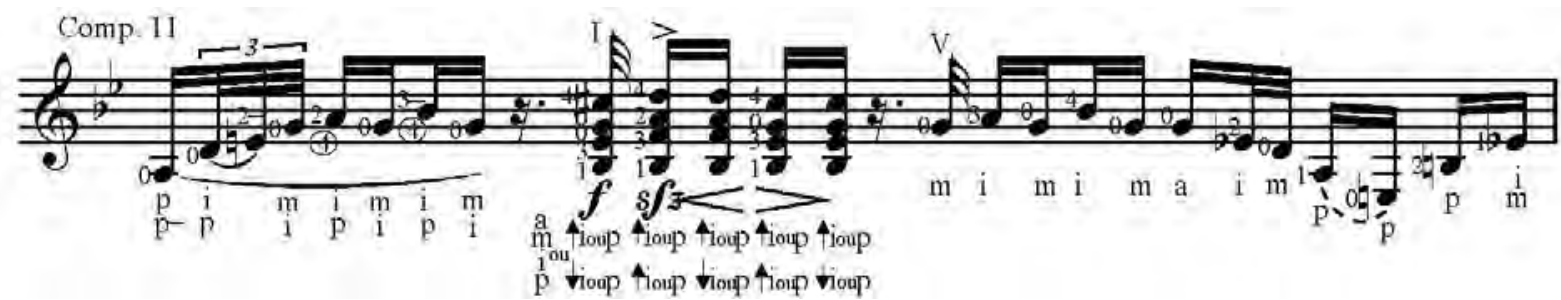

Exemplo 605: VIII $^{\circ}$ Estudo, compasso 11.

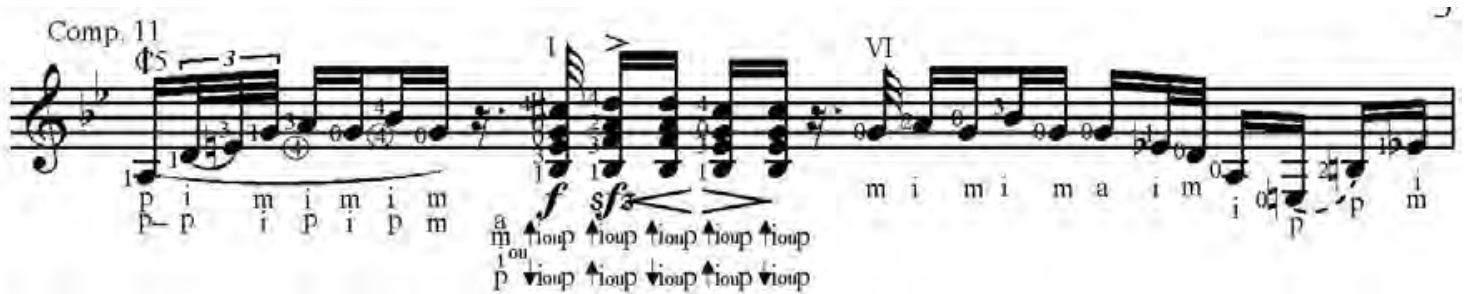

Exemplo 606: VIII $^{\circ}$ Estudo, compasso 11.

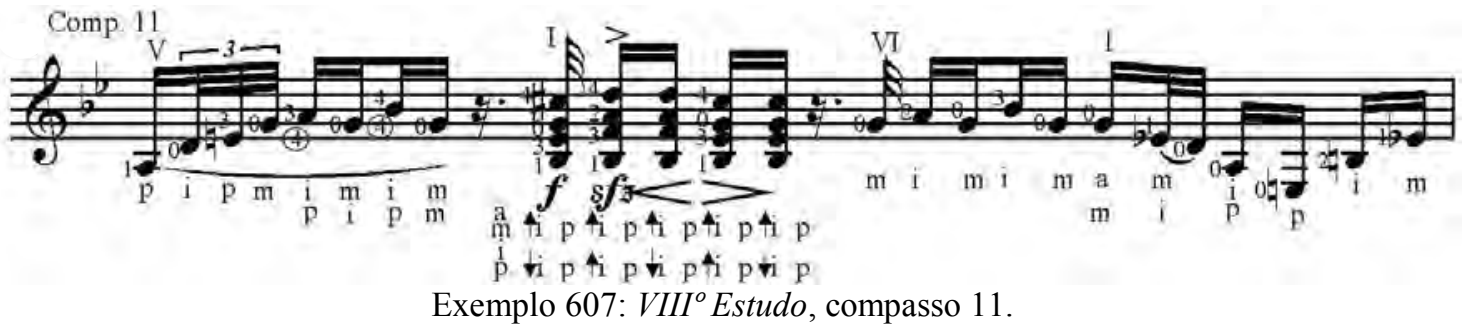

O exemplo 609 parte da versão BL, mas buscando a padronização dos ligados acaba trocando alguns dedos. Já o exemplo 610 busca propiciar o uso recorrente do polegar, tanto em passagens melódicas quanto acordais com resultado robusto. Existe nessa digitação a possibilidade, com caráter ainda mais experimental, de alternar pizzicati e toques ordinários requerendo habilidade de $m d$ nessa alternância de emissões. Nessa opção, o segundo trecho em pizzicato tem melhor funcionamento com o escovamento previsto do indicador.

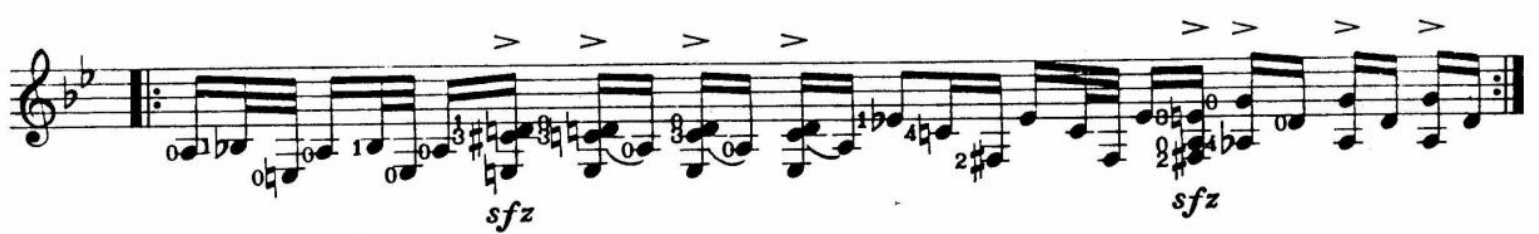

Exemplo 608: VIII $^{\circ}$ Estudo, compasso 12. Ed. Columbia/BL.

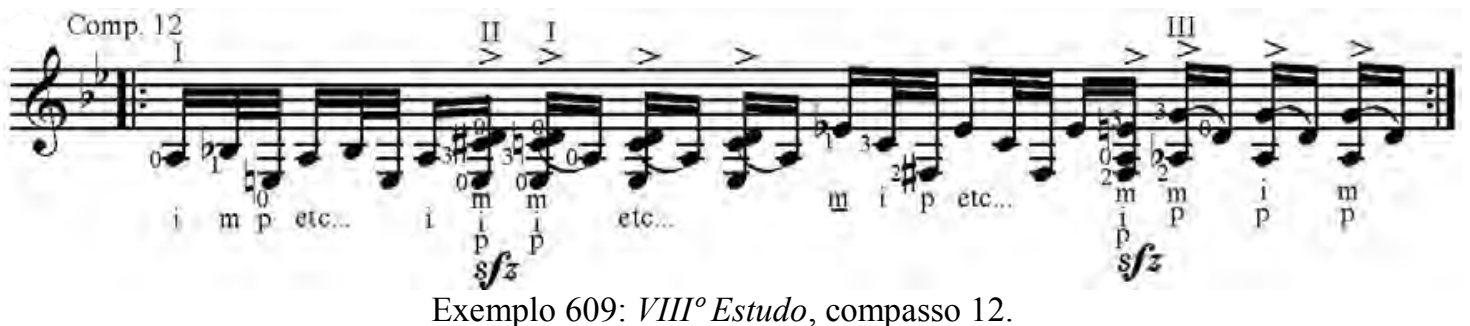




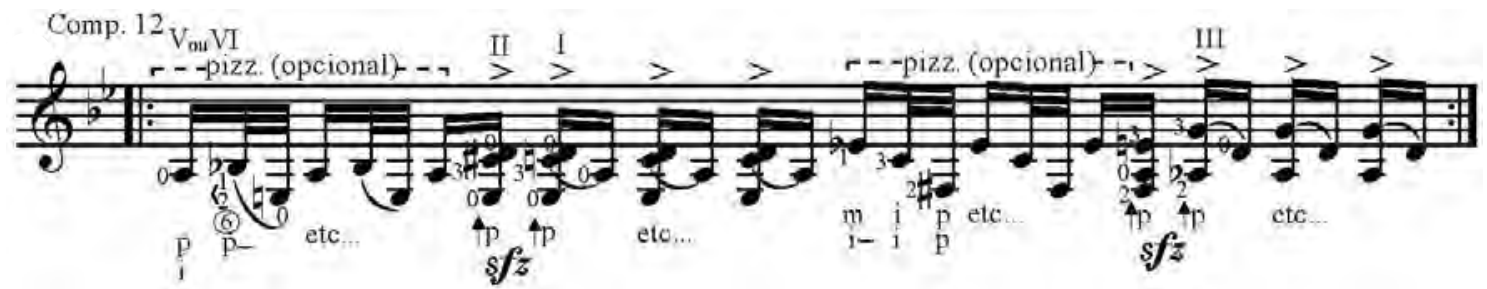

Exemplo 610: VIII $^{\circ}$ Estudo, compasso 12.

O compasso 13 já conseguiu gerar pequena polêmica na limitada literatura acadêmica sobre esta obra devido a uma divisão irregular do compasso por Mignone. Albergio Diniz Soares (1997, p.49) sugere uma correção rítmica ao trecho, enquanto Flávio Apro considera “ingênua qualquer reivindicação de 'descoberta' de supostos erros de escrita" (Apro 2004, p.106). Nossa leitura inicial do trecho também fomentou estranheza e a impressão de haver algum erro (mesmo antes de saber a opinião dos autores recém citados). Essa impressão foi completamente desfeita após grafá-lo em software musical (Finale 2014) e dividi-lo igualitariamente para assim constatar que as notas originais, com seu ritmo inalterado, completam perfeitamente o compasso sem sobra ou excesso. Complementa-se que a divisão proposta por Mignone é completamente justificável e coerente, embora bastante inusual e por isso confusa.

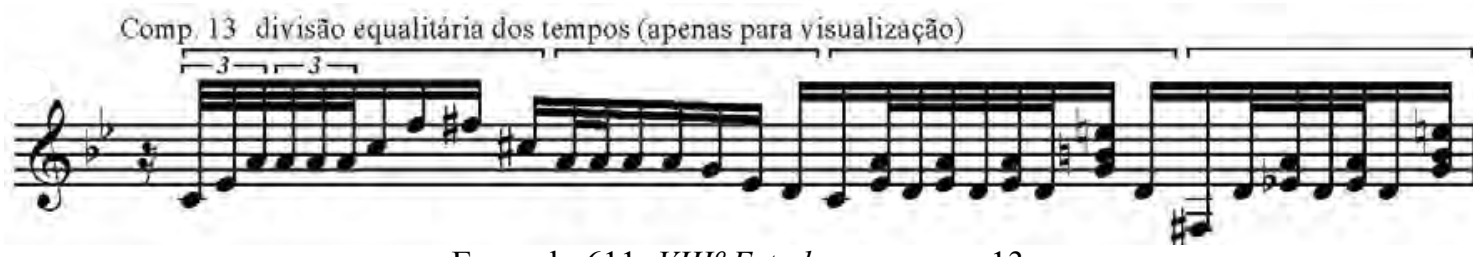

Exemplo 611: VIII $^{\circ}$ Estudo, compasso 13.

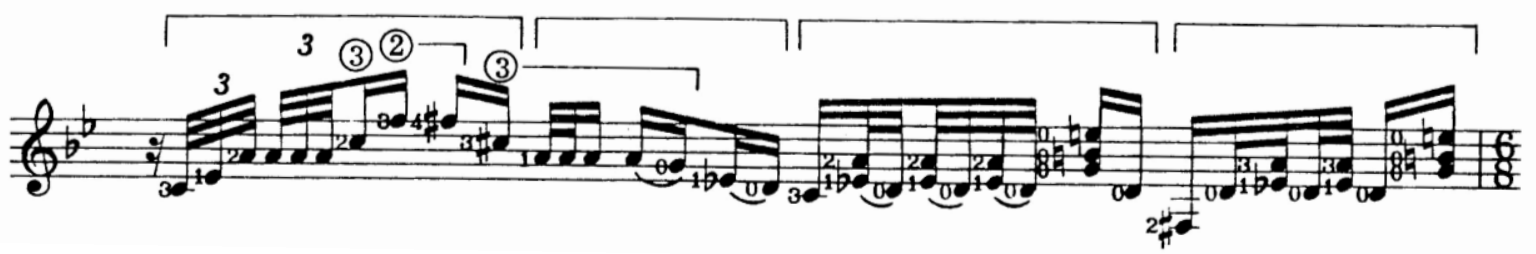

Exemplo 612: VIII $^{\circ}$ Estudo, compasso 13. Ed. Columbia/BL.

Esclarecida esta questão rítmica, passemos ao âmbito técnico: Mignone propõe aqui a maior ocorrência numérica de notas repetidas dentro de um arpejo, complicando o trabalho da $m d$.

A digitação BL prevê o uso da terceira e segunda cordas (nas notas Dó-Fá e Dó\#-Fá\#) necessitando translados que parecem adicionar ainda mais uma dificuldade, algo que talvez pudesse ser esclarecido se houvesse indicações de $m d$.

Os exemplos 613 e 614 simplificam a me de BL fazendo-a trabalhar nas primeiras casa do instrumento e especificam a $m d$ com várias opções. No exemplo 599 o polegar ajuda a prover a acentuação grafada por Mignone mas cria um cruzamento 
logo a seguir, enquanto o exemplo seguinte (ex. 600) propõe um padrão mais ágil, mas com tendência a deslocar o acento, algo passível de ser compensado. Na metade final, as alternâncias de acordes com a nota Ré em corda solta são pesadas para a $m d$, mas podem ser bastante aliviadas com ligados, porém com a necessidade de uma ligeira inversão.

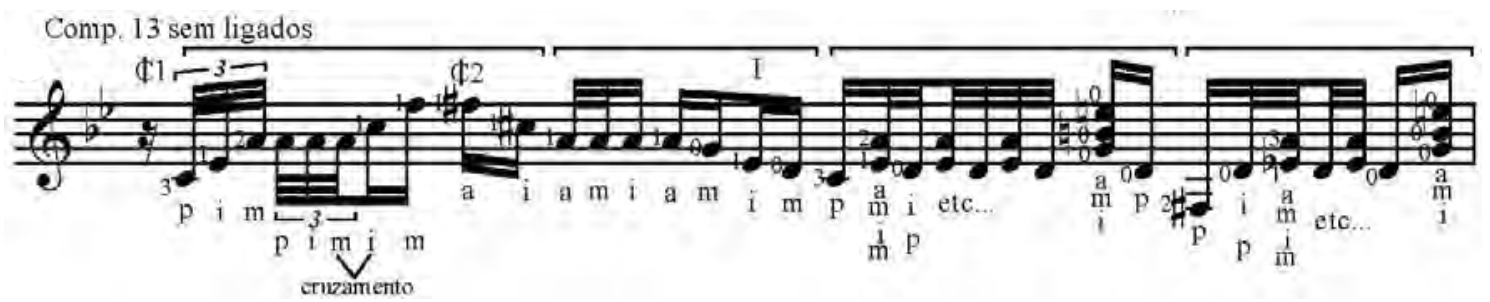

Exemplo 613: VIII $^{\circ}$ Estudo, compasso 13.

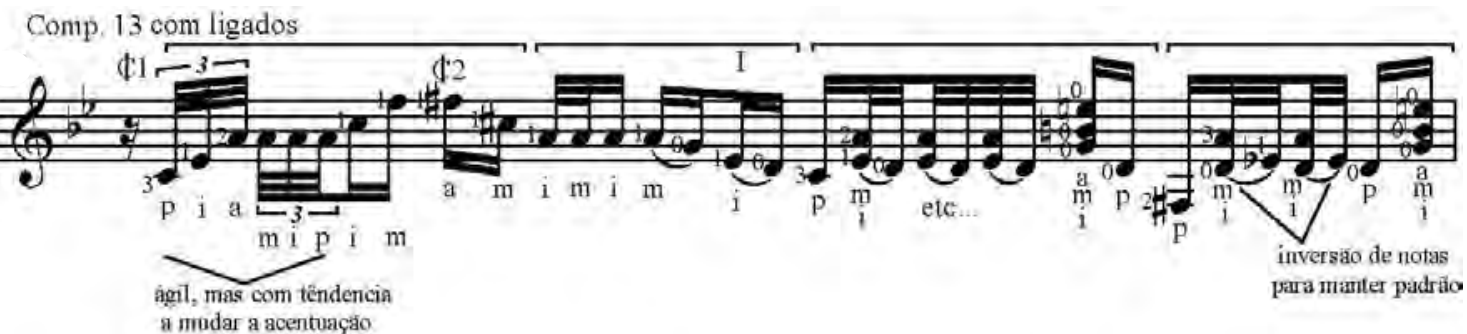

Exemplo 614: VIII $^{\circ}$ Estudo, compasso 13.

O exemplo 615 é o mais exploratório. Ele aproveita os translados de BL, mas adiciona portamenti opcionais nos mesmos. Nas notas alternadas ele insere repetições da nota Lá, para possibilitar pequenos rasgueios em dois padrões.

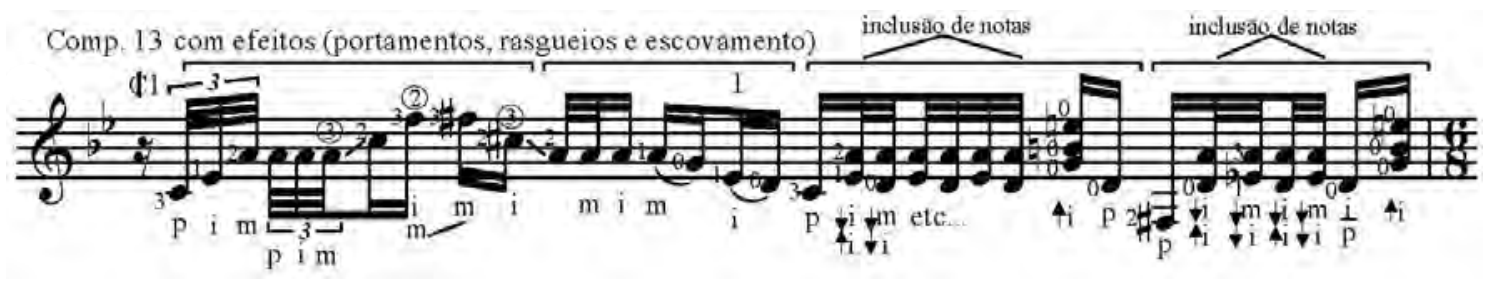

Exemplo 615: VIII $^{\circ}$ Estudo, compasso 13.

Uma intervenção acéfala em oitavas com ritenuto faz a conexão com o retorno do tema inicial e recebe abordagens tradicionais nos dois primeiros exemplos (com bom efeito em legato ou staccato) e versões com sobreposição de notas nos dois últimos.

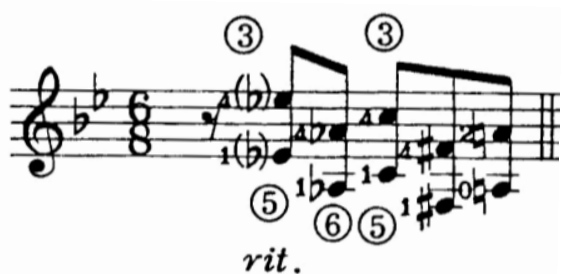

Exemplo 616: VIII ${ }^{o}$ Est., comp. 14. Ed. CB/BL.
Comp. 14 a partir de Barbosa Lima

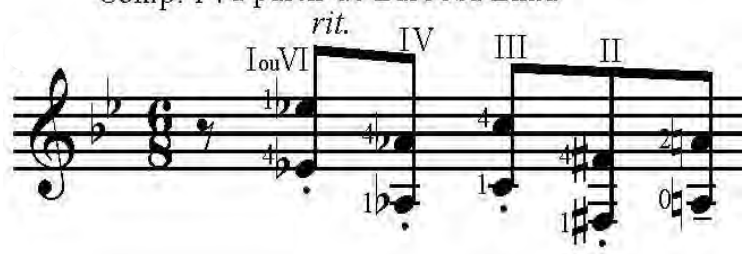

Exemplo 617: VIII $^{\circ}$ Est., comp. 14. 


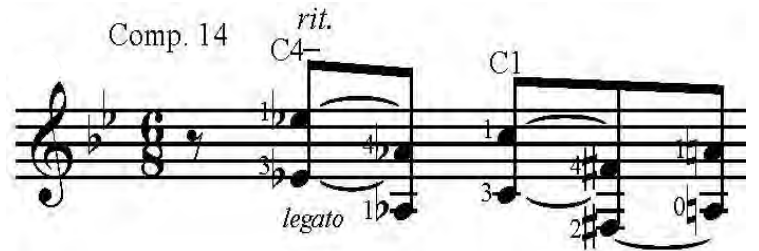

Exemplo 618: VIII $^{\circ}$ Est., compasso 14.

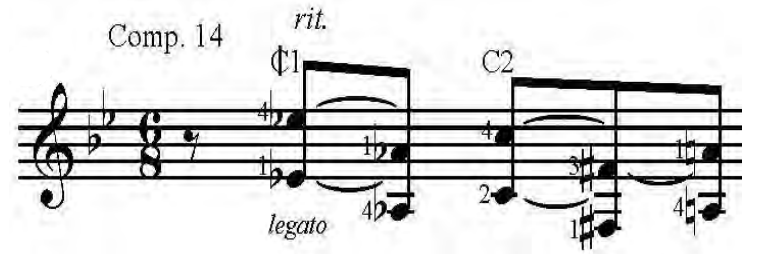

Exemplo 619: VIII $^{\circ}$ Est., compasso 14.

Mignone mostra seu consistente vocabulário composicional ao retornar com o tema em interessante variação descendente que oferece novos desafios sobretudo à $m d$, que necessita saltar verticalmente das primas para os bordões. A me muito se assemelha ao primeiro compasso da obra e portanto recebe apenas uma versão sem e outra com ligados, a primeira delas muito semelhante à BL.

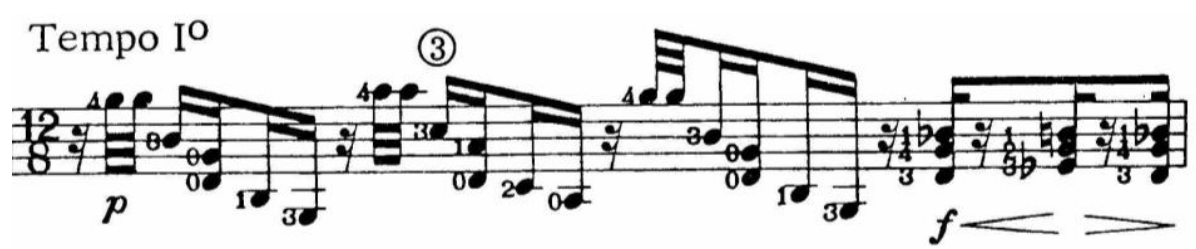

Exemplo 620: VIII ${ }^{o}$ Estudo, compasso 15. Ed. Columbia/BL.

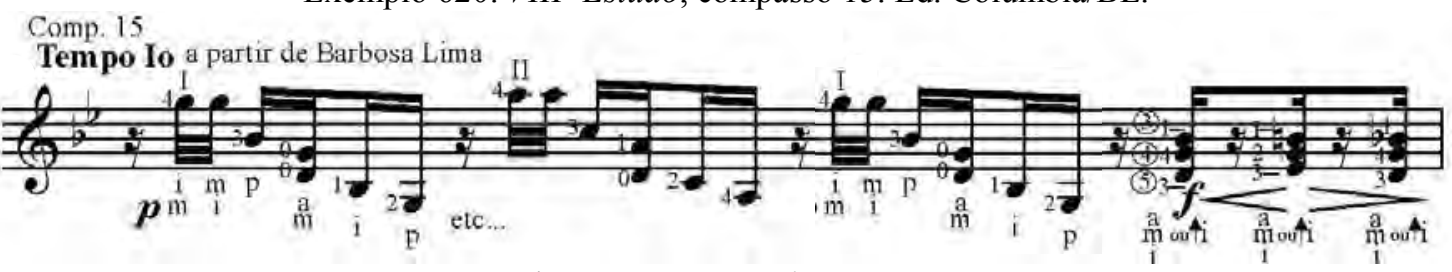

Exemplo 621: VIII ${ }^{\circ}$ Estudo, compasso 15.

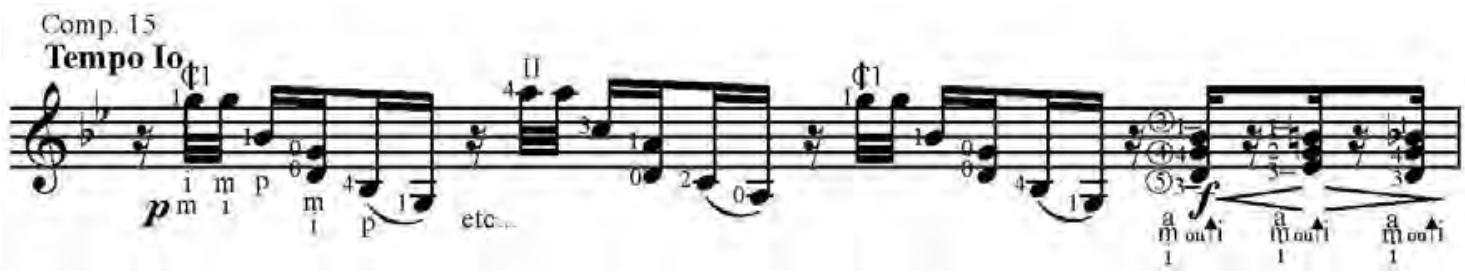

Exemplo 622: VIII ${ }^{o}$ Estudo, compasso 15.

O compasso seguinte também sofre inversão de direção tornando os arpejos ascendentes. Nosso exemplo 624 apresenta algumas sugestões à digitação BL, unificando os primeiros acordes e adicionando mais um ligado no final, a fim evitar o toque triplo descendente de polegar no arpejo de Sol menor.

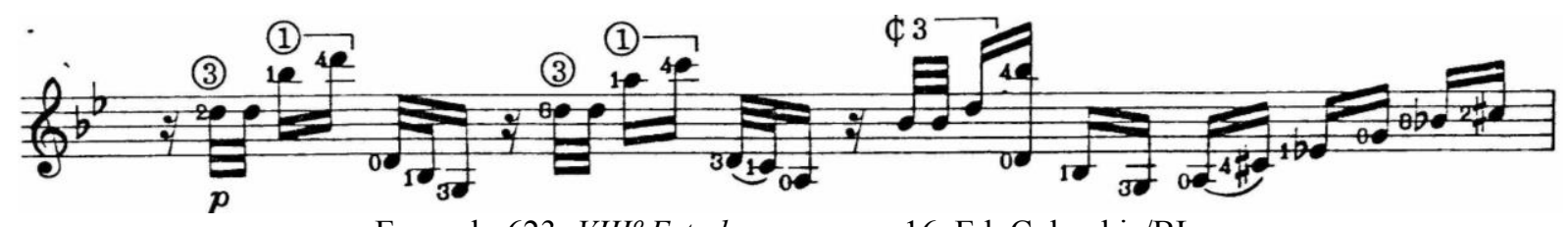

Exemplo 623: VIII ${ }^{\circ}$ Estudo, compasso 16. Ed. Columbia/BL.

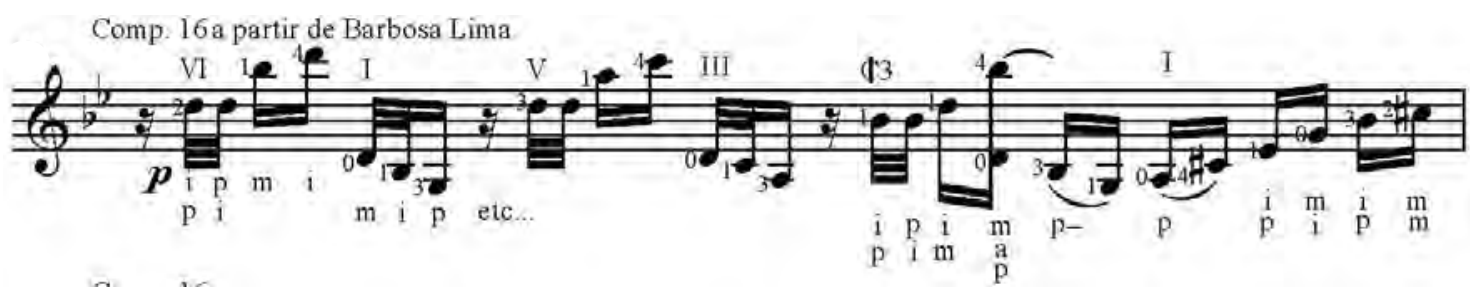

Exemplo 624: VIII ${ }^{\circ}$ Estudo, compasso 16. 
O exemplo 625 unifica todos os arpejos iniciais para ocuparem em três cordas e propõe uma alteração rítmica no último deles, padronizando-o a partir dos anteriores para com isso retirar a concomitância entre o baixo Ré e a nota Si e assim permite digitações mais fluidas de $m d$ para o trecho. $\mathrm{O}$ encaminhamento final também recebe ligado facilitador.

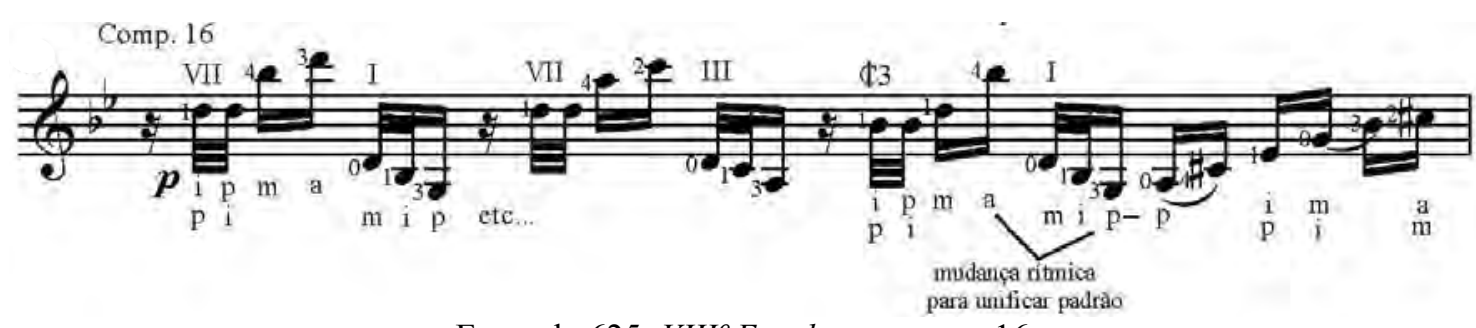

Exemplo 625: VIII $^{\circ}$ Estudo, compasso 16.

O último exemplo aplica ligados aos arpejos superiores e inferiores criando um pequeno jogo de pergunta e resposta. $O$ trecho também apresenta outro encaminhamento para o compasso seguinte.

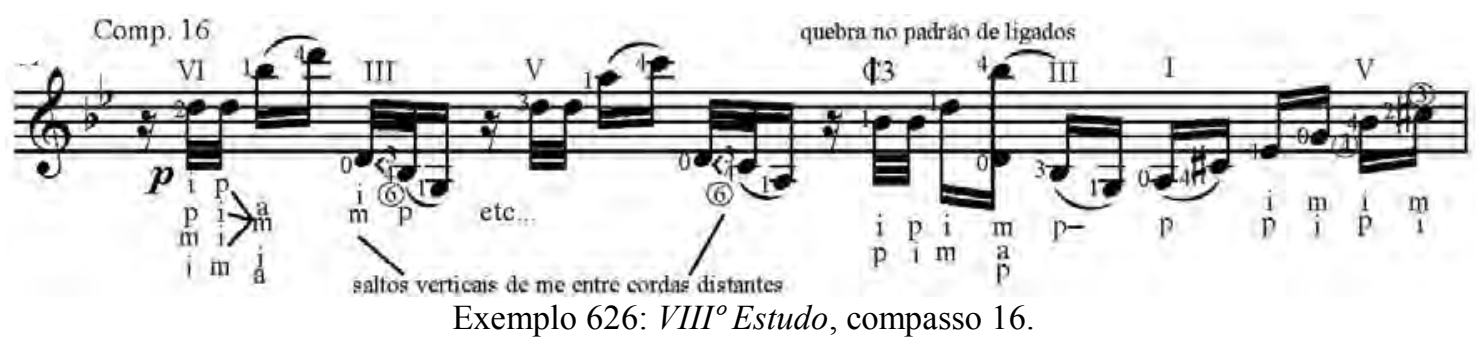

O exemplo 627 apenas registra duas outras alternativas de ligados para o sexto tempo do compasso 16 com igual desenvoltura.

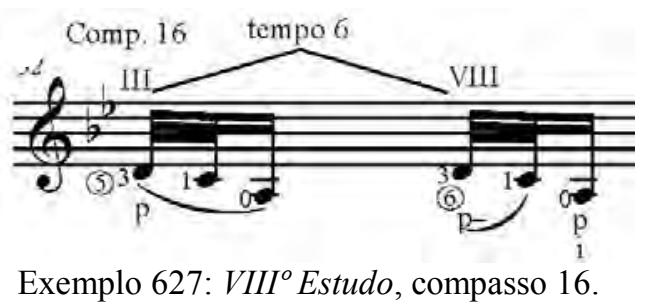

O compasso 17 firma um pedal na nota Sol para realizar a transição para uma nova seção. A digitação BL é satisfatória mas isso não encerrou nossa busca por outras soluções. Os exemplos 629 e 630 usam dedos mais firmes para os translados e coloca terças próximas nas mesmas cordas, com os mesmos dedos. O pedal permanece na terceira corda com exceção de uma rápida figuração que o alterna com a quarta. Os acordes mais cheios podem ser articulados com o polegar, mas isso exige maior controle para garantir seu rápido retorno em tempo de executar a nota seguinte. 


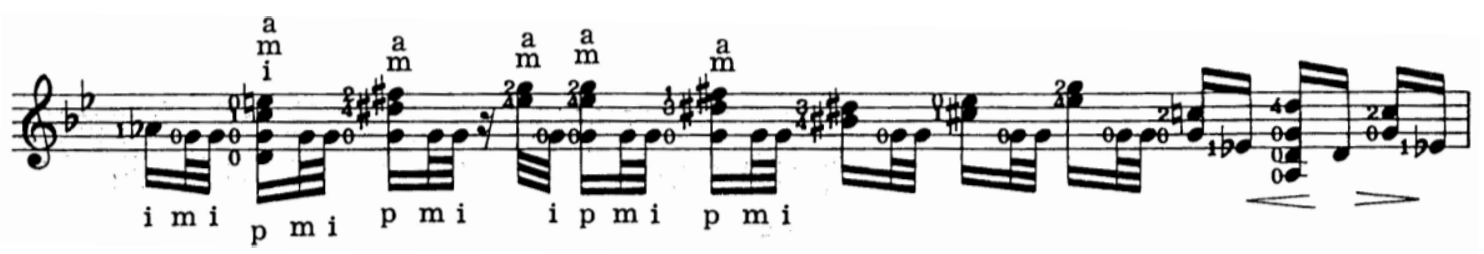

Exemplo 628: VIII $^{\circ}$ Estudo, compasso 17. Ed. Columbia/BL.

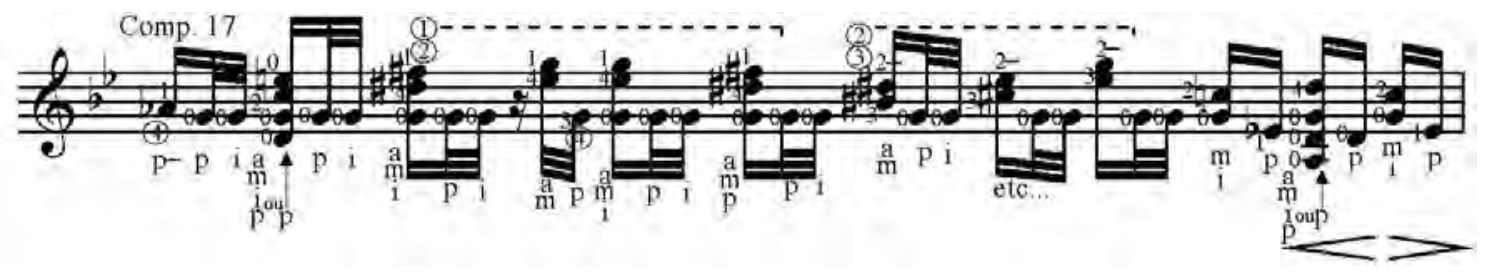

Exemplo 629: VIII $^{\circ}$ Estudo, compasso 17.

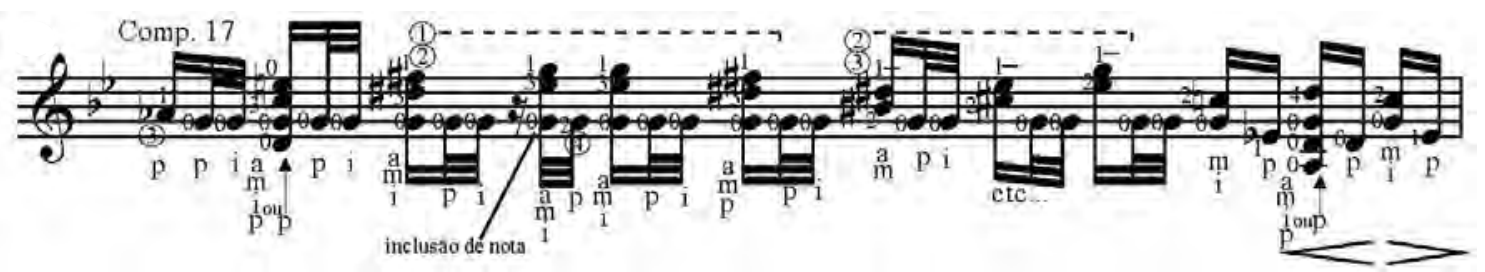

Exemplo 630: VIII $^{\circ}$ Estudo, compasso 17.

O exemplo 631 aproveita a ideia da alternância do pedal em duas cordas (terceira e quarta) e o aplica ao trecho inteiro fixando o dedo 3 na quarta corda. Sua primeira entrada (no segundo tempo) é difícil e pode ser substituída por corda solta.

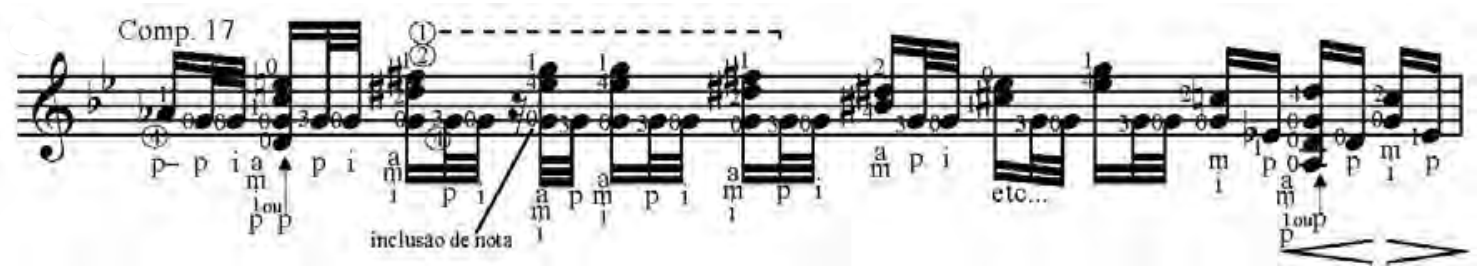

Exemplo 631: VIII $^{\circ}$ Estudo, compasso 17.

A seção seguinte novamente mostra o refinado métier composicional de Mignone, levando o tema inicial a ser retrabalhado em tonalidade maior, com intervenções escalares virtuosísticas e em forma literalmente espelhada. Essa estrutura facilitará nossa comunicação pois o que vale para o início do compasso 18 vale para o fim do compasso 19 e visse e versa. Dessa forma, apenas comentaremos o primeiro compasso, entendo que o leitor calculará as inversões do compasso seguinte.

BL propõe ligados bastante coerentes, mas parece envolver demasiadamente o dedo 4 nos mesmos, quando eles são naturalmente mais débeis para este expediente. $\mathrm{O}$ exemplo 633 facilita consideravelmente este aspecto. Nele, o terceiro acorde demanda uma rápida meia-pestana na segunda casa (com as falanges proximal e distal, sem uso portanto da medial) e as escalas são todas executadas com o mesmo padrão de dedos 3- 
1-4-2 (excetuando o momento com corda solta) em duas cordas que depois é invertido $^{129}$.
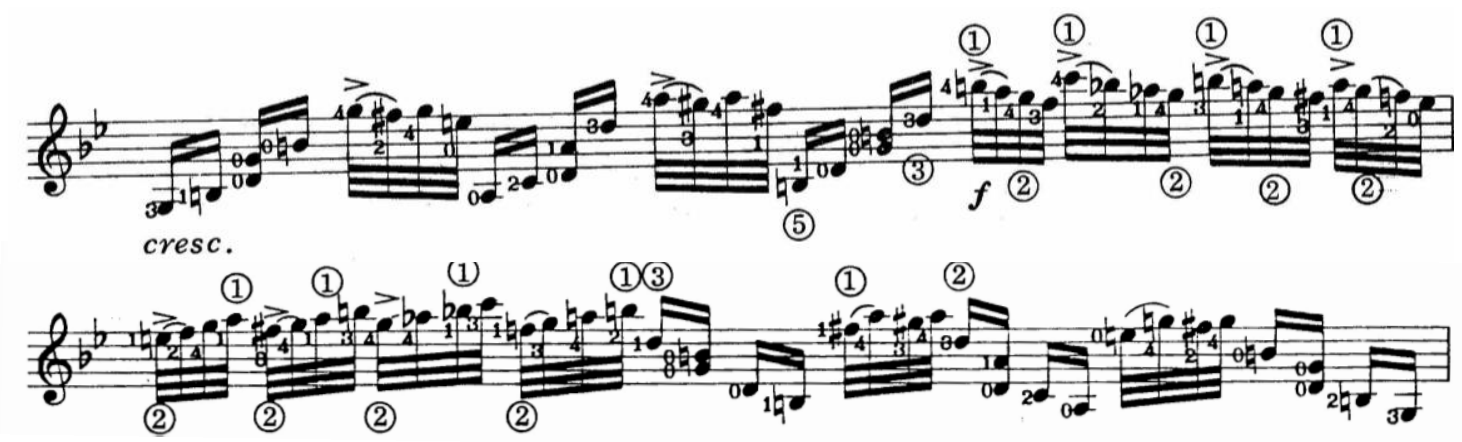

Exemplo 632: VIII ${ }^{\circ}$ Estudo, compasso 18. Ed. Columbia/BL.
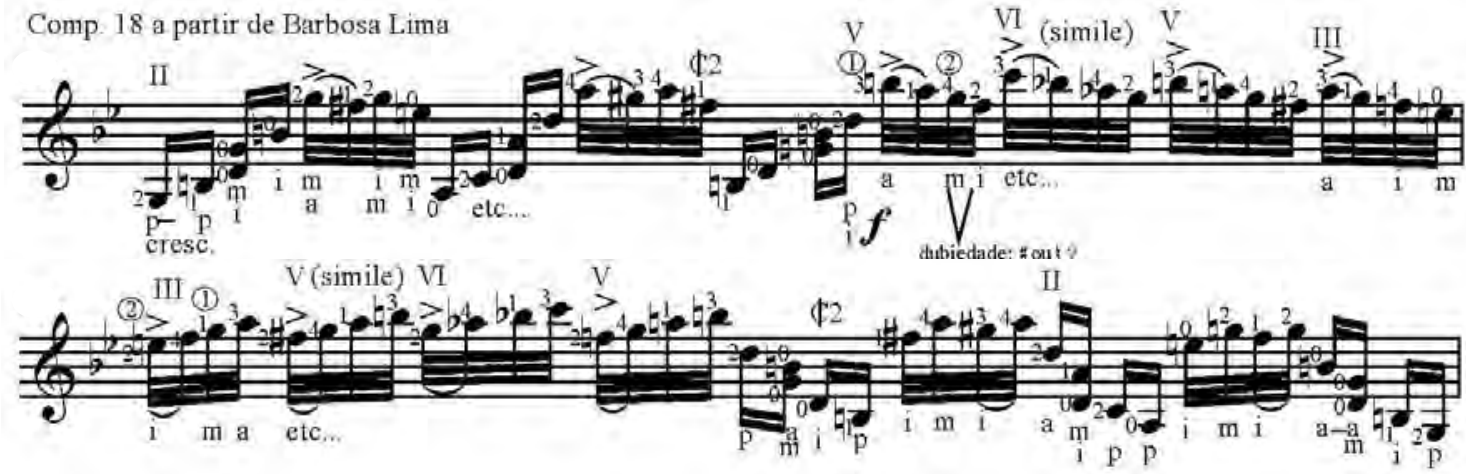

Exemplo 633: VIII $^{\circ}$ Estudo, compasso 18.

O exemplo 634 insere ligados nos primeiros acordes (de maneira análoga ao primeiro compasso da obra) e digita o terceiro deles pela sexta posição. As escalas recebem ligados em outra posição, em caráter mais experimental, mas também com digitação bastante padronizada.
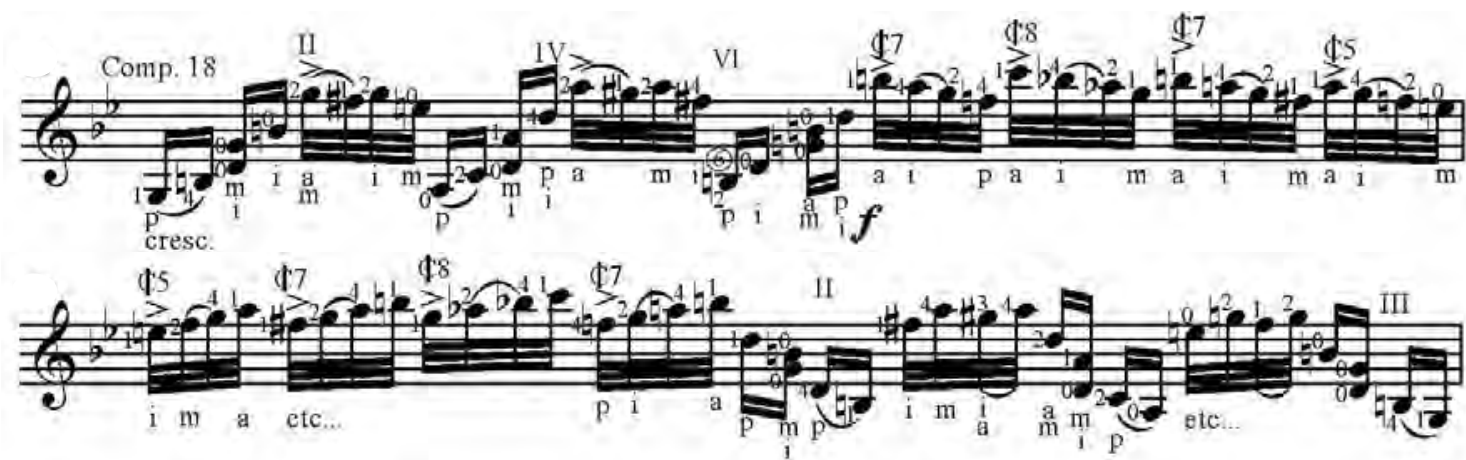

Exemplo 634: VIII ${ }^{\circ}$ Estudo, compasso 18.

Existem várias maneiras de integrar aspectos dessas versões, mas deixaremos ao leitor o papel de realizar essas colagens, se assim o desejar.

A derradeira transição desta pequena seção que a liga ao retorno do tema inicial recebe pedal na dominante e melodia em tercinas. Normalmente formada por duas notas iguais seguidas por grau conjunto abaixo, ela possui pequenas quebras neste padrão nos

${ }^{129}$ verbo do checklist de Osborn. 
tempos 7, 8, 11 e 12 (indicadas por setas e também existentes no manuscrito) que mais parecem erros de grafia por não resultarem em uma diferença relevante no aspecto musical. Por esse motivo nossa única versão alternativa a digitação BL apresenta o que seria a versão unificada dessa melodia, sem com isso querer reivindicar a razão sobre este assunto.

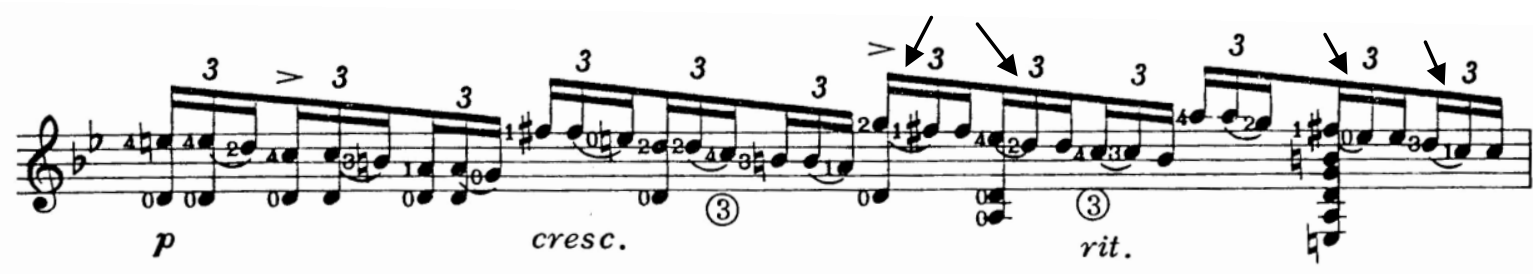

Exemplo 635: VIII $^{\circ}$ Estudo, compasso 20. Ed. Columbia/BL.

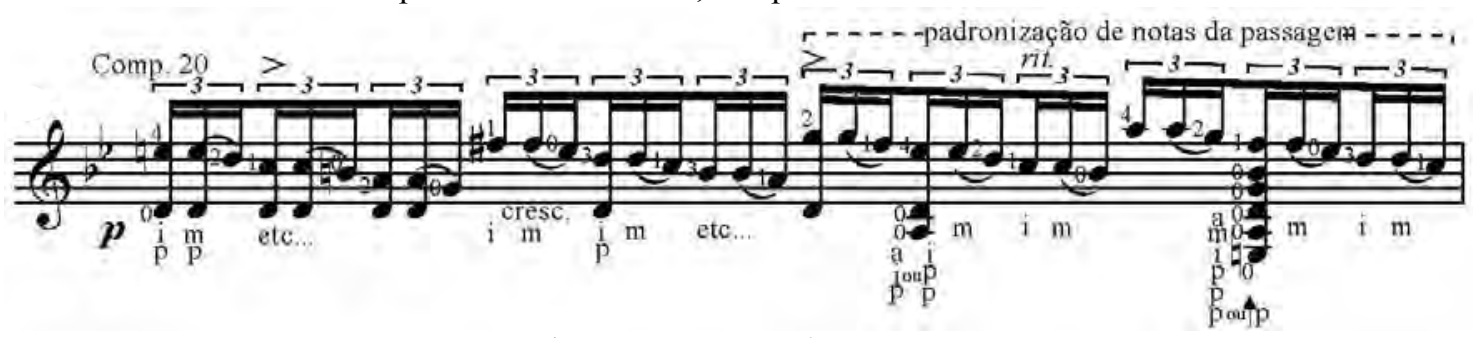

Exemplo 636: VIII $^{\circ}$ Estudo, compasso 20.

O baixo da passagem não atende a um padrão exatamente reconhecível, embora tenha funcionamento musical e seja memorizável com algum estudo. No entanto, ele pode ser facilitado por meio de padronização a partir dos três primeiros tempos, o que julgamos desnecessário grafar.

O retorno do tema se dá no compasso 21, com pequenas variações em um dos acordes neste compasso e no seguinte que serão, por este motivo, apresentados somente de maneira parcial focadas nas ditas modificações.

$\mathrm{Na}$ primeira ocasião, apenas oferecemos uma versão (ex. 638) com ligado opcional no primeiro tempo e digitação do semitom em acorde na terceira posição.

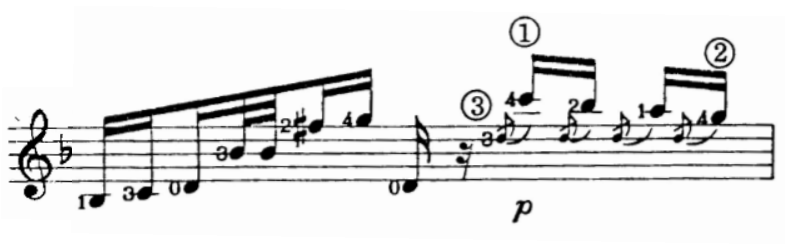

Exemplo 637: Est. 8, comp. 21 (parcial). Ed. CB/BL.

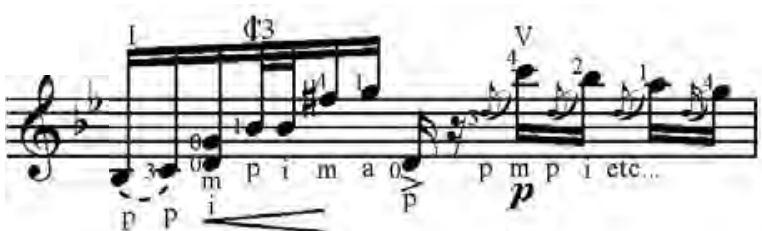

Exemplo 638: Est. 8, comp. 21 (parcial).

$\mathrm{O}$ mesmo ocorre no exemplo seguinte (idêntico a $\mathrm{BL}$, mas com um ligado opcional) em relação ao compasso 22 que também recebe uma versão na terceira posição no exemplo 640. 


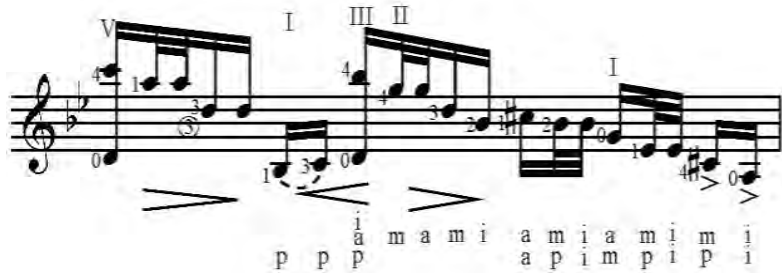

Exemplo 639: VIII ${ }^{\circ}$ Est., comp. 22 (parcial).

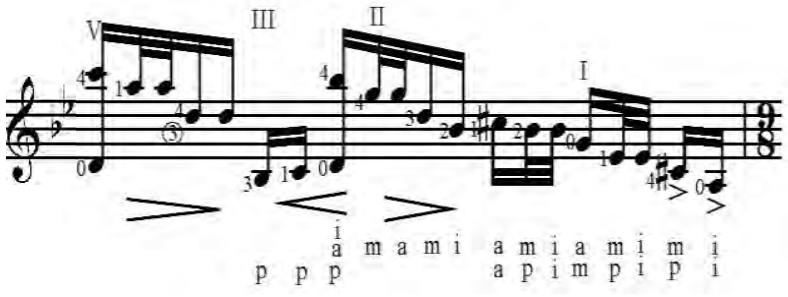

Exemplo 640: VIII $^{\circ}$ Est., comp. 22 (parcial).

Ocorre no compasso 24 o início de uma nova seção, agora com textura de terças rebatidas que posteriormente se transformam em outros intervalos. Nossa única versão (ex. 642) busca padronizar as terças iniciais para que ocupem sempre em duas cordas e visa alcançar a última nota (Sib) do trecho na quarta corda com o mesmo dedo que ela será articulada no compasso seguinte.
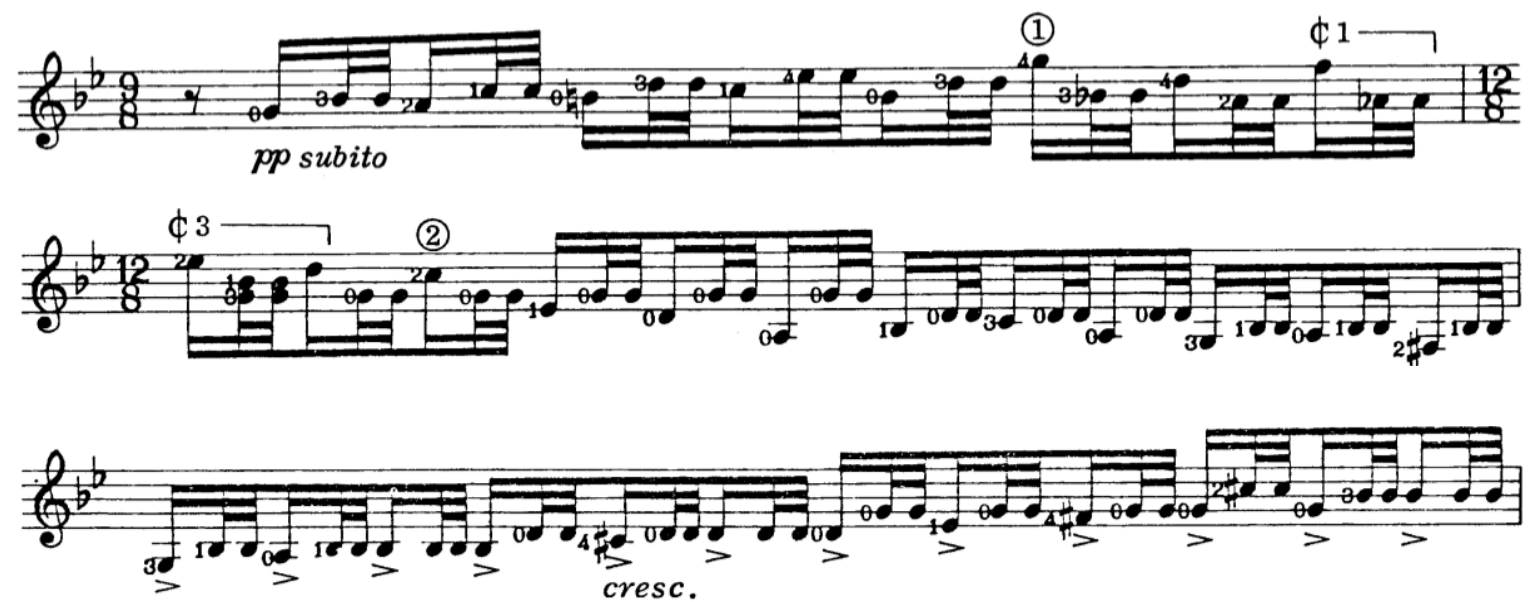

Exemplo 641: VIII ${ }^{\circ}$ Estudo, compasso 24. Ed. Columbia/BL.
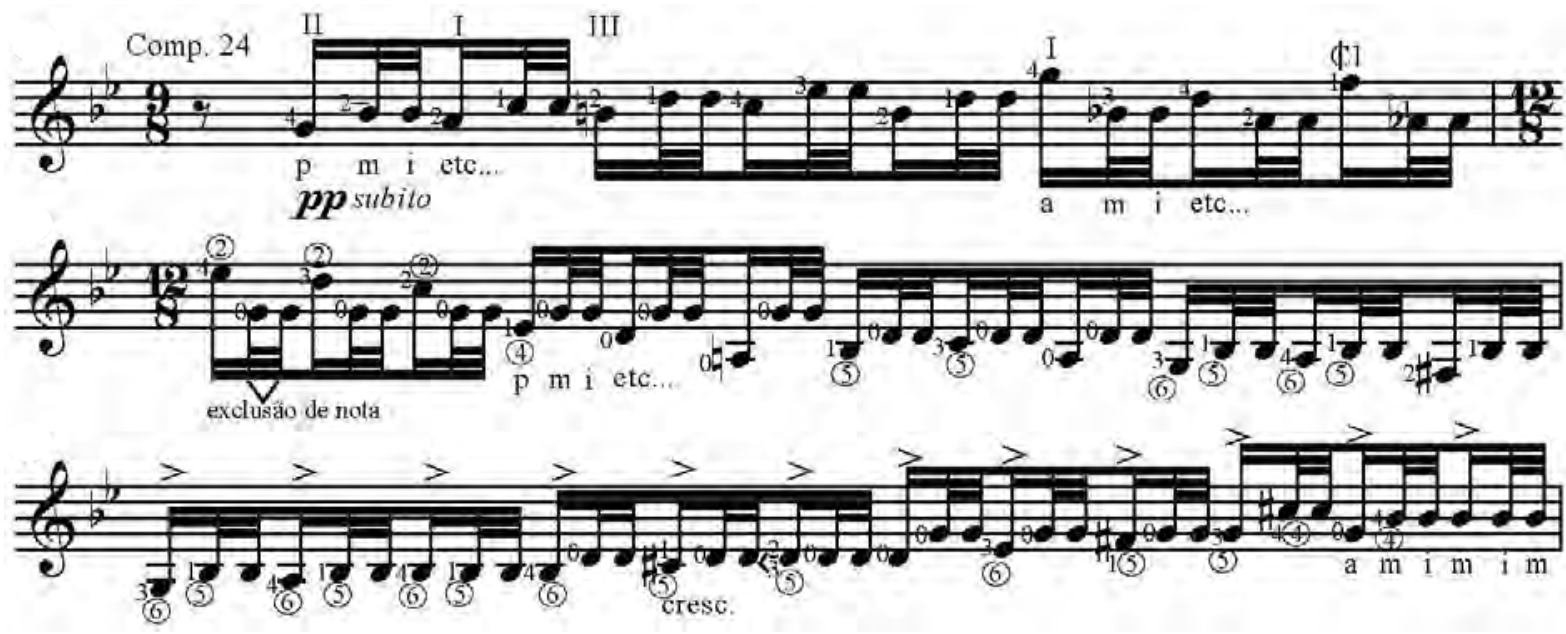

Exemplo 642: VIII ${ }^{\circ}$ Estudo, compasso 24.

Chegando ao ápice da frase, o compasso 27 inclui acordes dissonantes alternados com os bordões soltos, modulando para Mi menor. Duas conferências com o manuscrito precisam ser ressaltadas: o Mi grave é natural e o ritmo do segundo tempo é pontuado conforme esta fonte, configurando aspectos de maior coerência ao trecho.

A digitação BL (ex. 643) é bem resolvida (necessitando apenas da correção rítmica). Como os acordes em empilhamento de terças não permitem outras digitações, 
nossa única alternativa (ex. 644) oferece uma Ossia diminuindo as notas do acorde e propõe articulações distintas de $m d$, que podem ser aplicadas também ao exemplo anterior.

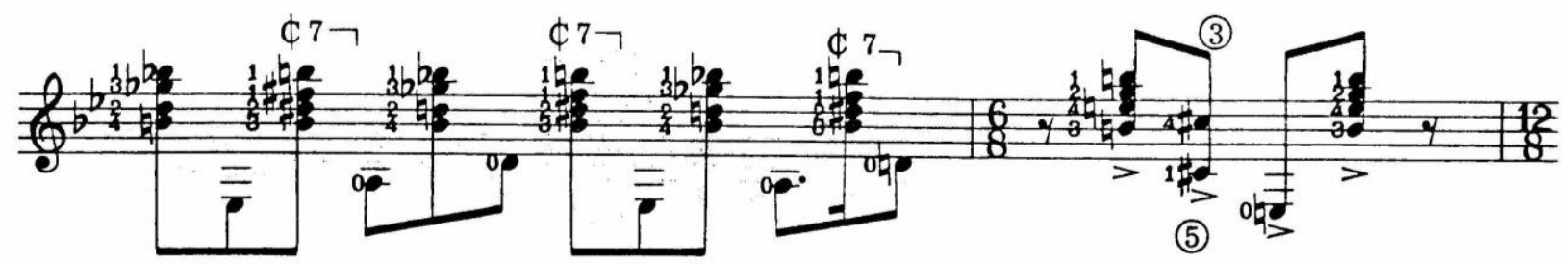

Exemplo 643: VIII ${ }^{o}$ Estudo, compasso 27. Ed. Columbia/BL.

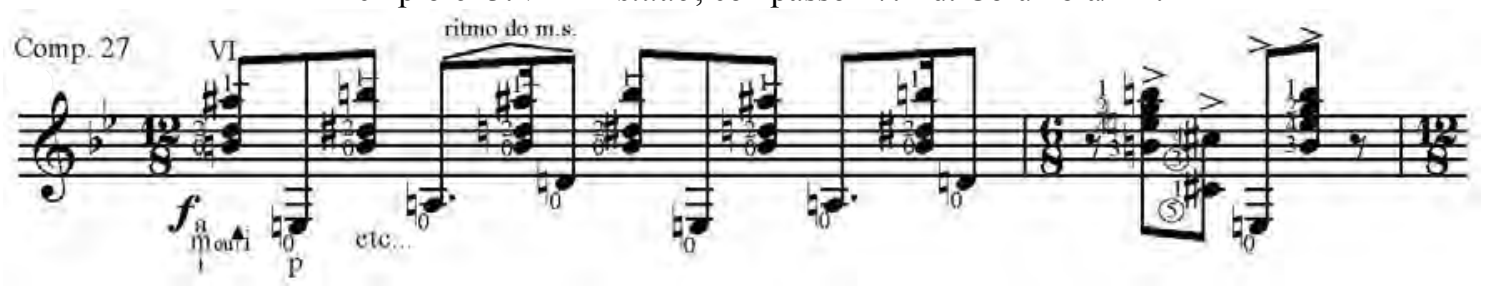

Exemplo 644: VIII ${ }^{\circ}$ Estudo, compasso 27.

O compasso 28 possui novamente uma imprecisão rítmica na edição Columbia quando comparada ao manuscrito, aspecto que bem assinalado no exemplo 646.
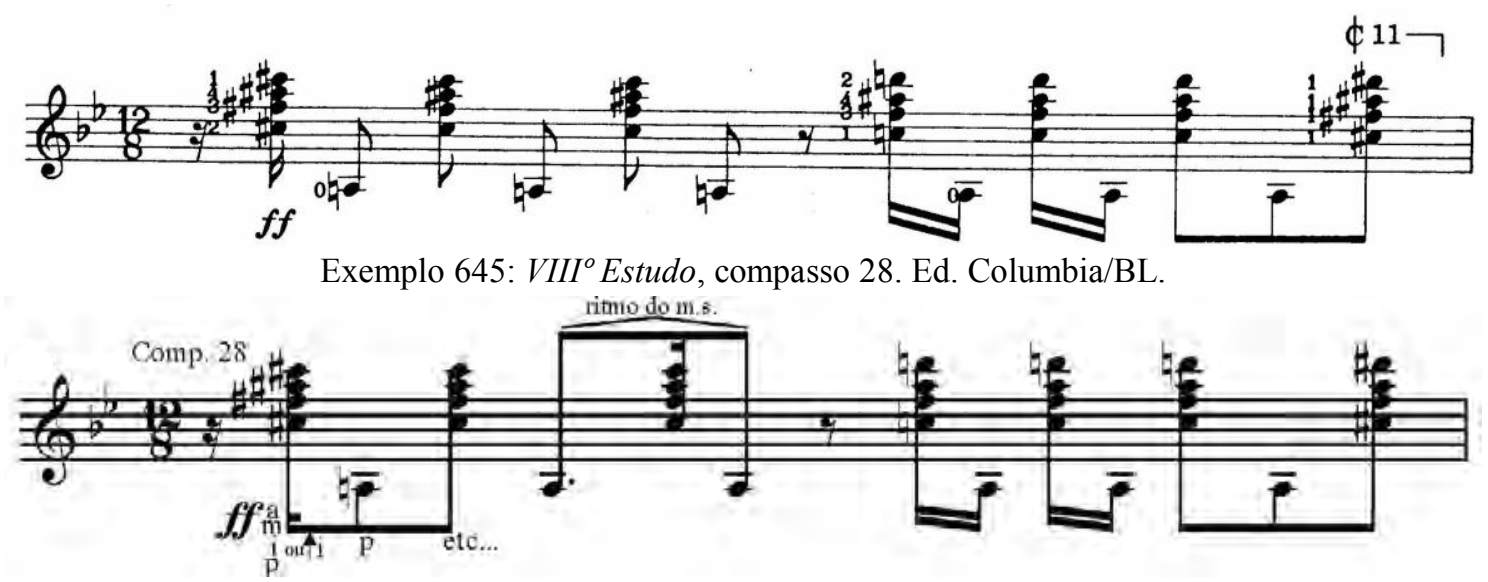

Exemplo 646: VIII ${ }^{\circ}$ Estudo, compasso 28.

O clímax da obra prevê acordes abertos (nas seis cordas soltas) alternados com acordes maiores (plaquê ou arpejados) em paralelismo descendente.

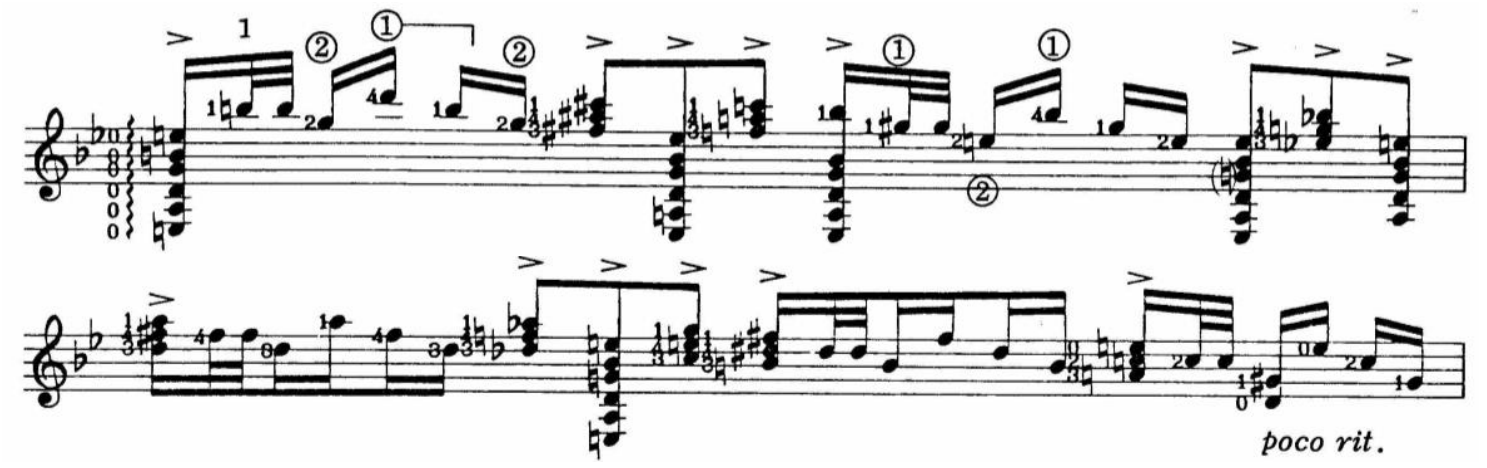

Exemplo 647: VIII ${ }^{\circ}$ Estudo, compasso 29. Ed. Columbia/BL. 
A digitação BL prevê alguns acordes arpejados em duas cordas, enquanto as nossas colocam eles sempre em três, em maior conformidade com os outros acordes. Os exemplos 648 e 649 apenas divergem nos dedos selecionados para os acordes maiores e ambos apresentam várias articulações de $m d$ e uma inclusão opcional de notas.

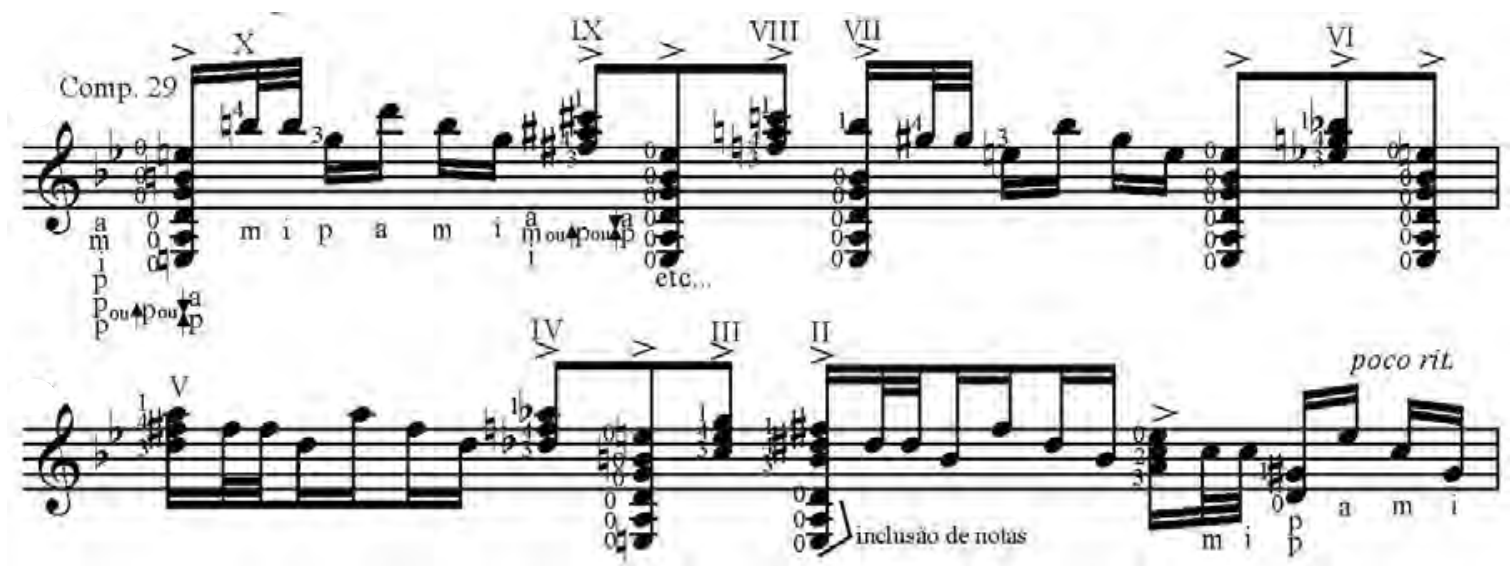

Exemplo 648: VIII ${ }^{\circ}$ Estudo, compasso 29.
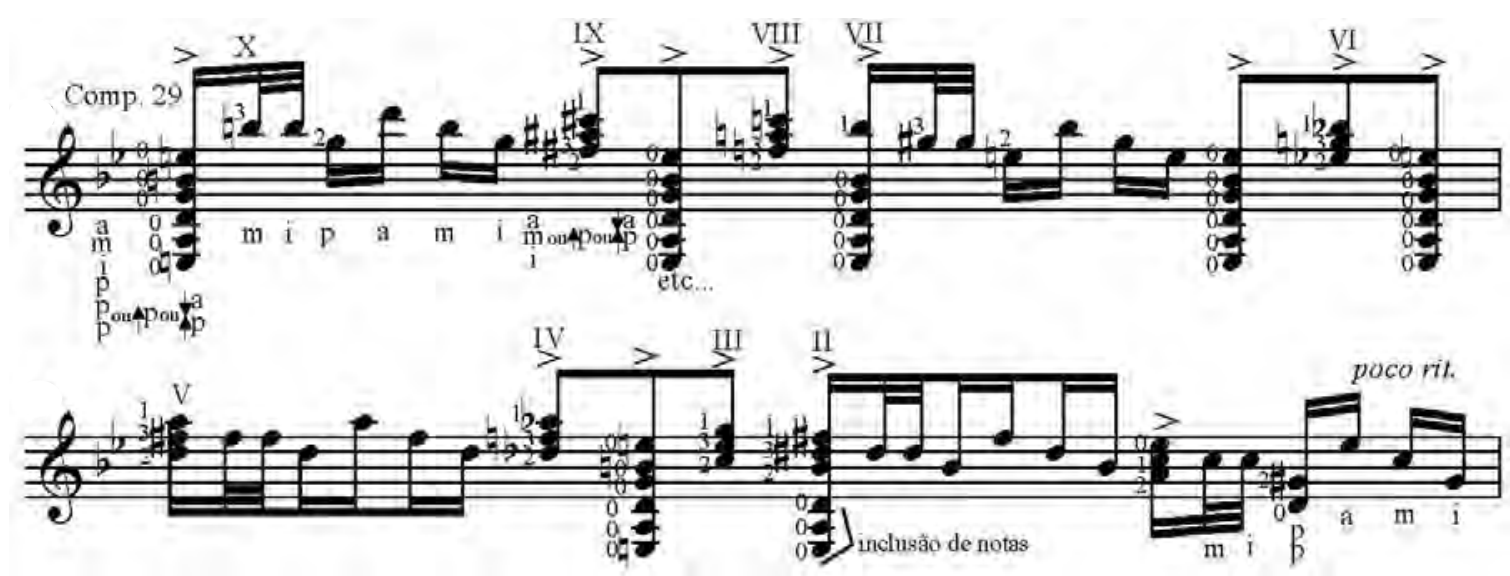

Exemplo 649: VIII ${ }^{\circ}$ Estudo, compasso 29.

Interpretado normalmente com caráter anticlimático o compasso 31 é marcado por uma redução textural onde um pedal em Ré é confrontado com intervenções de terças rapidamente rebatidas. Nossas versões buscam padronizar de diferentes maneiras a digitação das terças, sendo necessário ressaltar que a escolha de dedos para a última delas definirá a digitação do próximo compasso, que se iniciará com os mesmos dedos. O exemplo 653 é o único a testar o uso de cordas duplas no baixo pedal.

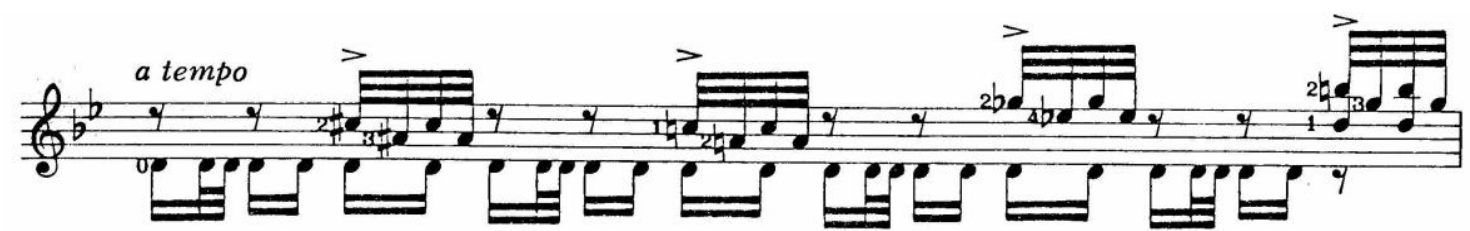

Exemplo 650: VIII $^{\circ}$ Estudo, compasso 31. Ed. Columbia/BL. 


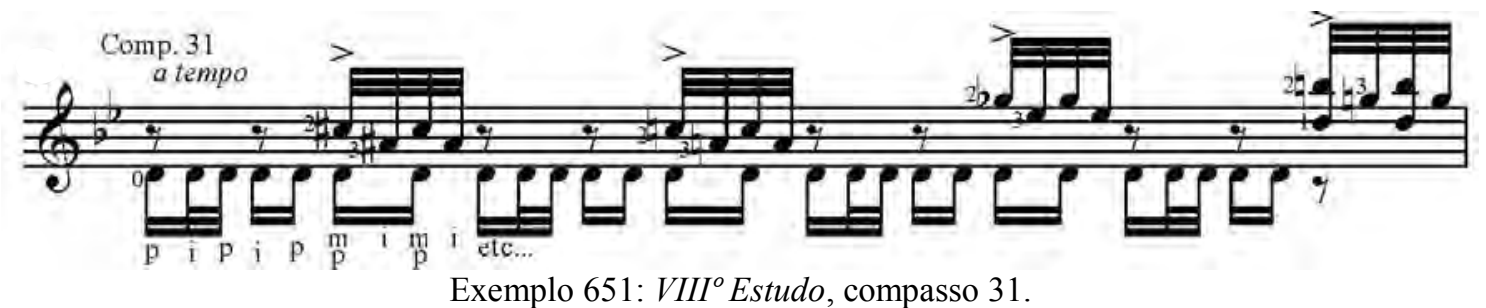

Exemplo 651: VIII $^{\circ}$ Estudo, compasso 31.

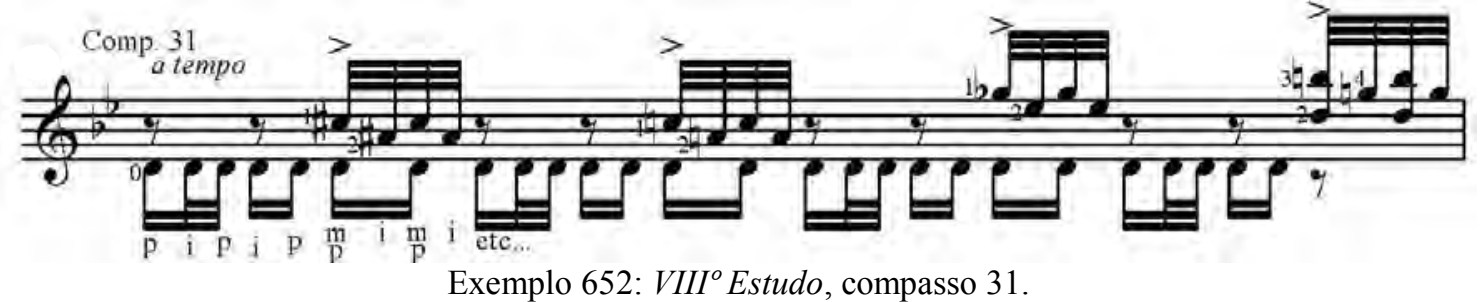

Exemplo 652: VIII $^{\circ}$ Estudo, compasso 31.

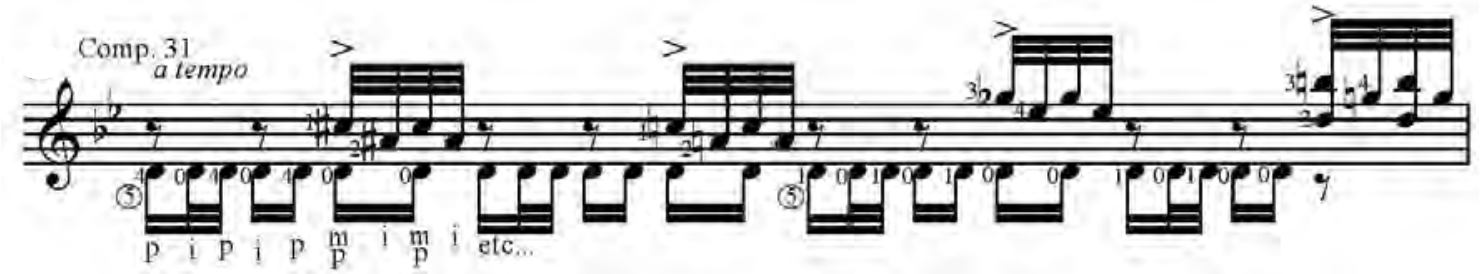

Exemplo 653: VIII $^{\circ}$ Estudo, compasso 31.

Para o fim, novos acordes maiores paralelos são articulados junto aos bordões soltos, com efeito de conotação levemente caipira. A digitação BL é bem delineada e preferível ao exemplo 654 que vem apenas sugerir outros dedos para os acordes, a fim de oferecer continuação a algumas das versões do compasso anterior.

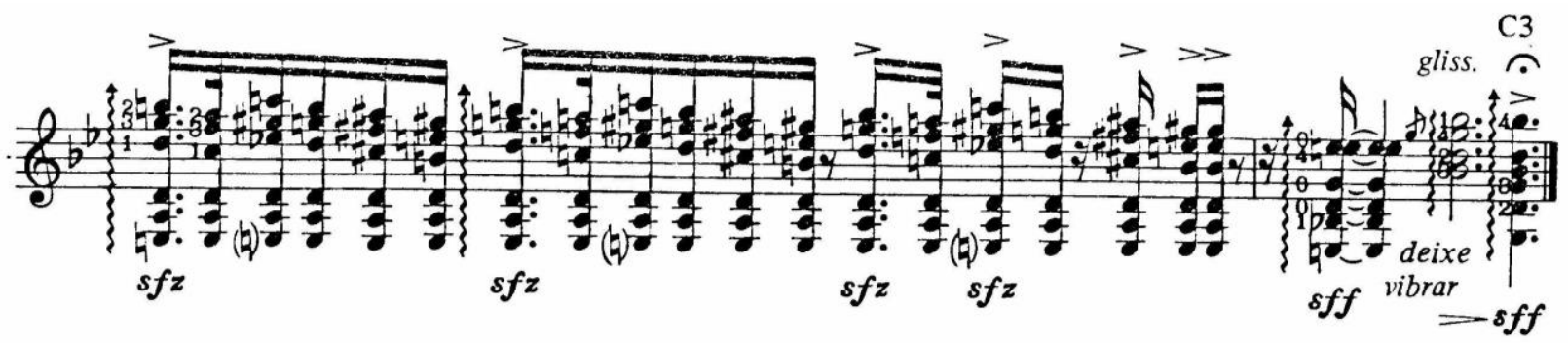

Exemplo 654: VIII ${ }^{\circ}$ Estudo, compasso 32. Ed. Columbia/BL.

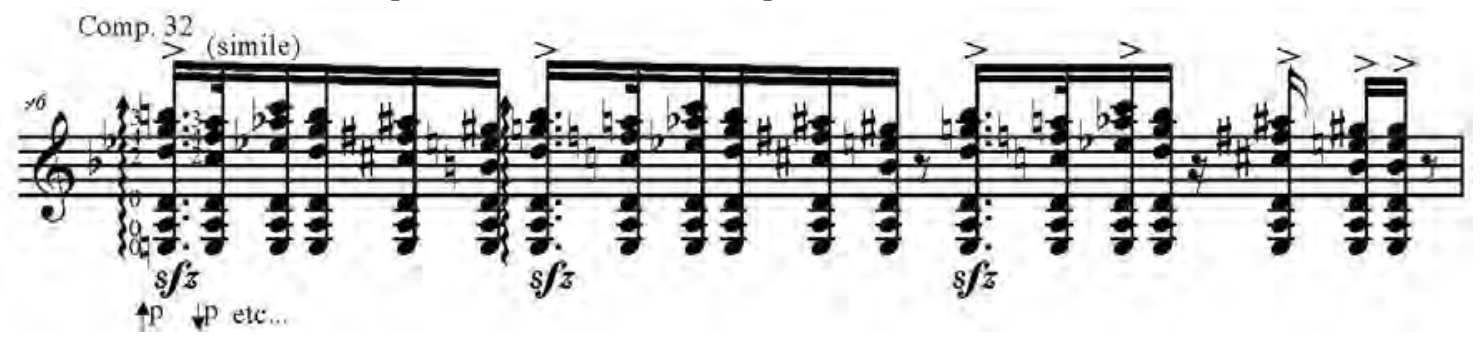

Exemplo 655: VIII $^{\circ}$ Estudo, compasso 32.

O último compasso da obra apresenta um detalhe pouco idiomático no manuscrito ao prever um acorde com glissando de oitava. Esse efeito não funciona exatamente como o esperado por vários motivos: 1) o primeiro acorde é infactível como está escrito por apresentar duas notas (Sol e Sib) que têm de ser digitadas na terceira corda, qualquer execução terá de escolher entre uma delas; 2) Os acordes não 
apresentam a mesma configuração de dedos (principalmente pelas cordas soltas no primeiro), não permitindo um glissando pleno em todas as vozes e 3) eles não conseguem ser conectados por translado utilizando as mesmas cordas já que isso colocaria o acorde agudo desconfortavelmente na posição XI.

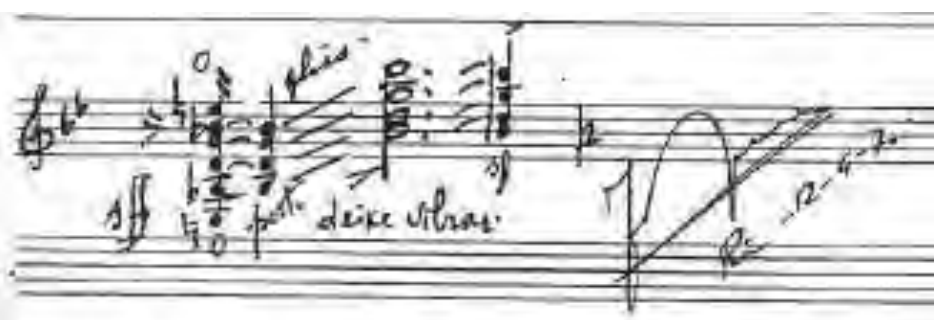

Exemplo 656: VIII $^{\circ}$ Estudo, compasso 33. Manusc.

Por tais motivos é necessária a intervenção do intérprete nesta passagem. A versão BL (ver ex. 654) propõe revisão coerente do primeiro acorde e boa digitação para o segundo, colocando na sexta posição, mas os conecta por um glissando de uma única nota, reduzindo ${ }^{130}$ demasiadamente a ideia original, em nossa opinião.

Nossa saída no exemplo 657 apenas preenche o acorde inicial do glissando com uma reordenação de notas do acorde anterior, dispostas nas mesmas cordas e com os mesmos dedos do acorde agudo, possibilitando assim, um translado total entre os dois acordes.

O exemplo 658 revisa o primeiro acorde duplicando a nota Ré e segurando-a com o dedo 3 para arrastá-lo pela segunda corda até o acorde agudo que por sua vez está levemente reduzido ${ }^{131}$ e com harmônicos naturais em algumas notas.

$\mathrm{O}$ acorde final é preenchido coerentemente por BL e mantido ${ }^{132}$ por nossas versões. O exemplo 659 apenas sugere a possibilidade de uma picardia, opção talvez um tanto polêmica, mas que dá maior sentido conclusivo ao trecho.

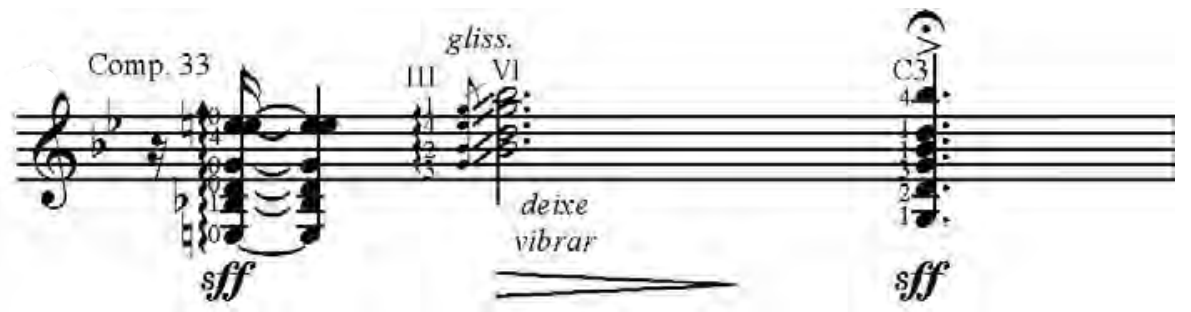

Exemplo 657: VIII $^{\circ}$ Estudo, compasso 33.

\footnotetext{
${ }^{130}$ verbo diminuir do checklist de Osborn.

131 verbo diminuir do checklist de Osborn.

132 item "deixar como está" do checklist de Osborn.
} 


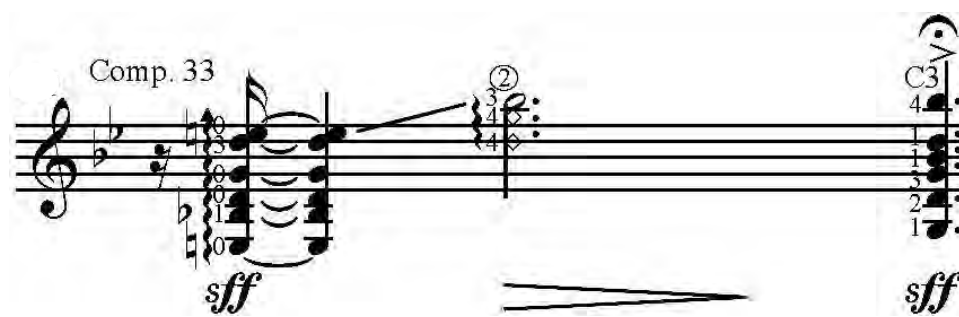

Exemplo 658: VIII $^{\circ}$ Estudo, compasso 33.

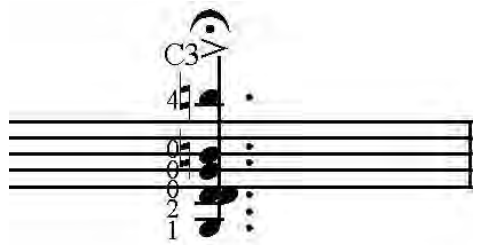

sff

Exemplo 659: VIII ${ }^{\circ}$ Estudo, compasso 33 (parcial). 


\section{9: IX Estudo "Allegro moderato"}

O nono estudo parece, ao nosso julgamento, uma nova confluência de aspectos do choro urbano com a moda de viola caipira suscitada anteriormente no subtítulo do terceiro estudo, que apresentava rápidas alternâncias entre estas influências. Na presente peça elas parecem conviver na primeira e longa seção por meio do ritmo do baixo que é pautado no paradigma do tresilho (Sandroni, 2001, p.28) aspecto presente em ambas as manifestações musicais bem como em uma enormidade de gêneros da América Latina.

Ademais, a influência do choro parece advir da acentuação (e eventuais mudanças na mesma) e na mudança ocorrente de padrões de arpejos conformando o que poderia ser considerado um estudo de "levadas" (termo que designa os padrões de acompanhamento chorão) muito inusitado e útil do ponto de vista técnico e ainda substanciado por musicalidade de interesse. Já a sonoridade "violeira" é suscitada na primeira seção através da ampla ocorrência de uníssonos em cordas duplas dentro dos arpejos, lembrando as ordens duplas do instrumento caipira. Ela se torna protagonista da seção lenta, pelo paralelismo de terças, décimas e blocos de acordes em melodia lânguida.

\section{a Barbosa-Lima \\ IX ${ }^{\circ}$ ESTUDO}

Fingered by

Carlos Barbosa-Lima

Allegro moderato $(d=88)$
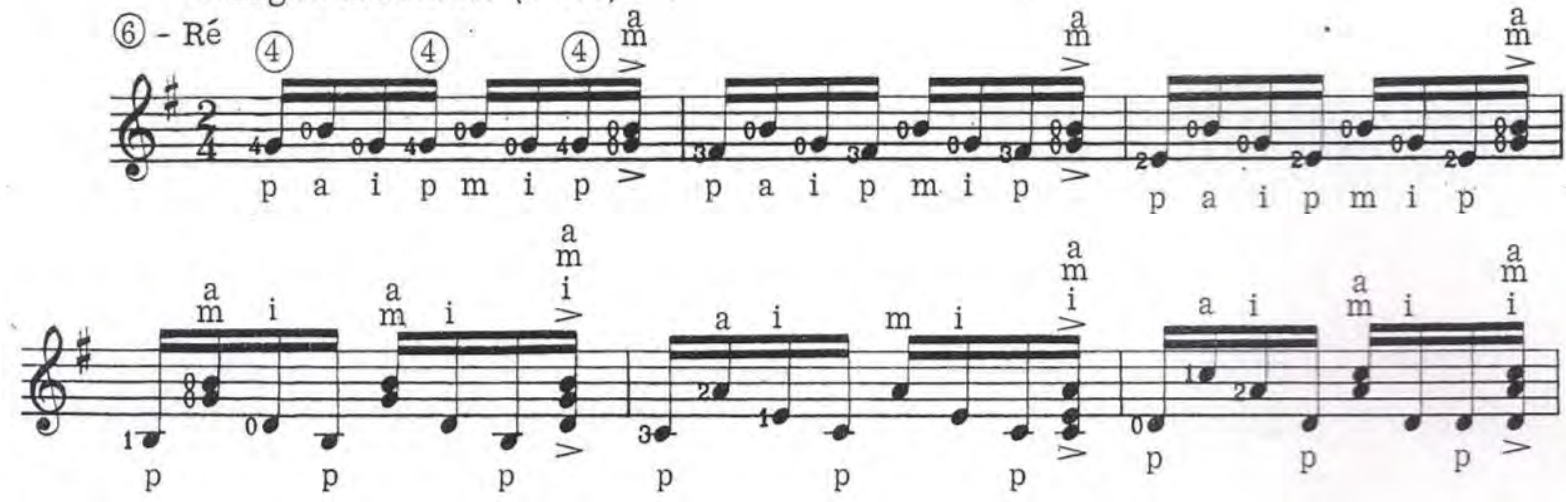

Exemplo 660: IX Estudo, compasso 1. Ed. Columbia/BL.

A digitação BL (ex. 660) é bastante condizente para os primeiros seis compassos, o que não nos demoveu na busca por outras soluções. O exemplo 661 apenas vem modificá-la ${ }^{133}$ em pequenos aspectos, ainda com o baixo circunscrito à

${ }^{133}$ verbo do checklist de Osborn. 
quarta corda e às primeiras posições, enquanto o exemplo 662 se pauta na quinta e sexta cordas e gira em torno da sétima posição.

Comp, 1 a partir de Barbosa Lima
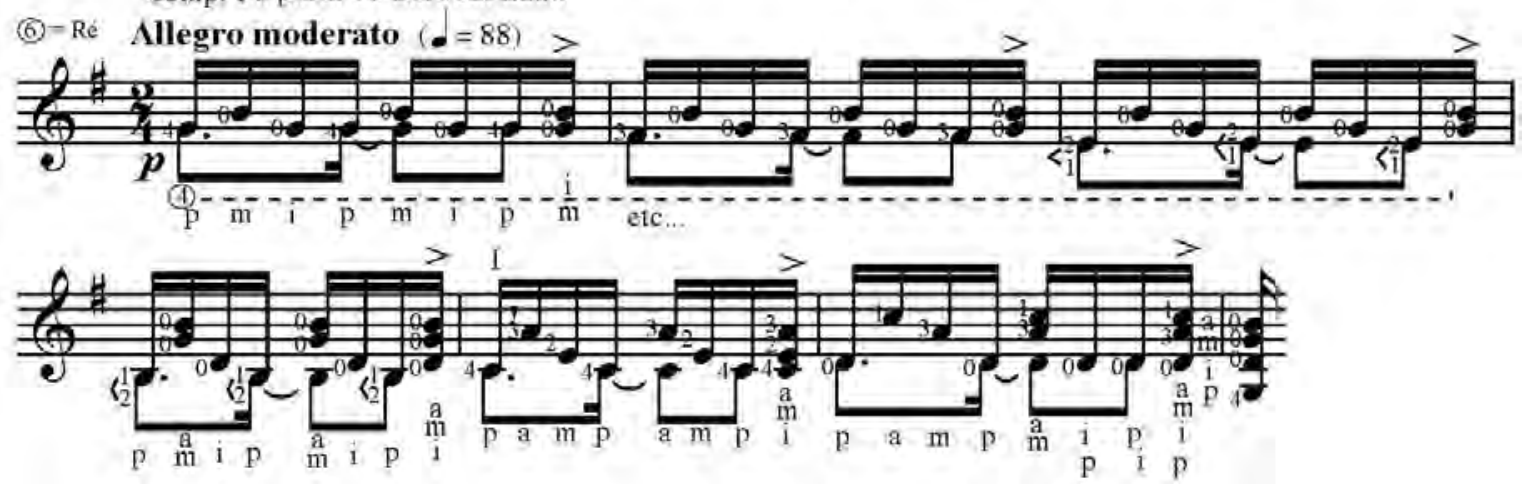

Exemplo 661: IX Estudo, compasso 1.
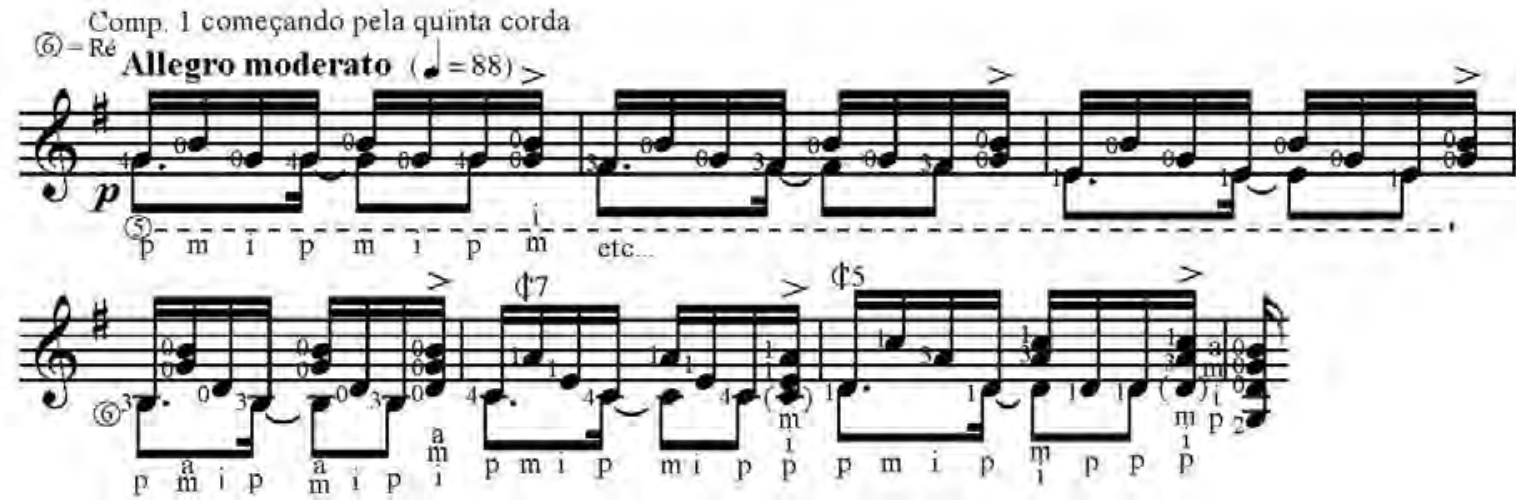

Exemplo 662: IX' Estudo, compasso 1.

Finalmente, os exemplos 663 e 664 "brincam" com diferentes alternâncias de cordas nos baixos demandando saltos que criam um efeito mais teatral do que sonoro, sendo o segundo melhor resolvido mas ainda sem muito custo-benefício.

Comp. 1 alternando cordas no baixo
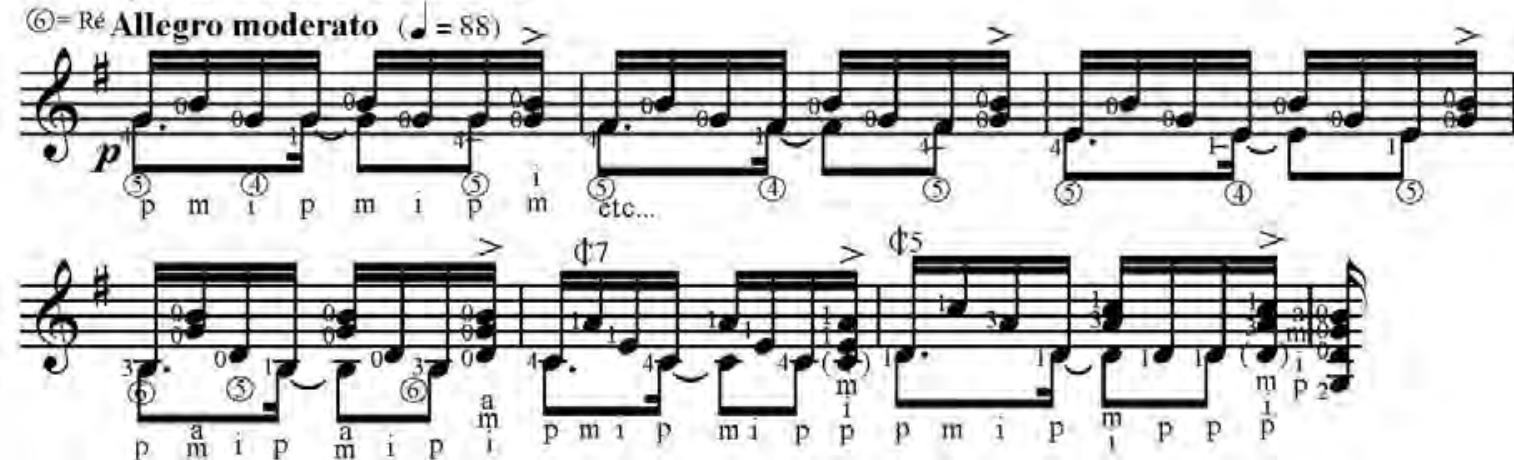

Exemplo 663: IX' Estudo, compasso 1. 
Comp. 1 alternando cordas no baixo

(6) - Re Allegro moderato $(d=88)>$
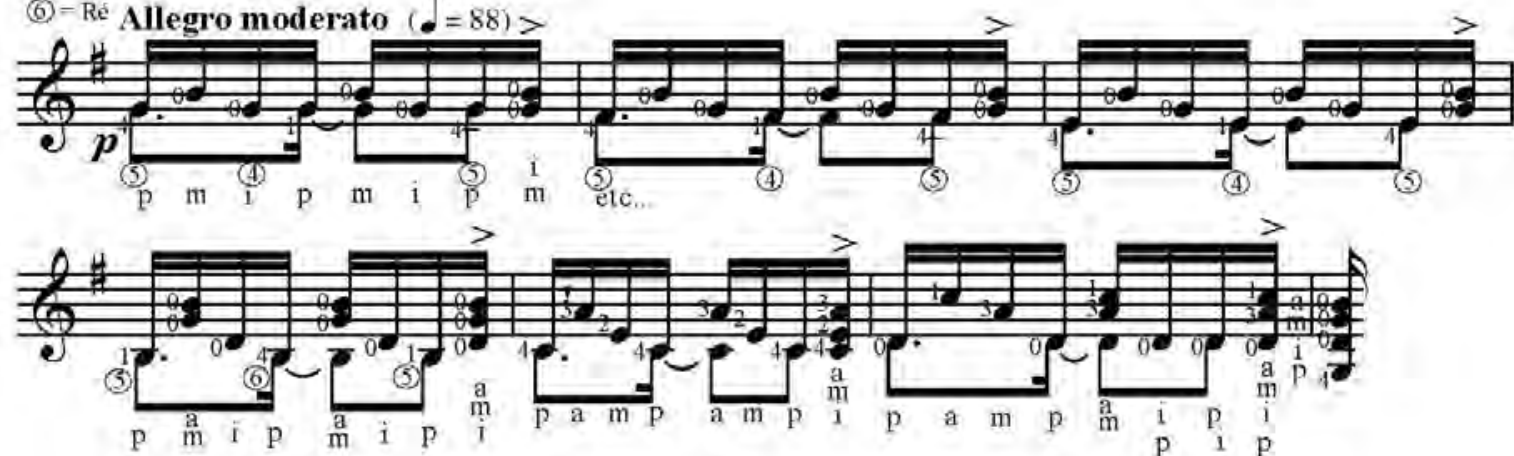

Exemplo 664: IX Estudo, compasso 1.

O final do sexto compasso ainda permite uma exclusão com caráter facilitador considerável, indicada no exemplo 665, que evita a reiteração de uma nota em dois acordes seguidos.

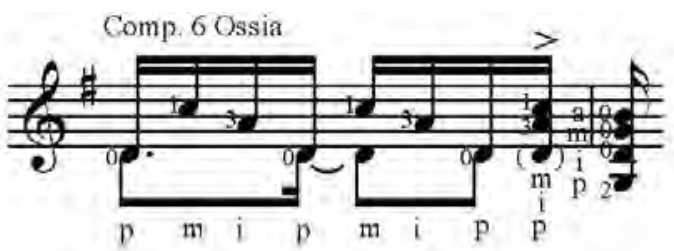

Exemplo 665: IX Estudo, compasso 6.

Segue-se um elemento de ligação para a uma reexposição retrabalhada do tema oitava acima. O exemplo 667 novamente se baseia em BL, modificando ${ }^{134}$ um portamento e apresentando opções de ligados e digitações de $m d$. Os ligados e distribuição das cordas geram padrões (mais ou menos regulares), assinalados por

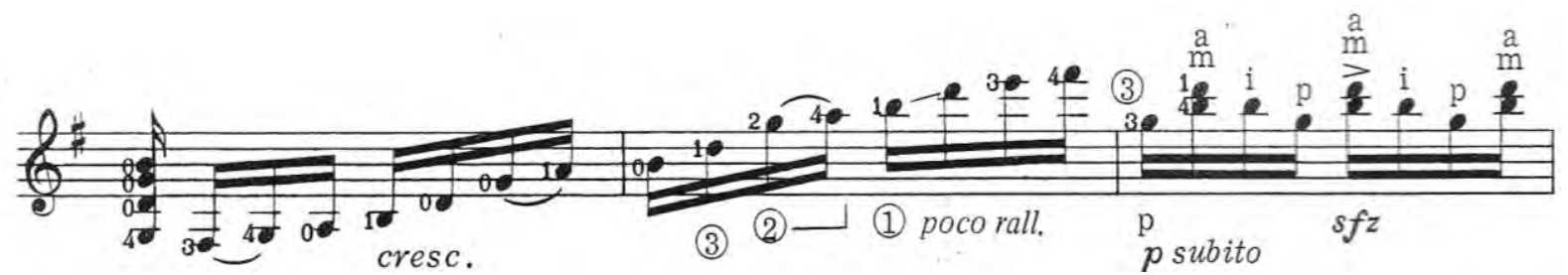

colchetes.

Exemplo 666: IX Estudo, compasso 7. Ed. Columbia/BL.

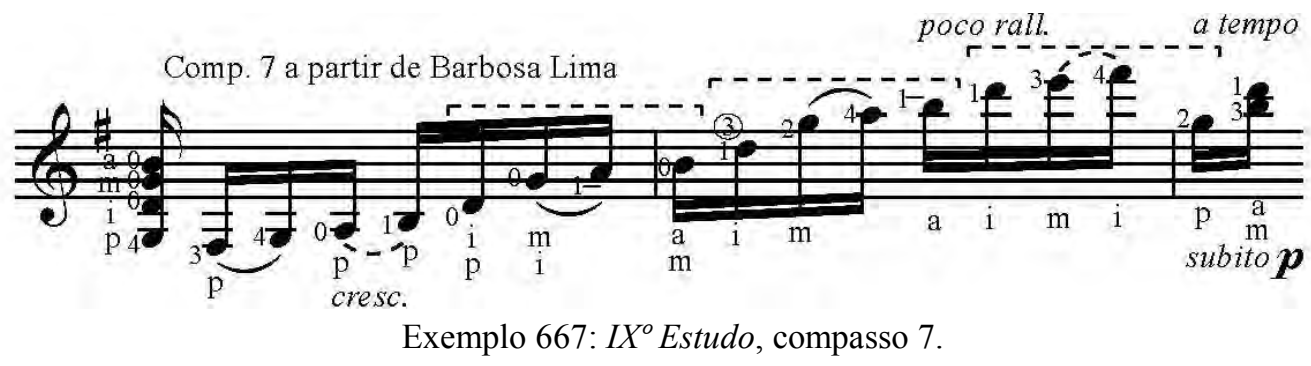

O exemplo 668 experimenta uma subida com maior aproveitamento da primeira corda, gerando abertura na terceira posição seguida de longo translado para a décima. $\mathrm{O}$ exemplo 669, mais paulatino, usa o dedo 2 como guia para alcançar a quinta posição e

\footnotetext{
${ }^{134}$ verbo do checklist de Osborn.
} 
depois o dedo 3 na mesma função para chegar à décima. Finalmente o exemplo 656 inicia pela quarta posição e ascende mais rapidamente à décima, com possibilidade de um ligado triplo (não muito equilibrado).

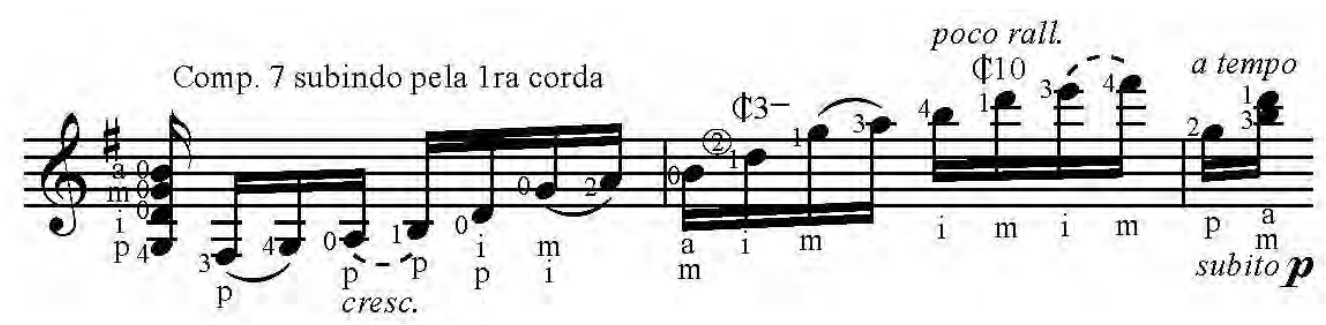

Exemplo 668: IX Estudo, compasso 7.
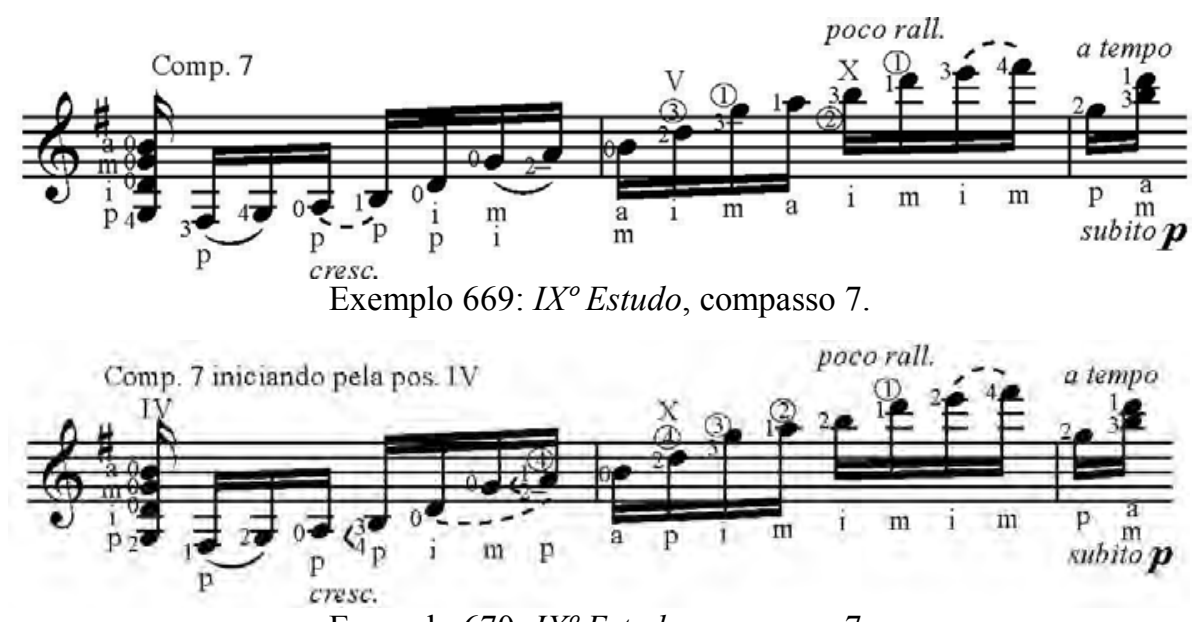

Exemplo 670: IX Estudo, compasso 7.

A reexposição expandida recebe digitação bastante funcional por BL. No entanto, preferimos o início com os dedos 2, 3 e 1 que dessa forma permeiam todas as nossas versões. A primeira delas (ex. 572) se mantém pelas primas em toda sua extensão enquanto a segunda (ex. 673) passeia mais pelas cordas atingindo a quarta corda no baixo em sua segunda porção.
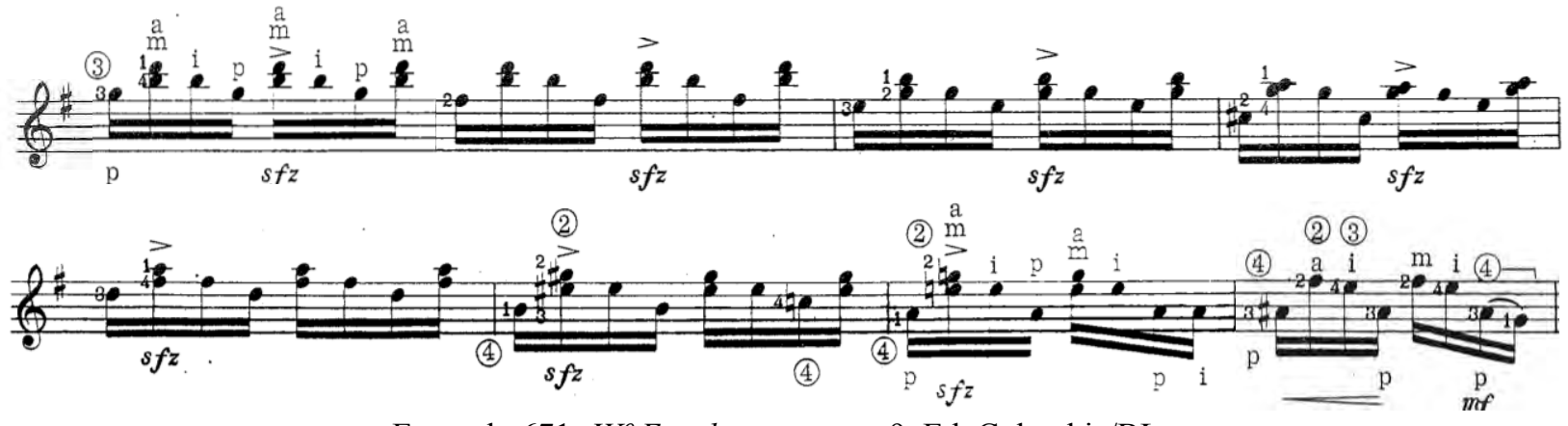

Exemplo 671: IX Estudo, compasso 9. Ed. Columbia/BL. 

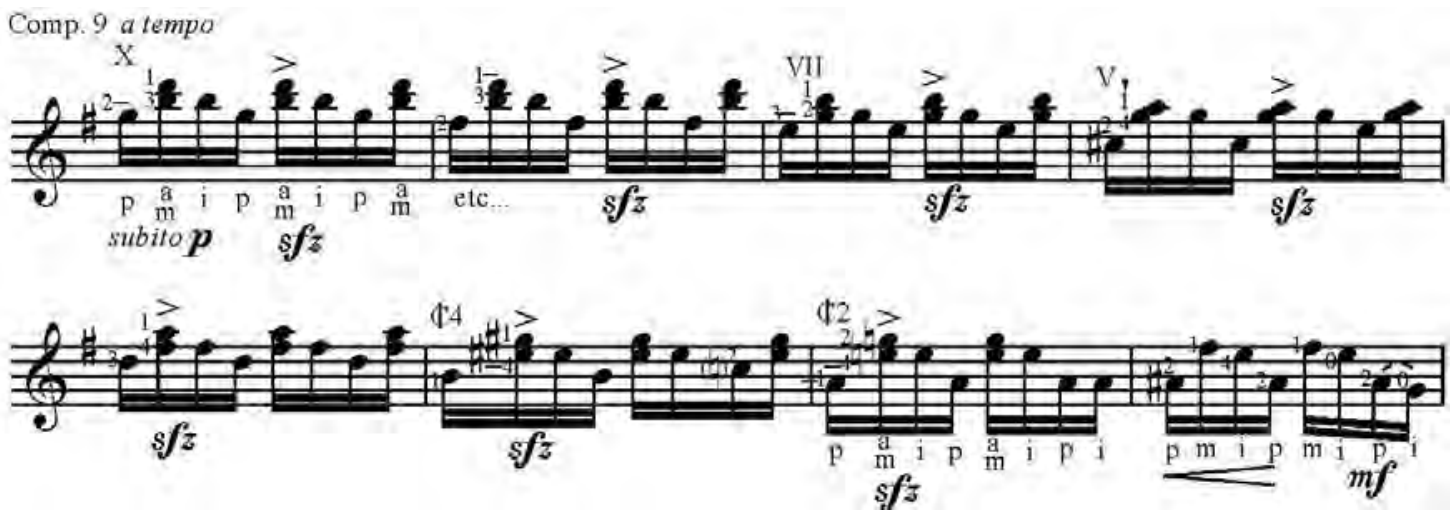

Exemplo 672: IX Estudo, compasso 9.
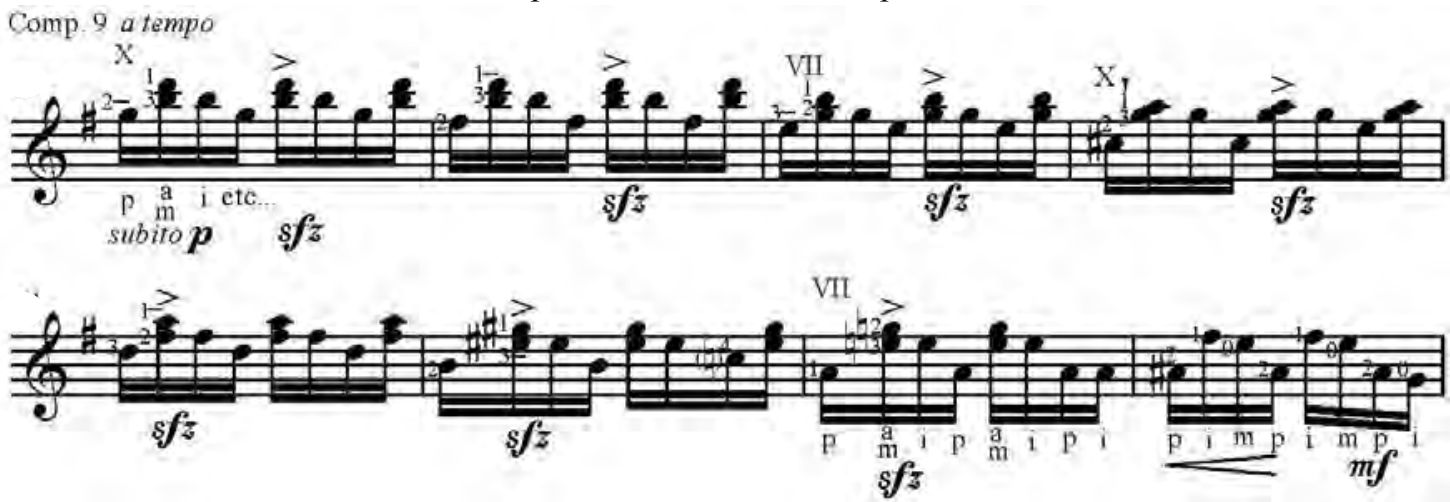

Exemplo 673: IX Estudo, compasso 9.

Um novo padrão de arpejos ocorre na região médio-grave do instrumento com boa digitação BL a qual recebe modificação ${ }^{135}$ em apenas no compasso 21 no exemplo 675 , porém com outro padrão de $m d$. Já o exemplo 676 alivia a grande abertura dos dois primeiros compasso e oferece outra opção para o último, pela quinta posição.

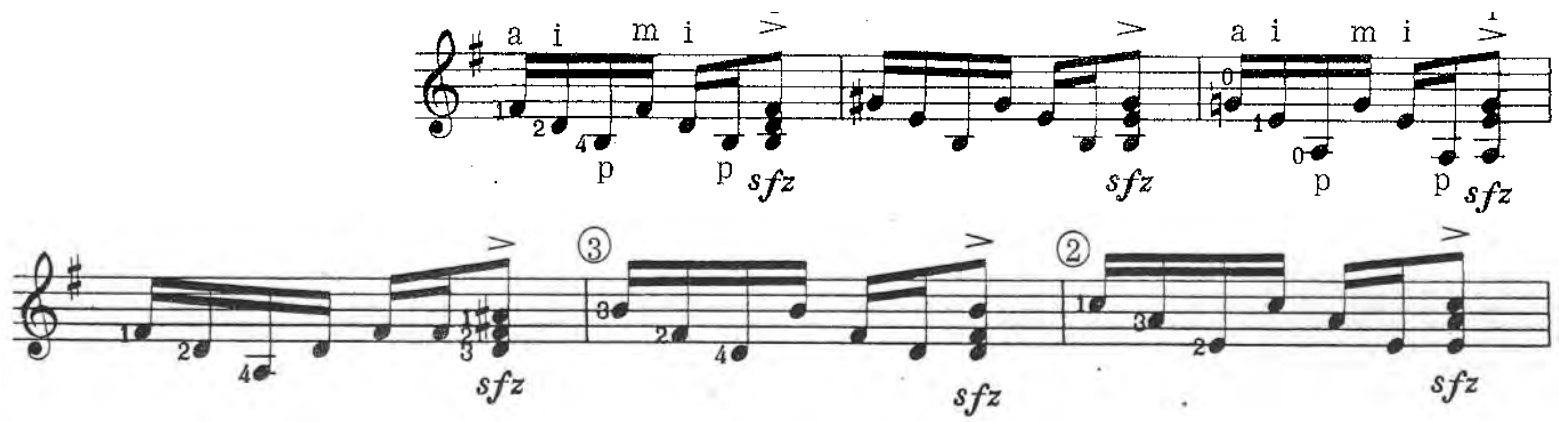

Exemplo 674: IX' Estudo, compasso 17. Ed. Columbia/BL.
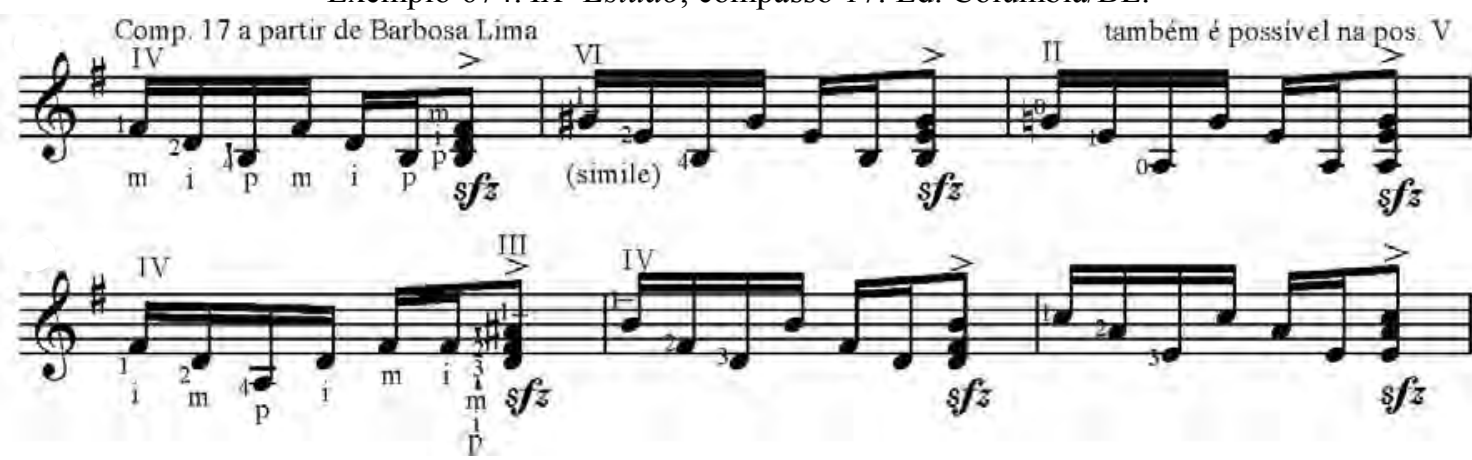

Exemplo 675: IX Estudo, compasso 17.

${ }^{135}$ verbo do checklist de Osborn. 

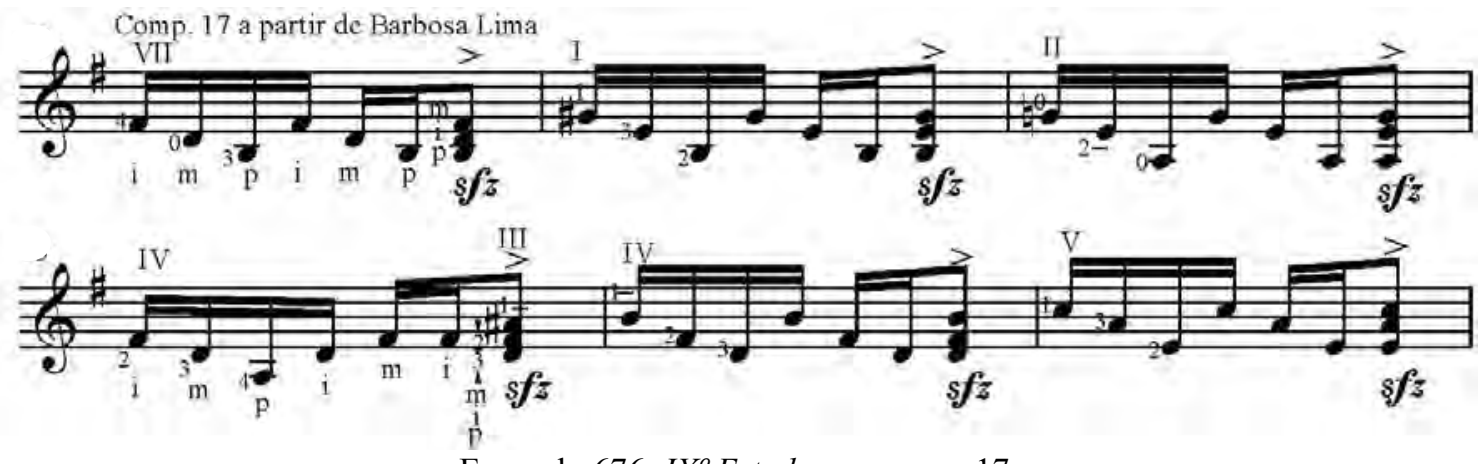

Exemplo 676: IX Estudo, compasso 17.

Um novo elemento de ligação e arpejos ascendentes leva a uma subida de oitava. Nela, o exemplo 678 alivia a sequência de ligados com dedos contíguos de $m d$ da proposta BL por substituição, também simplificando o tempo final. Já o exemplo 679 propõe digitação na região central com cordas soltas (que pode ser combinada ${ }^{136}$ com as anteriores), porém sem ligados e com menos padrões de $m d$.

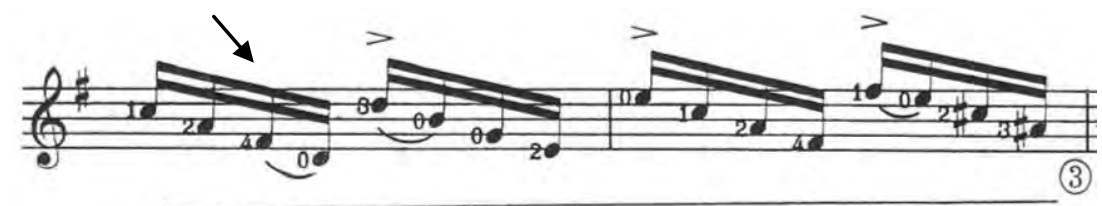

Exemplo 677: IX Estudo, compasso 23. Ed. Columbia/BL.

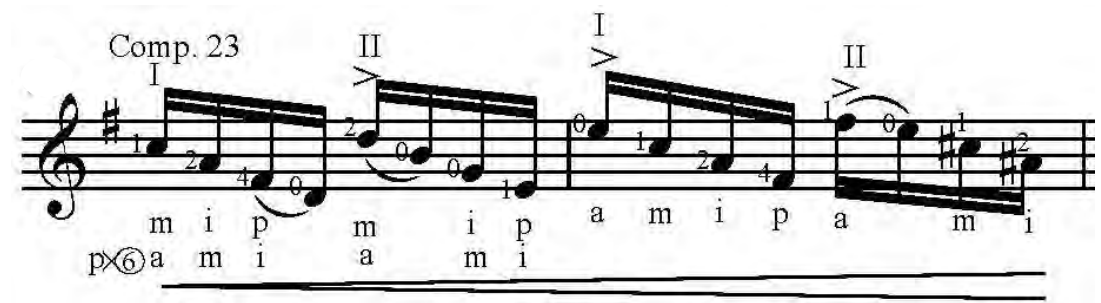

Exemplo 678: IX' Estudo, compasso 23.

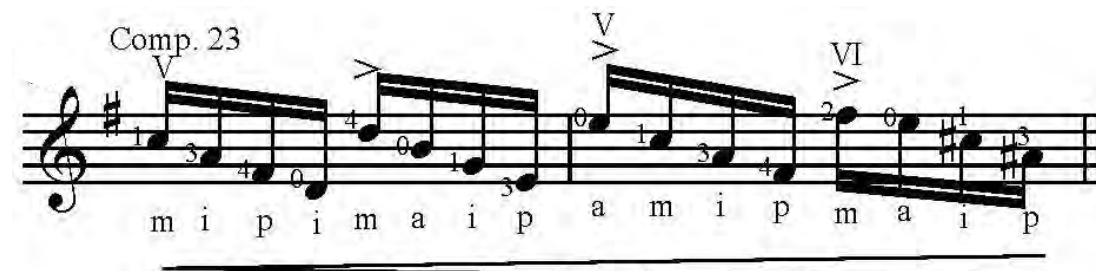

Exemplo 679: IX Estudo, compasso 23.

O compasso 25 inicia arpejos ascendentes em progressão harmônica baseada no ciclo das quintas, com maior movimentação do baixo e com aparição eventual de acordes. O exemplo 681 reduz $^{137}$ a ocorrência do dedo 4 da digitação BL (ex. 680) e propõe duas digitações de $m d$. O exemplo 682 inicia-se no compasso anterior para alcançar o compasso 25 na sétima casa e segue na região central por apenas três compassos, já que a partir de então ele pode recorrer às mesmas soluções anteriores.

\footnotetext{
${ }^{136}$ verbo do checklist de Osborn.

${ }^{137}$ verbo diminuir do checklist de Osborn.
} 


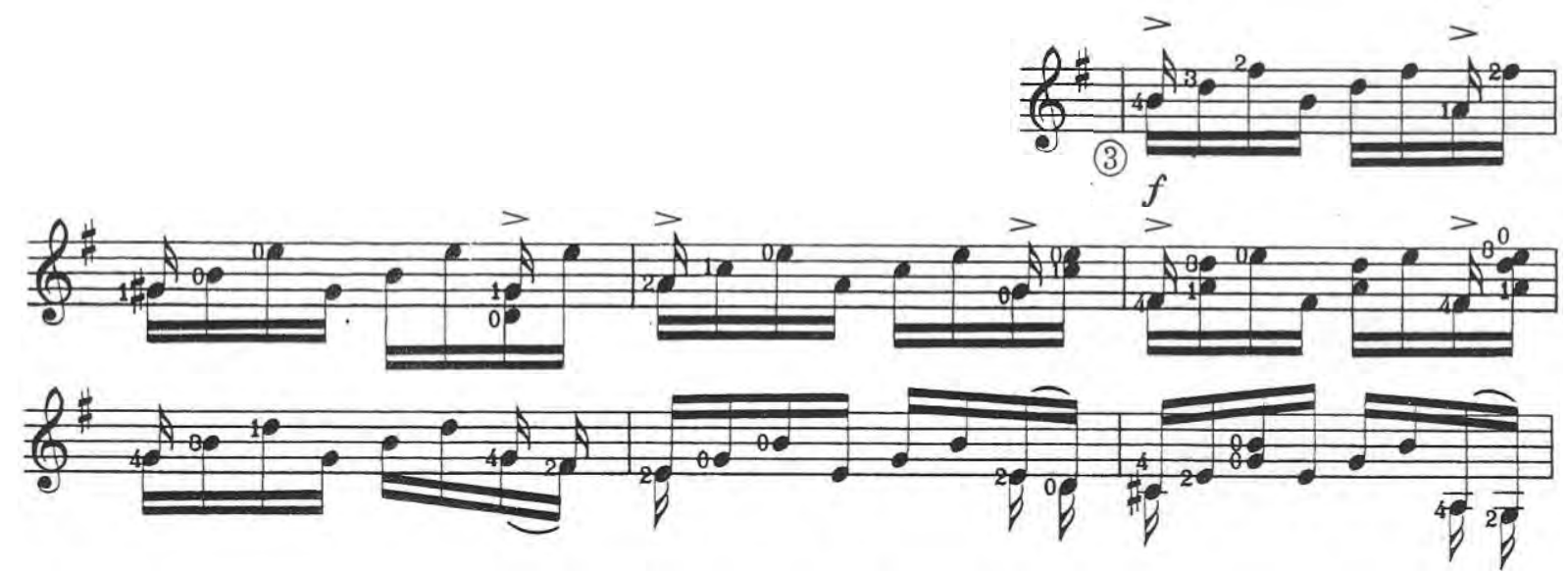

Exemplo 680: IX Estudo, compasso 25. Ed. Columbia/BL.
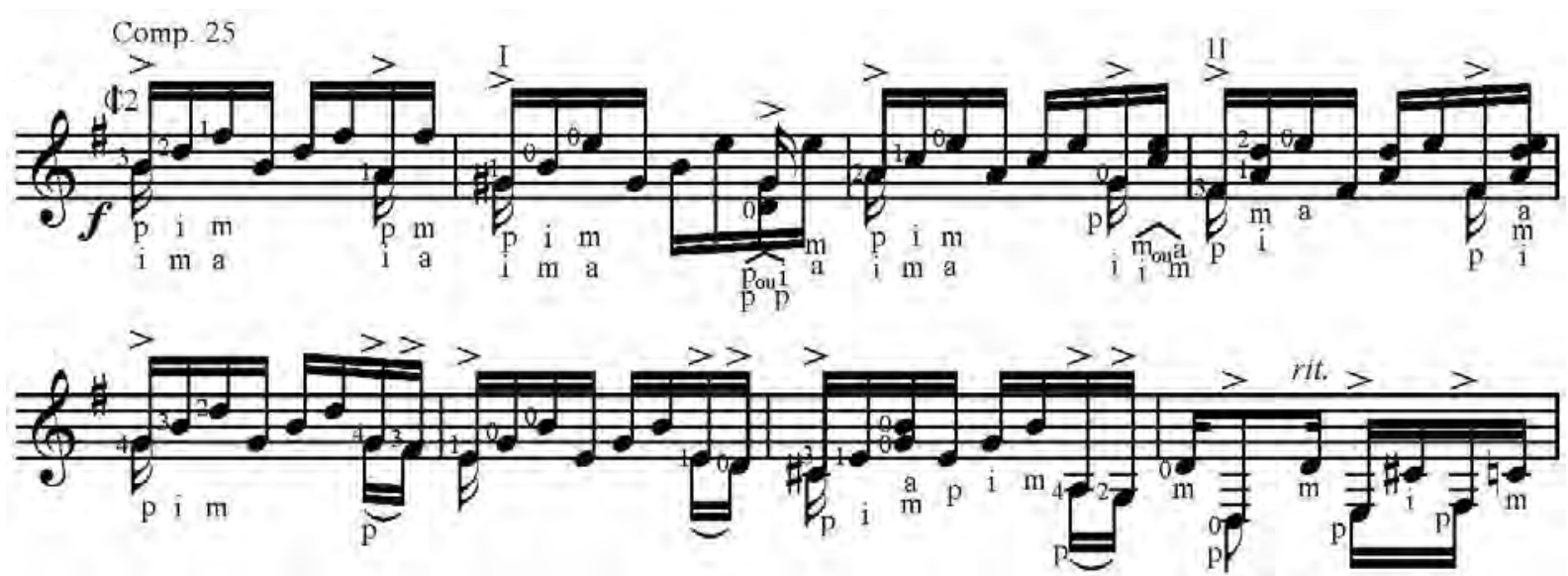

Exemplo 681: I $X^{\circ}$ Estudo, compasso 25.

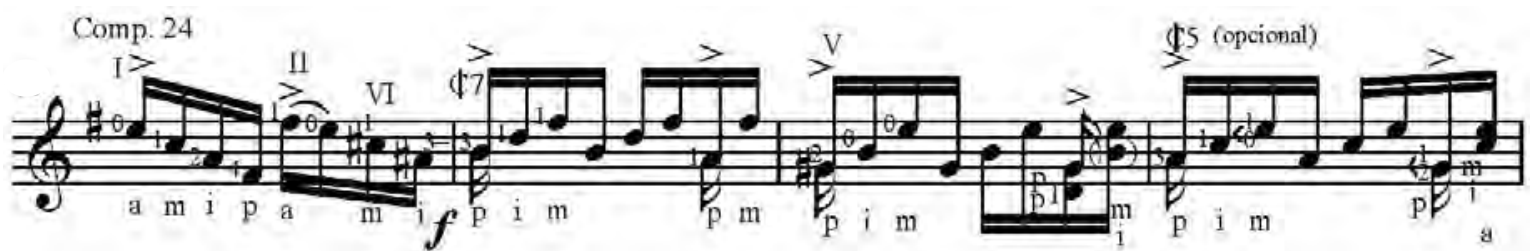

Exemplo 682: IX Estudo, compasso 24.

Segue-se uma aparição grave do mesmo tema que recebe uma única substituição facilitadora por nós (em relação a BL) e acréscimo opcional de nota para padronização do trecho.

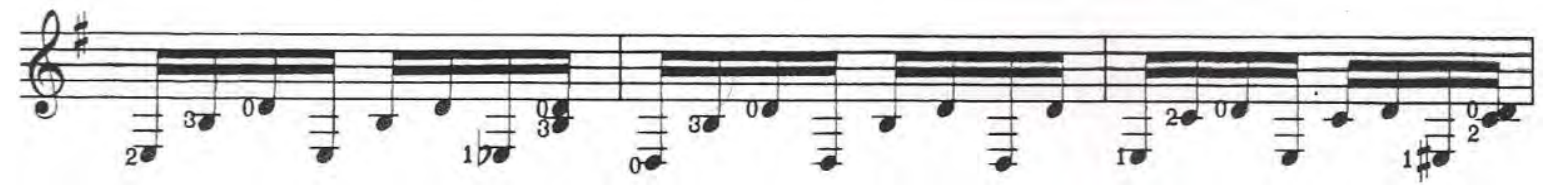

Exemplo 683: IX Estudo, compasso 35. Ed. Columbia/BL.

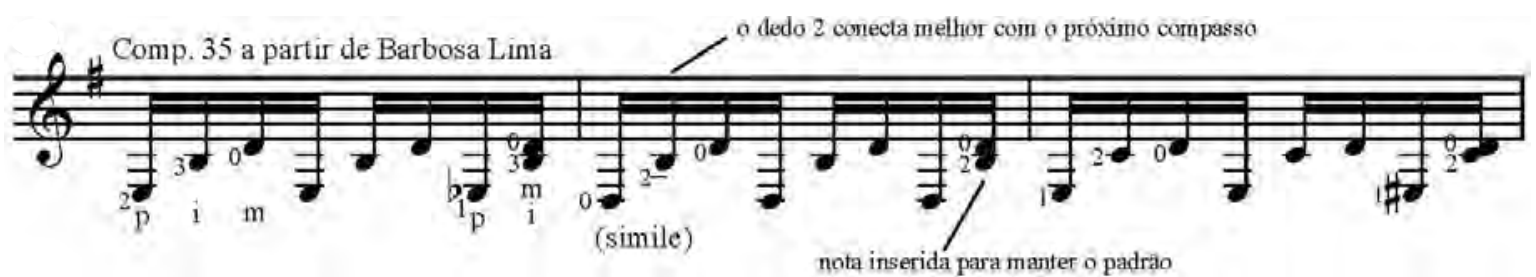

Exemplo 684: IX Estudo, compasso 35. 
Já a escala conectiva do compassos 39 e 40 possibilita múltiplas versões. O exemplo 686 apenas modifica ${ }^{138}$ o final da digitação BL e especifica sua $m d$, com ocorrência de um ligado opcional. O exemplo 687 avança para a quarta posição para melhor alcançar o final proposto por BL na terceira corda e finalmente o exemplo 688 propõe digitação apenas nos bordões, sendo o único a encaminhar o próximo compasso para a sétima posição.

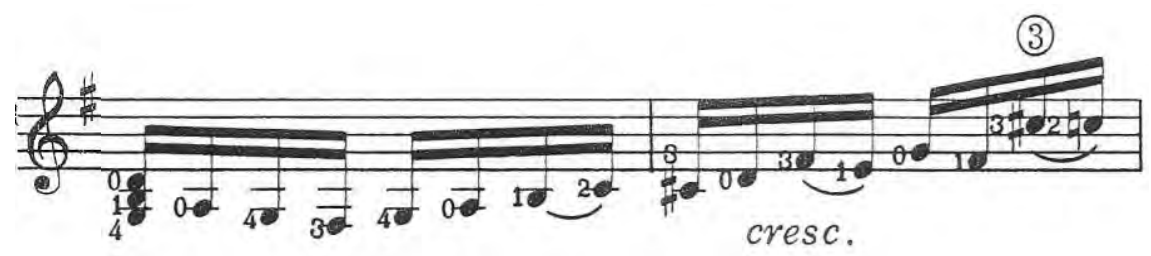

Exemplo 685: IX Estudo, compasso 39. Ed. Columbia/BL.

Comp. 39

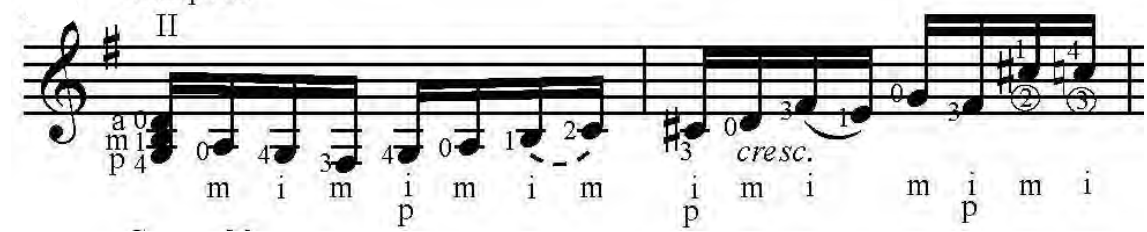

Exemplo 686: IX Estudo, compasso 39.

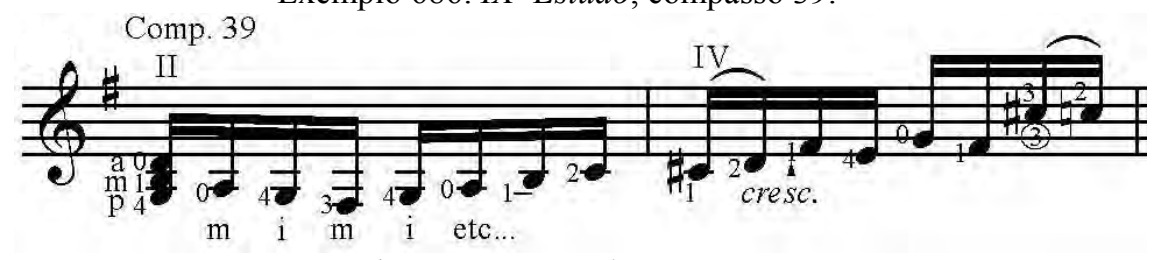

Exemplo 687: IX Estudo, compasso 39.

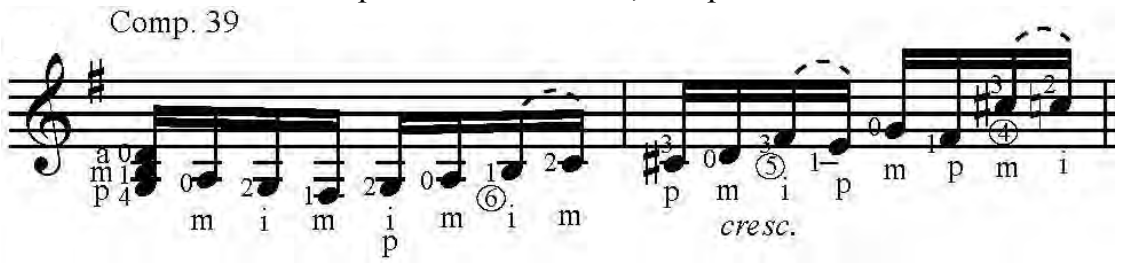

Exemplo 688: IX Estudo, compasso 39.

Segue-se uma nova progressão em círculo das quintas, mas com outro ritmo harmônico e configurando o ápice na mudança de padrões de levadas. Devido a seu maior fluxo musical ela será tratada por inteiro nos exemplos iniciais e posteriormente receberá versões adicionais tratando de compassos específicos ou trechos menores.

\footnotetext{
${ }^{138}$ verbo do checklist de Osborn.
} 

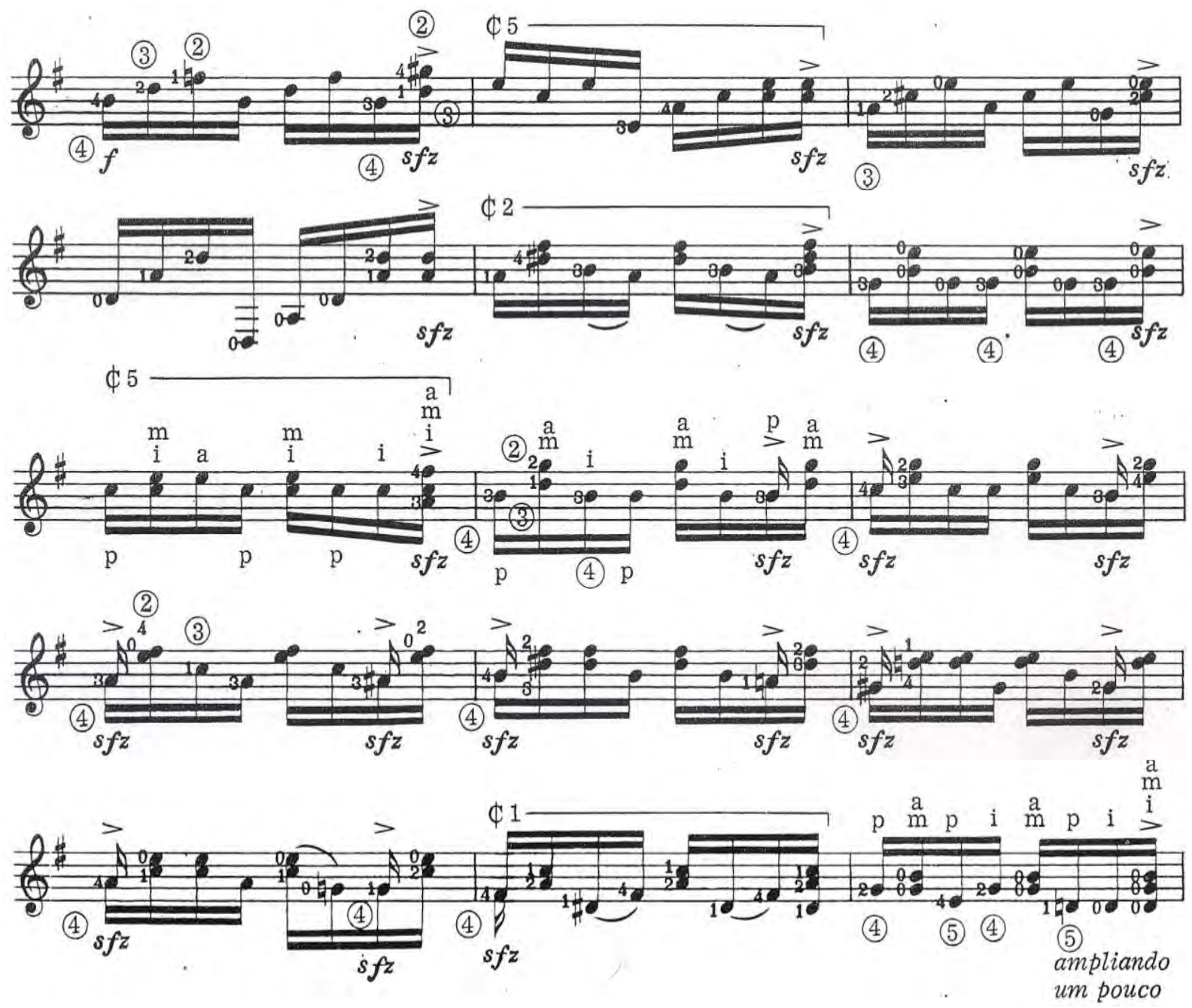

Exemplo 689: IX Estudo, compasso 41. Ed. Columbia/BL.

Partindo da digitação BL apenas por dois compassos, o exemplo 690 oferece diferenças consideráveis (com especificação de $m d$ ): compasso 43 na quinta casa; retirada de ligados no compasso 45; compasso 46 apenas com cordas soltas; compasso 47 na primeira posição; compassos 48 e 49 na terceira posição; final do compasso 50 na segunda posição encaminhando para desfecho em posições iniciais (com exceção do compasso 55); ligado defasado opcional no compasso 53; supressão de nota no compasso 54; substituição de dedos e inversão na alternância de cordas duplas no compasso 55; substituição de dedos no compasso 56. 

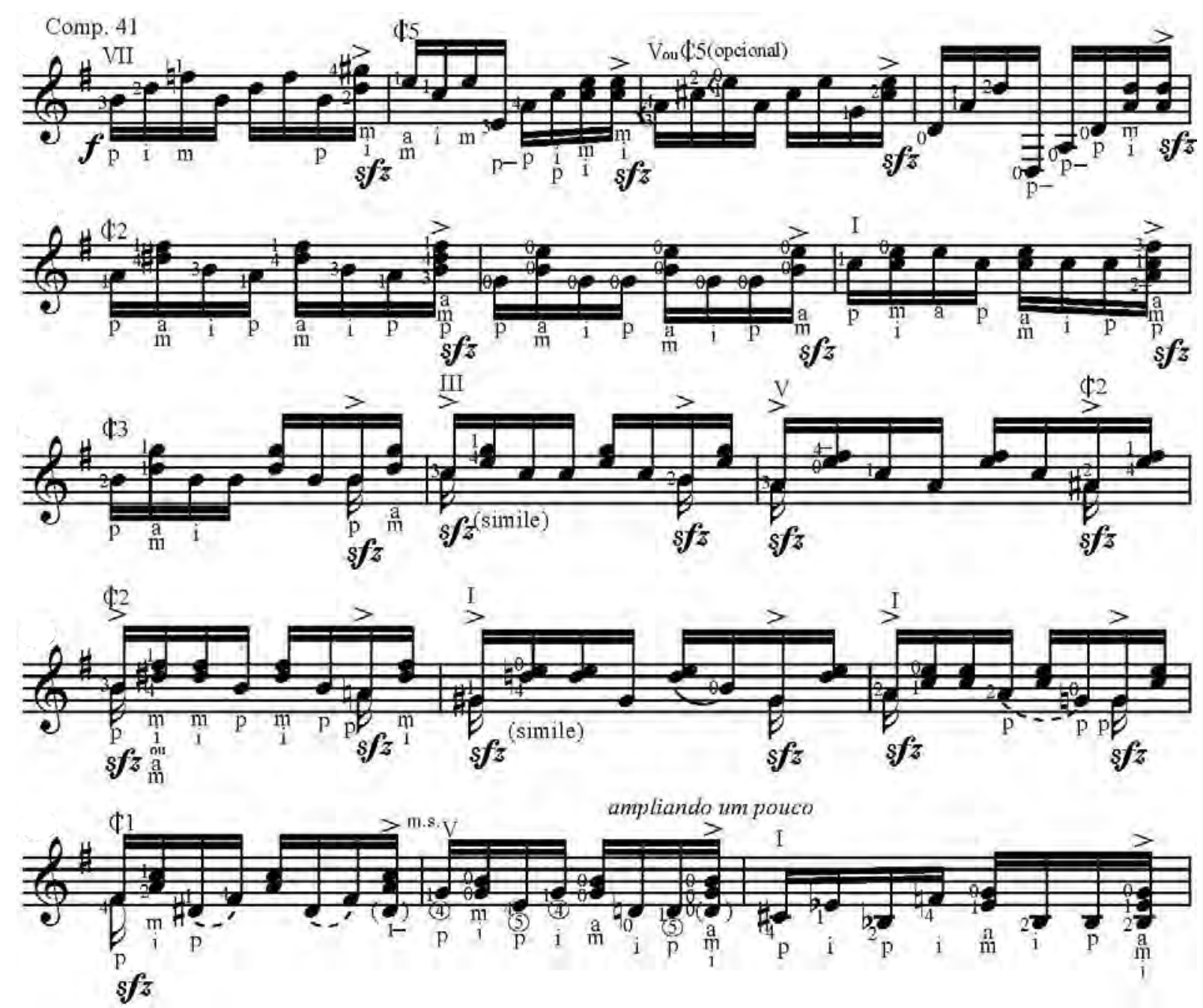

Exemplo 690: IX Estudo, compasso 41.

Estas duas versões anteriores podem ainda receber um ligado no compasso 48 (com mesma digitação BL).

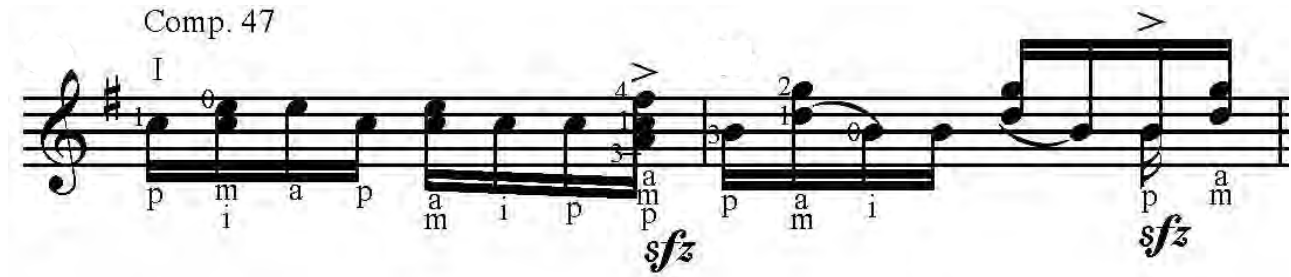

Exemplo 691: IX' Estudo, compasso 47.

Alternativamente o exemplo 692 se inicia pela primeira posição, facilita os ligados do compasso 45 (com supressão opcional de uma nota), substitui um dedo no compasso 46, acrescenta corda solta no 49, aplica ligado defasado no compasso 53, suprime nota no compassos 54 e 55, também substituindo dedo neste último e finalmente incluindo portamento e mudando a região do compasso 56 , passível de ser articulando com polegar em alçapúa (alternado para baixo e cima). 

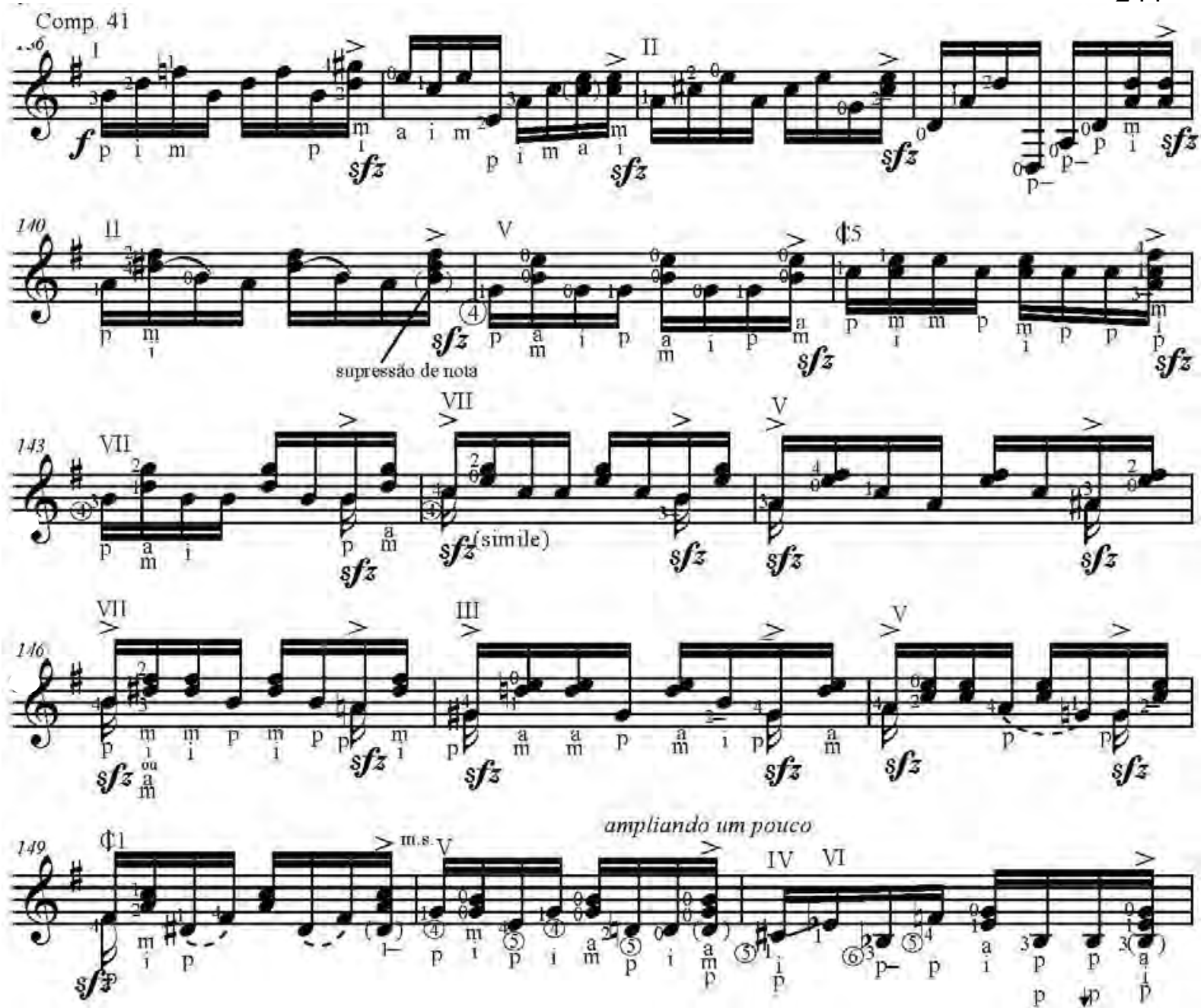

Exemplo 692: IX Estudo, compasso 41.

O compasso 44 pode ainda receber uma versão bastante experimental, como no exemplo seguinte, com ligados duplos que consequentemente encaminha os dois compassos seguintes para casas superiores. Ainda no mesmo exemplo, o compasso 47 recebe alternância de cordas no uníssono e o compasso 48 um ligado com o dedo 2 para corda solta, levemente ruidoso.
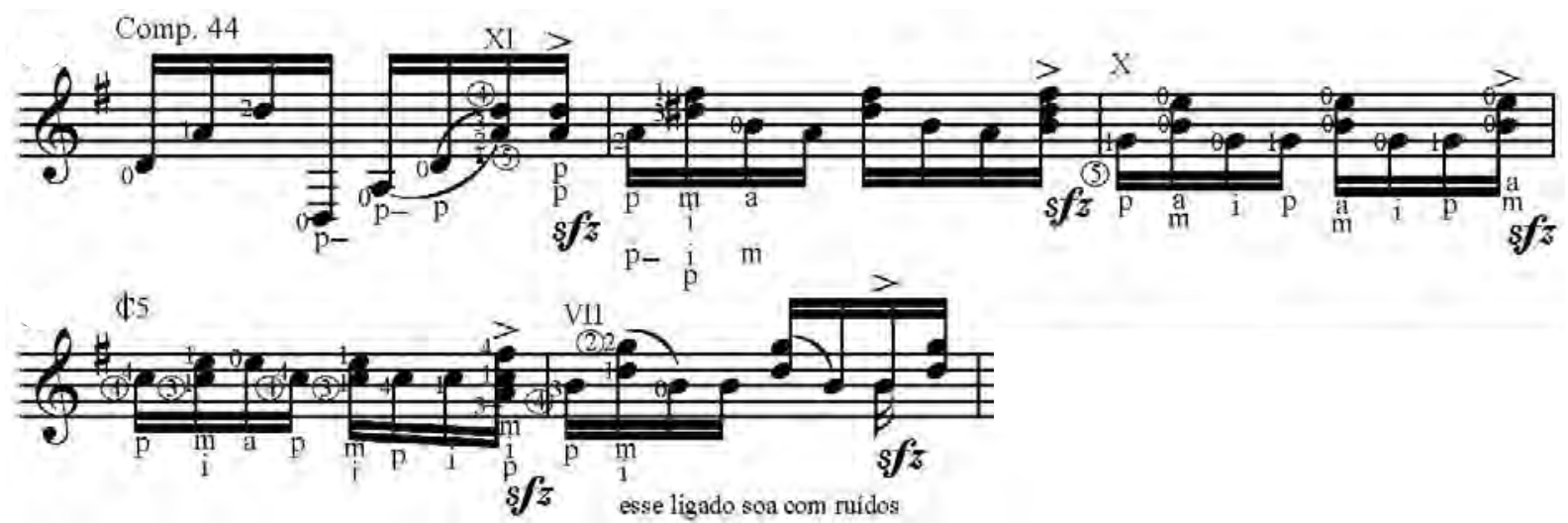

Exemplo 693: IX Estudo, compasso 44.

No exemplo 694 este mesmo artifício de ligados para cordas soltas em posições avançadas é empregado no compasso 45 com igual resultado: 


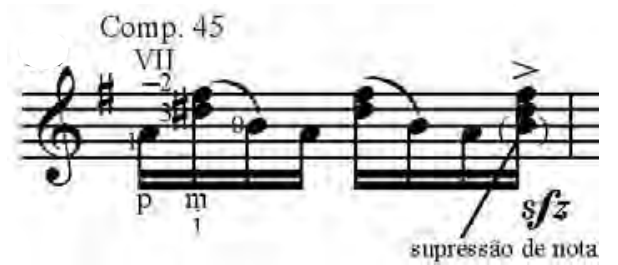

Exemplo 694: IX Estudo, compasso 45.

O exemplo 695 apresenta uma nova versão para o compasso 50 em diante, mantendo-o na região central do instrumento.

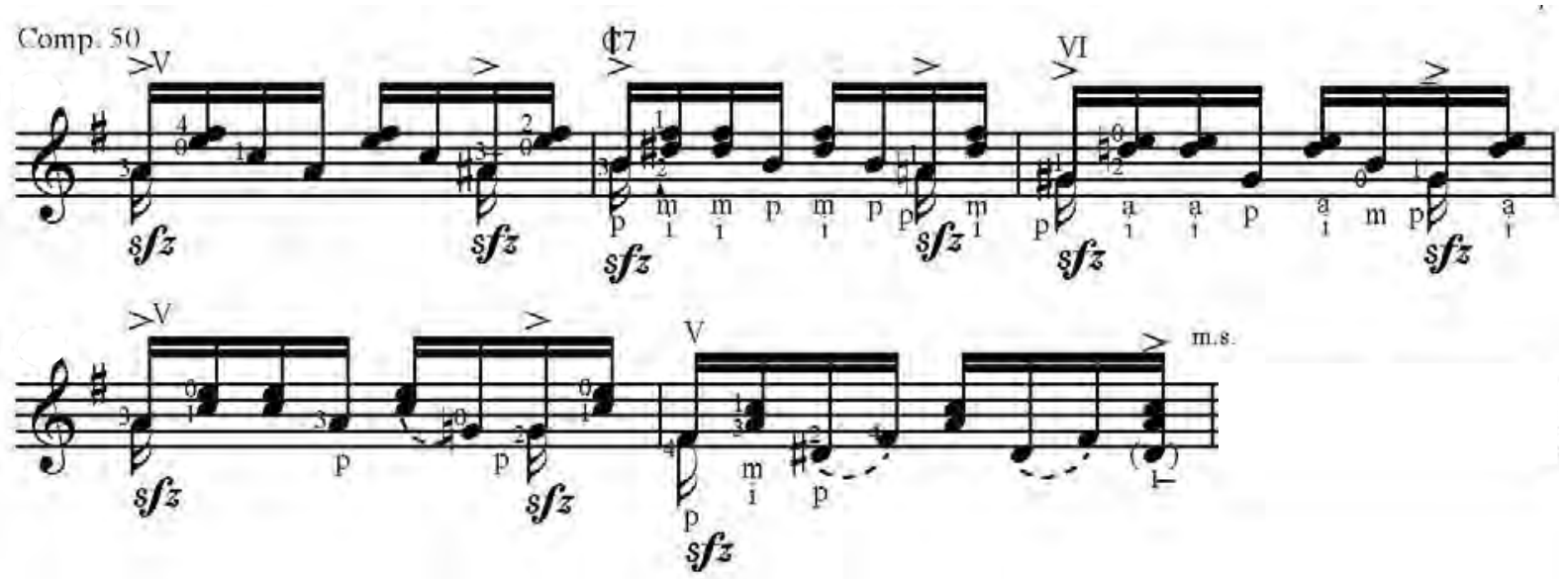

Exemplo 695: IX Estudo, compasso 50.

Finalmente, seguem duas últimas versões alternativas para o compasso 55 centradas na segunda posição diferindo apenas nas alternâncias das cordas duplas.

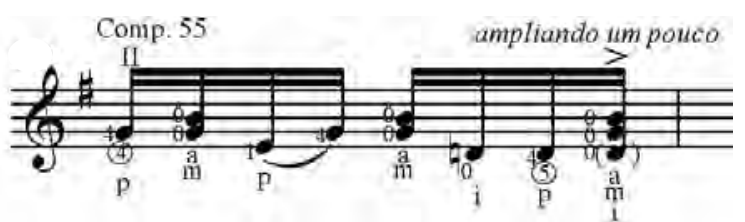

Exemplo 696: $I X^{o}$ Estudo, compasso 55.

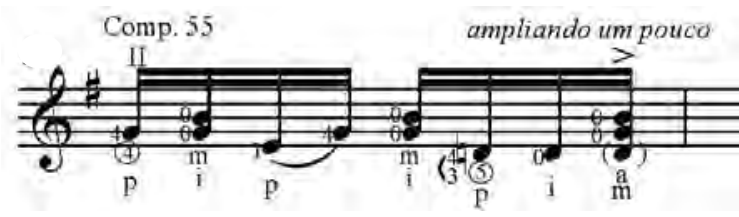

Exemplo 697: I $X^{\circ}$ Estudo, compasso 55.

Uma cadência descendente é iniciada no compasso 57 com baixo pedal em Ré, e será dividida por nós em duas partes. Tratando do primeiro trecho, o exemplo 699 modifica $^{139}$ apenas os dois primeiros tempos da digitação BL, por substituição ${ }^{140}$ de dedos e maior utilização da segunda corda.

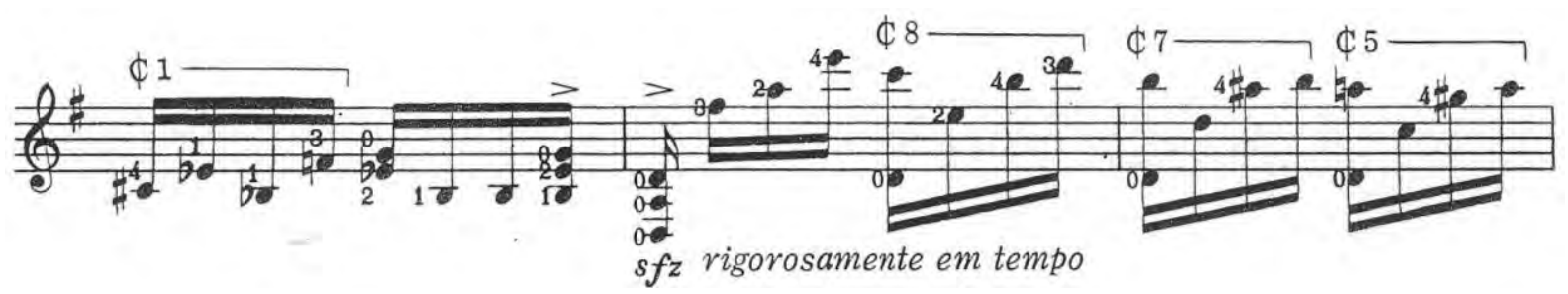

Exemplo 698: IX Estudo, compasso 56. Ed. Columbia/BL.

\footnotetext{
${ }^{139}$ verbo do checklist de Osborn.

${ }^{140}$ verbo do checklist de Osborn.
} 


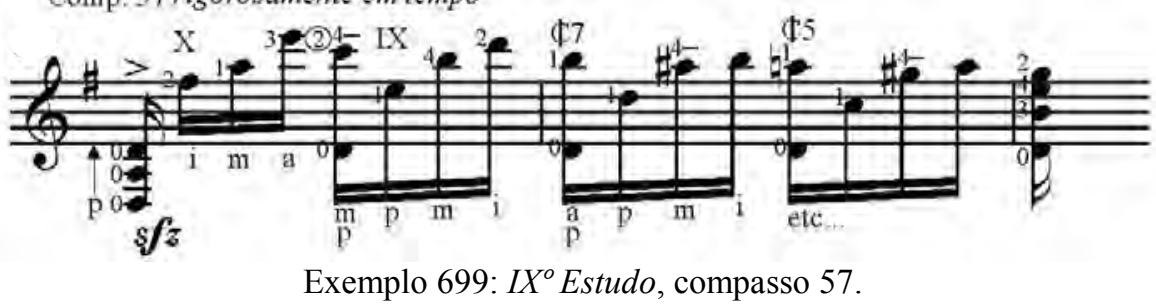

O exemplo 700 inclui ligados e nos foi sugerido por nosso orientador, Prof. Dr. Edelton Gloeden, sugestão esta que nos fomentou ainda o exemplo seguinte, também concebido por substituição de dedos.

Comp. 57 rigorosamente em tempo

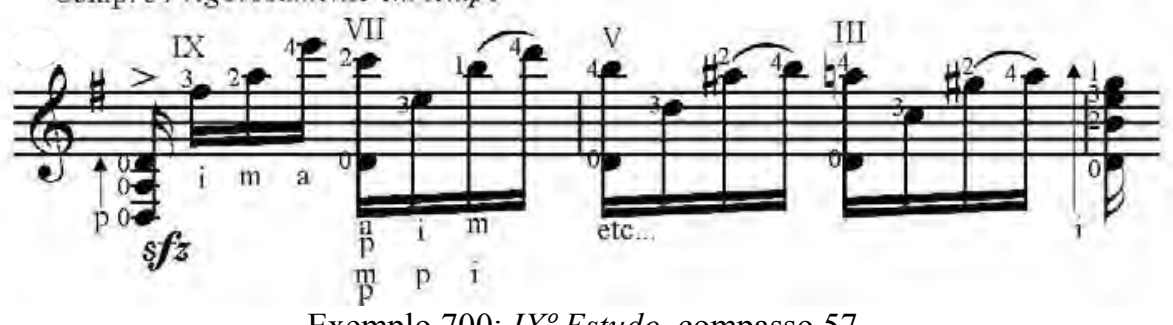

Exemplo 700: IX'Estudo, compasso 57.

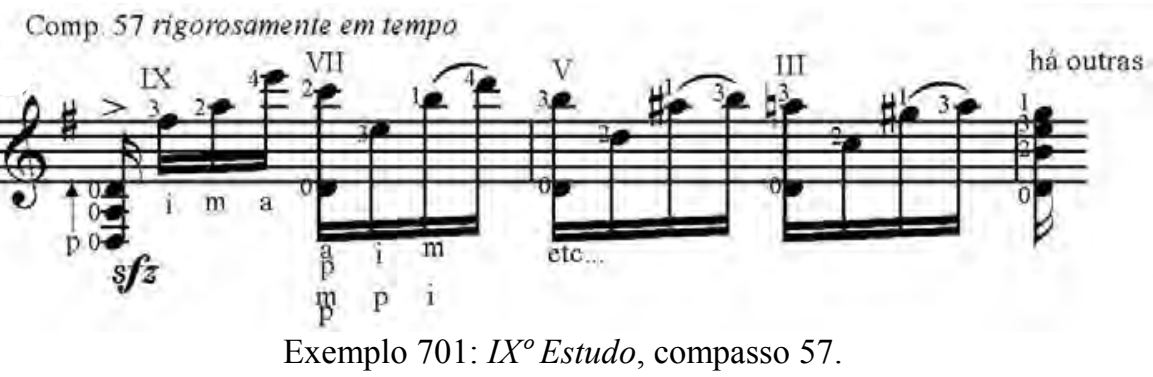

A segunda parte da cadência resolve o baixo pedal (Ré) em Sol maior para rapidamente modular com um encaminhamento cromático descendente para Mi maior tonalidade esta que protagonizará a próxima seção. Cada tempo é pontuado por acordes e a melodia tem bordaduras e retardos cromáticos que também acrescentam dificuldades ao trecho. O exemplo 703 é marcado por ligeiras substituições na digitação BL. O exemplo 704 tem me idêntica, mas demonstra outra articulação para os acordes em rasgueio de indicador ou polegar, gerando a necessidade de escoramento do anelar na primeira corda.

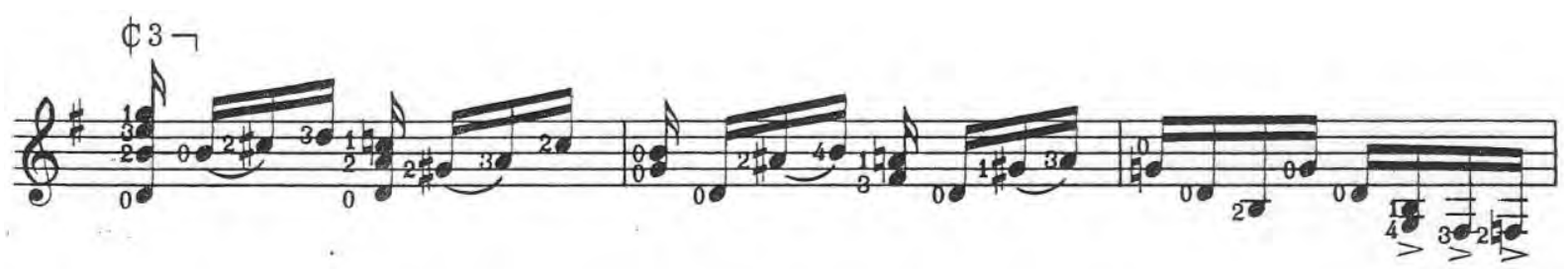

Exemplo 702: IX' Estudo, compasso 59. Ed. Columbia/BL.

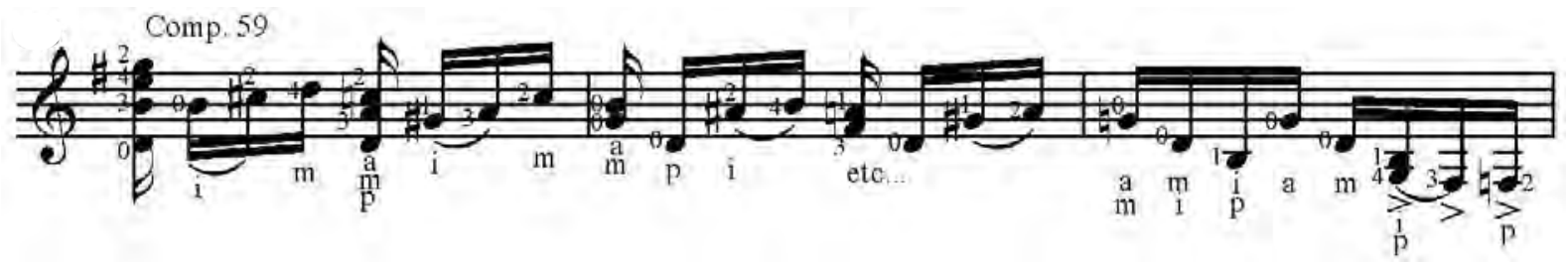

Exemplo 703: IX Estudo, compasso 59. 


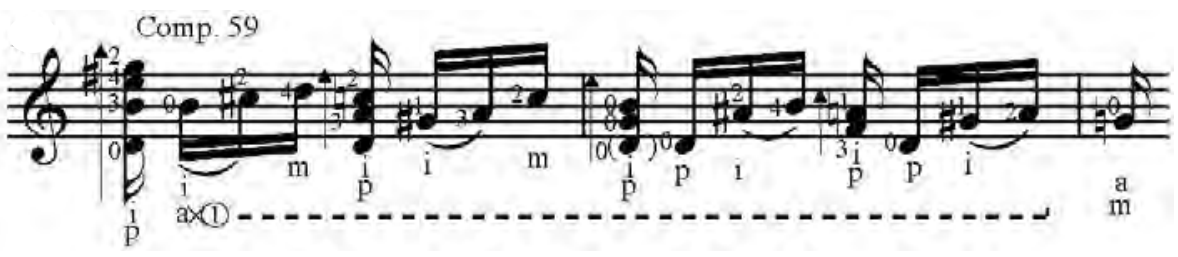

Exemplo 704: IX Estudo, compasso 59.

Os últimos dois exemplos do trecho demonstram possibilidades apenas para seu primeiro compasso, sendo a primeira delas uma sugestão de nosso orientador que por sua vez novamente estimulou a concepção de uma segunda.

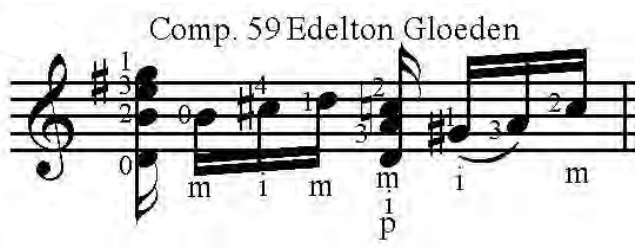

Exemplo 705: I $X^{\circ}$ Estudo, compasso 59.

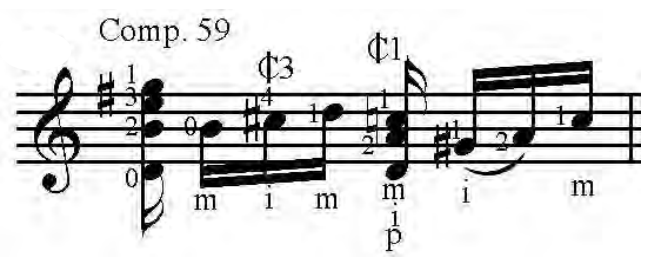

Exemplo 706: I $X^{\circ}$ Estudo, compasso 59.

A seção em Mi maior (iniciada no comp. 62) é talvez uma das mais pesadas para a $m d$, com arpejos complexos e acordes repetidos com inevitável repetição de dedos, como pode ser percebido nos exemplos 708 e 709, que especificam diferentes padrões de $m d$ e acrescentam alguns ligados facilitadores, mas seguem com me idêntica a BL.

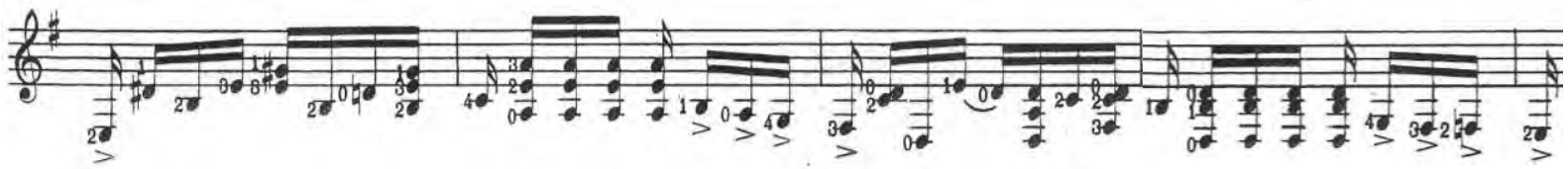

Exemplo 707: IX Estudo, compasso 62. Ed. Columbia/BL.

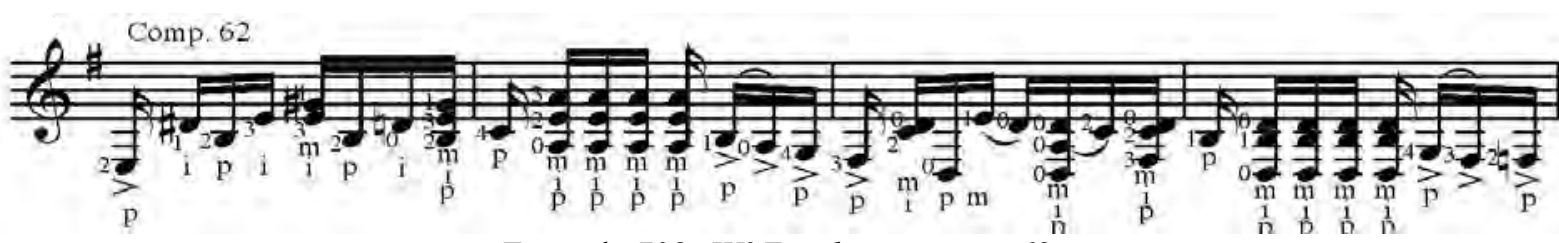

Exemplo 708: IX Estudo, compasso 62.

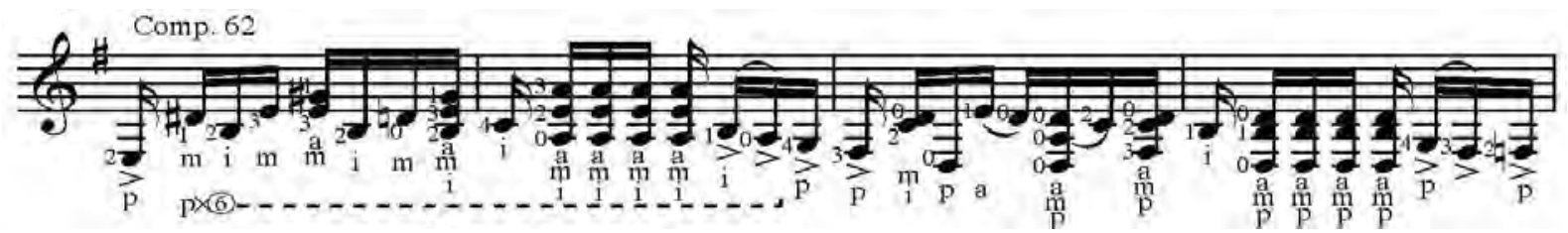

Exemplo 709: IX' Estudo, compasso 62.

A última versão (que é a da nossa preferência) foi concebida por sugestão de Turibio Santos de colocar pequenos rasgueios nos acordes repetidos que são possíveis apenas com criteriosos abafamentos das cordas soltas adjacentes, para não as articular desnecessariamente e também para prover ponto de referência à $m d$. Esses ragueios dão caráter popular ao trecho além de oferecer maior sonoridade e ao mesmo tempo maior leveza do trabalho da $m d$. 


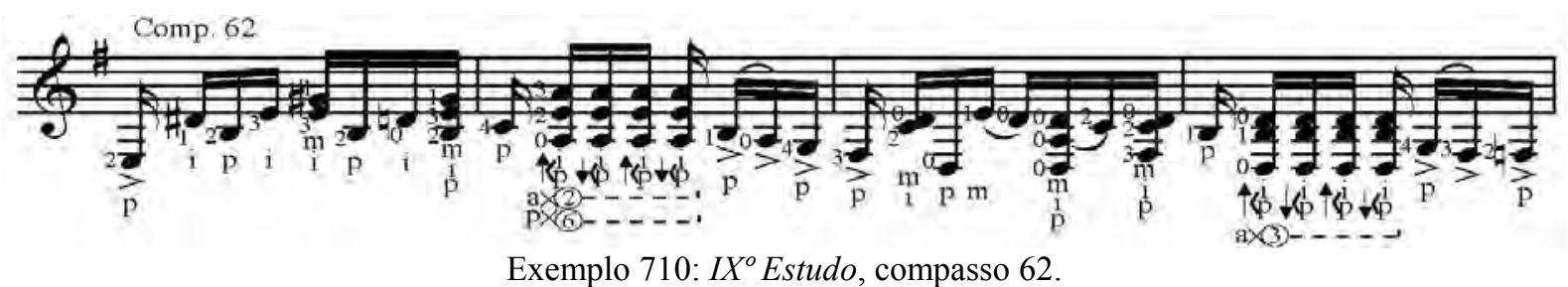

O exemplo 712 vem apenas registrar uma pequena sugestão à versão BL (ex.

711) no que tange à escolha dos dedos da escala cromática final do excerto, no qual preferimos a repetição do dedo 1 à do dedo 4 em escalas cromáticas ascendentes, por facilitar a troca de posições dessa natureza (lembrando que o compasso seguinte inicia com o Sol executado com o dedo 4).

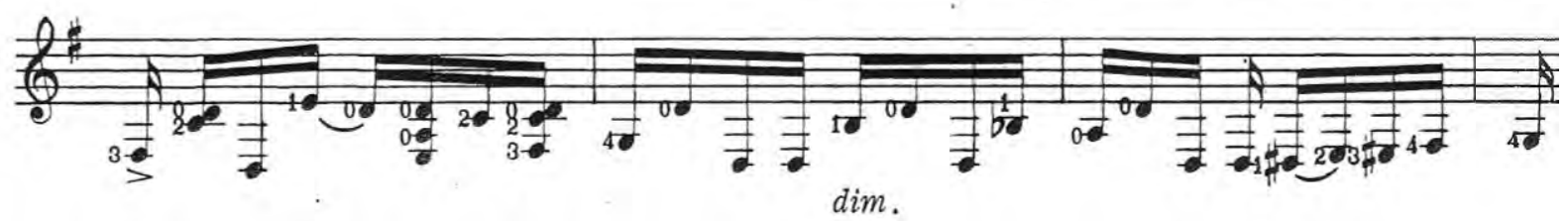

Exemplo 711: IX Estudo, compasso 68. Ed. Columbia/BL.

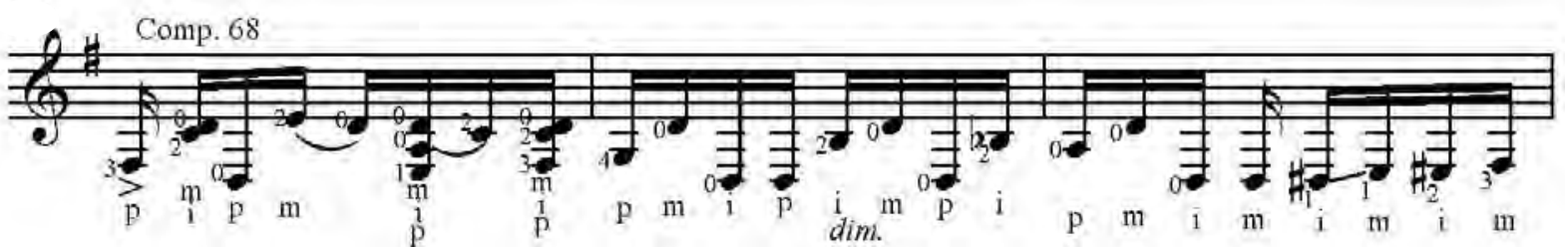

Exemplo 712: IX Estudo, compasso 68.

Algo semelhante ocorre nos compasso 74 e 76 mas no sentido contrário. Normalmente repetiríamos o dedo 4 em escalas cromáticas (ou quase cromáticas) descendentes, mas neste caso isso é desnecessário por se tratar de um encaminhamento finalizado por corda solta, sendo portanto possível usar um dedo para cada nota da escala (com abertura entre os dedos 3 e 2).

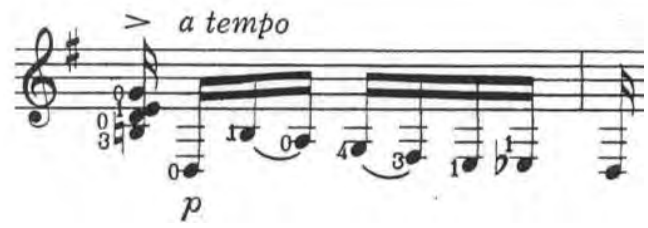

Exemplo 713: IX Estudo, compasso 74. Ed. Columbia/BL.

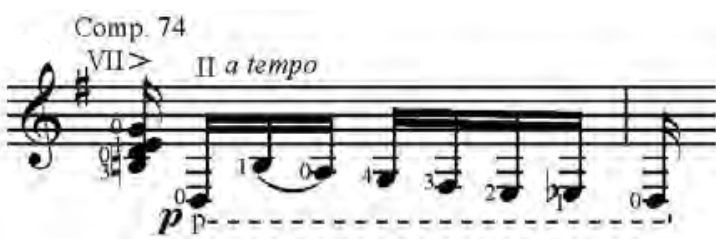

Exemplo 714: IXo Estudo, compasso 74.

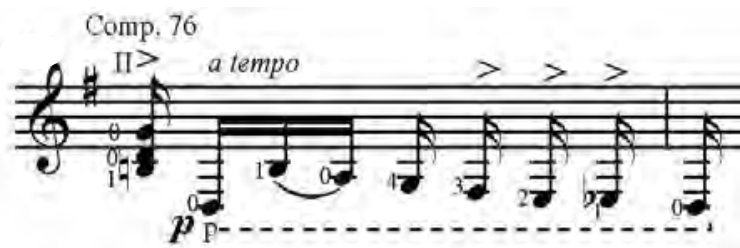

Exemplo 715: IX Estudo, compasso 76.

Adentra-se à seção lenta de lânguido caráter sertanejo, onde as melodias são "orquestradas" com diversos intervalos em paralelismo rígido ou flexível e "amolecidas" por portamenti com acentos anacrústicos (normalmente no contratempo). 
Também segmentaremos a seção em duas para facilitar sua discussão. O exemplo 716 registra a digitação BL da primeira porção, para qual proveremos nossas reflexões de forma mais fragmentada.

O longo portamento das terças iniciais não recebe modificação ${ }^{141}$ no exemplo 717 , mas aconselha-se sua realização com o polegar da $m d$, dando-lhe mais corpo. Ele é respondido por um eco não literal, que recebe digitação alternativa na quinta casa e que pode ser tratado com duas visões tímbricas antagônicas: ou busca-se unidade de som e intensidade ou cria-se uma resposta exacerbadamente díspar.
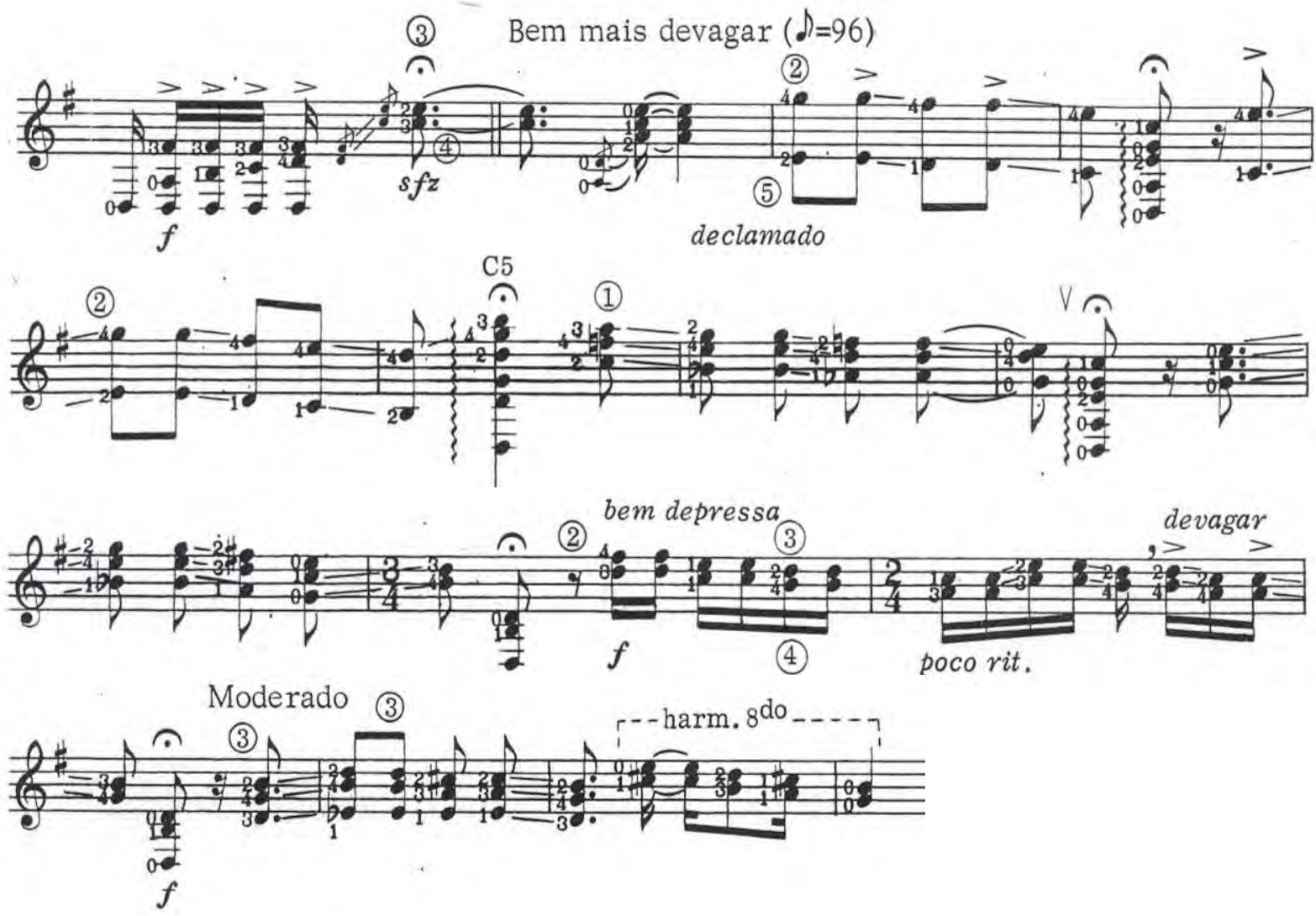

Exemplo 716: IX' Estudo, compasso 77. Ed. Columbia/BL.

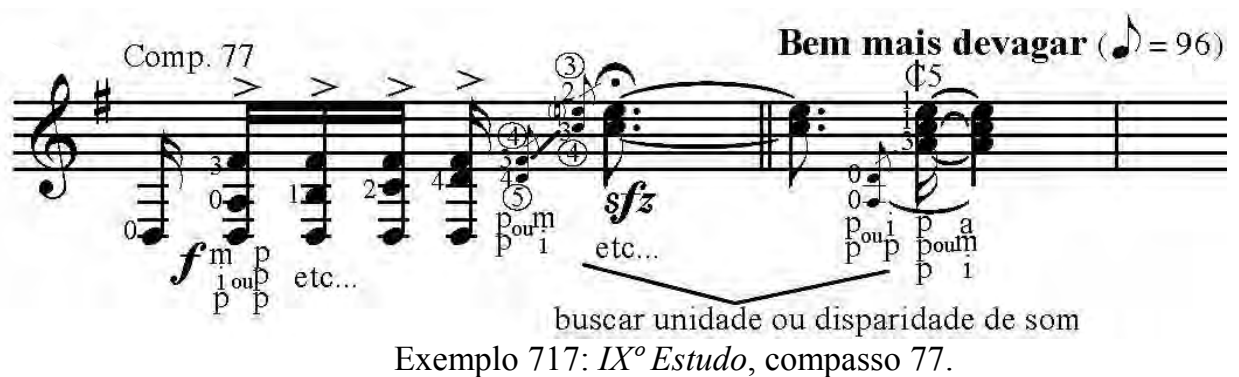

Inicia-se trabalho em décimas paralelas com portamenti. BL opta por trocar dedos conforme a natureza maior ou menor do intervalo, aspecto que é unificado nos exemplos 718 e 719 , este segundo da caráter mais experimental ao incluir a sexta corda.

${ }^{141}$ verbo do checklist de Osborn. 
O exemplo 720 vem demonstrar que é possível realizar uma digitação bastante simples pela primeira posição, mas com a exclusão total dos portamenti.

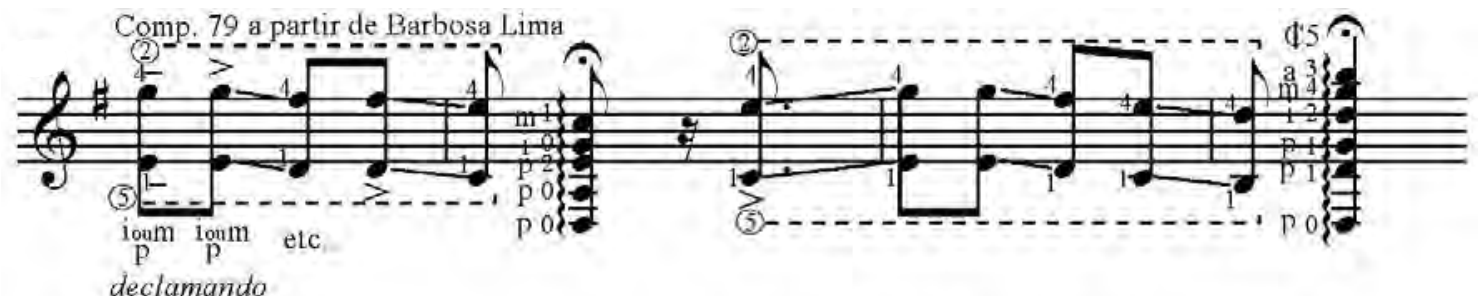

Exemplo 718: IX'Estudo, compasso 79.

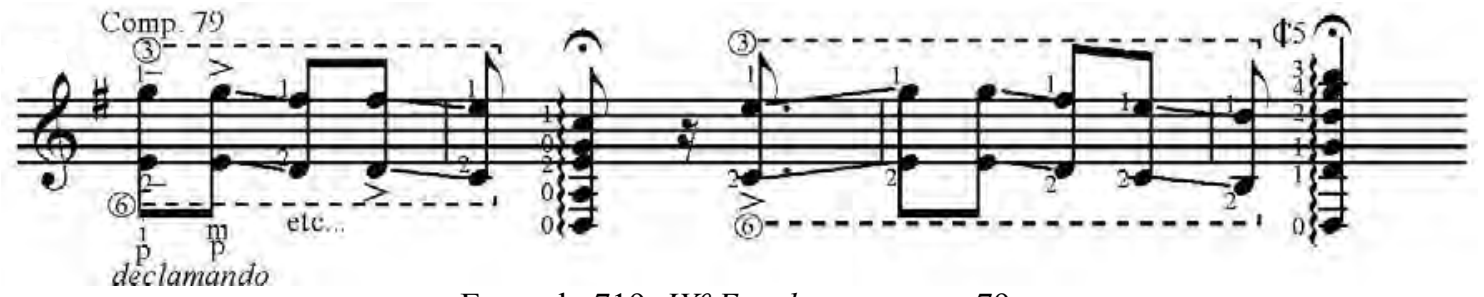

Exemplo 719: IX Estudo, compasso 79.

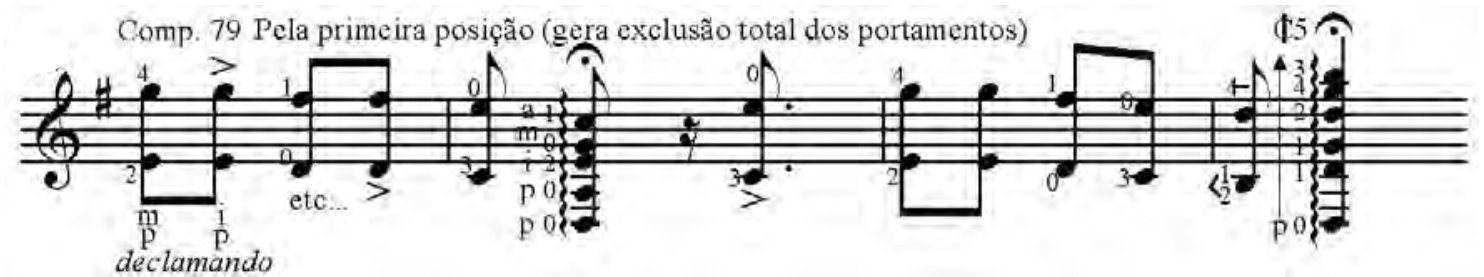

Exemplo 720: IX Estudo, compasso 79.

O próximo excerto inclui acordes paralelos. Nossas versões (ex. 721 e 722) buscam (de maneira análoga a outros portamenti discutidos nessa tese, manter os mesmos dedos em todos os acordes, espremendo-os ou expandindo-os conforme a necessidade) a fim de realizar portamenti em todas as suas notas (excetuando os acordes com cordas soltas). O primeiro exemplo foca-se nas primas (com perda total dos portamenti em um dos acordes) enquanto o segundo, mais exploratório, utiliza cordas internas (e pode ter consequentemente mais ruído na quarta corda).

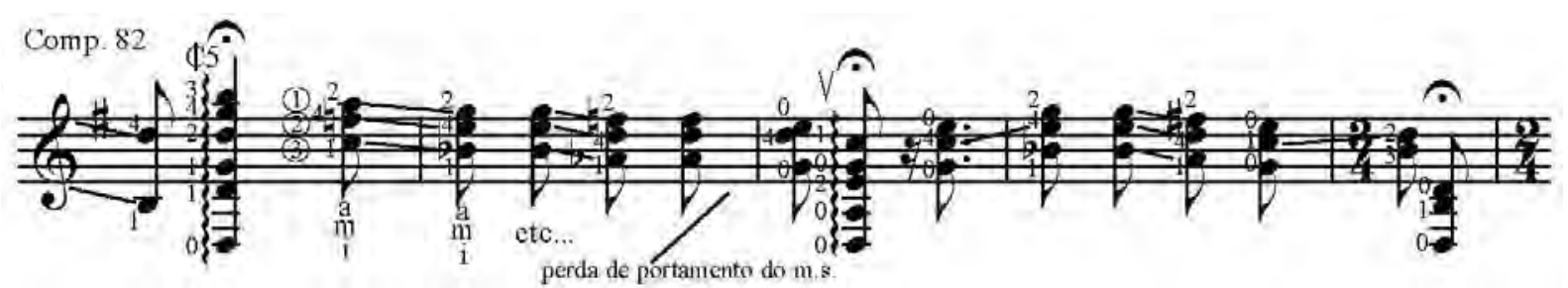

Exemplo 721: IX Estudo, compasso 82.

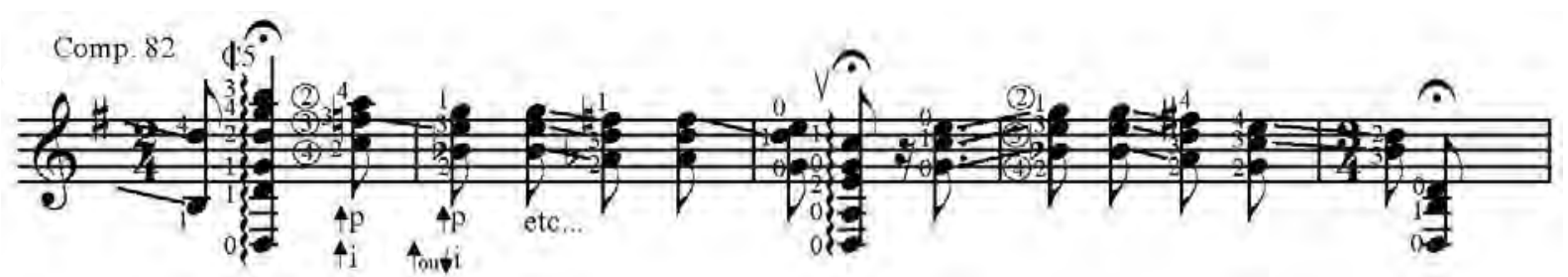

Exemplo 722: IX Estudo, compasso 82. 
Segue-se uma intervenção mais rápida em terças paralelas, também com portamenti eventuais. O exemplo 723 segue a ideia de BL mas unifica os dedos da digitação (em mesma abordagem anterior de expandi-los ou comprimir conforme a necessidade), enquanto o exemplo seguinte utiliza apenas as primas, por sua característica mais favoráveis a portamenti.

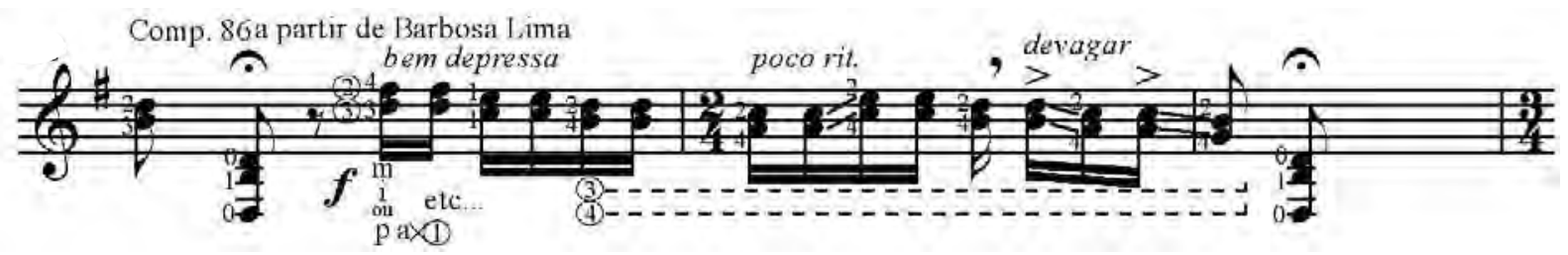

Exemplo 723: IX Estudo, compasso 86.

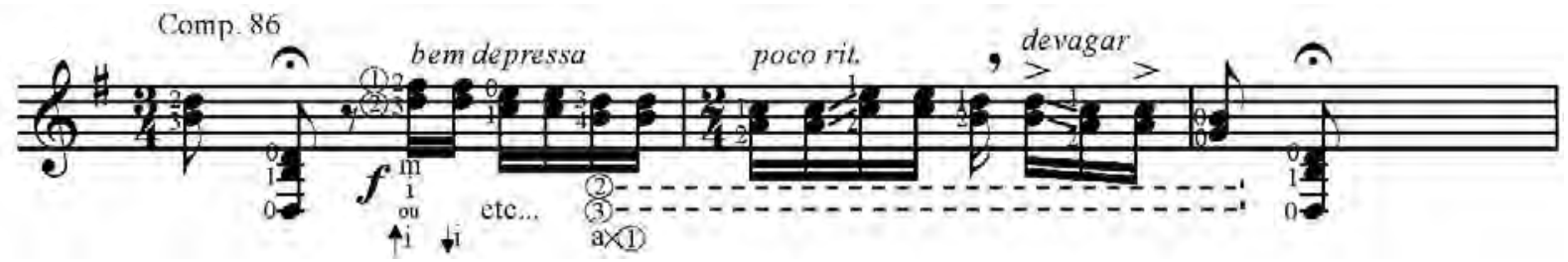

Exemplo 724: IX Estudo, compasso 86.

Novamente ocorre um trecho onde a unificação digitacional é válida para os acordes. Nele fixamos o dedo 4 na quarta corda enquanto BL o alterna com o dedo 3.

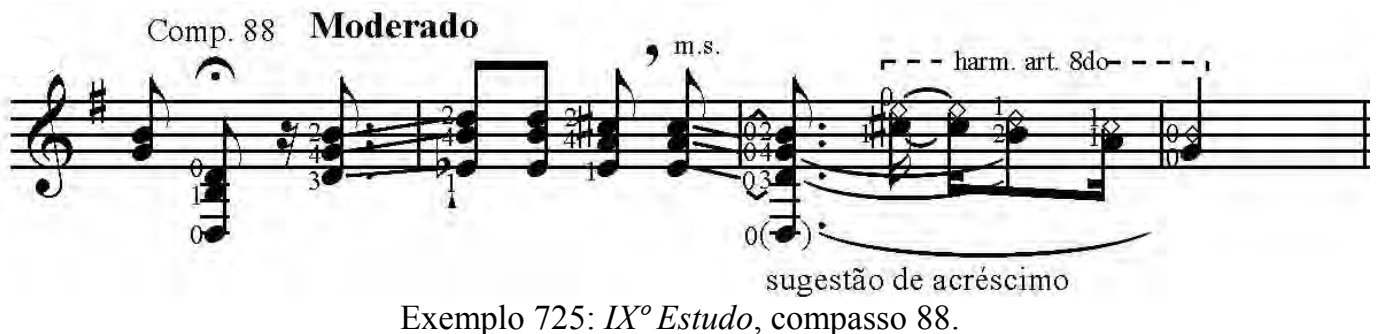

O exemplo 726 apenas aborda-o pela primeira posição, novamente perdendo os portamenti. Nele os harmônicos são duplos com uso já anteriormente relatado do indicador da $m d$ inclinado sobre as oitavas artificiais. Em ambos os exemplos consideramos válido o uso do acorde em cordas abertas para sustentar os harmônicos, mas para isso é inevitável abdicar do portamenti que o precede.

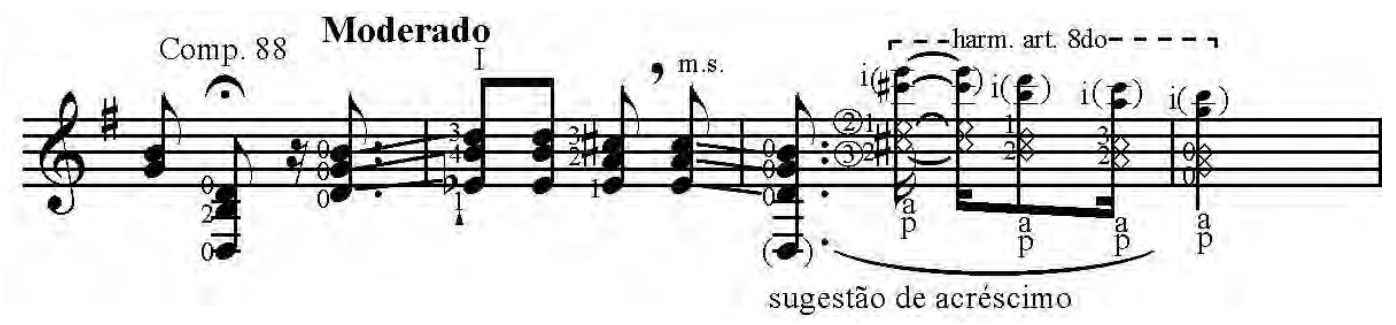

Exemplo 726: IX Estudo, compasso 88.

Os acordes ganham caráter mais insistente com articulações repetidas responsorialmente nos registros agudo e grave do instrumento e uma figuração arpejada em tercinas prepara o ritornello (ou ida para a coda). A dificuldade maior aqui é 
conseguir criar conexões entre os registros agudo e grave (e vise-e-versa) para evitar quebras de legato.

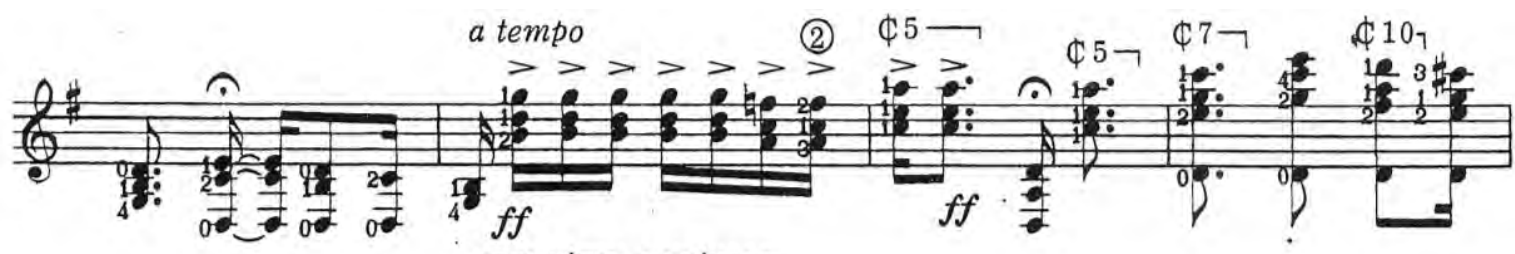

com vigor e raivoso

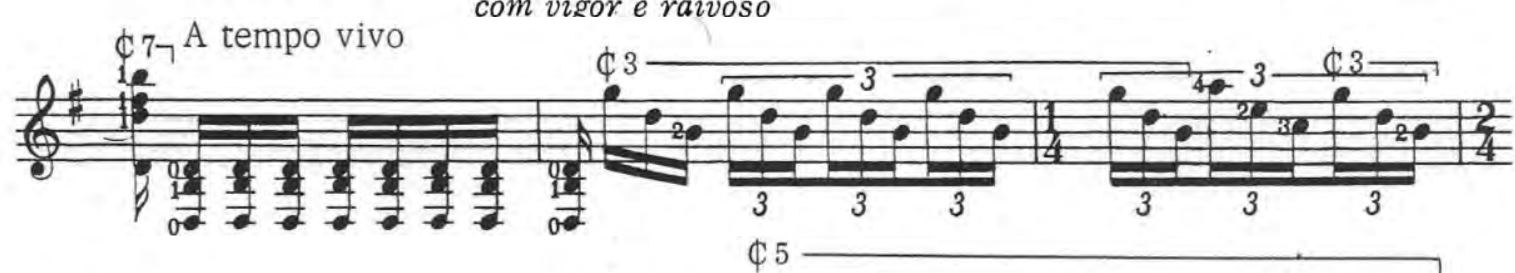

(2)

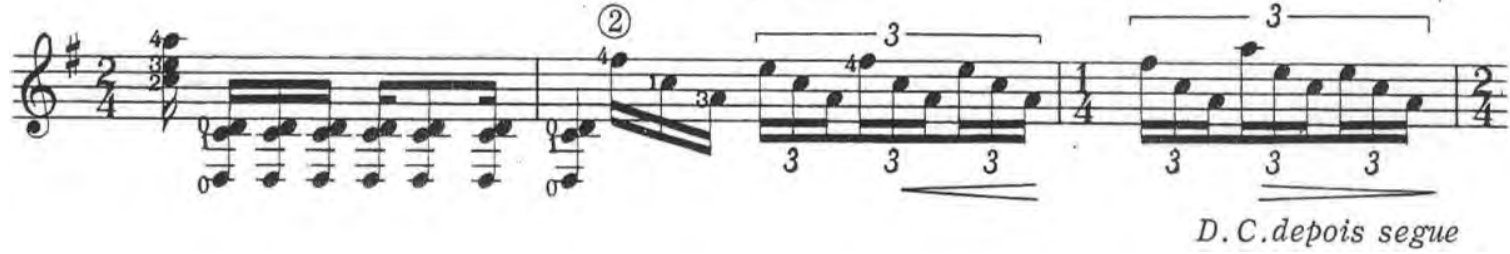

Exemplo 727: IX Estudo, compasso 93. Ed. Columbia/BL.
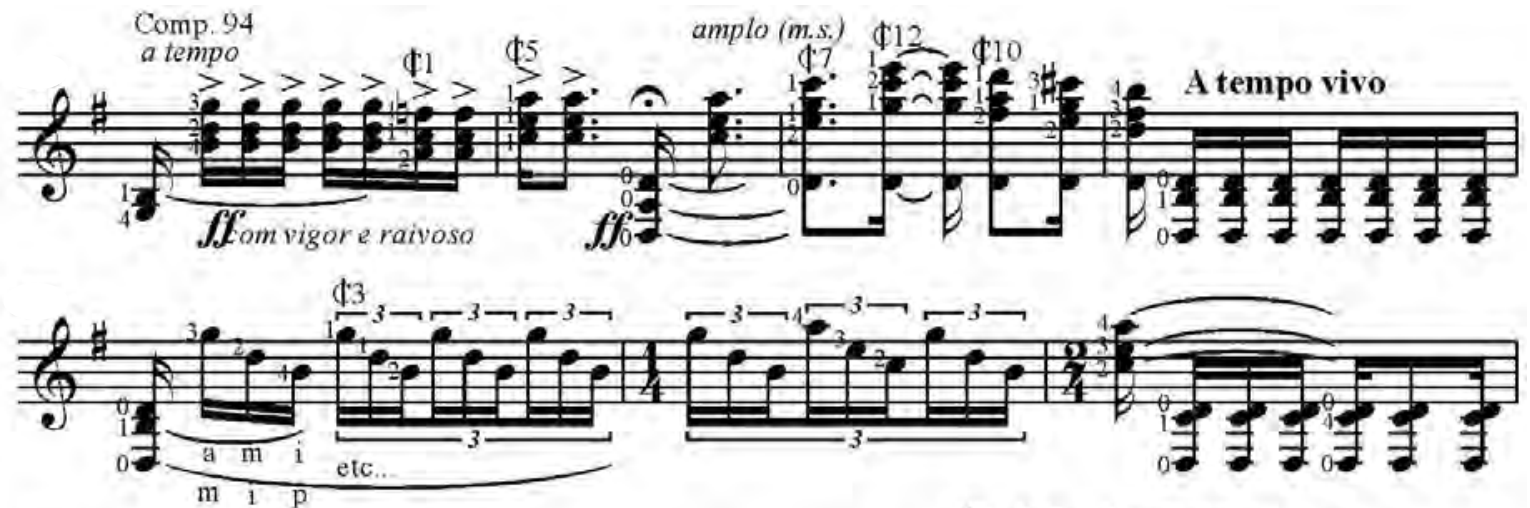

\$5 D.C.e depois segue

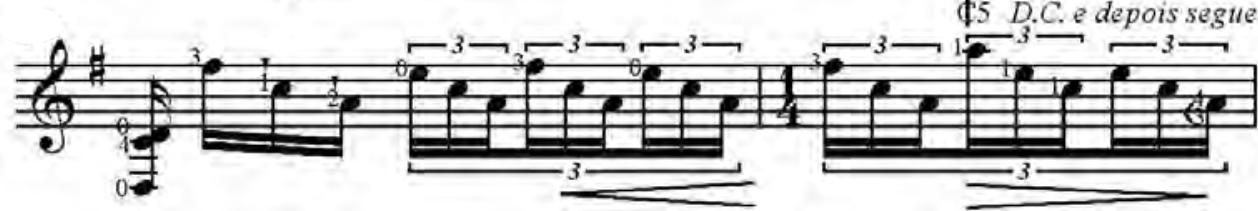

Exemplo 728: IX' Estudo, compasso 94.

Norteado por este aspecto o exemplo 728 grafa as prolongações de acordes com ligaduras e requer mais aberturas e compressões especialmente no compasso 100, onde há um troca de posição por substituição dos dedos 4 e 1 . O exemplo seguinte apenas registra um final alternativo com presença de um ligado.

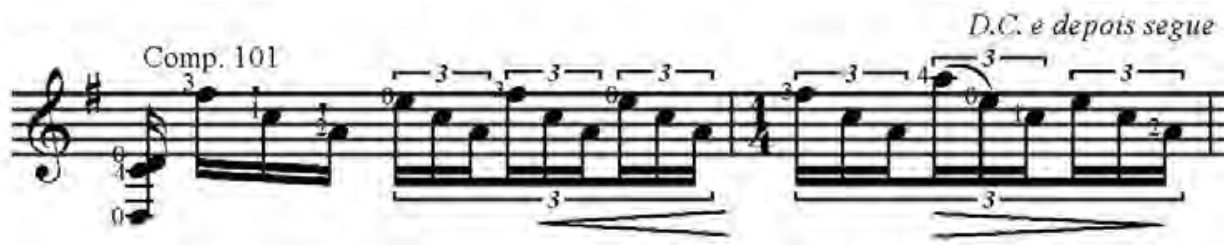

Exemplo 729: IX Estudo, compasso 101. 
A coda, a princípio, relembra o tema inicial retrabalhado com maiores movimentações no baixo (análogas ao compasso 25) e ao mesmo tempo introjeta no arpejo as tercinas do final da seção lenta. Em resposta anticlimática, as terças caipiras retornam uma última vez, preparando suspensivamente a entrada do grand finale.
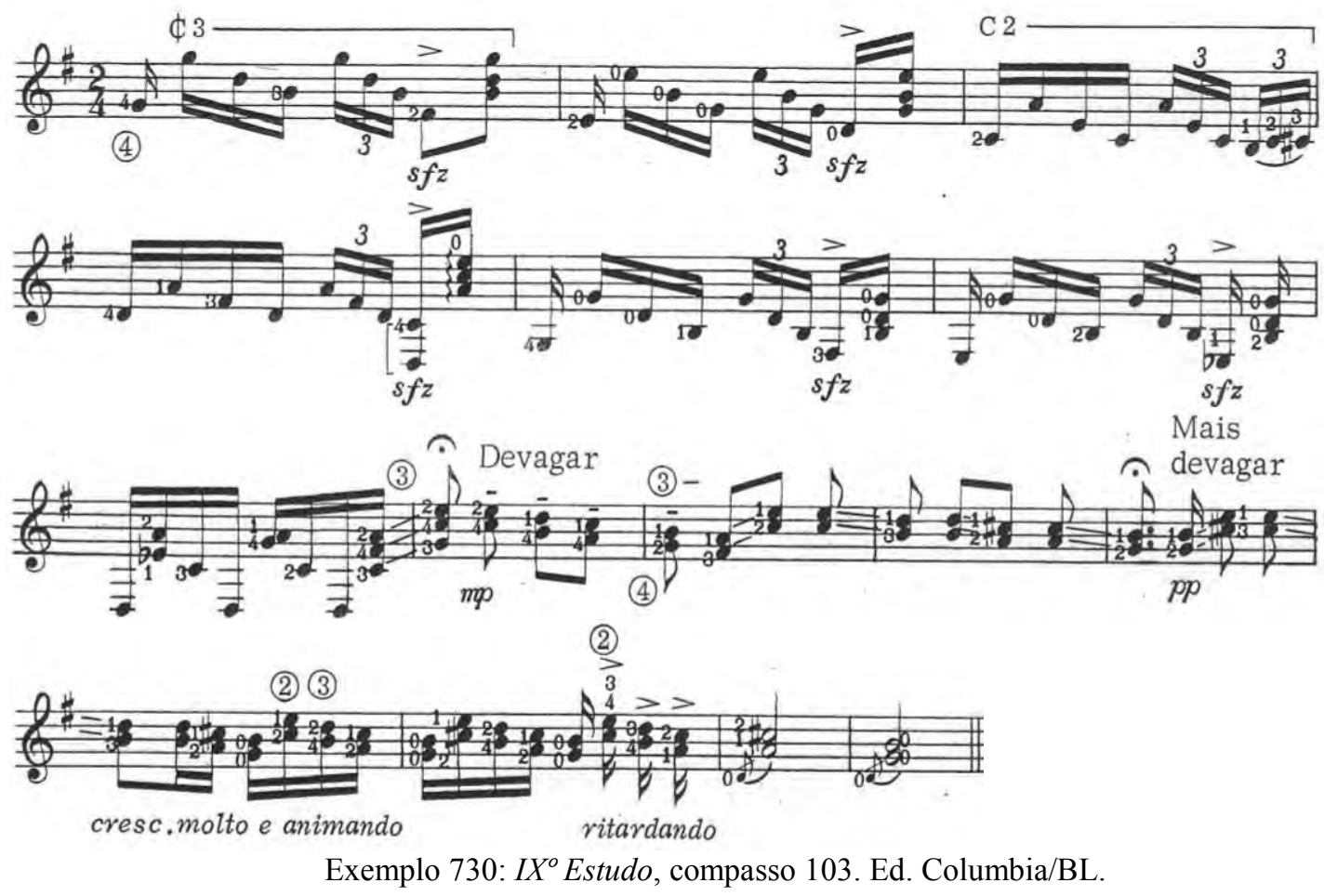

Na primeira parte desta coda encontramos uma única possibilidade, que evita uma repetição do dedo 4 com salto entre cordas da digitação BL no compasso 106 e substitui vários dedos nos dois últimos compassos do trecho, visando ascender o portamento com outro arranjo ${ }^{142}$ de dedos.

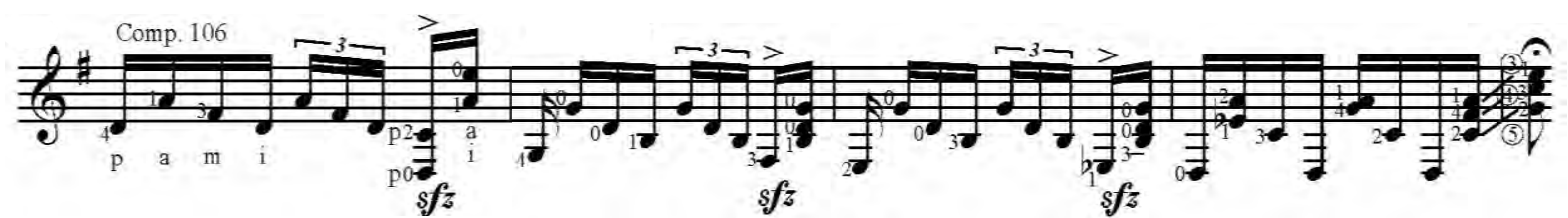

Exemplo 731: IX Estudo, compasso 106.

As terças paralelas com portamenti por sua vez geram maiores discussões. $\mathrm{O}$ exemplo 732 toma como base a digitação BL mas unifica parcialmente os dedos fixos das terças. Num primeiro momento, o dedo 4 é o guia, mas depois passa essa função para o dedo 1 e finalmente para o dedo 2 , quando o trecho atinge a segunda corda.

142 verbo do checklist de Osborn. 


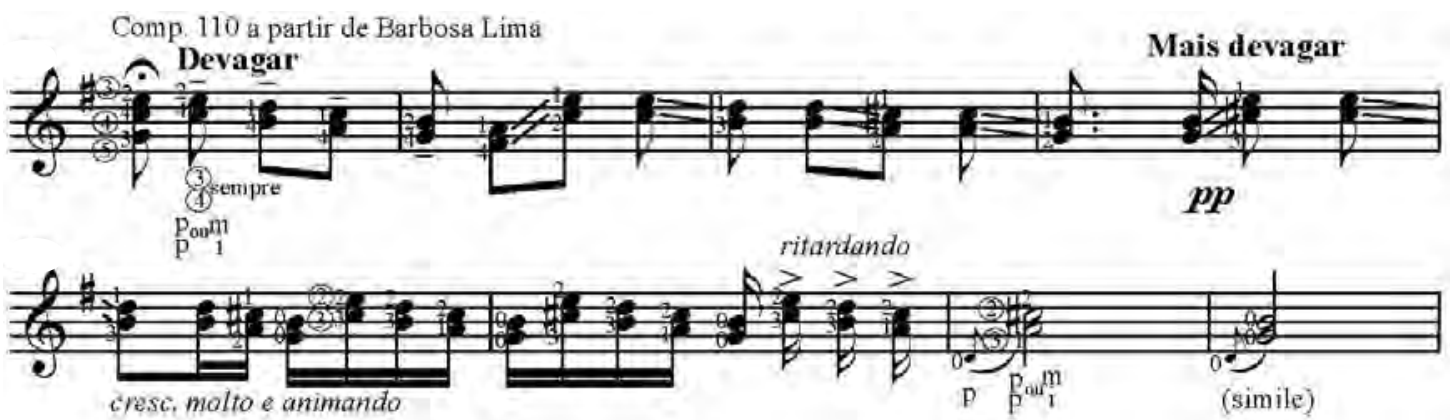

Exemplo 732: IX Estudo, compasso 110.

O desfecho ainda recebe duas versões alternativas, uma mantendo o dedo 1 como guia na segunda corda e outra, mais simples e óbvia na segunda posição, mas que tende a contrastar mais seu timbre com as terças anteriores que estavam circunscritas à terceira e quarta cordas.

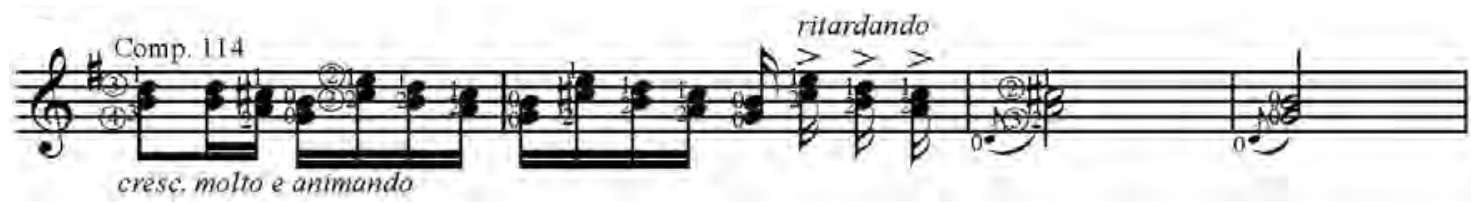

Exemplo 733: IX Estudo, compasso 110.

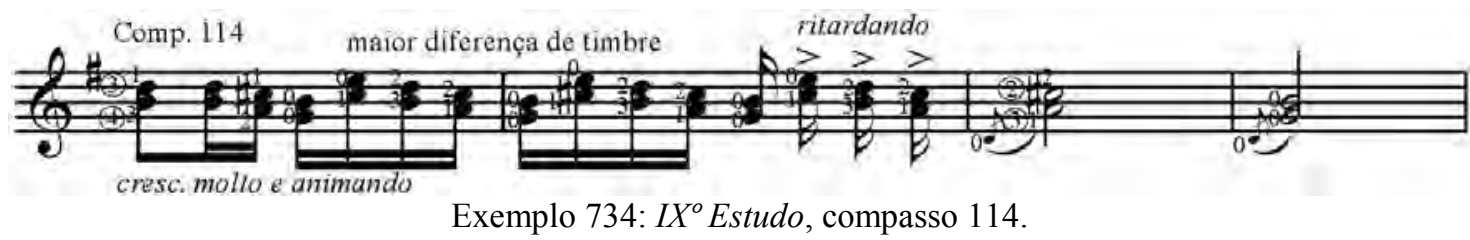

O exemplo 735 mantém o dedo 1 como guia fixo na terceira corda em todas as terças enquanto o exemplo 361 faz o mesmo com o dedo 3 na quarta corda (possivelmente com mais ruído) além de propor um desfecho distinto. Ao contrário de BL, essas versões utilizam praticamente as mesmas cordas em toda sua extensão.

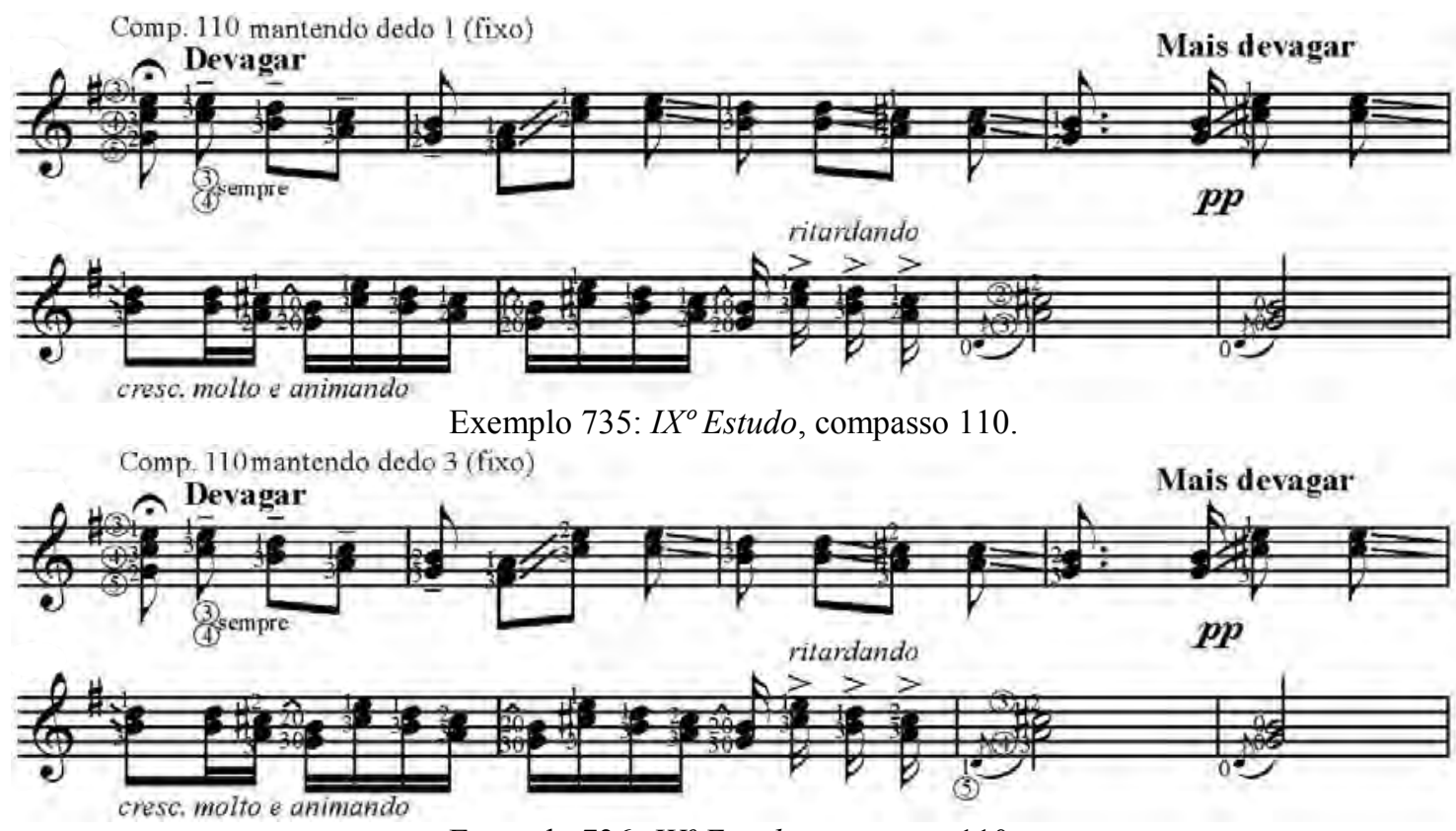

Exemplo 736: IX Estudo, compasso 110. 
O final virtuosístico é garantido pelo retorno da textura arpejada com tercinas introjetadas, mas agora em rápida aparição e com harmonia mais afirmativa. Nossa versão alternativa para a subida (ex. 738) destaca-se pelo uso do dedo 1 como guia na primeira corda para atingir os ligados finais com o dedo 3 e pela correção da nota mais aguda da peça a partir do manuscrito.

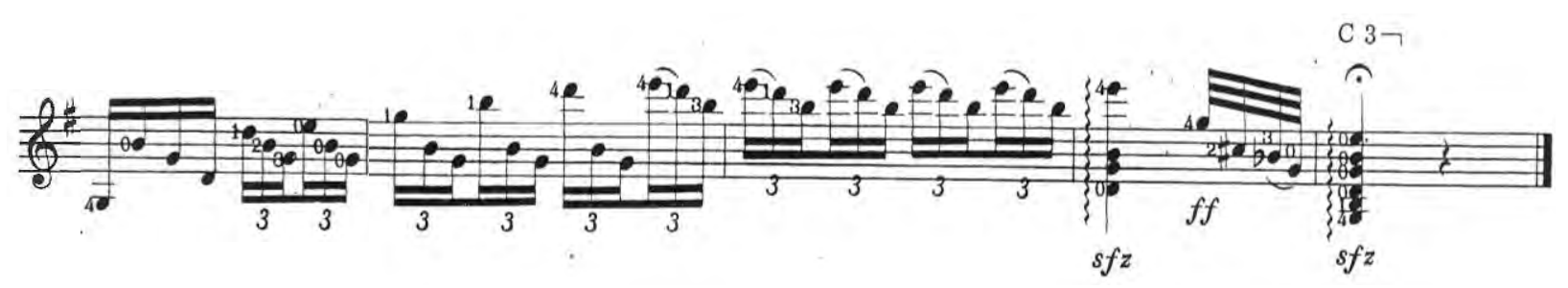

Exemplo 737: IX Estudo, compasso 122. Ed. Columbia/BL.

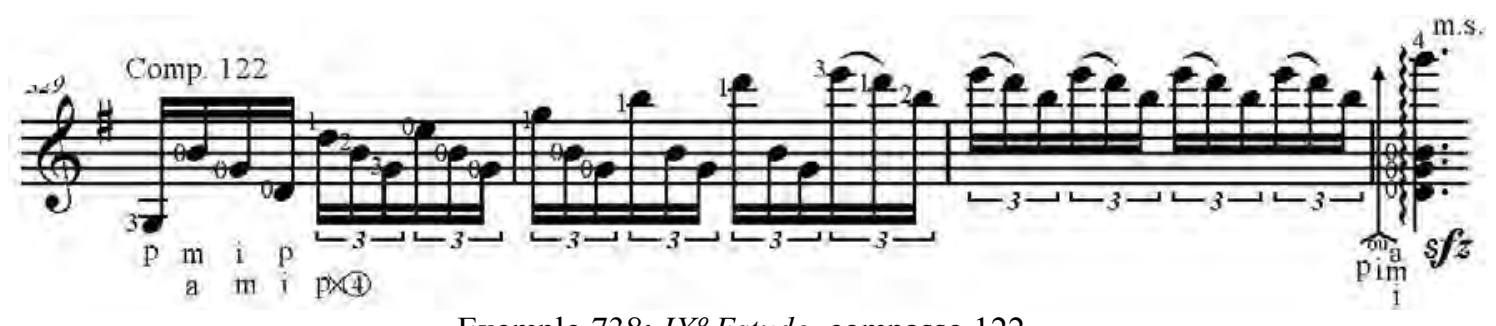

Exemplo 738: IX Estudo, compasso 122.

A ríspida conclusão recebe substituições no exemplo 739 e uma versão em campanella no exemplo 740 .

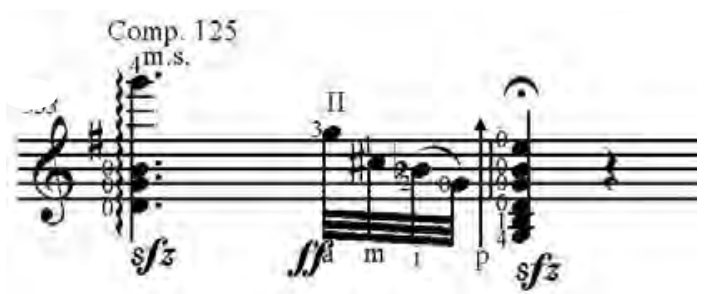

Exemplo 739: IX Estudo, compasso 125.

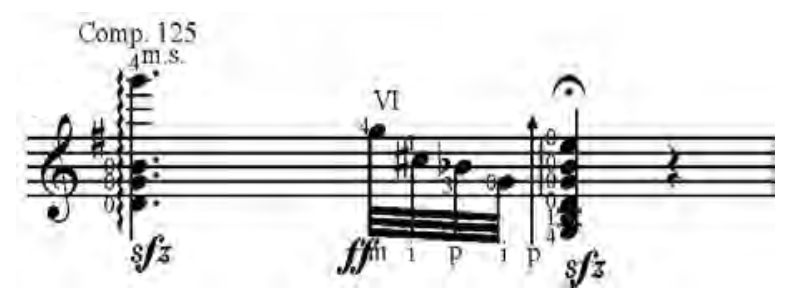

Exemplo 740: IX Estudo, compasso 125. 


\subsection{0: $X^{o}$ Estudo "Lento e com muito sentimento"}

O clima lânguido e arrastando (inicialmente evocado no $V I I^{o}$ Estudo) retorna na décima obra do ciclo. Em forma $\mathrm{ABA}$, sua primeira seção propõe uma melodia respondida por acordes repetidos cuja harmonia vai descendo cromaticamente a cada dois compassos. A seção contrastante tem caráter levemente mais movido e é conformada por uma melodia com acompanhamento em arpejos com harmonia mais diatônica.

O grande impasse desta obra é a definição de sua scordatura, dilema este que subteremos ao Pensamento Divergente, explorando suas várias possibilidades. O manuscrito (ex. 741) revela que Mignone concebeu a obra com a sexta corda afinada em Ré, provavelmente baseado na extensão da obra (que necessita de um baixo em Mi bemol) do que em algum aspecto técnico. Tocada de tal maneira, revisões são inevitáveis, conforme veremos adiante. Talvez isso tenha motivado BL (ex. 745) a publicá-la com a scordatura habitual (ou seja, com a sexta em Mi) ${ }^{143}$, abdicando do Mi bemol grave previsto no compasso 11. A necessidade desta nota grave nos levou ainda a testar outras duas possibilidades: a afinação da sexta em Mi Bemol (sugerida por Luis Carlos Barbieri a quem vimos executá-la em concerto desta maneira) e com a sexta em Ré, porém com um capotraste na primeira casa, ou seja, transformando o Mi bemol em corda solta.

Abordaremos estes quatro enfoques um a cada vez, a fim de não misturar exemplos com scordaturas diferentes, entendendo que isso seria penoso ao leitor que fosse eventualmente as testar. Com este mesmo zelo todos os exemplos terão sua scortadura expressa com clareza (e às vezes até redundância), a fim de evitar confusões.

Adiantamos que todas essas versões têm prós e contras e que a necessidade de revisões será bem provável principalmente no que tange as tétrates cromáticas na região grave nos primeiros quatro compassos, que são irrealizáveis em empilhamentos de terças.

Começaremos comentando a scordatura sugerida pelo compositor, ou seja, com a sexta corda em Ré. No exemplo 742, as duas primeiras tétrates (nos quatro primeiros compassos) foram reduzidas ${ }^{144}$, solução que foi empregada em todas as outras versões. Porém com esta afinação problemas emergem em outros acordes: no compasso 5 o

${ }^{143}$ A edição Columbia não indica afinação alguma. Esta ausência já seria o bastante para entender que o violão está em sua afinação standard (obedecendo convenção violonística), aspecto que pode ser confirmado pela natureza da digitação BL para a obra.

${ }^{144}$ verbo diminuir do checklist de Osborn. 
acorde original demandaria uma grande abertura para ser executado em posição fechada, posto que foi rearranjado ${ }^{145}$ para posição aberta; no compasso 9 a abertura é grande mas ainda factível (que pode ser aliviada com a exclusão do Dó bemol) e no compasso 13 uma nota têm de ser excluída já que a nota Lá está em posição muito avançada de forma a impedir a execução integral do acorde.

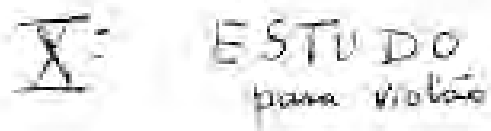

$$
\begin{aligned}
& \text { FRAHLACO } \\
& \text { MIQHONI }
\end{aligned}
$$

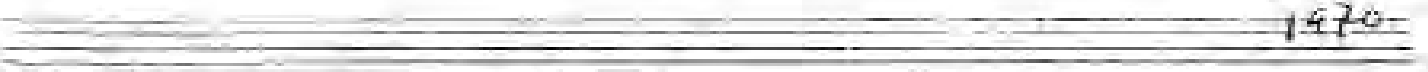

\section{Tereb scom muito sentimunto}
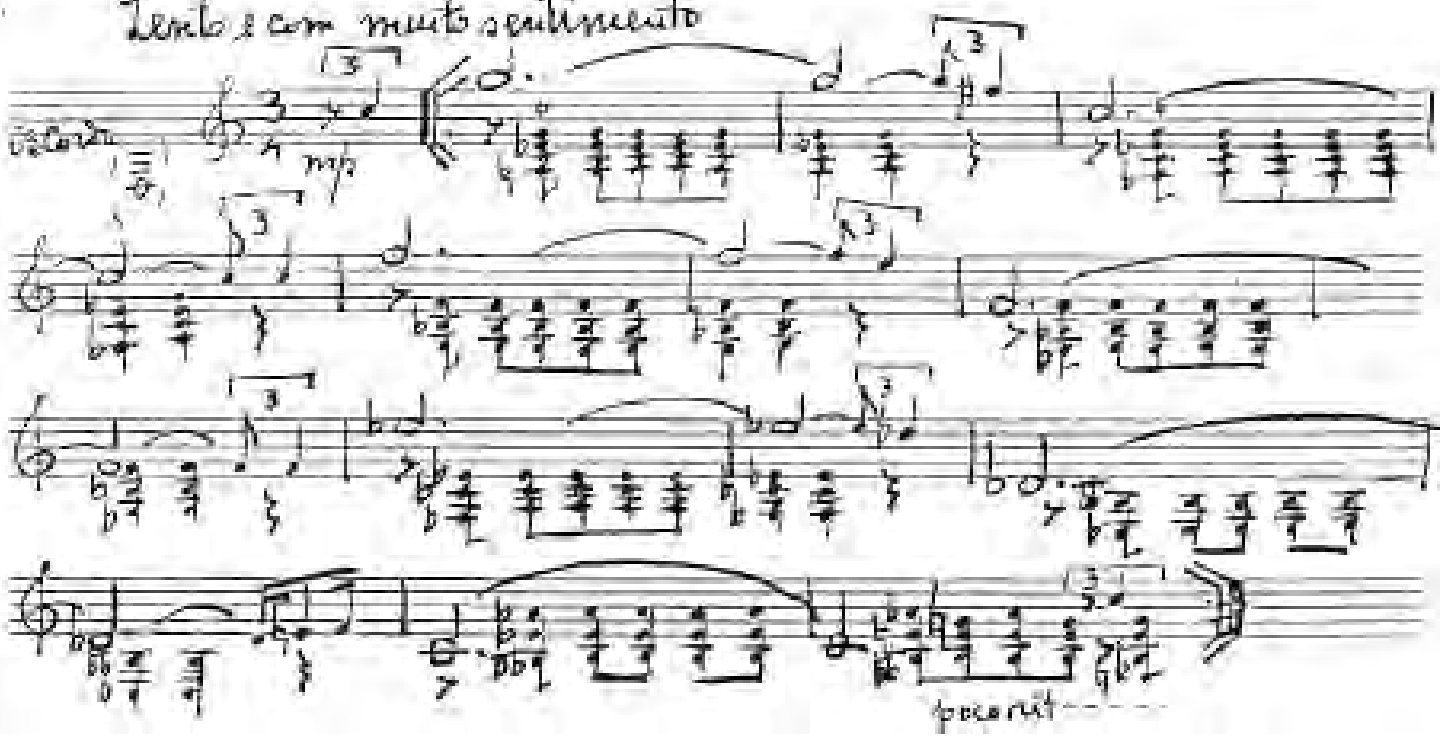

Exemplo 741: $X^{o}$ Estudo, compasso 1. Manuscrito. $6^{\text {a }}$ corda = Ré.
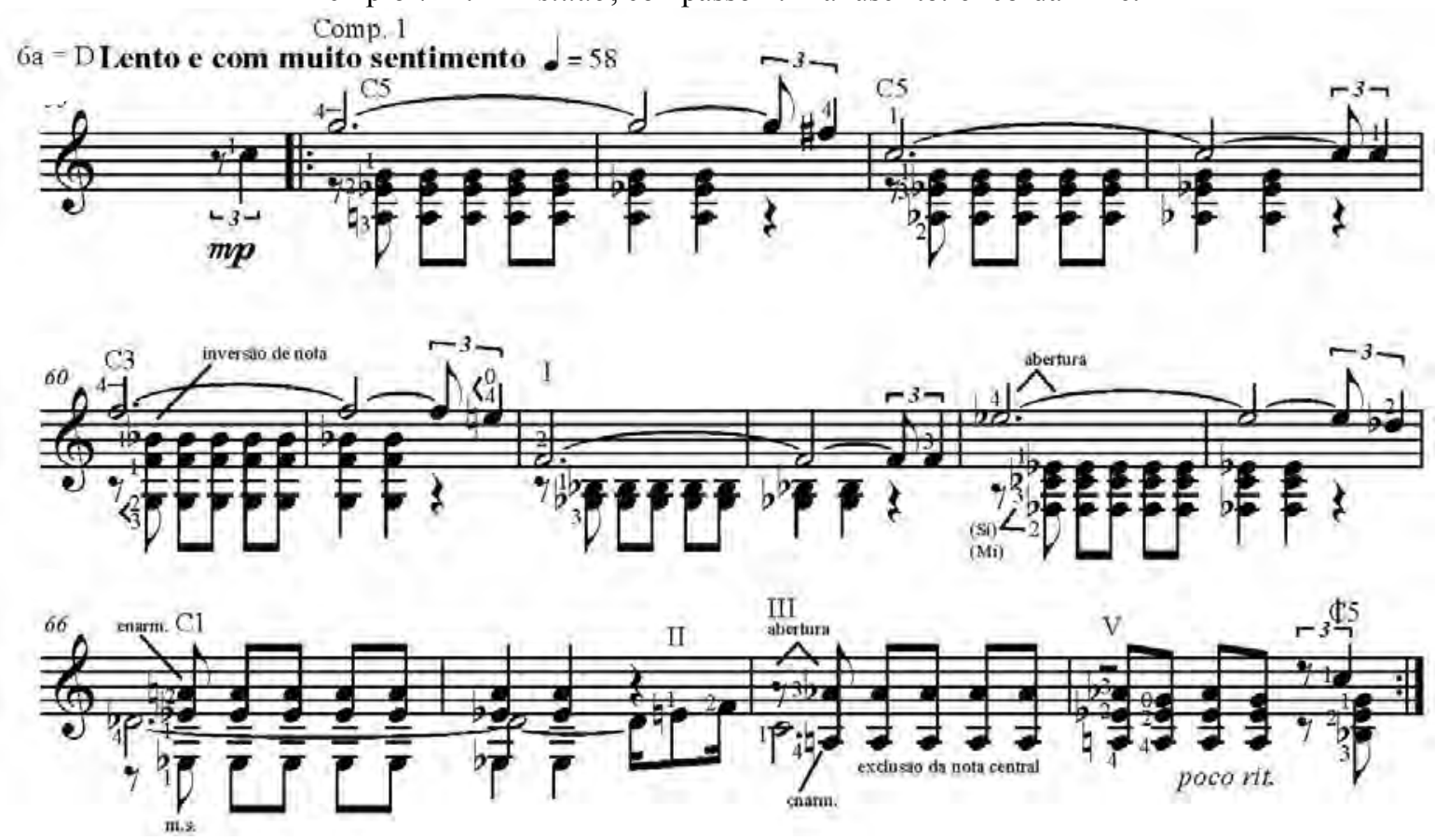

Exemplo 742: $X^{o}$ Estudo, compasso 1. $6^{\mathrm{a}}$ corda = Ré.

${ }^{145}$ verbo do checklist de Osborn. 
A segunda seção, que se articula principalmente nas primas não tem mudanças expressivas com essa scordatura (em relação a digitação BL), com e exceção da casa 2 , que precisa de encaminhamento específico pela terceira posição para se alcançar o Si bemol e o Lá bemol na sexta corda, ambos em posição avançada se comparados a outras scordaturas.

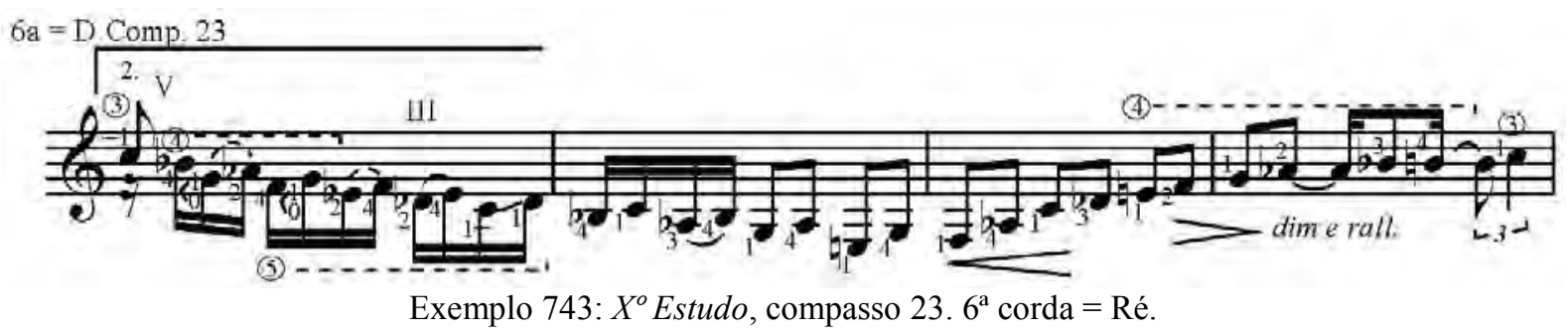

A reexposição possui apenas variações melódicas sem grandes implicações na digitação inicial e apresentando os mesmos dilemas nos acordes anteriormente comentados. O acorde do compasso 33 apresenta uma nota diferente da primeira aparição no compasso 7: o que era um Si bemol, passa a receber dobrado bemol, tornando-se um Lá natural. O resultado sonoro não parece coerente e imaginamos ser um de grafia (ao colocar dois bemóis na frente do Si ao invés de somente um), para o qual sugerimos uma execução igual ao compasso 7. Mesmo assim, deixamos o trecho como no original em nosso exemplo (apenas com enarmonias assinaladas).
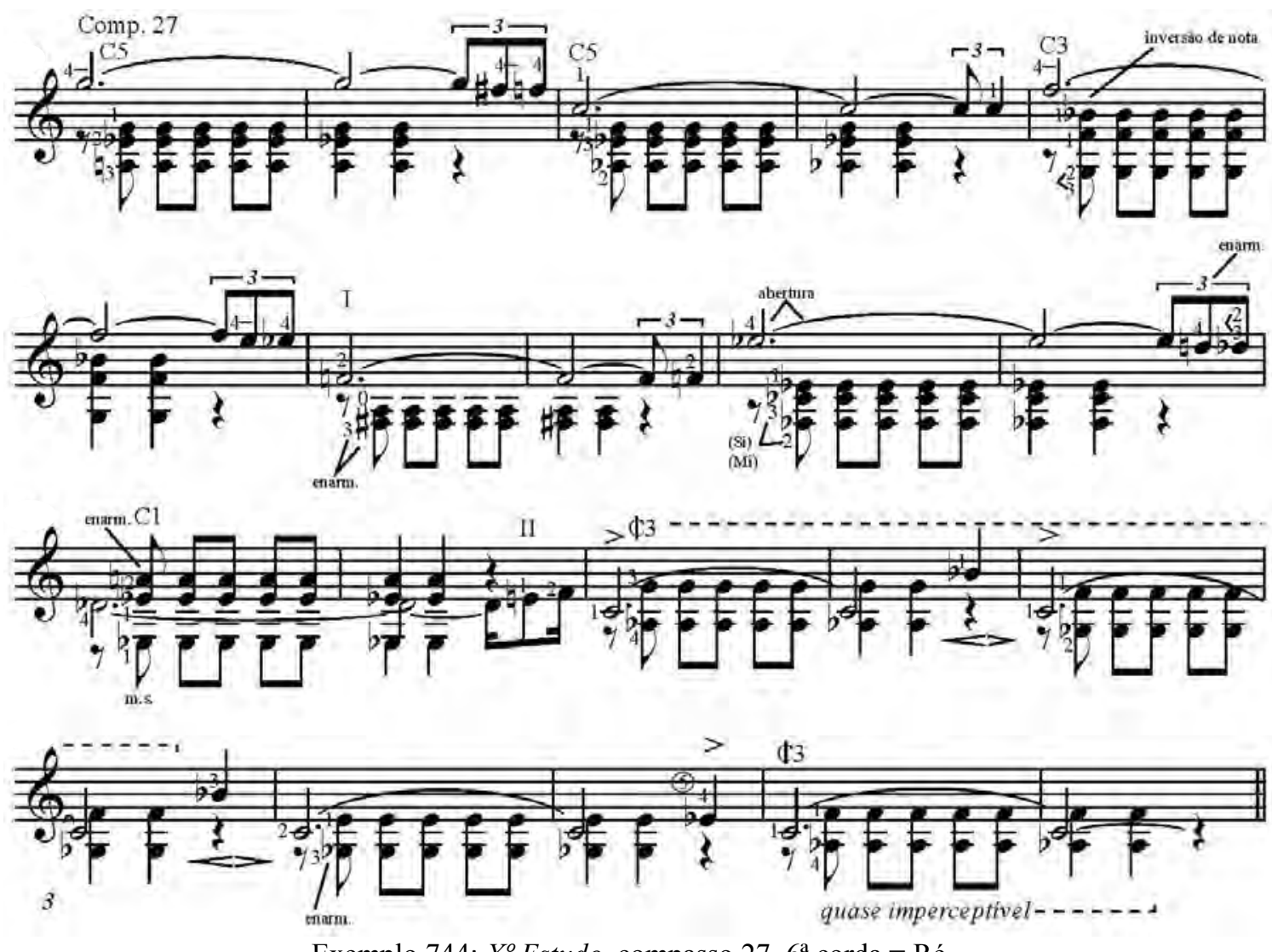

Exemplo 744: $X^{o}$ Estudo, compasso 27. $6^{\text {a }}$ corda = Ré. 
Esses problemas com acordes gerados pela scordatura sugerida pelo compositor (sexta corda em Ré) parecem ter sido o suficiente para BL buscar outra solução por meio da afinação standard (ex. 745). Nela, vemos que os acordes são bem mais factíveis com exceção das duas primeiras tétrates (problema ocorrente em todas as versões) e do compasso 11, onde um baixo em Mi bemol teve de ser excluído por BL.

Nossa versão com sexta corda em Mi (ex. 746) faz algumas pequenas modificações ${ }^{146}$ na versão BL: alivia a compressão entre os dedos 2 e 3 no compasso 3 mas cria uma abertura anterior (assinalada) e rearranja ${ }^{147}$ os dedos nos compassos 5 a 8 . No compasso 11, onde BL teve de excluir uma nota, tomamos a liberdade de sugerir o acréscimo de outro baixo (entre parêntesis), ainda baseado na mesma harmonia.

\section{a Barbosa-Lima \\ $\mathrm{X}^{\circ}$ ESTUDO}

Fingered by

Carlos Barbosa-Lima

Lento e com muito sentimento $(d=58)$
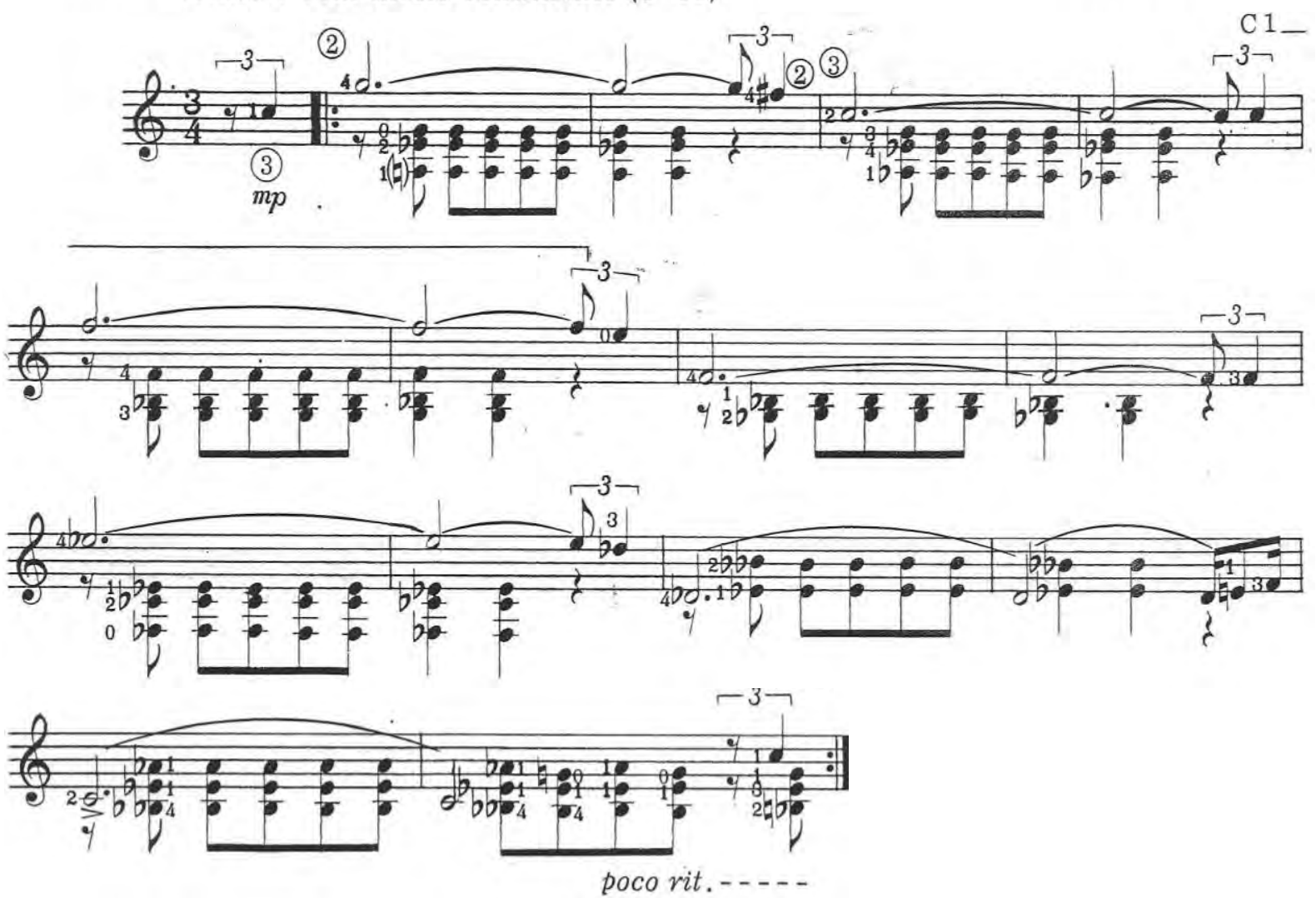

Exemplo 745: $X^{o}$ Estudo, compasso 1. Ed. Columbia/BL. $6^{\mathrm{a}}$ corda $=$ Mi.

\footnotetext{
${ }^{146}$ verbo do checklist de Osborn.

${ }^{147}$ verbo do checklist de Osborn.
} 
Comp. la partir de Barbosa Lima

$6 \mathrm{a}=\mathrm{E}$ Lento e com muito sentimento $d=58$
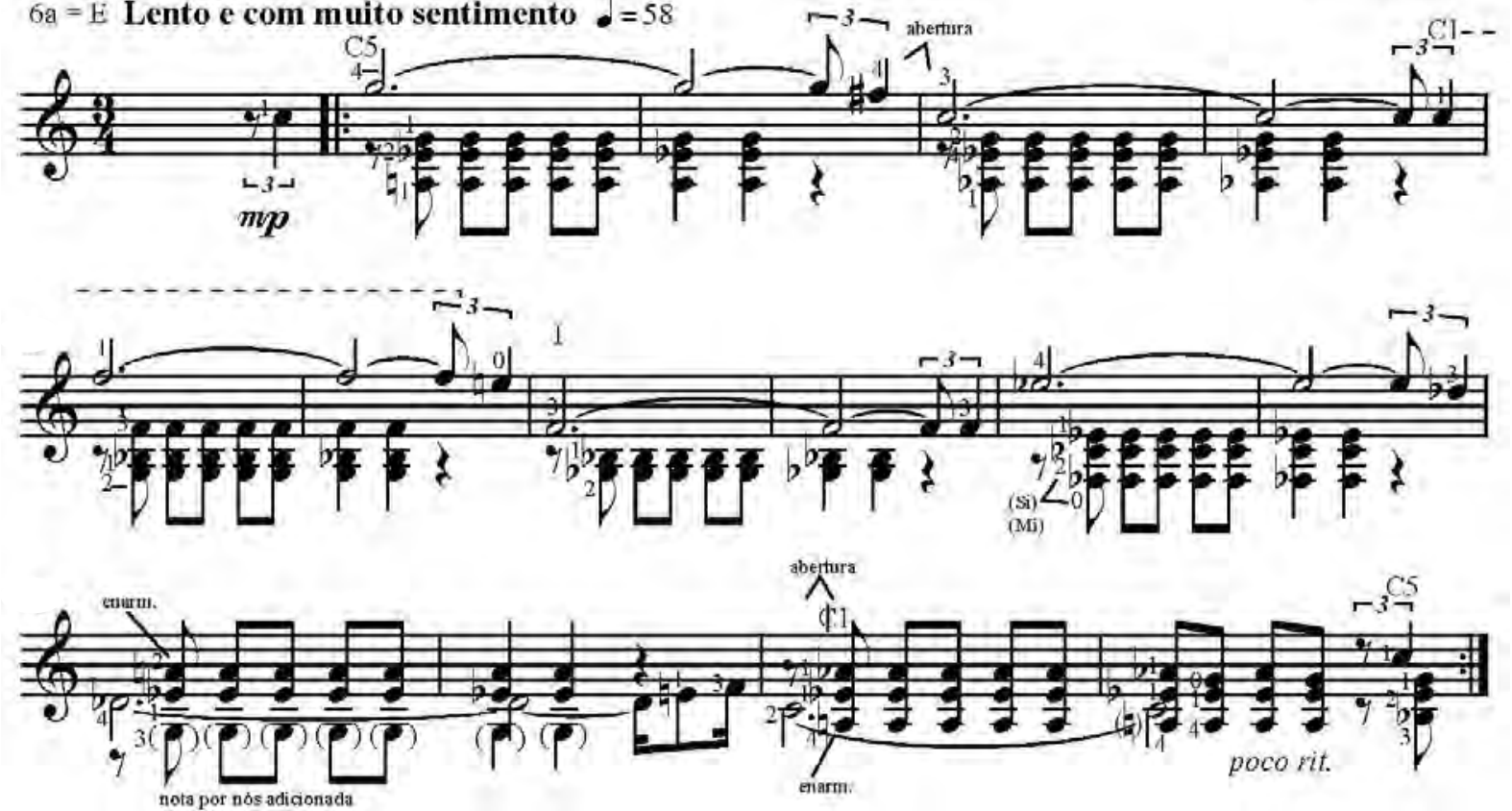

Exemplo 746: $X^{o}$ Estudo, compasso 1. $6^{\mathrm{a}}$ corda $=$ Mi.

O compasso 5 ainda pode receber inversão como na versão com sexta corda em

Ré (ex. 747) e o último acorde da seção pode receber digitação mais simples na primeira posição, porém com salto para o próximo compasso.

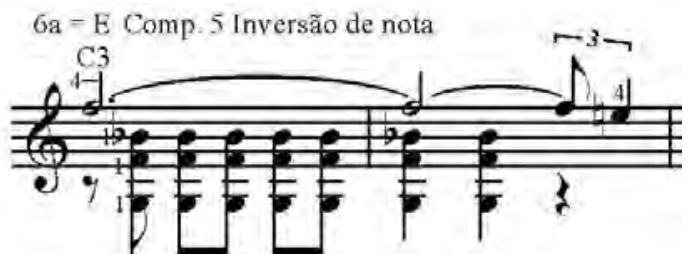

Exemplo 747: Est. 10, comp. 5. $6^{\mathrm{a}}=$ Mi.

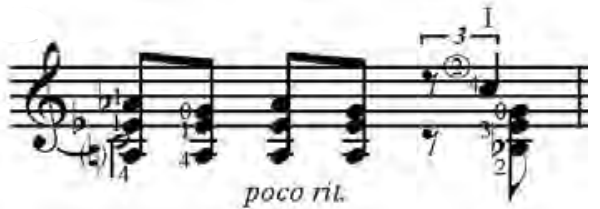

Exemplo 748: Est. 10, comp. 14. $6^{\mathrm{a}}=\mathrm{Mi}$.

A segunda seção novamente gera múltiplas versões apenas na casa 2. Antes porém, registramos no exemplo 750 uma divergência (assinalada) entre manuscrito e edição Columbia. 

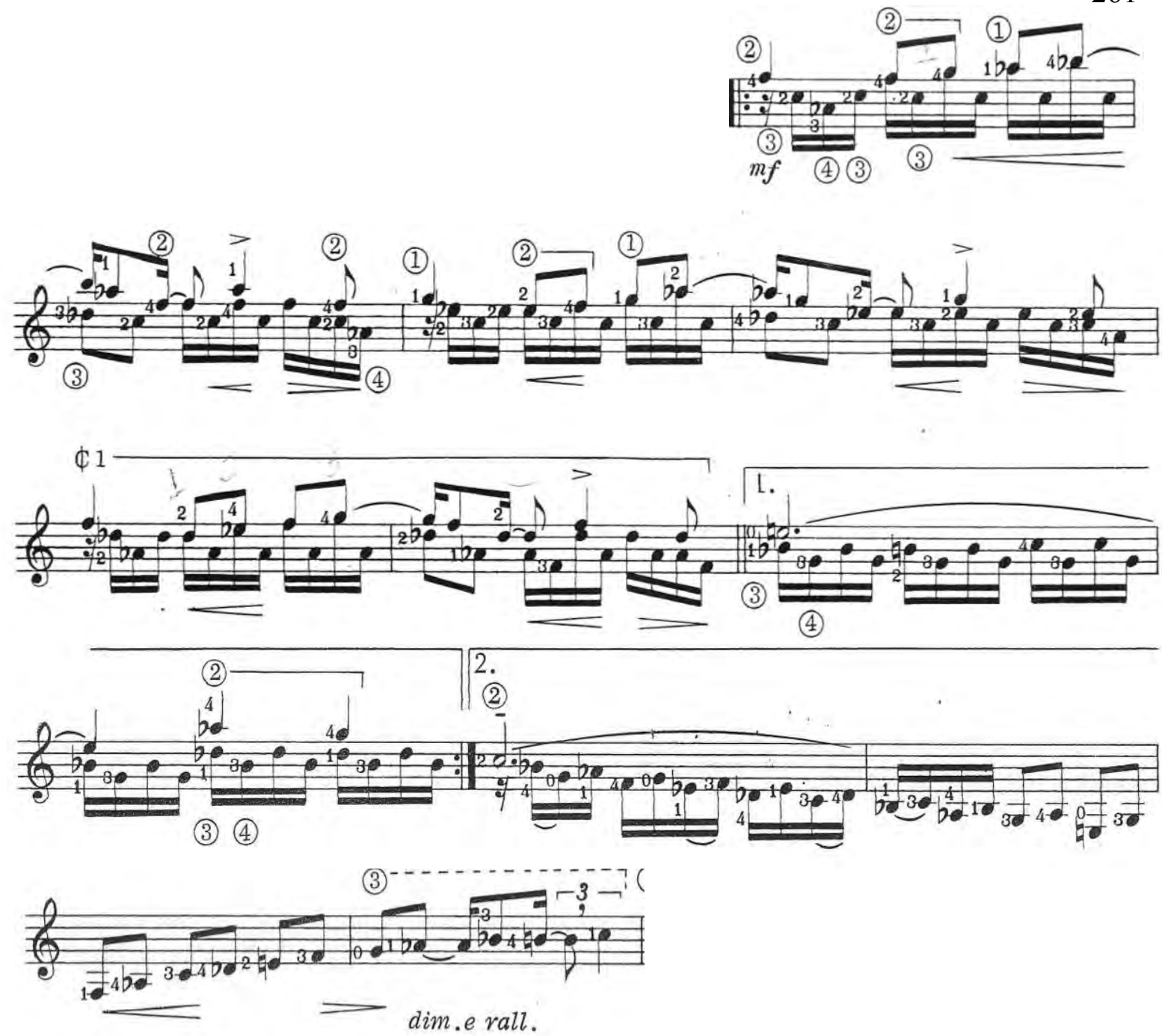

Exemplo 749: $X^{o}$ Estudo, compasso 15. Ed. Columbia/BL. $6^{\text {a }}$ corda $=$ Mi.

$6 \mathrm{a}=\mathrm{E}$ Comp. 17

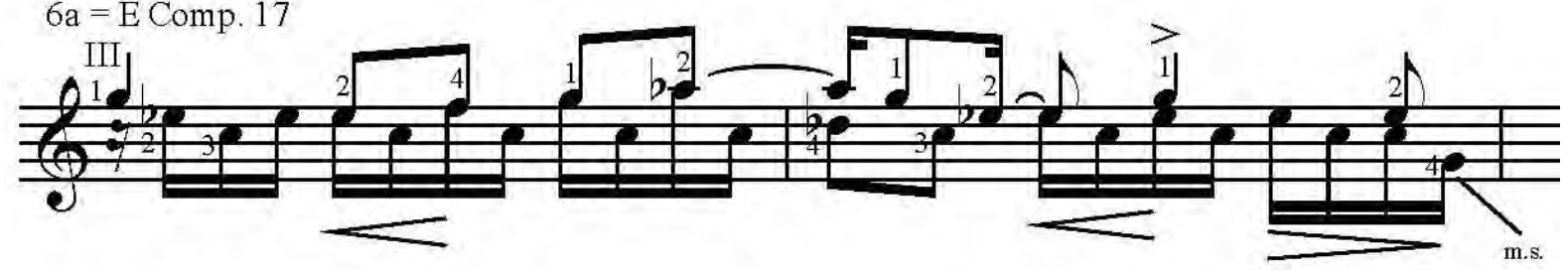

Exemplo 750: $X^{o}$ Estudo, compasso 17. $6^{\mathrm{a}}$ corda $=\mathrm{Mi}$.

A casa 2 recebe apenas uma digitação no exemplo 751, iniciada por uma campanella e levando ao retorno do tema inicial em una corda pela quarta corda.

$6 \mathrm{a}=\mathrm{E}$ Comp. 23 Campanella

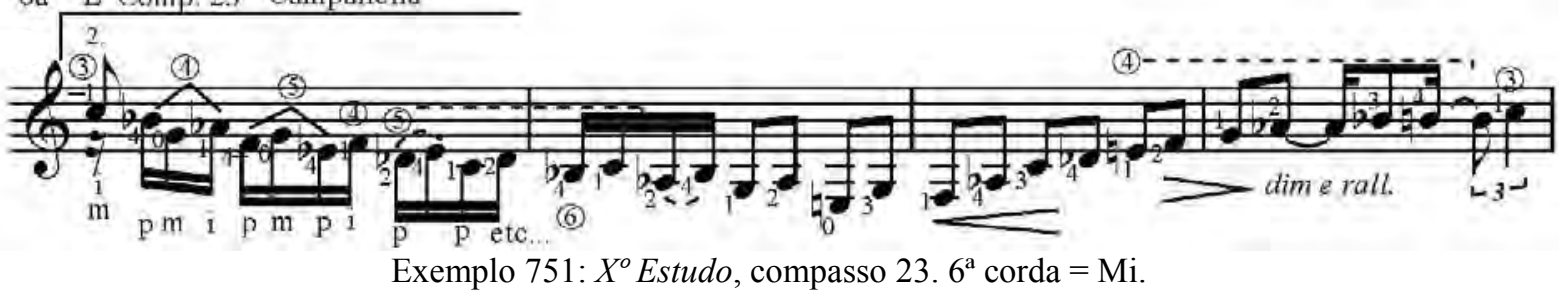

A repetição levemente variada do tema A recebe as mesmas sugestões com pequenas diferenças nos dedos escolhidos por BL para a melodia, também ocorrendo várias substituições na coda. 

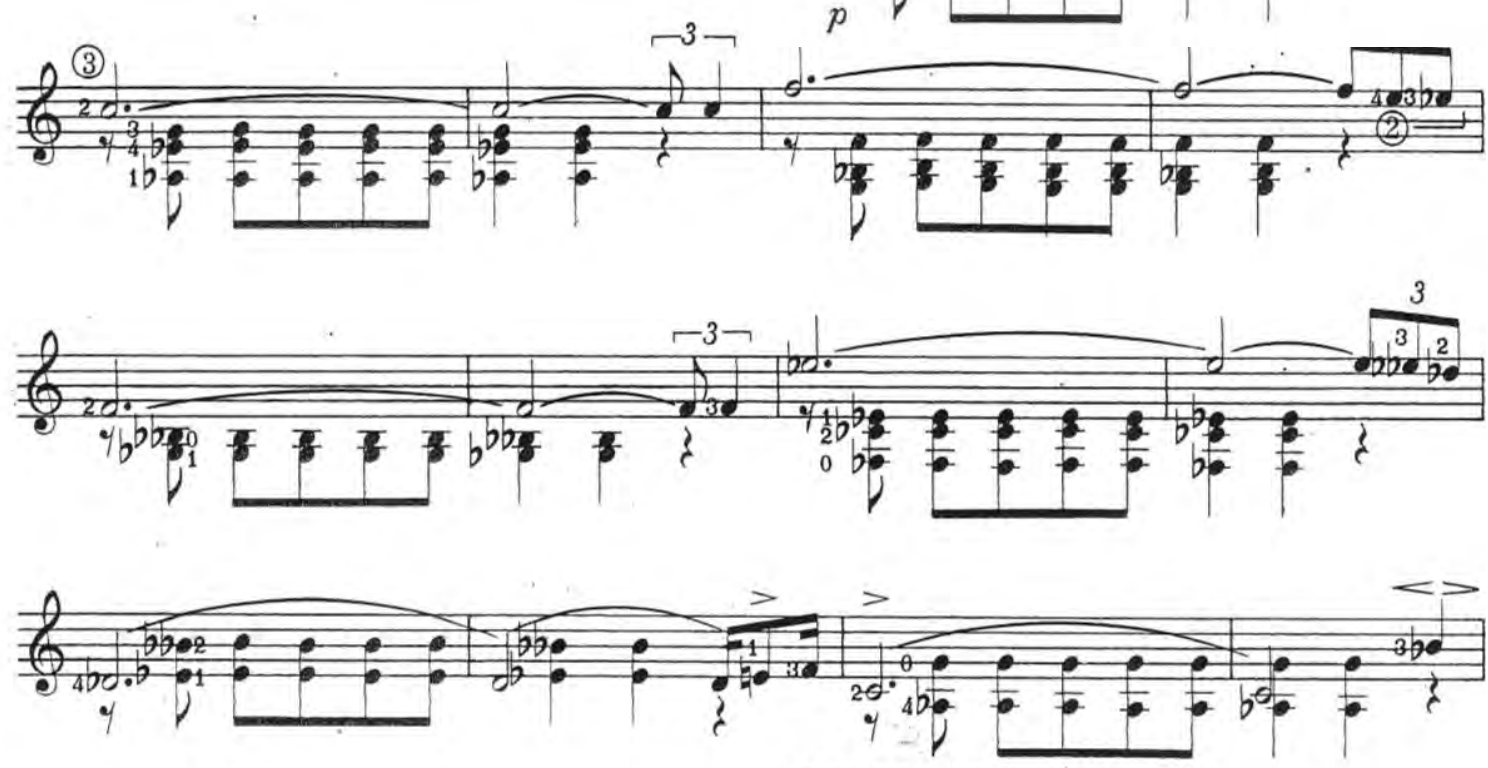
sempre pp e desaparecendo

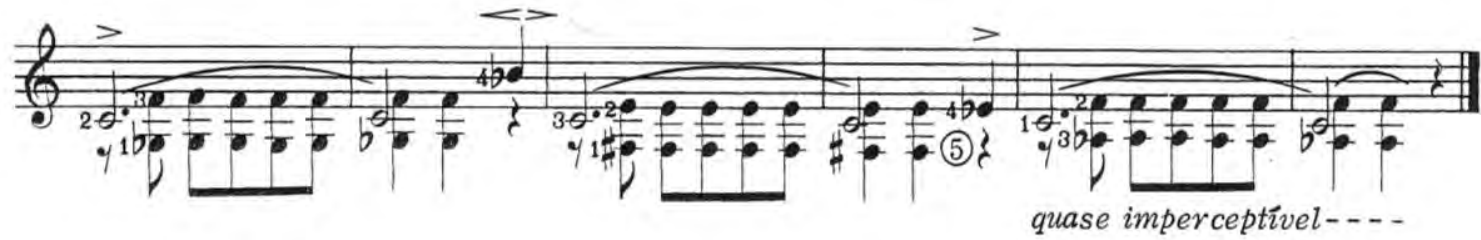

Exemplo 752: $X^{o}$ Estudo, compasso 15. Ed. Columbia/BL. $6^{\mathrm{a}}$ corda $=$ Mi.
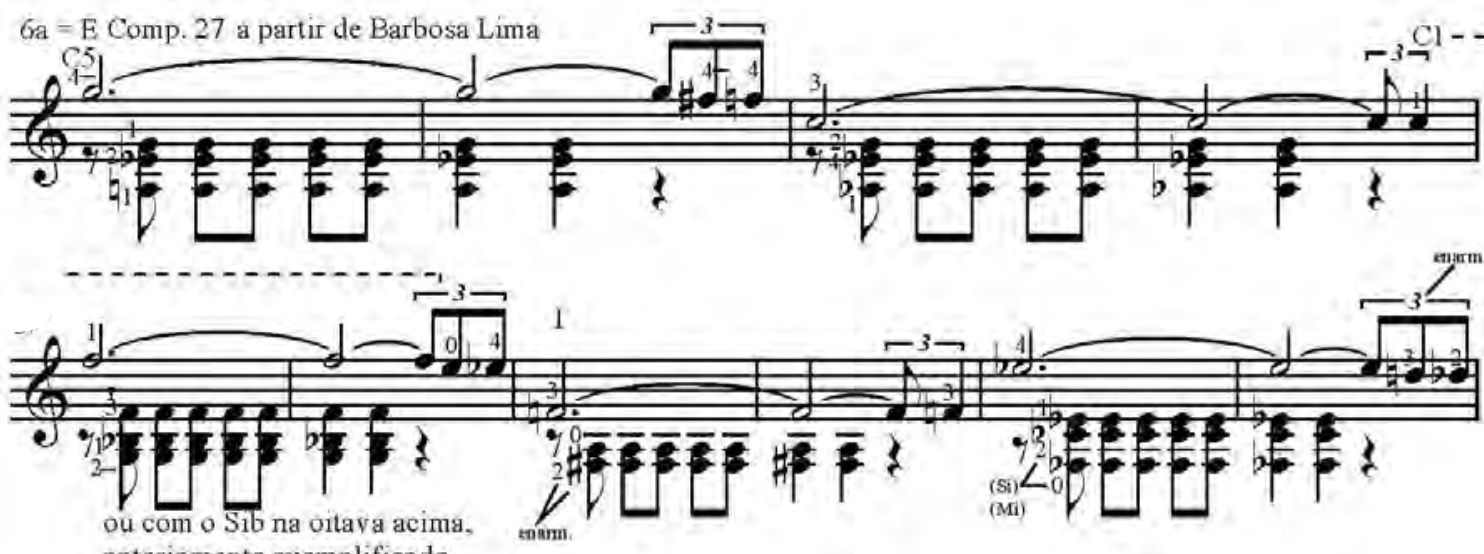
anteriomente exemplificado.
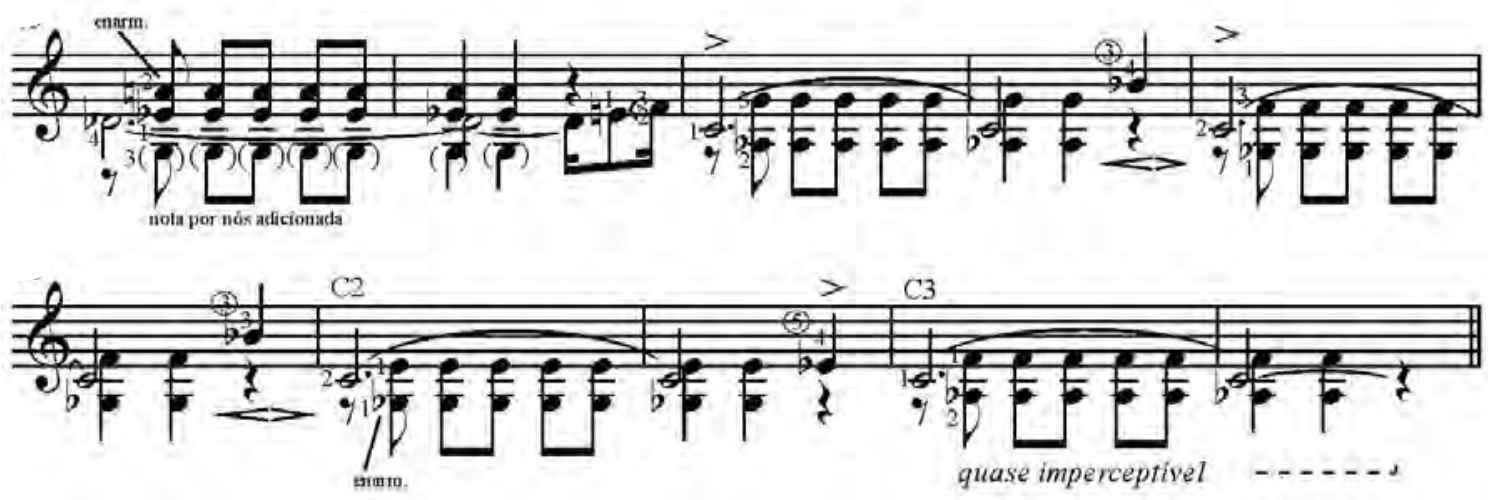

Exemplo 753: $X^{o}$ Estudo, compasso 23. $6^{\mathrm{a}}$ corda $=\mathrm{Mi}$. 
A scordatura em Mi bemol que nos foi sugerida por Luis Carlos Barbieri é curiosa: ela funciona muito bem para a maioria dos acordes aliviando locais onde havia aberturas em outras versões, porém ela apresenta uma configuração desconfortável no compasso 5 e necessita de exclusões no compasso 13 (de forma análoga à versão com sexta corda em Ré).

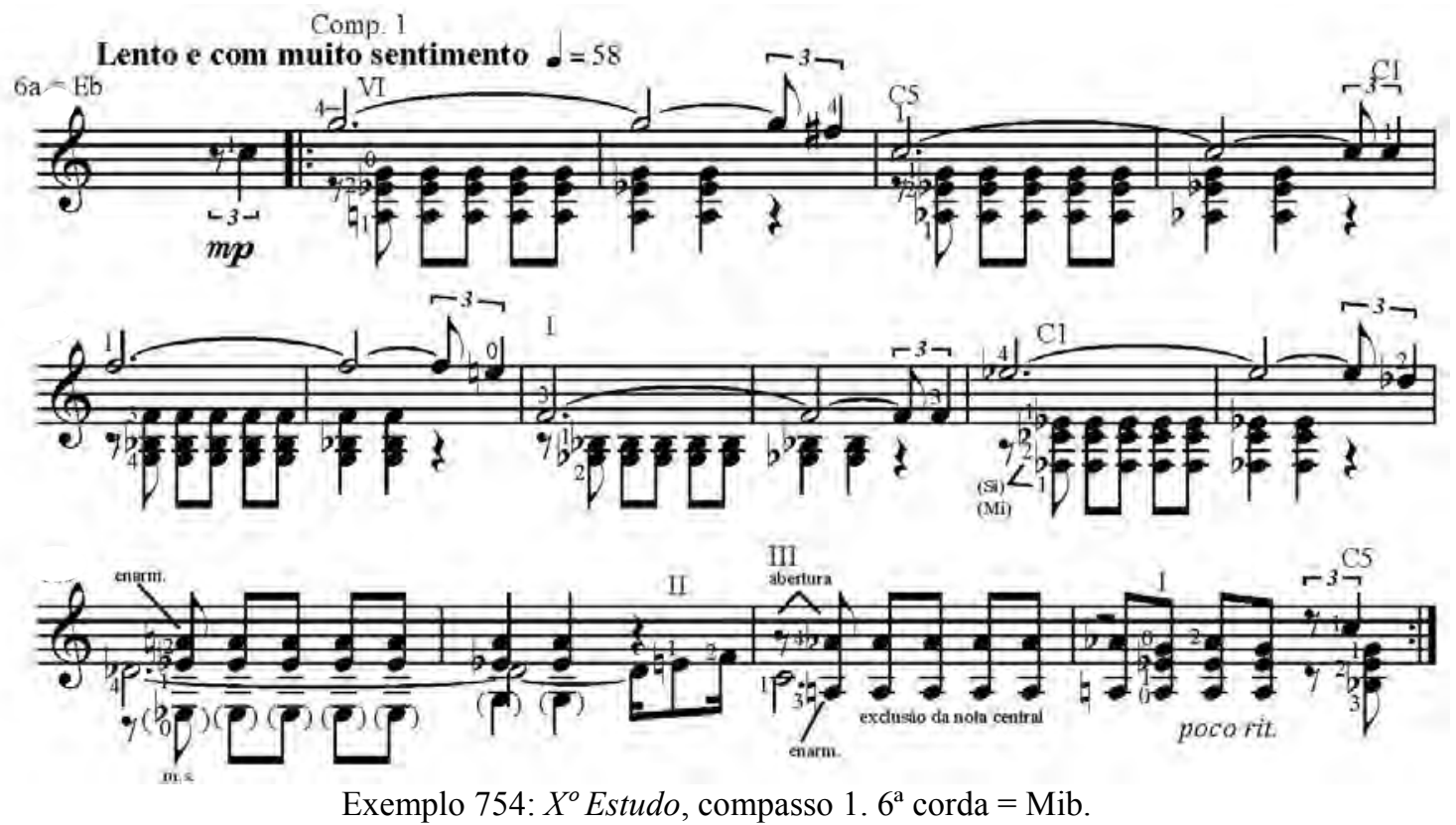

Felizmente ao menos o primeiro desses problemas pode ser resolvido por meio da inversão de notas proposta nas versões anteriores, porém com pequena diferença digitacional no baixo por óbvio motivo.

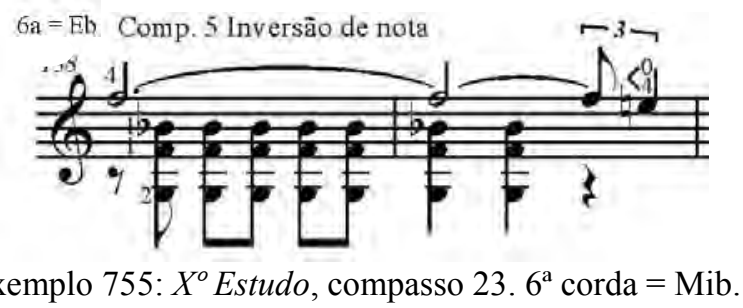

A segunda seção novamente exige (pela troca de scordatura) versões alternativas para a casa 2 . A primeira se mantém mais pela primeira posição, enquanto a segunda inicia com campanellas de versões anteriores e faz as adaptações ${ }^{148}$ necessárias quando chega à sexta corda.

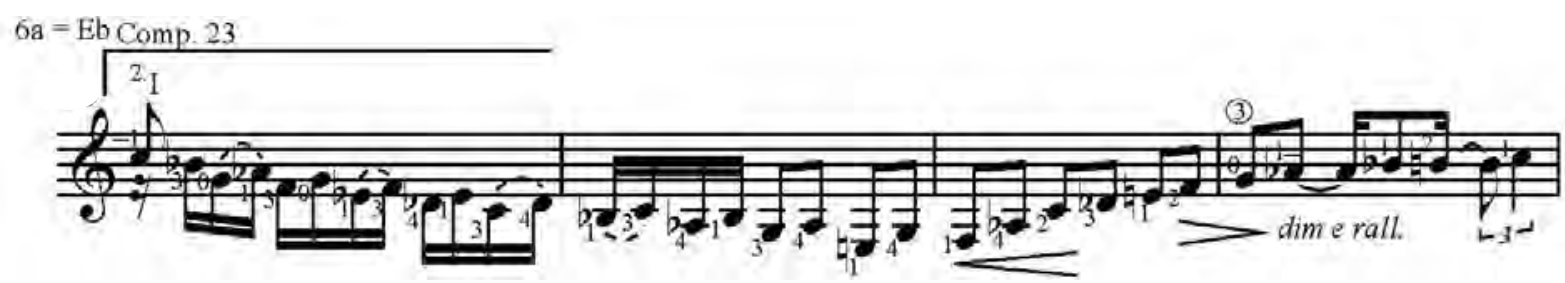

Exemplo 756: $X^{o}$ Estudo, compasso 23. $6^{\mathrm{a}}$ corda $=$ Mib.

${ }^{148}$ verbo do checklist de Osborn. 


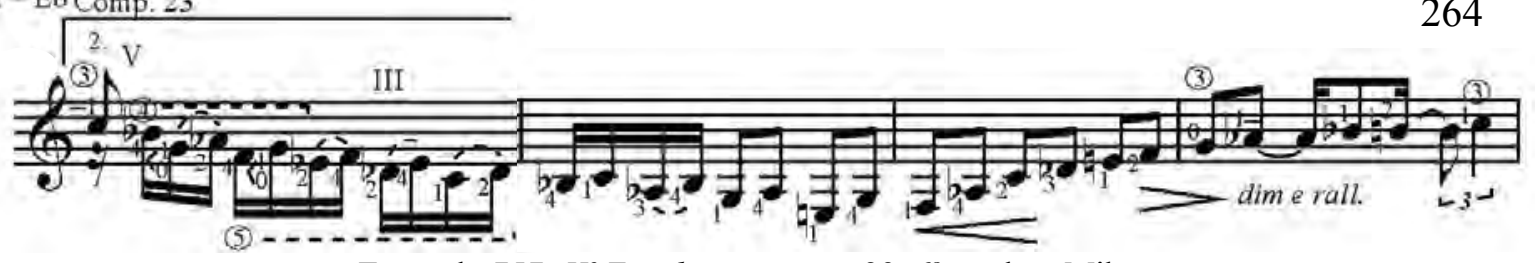

Exemplo 757: $X^{\circ}$ Estudo, compasso 23. $6^{\mathrm{a}}$ corda $=$ Mib.

A reexposição (ex. 758) obedece à mesma lógica de primeira aparição, mas com as devidas acomodações de dedos nas variações melódicas e ainda com a possibilidade de aliviar as aberturas do compasso 31 como no exemplo 755.

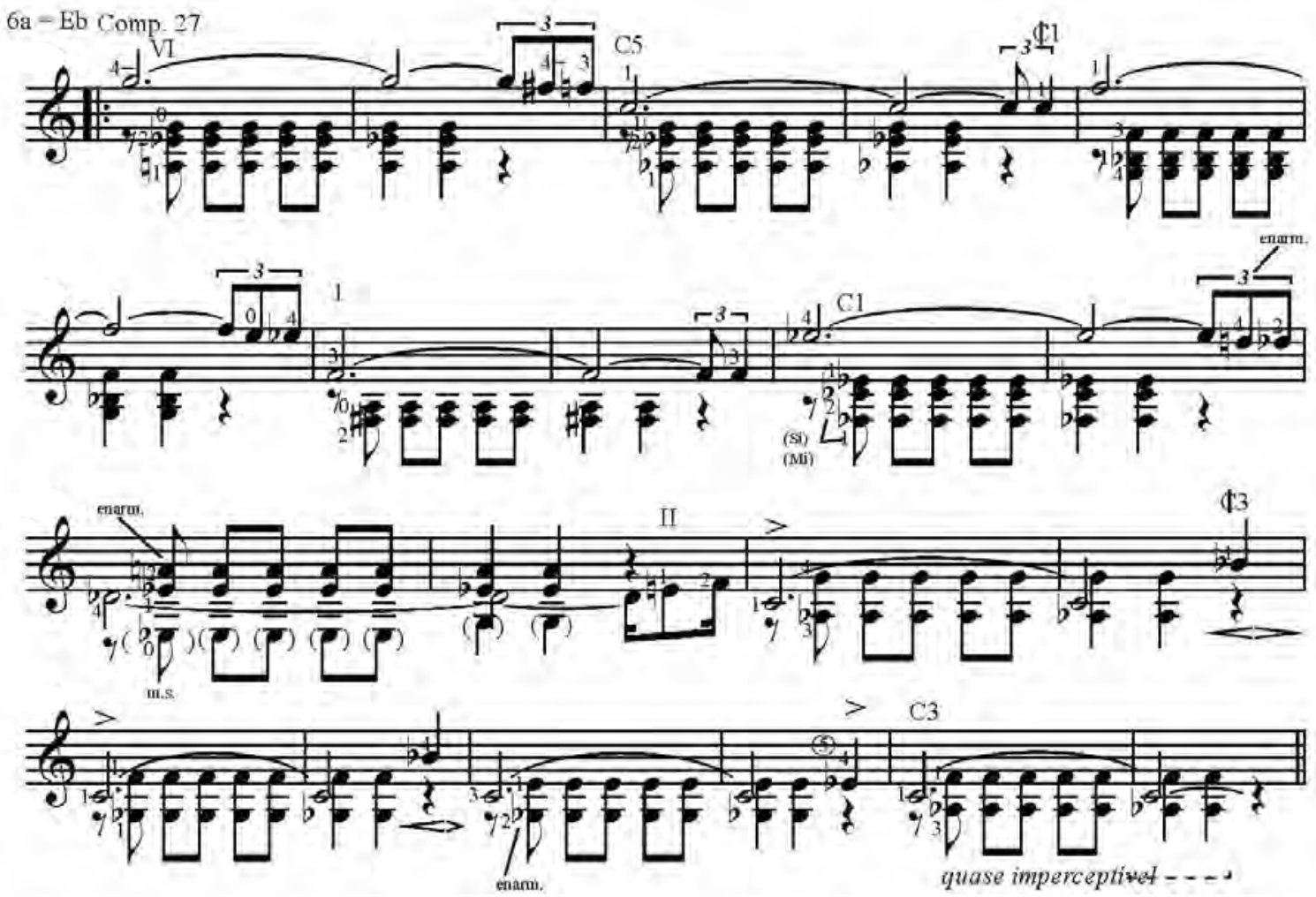

Exemplo 758: $X^{o}$ Estudo, compasso 23. $6^{\mathrm{a}}$ corda $=$ Mib

Além de testar as afinações sugeridas por outras fontes (reprisando: Manuscrito do compositor, edição Columbia/BL e performance de Luis Carlos Barbieri), aventuramos a possibilidade de uma quarta visão, afinando a sexta corda em Ré e usando um capotraste na primeira casa. Nosso intuito com tal ideia era resolver a aparição do Mi bemol, transformando-o em corda solta, porém, com o recurso do capotraste, várias outras cordas puderam ser aproveitadas no decorrer do estudo por coincidirem com notas utilizadas nesta composição (a saber: Mib na sexta, Sib na quinta, Mib na quarta, Láb na terceira, Dó na segunda e Fá na primeira corda).

No exemplo 759, convivem opções de cordas soltas ou presas para algumas notas. As primeiras facilitam o trecho, enquanto as outras permitem maior controle de vibrato e timbre. Independentemente dessa escolha todos os acordes são exequíveis sem modificações (com exceção dos tetracordes iniciais que foram reduzidos ${ }^{149}$ em todas as

149 verbo diminuir do checklist de Osborn. 
versões) com boa tocabilidade. As duas únicas aberturas ocorrem nos compassos 9 e 13 mas são aliviadas pela presença de cordas soltas. No primeiro caso (comp. 9) ainda é possível a exclusão da voz central (Dób) expediente facilitador anteriormente sugerido.
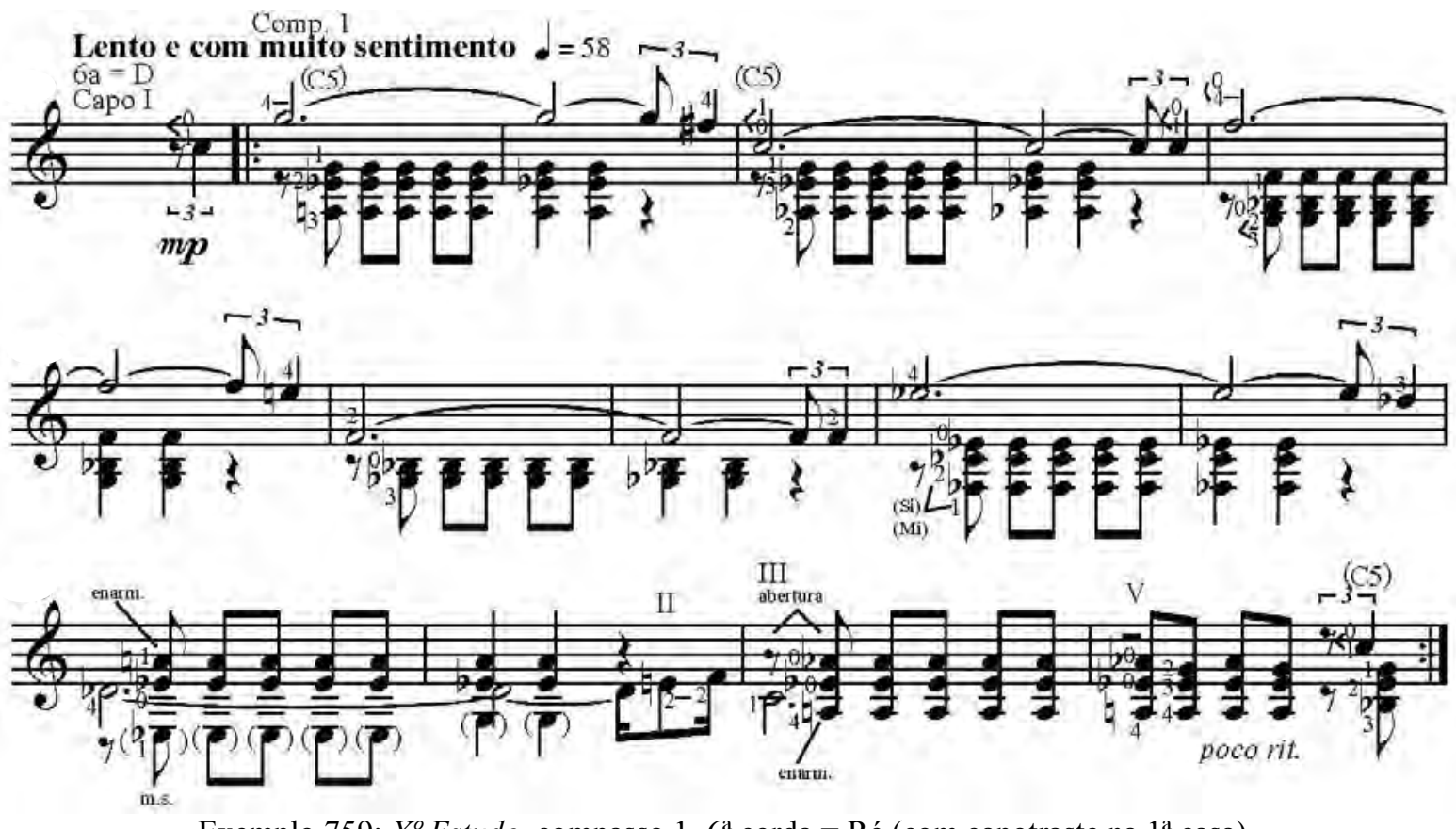

Exemplo 759: $X^{o}$ Estudo, compasso 1. $6^{\text {a }}$ corda $=$ Ré (com capotraste na $1^{\mathrm{a}}$ casa).

Com este arranjo de afinação e capotraste a segunda seção também ganha várias cordas soltas. Seu início pode ser executado em um acorde aberto como no exemplo 760 ou como na versão BL. Cordas soltas também ocorrem no compasso 19 e 20 (ex. 761) mas são impossíveis na casa 1 (como eram na digitação $\mathrm{BL}$ ) que portanto sofre pequenas readequações.

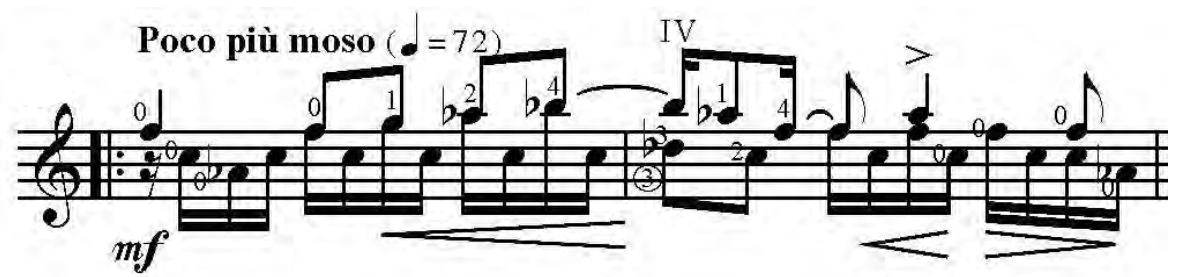

Exemplo 760: $X^{o}$ Estudo, compasso 15. $6^{\mathrm{a}}$ corda $=$ Ré (com capotraste na $1^{\mathrm{a}}$ casa).
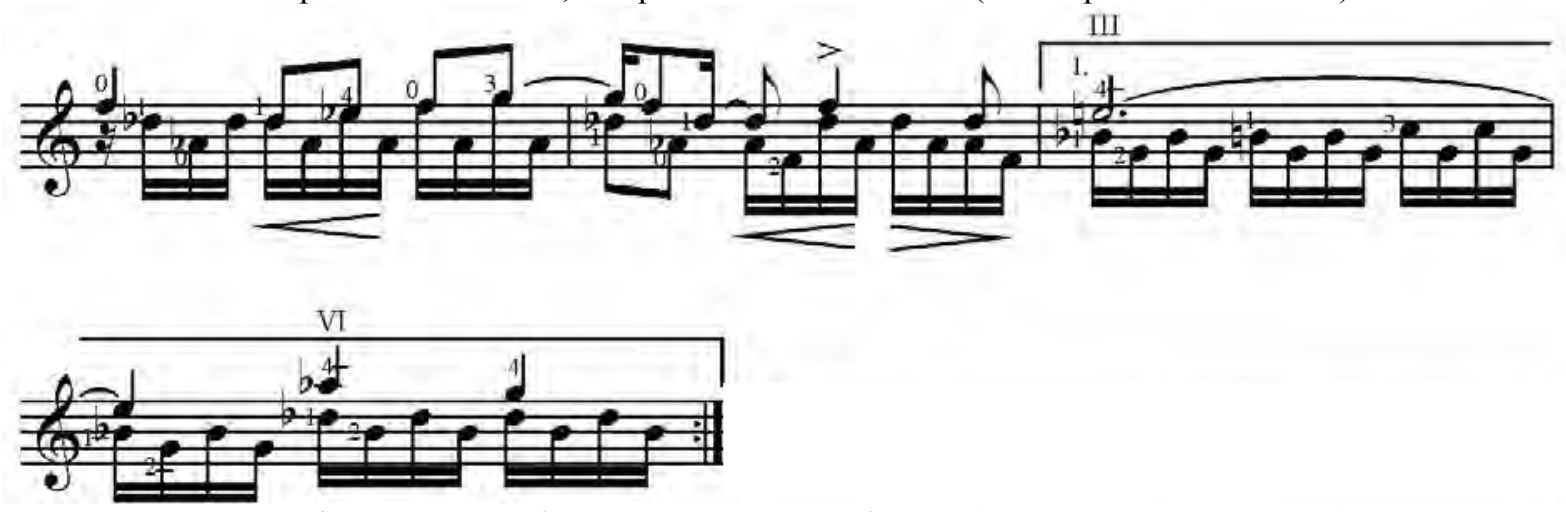

Exemplo 761: $X^{o}$ Estudo, compasso 19. $6^{\mathrm{a}}$ corda = Ré (com capotraste na 1a casa). 
A casa 2, por sua vez, ganha configuração completamente diferente de cordas soltas necessitando novo exemplo, mas ainda se conectando ao retorno da seção inicial pela quarta corda.

O da capo variado obedece a mesma lógica inicial apenas com as adaptações ${ }^{150}$ necessárias para acomodar as variações melódicas. Uma nota é necessária sobre o compasso 33, originalmente com Si dobrado bemol na voz intermediária (ou seja, Lá natural), que se torna impossível de ser executado já que a quinta corda agora está meio tom acima do habitual (ou seja, Si bemol). Entendendo esta ocorrência do dobrado bemol parece ser um erro de cópia do manuscrito, adotamos na reexposição a repetição do compasso análogo advindo da exposição (ou seja, compasso 7), que têm por sua vez, sonoridade harmonicamente mais compreensível. Por fim, a coda é praticamente idêntica à versão com sexta em Ré.

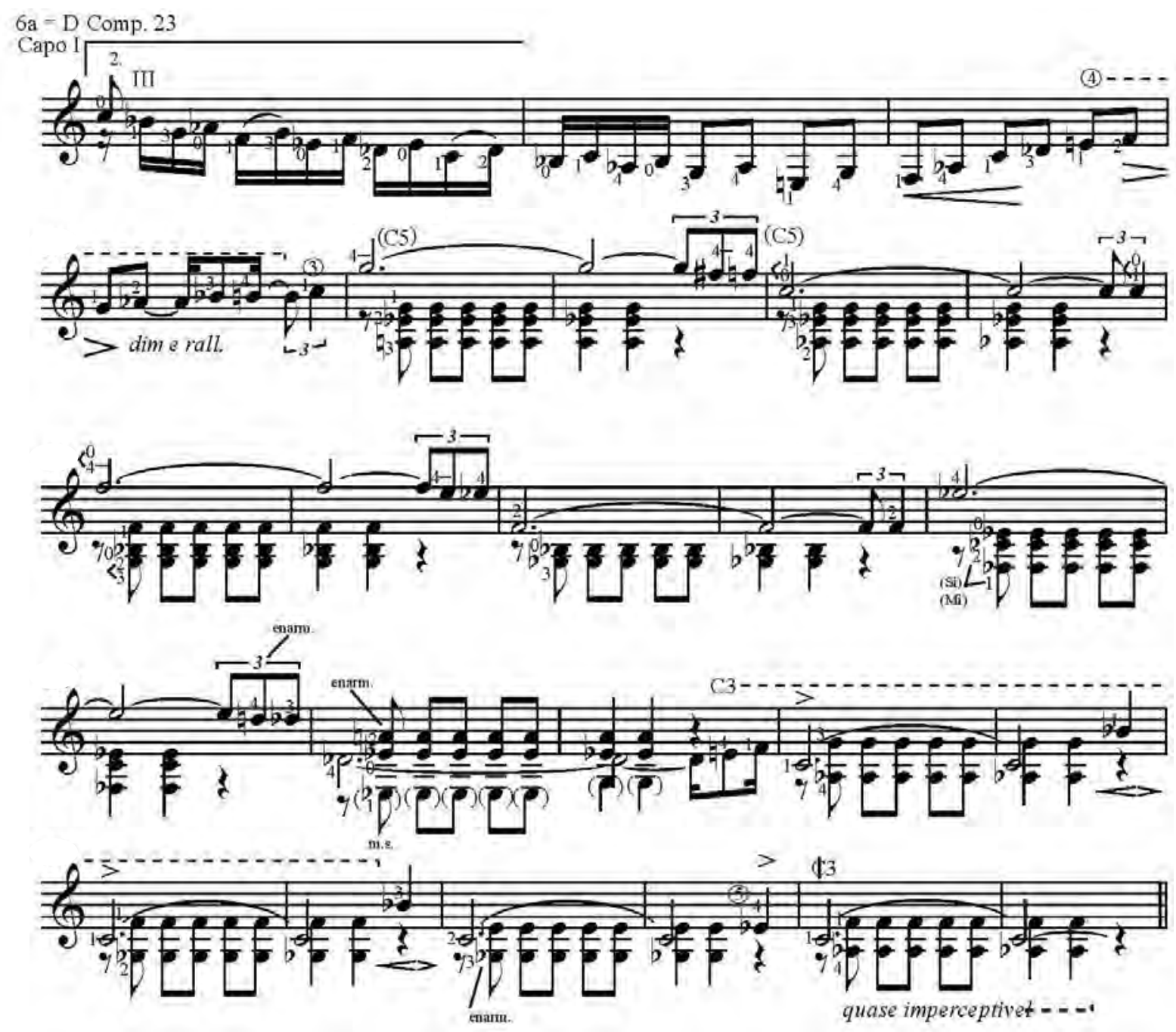

Exemplo 762: $X^{o}$ Estudo, compasso 19. $6^{\mathrm{a}}$ corda $=$ Ré (com capotraste na $1^{\mathrm{a}}$ casa).

${ }^{150}$ verbo do checklist de Osborn. 
Apesar de todas essas opções de afinação serem funcionais com seus prós e contras, algumas com mais outras com menores adaptações ${ }^{151}$. Em um resumo geral lembraríamos que as versões com scordatura da sexta corda em Ré e em Mi bemol precisam de reescrita no compasso 5 e de exclusão considerável no compasso 13, enquanto a versão com sexta em Mi carece do peso do Mi bemol que é esperado pelo ouvinte pelo encaminhamento cromático da harmonia. A versão com sexta em Ré e com capotraste na primeira corda necessita de menor alteração nos acordes, propicia configuração de me mais anatômica dos mesmos (com menos aberturas) e têm presença de cordas soltas facilitadoras, porém não executa o compasso 33 (com seu provável erro de grafia) conforme o original.

Um último aspecto diz respeito apenas a performances integrais (ou parciais incluindo este estudo e seus adjacentes): tendo em conta que o estudo anterior $\left(I X^{\boldsymbol{\rho}}\right)$ e o próximo $\left(X I^{\circ}\right)$ exigem a sexta corda em Ré, as versões do $X^{o}$ Estudo que propiciam maior estabilidade de afinação desta corda são a scordatura original e a com sexta corda em Ré e capotraste na primeira casa, das quais preferimos esta última, por todos os benefícios acima descritos.

\footnotetext{
${ }^{151}$ verbo do checklist de Osborn.
} 


\subsection{1: XI Estudo "Andante"/"Spleen"}

Ainda com caráter lento e melancólico o $X I^{o}$ Estudo recebe, em seu manuscrito apenas (ex. 763) o subtítulo de Spleen, "proveniente da literatura dos poetas românticos inspirados pelo byronismo de Alfred de Musset e Charles Baudelaire" configurando "um dos termos favoritos do jargão romântico, originário da palavra inglesa que significa baço (órgão considerado a sede da melancolia), e cujo uso passou a ser sinônimo desse sentimento: pessimismo, ceticismo e irresistível tédio" (Apro, 2004, p.109). Apro ainda aprofunda a relação entre música, literatura e aspectos biográficos do compositor:

"Mignone era um admirador contumaz de literatura e poesia, e seu projeto poético musical nesse estudo encontra eco na poesia dos românticos imersos em spleen, termo que, aliás, ainda estava em uso durante a juventude do compositor. $\mathrm{O}$ uso dos timbres escuros do violão (sul tasto), o rubato e a expressão meditativa e fantasiosa parecem ser os ingredientes necessários para expressar toda a gama de sentimentos mórbidos exigidos pelo "mal do século"' (Apro, 2004, p.110).

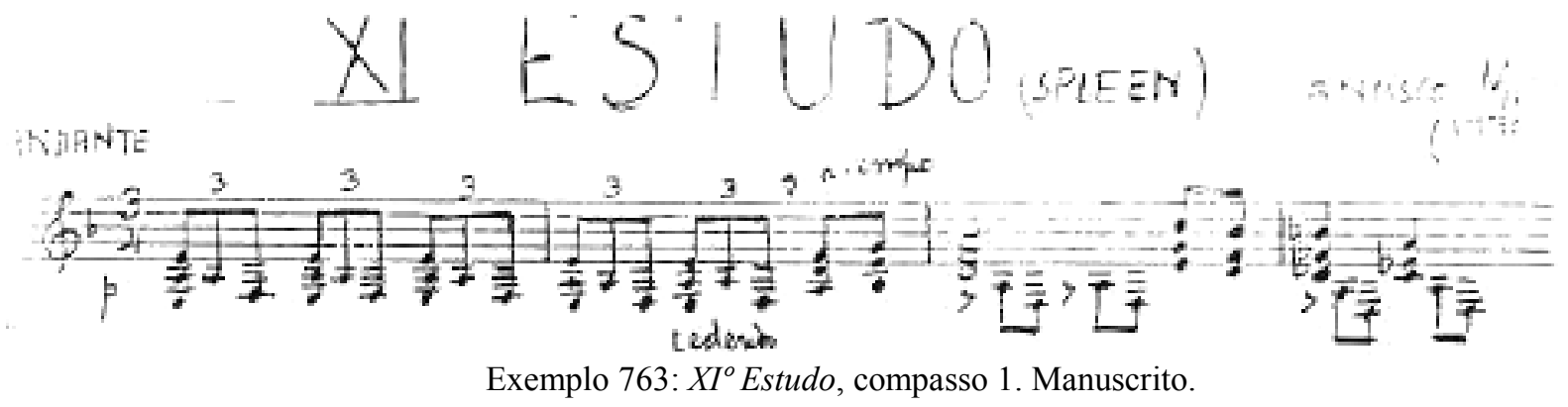

Uma pequena introdução na região grave impõe a rítmica de tercinas que permeará boa parte da obra. Nela, BL opta pela colocação inteligente de ligados defasados (ou seja entre notas não contíguas). Essa sugestão é mantida nos exemplos 765 e 766 apenas uma opção alternativa de me (onde os dedos 2 e 1 oferecem mais firmeza ao ligado) e duas de $m d$. O exemplo 767 apenas registra uma versão sem ligados.

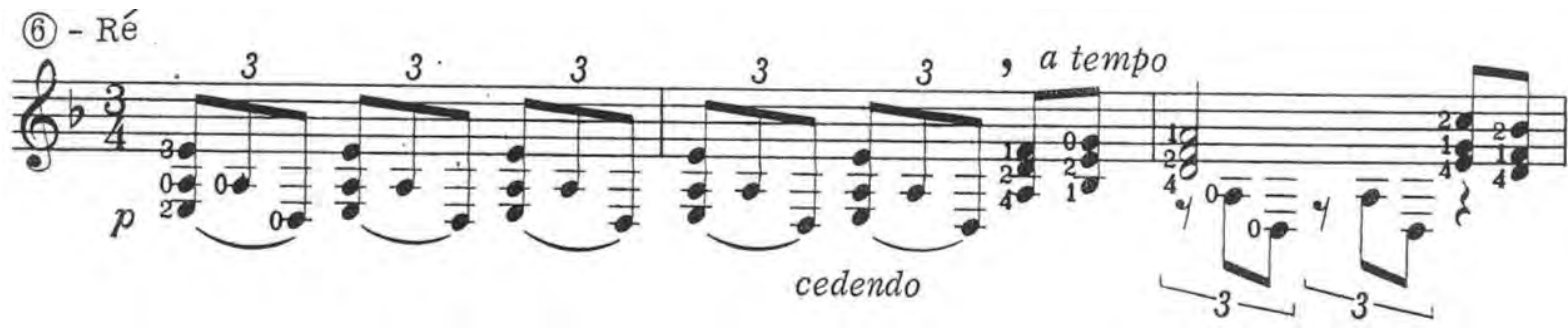

Exemplo 764: XI Estudo, compasso 1. Ed. Columbia/BL. Comp. 1 com ligados defasados

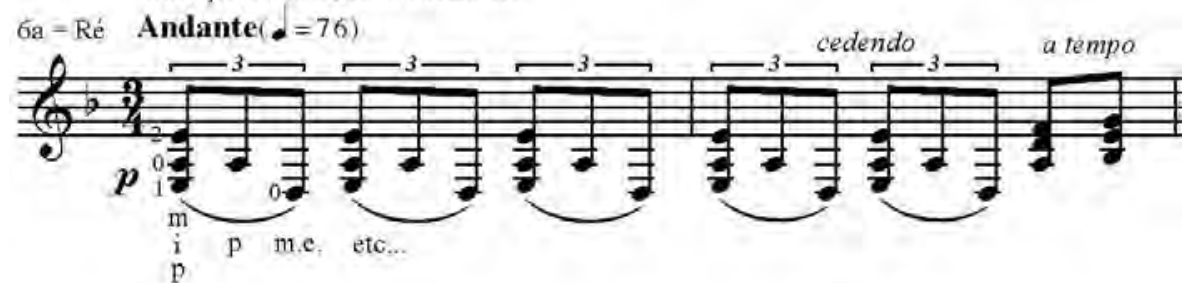

Exemplo 765: XI Estudo, compasso 1. 


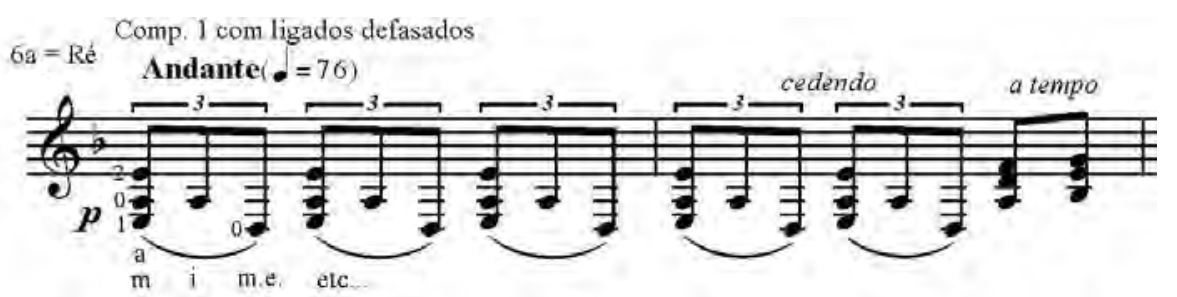

Exemplo 766: XI Estudo, compasso 1.

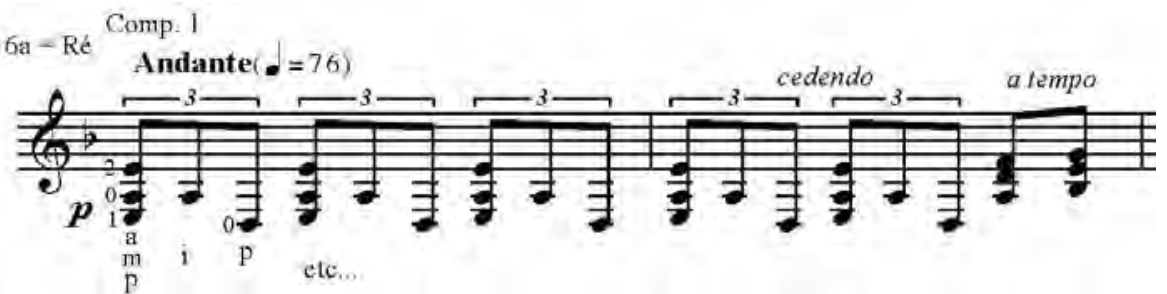

Exemplo 767: XI Estudo, compasso 1.

A primeira seção oferece dificuldades por trabalhar com melodia de acordes principalmente quando eles estão nas cordas graves, como é o caso das anacruses para os compassos 3 e 5. Nelas BL (ex. 768) digita sempre o primeiro acorde longe e desconectado dos demais, atitude arriscada ainda que esses saltos funcionem. Além disso, ele inclui ligados entre as vozes superiores e inferiores de certa forma alinhados com a introdução, mas os apresenta em alguns momentos e em outros não, faltando portanto unidade a este procedimento.
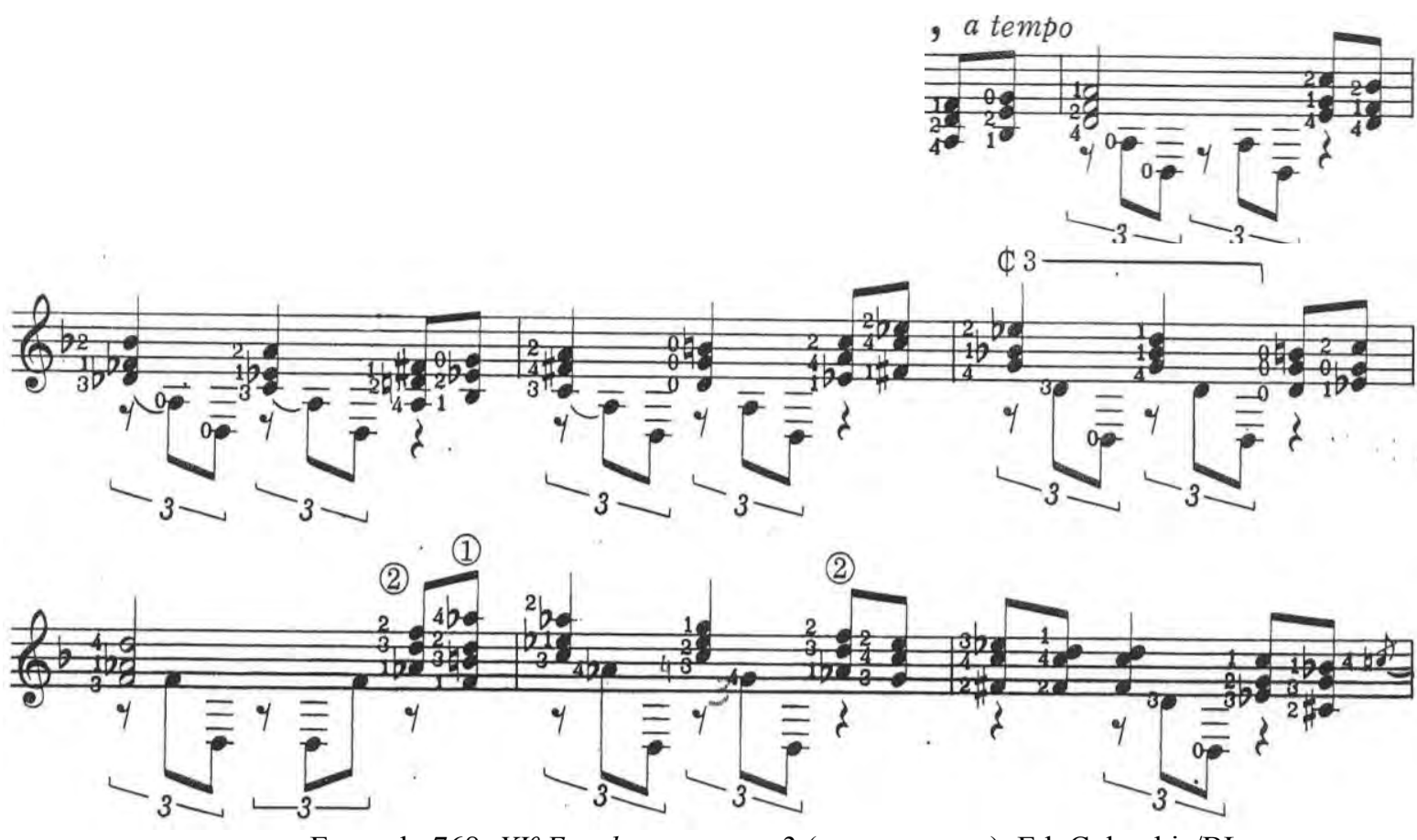

Exemplo 768: XI Estudo, compasso 3 (com anacruse). Ed. Columbia/BL.

Os exemplos 769 e 770 tratam da primeira anacruse. O primeiro deles digita os dois acordes anacrústicos na região central, aliviando os saltos pela presença de cordas soltas, sem contudo apresentar grande melhora. Esse exemplo inclui ligados no acompanhamento grave, caso desejado. $\mathrm{Na}$ impossibilidade de oferecer outras opções a esta anacruse, o exemplo 770 regista uma Ossia, com a retirada apenas de uma nota do primeiro acorde. 


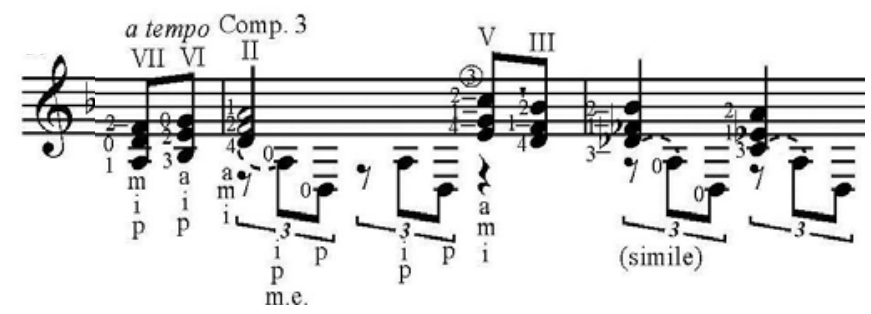

Exemplo 769: XI Estudo, compasso 3.

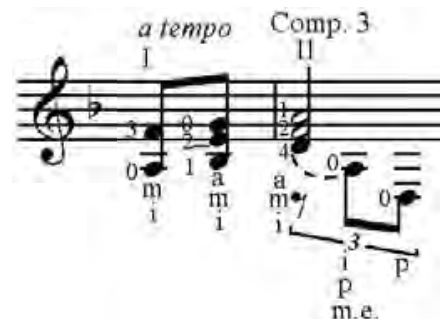

Exemplo 770: XI Estudo, compasso 3.

Os exemplos 771 e 772 demonstram a mesma lógica aplicada à anacruse do compasso 5 , o primeiro pela região central com cordas soltas e o segundo aliviando uma nota do primeiro acorde. O exemplo 771 também experimenta outra digitação para os compassos seguintes, mais pautada no aproveitamento de cordas graves, sem necessariamente ser superior à proposta de BL. Ela também inclui ligados opcionais no acompanhamento baseados em BL.

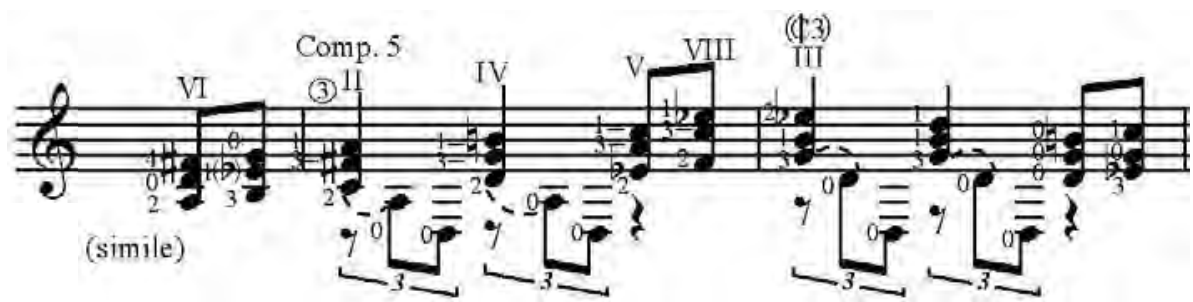

Exemplo 771: XI Estudo, compasso 5.

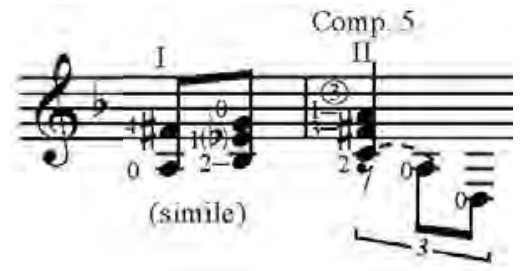

Exemplo 772: XI Estudo, compasso 5.

O trecho iniciado no compasso 7 por sua vez permite múltiplas versões, a primeira delas parte de algumas ideias de BL mas modifica ${ }^{152}$ outras, como os dedos da anacruse inicial, o uso do Fá na quinta corda, a pestana na quarta casa, e os dedos do final da descida. Em todos os nossos exemplos aconselhamos a supressão de uma nota no primeiro acorde do compasso 7 , já que a mesma será reiterada logo em seguida pela voz inferior. Também registra-se uma nota grave advinda do manuscrito e omitida na edição BL por não ter caráter estrutural.

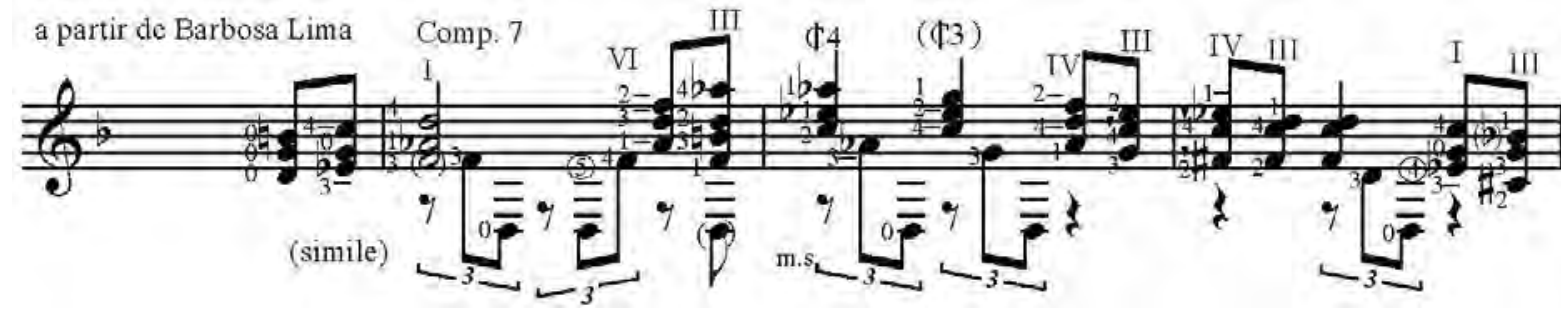

Exemplo 773: $X I^{\circ}$ Estudo, compasso 7.

\footnotetext{
152 verbo do checklist de Osborn.
} 
O exemplo 774 utiliza mais pestanas na parte inicial, transladando-as conforme a necessidade. Seu desfecho, de caráter experimental, utiliza posições avançadas para descer sempre pela terceira, quarta e quinta cordas. $\mathrm{O}$ exemplo seguinte apenas registra a possibilidade de uma Ossia facilitadora aplicável ao exemplo anterior.

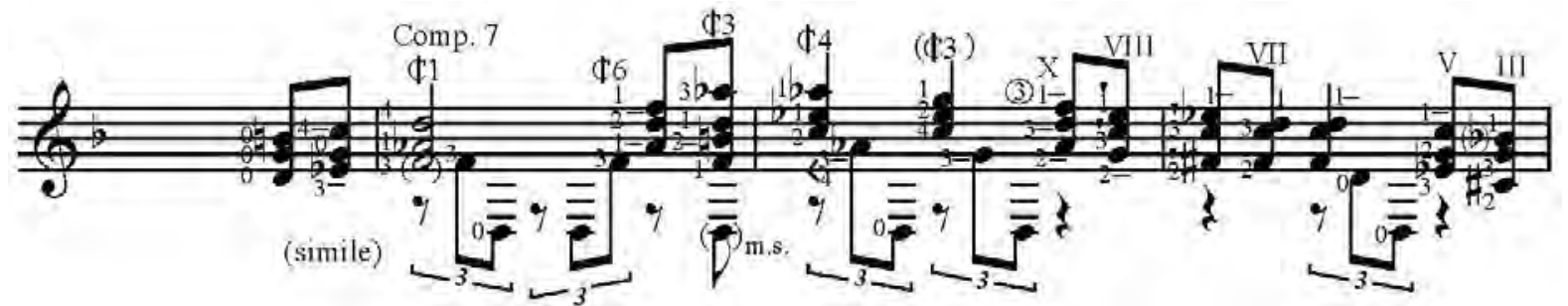

Exemplo 774: XI Estudo, compasso 7.

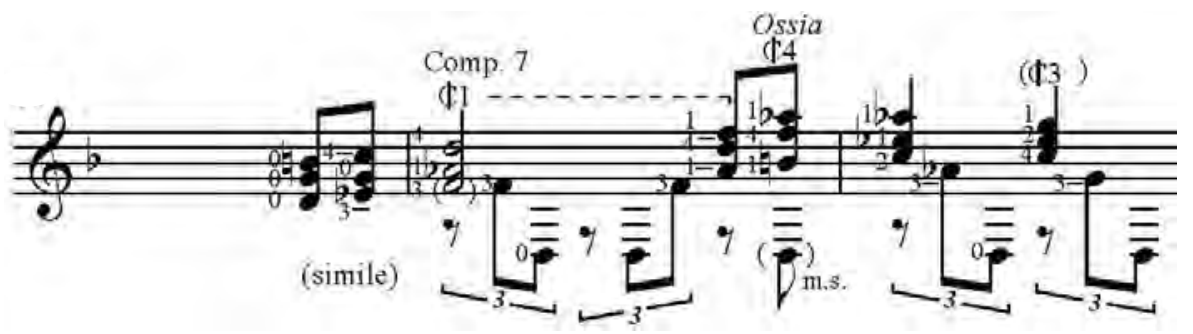

Exemplo 775: XI Estudo, compasso 7.

O exemplo 776 experimenta o uso de cordas graves na anacruse, enquanto o desfecho coloca um acorde do compasso 8 na primeira posição, sem grande alteração no trecho.

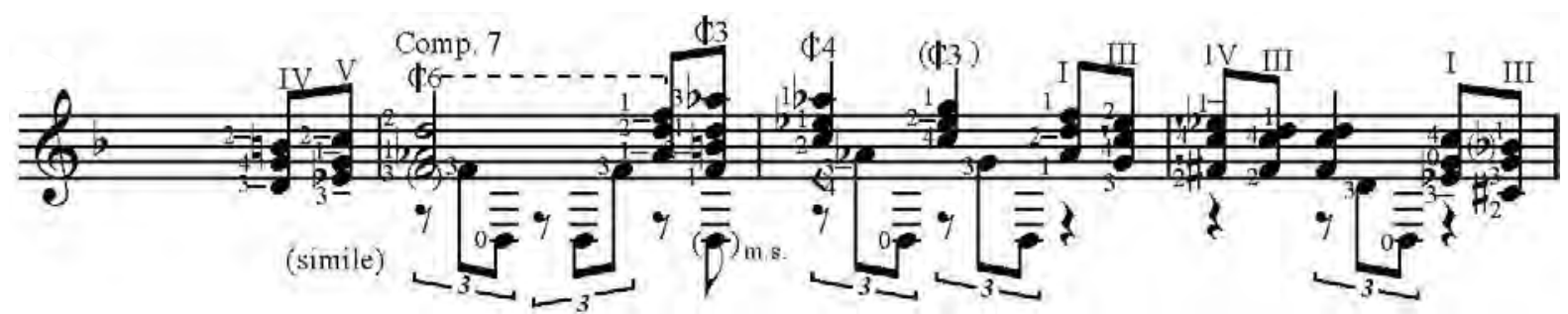

Exemplo 776: $X I^{\circ}$ Estudo, compasso 7.

O exemplo 777 aplica a ideia de ligados de BL a este trecho e o 778 facilita esta ideia pela inclusão de nota no início do compasso 7 e também inclui a Ossia anteriormente exposta no final deste mesmo compasso.

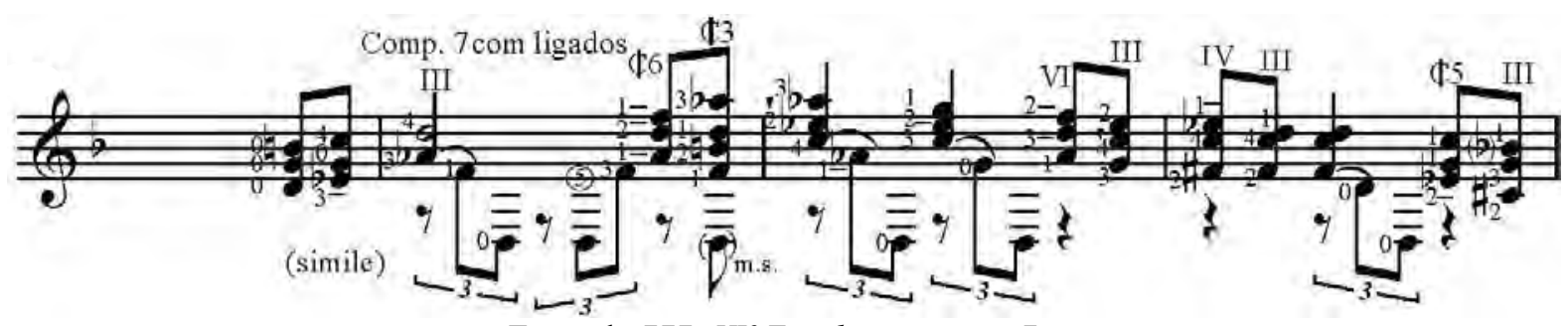

Exemplo 777: XI Estudo, compasso 7. 


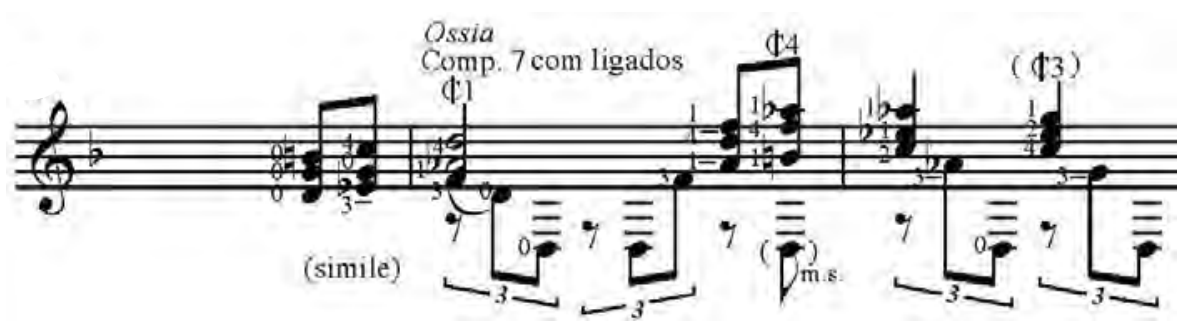

Exemplo 778: XI Estudo, compasso 7.

No final desta mesma seção os acordes não somente atingem região grave, mas recebem notas melódicas e novas notas no acompanhamento (antes normalmente circunscrito a cordas soltas), criando novas dificuldades, especialmente no compasso 13 e 14, com grandes e anti-anatômicas aberturas. Nossa única versão alternativa (ex. 780) prevê a exclusão de um baixo nesses acordes, sem grande prejuízo em nossa opinião.

A seção seguinte (iniciada anacruse para o compasso 15) é consideravelmente mais fácil, já que a melodia volta a ser monódica e os acordes passam para o acompanhamento. No exemplo 781 propusemos algumas alterações na digitação BL e registramos uma nota advinda do manuscrito, que agrega pequena dissonância ao trecho.
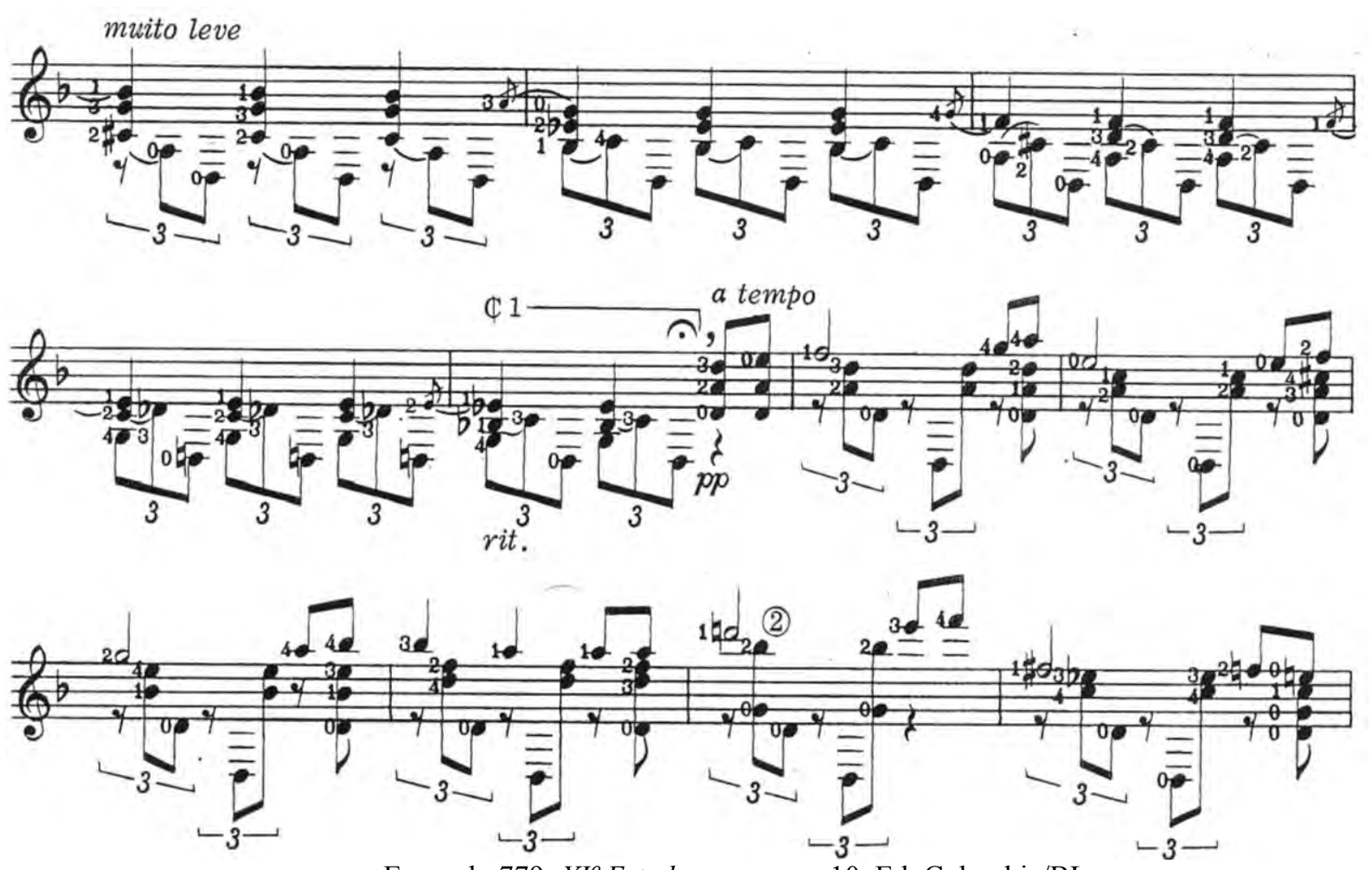

Exemplo 779: $X I^{\circ}$ Estudo, compasso 10. Ed. Columbia/BL.

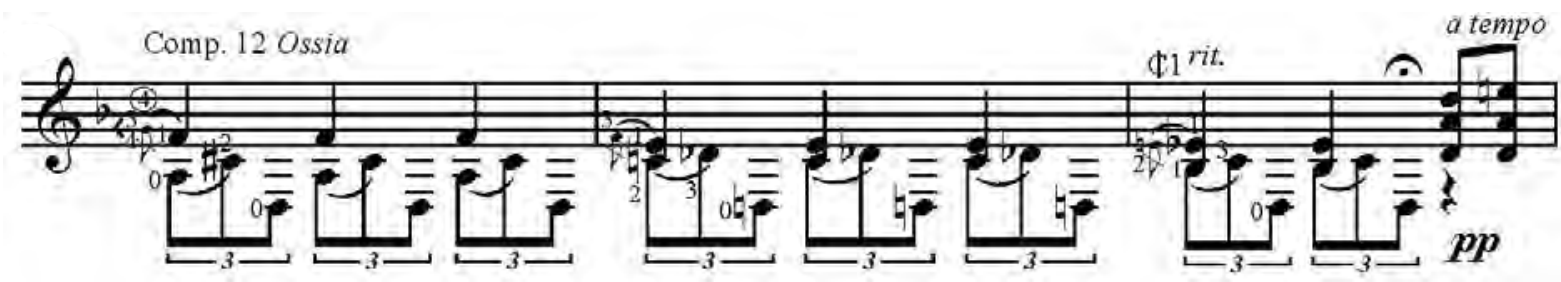

Exemplo 780: XI Estudo, compasso 12. 

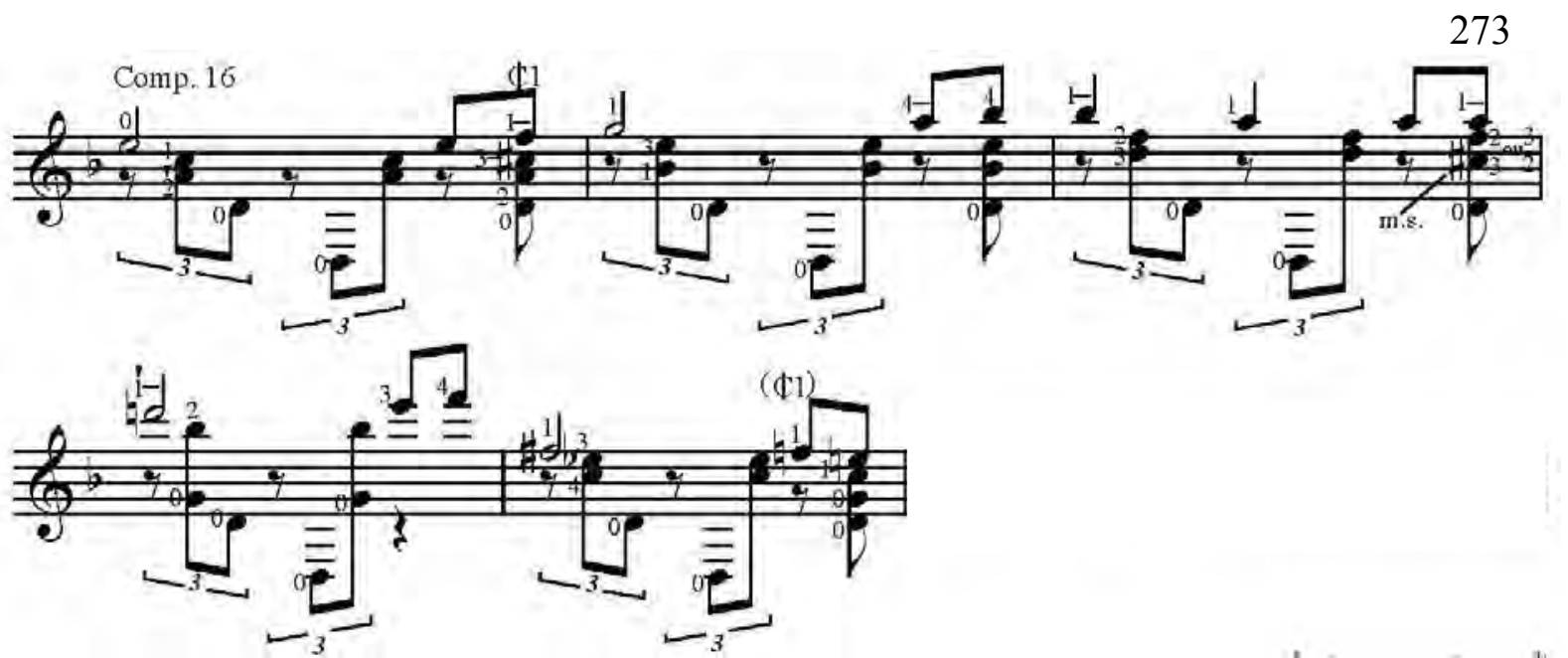

Exemplo 781: XI Estudo, compasso 16.

Esta seção também atinge a região grave conforme seu desfecho se aproxima e visa dar encaminhamento à um novo trabalho a partir do compasso 26. Ela ainda é marcada por tercinas e apresenta um pequeno fragmento cadêncial sob a indicação de "rubato senza rigore di tempo". A abordagem de BL (ex. 782) é bastante tradicional e funcional, trabalhando nas casas iniciais do violão e com ligados nas tercinas.

Nossa única versão alternativa para o trecho integral (ex. 783) propõe uma digitação em campanella pela utilização maior da sexta corda na melodia. A cadência coerentemente também obedece a este mesmo recurso de sustentação e um ligado é adicionado ao último compasso.
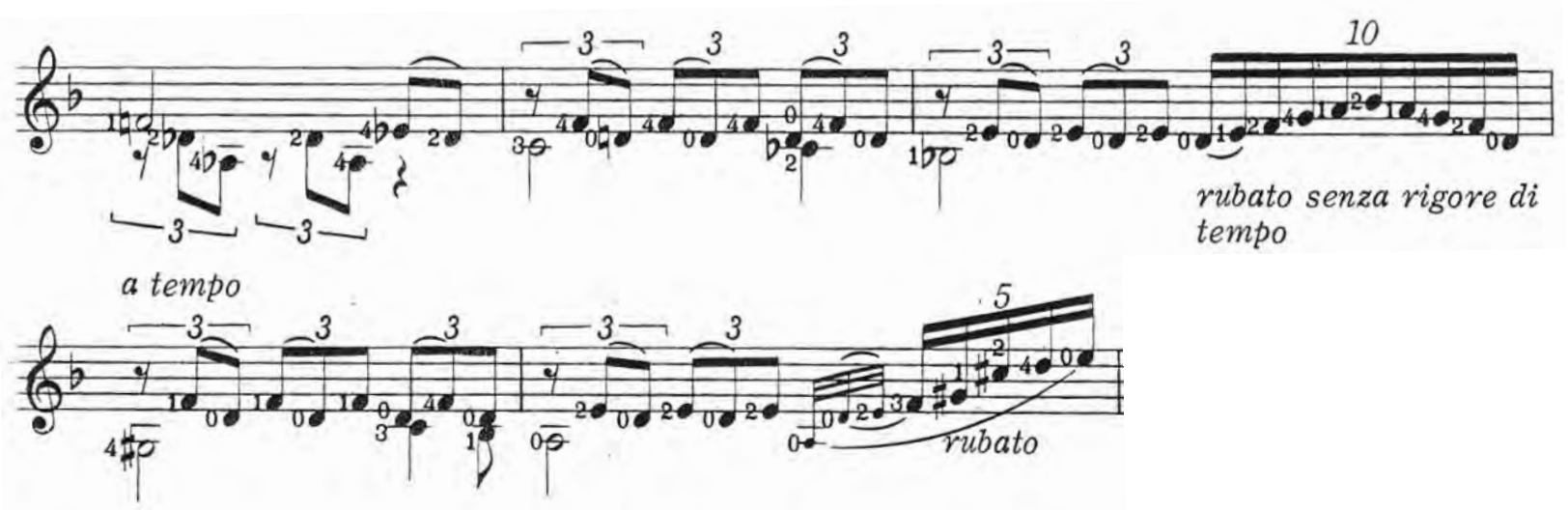

Exemplo 782: XI Estudo, compasso 21. Ed. Columbia/BL.
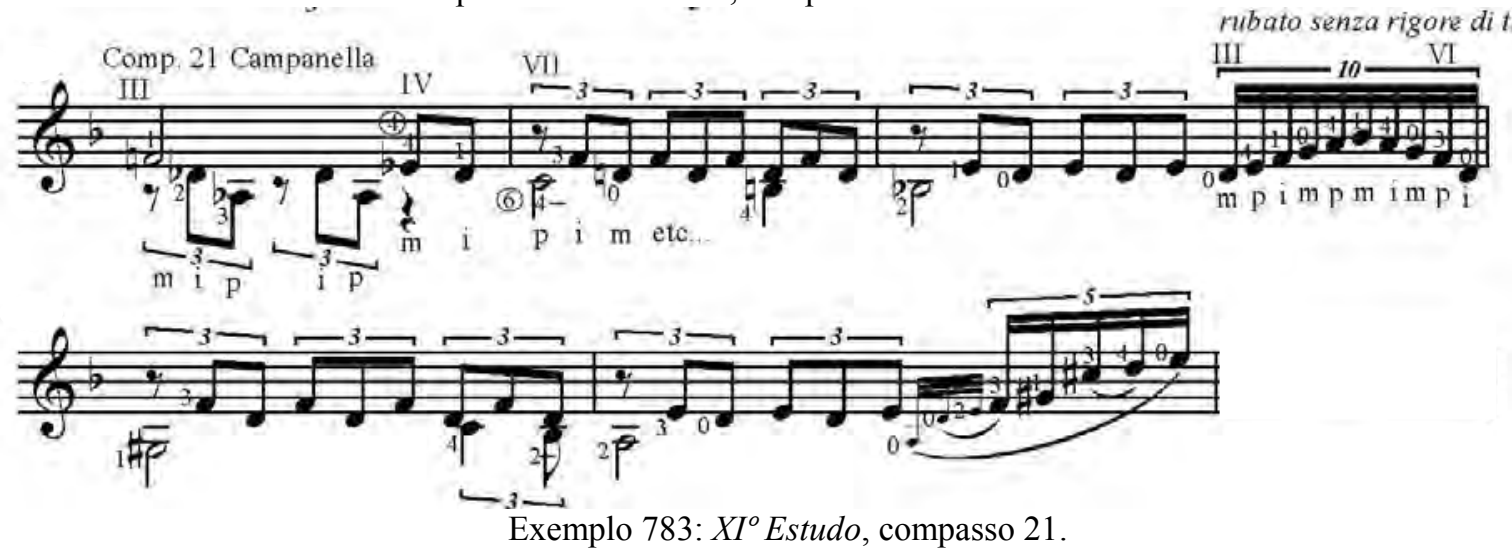
A cadência do compasso 23 ainda possibilita outras interpretações. A primeira delas (ex. 784) adiciona ligados à versão $\mathrm{BL}$, funcionando principalmente com articulações repetidas do polegar. O exemplo 785 ainda recorre à ligados múltiplos, mas aproveita cordas soltas, ainda sendo favorável ao uso do polegar, enquanto o exemplo 786 retira os ligados da versão anterior para propor uma articulação integral das notas pela $m d$ em padrão ternário $(p-m-i)$, sem com isso encerrar as possibilidades para este pequeno gesto musical.

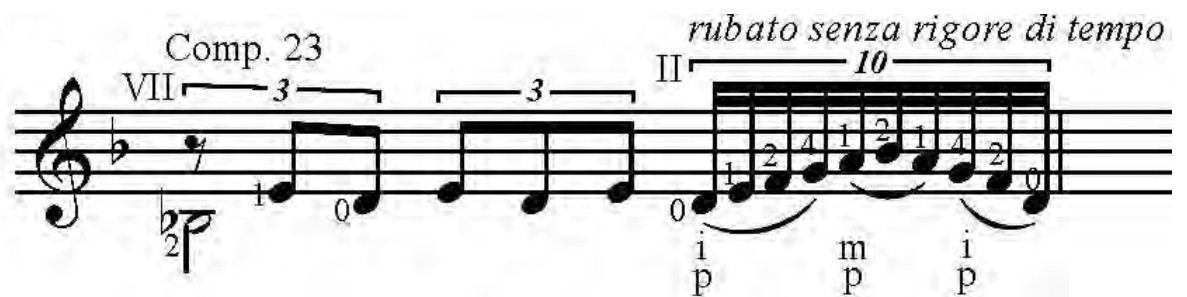

Exemplo 784: XI' Estudo, compasso 23.

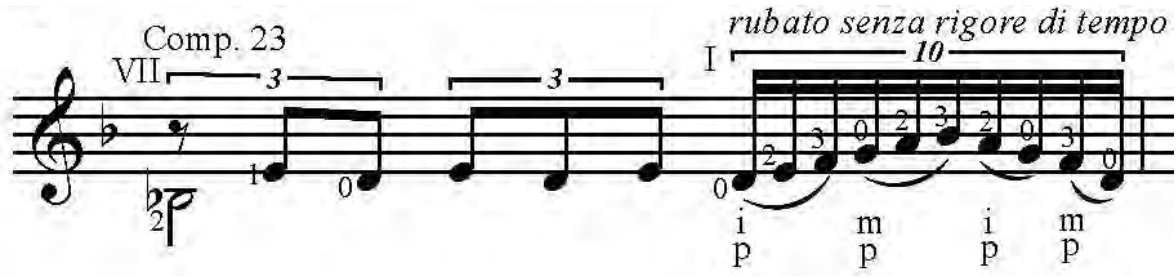

Exemplo 785: XI Estudo, compasso 23.

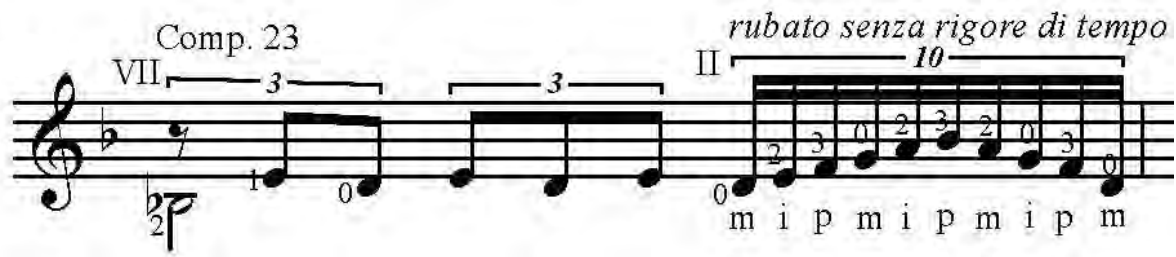

Exemplo 786: XI Estudo, compasso 23.

Segue-se um interessante e belíssimo trecho com motivo em quiálteras de 7 a partir do compasso 26, bastante apoteótico. A digitação BL tem ideias coerentes mas mesmo assim algumas pequenas passagens podem ser melhoradas: o primeiro compasso pode ser facilitado pela redução ${ }^{153}$ na duração da voz interna (como no ex. 788) e o salto vertical do dedo 3 na passagem do compasso 27 para o 28 pode ser evitado pelo acréscimo de uma pestana (como no ex. 789). O exemplo 790 vem apenas registrar outra possibilidade para o compasso 30 .

${ }^{153}$ verbo diminuir do checklist de Osborn. 
a tempo

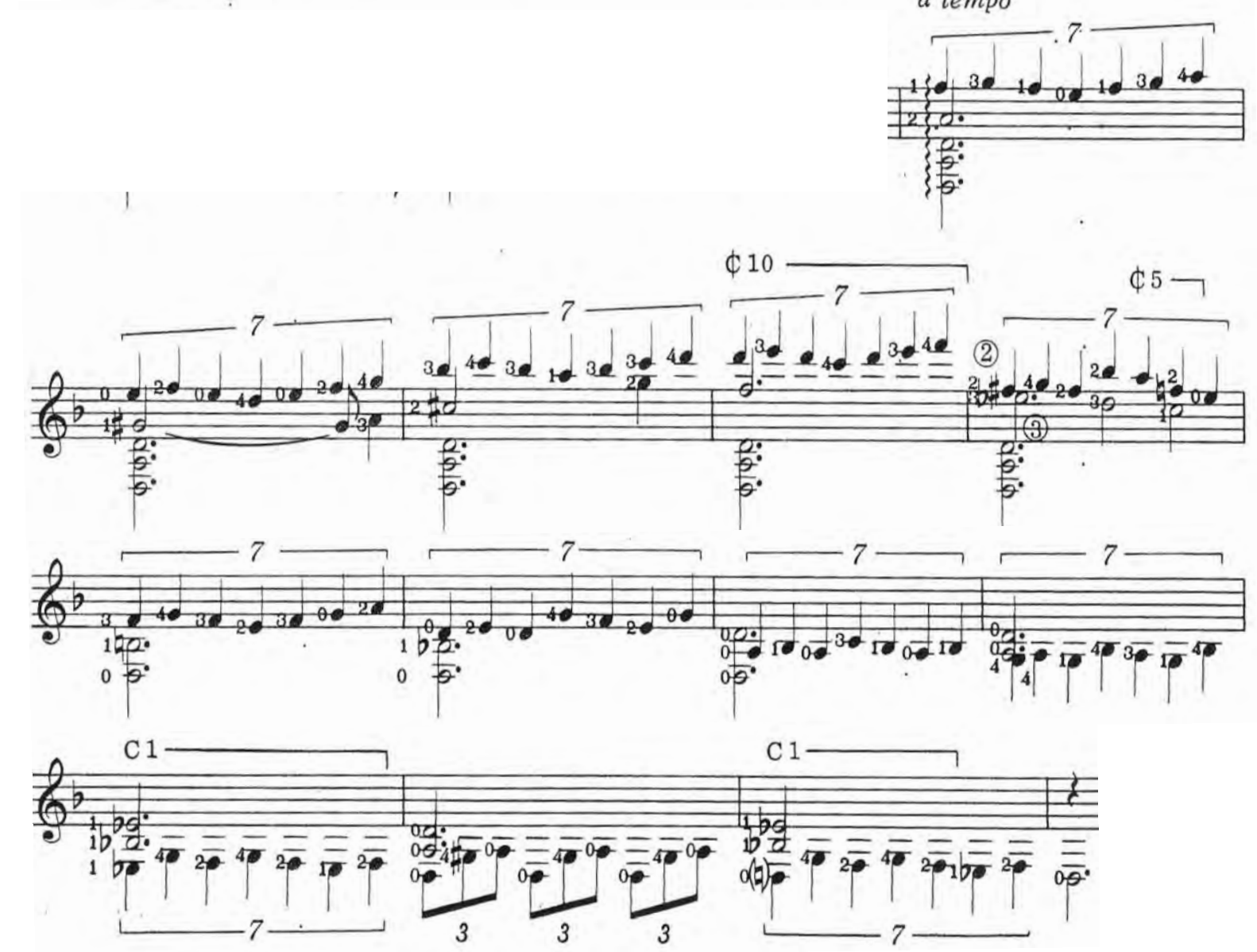

Exemplo 787: XI Estudo, compasso 26. Ed. Columbia/BL.
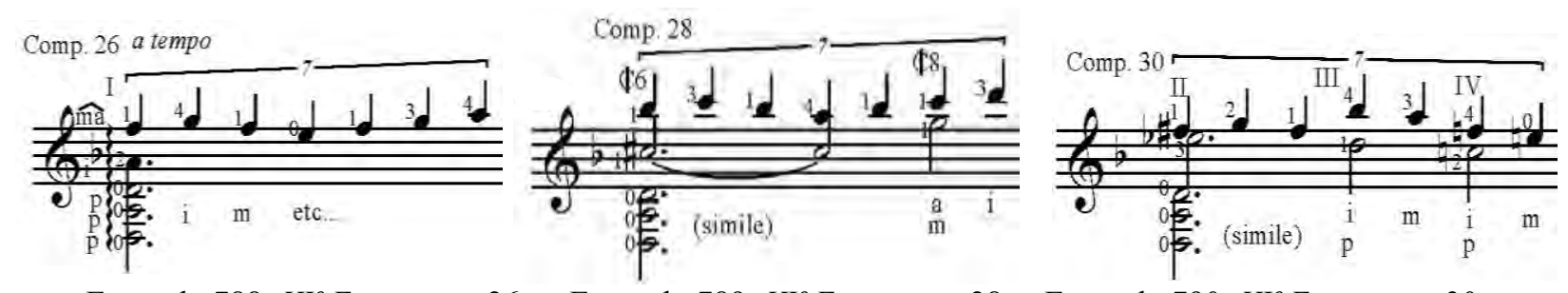

Exemplo 788: XI Est., comp. 26. Exemplo 789: XI ${ }^{o}$ Est., comp. 28. Exemplo 790: XI Est., comp. 30.

O exemplo 791 oferece visão completamente distinta para trecho inicial desta seção, ao digitá-la em campanellas, porém com o custo de maiores aberturas de me.

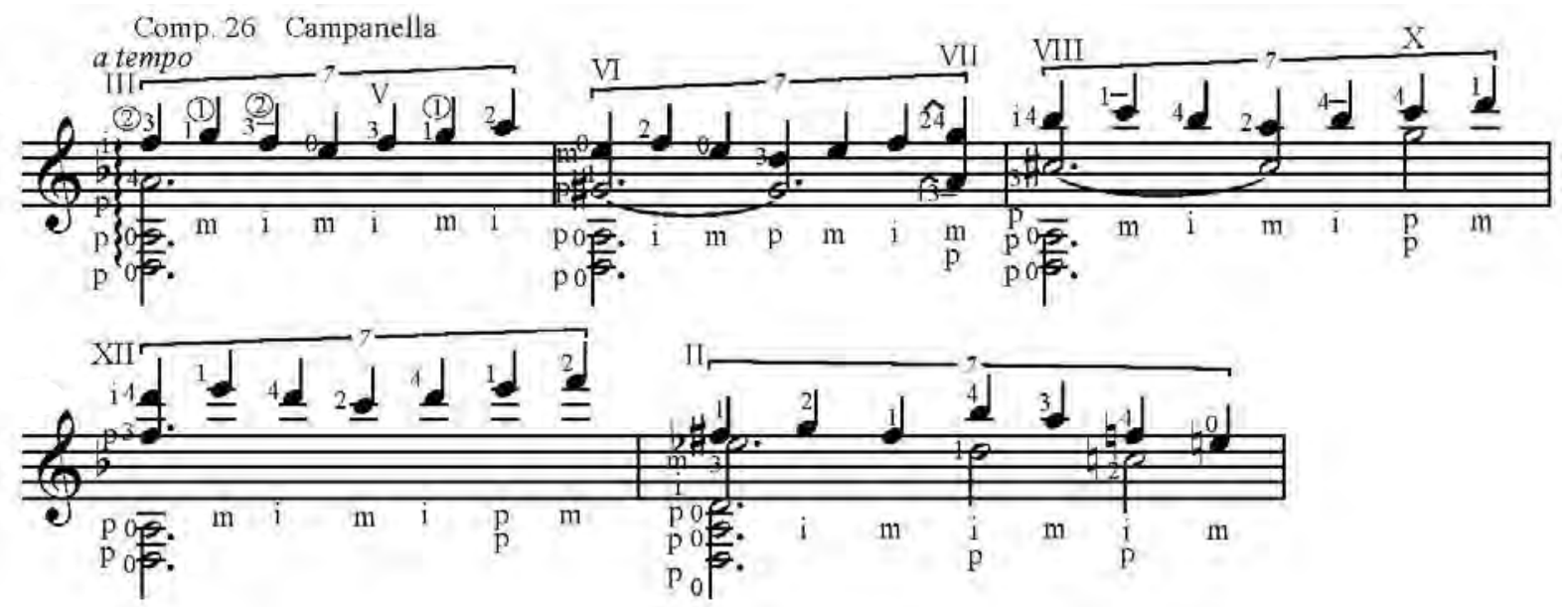

Exemplo 791: XI Estudo, compasso 26. 
Algumas modificações ${ }^{154}$ ainda são factíveis a essa proposta. O exemplo 792 reduz $^{155}$ a duração da voz intermediária do compasso 26 a fim de criar uma maior sobreposição nas últimas três notas da melodia na quinta posição. Esta experiência levou também a concepção do exemplo 793 que apresenta esta mesma sobreposição final mas inicia o compasso pela sétima posição com aproveitamento da terceira corda e com mais dedos fixos para preparar a abertura nas últimas notas. Essa ideia do aproveitamento da terceira corda e maior sobreposição das últimas notas é levada também ao compasso seguinte, mas para ser factível exige a exclusão de uma nota da voz intermediária.
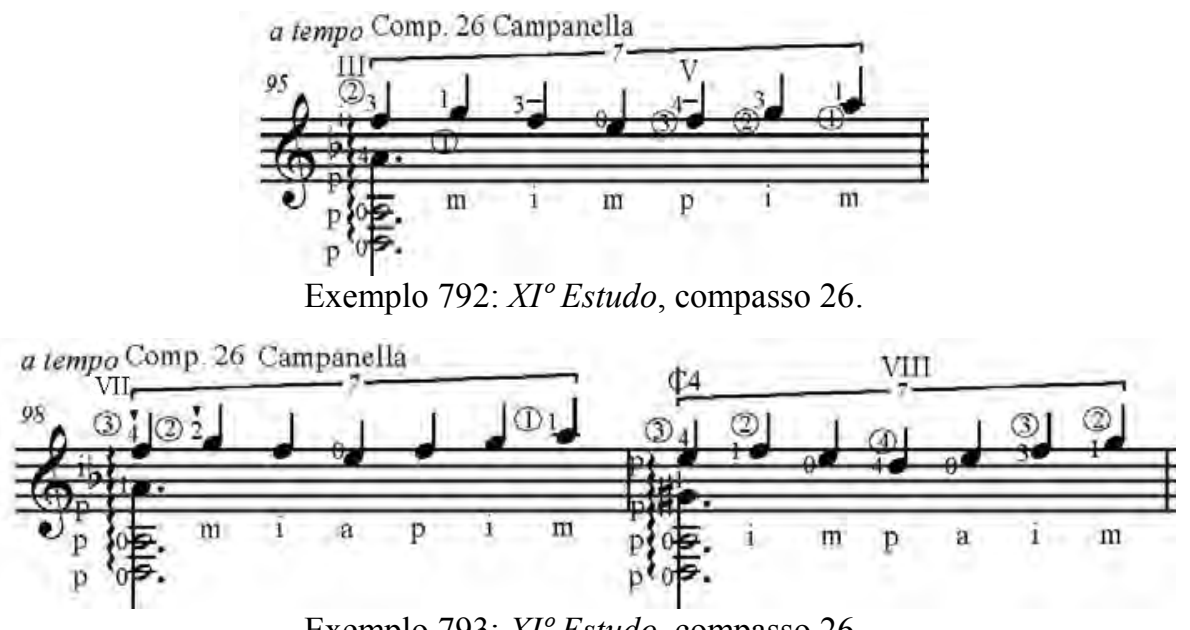

Exemplo 793: XI Estudo, compasso 26.

O exemplo 794 ainda oferece uma campanella para o compasso 30, factível, porém com amplas aberturas.

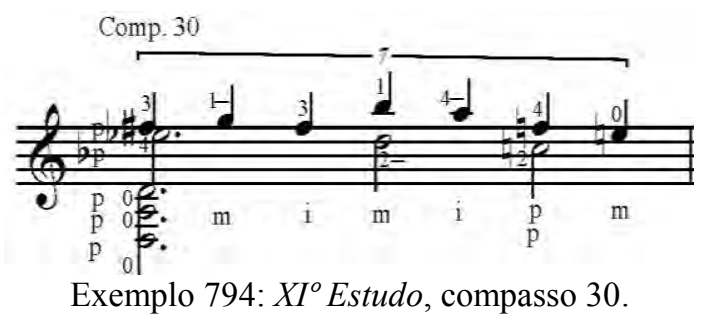

Nossa proposta para o compasso 31 tenta unificar a melodia em una corda, abdicando de algumas cordas soltas e propõe uma entrada antecipada para a sexta corda no final do compasso 33, fornecendo outra transição para o compasso seguinte.

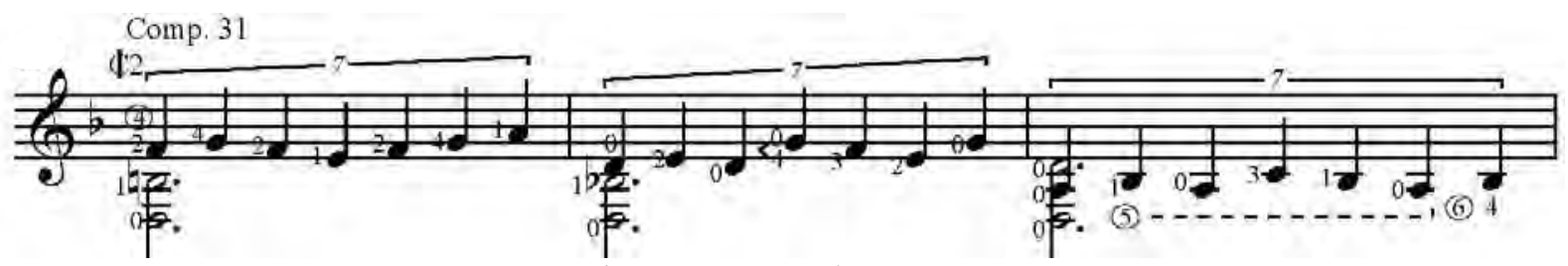

Exemplo 795: XI Estudo, compasso 31.

\footnotetext{
${ }^{154}$ verbo do checklist de Osborn.

${ }^{155}$ verbo diminuir do checklist de Osborn.
} 
Nos compassos finais desta seção a melodia atinge a primeira porção da sexta corda, exigindo aberturas inevitáveis. No exemplo 796 escolhemos dedos distintos para elas (em relação a BL) e propusemos a possibilidade de inserção de ligados nos compasso 36 (com dedos mais favoráveis a esta técnica).

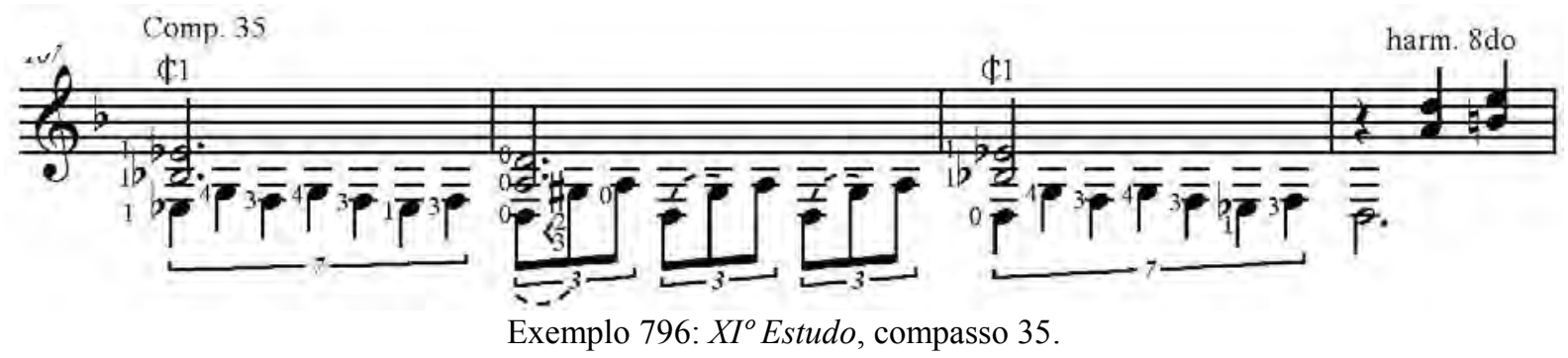

O final suspensivo e misterioso da obra é construído por melodia em harmônicos e uma rápida recapitulação modificada da introdução. Os harmônicos são abordados por BL nas duas primas o tempo inteiro levando os últimos dois compassos à primeira posição.

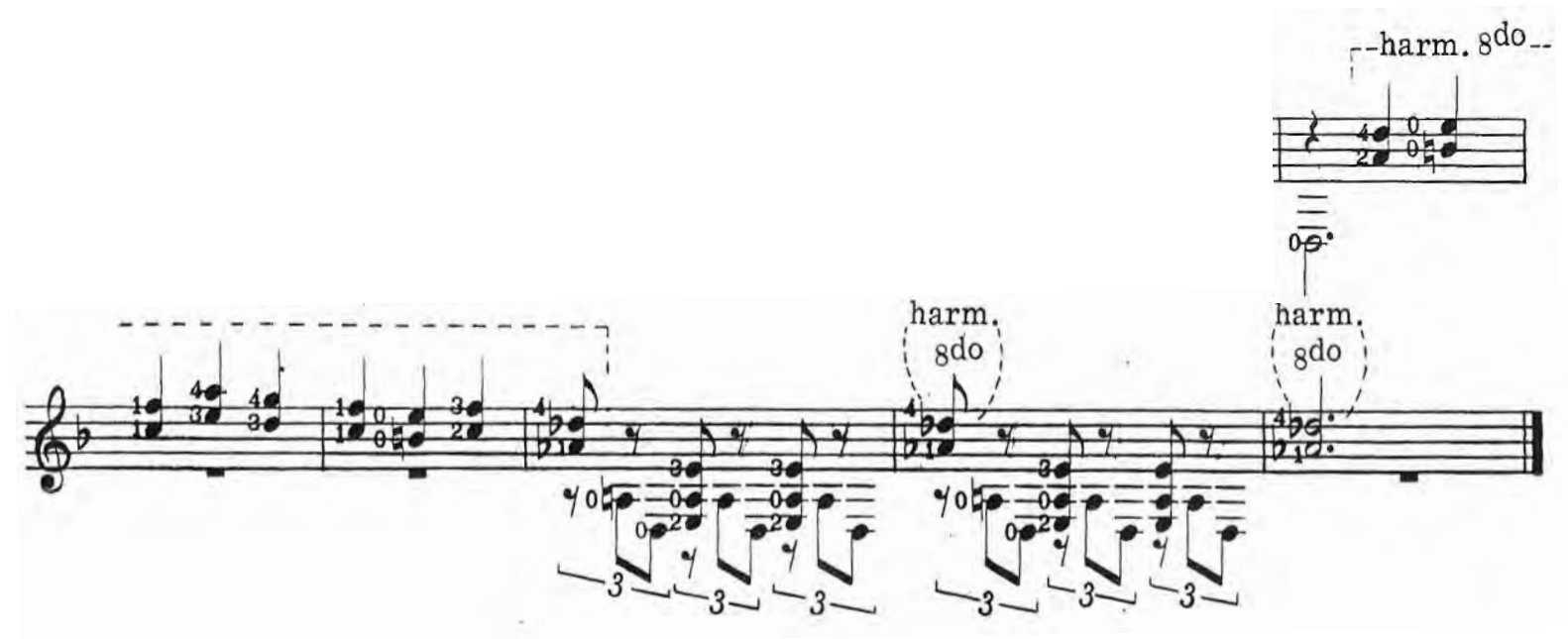

Exemplo 797: XI Estudo, compasso 19. Ed. Columbia/BL.

Uma versão pelo prof. Dr. Edelton Gloeden (ex. 798) dá maior sobreposição aos harmônicos com uma pestana na quinta casa, circunscrevendo o último deles à terceira corda e necessitando de salto para alcançar a figuração grave. Este último aspecto é modificado ${ }^{156}$ por nós no exemplo 799 , unindo as duas versões por meio de meiapestana na primeira casa. Essas duas versões apresentam ligados defasados opcionais na figuração grave para unificá-la com o início da obra.

${ }^{156}$ verbo do checklist de Osborn. 
Comp. 38 Edelton Gloeden

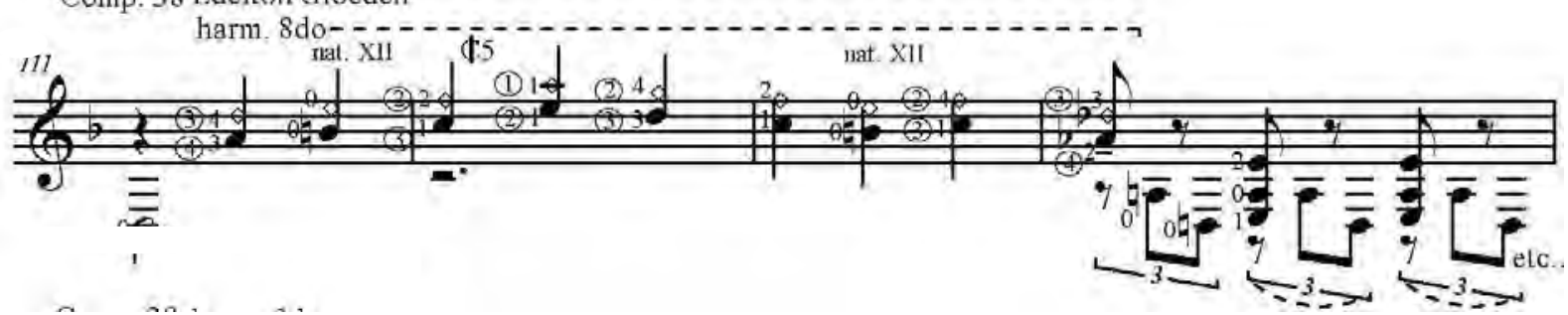

Exemplo 798: XI Estudo, compasso 38.

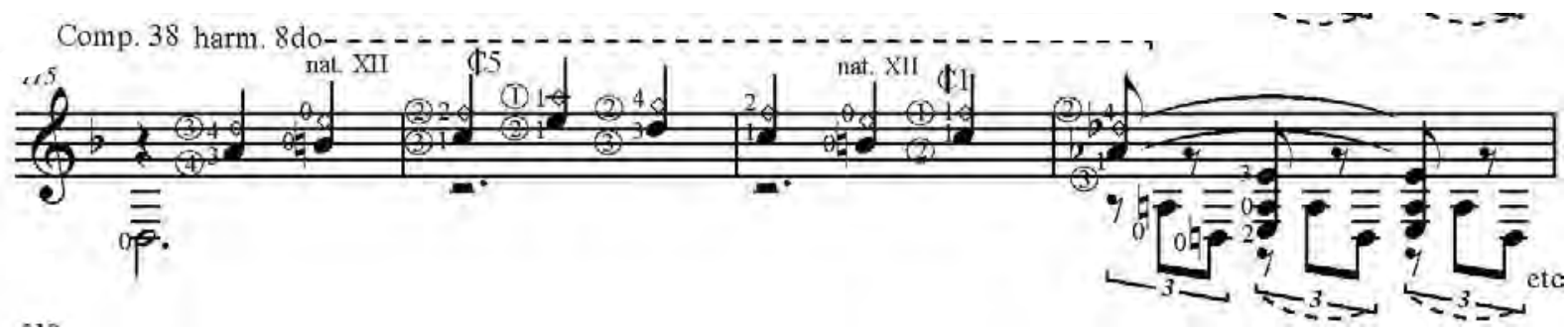

Exemplo 799: XI Estudo, compasso 38.

Caso o leitor deseje seguir os harmônicos duplos previstos no manuscrito original basta utilizar a primeira parcela da digitação BL, com o indicador inclinado pressionando às oitavas artificiais e concluir com o último compasso do exemplo 798 que também permitirá essa técnica. 


\subsection{2: XII ${ }^{o}$ Estudo "Com velocidade"}

Estudo considerado um dos mais difíceis da série, principalmente por sua extenuante primeira seção de escrita muito pianística e consequentemente pouco violonística (sobretudo para me), que trabalha acordes chapados com melodia em ligados, passagens escalares, arpejos e finaliza-se com uma interessante rememoração do tema melódico no baixo com intervenções de acordes dissonantes. A seção contrastante é diametralmente mais simples, com melodia (em décimas e oitavas) quase "folclórica" (segundo Apro, 2004, p.111), com provável propósito de dar descanso ao intérprete. Após repetição da primeira seção, o tema quase folclórico retorna, dessa vez levemente modificado e em acordes mais cheios sob a indicação molto arpeggiato, finalizados com súbita escala descendente e acordes sforzando.

Objetivando dar fechamento virtuosístico a série, este estudo demanda um andamento veloz em uma estrutura pouco orgânica para o instrumento gerando grandes dificuldades. Com certo exagero, ganhou junto à comunidade violonística a fama de que seus obstáculos seriam quase instransponíveis. Possivelmente, boa parte da disseminação dessa impressão se deu pelo relato de Sérgio Abreu que teve a oportunidade de escutar todos os doze estudos tocados ao piano pelo próprio compositor em audição informal a época de sua composição, ficando impressionado com a velocidade do último estudo, declarando-a improvável de ser alcançada no violão:

\footnotetext{
Me lembro que ele tocou o último Estudo num andamento rapidíssimo, de esplêndido efeito, mas totalmente impossível de se conseguir no violão. Comentei isso com ele e ele ponderou que, se necessário, poderia ser tocado num andamento um pouco menos rápido (Apro, 2004, anexos).
}

Sérgio Abreu também comenta a redução de andamento impresso na edição Columbia após revisão de Barbosa-Lima, declarando que "o novo andamento indicado ficou muito mais apropriado em termos de técnica violonística, mas havia muito mais sentido musical na maneira vertiginosa e arrebatadora como o Mignone o tocou" (Apro, 2004, anexos).

Como tal performance infelizmente não foi registrada em áudio, é impossível saber exatamente qual era este andamento na performance pianística do compositor, mesmo assim, a obtenção de uma agilidade condizente é o primeiro problema a ser resolvido neste estudo. Acreditamos que o emprego do Pensamento Divergente aliado aos conceitos anteriormente relacionados pode propiciar soluções para a obtenção de um andamento minimamente virtuosístico, baseado na informação metronômica indicada pelo compositor. 
Com estes esclarecimentos, eis, portanto, os dois primeiros compassos do $X I I^{\circ}$ Estudo:

\section{a Barbosa-Lima \\ $\mathrm{XII}^{\circ}$ ESTUDO}

Fingered by

Carlos Barbosa-Lima

Com velocidade $(d=100)$

FRANCISCO MIGNONE

(1970)
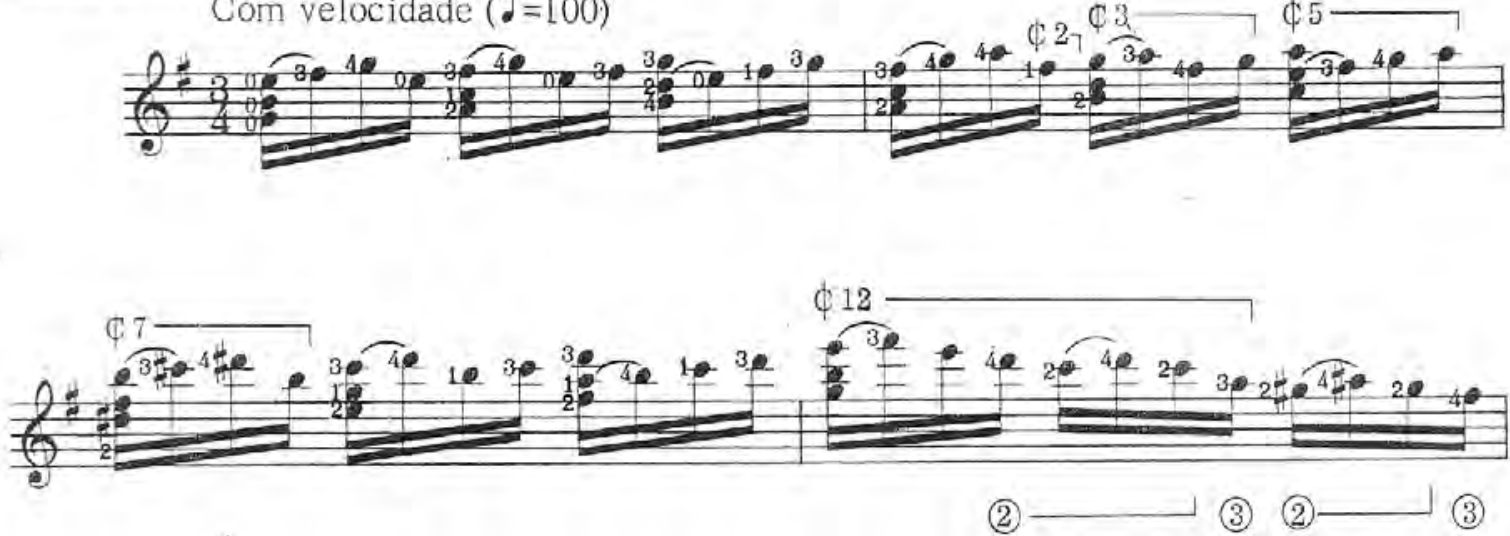

Exemplo 800: XII ${ }^{\circ}$ Estudo, compasso 1. Ed. Columbia/BL.

Tratando-se de uma frase musical de extrema dificuldade, faremos uso da lei Heurística da subdivisão de problemas e assim, analisaremos as opções compasso a compasso e também discutiremos o funcionamento das mãos separadamente, o que consequentemente facilitará a comunicação com o leitor.

A digitação BL (de ambas as mãos) é funcional, podendo-se compreender sua lógica de pensamento, que parece buscar a duração de semínima na maioria dos acordes da frase. No que tange a me, no compasso 1 (ex. 801) ele opta pela compressão da mão para a utilização dos dedos 3 e 4 e preconiza o dedo 3 como guia. Embora viável, estes dedos são menos ágeis e o uso reincidente (principalmente do dedo 4) torna a frase extenuante, sendo aconselhável deixar seu uso apenas quando estritamente necessário.

No entanto, a dificuldade mais considerável é a ocorrência de um ligado no dedo 3 no terceiro tempo. A escolha deste dedo é decorrência de sua chegada por dedo guia, mas este ligado nos parece ser desconfortável para a maioria dos violonistas, já que o dedo 3 está comprimido pelos dedos 2 e 4, que seguram as notas mais graves do acorde.

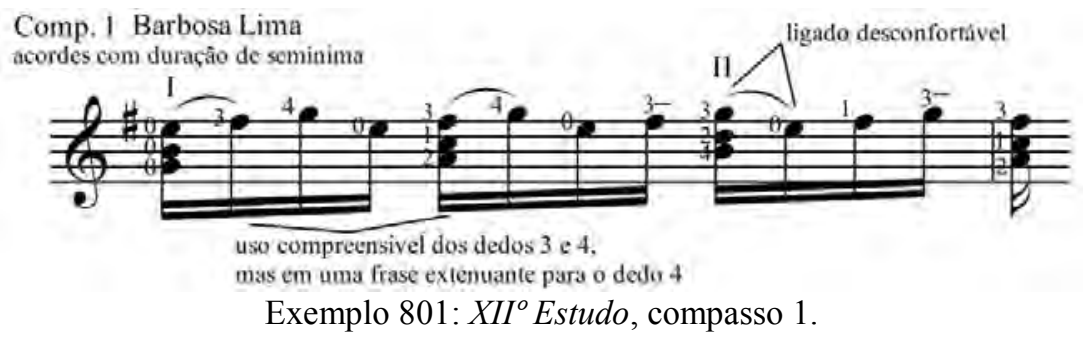


Buscando melhorar estes aspectos nossa primeira solução substitui os dedos do primeiro tempo e inclui uma pestana no terceiro, transformando um ligado descendente em ascendente:

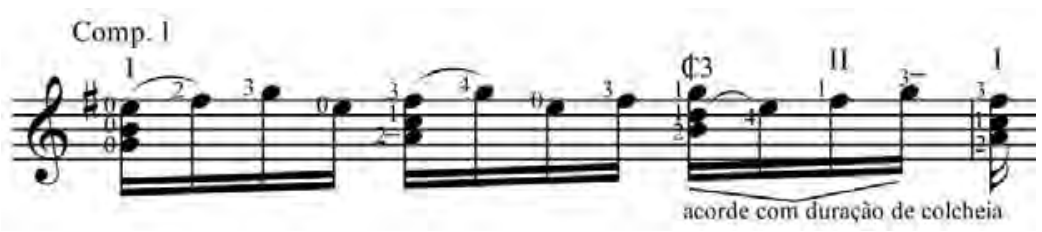

Exemplo 802: XII Estudo, compasso 1.

Embora já proporcione uma maior leveza geral para a me, a inclusão da pestana e ligado ascendente no terceiro tempo acarretam uma rápida mudança da posição 3 para a 2, para se tocar duas últimas notas do compasso, o que gera também uma menor duração do acorde (o que para nós é defeito secundário). É possível tocar essas mesmas notas na terceira posição e com duração integral do acorde, porém com o prejuízo de uma abertura um pouco desconfortável quando somada a pestana, embora ainda funcional:

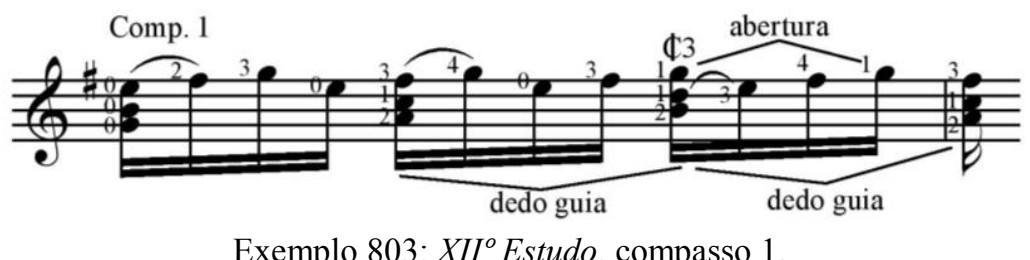

A próxima opção nos parece a mais leve para o terceiro tempo por propiciar boas mudanças de posição, ainda com dedos guias nos mesmos locais de Barbosa-lima e com pouco prejuízo na duração dos acordes:

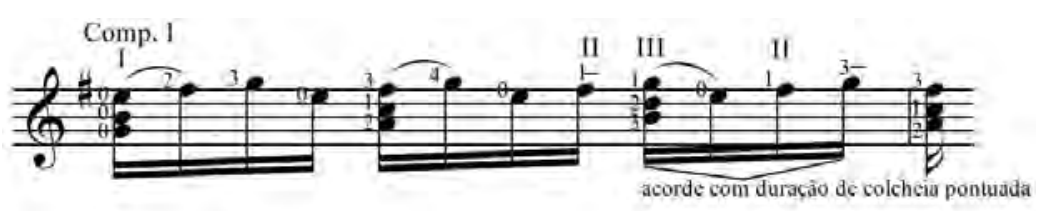

Exemplo 804: XII Estudo, compasso 1.

Não satisfeitos ainda somos impelidos a testar outras ideias. A primeira delas passa a melodia superior para a segunda corda, gerando não somente uma ausência de cordas soltas, mas também muitas mudanças de posição e trocas de dedos (para conseguir dedos guias) e por isso são menos ágeis.

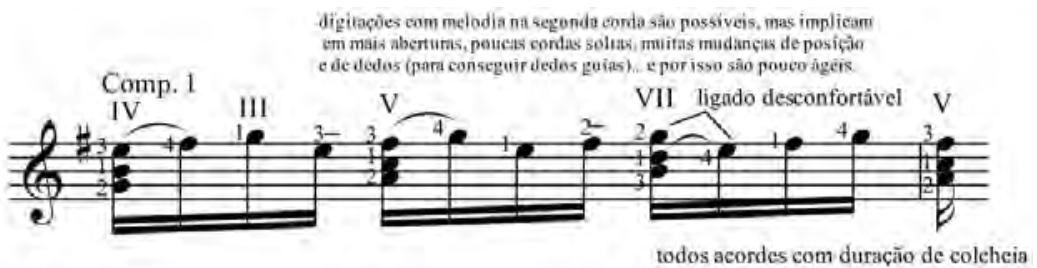

Exemplo 805: XII Estudo, compasso 1. 
No entanto, essa digitação nos leva a outra ideia, a de usar o efeito de campanella sempre que possível, com duas opções digitacionais nas mesmas posições:
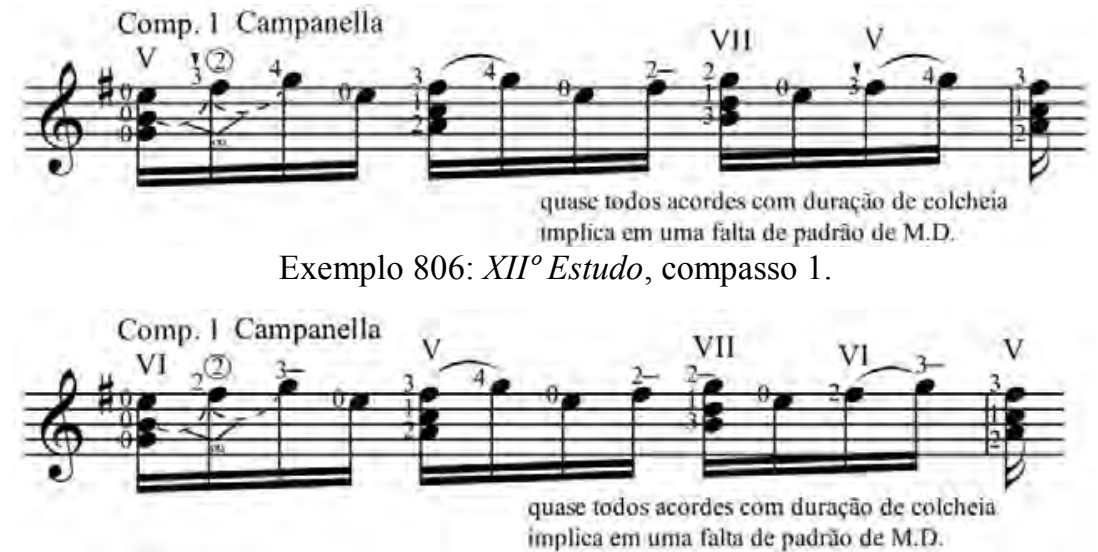

Exemplo 807: XII ${ }^{\circ}$ Estudo, compasso 1.

Essa atitude cria melhoras visíveis na versão anterior em termos de me, ainda havendo mais uma possibilidade através da modificação ${ }^{157}$ da parte final do trecho com a utilização de mais cordas soltas e também integrando a terceira corda na condução de algumas notas da melodia, ainda com resultado similar a anterior, mas com o prejuízo de um salto da quinta para décima posição:

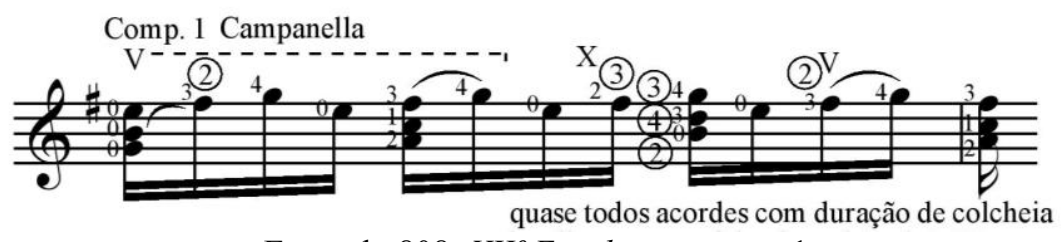

Exemplo 808: XII ${ }^{\circ}$ Estudo, compasso 1.

Todas essas digitações em campanella, para serem fluidas, requerem o uso de um ligado nas últimas semicolcheias do compasso. Isso, somado à distribuição da melodia em várias cordas pode reduzir a unidade sonora do trecho (algo que conjecturamos ser possivelmente superado pelo estudo e/ou até mesmo imperceptível quando tocado no andamento).

Outro problema dessas versões é que, a primeira vista, há uma falta de padrão na md (se articulada da forma convencional), porém também conseguimos mapear diferentes digitações para essa mão que serão pormenorizadas posteriormente.

Se o primeiro compasso já era penoso, a partir do segundo a maior ocorrência de pestanas cria ainda maiores dificuldades e conforme a passagem vai ficando mais aguda menores são as opções digitacionais. A digitação BL parece objetivar uma mudança sempre ascendente de posições:

${ }^{157}$ verbo do checklist de Osborn. 


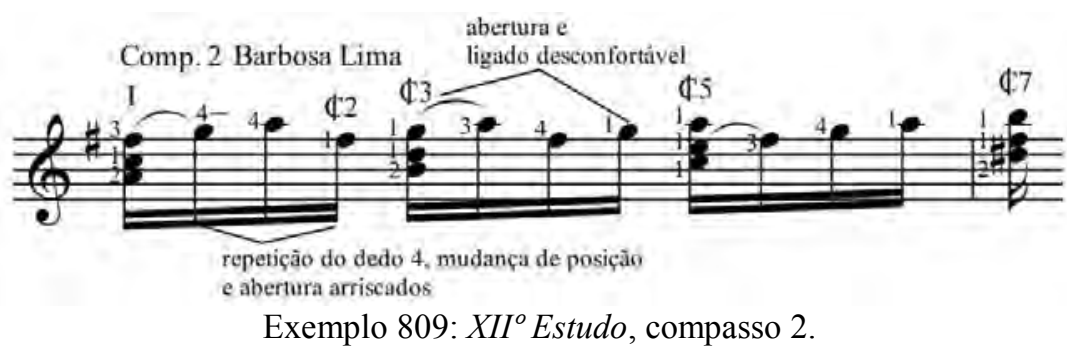

A primeira opção tenta oferecer alternativa digitacional à abertura com ligado desconfortável do segundo tempo, mas faz isso ao custo de mais mudanças de posição, em ritmo de colcheias e sempre retornando para casa dois antes de ascender.

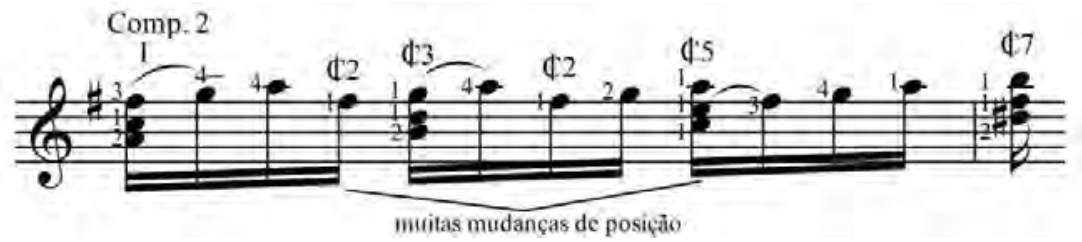

Exemplo 810: XII ${ }^{\circ}$ Estudo, compasso 2.

O primeiro tempo apresenta um translado do dedo 4 (sobrecarregando-o), somado a uma troca de posição e abertura, características que o tornam dispendioso. A tentativa de solução para este impasse parte da quinta posição, mas gera uma compressão no segundo tempo. A chegada coerente a esta versão dependerá da escolha de digitação do primeiro compasso.

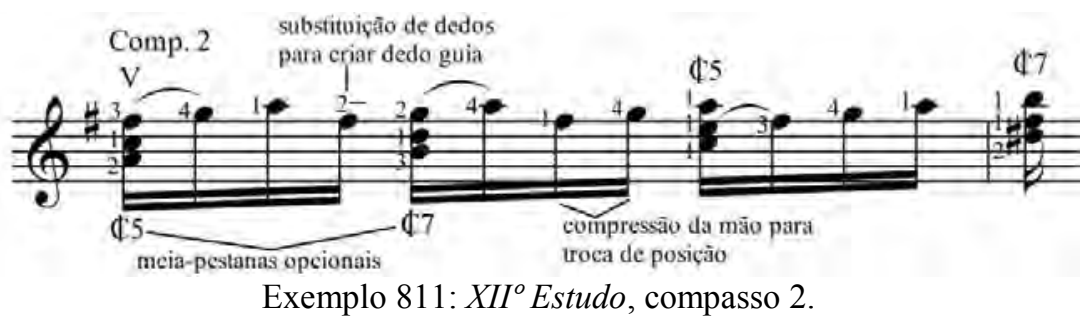

Esse é um típico caso no violão onde nenhuma digitação possível atende todos os critérios, e assim sendo, dependerá da preferência do intérprete, bem como de suas especificidades (facilidades e dificuldades). O terceiro tempo está muito bem resolvido de forma a permanecer inalterado nas três versões ${ }^{158}$. A digitação BL também é ideal no compasso seguinte, onde a única outra opção (que encontramos) exigiria contrair a mão na $11^{\mathrm{a}}$ posição, sendo portanto inviável. A passagem demanda aberturas concomitantes ao uso reincidente do dedo 4 e pestanas.

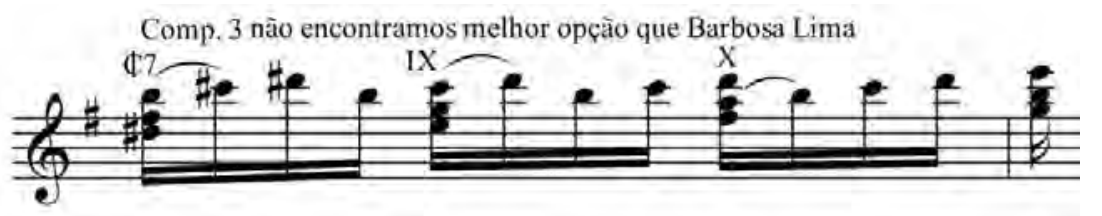

Exemplo 812: XII Estudo, compasso 3.

No compasso 4, novamente BL prefere a reincidência do dedo 4, algo que parece ser uma de suas marcas individuais, quando a maioria do intérpretes tenta, em regiões

158 item "deixar como está" do checklist de Osborn. 
sobreagudas (a partir da 12 $2^{\mathrm{a}}$ casa), substituí-lo pelo dedo 3 sempre que possível (conforme foi expresso anteriormente em lei Heurística), algo oferecido pela nossa versão alternativa.

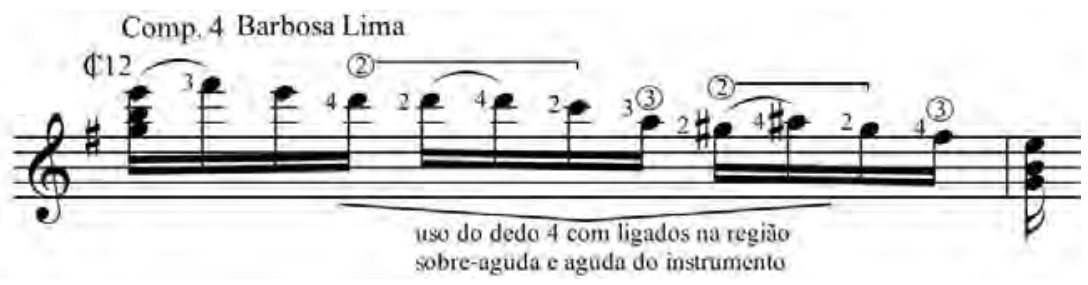

Exemplo 813: XII Estudo, compasso 4.

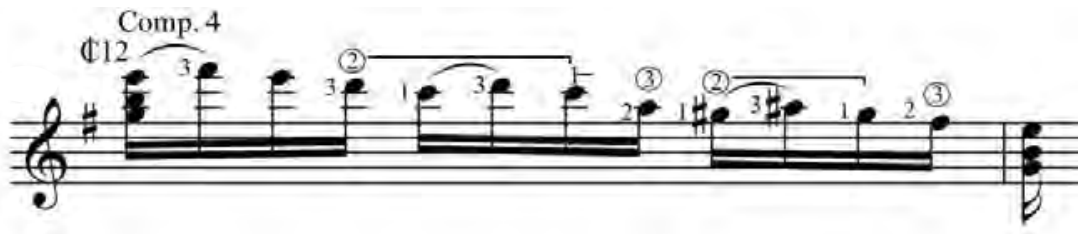

Exemplo 814: XII ${ }^{\circ}$ Estudo, compasso 4.

Uma última alternativa no uso da me provém do uso mais numeroso de ligados. Enquanto normalmente este é considerado um "recurso facilitador", seu uso excessivo nesta passagem causa apenas a simplificação da $m d$, mas penaliza a me ao invés de ajudá-la.

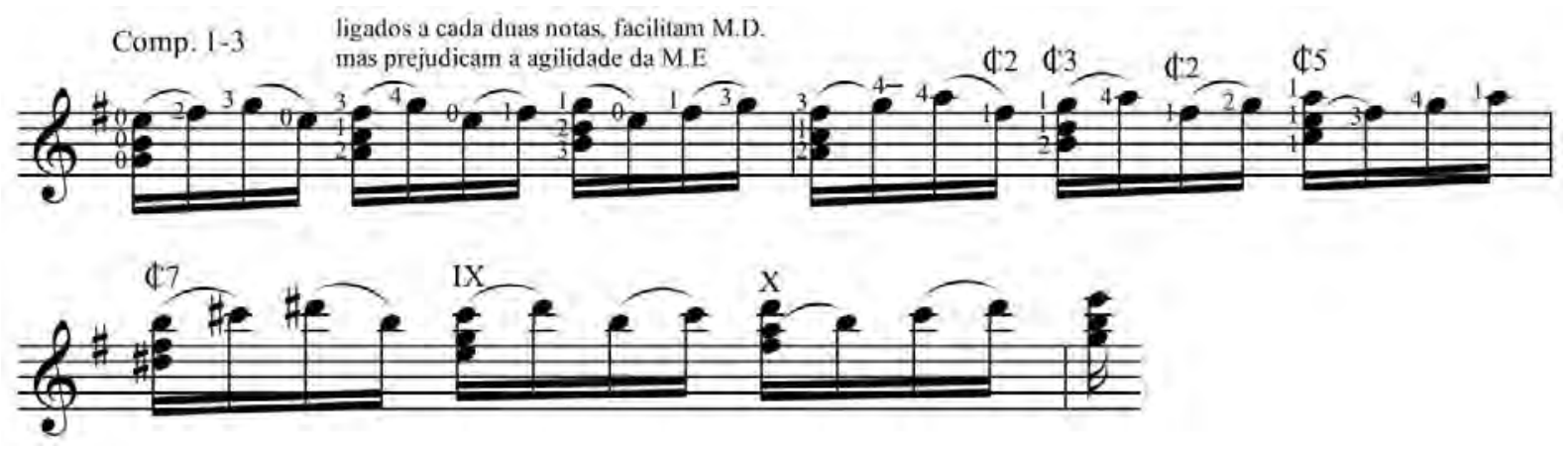

Exemplo 815: XII Estudo, compasso 1-3.

Já a escolha de articulação da $m d$ diz respeito a um dos maiores problemas da passagem: tratando-se do estudo final da série, ele parece exigir não só virtuosismo, mas maior intensidade, que por sua vez é difícil de ser alcançada em andamentos velozes. As digitações de $m d$ habituais para o trecho seriam as seguintes:

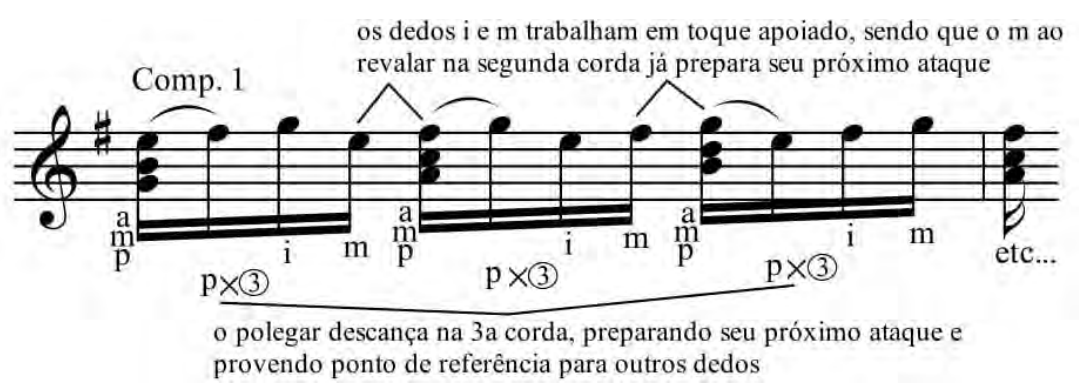

Exemplo 816: XII Estudo, compasso 1. 


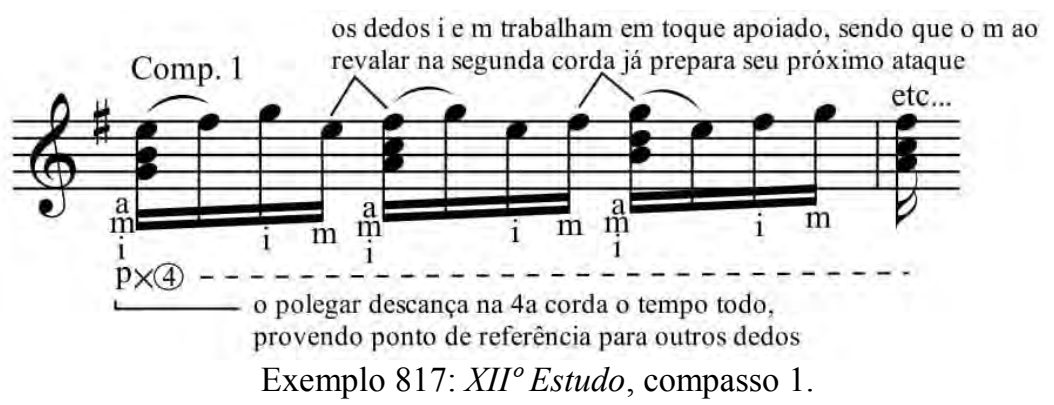

A diferença crucial de ambas reside no uso do dedo indicador ou polegar na articulação do acorde e na corda onde o polegar descansa, sempre provendo referência aos outros dedos, mas propiciando durações diferentes para os acordes (na primeira opção o acorde dura menos do que na segunda). O uso do toque apoiado dos dedos $i$ e $m$ em ambas é benéfico (e portanto será mantido nas próximas versões) e cria um aspecto interessante: o ato de resvalar o $m$ na corda adjacente $\left(2^{a}\right)$ já o coloca no lugar para articulação do acorde, preparando seu próximo ataque.

Infelizmente, apesar de bastante eficaz e ágil, a dinâmica obtida ainda parece limitada (para não dizer débil) mesmo ao fazer uso do toque apoiado. Novamente, o Pensamento Divergente aliado ao uso dos recursos rapidamente elencados anteriormente na "caixa de ferramentas do violonista" se revelaram de grande ajuda nesta questão provendo alternativa mais sonoras para a articulação dos acordes, que por conseguinte também auxiliam a clareza dos ligados. A primeira delas aproveita a versatilidade e maior peso do polegar para articular os acordes, ainda o preparando na terceira corda, mas sob o custo de um rápido porém viável giro de pulso:

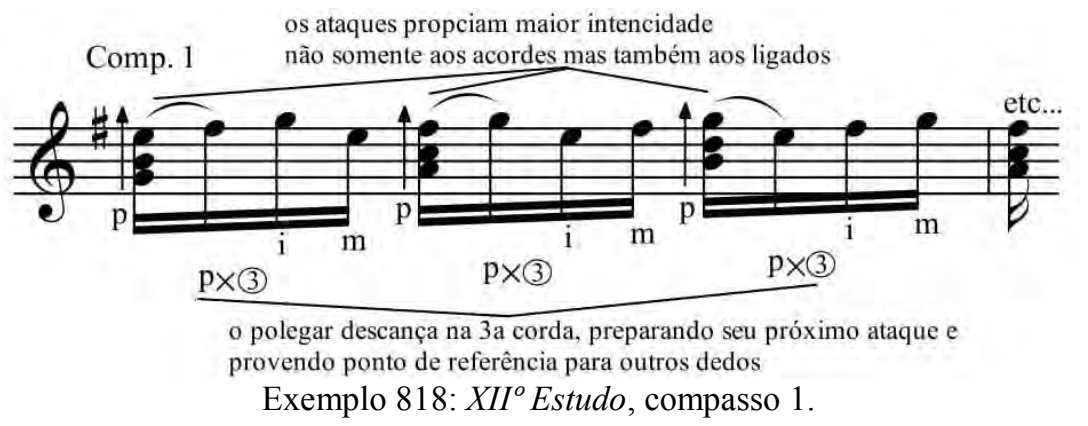

Já a alternativa seguinte busca menor movimentação da $m d$ ao aproveitar o descanso constante do polegar na quarta corda alcançado pela opção 2 e delegando o ataque do acorde para o dedo indicador em pequeno rasgueio. Embora o indicador seja responsável por tocar várias notas atravessando três cordas (ou seja, num movimento aparentemente amplo), surpreendentemente a alternância entre as costas e ponta do dedo gera um movimento circular semelhante a um plecto (ou popularmente, palheta), configurando o que consideramos a alternativa de menor tensão e maior estabilidade e 
sonoridade para a $m d$. Como nada é perfeito em nosso instrumento, essa opção pode gerar maior ruídos de unha (pelo ataque das costas do dedo indicador), sendo possivelmente mais eficaz em performances ao vivo do que em gravações.

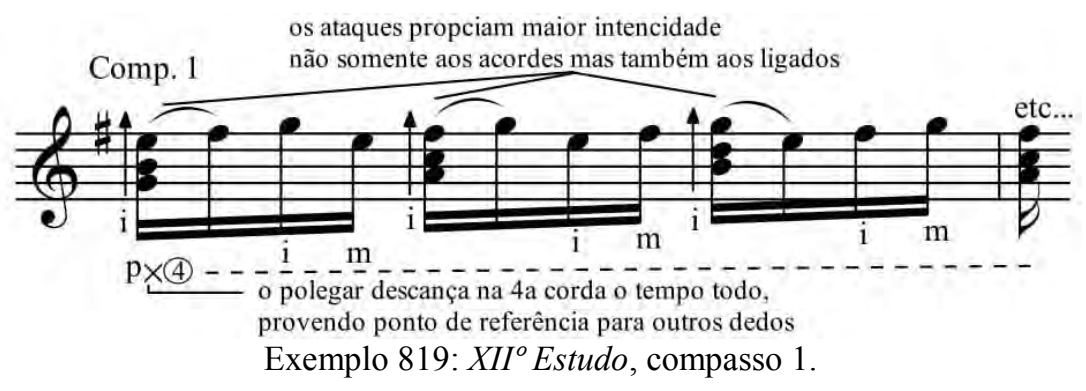

As próximas duas versões foram obtidas a partir de conversa informal com o Prof. Dr. Nícolas de Souza Barros, que sugeriu considerar a inclusão do uso de digitações escovadas para o trecho, algo que não havíamos considerado antes e que também gerou bons resultados. Novamente, duas versões são possíveis, diferindo no uso do polegar e na quantidade de notas escovadas pelo anelar. $\mathrm{O}$ aspecto mais interessante e funcional de ambas é que o conjunto $a-m-i$ funciona de maneira similar a um trêmulo (com um ligado inserido no meio do padrão), onde o anelar "escova" os acordes.

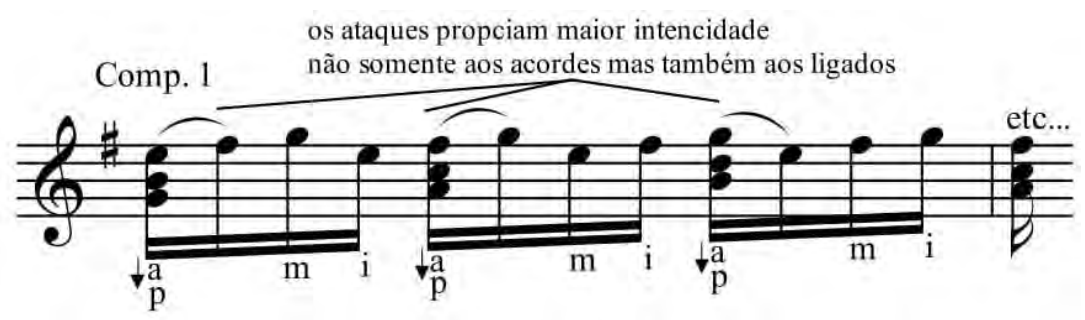

Exemplo 820: XII ${ }^{\circ}$ Estudo, compasso 1.

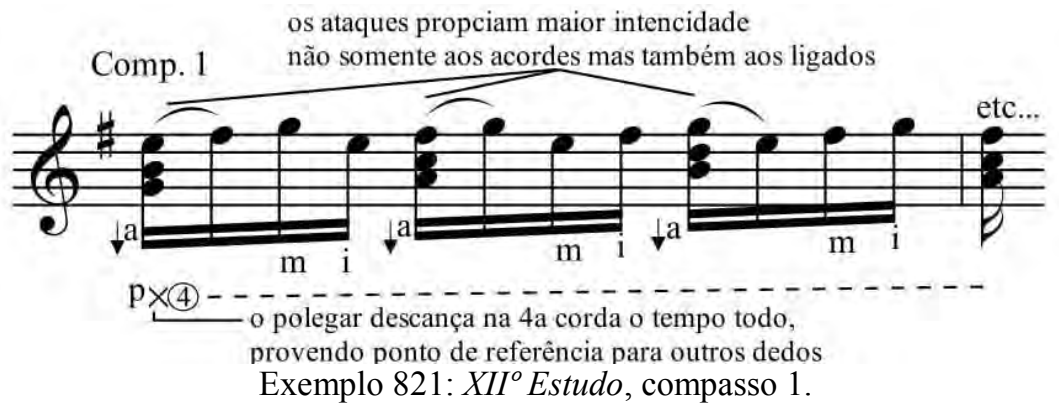

A frase seguinte, ainda baseada no mesmo motivo, leva os acordes para a região sobreaguda do instrumento e trata-os de forma descendente, com cromatismos. $\mathrm{Na}$ impossibilidade executá-los conforme o original, BL propõe uma redução ${ }^{159}$ considerável de notas e com isso exclui a interessante mudança cromática na voz

${ }^{159}$ verbo diminuir do checklist de Osborn. 
interior nos compassos 11, 12 e 13 (assinaladas com setas no manuscrito e na edição Columbia).

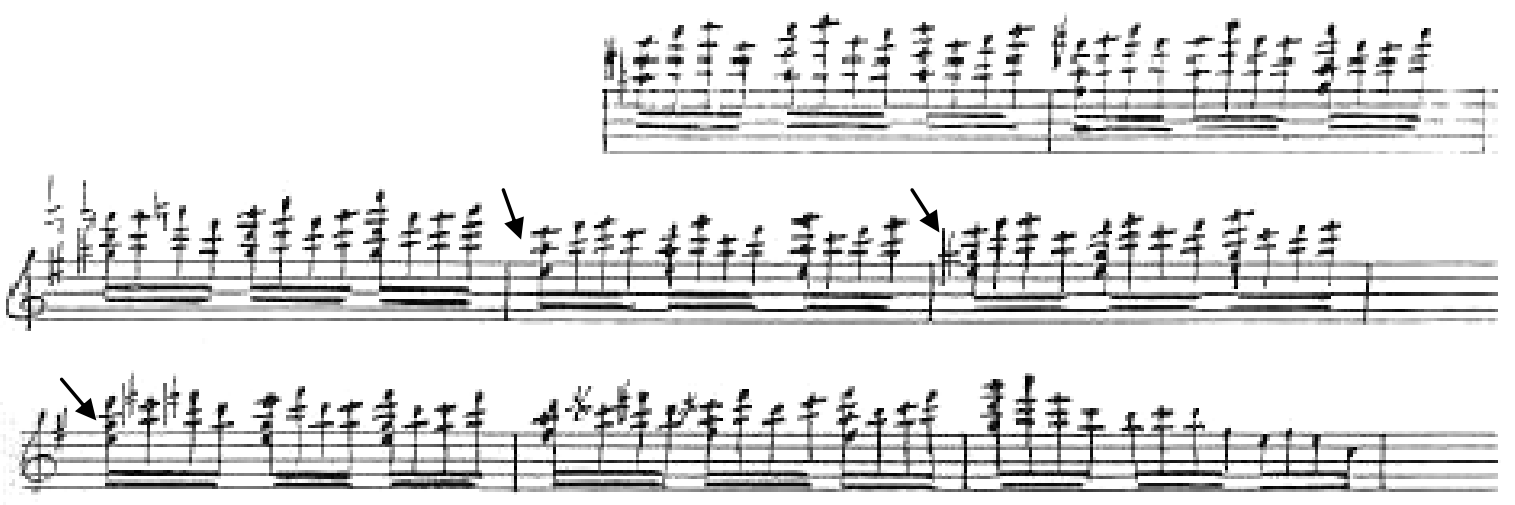

Exemplo 822: XII Estudo, compasso 8. Manuscrito.
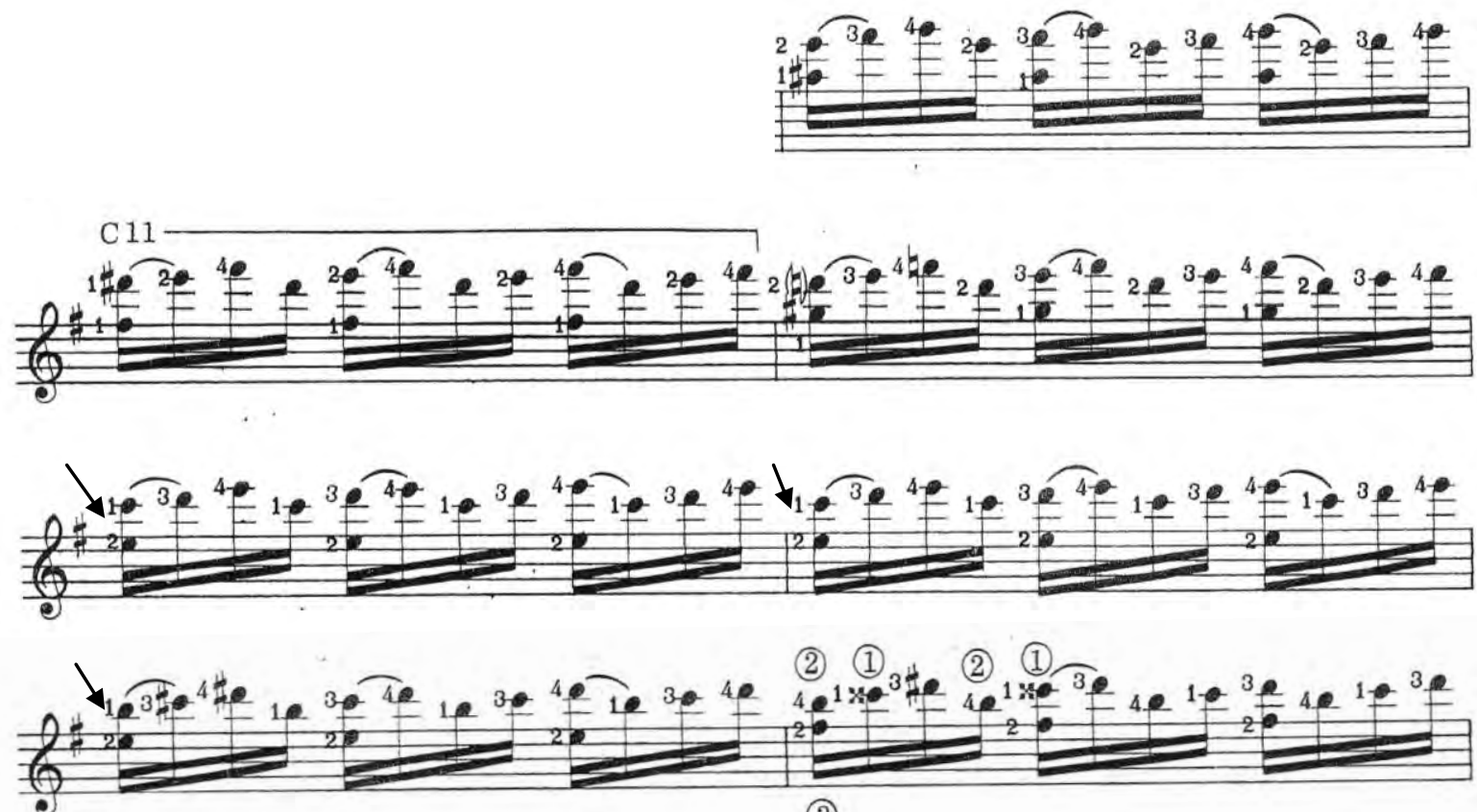

(3)

Exemplo 823: XII Estudo, compasso 8. Ed. Columbia/BL.

Tentando contornar esta perda, o exemplo 824 parte da ideia geral da versão BL, (de manter apenas duas notas do acorde) mas realiza outra seleção de notas a serem mantidas, preservando o cromatismo das vozes intermediárias, mas obviamente perdendo outras vozes e com isso ainda oferecendo algum dano ao encaminhamento harmônico. No aspecto técnico os três primeiros compassos passam a obedecer ao mesmo padrão digitacional e outros, como o 11, 12 e 13, ganham bastante similaridade, calcados em um mesmo dedo fixo.

Os ligados da versão BL são bastante coerentes e ágeis, mas tomamos a liberdade de sugerir concomitantemente outro ligado em posição acéfala, o qual perde a 
unidade com a frase anterior, mas ganha clareza na projeção das notas, além de propiciar uma pequena respiração entre o primeiro acorde e a nota seguinte.

Outro aspecto relevante é a articulação de $m d$ nos acordes: a opção mais tradicional seria executá-los com $a-m$, mas o trecho também permite articulação integral pelo $p, i$ (descendentes) ou $a$ (em movimento ascendente), sendo que os dois últimos permitem a fixação do polegar na terceira corda como ponto de apoio.
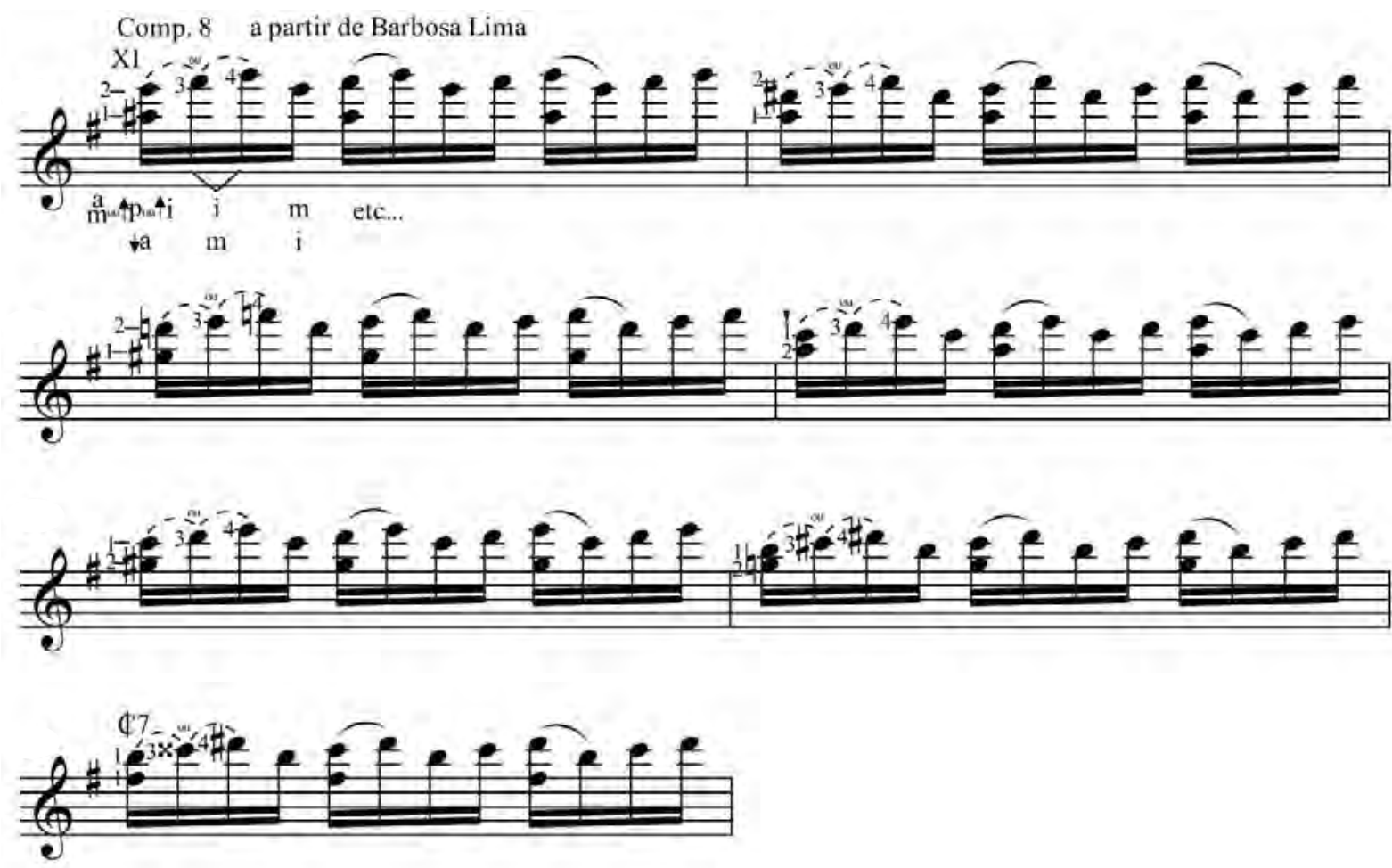

Exemplo 824: XII ${ }^{\circ}$ Estudo, compasso 8.

O exemplo 825, por sua vez, busca outra estratégia: os acordes de três notas aparecem em todos os tempos fortes e são reduzidos ${ }^{160}$ a um baixo nos tempos fracos dos compassos, porém foi necessária a inversão nas vozes de certos acordes. Outro aspecto desvantajoso, porém superável com estudo, diz respeito aos rápidos saltos verticais que o dedo 3 tem de fazer entre o acorde tético e a nota seguinte, algo ocorrente nos compassos 10,11, 12 e 13 mas que pode ser facilitado por meio de pequeno rubato neste ponto. Apesar desta versão não ser literal em termos de notas ela parece manter melhor alguns aspectos do manuscrito, como o encaminhamento harmônico mais completo, seu ímpeto e projeção geral e sendo, com isso, a de nossa preferência.

${ }^{160}$ verbo diminuir do checklist de Osborn. 

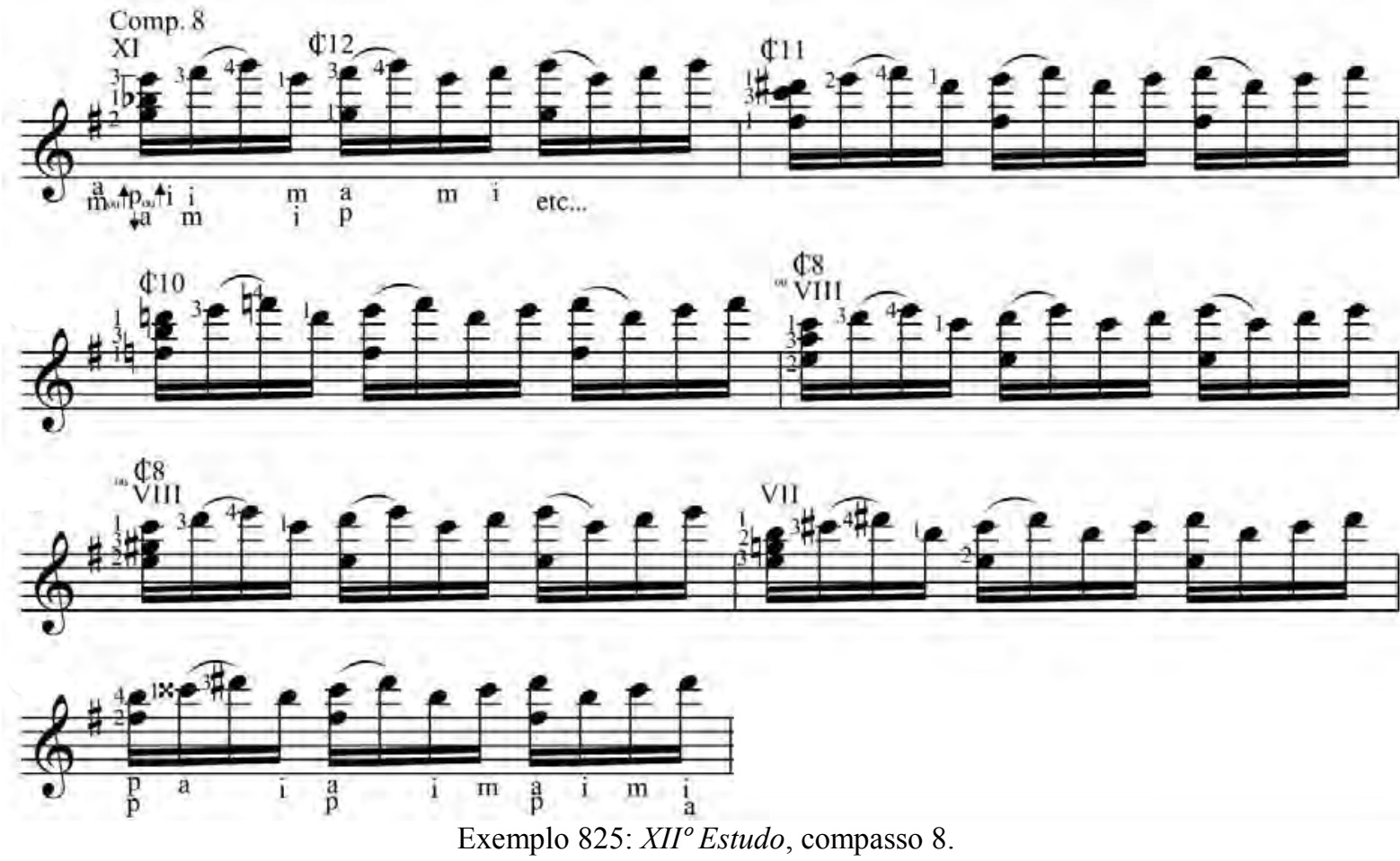

O compasso 13 ainda recebe um exemplo complementar, que aproveita a retirada do acorde inicial para adicionar uma pestana na nona casa.

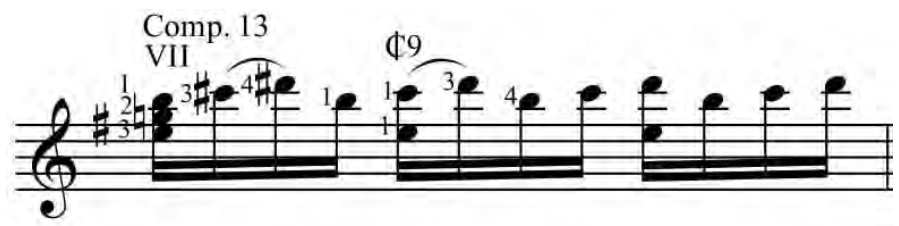

Exemplo 826: XII ${ }^{\circ}$ Estudo, compasso 13.

Segue-se uma passagem conectiva à uma sequência de arpejos, também de interessante cromatismo.
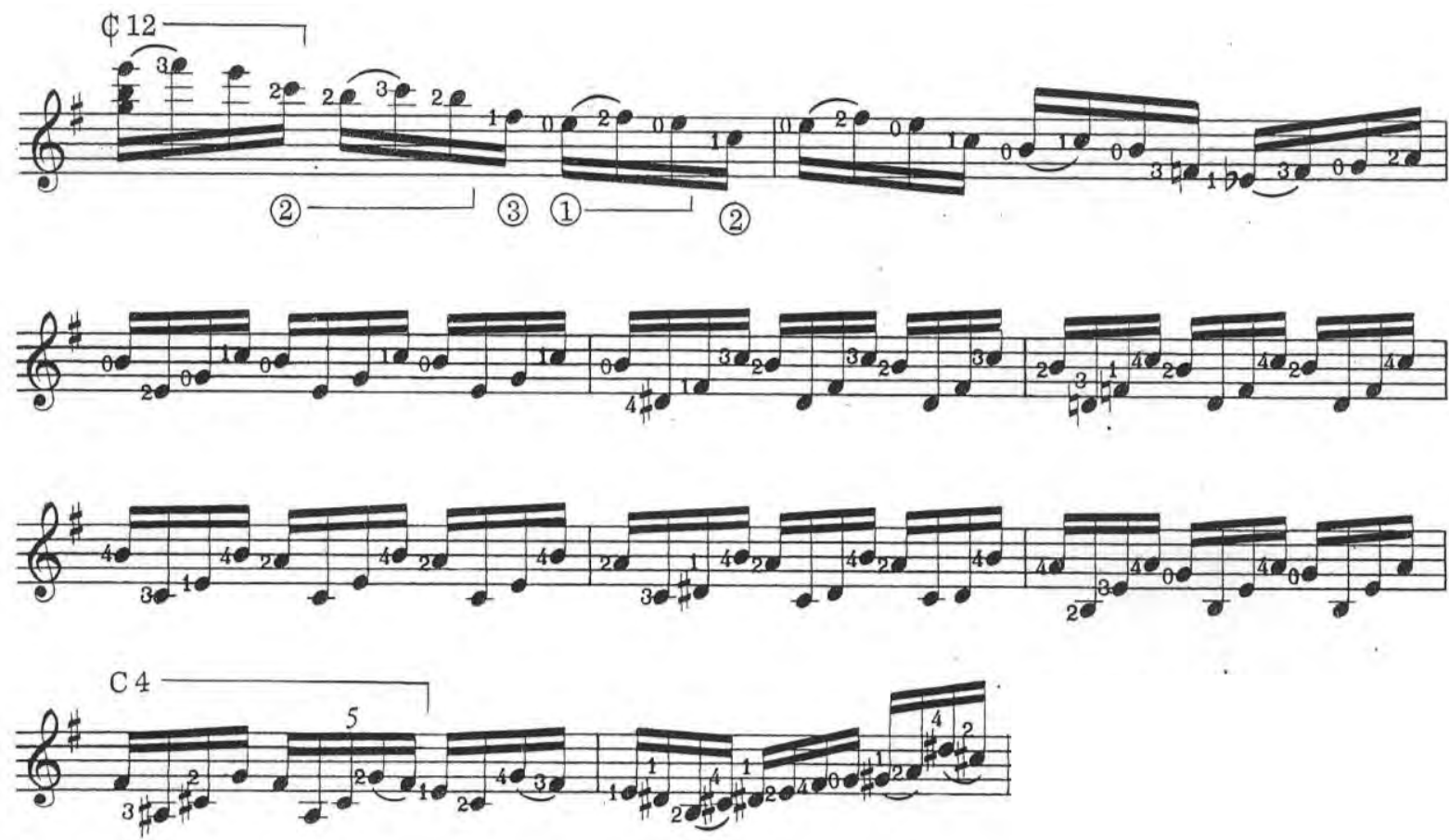

Exemplo 827: XII ${ }^{\circ}$ Estudo, compasso 15. Ed. Columbia/BL. 
Nosso exemplo 828 aproveita os ligados de BL, mas oferece outros caminhos. $\mathrm{Na}$ descida inicial o salto da décima segunda posição a primeira é "quebrado" por uma passagem pela sétima e os arpejos são padronizados e passam a ocupar sempre quatro cordas dos instrumento aproveitando melhor as cordas soltas envolvidas e conectando os acordes por dedos fixos, guias ou cordas soltas. A md também apresenta padrão considerável que recebe pequenas modificações ${ }^{161}$ nos compassos 20, 22 e 23.
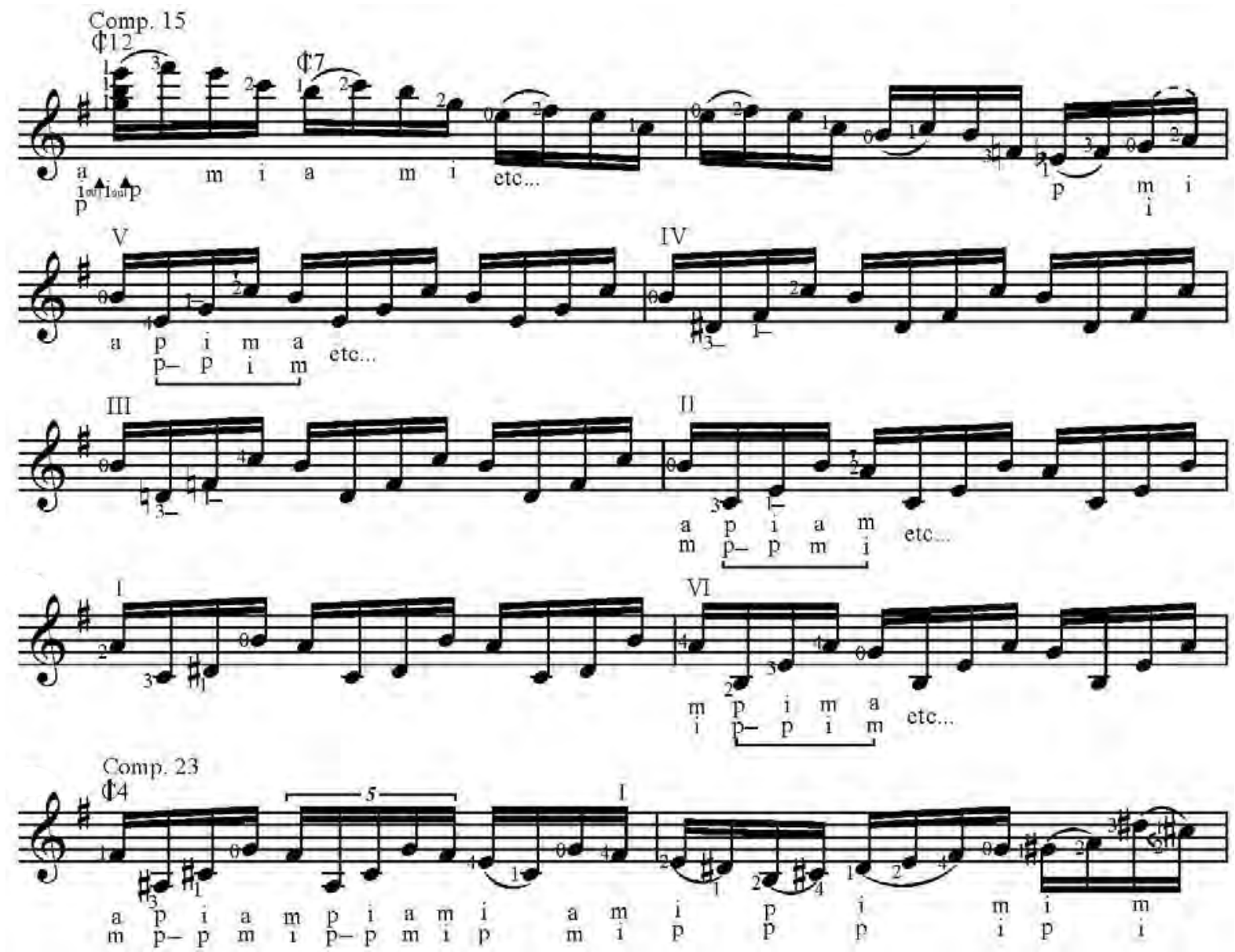

Exemplo 828: XII ${ }^{\circ}$ Estudo, compasso 15.

O compasso final visa dar encaminhamento a um novo padrão de arpejo e pode ser abordado inteiramente pela primeira posição (como na digitação BL), iniciar-se pela primeira posição e alcançar a sexta (como no ex. 828), ou manter-se por mais tempo na quarta para também finalizar-se pela sexta posição (ex. 829), com diferenças notáveis também no uso dos ligados.

\footnotetext{
${ }^{161}$ verbo do checklist de Osborn.
} 


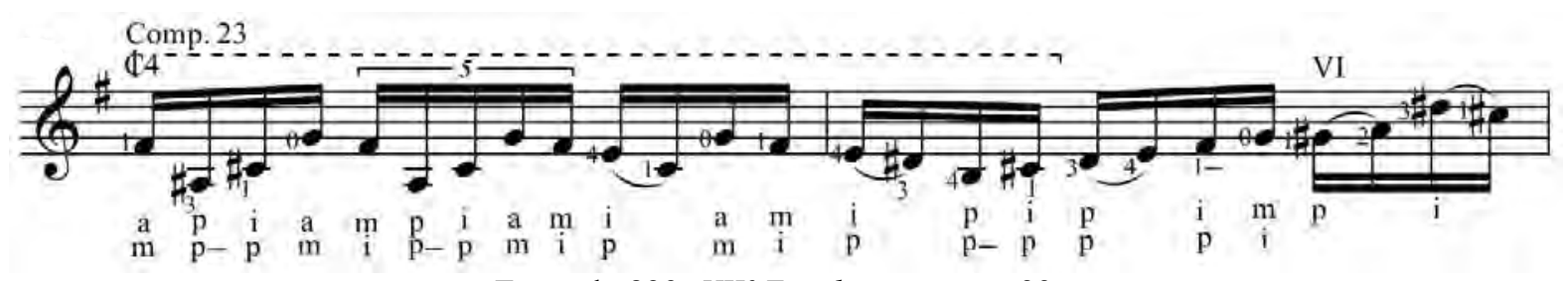

Exemplo 829: XII Estudo, compasso 23.

O padrão de arpejo iniciado no compasso 25 ainda se baseia no mesmo motivo do arpejo anterior, porém a melodia e acompanhamento se "espremem" de forma que a primeira passa para a voz intermediária, ainda com mesmo ritmo e padrão intervalar por grau conjunto.

Em atitude coerente com a passagem anterior BL também digita este arpejo em três cordas. As reorganizações digitacionais necessárias em algumas mudanças de acordes parecem ocorrer durante a última nota de cada compasso. Os ligados no último compasso também são musicalmente interessantes.

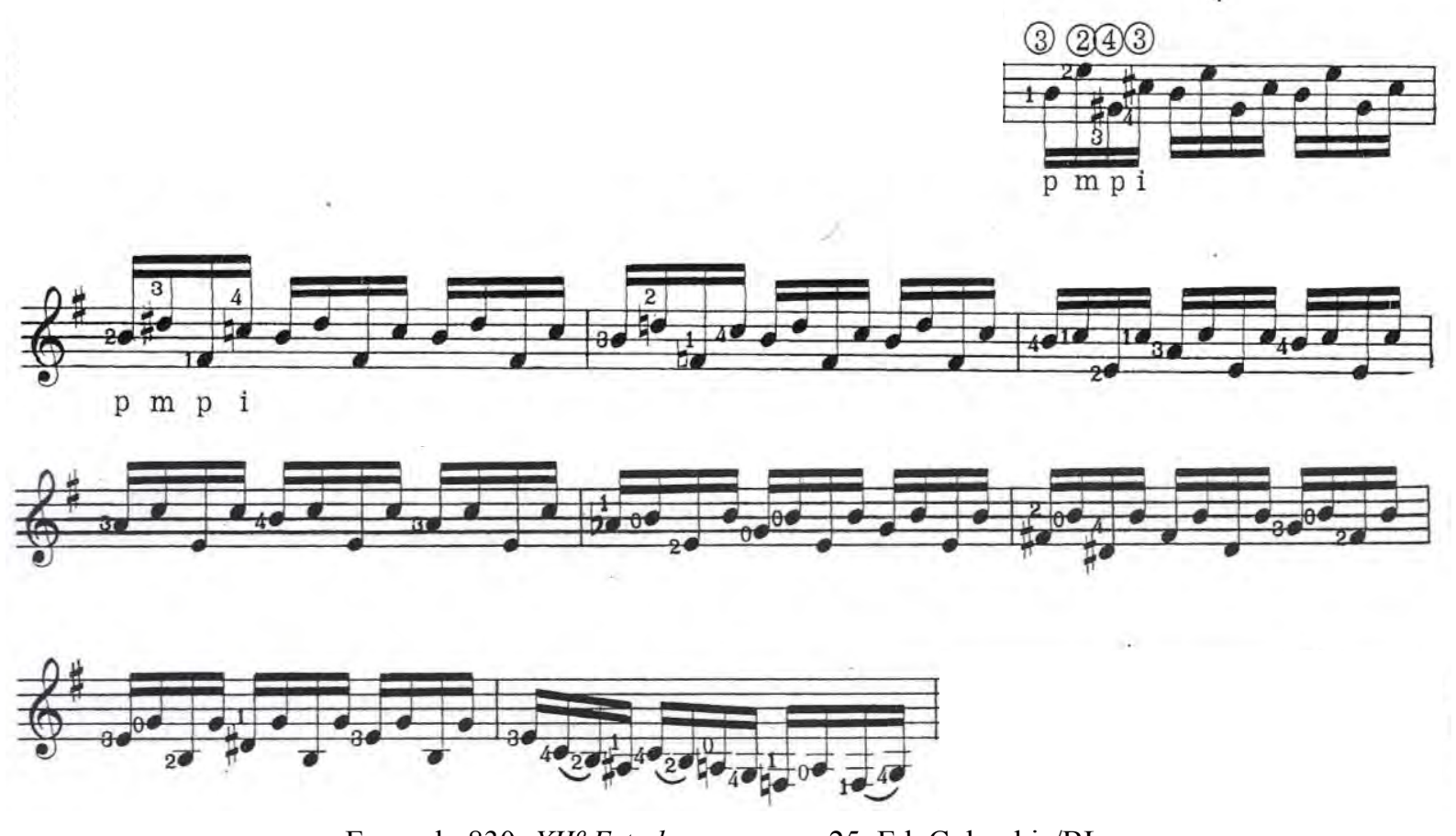

Exemplo 830: XII Estudo, compasso 25. Ed. Columbia/BL.

Nossa primeira versão alternativa também busca coerência com a passagem anterior onde os arpejos ocupavam quatro cordas (ex. 828), novamente recorrendo à cordas soltas e dedos guias. Em decorrência ao encaminhamento que os dedos tomam, chega-se ao último compasso com um padrão consideravelmente mais simples mas ainda com os mesmos ligados de BL. 
292
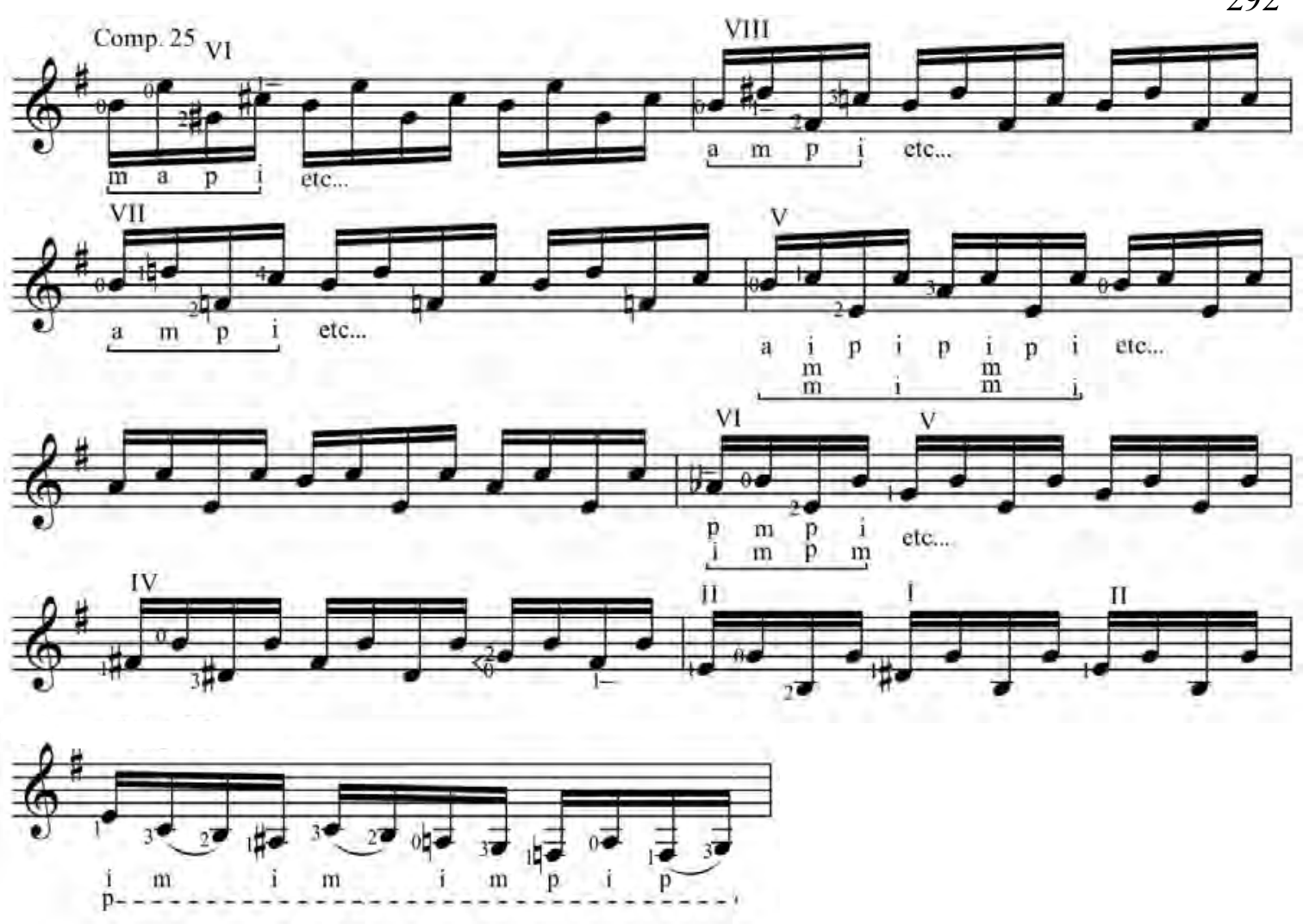

Exemplo 831: XII ${ }^{\circ}$ Estudo, compasso 25.

As duas versões seguintes são de caráter mais experimental no que tange o uso de ligados neste arpejo. O exemplo 832 insere um ligado no início de cada tempo, de forma bastante facilitadora por aproveitar a segunda corda solta, enquanto o exemplo 833 insere ligados em posições anacrústicas (e portamenti na mesma posição nos compassos 28 e 29) obtendo resultado um pouco mais árduo por necessitar de mais cordas presas. Ambas as opções com ligados naturalmente podem soar disruptivas em relação ao trecho anterior sem o uso dos mesmos.
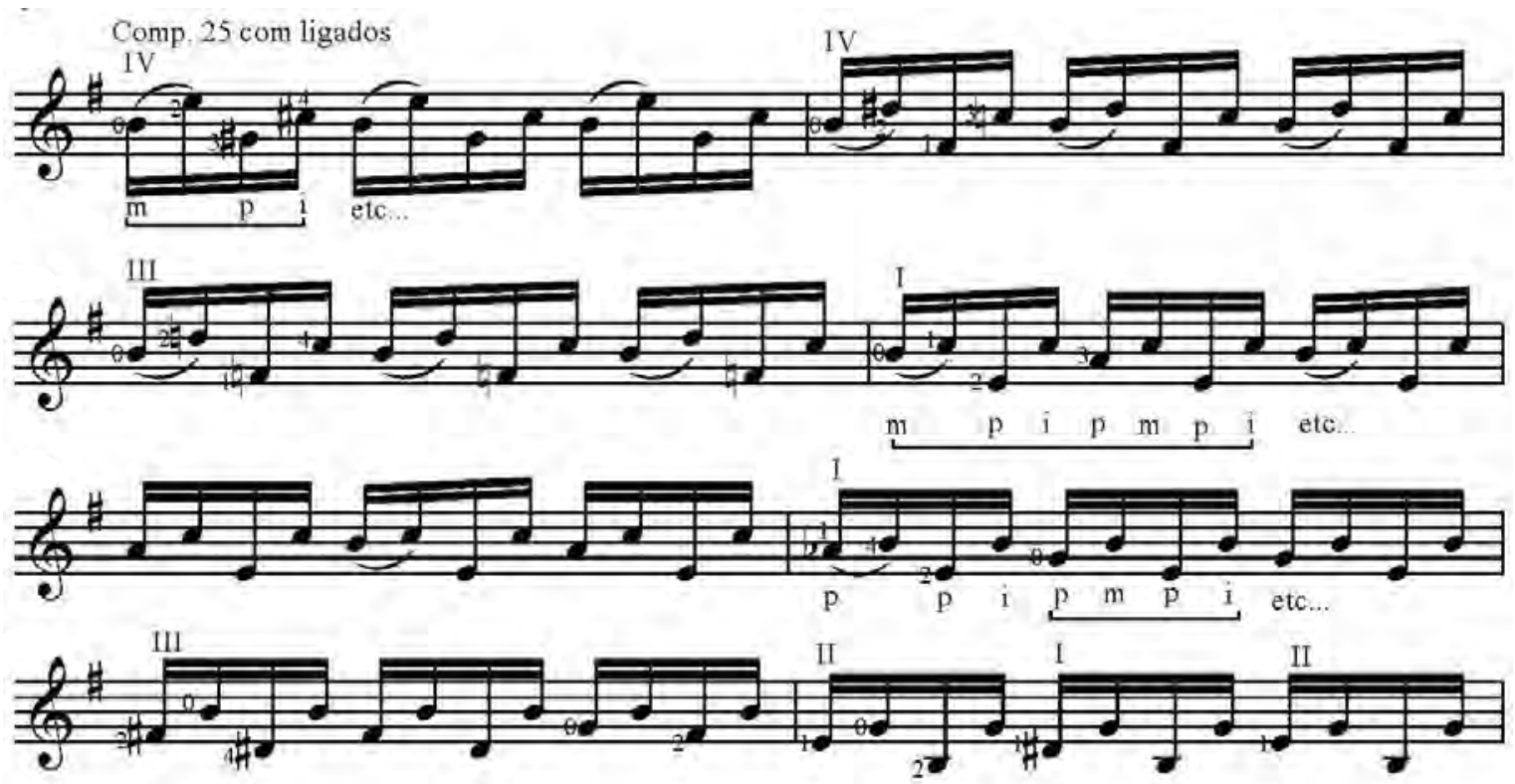

Exemplo 832: XII ${ }^{\circ}$ Estudo, compasso 25. 


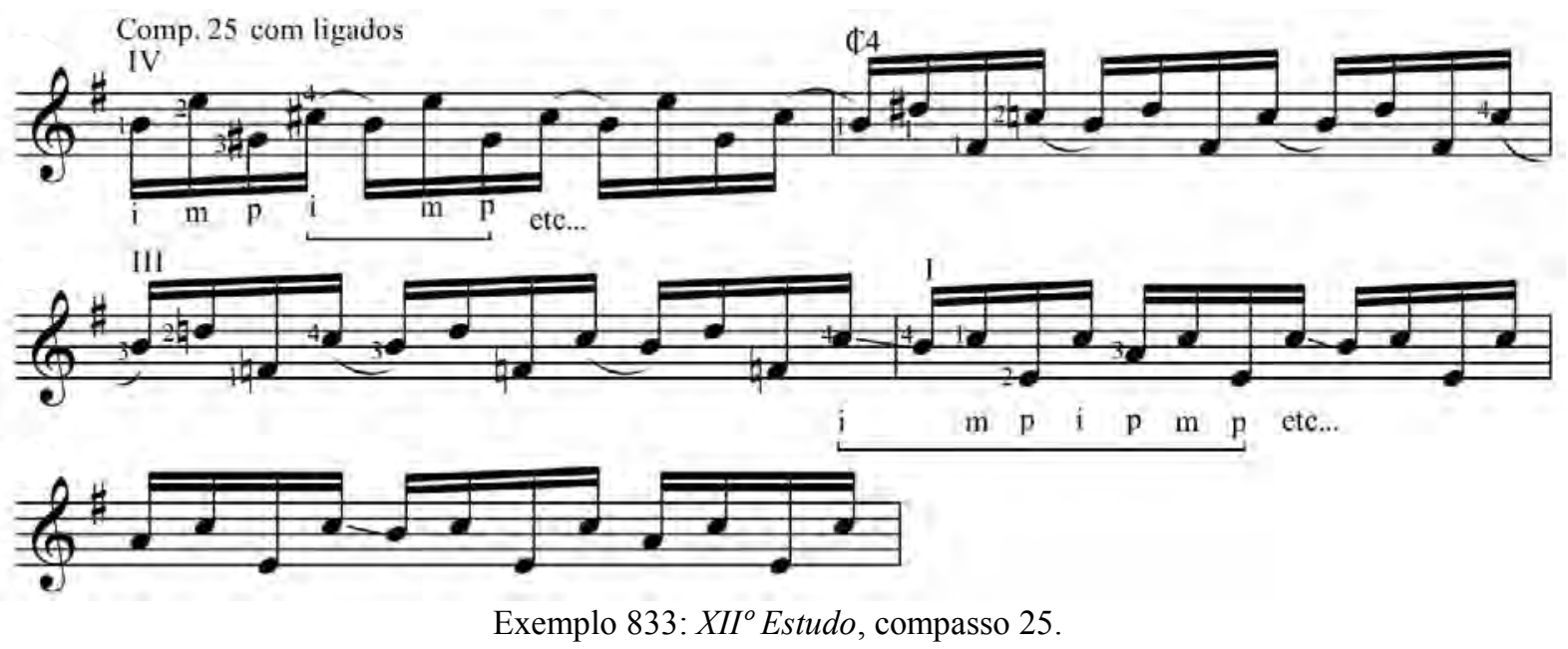

O compasso 34 marca o retorno do motivo inicial da peça, mas agora no baixo, confrontado por ríspidos acordes em sforzando em uma dicotomia musicalmente interessante mas tecnicamente desafiadora, pela difícil conexão entre as passagens escalares e alguns dos acordes (especialmente os do final do trecho).

A abordagem de BL mantém o trecho nas primeiras casas do instrumento. Seus ligados são bom ponto de partida, mas levam a uma discussão importante: na primeira aparição, este motivo musical (formado por grupos de três notas) recebeu ligados a cada tempo, ou seja, a cada quatro notas, aspecto que era propiciado por haver acordes que coincidiam com este ritmo. Nesta reaparição grave, o motivo perderia sua fluência com o mesmo padrão de ligados (sugerimos ao leitor tentar aplicá-los ao compasso 36, por exemplo).

Com essa nova realidade, BL aplica o padrão de ligados do início da peça apenas ao compasso 34 e depois o reequaciona no compasso seguinte a esta nova realidade, aproveitando inteligentemente o padrão ternário do motivo, apenas com uma quebra de padrão no compasso 38. Nesse sentido, nossas propostas assumem logo o novo contexto e já iniciam com um novo padrão de ligado desde o princípio do trecho.

Outro aspecto curioso da digitação BL é o uso, em alguns momentos, da reincidência de dedos da me nos acordes e em notas imediatamente anteriores ou posteriores (assinalado por setas), algo que buscamos facilitar nos exemplos 835 e 836 . 

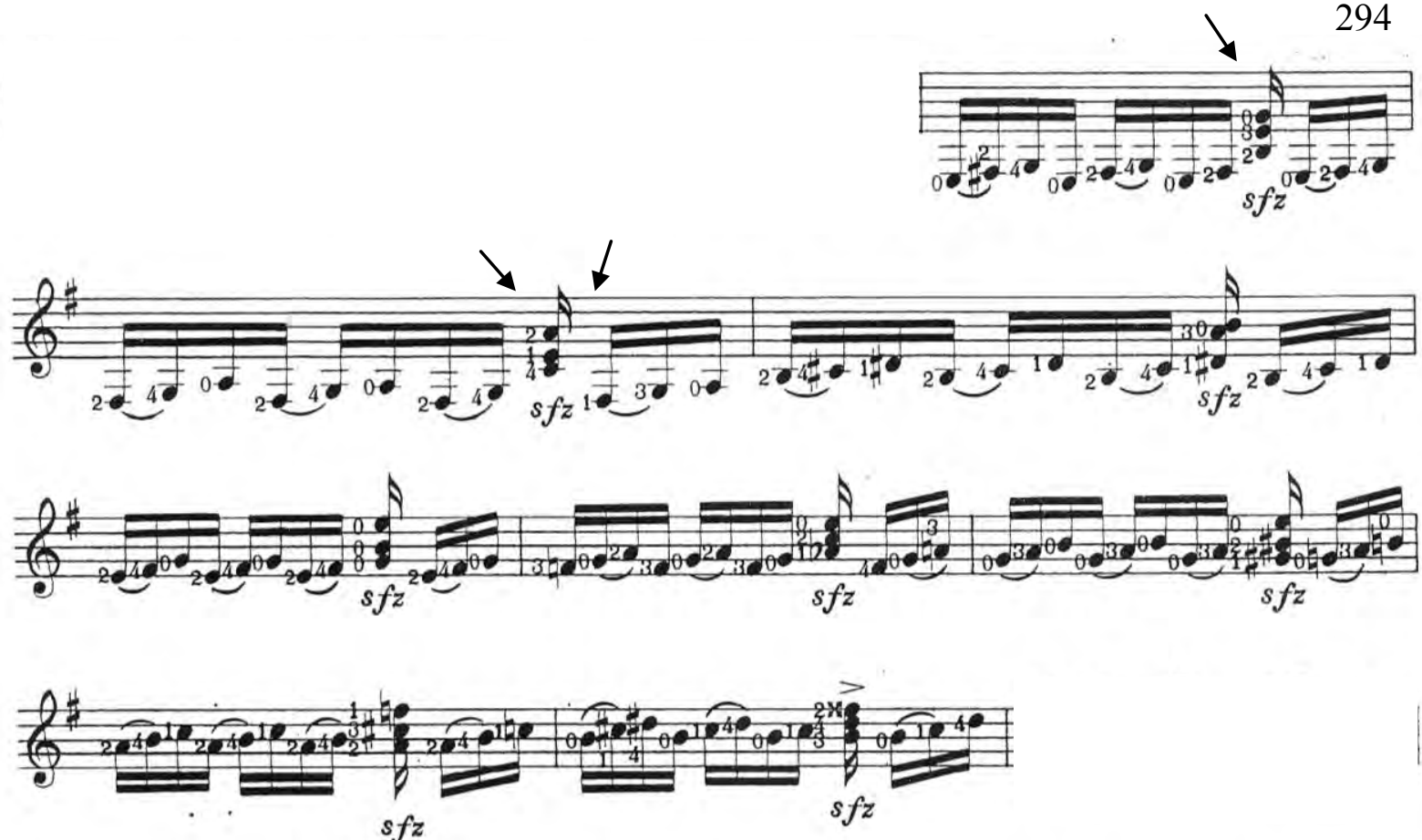

Exemplo 834: XII ${ }^{o}$ Estudo, compasso 34. Ed. Columbia/BL.
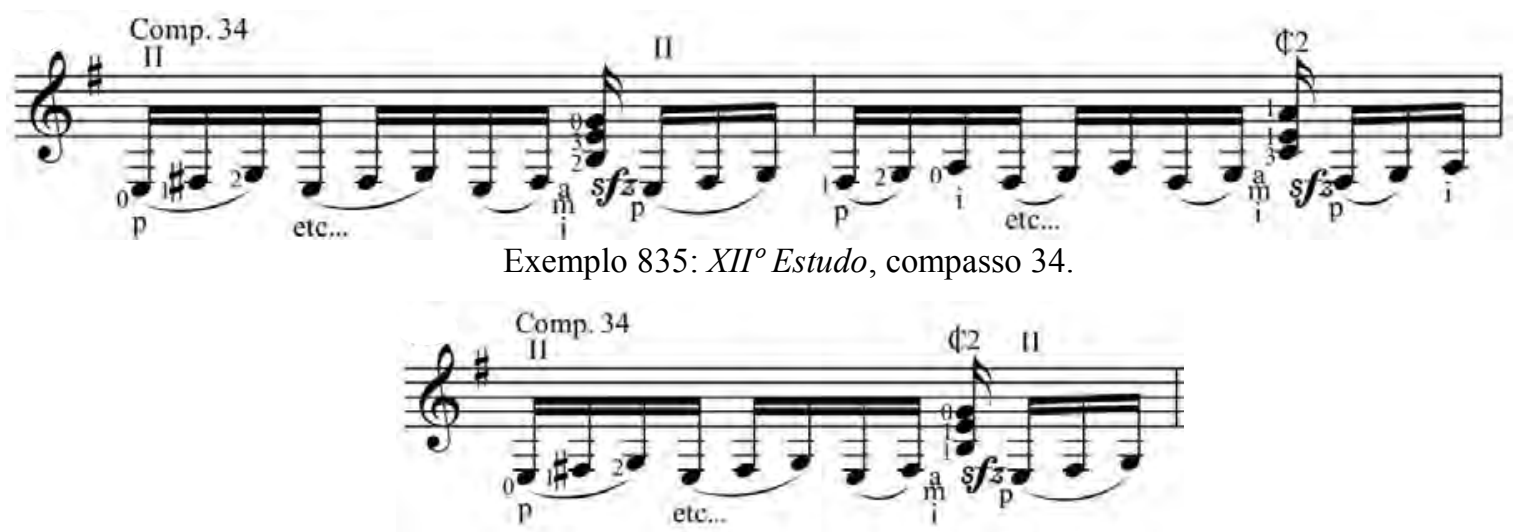

Exemplo 836: XII Estudo, compasso 34.

Já os quatro compassos finais oferecem soluções mais numerosas. As três primeiras partem da estratégia de BL de buscar manter-se nas casas iniciais do violão. $\mathrm{O}$ exemplo 837 regulariza os ligados do compasso 39 e tenta criar mais padrões, primeiro com a pestana na primeira casa (nos compassos 38 e 39) e depois tentando deixar os compassos finais mais similares, porém em casas distintas. Os exemplos 838 e 839 abdicam da padronização de ligados, na esperança de facilitar os dois últimos compassos, que são abordados com dedos distintos nesses excertos.

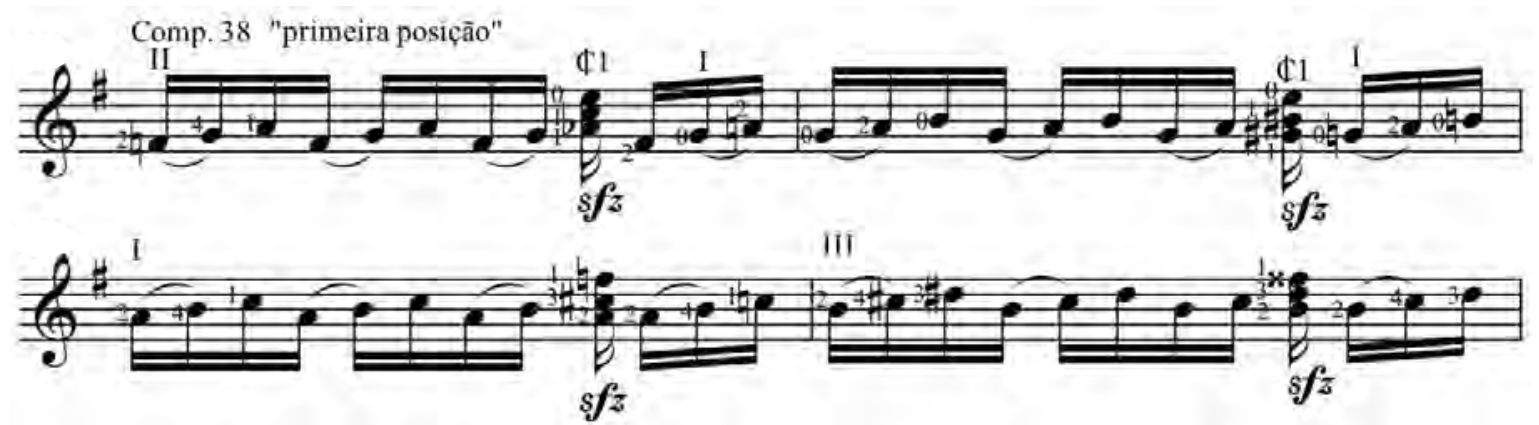

Exemplo 837: XII Estudo, compasso 38. 


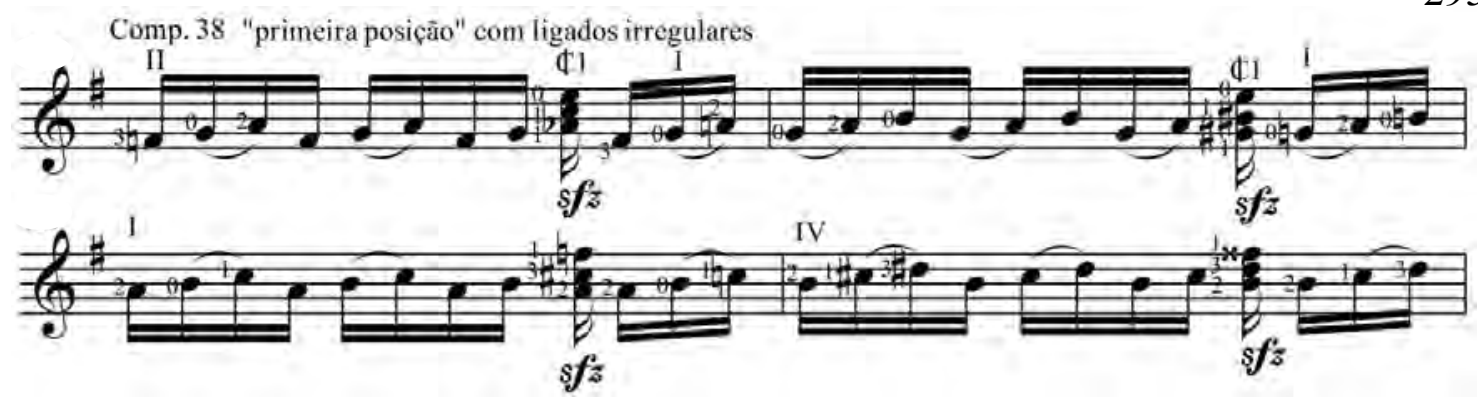

Exemplo 838: XII ${ }^{\circ}$ Estudo, compasso 38.

Comp. 38 "primeira posição" com ligados irregulares
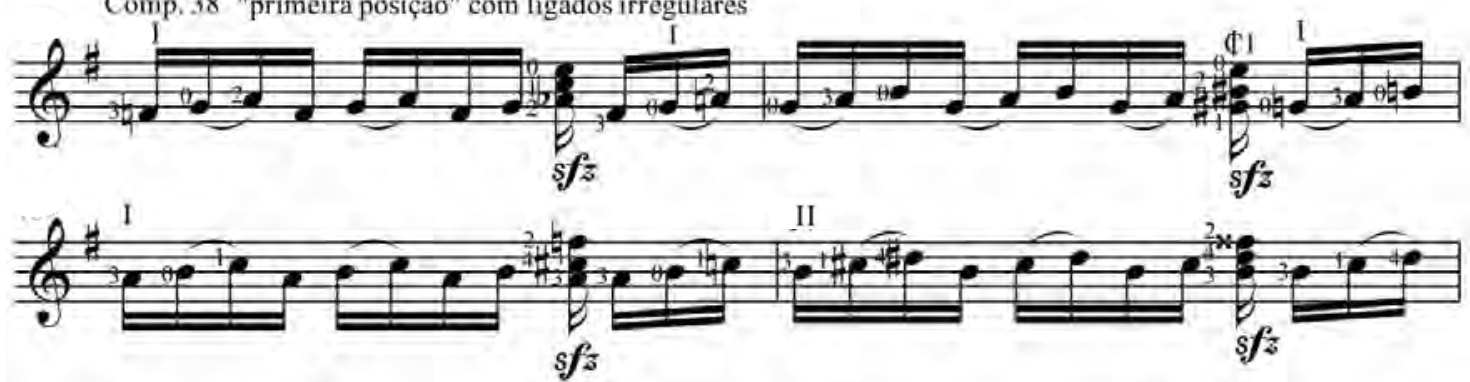

Exemplo 839: XII Estudo, compasso 38.

As opções seguintes exploram casas à frente e se pautam em duas estratégias: 1) nos compassos 38 e 39 aproveitam a semelhança de disposição dos dedos 2 e 1 (na quarta e terceira cordas, respectivamente) durante o movimento melódico e os acordes apenas arrastando esse grupo e 2) nos compassos 40 e 41 o dedo 2 fixo cria a conexão com os acordes que por sua vez são dispostos em meias-pestanas.

No exemplo 840 esse avanço de posições segue ligados regulares e obedece a uma padronização maior na digitação das notas, enquanto os seguintes abdicam dessa dupla rigidez para facilitar certos momentos (como o final do compasso 38) sendo que o último deles ainda utiliza cordas soltas em várias trocas de posição, num processo facilitador progressivo.
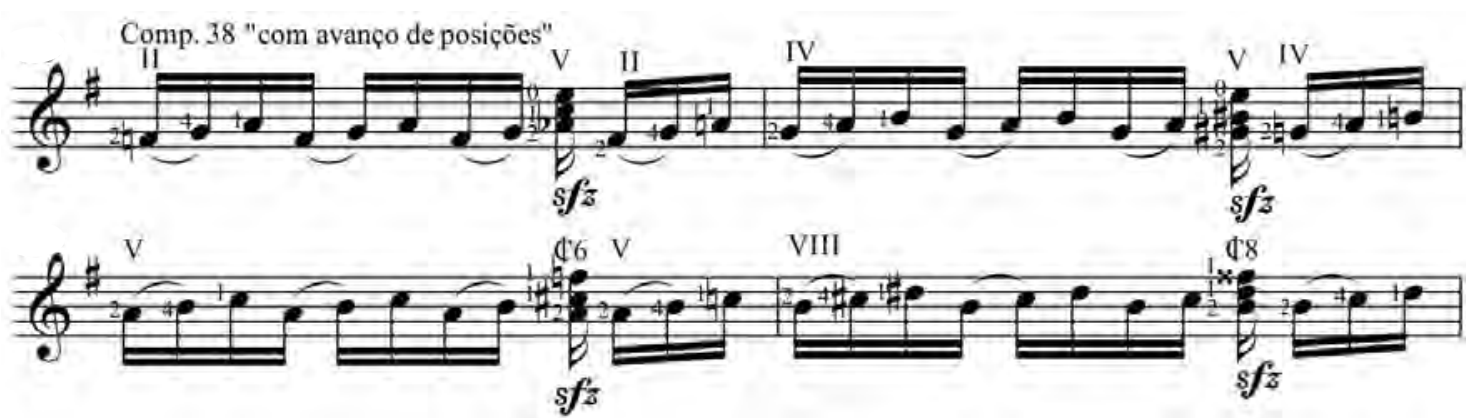

Exemplo 840: XII Estudo, compasso 38.
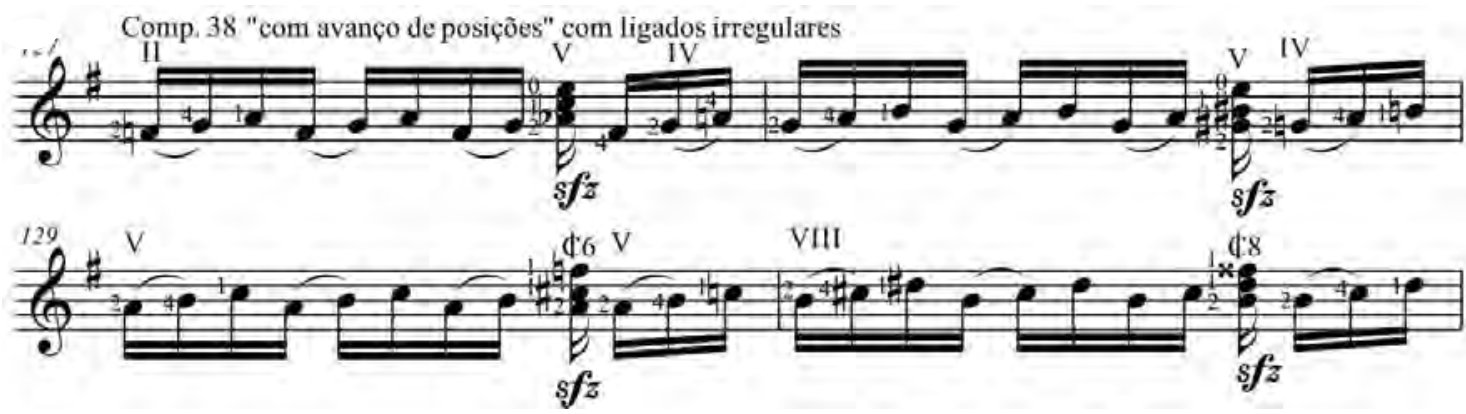

Exemplo 841: XII Estudo, compasso 38. 

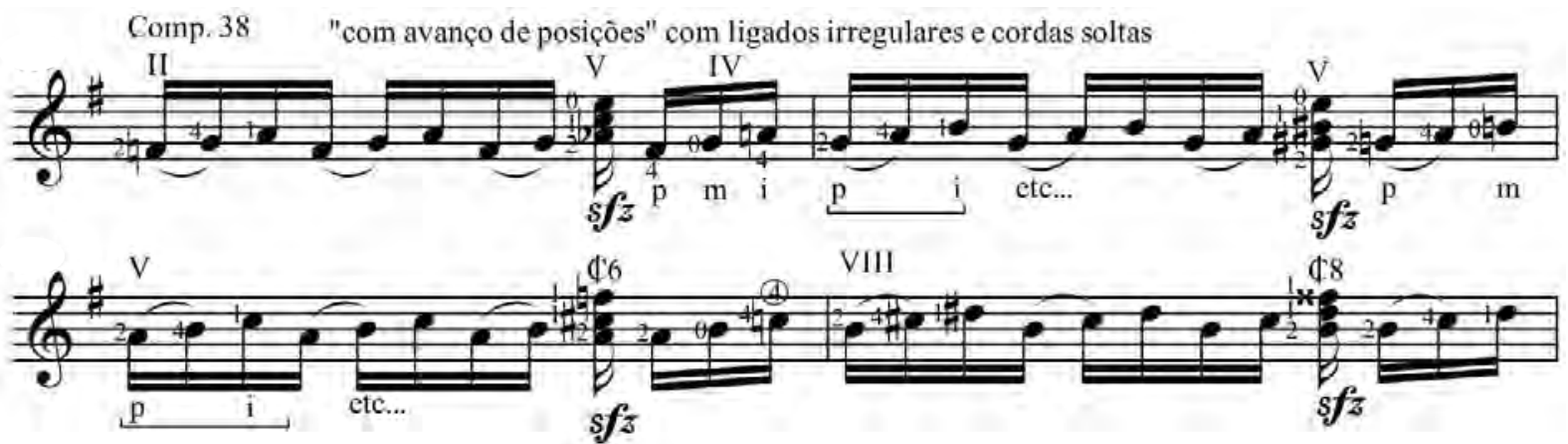

Exemplo 842: XII Estudo, compasso 38.

Embora já tenhamos oferecido múltiplas opções para este trecho, ainda há questões para serem exploradas no funcionamento da $m d$, especialmente no que tange a articulação do acorde. Anteriormente digitada com o tradicional grupo $i-m-a$, resolvemos explorar articular os acordes com rasgueios de indicador no exemplo $843 \mathrm{e}$ com o polegar nos dois seguintes, sendo que o último deles (ex. 845) utiliza apenas o polegar em todas as notas, em um trejeito quase flamenco.

Em todos eles o anelar pode ser usado como ponto de apoio nas primas, no entanto, conforme os acordes chegam a estas cordas o anelar rapidamente dá espaço (ou seja, interrompe o abafamento) para dar vez à articulação do acorde e logo em seguida retorna a sua função de ponto fixo (esse processo de retirada e reentrada está assinalado por chave pontilhada).
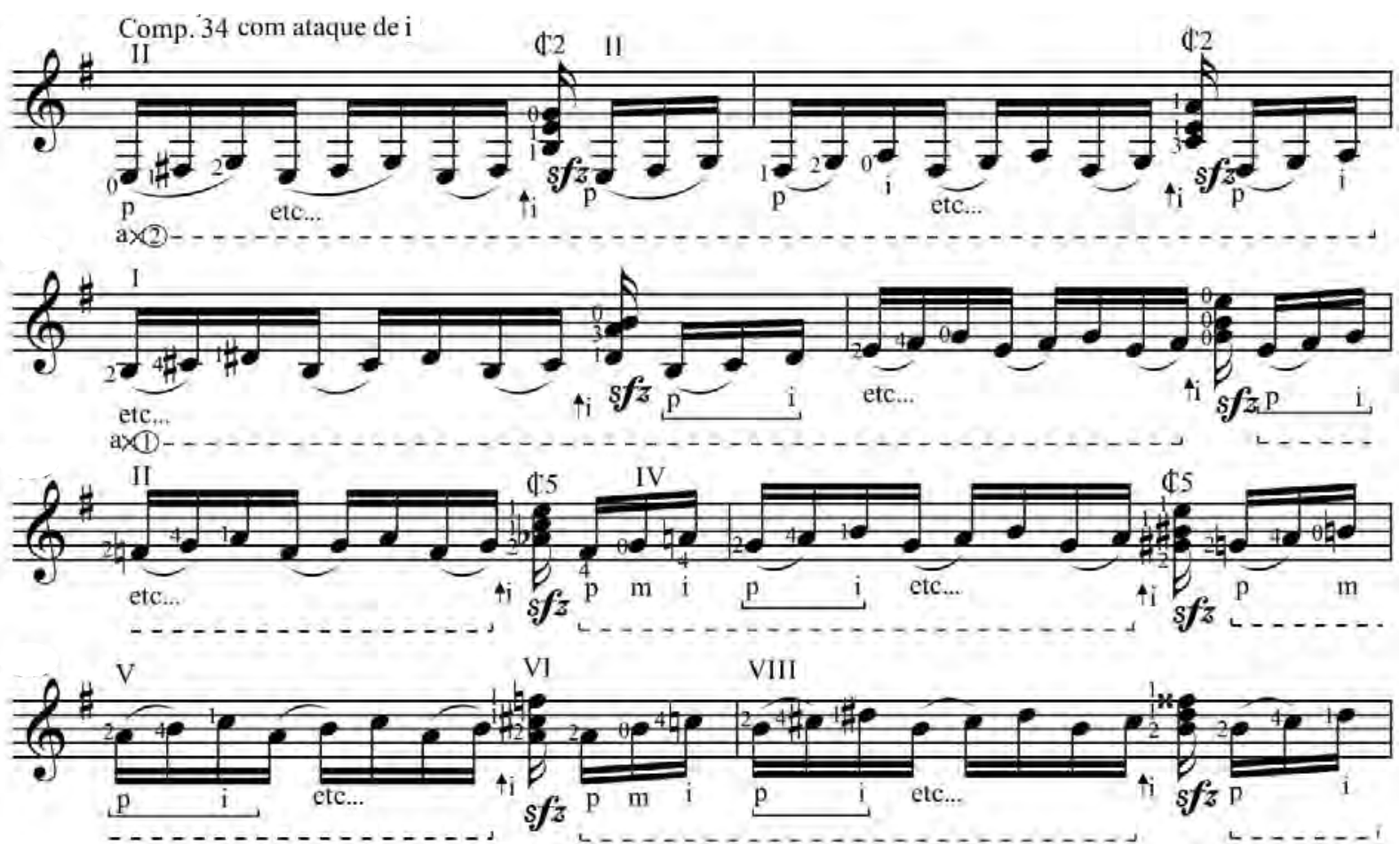

Exemplo 843: XII Estudo, compasso 34. 

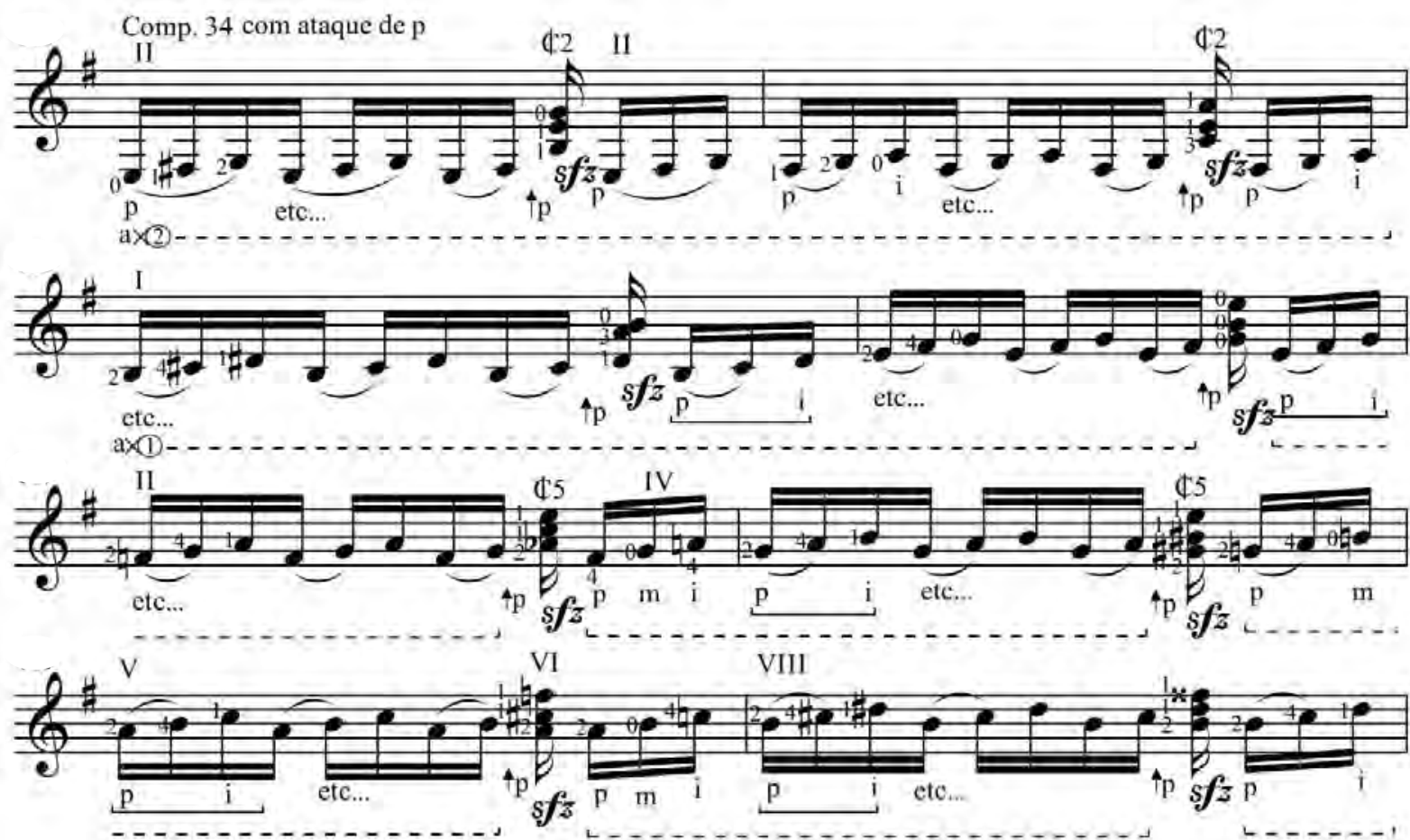

Exemplo 844: XII ${ }^{\circ}$ Estudo, compasso 34.
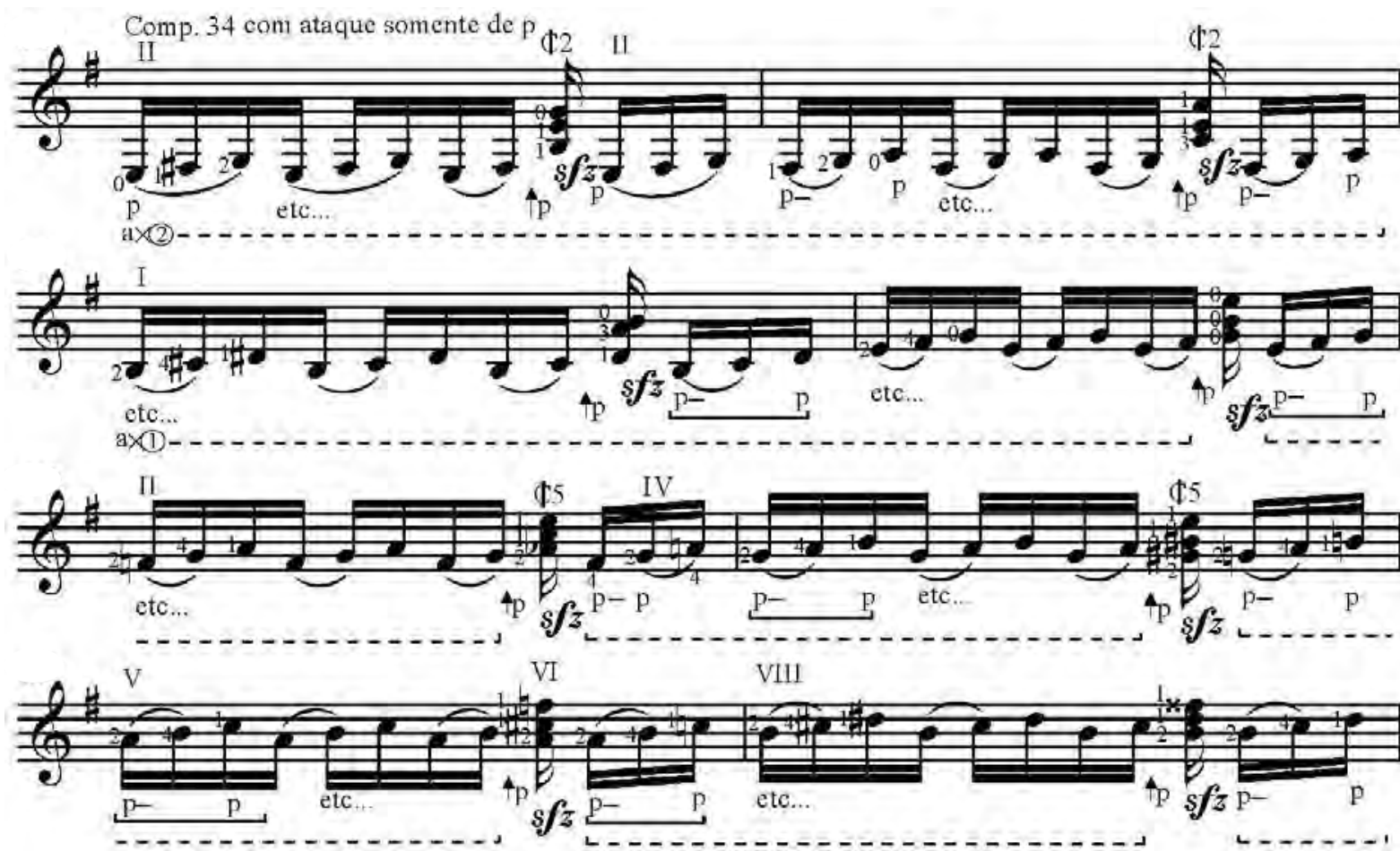

Exemplo 845: XII ${ }^{\circ}$ Estudo, compasso 34.

Após uma rápida repetição literal do princípio da peça, o motivo descendente do compasso 48 é expandido para encaminhar para a seção lenta, de melodia quase folclórica. Esse ágil trecho descendente recebe uma única versão alternativa a BL no exemplo 847, o qual evita o dedo 4 em posições extremo-agudas e padroniza ligados (sempre téticos) de todas as aparições do motivo. 

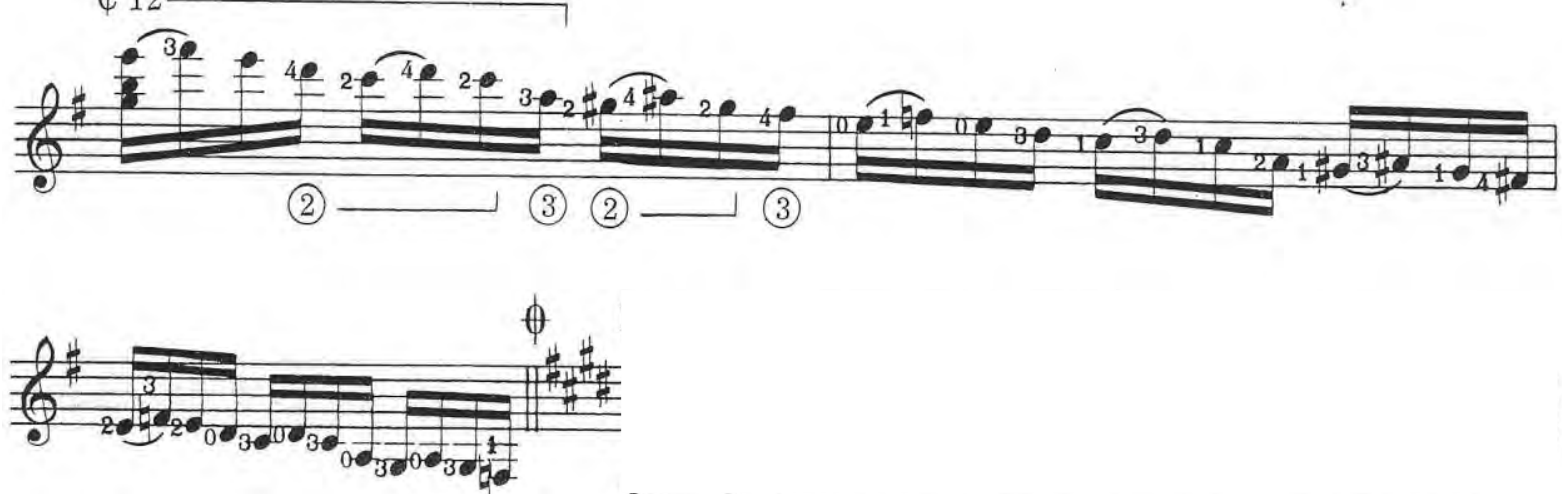

Exemplo 846: XII Estudo, compasso 48. Ed. Columbia/BL.

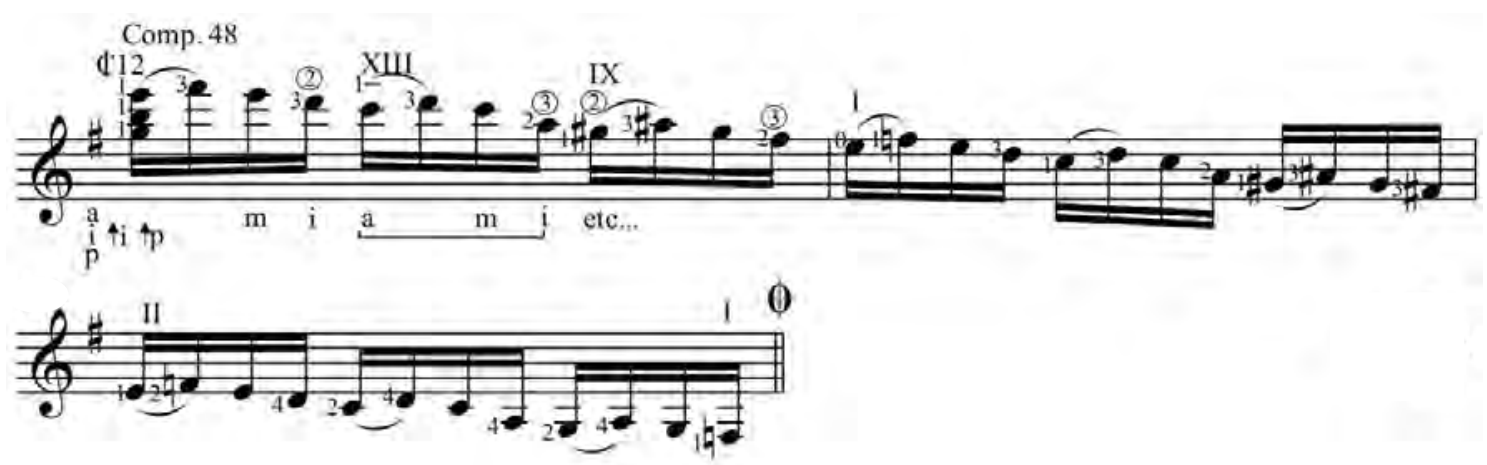

Exemplo 847: XII Estudo, compasso 48.

A seção lenta é diametralmente mais simples e recebe digitação relativamente tradicional por BL (ex. 848). No entanto não nos sentimos plenamente confortáveis com a utilização dos dedos 2 e 4 em oitavas (na segunda e quinta ou primeira e quarta cordas, sempre indicados por setas), aspecto que buscou ser acessibilizado em nossas versões. Similarmente, o uso se dedos repetidos de me em cordas diferentes, exigindo saltos verticais também foi ao máximo evitado. Nesta seção nossos exemplos foram divididos por sistemas para melhor comparação.
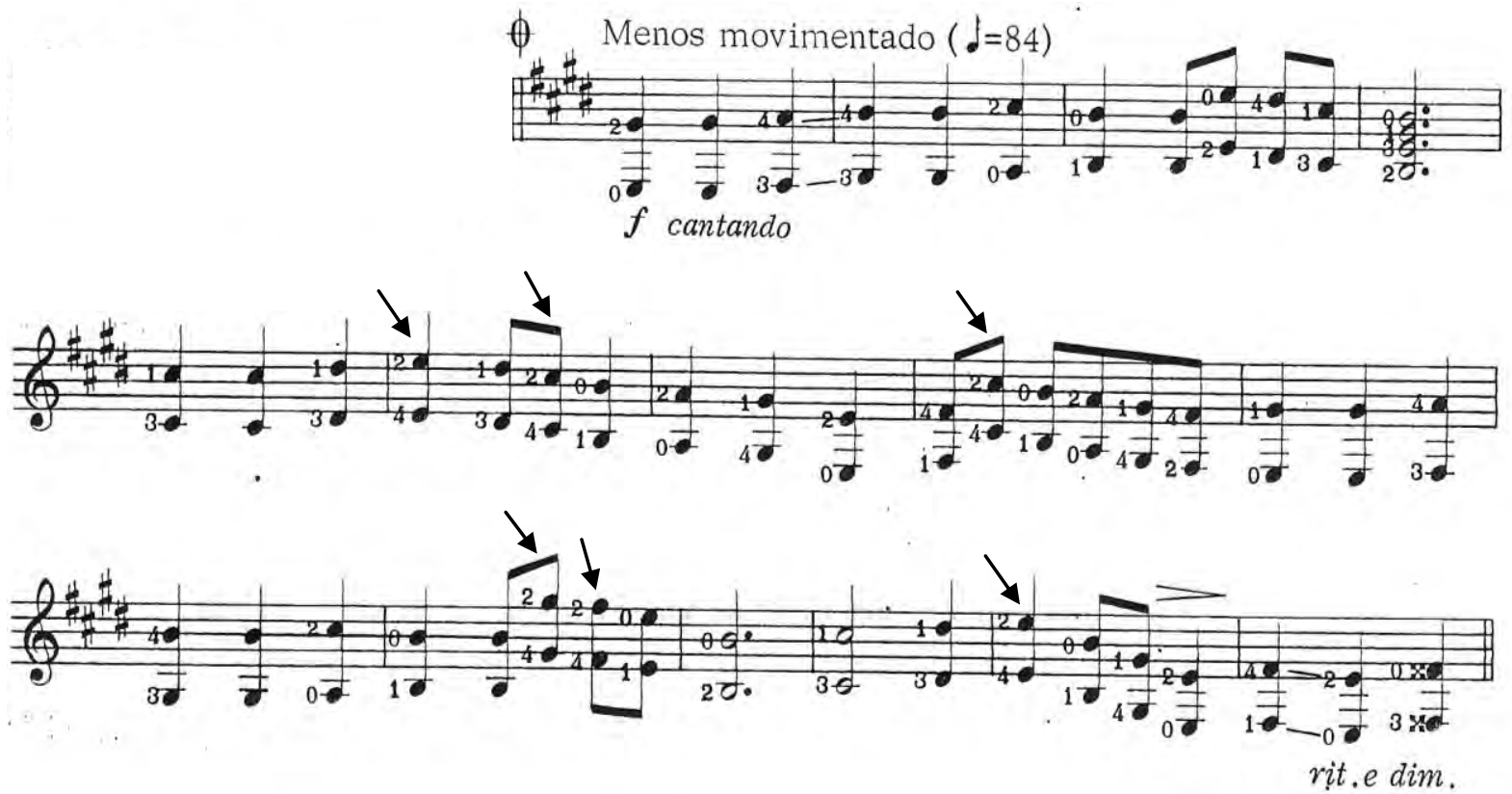

Exemplo 848: XII Estudo, compasso 51. Ed. Columbia/BL. 
O exemplo 849 se baseia em BL, mas demonstra outra opção concomitante no ápice da frase. Já o exemplo seguinte (850) substitui vários dedos iniciais e privilegia o uso da segunda e quinta cordas com translados dos dedos 1 e 2 nas oitavas em colcheias.

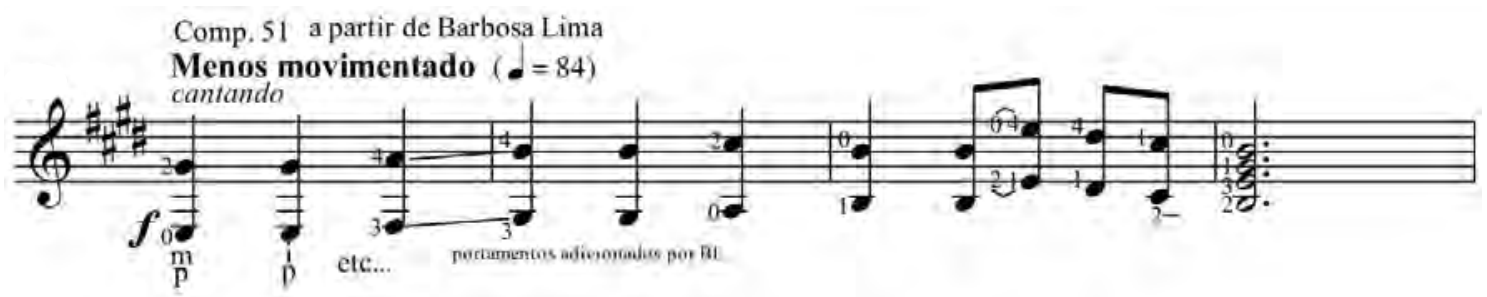

Exemplo 849: XII Estudo, compasso 51.

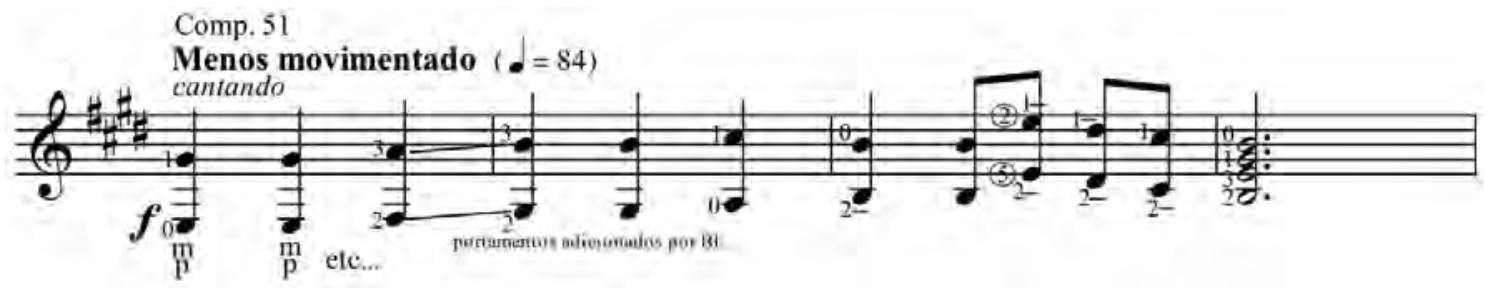

Exemplo 850: XII Estudo, compasso 51.

O compasso 55 recebe uma versão mais simples no exemplo 851, mais ou menos em consonância com o espírito do exemplo 849. Seu desfecho utiliza uma pestana para abrigar as três primeiras oitavas em colcheias, aspecto facilitador considerável e que cria maior sobreposição de notas. Já o exemplo 852 está alinhado ao exemplo 850 com sua maior utilização dos dedos 1 e 2 na segunda e quinta cordas. Seu desfecho oferece outra proposta facilitadora.

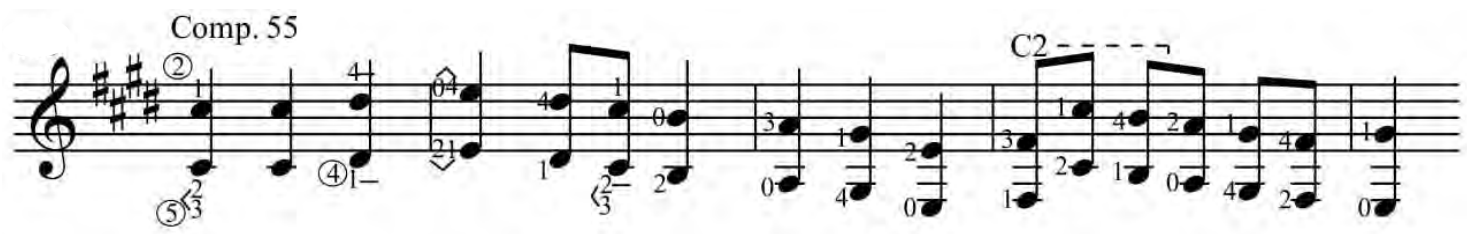

Exemplo 851: XII Estudo, compasso 55.

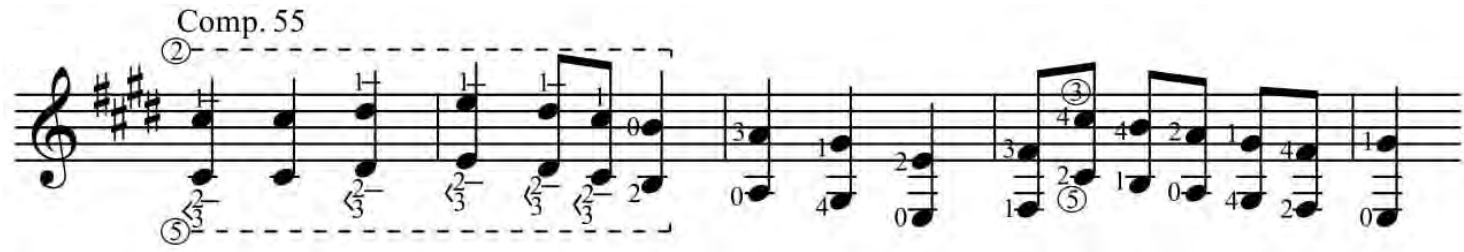

Exemplo 852: XII Estudo, compasso 55.

O sistema seguinte apresenta as oitavas mais agudas do trecho. Os exemplos 853 e 854 se baseiam em BL, mas oferecem outras saídas para as oitavas em colcheias. O segundo deles ainda inclui portamenti que apareceram compassos antes, mas que aqui foram excluídos. O exemplo 855, alinhado aos exemplos 850 e 852 também propõe maior uso da segunda e quinta cordas, mesmo nas oitavas agudas, gerando efeito dramático para as mesmas. 


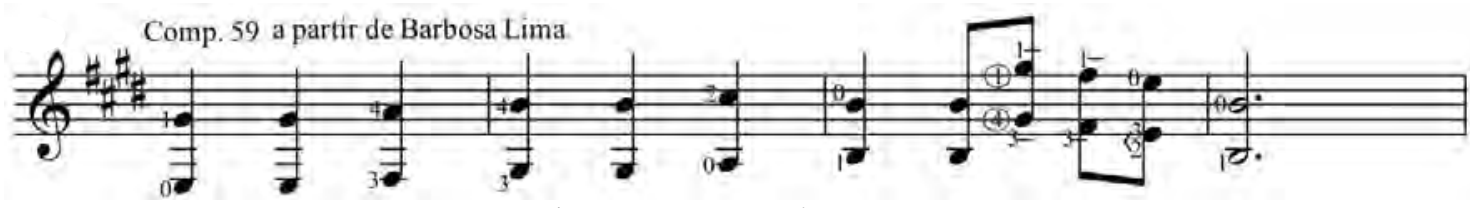

Exemplo 853: XII Estudo, compasso 59.

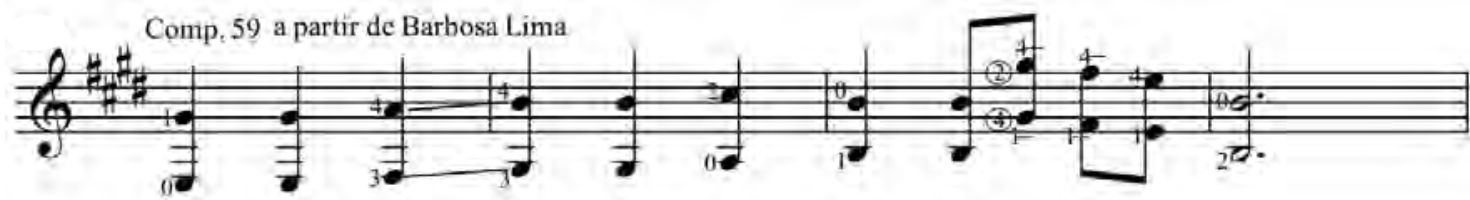

Exemplo 854: XII Estudo, compasso 59.

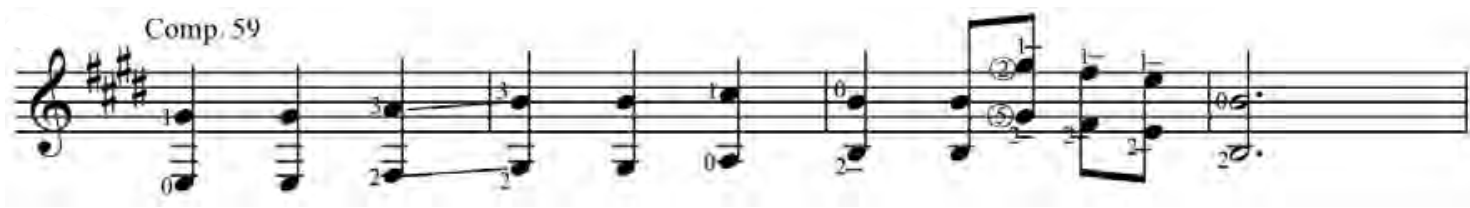

Exemplo 855: XII Estudo, compasso 59.

No desfecho do trecho, novamente oferecemos uma versão mais pautada nas primeiras posições (ex. 856) e outra com aproveitamento da segunda e quinta cordas (ex. 857).

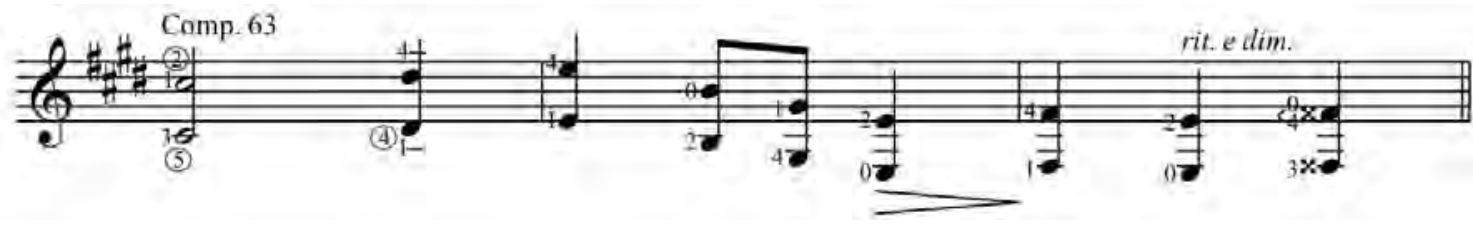

Exemplo 856: XII Estudo, compasso 63.

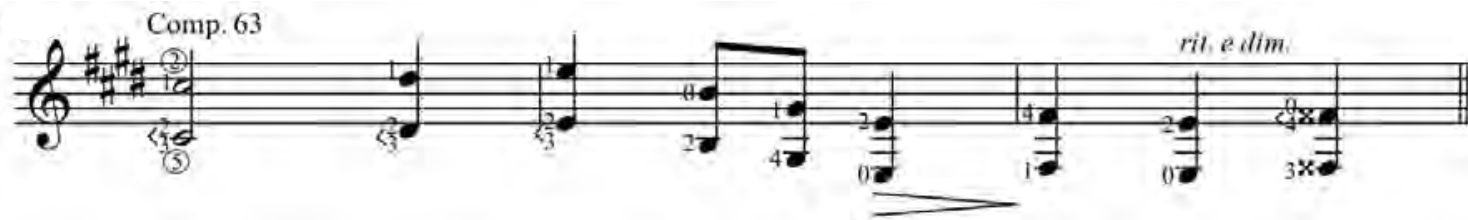

Exemplo 857: XII Estudo, compasso 63.

Apesar de todas essas versões atestarem a funcionalidade do trecho original, consideramos haver uma grande disparidade de projeção e sustentação entre o mesmo e a primeira parte da música. Entendemos que o compositor buscava um interessante e sábio contraste entre a simplicidade desta seção e a complexidade da anterior, porém julgamos que as décimas e oitavas paralelas (mesmo com toque apoiado) criaram uma sensação de vazio considerável em performances ao vivo (algo que não necessariamente ocorreria em gravações), justamente no estudo de caráter mais grandioso da série.

Nossa alternativa foi nos basearmos na coda da obra, onde este tema reaparece de forma não literal, porém harmonizada com densos acordes que dão maior imponência ao trecho. Dessa forma, propomos no exemplo 858 uma versão harmonizada por nós do mesmo segmento, ainda com uma versão alternativa para o compasso 55 no exemplo 859. 


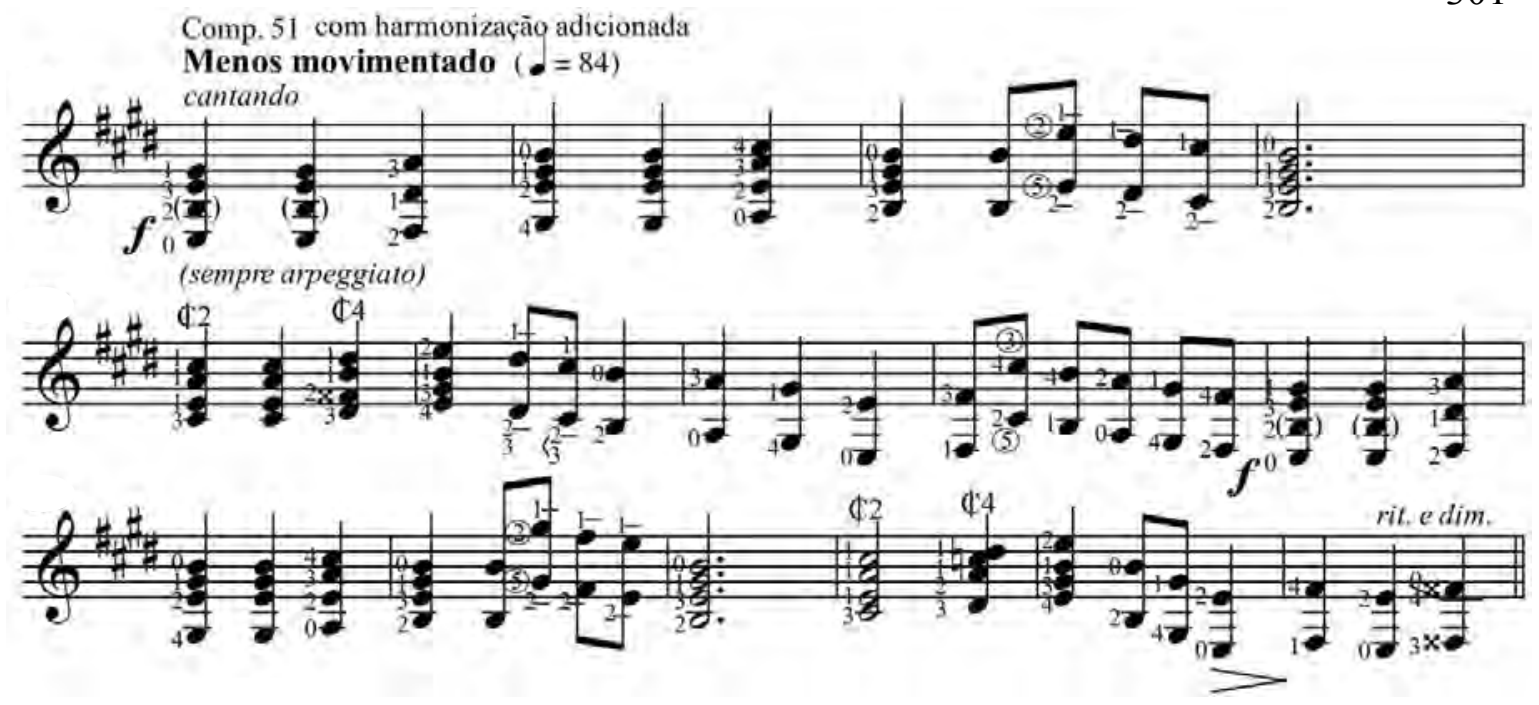

Exemplo 858: XII ${ }^{\circ}$ Estudo, compasso 51.

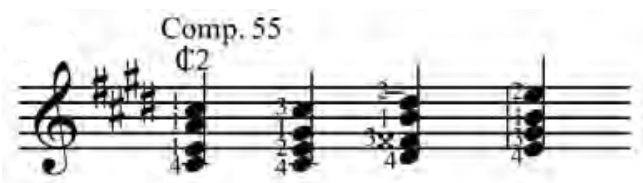

Exemplo 859: XII ${ }^{\circ}$ Estudo, compasso 55.

Devemos revelar todavia, que esta versão causou espanto inicial na esposa do compositor, a pianista Maria Josephina Mignone, quando executamos todos os estudos para a mesma em sua residência, sentimento que foi dissipado após explanar as justificativas que balizaram esta proposta.

Sobre esse tipo de intervenção pesa também o depoimento do próprio compositor ao Museu da Imagem e do Som (RJ) em 1968:

\footnotetext{
"como não conheço bem o instrumento, prefiro não escrever, porque tem de pedir a outro o arranjo, sabe como são essas coisas, acabam dizendo que arrumaram a música para mim, que não conheço o violão e a gente tem que ter amor próprio" (Mignone apud Barbeitas, 1995, p.76).
}

Porém esta entrevista foi antes de ele ser impactado pela performance de Barbosa-Lima em 1970 e se aproximar do instrumento e deste intérprete, escrevendo os doze estudos para o mesmo. Acreditamos que essa opinião poderia ter-se no mínimo atenuado, já que várias divergências entre o manuscrito do compositor e a edição Columbia foram sugeridas por Barbosa-Lima, no seu papel de revisor, e imaginamos que elas teriam passado pelo crivo do compositor. No entanto temos de ressaltar que nenhuma delas é tão aditiva quanto a presente proposta.

Respeitando a única opinião registrada do compositor, não queremos portanto, reivindicar qualquer status que não nos compete. Nosso ímpeto artístico, por meio do Pensamento Divergente e no intuito de resolver um problema de projeção e equilíbrio, foi levado a esta concepção harmonizada do trecho, a qual passou a integrar nossas performances, sem conduto ignorarmos possíveis polêmicas que essa atitude pode 
fomentar. O julgamento do leitor o levará a suas respostas pessoais na eventual construção de sua interpretação desta obra e deste trecho em especial e que por ventura poderá se basear nas opções oferecidas por nós, ou em outras que fomos incapazes de gerar.
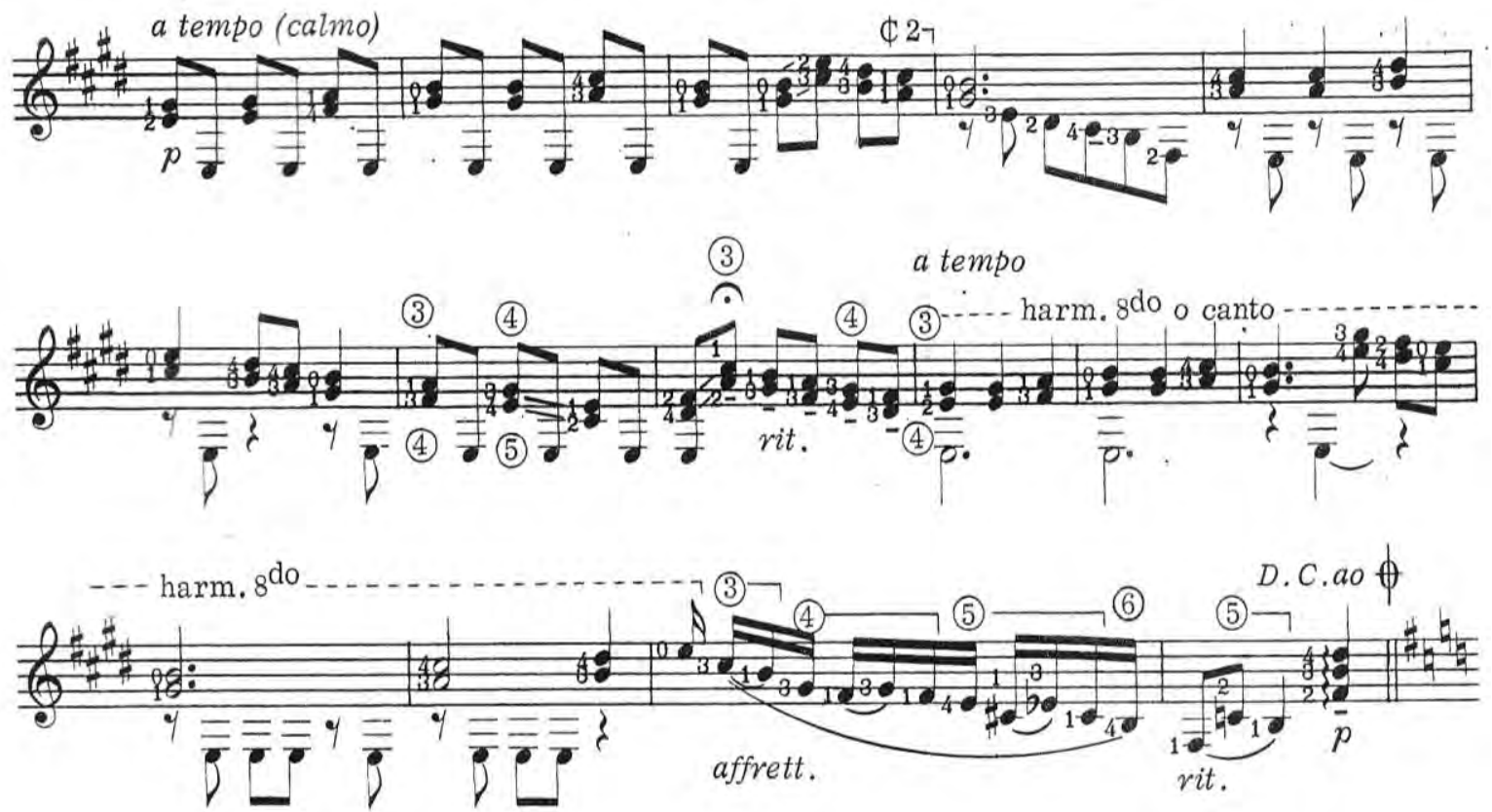

Exemplo 860: XII Estudo, compasso 66. Ed. Columbia/BL.

No compasso 66 a mesma melodia recebe variação em terças e baixo pedal e posteriormente, em sua conclusão, harmônicos. Nosso exemplo 861 se baseia em BL muito superficialmente e assim oferece outras soluções, principalmente para as terças em colcheias do compasso 68 e 73 e para o movimento do baixo no compasso 69. Já o exemplo 862 mantém inicialmente a melodia em terças (no primeiro sistema) na terceira e quarta cordas, com efeito mais caipira, aspecto similarmente empregado no compasso 73 colocando as terças na quarta e quinta cordas.

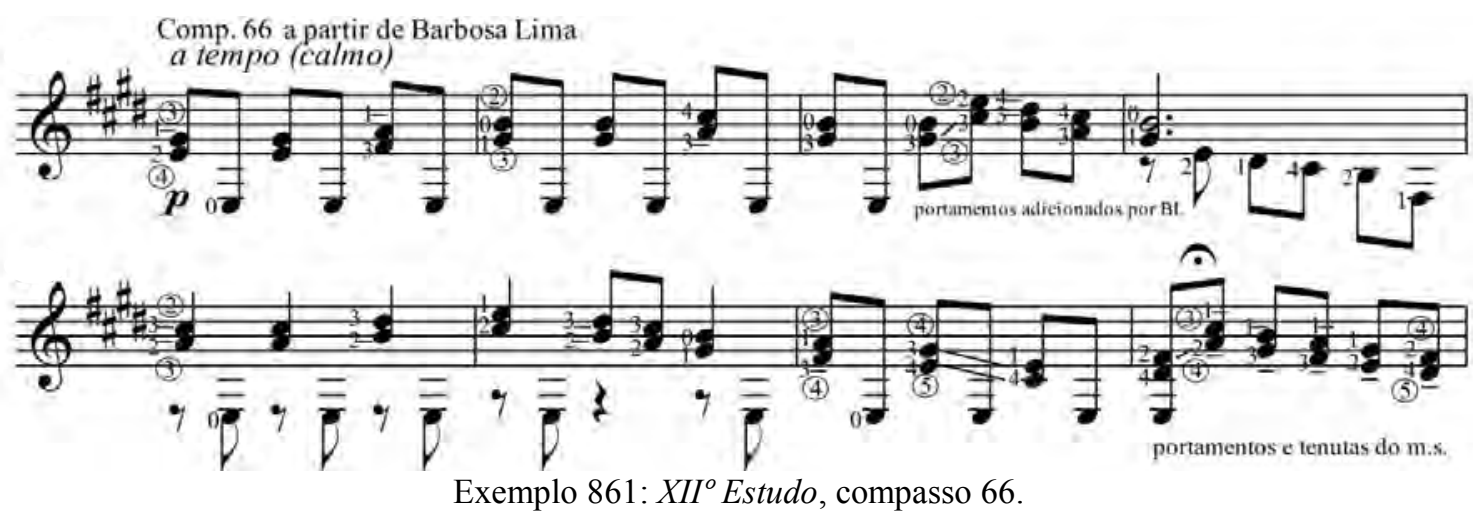




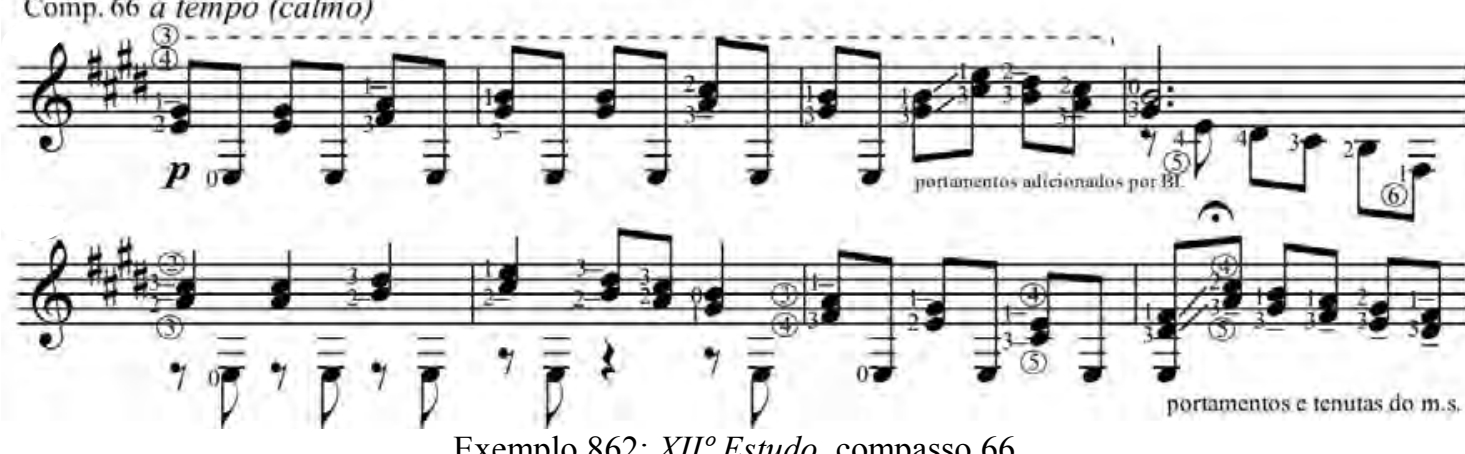

Exemplo 862: XII ${ }^{\circ}$ Estudo, compasso 66.

A repetição em harmônicos recebe uma versão ligeiramente diferente (ex. 863), iniciada pela sexta posição e com aproveitamento de um harmônico natural que intermedia a troca de posição. No manuscrito Mignone prevê harmônicos duplos, algo pouco factível neste trecho. Mesmo assim, caso o leitor insista em os realizar, basta se basear na digitação de BL oitavando as terças com o indicador da md inclinado, articulando as notas com polegar e anelar. Porém essa inclinação mudará conforme a natureza do intervalo (maior ou menor) e as cordas envolvidas, algo de dificulta a precisão dos harmônicos duplos. A cadência escalar final também é modificada ${ }^{162}$ ao ganhar uma corda solta, ligados triplos e um portamento expressivo na sexta corda.

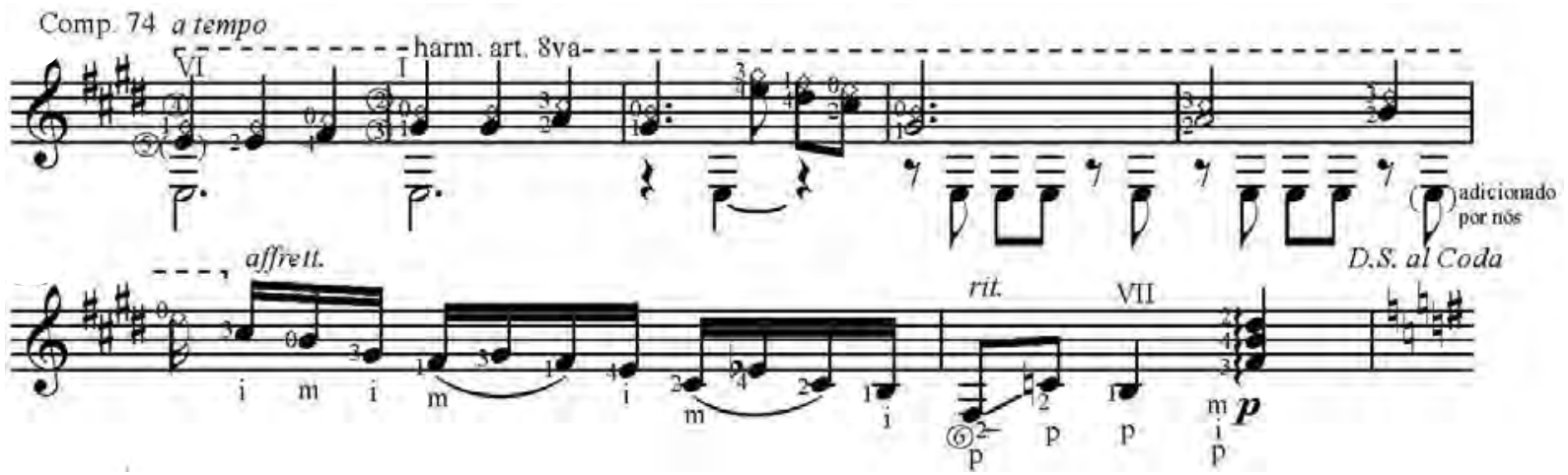

Exemplo 863: XII Estudo, compasso 74.

Após uma repetição integral da primeira seção a coda inicia-se com um elemento ligação que prenuncia o retorno da seção lenta, agora modificada ${ }^{163}$ e harmonizada. Essa escala utiliza todas as cordas soltas do instrumento e permite portanto diferentes efeitos todos com boa agilidade. BL, no exemplo 864 insere um ligado simples e digita principalmente pela segunda posição, digitando em cordas duplas os uníssonos. O exemplo 865 apenas amplia o ligado para abarcar três notas.

\footnotetext{
162 verbo do checklist de Osborn.

163 verbo do checklist de Osborn.
} 
申

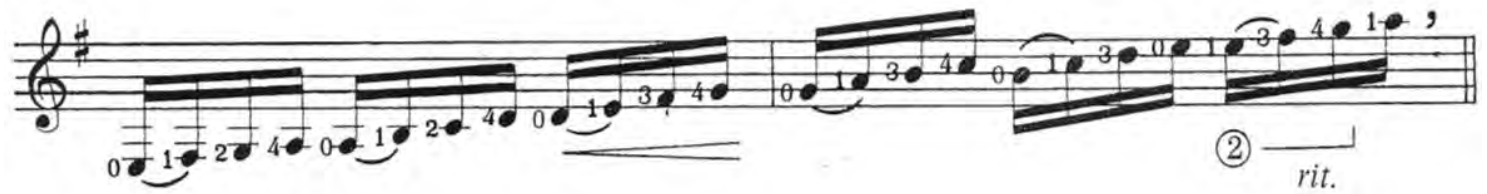

Exemplo 864: XII Estudo, compasso 32. Ed. Columbia/BL.

O Comp. 81

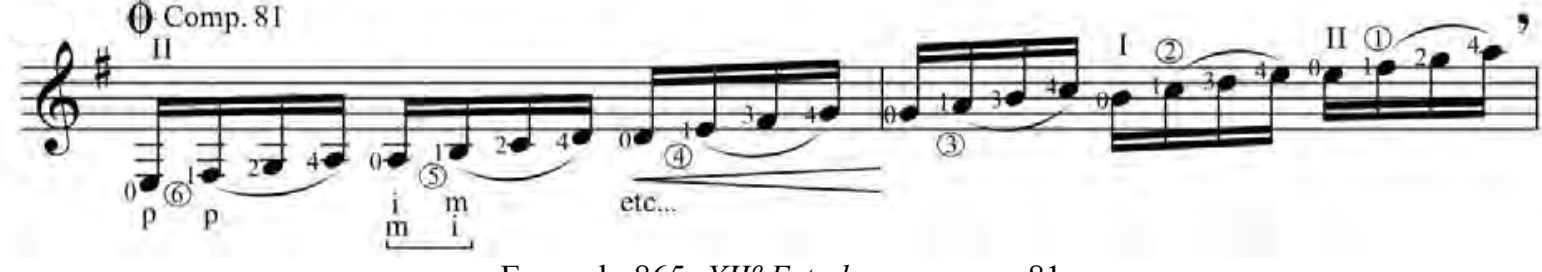

Exemplo 865: XII Estudo, compasso 81.

O exemplo 866 retira as cordas duplas nos uníssonos, executando-os portanto, em uma só corda e com ligado triplo a cada tempo. Já a última versão propõe digitação em campanella principalmente pela terceira posição com maior uso dos dedos 1 e 4 .

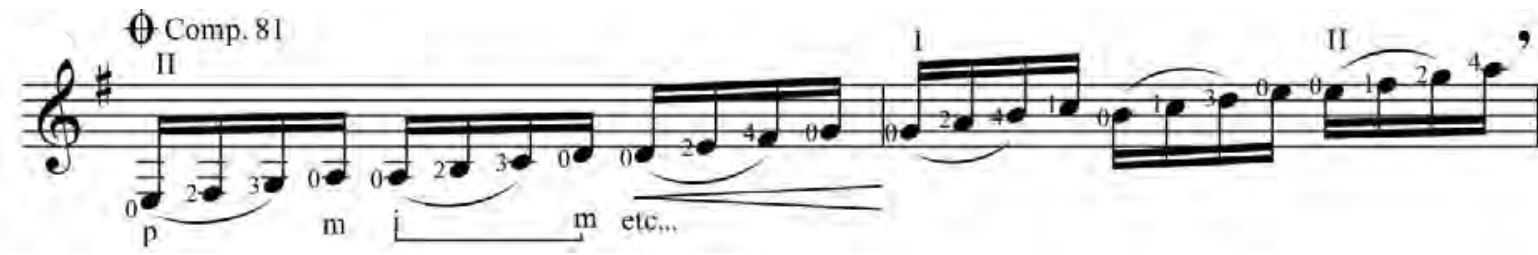

Exemplo 866: XII Estudo, compasso 81.

Ө Comp. 81 Campanella

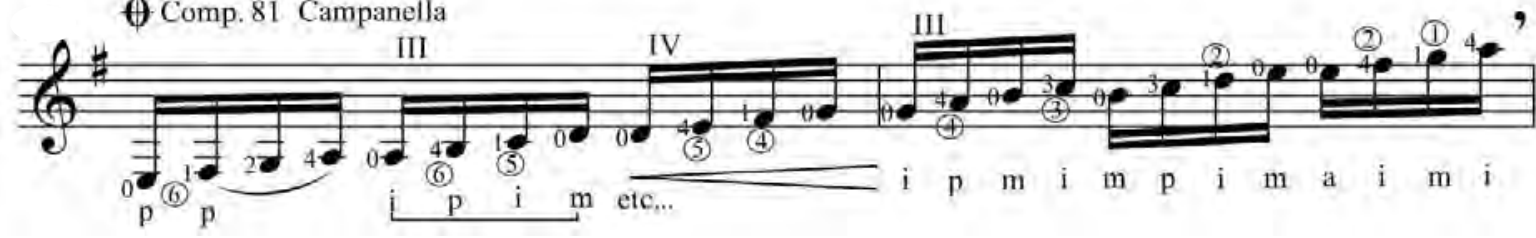

Exemplo 867: XII Estudo, compasso 81.

A apoteótica reexposição do tema lento prevê acordes em molto arpeggiato e recebe digitação bastante lógica por BL (ex. 868) apenas levemente modificada ${ }^{164}$ no exemplo 869.

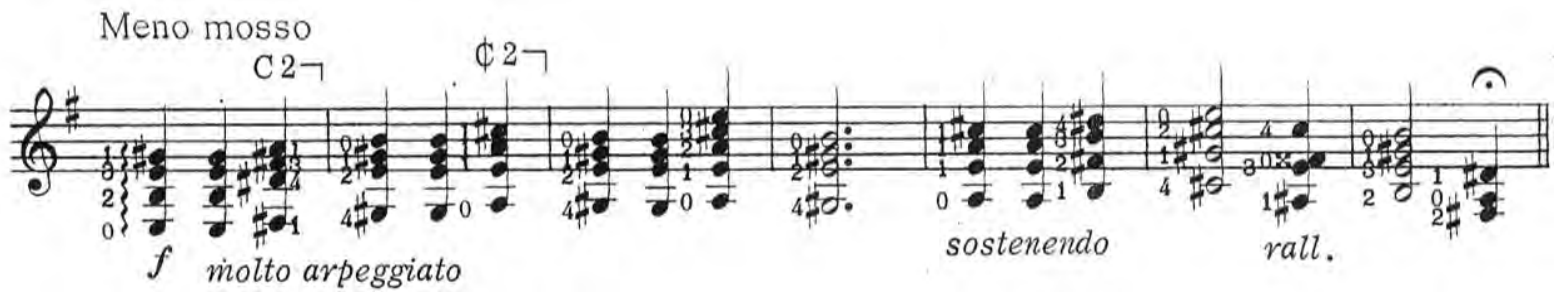

Exemplo 868: XII ${ }^{\circ}$ Estudo, compasso 83. Ed. Columbia/BL.

Comp. 83 a partir de Barbosa Lima

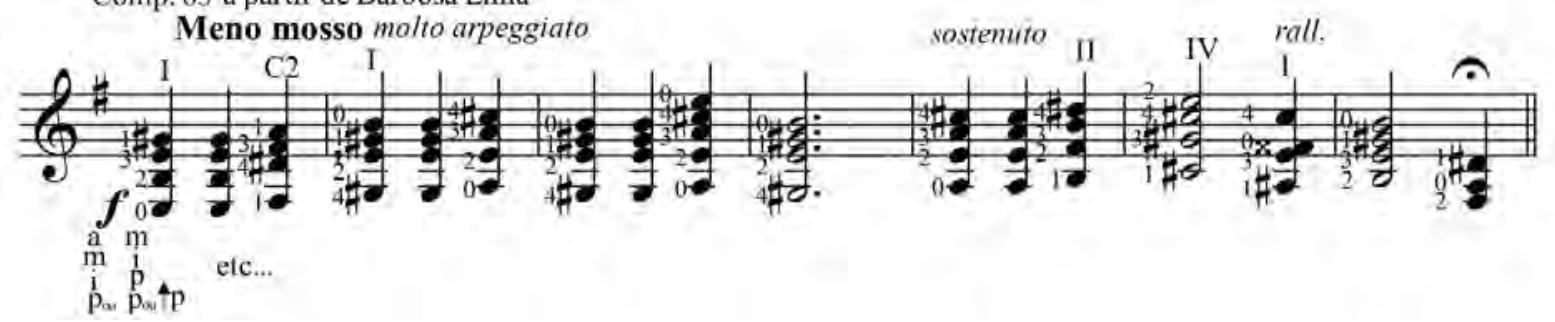

Exemplo 869: XII ${ }^{\circ}$ Estudo, compasso 83.

\footnotetext{
${ }^{164}$ verbo do checklist de Osborn.
} 
Já o exemplo 870 explora uma versão com maior utilização da sexta corda no intuito de deixá-la mais afeita à arpejos integralmente articulados pelo polegar, porém ela demanda pestanas em praticamente todos os acordes.

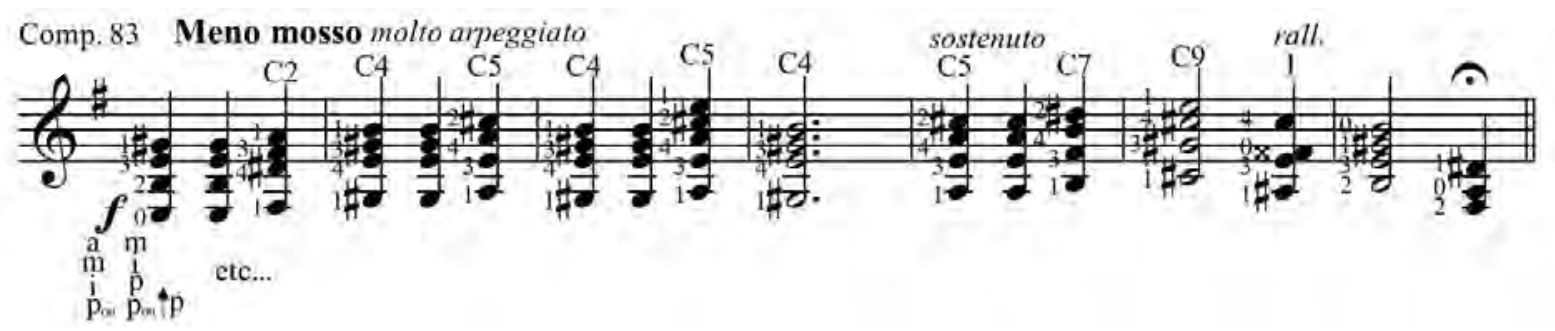

Exemplo 870: XII Estudo, compasso 83.

Neste momento, a proposta de adicionar harmonia à primeira exposição do tema lento no exemplo 858 esvazia consideravelmente o efeito epifânico da reexposição simplesmente por ter antecipado o elemento surpresa que seria gerado por esta aparição harmonizada do tema ao final deste estudo e do ciclo. Com isso, para execuções que incluam a versão por nós harmonizada na seção "Menos movimentado" (compasso 51) geramos uma nova versão (ex. 871) para a reaparição do tema na coda, onde o contraste agora é gerado pela troca de oitava e por harmonização mais densa, por vezes utilizando todas as cordas do instrumento.

Nessa versão modificada ${ }^{165}$, a melodia subiu uma oitava (excetuando os três últimos acordes) e sua harmonia foi completamente respeitada porém ampliada por dobramentos, garantindo assim o mesmo clima geral da versão original, mas com maior projeção, sustentação e com arpejos ainda mais "demorados", por contarem com mais notas a serem articuladas.

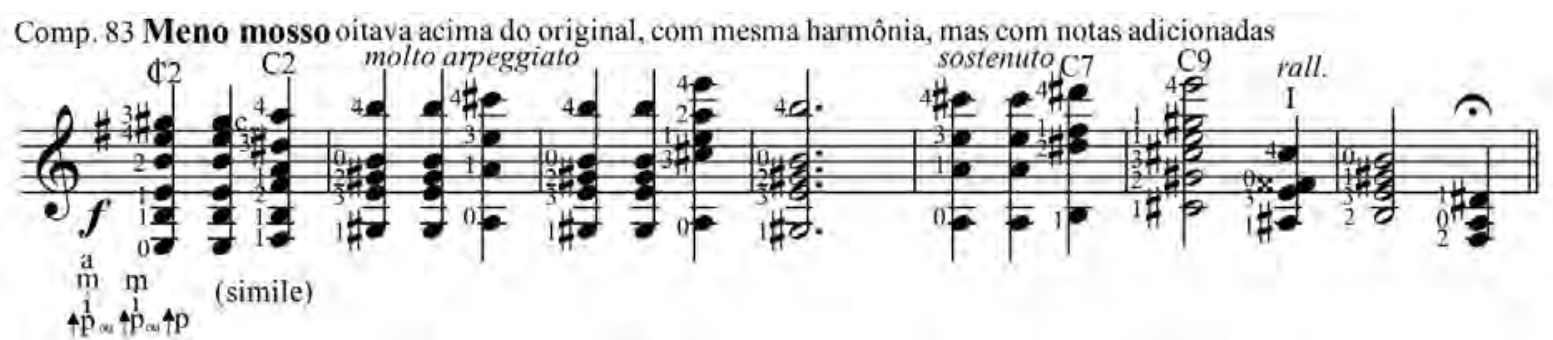
Exemplo 871: XII Estudo, compasso 83.

O encerramento virtuosístico se dá pelo súbito ataque assai veloce de uma escala descendente, que por sua vez é a exata inversão da escala ascendente do início da coda. Apesar das notas serem as mesmas, essa inversão de direção dá sensação bem diferente ao trecho e requer digitações pensadas exclusivamente para esta nova realidade (especialmente de $m d$ ). BL adota um ligado na cabeça de cada tempo e digita cada

${ }^{165}$ verbo do checklist de Osborn. 
grupo de quatro notas em uma corda mas lamentavelmente quebra esse padrão em sua segunda aparição, lapso este que é contornado no exemplo 873.

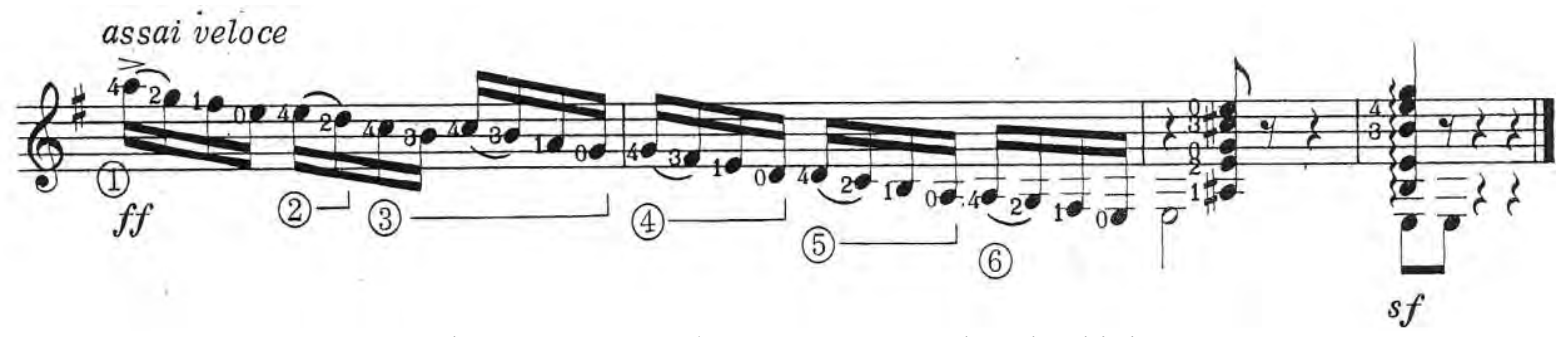

Exemplo 872: XII ${ }^{\circ}$ Estudo, compasso 90. Ed. Columbia/BL.

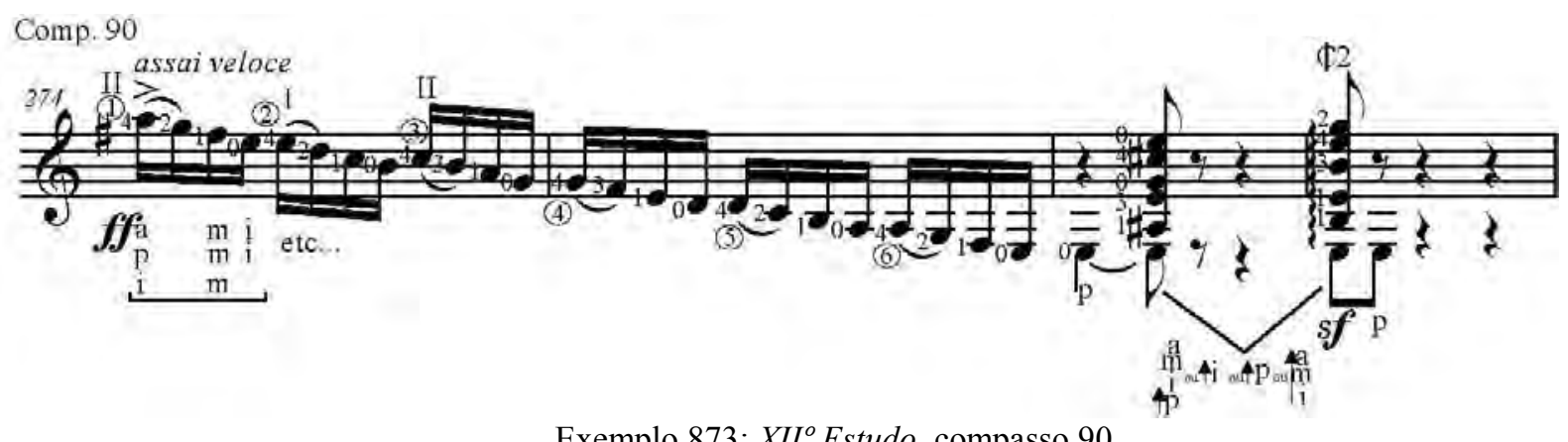

Exemplo 873: XII ${ }^{o}$ Estudo, compasso 90.

Ainda com mesmo padrão de ligados e mesmo aproveitamento de cordas soltas, os exemplos seguintes centram-se em posições distintas. O primeiro deles (ex. 874) privilegia a terceira posição, enquanto o último explora as posições avançadas do instrumento. Os acordes finais recebem várias articulações possíveis e apenas uma digitação alternativa de me.

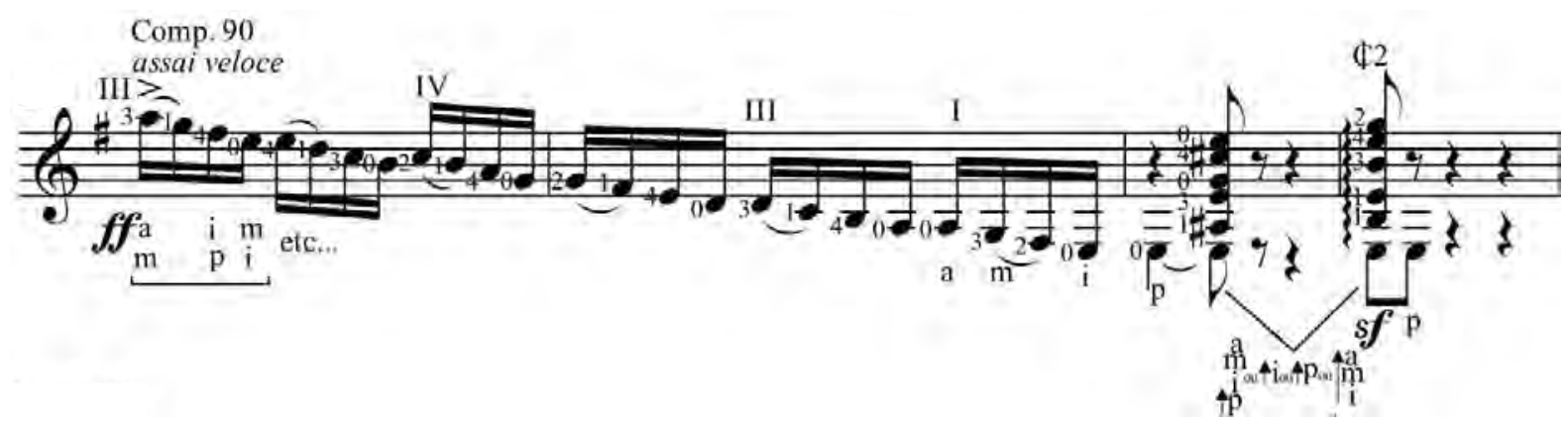

Exemplo 874: XII Estudo, compasso 90.

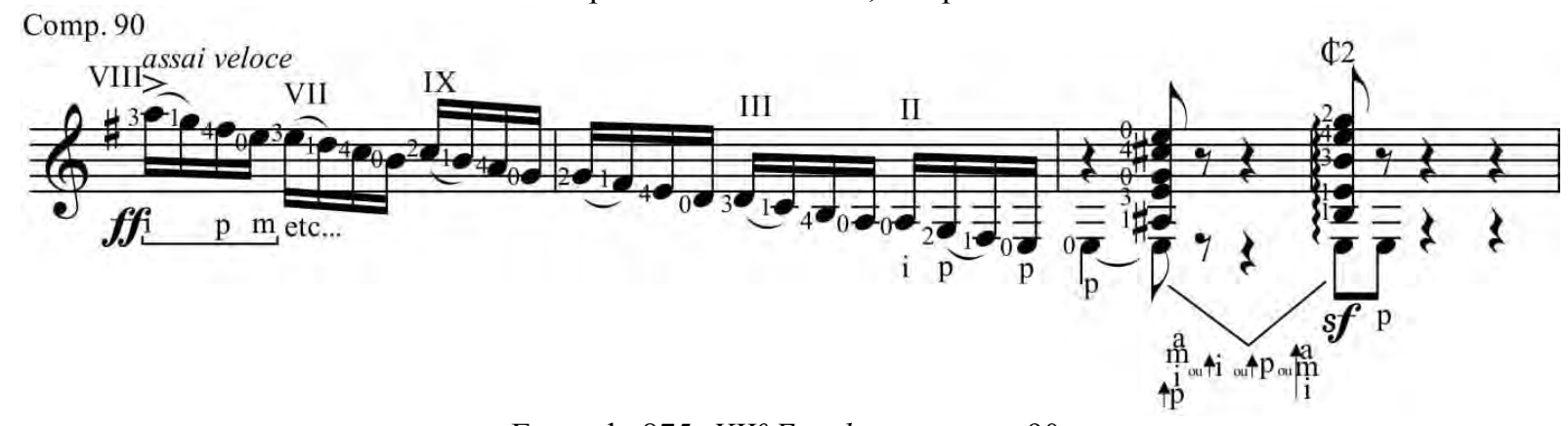

Exemplo 875: XII Estudo, compasso 90. 


\section{Considerações Finais}

Toda pesquisa pressupõe um processo, uma jornada que não necessariamente se encerra no ponto final de um trabalho acadêmico, seja ele um artigo, monografia, dissertação ou tese, como é o caso do presente trabalho.

Nossa jornada se iniciou pelo reconhecimento da ocorrência de incontáveis problemas em música, seja em sua escuta ("compreensão" e apreciação), em sua composição, aprendizado, estudo ou execução (ao vivo ou em gravações) e que as "respostas" obtidas pelos agentes envolvidos seriam fruto de avaliações estéticas de cunho subjetivo e portanto abertas à múltiplas soluções. Focados especialmente nos problemas "performáticos" musicais e mais especificamente técnico/violonísticos, iniciamos uma investigação sobre como ocorre a resolução de problemas dessa ordem e como facilitar sua ocorrência.

Talvez por estes desafios serem tão corriqueiros e pessoais e por receberem muitas vezes respostas quase imediatas seu processo foi relativamente negligenciado pelos próprios músicos, gerando consequentemente uma insuficiência de literatura específica acerca da solução de problemas no campo musical. Tal escassez nos fez estender nosso levantamento à outras áreas do conhecimento e a travar relações musicais com os conceitos advindos das mesmas.

Além disso, notamos várias similaridades e paralelos entre os próprios conceitos, aspecto que auxiliou nossa compreensão dos mesmos e sua aplicação na obra selecionada, os 12 estudos para violão de Francisco Mignone, que há muito representava desafios pouco enfrentados pelos violonistas.

Desses conceitos, o Pensamento Divergente de Guilford (1950) nos deu a noção de que o ser humano está naturalmente apto a encontrar múltiplas soluções para um problema e que tal capacidade pode anteceder a escolha da única resposta "correta", em situações onde ela existe. Tal busca prospectiva também é considerada um estímulo à criatividade, ou até mesmo seu "motor", pois o processo de fabricar mais respostas poderá gerar consequentemente uma quantidade maior de respostas pouco comuns, que travem relações inusitadas até mesmo com outras áreas e que sejam não somente satisfatórias ou "corretas", mas surpreendentes. Usando essa capacidade nas artes plásticas, um quadro cubista pode exagerar as formas geométricas presentes em um objeto sem contudo desfigurá-lo por completo. É uma resposta inusitada para a 
representação daquele objeto (principalmente em seu contexto histórico), mas ainda reconhecível satisfatoriamente.

Em muitos casos, o sentimento epifânico da arte vem quando o apreciador se dá conta, não necessariamente de forma consciente, de algumas dessas relações ou as fabrica por si só (também fazendo uso de seu Pensamento Divergente). Num exemplo simples, é quando uma obra finalmente retorna à tônica após ter passado por inúmeras relações harmônicas em seu discurso, ou quando retorna ao tema inicial após uma seção de desenvolvimento em uma forma sonata. Um exemplo talvez mais complexo e violonístico é suscitado pela aparição do tema Come, Heavy Sleep de John Downland ao final do Nocturnal After John Downland, Op. 70, de Benjamin Britten fazendo o ouvinte elucubrar relações com tudo o que havia escutado anteriormente e reequacionálas, resignificá-las.

Em todos esses exemplos, seus autores tiveram que prospectar inúmeras possibilidades antes de definirem suas respostas finais. Intrigados por este processo, resolvemos aplicar este tipo de pensamento multifacetado aos estudos violonístico de Francisco Mignone na expectativa de que isto nos ajudasse a decodificá-los.

Já o Método Científico, talvez a ferramenta mais célebre de soluções de impasses, foi aproximado do universo artístico e musical ao ser levemente desconstruída por Tang (1984). Para ele, tanto a descoberta científica quanto a criação musical possuem aspectos objetivos e subjetivos e ambas passam por um processo muito similar, onde o Pensamento Divergente se faz presente na formulação inicial de hipóteses (científicas ou musicais). Essa relação também foi abordada de maneira mais prática por Oare (2011), demonstrando que o estudante de música pode se servir do Método Científico experimental em suas seções de estudo, ao criar hipóteses para eventuais problemas, testá-las e avaliar seus resultados. Essa atitude prospectiva também governou nosso olhar sobre os estudos de Mignone, sem contudo passar por um processo rigoroso e controlado de teste das hipóteses levantadas.

Aprofundando o elemento contemplativo da descoberta, o Pensamento Reflexivo de Dewey (1933) por sua vez trouxe a noção de que uma reflexão pode ser fomentada pela supressão da decisão e por um estado de perplexidade ou de desafio. Além disso, o autor tem em conta que neste processo as memórias pregressas serão ativadas na resolução daquele empasse. Dessa forma nos permitimos mais tempo para refletir sobre os estudos de Mignone, sem pressa em definir suas soluções e mesmo quando as encontrávamos não as tínhamos como definitivas. 
As fases do Pensamento Reflexivo também lembraram muito o Método Científico e sua dicotomia com o Pensamento Não Reflexivo apresentando similaridades com a dualidade entre o Pensamento Divergente e Pensamento Convergente de Guilford (1950).

A técnica do Brainstorm de Osborn (apud Dell'Isola, 2002) também veio, de maneira menos acadêmica, demonstrar com outras palavras a importância dessa supressão de decisões, mas agora, chamada de "julgamento adiado" (pois convenhamos, "decidir" envolve "julgar", mesmo que impulsivamente). $\mathrm{O}$ ato de deixar a avaliação para depois, viria propiciar o nascimento livre de ideias, sem preconceitos e amarras, favorecendo o uso do Pensamento Divergente. Tais ideias ainda poderiam ser multiplicadas pelo uso de verbos modificadores, o chamado checklist de Osborn. Somente após encerrar o processo de criação de ideias o julgamento entraria em ação, lapidando, descartando ou testando as mais promissoras. Tal processo também foi aplicado à obra selecionada, sem obedecer literalmente o rito processual de uma seção de Brainstorm.

A última ferramenta na solução de problemas foi a Heurística (Duailibi e Simonsen, 1990), uma "regra" processual flexível e de enunciado curto. Seis leis Heurísticas iniciais foram propostas por Duailibi e Simonsen (1990) e proveram a consciência do valor da simplicidade no processo de resolução de problemas bem como da importância das fontes primárias, do questionamento delas, do afastamento do fenômeno, da temporalidade das soluções e da possibilidade do caos e do imprevisto deturparem o resultado esperado. A Heurística também nos permitiu sintetizar e reprisar os conceitos anteriores de maneira sucinta, bem como demonstrar a possibilidade de se elaborar "procedimentos padrões" violonísticos, a título de exemplo.

$\mathrm{Na}$ segunda parte da tese, esmiuçamos e contextualizamos sucintamente a obra selecionada, comparando-a de forma mais ou menos "imparcial" com seu antecedente mais célebre, os 12 Estudos para violão de Villa-Lobos a fim de desmistificar e desanuviar algo que já ocorria em um ambiente informal e improfícuo. Assim organizamos suas origens, funções didáticas técnico/interpretativas, suas similaridades e diferenças, seus arcos de discurso ou duração, seus graus de dificuldade e o processo histórico que permeou o nascimento dessas obras e sua acolhida por intérpretes, concluindo que a pouca discussão acadêmica sobre os estudos mignonianos pode ter favorecido seus 43 anos de difusão insuficiente se comparada ao que era merecido em nossa opinião. 
Com todos esses saberes organizados e com os estudos introduzidos ao leitor, foi a vez de aplicar os conceitos de solução de problemas à obra selecionada na terceira e mais extensa parte da tese. Nela, um grande número de opções foi desenvolvida para a maior parte das passagens dos estudos.

Apesar dessa parte contabilizar 875 exemplos musicais, o exato número de possibilidade levantadas por nossa pesquisa é de difícil precisão, primeiro por haver um pequeno número de exemplos advindos da edição Columbia e do Manuscrito do compositor. Por outro lado, a grafia de várias possibilidades em um mesmo exemplo associada à relatada possibilidade de combinação ${ }^{166}$ entre versões gerariam um número ainda mais exponencial e incalculável ${ }^{167}$ de soluções. A maior parte das passagens recebeu de dois (2) a seis (6) exemplos e apenas superaram dez (10) exemplos em seis ocasiões. O trecho com maior número de exemplos foi o compasso 7 do $I V^{o}$ Estudo com quatorze (14) ocorrências (ex. 268 a 281) seguido pelo compasso 14 do $I^{o}$ Estudo com treze (13) ocorrências (ex. 32 a 44). Por outro lado, os $I I^{o}, V^{o}, X I^{o}$ Estudos tenderam a ter menos opções para cada passagem.

Essa ocorrência de mais ou menos possibilidades para uma passagem é de difícil explicação. Hipotetizamos que no violão quanto mais monódica for a passagem, normalmente mais possibilidades ela gerará e ao contrario, quanto mais notas simultaneamente presas ela tiver, menos versões ela propiciará. Mesmo assim, este último caso ainda estará sujeito a ocorrência de diferentes ordenações e articulações de $m d$, ligados entre notas e a própria revisão das notas envolvidas se necessário.

À parte dessa questão quantitativa, os ganhos mais expressivos foram de ordem qualitativa. Em nossa experiência pessoal, a procura por múltiplas soluções auxiliou em um melhor conhecimento do instrumento, tanto na distribuição da notas quanto no domínio de seus recursos e também se manifestou em uma melhora de leitura em geral e especialmente na leitura de digitações. Além disso, possibilitou neste caso específico, uma execução dos estudos violonísticos de Mignone pautada em uma escolha mais ampla e consciente das opções digitais selecionadas.

Ademais, o uso dos conceitos selecionados se provou ferramenta bastante útil quando nos levou repetidamente à soluções não somente melhores do que dispúnhamos

\footnotetext{
${ }^{166}$ verbo do checklist de Osborn.

${ }^{167}$ Pelo menos para nós que não possuímos e nem almejamos possuir conhecimento avançado em cálculo matemático.
} 
mas às vezes inesperadas, ou seja, que dificilmente teriam sido concebidas por nós sem o processo de livre procura por respostas múltiplas fomentado por nosso campo teórico.

Este aspecto (opções melhores do que anteriores e ou inusitadas) ocasionaria uma listagem demasiadamente laboriosa para ser pormenorizada, além de que seu resultado estaria atrelado a um julgamento completamente subjetivo e portanto, relativo. Por isso, nos ocuparemos apenas de relembrar algumas passagens onde o processo de busca por múltiplas soluções foi especialmente promissor como metodologia de solução de problemas.

No $I^{o}$ Estudo foram levantados dois padrões de $m d$ para "governar" a obra como um todo (ex. 4), foram geradas opções relevantes para os arpejos amplos dos compassos 1 (ex. 2-3), 3 (ex. 6), 14 (ex. 32-44), 88, (ex. 93), entre outros e passagens problemáticas como as dos compassos 4 (ex. 8-15), 7 (ex. 17-23), 10 (ex. 24-31), 21 (ex. 57-66), 24 (ex. 67-72) e sustentação dos harmônicos finais (ex. 94-96), entre outros.

O $I I^{o}$ Estudo recebeu versões diversas da melodia da primeira seção (ex. 97-104) com e sem ligados e com harmônicos integrados à notas reais (esta última de caráter criativo), duas visões para a seção "Calmo" (ex. 113-116), a segunda delas com maior aproveitamento dos bordões na melodia.

O $I I I^{\circ}$ Estudo ganhou várias soluções para as notas repetidas dos compassos 4 (ex. 142-144), 6 e 7 (ex. 145-150), para suas "baixarias" nos compassos 18 (ex. 152157), 20 (ex. 162-166), 22 (ex. 167-170), 28 (ex.175-179), 32/36 (ex. 190-195), 34/38 (ex. 196-201), 59 (ex. 231-233), melodias em acordes (comp.19, ex.158-161), acordes em rasgueios (ex. 202-212, vários compassos) e arpejados (ex. 213-216, este último recorrendo a pestana cruzada), entre outros.

O $I V^{o}$ Estudo teve suas possibilidades "dissecadas" para seu padrão vigente de galope nos compassos 1 (ex. 239-245), 3 (ex. 246-255), 5 (ex. 256-267), 7 (ex. 268281), 23 (ex. 290-292), 27 (ex. 296-299), 28 (ex. 300-303), 29 (ex. 304-308), 69 (ex. 325-330) e 77 (ex. 335-338) e diferentes articulações de $m d$ para os compassos 11 (ex. 282-287), 31 (ex. 309-314) e 80 (ex. 339-340), entre outros.

O $V^{o}$ Estudo foi particularmente diversificado nos padrões de arpejos em tercinas dos compassos 20 (ex. 350-351), 22 (ex. 352-353), 31 (ex. 354-356) e 104 (ex. 409411), na escala cromática do compasso 87 (ex. 396-399), no arpejo descendente do compasso 113 (ex. 441-414) e no ríspido encerramento no compasso 122 (ex. 417), entre outros. 
$V I^{o}$ Estudo teve discussões mais proeminentes nos compassos 1-8 (ex. 418-423), na variação rítmica com nota repetida do compasso 9-16 (ex. 424-428), na seção central de arpejos (ex. 429-435), na subida cadêncial do compasso 43 (ex. 436-439) e em sua descida no compasso 50 (ex. 446-449), na abertura do compasso 59 (ex. 450-453), no arpejo cadêncial do compasso 68 (ex. 456-461), na escala do compasso 70 (ex. 462465), na subida em terças a partir do compasso 73 (ex. 466-470), na repetição variada dos compassos 76-84 (ex. 471-474) e na escala final do compasso 90 (ex. 476-482), entre outros.

No VII ${ }^{o}$ Estudo foi priorizada em geral uma busca por maior sustentação de seus acordes, aspecto ocorrente em toda a obra o que torna desnecessário citar exemplos específicos. Dignas de nota são as passagens iniciadas nos compassos 3 (ex. 495-511), 4 (ex. 512-521) e 26 (563-570) que além da questão da sustentação, receberam múltiplas versões com harmônicos duplos (previstos no manuscrito), simples (redução ${ }^{168}$ sugerida pela edição BL/Columbia) e sem os mesmos (ainda em maior simplificação).

O desafiador $V_{I I I}{ }^{\circ}$ Estudo recebeu novas versões para os compassos 1 (ex. 581585), 7 (ex. 599-601), 11 (ex. 602-607), 12 (ex. 608-610 com diferentes articulações de $m d$ ), 13 (ex. 612-615, com notas repetidas), 15 (ex. 620-622), 16 (ex. 623-627), 17 (ex. 628-631), 18 (ex. 632-634) e revisão gerando novas possibilidades para o compasso 33 (ex. 656-658).

O $I X^{o}$ Estudo, talvez aquele com mais mudanças de padrões da série, gerou opções consideráveis para os compassos 1 (ex. 660-664), 7 (ex. 666-670), 39 (ex. 685688), 41-56 (ex. 689-697), 62 (ex. 707-710, algumas delas com rasgueios), nas melodias com intervalos paralelos (terças, décimas, blocos de acorde, etc.) dos compassos 79 a 88 (ex. 718-726) e 110-117 (ex. 732-336), além de outros.

No $X^{o}$ Estudo criamos versões com quatro scordaturas diferentes (a saber: sexta em Ré, Mi, Mi bemol e sexta em Ré com capotraste na primeira posição) que resultaram em digitações também distintas num processo paulatino de raciocínio que nos fez preferir a última opção (as razões estão expressas no tópico referente ao estudo em questão).

O $X I^{\circ}$ Estudo foi facilitado no compasso 1 (ex. 764-767) no compasso 12 (ex. 780) e nas anacruzes dos compassos 3 (ex. 768-770) e 5 (ex. 771-772). Recebeu várias

${ }^{168}$ verbo diminuir do checklist de Osborn. 
versões para os compassos 7 (ex. 773-778), 23 (ex. 782-786) e a seção iniciada no compasso 26 ganhou versão em campanella (ex. 787-796).

O XII Estudo inicialmente recebeu versões focadas no funcionamento de cada mão em separado. No aspecto da $m d$, sua seção inicial ganhou seis possibilidades de articulação (ex. 816-821), muitas das quais com maior agilidade e projeção. Os compassos iniciais também receberam tratamento isolado e profícuo (ex. 801-815). A segunda frase iniciada no compasso 8 , recebeu detalhada revisão e readequações (ex. 822-826) devido à impossibilidade de ser executada conforme o manuscrito. A seção iniciada no compasso 34 teve ampla e benéfica discussão (ex. 834-845) fomentada por nosso enfoque teórico a fim de lograr fluência no rápido motivo em semicolcheias interrompidos por ataques de acordes. A seção com melodia em décimas paralelas (a partir do compasso 51) foi revista nos exemplos 848-859, sendo que os últimos propuseram a adição de um preenchimento harmônico baseado na coda da mesma obra. As escalas de início (comp. 81, ex. 864-67) e fim (comp. 90, ex. 872-875) da coda, construídas de forma espelhada, receberam múltiplas versões, assim como a melodia em acordes (ainda na coda, ex. 868-871). O último exemplo citado ainda criou uma versão oitava acima do original, para resgatar o contraste com a seção central da obra em versão harmonizada por nós.

No âmbito geral dos referidos estudos, nos parece que o efeito de campanella foi um acréscimo inovador à várias de suas passagens, por configurar ferramenta digitacional de popularização recente e posterior à edificação da mentalidade violonística de Barbosa-Lima, conforme explicamos anteriormente.

Mas além dos exemplos de sucesso, também deve-se relembrar algo importante: no decorrer do processo habitual de geração de ideias para um determinado trecho, podem ser criados alguns exemplos ainda "imaturos" ou aparentemente "ruins" num primeiro julgamento, mas muitas vezes os mesmos são aprimorados e recombinados em versões subsequentes de forma a superarem seus defeitos e finalmente criarem a solução almejada. Ou seja, estes exemplos "primitivos" ou "desajeitados" são essenciais ao processo de solução de ideias e sem eles, muitas vezes não se obteria o resultado final esperado.

Isso nos fez compreender a busca de soluções de problemas como um processo, não raramente complexo, longo e trabalhoso, mas também prazeroso, desafiador e divertido. Além disso, ele parece aceitar melhor o "erro" ou o "indesejado" e por vezes até o transforma na solução ideal por meio de aprimoramentos. Por isso esta pesquisa 
nos deu a consciência, advinda do "julgamento adiado" do Brainstorm, de desviar o foco do resultado e voltá-lo para o processo, compreendendo a partir de então, a prática violonística como um eterno trabalho em progresso, onde às vezes andamos rápido, às vezes lentamente, às vezes estagnamos, mas dificilmente andamos para trás.

Essa pesquisa também nos deu a perspectiva mais palpável do quão variada pode ser a performance musical de uma obra. Se no âmbito técnico nossos 875 exemplos já parecem substanciar tal impressão, imaginamos que as possibilidades interpretativas seriam ainda mais numerosas. Acreditamos que é neste aspecto incomensurável e pessoal que reside parte de nossa grande admiração pela arte. E mesmos quando eles não são aproveitados, oferecem um julgamento mais substanciado, mais amplo.

Cremos que se um artista busca a alta performance artística, ele deve considerar injusto não tentar extrair o máximo potencial estético (ainda que subjetivo) de uma passagem, ou por outro lado, não buscar uma opção que lhe permita aflorar a sua máxima desenvoltura (ou seu máximo potencial estético) naquela mesma passagem. $\mathrm{O}$ uso consciente e reflexivo do Pensamento Divergente e dos demais conceitos de soluções de problemas parece prover método valioso para exercer a plena função do artista que reside nesse criterioso e exigente compromisso estético de elevação das capacidades humanas.

Porém também reside neste aspecto pessoal a qualidade e o demérito da presente pesquisa. Ela optou metodologicamente por abordar os conceitos interdisciplinares de solução de problemas inicialmente por um prisma individual, objetivando-o um primeiro passo em sua aplicação, compreensão e em sua "tradução". Nos sentimos porém, impelidos a reconhecer a necessidade de estudos posteriores com caráter coletivo e experimental, ou seja, com grupos de controle, de experimento e com metodologias mais rigorosas de avaliação, com o objetivo de mensurar comparativamente a maior ou menor eficácia do uso das referidas ferramentas de solução de problemas. Almejamos, num futuro próximo, poder concretizar tais pesquisas.

Outra derivação da presente pesquisa parece residir nas próprias opções digitacionais geradas. Cremos que esta profusão de possibilidades poderá auxiliar o caminho de futuros intérpretes dos estudos selecionados, ao mostrar-lhes "atalhos" trilhados por nós. Por outro lado, acreditamos ter também auxiliado futuros estudantes de violão com a demonstração de um "processo" de solução de problemas que poderá 
ser replicado (não literalmente), implementado, adaptado, personalizado por eles em outras obras.

Também estamos abertos à possibilidade de que eles poderão encontrar soluções não consideradas por nós, até mesmo baseadas ou não em nossas opções, uma vez que não tivemos a arrogância de querer abarcar todas as possibilidades digitacionais para os estudos violonísticos de Mignone, apenas buscamos criar as nossas e com isso demonstrar a existência de um processo de solução de problemas violonísticos.

Resta aqui reconhecer que a presente tese também obedecerá à sexta lei Heurística de Duailibi e Simonsen, a chamada "Lei da obsolescência" que prevê que "o projeto torna-se obsoleto no momento em que deixa sua prancheta" (Duailibi e Simonsen, 1990, p. 10). 


\section{Fontes Bibliográficas}

ABDALLA, Thiago. Análise Técnico-Interpretativa dos Ciclos de Estudo para Violão de César Guerra-Peixe (Lúdicas), Radamés Gnattali e Heitor Villa-lobos. Trabalho de Conclusão de curso (TCC). ECA-USP, 2005.

AMORIM, Humberto. Heitor Villa-Lobos e o violão. Academia Brasileira de Música, Rio de Janeiro, 2009.

AMORIM, Humberto. Heitor Villa-Lobos: uma revisão bibliográfica e considerações sobre a produção violonística. Dissertação de mestrado, UNIRIO, 2007.

ANDRADE, Maria Margarida. Como preparar trabalhos para cursos de pósgraduação. Editora Atlas, 8 ed. 2008.

ANTUNES, Gilson e FERNANDES, Marcelo. Aplicações TécnicoInstrumentais e Similaridades nos Estudos para Violão De Heitor Villa-Lobos, Radamés Gnattali e Francisco Mignone. Simpósio Internacional Villa-Lobos, USP, 2009. Disponível no link http://www2.eca.usp.br/etam/vilalobos/resumos/CO005.pdf acesso em 03/12/2016.

APRO, Flávio. Os Fundamentos da Interpretação Musical: Aplicabilidade nos 12 Estudos para Violão de Francisco Mignone. Dissertação de mestrado, UNESP, 2004.

BARBEITAS, Flávio T. Circularidade Cultural e Nacionalismo nas Valsas de Mignone. Dissertação de mestrado, UFRJ, 1995.

BOHLMAN, Philip V. Musics and Canons In "Disciplining Music: MUSICOLOGY AND ITS CANONS" BOHLMAN, Philip V e BERGERON, Katherine (org.). University of Chicago Press, 1992.

BORGES, João Pedro. O Violão na Obra de Francisco Mignone. In: MARIZ, Vasco (org.). Francisco Mignone, O homem e a obra. Rio de Janeiro, p.45, Funarte \& ED.UERJ, 1997, p.101-105.

BROOMHEAD, Paul. Shaping Expressive Performance: A Problem-Solving Approach. In: Music Educators Journal, Vol. 91, No. 5 (May, 2005), p. 63-67. Sage Publications, Inc. on behalf of MENC: The National Association for Music Education. http://www.jstor.org/stable/3400145 Acessado em: 25-10-2016 $20 \mathrm{~h} 40$. 
BYO, James L. Practicing: Beyond Hoping They Will. In: American Music Teacher, Vol. 54, No. 2 (October/November 2004), p. 22-24. Music Teachers National Association. http://www.jstor.org/stable/43545861 Acessado em: 25-10-2016 21h09.

CARLEVARO, Abel. Serie didactica para guitarra: cuadernos 1-4. Barry Buenos Aires, 1966.

DEL NERO, Carlos. Acalantos e cantigas de um folclore tenebroso. In: Revista do Arquivo Municipal, Vol. CLXXI - Separata. São Paulo: Gráfica Municipal, 1965 apud Apro, 2004.

DELIÈGE, Irene e WIGGINS, Geraint A. Musical Creativity: multidiciplinary research in theory and practice. Psychology Press, 2006.

DELL'ISOLA, Alberto. Mentes Brilhantes. Universo dos Livros, São Paulo, 2002.

DELVIZIO, Cyro. Agustín Barrios e o Brasil: um relato histórico sobre sua interação com o meio artístico brasileiro. Dissertação de mestrado, UFRJ, 2011.

DEWEY, John. How we Think. D. C Health and CO Publishers. USA, 1933.

DUAILIBI, Roberto e SIMONSEN Jr, Harry. Criatividade e Marketing. McGraw-Hill, 1990.

FREYRE, Gilberto. Casa-grande \& senzala: formação da família brasileira sob o regime da economia patriarcal. $31^{\text {a }}$ ed. Rio de Janeiro: Record, 1996 apud Apro, 2004.

GAlvão, A. Cognição, emoção e expertise musical. Psicologia: Teoria e Pesquisa, v. 22, n. 2, p.169-174, 2006. Disponível em: www.scielo.br/scielo.php?script $=$ sci arttext\&pid $=\mathrm{S} 0102-$

37722006000200006\&lng=en\&nrm=iso. Acesso em: 9 de janeiro, 2019.

GIBSON, Crystal; FOLLEY, Bradley S. e PARK, Sohee. Enhanced divergent thinking and creativity in musicians: A behavioral and near-infrared spectroscopy study. 2008. In: Brain and Cognition 69 (2009) p.162-169.

GLOEDEN, Edelton. As 12 Valsas Brasileiras em Forma de Estudos para Violão de Francisco Mignone: um ciclo revisitado. Tese de doutorado, USP, 2002.

GORDER, Wayne Douglas. Divergent Production Abilities as Constructs of Musial Creativity. In: Journal of Research in Music Education, Vol. 28, No. 1 (Spring, 1980), p. 34-42. Sage Publications, Inc. on behalf of MENC: The National Association for Music Education. http://www.jstor.org/stable/3345051. Acessado em: 01-11-2016 $12 \mathrm{~h} 46$. 
GORDON, Edwin (2000). Teoria de aprendizagem musical: Competências, conteúdos e padrões (Ed. Trad.). Lisboa: Fundação Calouste Gulbenkian, (1980).

GUILFORD, J. P. Creativity. American Psychologist, 1950, 5, 444-454.

GUILFORD, J. P. The nature of human intelligence. Mcgraw-Hill, New York, 1967.

GUILFORD, J. P. Way beyond the IQ. Creative Education Foundation. June 1, 1977.

GUILFORD, J.P. e HOEPFNER, R. The analysis of intelligence. New York: McGraw-Hill, 1971.

JAMES, William. Principles of Psychology. Holt. 1890. Apud Leathwood.

KOLODZIEISKI, Allan. Os Doze Estudos para Violão de Francisco Mignone. Artigo. Anais do II Simpósio de Violão da Embap, 2008.

LAWSON, Colin. Performing through history. In: Musical Performance: a guide to understanding por RINK, John (org.), Cambridge University Press, p. 4-16, 2002.

LEATHWOOD, Jonathan. Improvisations, Structures and Schemata: towards virtuosity in performance and cognition. Folheto de suporte à palestra conferida no GFA Guitar International Convention, Denver, 2016. Não publicado.

MARIZ, Vasco (org.). Francisco Mignone, O homem e a obra. Rio de Janeiro, p.45, Funarte \& Ed. UERJ, 1997.

OARE, Steve. Practice Education: Teaching Instrumentalists to Practice Effectively. In: Music Educators Journal, Vol. 97, No. 3 (March 2011), p. 41-47. Sage Publications, Inc. on behalf of MENC: The National Association for Music Education. http://www.jstor.org/stable/23012590 Acessado em: 02-11-2016 12h26.

OLIVEIRA, Rodrigo Carvalho de. Estudos para Violão de Villa-Lobos, Mignone e Gnattali: o idiomatismo revisitado. Dissertação de mestrado em música. UFG. 2006.

PUJOL, Emilio. La Escuela Razonada de la Guitarra. Buenos Aires: Ricordi Americana, 1934, Vol. I.

RANDEL, Dan Michael. The Canons in the Musicology Toolbox. in: BERGERON, Katherine e BOHLMAN, Philip. "Disciplining Music” p. 10-22. Chicago University of Chicago Press, 1992.

$\mathrm{ROCH}$, Pascual. A modern method for the guitar (school of Tárrega) in three volumes. G. Schirmer, Boston/New York, 1917. 
RYAN, Lee. The Natural Guitar: 10 principles for effortless playing. The bold Strummer, Ltd 1991.

SANDRONI, Carlos. Feitiço Descente: Transformações do samba no Rio de Janeiro (1917-1933). Zahar, 2001.

SANTORO, Ricardo Rossi. Edição crítica do Primeiro Trio para flauta, violoncelo e piano de Francisco Mignone. Dissertação de mestrado, UFRJ, 2010).

SANTOS, Turibio. Caminhos, encruzilhadas e mistérios..., $2^{\mathrm{a}}$ ed. ARTVIVA, 2015.

SANTOS, Turibio. Heitor Villa-Lobos e o Violão. Rio de Janeiro: MEC/DAC/Museu Villa-Lobos, 1975 Apud Amorim, 2007.

SCHMIDT, R. A. A schema theory of discrete motor learning. Psychol. Rev. 82, 225-260, 1975. Apud Leathwood.

SILVA, Carlos Alberto Pereira. Arte e Ciência: duas irmãs no caminho da reconciliação. $\quad$ www.uesb.br/labtece/artigos/Arte $\% 20 \mathrm{e} \% 20 \mathrm{Ci} \% \mathrm{C} 3 \% \mathrm{AAncia} \% 20$ \%20duas $\% 20 \mathrm{irm} \% \mathrm{C} 3 \% \mathrm{~A} 3 \mathrm{~s} \% 20 \mathrm{no} \% 20$ caminho $\% 20 \mathrm{da} \% 20$ reconcilia $\% \mathrm{C} 3 \% \mathrm{~A} 7 \% \mathrm{C} 3 \%$ A3o.pdf Acessado em: 19-01-2017 às 17h44.

SILVA, Flávio (org.). Francisco Mignone: catálogo de obras. Academia Brasileira de Música, 2007.

SOARES, Albérgio Claudino Diniz. Orientadores Técnicos nos Estudos IV e VII de Francisco Mignone. Dissertação de Mestrado. UFBA. 1998.

STERNBERG, Robert and Karin. Cognitive Psychology 6th Edition, 2012/2009 Wadsworth, Cengage Learning.

TABORDA, Márcia. Violão e identidade nacional - Rio de Janeiro 1830-1930. Tese de Doutorado, UFRJ, Rio de Janeiro, 2004. Editado pela Civilização Brasileira, Rio de Janeiro, 2011.

TANG, Paul C. L. On the Similarities between Scientific Discovery and Musical Creativity: A Philosophical Analysis. Source: Leonardo, Vol. 17, No. 4 (1984), pp. 261-268. The MIT Press. www.jstor.org/stable/1575103 Acessado em: 2803-2016 16h47.

TENNANT, Scott. Pumping Nylon: the Classical Guitarist's Technique Handbook. Lakeside (Connecticut; EUA): Alfred Publishing Co., 1995.

WAlle, John A. Van de e HOLBROOK, Helen. Patterns, Thinking, and Problem Solving. In: The Arithmetic Teacher, Vol. 34, No. 8 (April 1987), p. 6-12. 
National Council of Teachers of Mathematics. http://www.jstor.org/stable/41193145 Acessado em: 28-03-2016 16h35.

WhITAKeR, Nancy L. Theoretical Model of the Musical Problem Solving and Decision Making of Performers, Arrangers, Conductors, and Composers. Source: Bulletin of the Council for Research in Music Education, No. 128 (Spring, 1996), p.1-14. University of Illinois Press on behalf of the Council for Research in Music Education. www.jstor.org/stable/40318784 Accessado em: 25-10-2016 21h09.

\section{Leituras de apoio}

BARROS, Nícolas de Souza. Gradações do Toque Digital. Anais do VI Simpósio Acadêmico de Violão da Embap, 2012. Curitiba, PR, Brasil.

BRASIL, André. Mega memória. Ed. Elsevier, 2005.

CARLEVARO, Abel. Escuela de la guitarra, Barry Editorial, Buenos Aires, 1979.

CARLEVARO, Abel. Guitar Masterclasses, vol. 1-4, Chanterelle Verlag, 1988.

CASTAGnA, Paulo. A Musicologia enquanto método cientifico. Revista do Conservatório de Música da UFPel. Pelotas, n.1, 2008. p.7-31. ISSN 1984-350X.

CONTRERAS, Antonio de. La técnica de David Russel en 165 consejos. Edição em pdf autorizada pelo autor. http://guitarra.artelinkado.com, 2004.

CROSS, Ian. Music and Science: Three Views. Source: Revue belge de Musicologie / Belgisch Tijdschrift voor Muziekwetenschap, Vol. 52 (1998), p. 207-214. Societe Belge de Musicologie. www.jstor.org/stable/3686926 Acessado em: 02-11-2016 12:19 UTC

DEMO, Pedro. Introdução a Metodologia da Ciência. Ed. Atlas,1994.

ECO, Umberto. Como se faz uma tese. Editora Perspectiva, 1977.

FREIRE, Vanda Bellard (org.). Horizontes da pesquisa em música, 7 Letras, 2009.

FREIRE, Vanda Bellard e CAVAZOTTI, André. Música e pesquisa: novas abordagens. Música UFMG, 2007.

GARDNER, Howard. Arte, mente, cérebro. Artmed editora, 1999.

GOLÇALVES, Hortência de Abreu. Manual de Monografia, Dissertação e Tese. $2^{\mathrm{a}}$ edição. Avercamp Editora, 2008.

GOLDENBERG, Mirian. A arte de pesquisar. 10ª ed. Editora Record, 2007. 
GUILFORD, J. P. Can Creativity Be Developed?. In: Art Education, Vol. 11, No. 6 (Jun., 1958), p. 3-7 e 14-18. National Art Education Association http://www.jstor.org/stable/3184459 Acessado em: 18-11-2016 21h57.

GUILFORD, J. P. e HOEPFNER, R. Sixteen Divergent-Production Abilities at the Ninth-Grade Level. Multivariate Behavior Research, January 1966, 1, 43-66.

GUILFORD, J. P. Intelligence: 1965 Model. American Psychologist, January 1966, 21, 20-26. New York: McGraw-Hill Book Company, Inc., 1967 (in press).

GUILFORD, J. P. Measurement and Creativity. In: Theory Into Practice, Vol. 5, No. 4, Creativity (Oct., 1966), p. 186-189 e 202. Taylor \& Francis, Ltd. http://www.jstor.org/stable/1475131 Acessado em: 18-11-2016 21h57.

GUILFORD, J. P. Three Faces of Intellect. American Psychologist, August 1959, 14, 469-79.

HOWES, Frank. Science and Music. In: Music \& Letters, Vol. 15, No. 1 (Jan., 1934), p. 66-70. Oxford University Press. http://www.jstor.org/stable/727141 Accessado em: 02-11-2016 12h19.

IZNAOLA, Ricardo. On practicing. Mel Bay Publications, Inc. 1992.

IZQUIERDO, Iván. Questões sobre memória. Coleção Aldus, Editora Unisinos, 2003.

JOURDAIN, Robert. Música, Cérebro e Êxtase. Ed. Objetiva, 1998.

RAWLINS, F. I. G. Scientific Methods in the Care of Works of Art. In: Journal of the Royal Society of Arts, Vol. 108, No. 5047 (JUNE 1960), p. 519-532. Royal Society for the Encouragement of Arts, Manufactures and Commerce. http://www.jstor.org/stable/41368914 Accessado em: 02-11-2016 12h17.

SOUZA BARROS, Nicolas de. Tradição e inovação no estudo da velocidade escalar ao violão. Tese (Doutorado em Música); Universidade Federal do Estado do Rio de Janeiro (UNIRIO), Rio de Janeiro, 2008.

\section{Partituras}

CARCASSI, Matteo. 25 Estudios para guitarra Op. 60. Revisão de Miguel Llobet. Buenos Aires: Ricordi, 1974.

CARCASSI, Matteo. 25 Etudes Op.60. Organização de Simon Wynberg. Heidelberg: Chanterelle, 1985. 
CARCASSI, Matteo. Carcassi: 25 Etudes for Guitar, op. 60. Revisador por Brian Jeffery. Tecla Editions, London, 2006.

CARCASSI, Matteo. Méthode complète pour guitare, Op.59. Mainz: B. Schott's Söhne, [s.d].

CARCASSI, Matteo. Venticinque studi melodici progressivi op.60 per chitarra. Revisão e digitação Giovanni Podera e Giulio Tampalini. Milão: Edizioni Curci S.r.l., 2015. Disponível em: $<$ https://issuu.com/edizionicurci/docs/ec11866_anteprima_issuu $>$. Acesso em: 18 abr. 2017.

MIGNONE, Francisco. 12 Estudos para violão, manuscrito, 1970. Apud Apro, 2004, Anexos. Atualmente disponível no acervo da Acadêmia Brasileira de Música.

MIGNONE, Francisco. Twelve Etudes, Columbia Music Company, 1973.

VILLA-LOBOS, Heitor. Douze Etudes pour guitare, Max Eschig, 1953.

\section{Gravações}

APRO, Flávio. "Francisco Mignone - Doce Estudios Para Guitarra" selo Tempus $\begin{array}{llll}\text { Clasico } & \text { (Mexico). } & 2013 . & \text { Disponível em }\end{array}$ www.tempusclasico.com/Catalogo/doce estudios.html, acesso em 13/12/2018, às 14hs.

BARBOSA-LIMA, Antonio Carlos. "Barbosa-Lima interpreta os 12 Estudos para violão de Francisco Mignone”. LP (esgotado), Philips Polygram, 1978.

\section{Entrevistas}

Entrevista com Antonio Carlos Barbosa-Lima (arquivo pessoal).

Entrevista com Maria Josephina Mignone (arquivo pessoal). 